
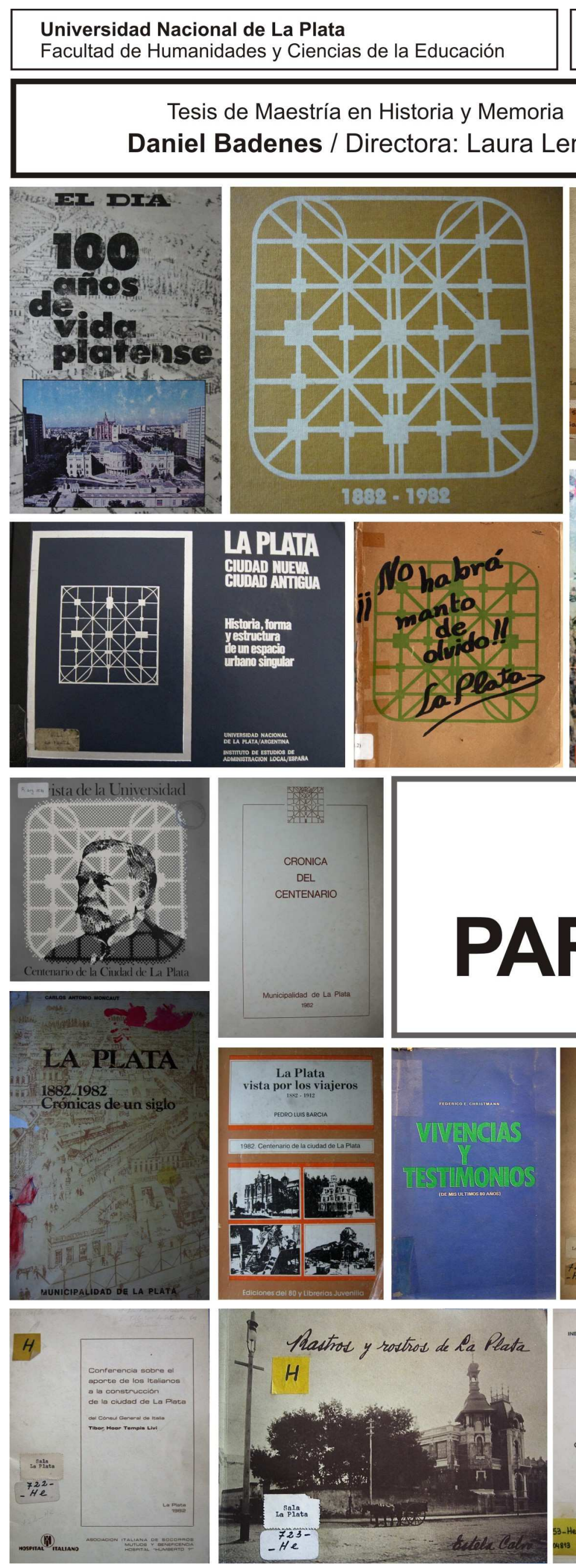
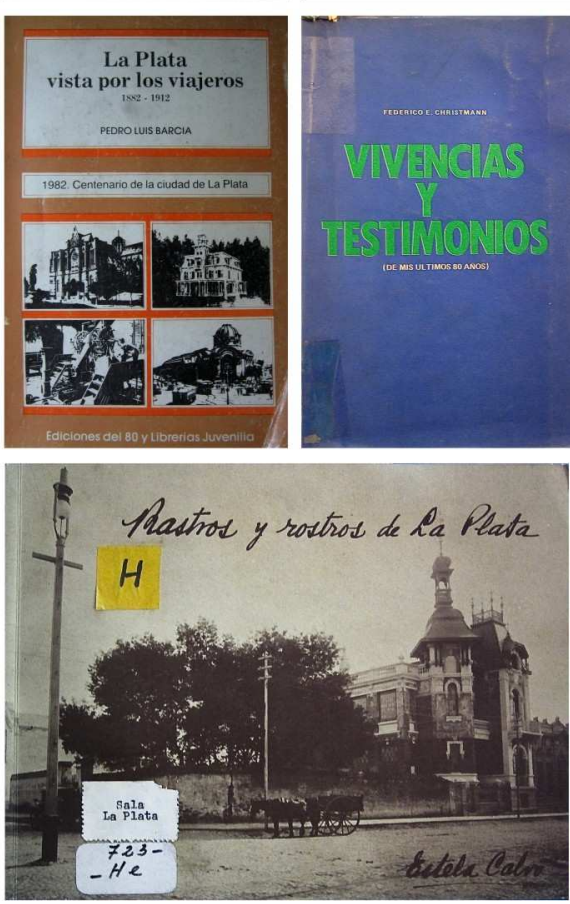

\section{2}

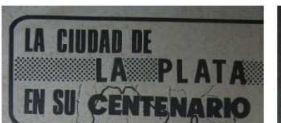

(H) SENTENAR

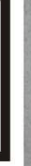

LAA PLATA

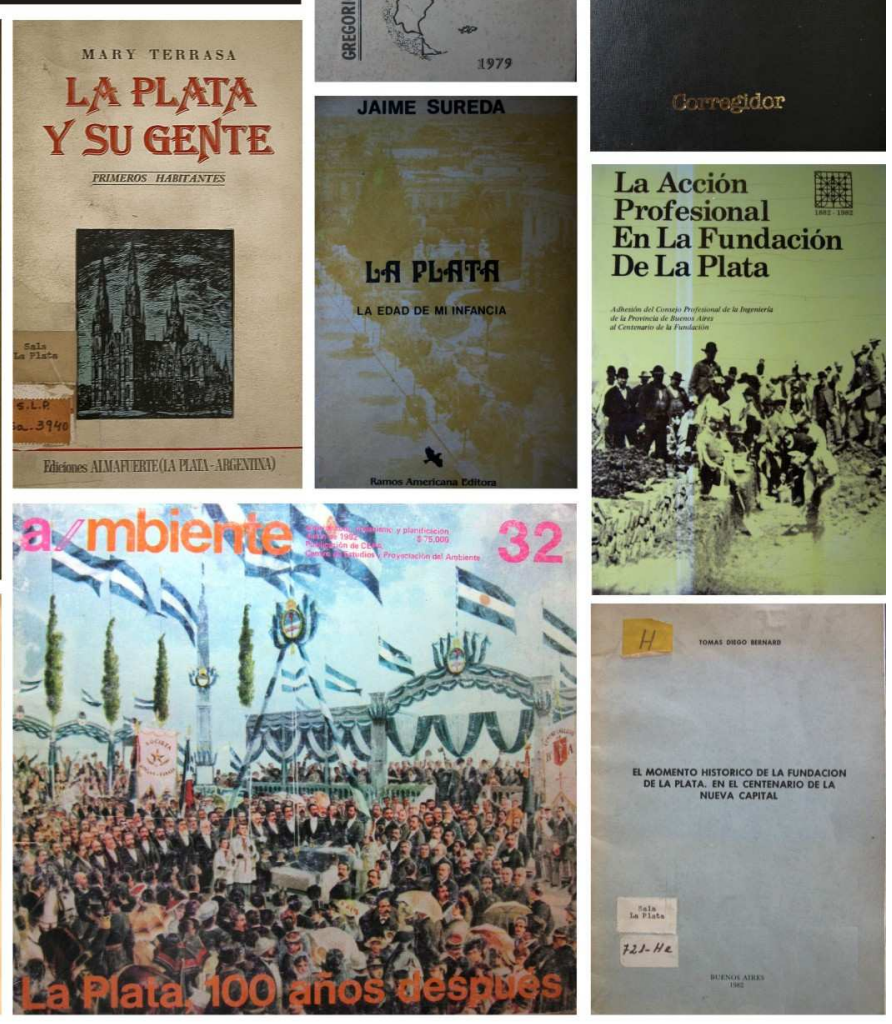

\title{
UN PASADO PARA LA PLATA
}
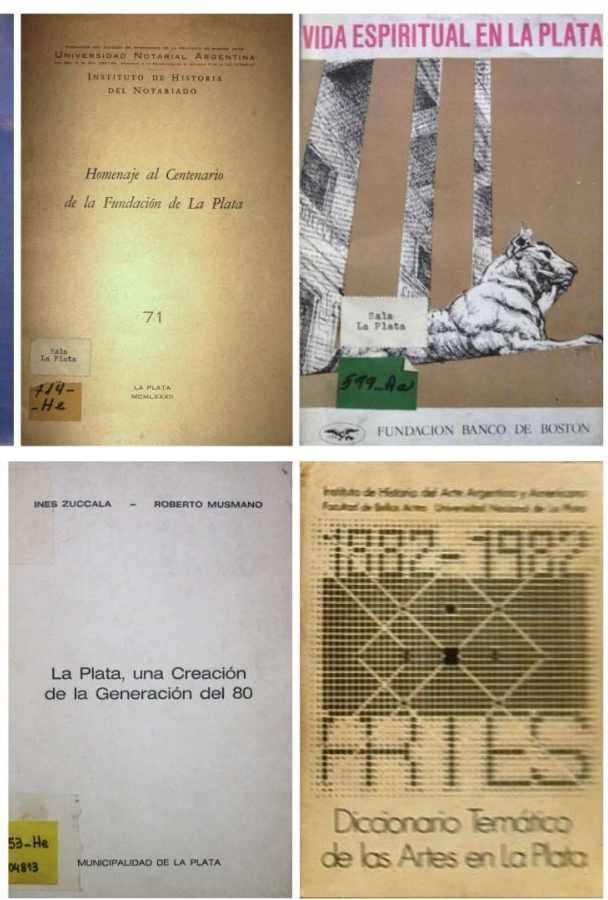

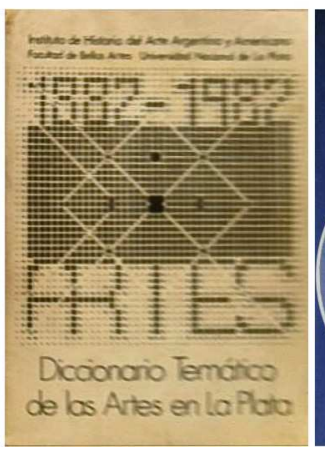

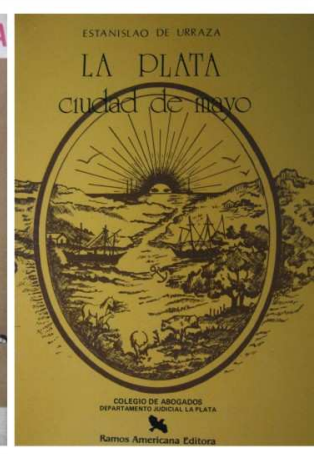

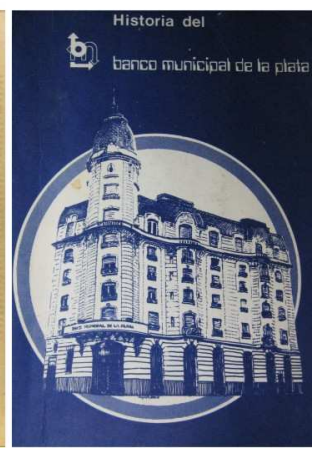


Universidad Nacional de La Plata

Facultad de Humanidades y Ciencias de la Educación

Maestría de Historia y Memoria

$\underline{\text { Tesis para obtener el grado de magíster }}$

\section{Un pasado para La Plata}

Producción editorial y disputa de sentidos sobre la historia de la ciudad en su centenario -1982-

AUTOR: Daniel Badenes

DIRECTORA: Laura Lenci

FECHA: $1^{\circ}$ de febrero de 2012 
Badenes, Daniel (2012).

Un pasado para La Plata. Producción editorial y disputa de sentidos sobre la historia de la ciudad en su centenario -1982-.

Tesis de Maestría. La Plata: Facultad de Humanidades y Ciencias de la Educación, Universidad Nacional de La Plata.

\section{Contacto}

\section{danibadenes@gmail.com}

\section{(c) Esta obra está bajo una licencia Atribución-No comercial- Sin obras derivadas 2.5 Argentina de Creative Commons.}

Está permitido compartir, copiar, distribuir, ejecutar y comunicar públicamente la obra, bajo las condiciones siguientes:

Atribución - Debe reconocer los créditos de la obra de la manera especificada por el autor o el licenciante (pero no de una manera que sugiera que tiene su apoyo o que apoyan el uso que hace de su obra).

No Comercial - No puede utilizar esta obra para fines comerciales.

Sin Obras Derivadas - No se puede alterar, transformar o generar una obra derivada a partir de esta obra.

* Dominio Público - Cuando la obra o alguno de sus elementos se halle en el dominio público según la ley vigente aplicable, esta situación no quedará afectada por la licencia. * Otros derechos - Los derechos siguientes no quedan afectados por la licencia de ninguna manera: Los derechos derivados de usos legítimos u otras limitaciones reconocidas por ley no se ven afectados por lo anterior; Los derechos morales del autor; Derechos que pueden ostentar otras personas sobre la propia obra o su uso, como por ejemplo derechos de imagen o de privacidad.
} 


\section{Indice}

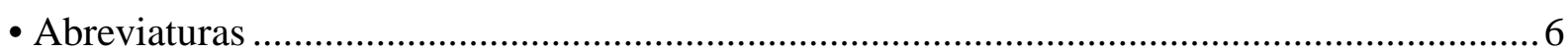

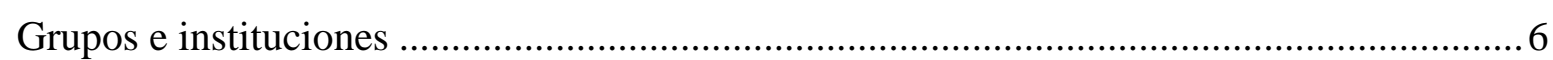

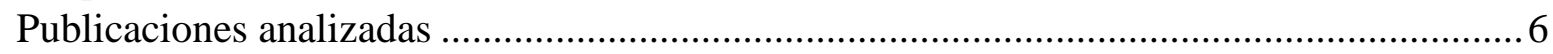

- I. Introducción | Preguntas y caminos de la investigación ................................................ 8

- II. El desfile editorial | Libros, revistas y folletos del centenario platense .......................... 18

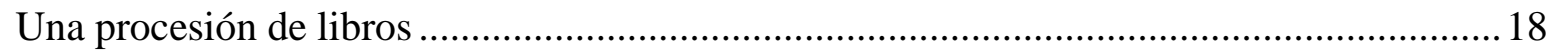

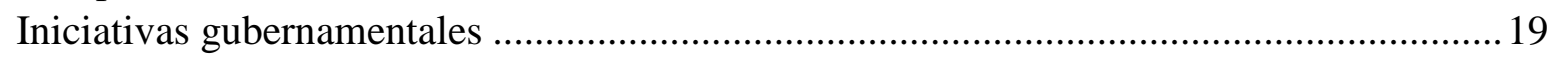

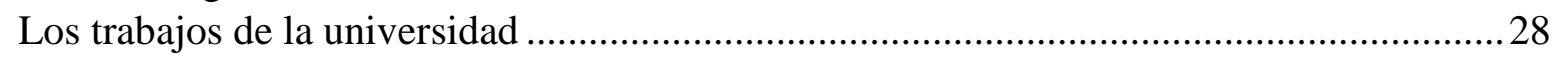

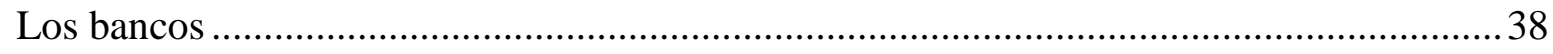

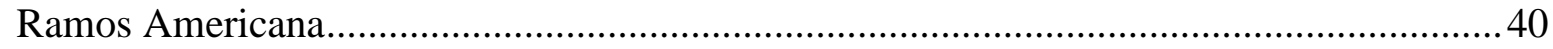

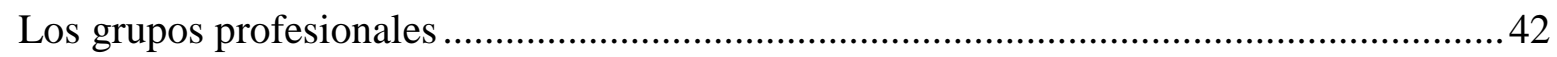

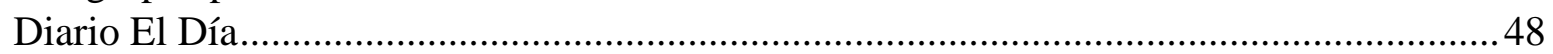

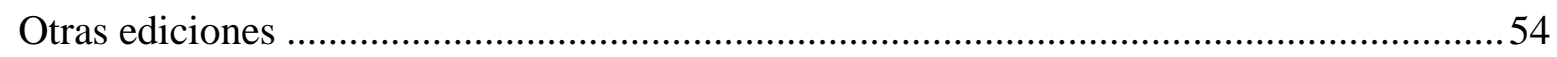

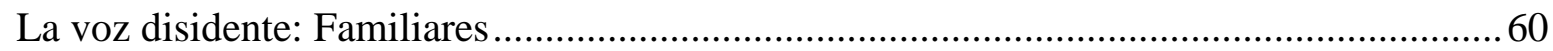

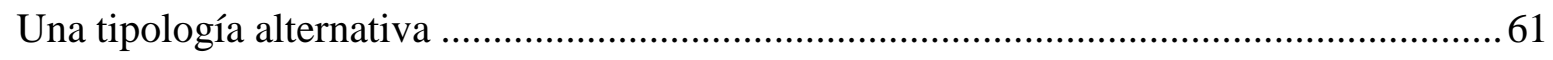

- III. Entre historia y memoria | El registro de los relatos locales publicados .....................63

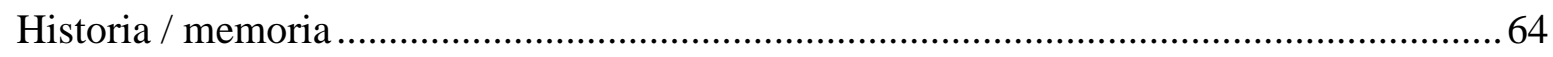

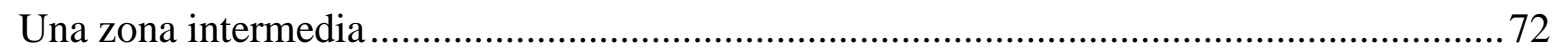

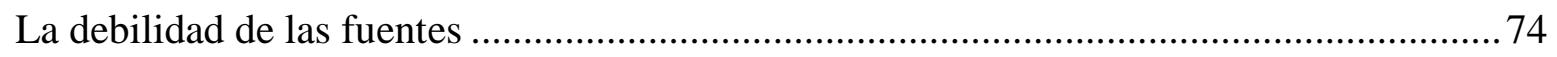

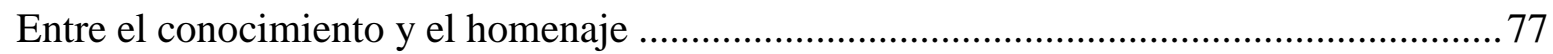

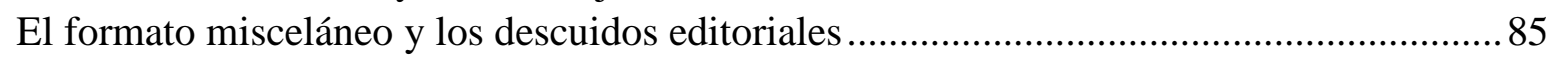

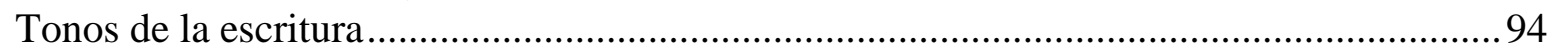

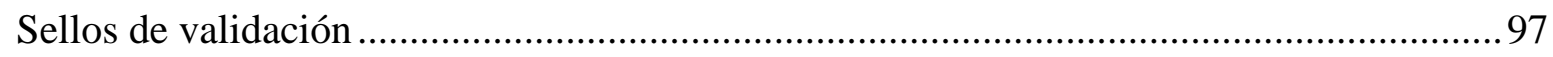

- IV. Ciudad de sabios y poetas | Los autores, sus títulos y sus círculos sociales ............... 101

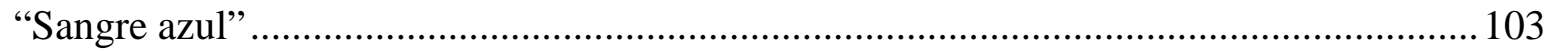

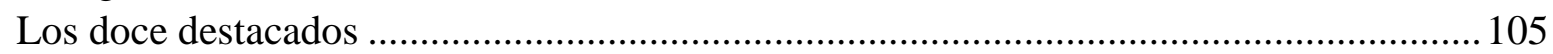

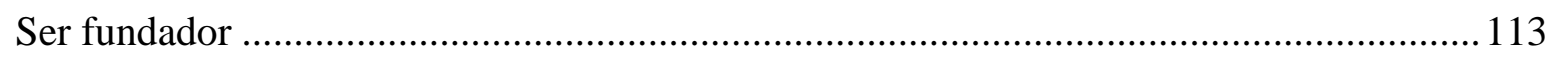

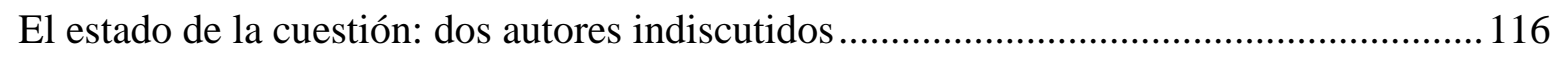

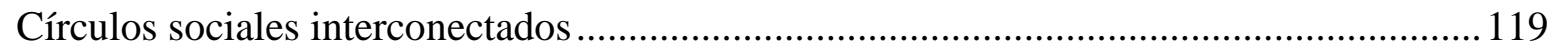

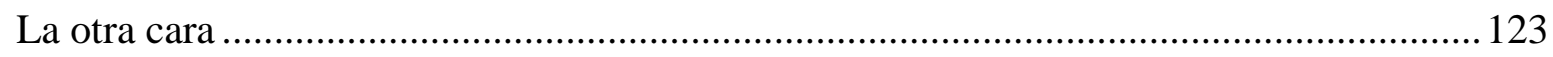

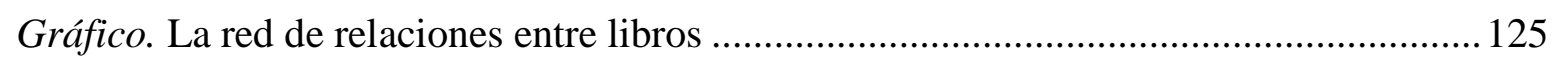

-V. Ciudad perfecta | La celebración del trazado, el orden y sus límites ........................... 126

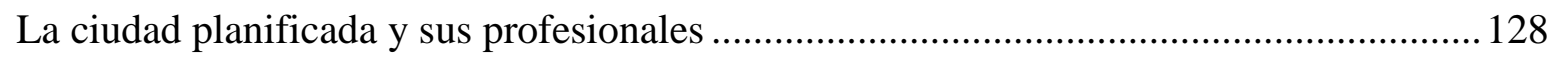

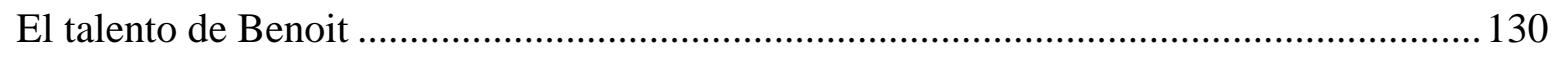

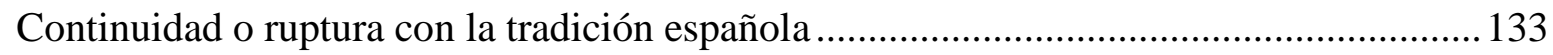

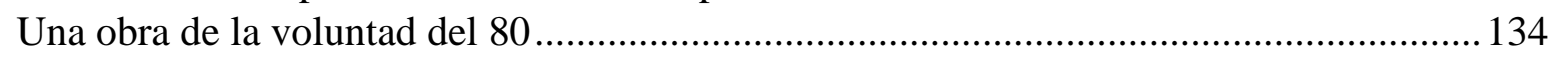

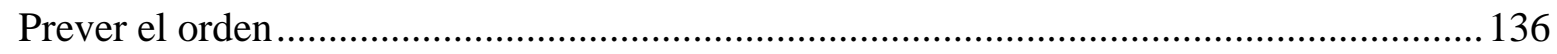

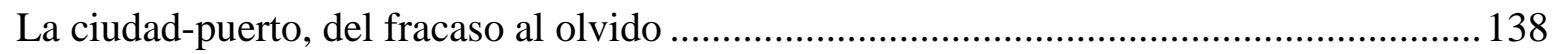

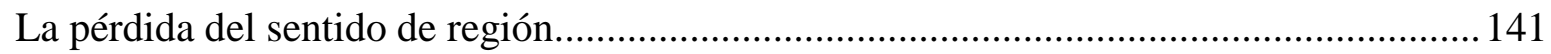

- VI. Ciudad universitaria, capital de cultura | La invención de una razón de ser ............. 146

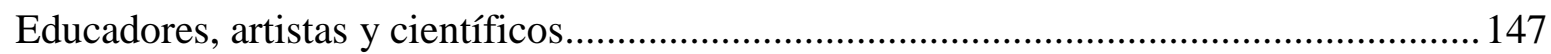

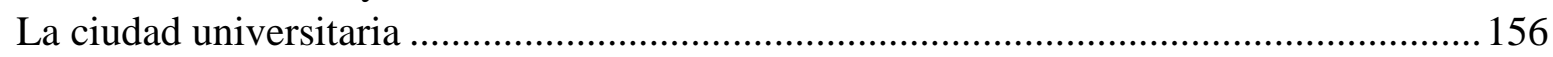

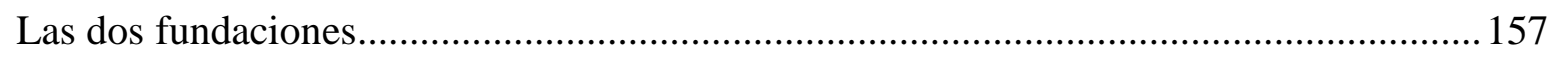




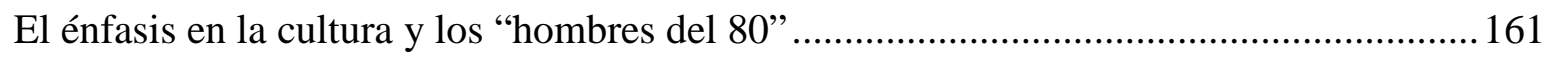

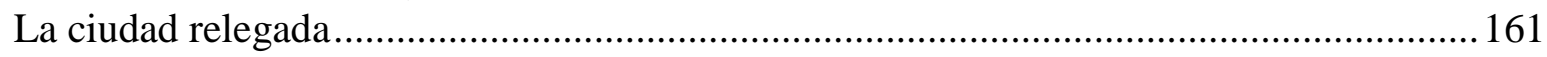

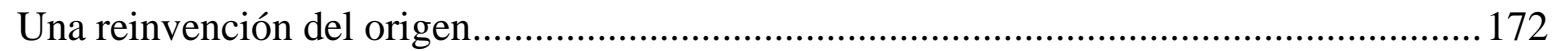

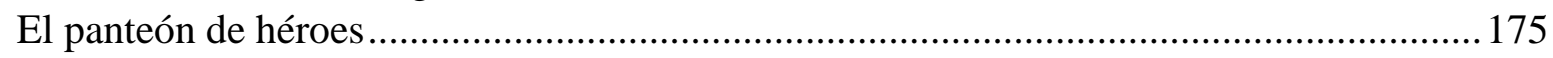

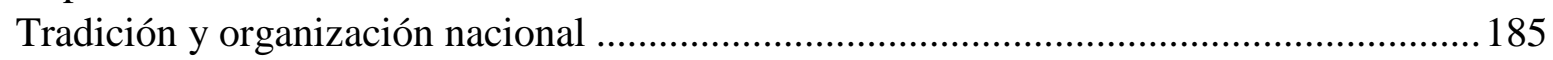

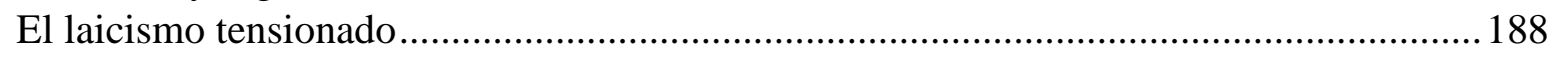

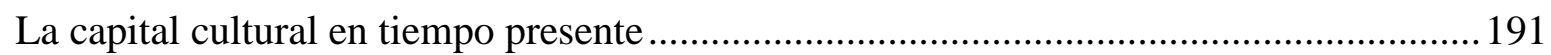

- VII. Ciudad de la conciliación | La historia reciente y los usos del pasado ...................... 194

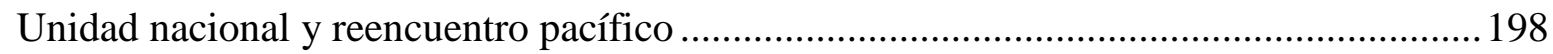

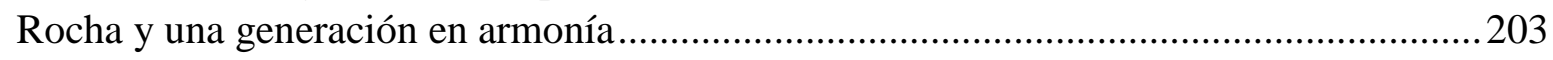

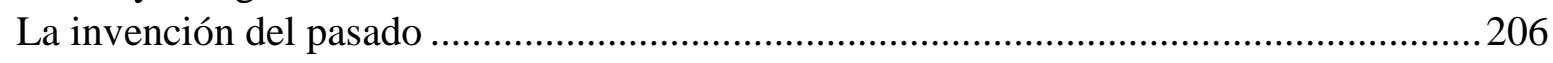

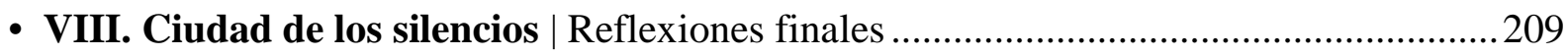

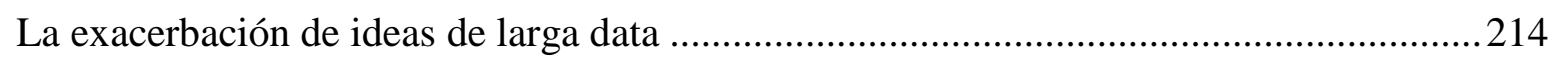

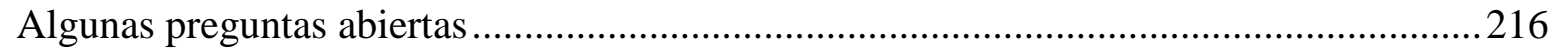

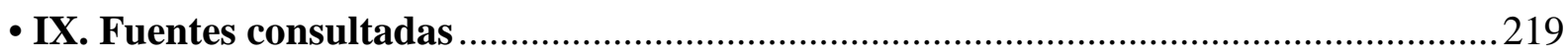

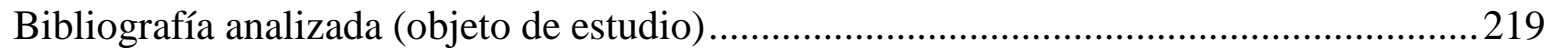

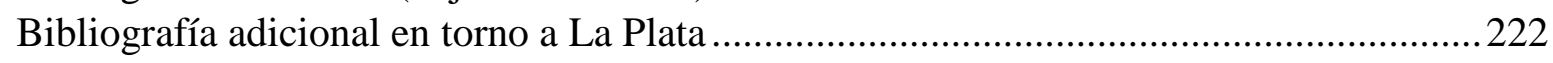

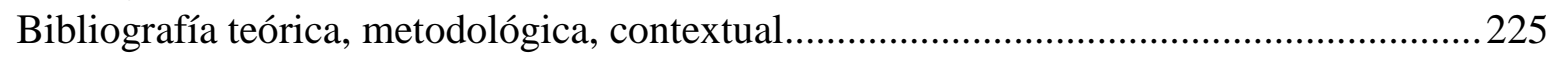

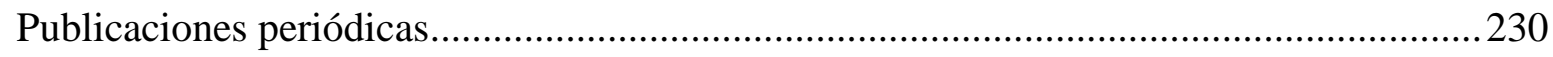

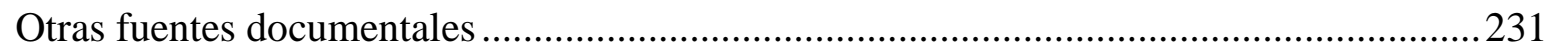

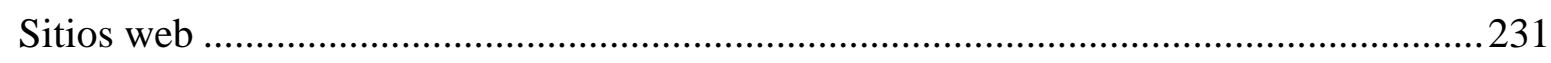

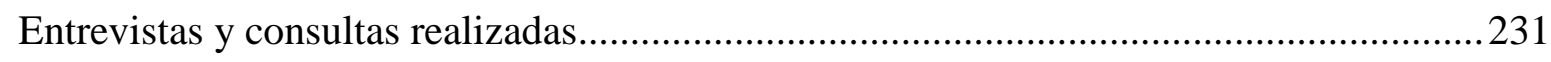

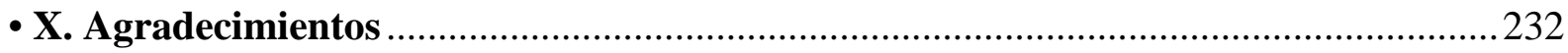




\section{Abreviaturas}

\section{Grupos e instituciones}

\section{CELS}

Familiares

SADE La Plata

SEP

UNLP

UPAK

YPF

12 personalidades

Acción profesional

Ambiente

Años veinte

Calles numeradas

Ciclo Cien años

Ciudad de mayo

Ciudad milagro

Ciudad nueva ciudad antigua

Crónica del centenario

Crónicas de un siglo

Diccionario de arte

Económica
Centro de Estudios Legales y Sociales

Familiares de Desaparecidos y Detenidos por Razones Políticas

Sociedad Argentina de Escritores - Filial La Plata

Sociedad de Escritores de la Provincia de Buenos Aires

Universidad Nacional de La Plata

Universidad Popular Alejandro Korn

Yacimientos Petrolíferos Fiscales

\section{Publicaciones analizadas}

SADE La Plata (1982). 12 personalidades del siglo. La Plata: Almafuerte.

Tartarini, Jorge Daniel (1982). La acción profesional en la fundación de La Plata. La Plata: Consejo Profesional de la Ingeniería de la Pcia. de Bs. As.

Revista Ambiente (arquitectura, urbanismo y planificación), $\mathrm{N}^{\circ} 32$, Centro de Estudios y Proyectación del Ambiente (CEPA), La Plata, junio de 1982.

Szelagowski, Miguel Blas (1979). La Plata, los años veinte. La Plata: Librería Editora Platense SRL.

Massa, Ricardo (1982). La ciudad de las calles numeradas. La Plata: Banco Platense.

Ciclo de conferencias "Cien años de La Plata. Sus realizaciones, su cultura y su gente”. Museo y Archivo Dardo Rocha (1978-1982).

De Urraza, Estanislao (1981). La Plata Ciudad de Mayo. La Plata: Colegio de Abogados Dpto. Judicial La Plata / Ramos Americana.

Lerange, Catalina -directora- (1982). La Plata Ciudad milagro. La Plata: Sociedad de Escritores de la Provincia de Buenos Aires - Ediciones Corregidor.

Morosi, Julio A. (1983). LA PLATA Ciudad nueva, ciudad antigua. Historia, forma y estructura de un espacio urbano singular. Madrid: Instituto de Estudios de Administración Local/España y Universidad Nacional de La Plata/Argentina.

Szelagowski, Miguel Blas (1982). Crónica del centenario. La Plata: Municipalidad de La Plata.

Moncaut, Carlos Antonio (1982). La Plata 1882-1982. Crónicas de un siglo. La Plata: Municipalidad de La Plata.

Nessi, Angel Osvaldo -director- (1982). Diccionario temático de las artes en La Plata. La Plata: Instituto de Historia del Arte Argentino y Americano, Facultad de Bellas Artes, UNLP.

Revista Económica, Año XXVIII, N³, Facultad de Ciencias Económicas de la UNLP, La Plata, septiembre-diciembre de 1982. 
Edad de mi infancia Sureda, Jaime (1982). La Plata. La edad de mi infancia. La Plata: Ramos Americana Editora.

Historia del Banco

Municipal

Homenaje de la

Universidad

Notarial

Italianos

\section{La Plata 100}

No habrá manto de olvido

Obra de arte

Primeros habitantes

Rastros y rostros

Revista de la

Universidad

¿Será justicia?

Si yo fuera

intendente

Creación de la

generación del 80

Nueva Argentina

Viajeros

Vida espiritual

Vida platense

Vieja amistad

Vivencias y

testimonios
Giuliano, Ethel Leonor (1983). Historia del Banco Municipal de La Plata. La Plata: Talleres Gráficos de la División Impresiones de la Municipalidad de La Plata.

VV. AA. (1982). Homenaje al Centenario de la Fundación de La Plata. La Plata: Instituto de Historia del Notariado - Universidad Notarial Argentina.

Hoor Tempis Livi, Tibor (1982). "Conferencia sobre el aporte de los italianos a la construcción de la ciudad de La Plata". La Plata: Hospital Italiano - Asociación Italiana de Socorros Mutuos y Beneficencia Hospital "Humberto 1 ".

VV. AA. (1982). La Plata 100. Guía turística. La Plata: Sociedad de Arquitectos de la Plata.

Familiares de Detenidos Desaparecidos y Presos por Razones Políticas en La Plata (1983). ;No habrá manto de olvido! La Plata. La Plata.

Díaz, Benito -director general- (1982). La Plata, una obra de arte 18821982. La Plata: Universidad Nacional de La Plata.

Terrasa, Mary (1982). La Plata y su gente. Primeros habitantes. La Plata: Almafuerte.

Calvo, Estela (1982). Rastros y rostros de La Plata. La Plata: sin datos editoriales (Impreso en Artes Gráficas San Miguel).

Revista de la Universidad, números 26, 27 y 28. Universidad Nacional de La Plata.

Szelagowski, Miguel Blas (s/f). ¿Será justicia?. La Plata: Colegio de Abogados - Departamento Judicial La Plata.

Szelagowski, Miguel Blas (1982). Si yo fuera intendente. La Plata: Ramos Americana.

Zuccalá, Inés y Musmano, Roberto (1981). La Plata, una Creación de la Generación del 80. La Plata: Municipalidad de La Plata.

Cygan, Gregorio Manuel (1981 [1979]). La ciudad de La Plata en su centenario. Fundamentos para una nueva Argentina. Granada, España: edición de autor, $3^{\mathrm{a}}$ edición.

Barcia, Pedro Luis -compilador- (1982). La Plata vista por los viajeros. 1882-1912. La Plata: Ediciones del 80 y Librerías Juvenilia.

Bartholomew, Roy -compilador- (1982). Vida espiritual en La Plata. Buenos Aires: Fundación Banco de Boston.

Soler, Ricardo (1982). 100 años de vida platense. La Plata: El Día Sociedad Impresora Platense.

Bernard, Tomás Diego (1982). Una vieja amistad con los Rocha. La Plata: Universidad Notarial Argentina.

Christmann, Federico E. (1982). Vivencias y testimonios (de mis últimos 80 años). La Plata: Agremiación Médica Platense. 


\title{
I. Introducción Preguntas y caminos de la investigación
}

\author{
"En todas las ciudades hay una historia admitida, por lo común \\ lanzada en grageas por el diario más 'representativo', comentada por \\ las personalidades más o menos importantes y aceptada por el \\ poblador medio. La Plata no es la excepción" (Gabriel Fernández, s/f)
}

1.

Cualquier experiencia de investigación lo comprueba: los manuales de metodología, igual que los planes de tesis y los curriculum vitae, son obras de ficción. Basadas en la realidad, pero ficciones al fin. Pues nunca hay un camino fijo, ni primeros pasos predefinidos.

Esta tesis, por ejemplo, empezó por la bibliografía. No partió de una pregunta, una hipótesis o un artefacto teórico, sino a partir del armado de una lista de publicaciones.

Sí. Nació durante ese trabajo explorador que significa buscar ciertos libros en nuestras sociedades; un verano dedicado a un informe, mientras pulía el copy-paste de referencias bibliográficas. Haciendo esa tarea descubrí que la mayoría de las historias publicadas sobre la ciudad estaban fechadas un año en particular: 1982. El centenario. Afinando más el ojo, advertí que la mayor parte de los textos sobre la historia platense -semblanzas, crónicas o indagaciones académicas- estaba asociada a tiempos de celebración, ratificando la idea de que los aniversarios y las "fechas redondas" (Jelin, 2002b) son coyunturas que activan procesos de elaboración/reelaboración de narrativas sobre el pasado (Jelin, 2005: 231-232).

Decía el primer diagnóstico, plasmado en el proyecto de tesis: "de unas 56 publicaciones identificadas, 12 están comprendidas entre las 'bodas de oro' de la ciudad y el centésimo aniversario del nacimiento de su fundador en 1939, otras 6 rondan la fecha de las 'bodas de platino' (75 años), y al menos 21 fueron producidas en torno al centenario de la ciudad. Algunas de estas últimas constituyen la bibliografía más accesible sobre la historia platense".

Esta tesis surgió, entonces, de la repetida aparición de un número en la bibliografía de un informe aburrido y pesado que probablemente no hayan leído más de dos personas, pero que contribuyó a entrenar la mirada con la que construí las preguntas que guían esta investigación; preguntas que maduraron aún cuando no había tiempo para la tesis, y que me acompañaron en las esporádicas incursiones en librerías de usados. Venía de repasar distintos modos de mirar la ciudad (Badenes, 2007) y de reconocer categorías de un análisis cultural que pone el foco en los imaginarios urbanos en disputa, en "la definición de sentidos sociales y culturales del territorio", es decir, "la imaginación socioespacial" (Gorelik, 2004: 18) o las "poéticas de la ciudad" (Pereira, 1995), convertidas en el objeto de estudio de una historia cultural urbana:

“...que no separe la historia de la ciudad -en términos materiales- de la sociedad -en términos sociales o políticos-, sino que sea una historia del modo en que la ciudad, como objeto de la cultura, produce significaciones; es decir, una historia cultural de las representaciones de la ciudad, pero siempre que se advierta que el modo en que los artefactos urbanos producen significaciones afecta tanto la cultura como revierte sobre su propia materialidad" (Gorelik, 1998: 16)

Germinó así la idea de pensar la producción de relatos históricos como parte de aquella imaginación socioespacial, una idea atravesada por mis primeras lecturas de estudios sociales sobre la memoria, que proponen estudiar el "conflicto entre memorias en competencia" 
(Pollak, 2006), los "trabajos" y las "luchas políticas" (Jelin, 2002a) en torno a las significaciones del pasado. Se podría, así, releer la historiografía sobre la ciudad, pero "adoptándola como objeto de estudio en sí misma, en tanto cuerpo de relatos que participaron de la producción de sentidos sobre una urbe [...] Ejercer una crítica sobre los propios documentos que conforman el 'estado de la cuestión'..." (Badenes, 2007).

2.

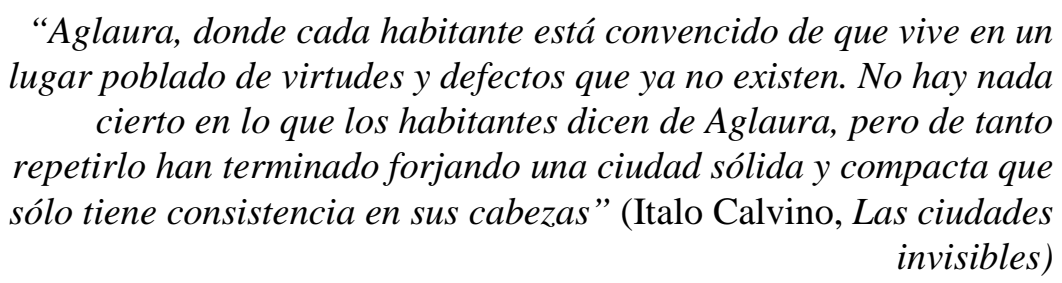

"El pasado urbano es una obra en construcción, que lejos de ser un hecho histórico dado, único e indiscutible es el resultado de reapropiaciones, clasificaciones y significaciones simbólicas diferenciadas", reflexiona Natalia Milanesio al examinar un debate en la historiografía de Rosario sobre el origen de esa ciudad, generado en la década de 1920 cuando se aproximaba su bicentenario. La investigadora afirma que "como ocurre con la ciudad presente, también la pasada se convierte en objeto de reinvención representacional: el pasado colectivo también es reorganizado..." (Milanesio, 2004: 293-294)

Con el foco puesto en la producción editorial, esta tesis se propone estudiar esas construcciones sobre el pasado en el caso de La Plata, fundada el 19 de noviembre 1882 para ser capital de la provincia más grande del país, tras la federalización de la ciudad de Buenos Aires a la que se arribó después de cruentos conflictos político-armados (Sábato, 2008). Por sus características físicas ha sido llamada ciudad de las diagonales, ciudad geométrica, ciudad de calles paralelas, ciudad del bosque o ciudad de los tilos, pero también recibió los apotegmas de ciudad de los poetas, ciudad universitaria y capital intelectual, ciudad de la conciliación o ciudad de la unión nacional. La Plata fue, en distintas lecturas, en diferentes escrituras, la Salamanca de Iberoamérica, la Boston o la Filadelfia del continente del Sur, el templo de Minerva, la nueva Tebas, la Oxford o la Atenas argentina; la ciudad perfecta ${ }^{1}$. Y su gestación acelerada produjo las "designaciones de «ciudad nueva», «ciudad flamante», «ciudad sin historia», «sin pátina», «ciudad más joven que sus habitantes», «ciudad que no tuvo infancia»" (Barcia, 1982: 41). Se afirmó y se afirma que La Plata nació de cero, planificada de antemano:

"No hubo en su origen como lo hay en el de casi todas las ciudades del mundo, exigencias militares o necesidades económicas. No fue puesto fronterizo adonde afluyesen las gentes en demanda de protección, ni fue encrucijada comercial. Nació de una vez para siempre, en plena adultez, sin pasado propio. Tuvo pues un destino extraño y en cierto modo inverso al de todas las ciudades; no nació históricamente para alcanzar sólo muy tarde la plenitud de la razón: nació de la razón misma, al margen de la historia"2 (Las cursivas son mías)

\footnotetext{
${ }^{1}$ Las voces detractoras, en tanto, planteaban otros términos: ciudad oficial, ciudad política, ciudad decretada... O como escribió Ignacio Anzoátegui : "La Plata no es una ciudad, es un decreto" (citado en Barcia, 1982: 41). 2 "Nació con todo". Artículo publicado por el diario El Día, La Plata, 4 de noviembre de 1982. El texto no cita fuente, pero es casi textual del aporte de Sánchez Reulet al libro que realizó la Municipalidad en homenaje al fundador Dardo Rocha, cuatro décadas antes (Korn, 1939).
} 
La cita es ilustrativa de uno de los sentidos construidos más fuertes que identifican a la ciudad y atraviesan sus relatos publicados. En rigor, su condición ex novo no la hace única: muchas ciudades occidentales en nuestro continente existieron primero en los papeles. Como apunta José Luis Romero, América asistió en el siglo XVI a un "fenómeno homérico" de fundación de "cientos de ciudades en pocas décadas" donde "cada una de ellas se estableció mediante un acto jurídico: cierto día, un notario leía un acta, y a partir de ese momento la ciudad estaba fundada. Quien mirara en el área donde se decía que estaba la ciudad descubriría que todavía era campo y que no había allí más que unos pocos mojones". Sin ir más lejos, la propia Buenos Aires "fue, antes que una ciudad real, un acta y un plano" (Romero, 2009: 56, 299).

Sin embargo, no existen las ciudades al margen de la historia: "si no nos precede, nos toca inventarla" (Bernazza, 2004). Esta tesis indagará entonces esa creación de una historia, esa invención de una tradición que en La Plata parece condensarse en la coyuntura de ciertos aniversarios, y en particular en el centenario. Como asume un urbanista que participó de varias iniciativas editoriales que analizaremos, al prologar la traducción de El cuadrado roto: "el primer centenario de la fundación de La Plata motivó la publicación de diversos trabajos que, como es natural, (respondieron) a diversos propósitos" (Morosi, en Garnier, 1992: 5).

Como se proponía en el Plan de Tesis, estudiaremos qué sentidos se imprimieron sobre el pasado de la ciudad en su centenario, reconociendo allí las marcas de su contexto de producción, de las políticas de memoria de la dictadura y de quienes la resistieron, así como los imaginarios urbanos de los distintos actores en pugna.

3.

“...La Plata es una ciudad, aunque no tenga la existencia orgánica de una ciudad. Improvisada y constituida a expensas de uno de los más poderosos bancos de Sudamérica y producto de una crisis política que amenazaba echar abajo la organización nacional, fue el resultado de un pacto. El banco quebró, pero el problema de la sede federal quedó resuelto" (Martínez Estrada, 1991: 224-226)

En los años 30 el ensayista Ezequiel Martínez Estrada escribió que, más que una Oxford americana, La Plata era Hollywood: una seudo-estructura, una ciudad de decorados (Martínez Estrada, 1991; Terán, 1994) ${ }^{3}$.

Los relatos de algunos de los viajeros que conocieron la ciudad en las primeras décadas confirman que los atributos identitarios de La Plata se fueron transformando, desvaneciendo y reemplazando, y que imaginarios sólidos y compactos como el que enarbola una ciudad universitaria, son producto de la reiteración en el tiempo de una construcción razonada. Es interesante revisar la compilación de Amaral Insiarte (1959), como así también la que Barcia (1982) produce en el contexto del centenario, para aproximarse a ciertas discusiones en torno a la "razón de ser" de La Plata que formaron parte del clima cultural de sus primeras décadas. Después del primer lustro posterior a la fundación, en el que hallamos elogios y admiración por la ciudad progresista que se proyectaba, muchos de esos textos hablan de "otro fracaso después de un esplendor repentino y efímero" (Resasco, 1891, en Barcia, 1982).

\footnotetext{
${ }^{3}$ Entre los libros publicados en torno al centenario, el único que recupera esa expresión de Martínez Estrada es Edad de mi infancia, cuestionando tal analogía por portar "un poco de ese elegante desdén que el porteño -o el provinciano aporteñado en su caso- sintió hacia la ciudad nacida" (Sureda, 1982: 13). En cambio, varios le adjudican al ensayista la expresión ciudad milagro que, como veremos, tiene una genealogía más compleja.
} 
Cabe recordar que la reconocida planificación inicial de la capital bonaerense no incluía un espacio para la academia. Años después de la fundación se creó una Universidad "sin locales propios en la ciudad de los paseos palacios públicos", que inicialmente "conoció, en nueve años, todas las penurias y vivió muriendo" (Arrieta, 1935: 62-63). La nacionalización de la Universidad en 1905 fue una propuesta que asumía la necesidad de rever las razones de ser proyectadas originalmente, para adoptar un "destino de ciudad universitaria", que pudo y puede interpretarse como una "segunda fundación" de La Plata. Luego, algunas operaciones sobre la historia llegarán a explicar el origen y hasta el nombre de la ciudad por su destino académico, y dejarán de lado el costado industrial de la región y la presencia activa de clases populares. Sobre esa "gestión del pasado" en una coyuntura específica, tratará precisamente esta tesis.

4.

\footnotetext{
"El arte de modificar el pasado, cuando es lejano, es una tarea a la que se han dedicado con empeño muchos historiadores; $y$, cuando es reciente, constituye la práctica predilecta de no pocos comunicadores" (Calcagno y Calcagno, 2004: 69)

“...la dictadura nuevamente intenta utilizar el sentimiento genuino de la población para convertir cien años de historia popular en un acto oficialista..." (Folleto elaborado por Familiares, 19-11-82)
}

Como veremos, una parte importante de la bibliografía sobre La Plata publicada en el '82 es encargada y/o financiada por el gobierno, y producida por instituciones que formaron un entramado civil siempre próximo al poder político, incluso con actores individuales en común. Se puede afirmar, en este sentido, que dichos relatos constituyen lo que Ricœur denomina como "una historia 'autorizada', la historia oficial, la historia aprendida y celebrada públicamente" (Ricœur, 2008: 116), esa historia oficial que suele "generar una literatura asfixiante, que se desvive por inscribirse en esa misma historia y sólo se ocupa de ella" (Feiling, citado en Duizeide, 2010: 141). Se trata de una memoria puesta en un plano institucional, donde

"la memorización forzada se halla así enrolada en beneficio de la rememoración de las peripecias de la historia común consideradas como los acontecimientos fundadores de la identidad común. De este modo, se opone el cierre del relato al servicio del cierre identitario de la comunidad. Historia enseñada, historia aprendida, pero también historia celebrada. A la memorización forzada se añaden las conmemoraciones convenidas" (Ricœur, 2008: 116)

Hay que agregar, por otra parte, que el contexto de planificación, producción e impresión de estas publicaciones abarca el período de la última dictadura (1976-1983), cuyas políticas de persecución, represión y censura afectaron las reglas constitutivas de las tareas profesionales o intelectuales (Novaro y Palermo, 2003: 139).

Aunque no sea su objeto específico, este trabajo adscribe a la búsqueda de construir un enfoque político sobre el autodenominado Proceso de Reorganización Nacional, que agregue a su comprensión algo más que el plan económico que buscó instaurar (Canelo, 2008). Trabajos como el de Philip (2006) echan luz acerca de las transformaciones pretendidas sobre lecturas de la historia, que se observan por ejemplo en las conmemoraciones del día del ejército o en los nuevos usos y sentidos de la figura de San Martín producidos en 1978, el 
bicentenario de su nacimiento ${ }^{4}$. En el marco de aquella mirada más abarcadora advertimos que "en los procesos de construcción de legitimación del poder, la resignificación del pasado constituye un recurso clave dado que los distintos actores políticos materializan, a través de una serie de rituales como los homenajes y las conmemoraciones, la reescritura de la historia en función de las demandas políticas del presente" (Philip, 2006).

A su vez, sabemos que las interpretaciones del pasado son siempre "objeto de controversias sociales" (Jelin, 2002a: 6). Por eso, desde un principio prestamos atención a la existencia de contra-relatos, de producción menos visible y circulación más restringida, como así también de discursos que sin confrontar con la "versión oficial" celebrada públicamente, presentan énfasis específicos y se permiten algunas discrepancias.

Esa riqueza de matices, en un corpus de publicaciones más extenso que el mapeado inicialmente, llevó a la decisión de concentrar esta tesis en los textos del centenario, redefiniendo el proyecto primigenio que incluía también las conmemoraciones en el espacio público 5 .

5.

En 1982 o fechas próximas se editaron más de 6000 páginas sobre el pasado de La Plata, si contamos sólo un ejemplar por cada uno de los 54 libros, cuadernos o revistas especiales que forman nuestro objeto de estudio. Son varios millones de páginas si multiplicamos por la tirada de ejemplares de cada edición.

No aludimos sólo a producciones estrictamente presentadas como textos de historia, sino a una serie diversa de relatos que se referencian en el pasado local y cuya escritura y publicación aparece motivada por el contexto del centenario de la ciudad. Esto implica que aquella constatación inicial sobre la historiografía platense -su producción activada por conmemoraciones- definió el tema de interés, pero no el corpus de análisis: éste se completó con otros textos producidos en esa coyuntura y que, si bien a priori no definiríamos como historiografía local, también participan de la disputa por los sentidos del pasado de la ciudad.

En otras palabras, hemos entendido la idea de producción historiográfica con una amplitud semejante a la que plantea Roberto Pittaluga en su trabajo sobre las narraciones de la militancia setentista en Argentina:

"se considera el carácter historiográfico de un texto en tanto remite a una escritura formalmente no ficcional que pretende encontrar, otorgar y/o construir sentido sobre el pasado, suspendiendo las dimensiones epistemológicas inherentes a las formas de realizar dicha práctica [...] Así, se contemplan diferentes modos de construcción narrativa incluyendo por igual a aquellas escrituras académicas como a las producidas fuera de ese campo" (Pittaluga, en Franco y Levín, 2007: 125-126)

Por otra parte, debemos señalar que nuestro interés no está sólo en los textos, sino también en los libros; es decir, en el proceso editorial que convierte la obra "inmaterial" del

\footnotetext{
${ }^{4}$ Otras políticas de memoria de la dictadura fueron la conmemoración del centenario de la Campaña del Desierto (1979) o, en una efeméride de su propia cosecha y referida a la "historia reciente", la recordación del secuestro y asesinato de Pedro Eugenio Aramburu, cuando se cumplieron diez años del hecho, en 1980.

${ }^{5}$ El Plan de Tesis preveía construir el objeto de estudio teniendo en cuenta "dos modos de producción de sentidos sobre el pasado: - las representaciones textualizadas, constituidas por los relatos publicados en la época en cuestión, a los que provisoriamente denominamos historiografía local; y

- las representaciones teatralizadas, es decir, las conmemoraciones que se realizaron en noviembre de 1982 (particularmente el día 19) e implican una 'puesta en escena' en el espacio público de ciertos significantes". Finalmente, la tesis se concentró sobre las publicaciones, ampliando el corpus de dicho análisis.
} 
autor en un objeto en circulación ${ }^{6}$. En ese sentido, varias cuestiones abordadas aquí atravesarán terrenos poco explorados académicamente. La edición de libros, "uno de los momentos más evidentemente sociales de la producción intelectual", es uno de ellos: "En la Argentina, donde hay una profusión de estudios referidos a los intelectuales y a la literatura, son relativamente escasos los estudios que se ocupan de la producción de libros", sintetiza De Sagastizábal (1995: 14, 15). Los trabajos existentes llegan hasta la década del '70, y luego de esa fecha "sólo pueden encontrarse trabajos aislados y fragmentarios" (De Diego, 2006: II).

En términos más específicos, la tesis contribuye a pensar la cuestión editorial en dictadura. Corrientemente este tema ha sido investigado con el foco puesto en la censura y la represión sistemática (Invernizzi y Gociol, 2003), más que en la producción específica de esos años. Como plantea Mangone (2011) es necesario "desmontar algunos lugares comunes que sirvieron de base a numerosos trabajos [...] que opusieron dictadura a cultura", para comprender la época ya no sólo por lo que reprimió, sino también por lo que produjo ${ }^{7}$.

6.

A lo largo de este trabajo, entonces, buscaremos cumplir tres objetivos planteados en el Plan de Tesis, a saber:

$\checkmark$ Realizar un análisis crítico de las representaciones sobre el pasado de la ciudad de La Plata producidas en la coyuntura de su centenario (1982);

$\checkmark$ Proponer un análisis crítico exhaustivo de una parte de la historiografía local;

$\checkmark$ Aportar al conocimiento de las políticas de memoria y los usos del pasado operados por los actores cívico-militares que condujeron el Estado en la época referida, advirtiendo asimismo las expresiones de oposición o resistencia. ${ }^{8}$

La meta no es, claro está, hacer una historia de La Plata, también válida y ciertamente necesaria ${ }^{9}$. Algún día alguien asumirá el desafío de escribir la historia de La Plata más allá de las celebraciones, del anecdotario urbano y los grandes hombres. Hete aquí, por ahora, una historia de la historia de La Plata: de su escritura, sus usos, reciclajes, invenciones y reinvenciones. Y será además una incompleta historia de la historia, ya que nos concentraremos en momento particular de la producción de relatos sobre el pasado, iniciada antes y continuada después.

Se trata de pensar en una escala local el "proceso de 'invención de la tradición" entendida como la redistribución de los datos del pasado que modificaba los 'recuerdos'́ y los

\footnotetext{
${ }^{6}$ Excede a esta tesis el estudio de procesos de recepción y resignificación de las publicaciones del corpus. A tientas plantearemos algunos indicios sobre la circulación. En su mayoría, los libros analizados son poco conocidos, incluso difíciles de obtener en bibliotecas públicas, lo que permite inferir una exigua distribución. Entre las inquietudes que pueden incentivar otras investigaciones, queda abierta la pregunta acerca del público de estos trabajos. No estando contemplada en la educación formal, ¿quiénes y para qué leen historia local?

${ }^{7}$ Por supuesto, eso no implica negar que la dictadura tuvo amplia estrategia de censura y represión, "que implementó un proyecto racional, sistemático, con objetivos definidos, claramente enunciado, centralizado y llevado a la práctica en diversas áreas a lo largo de los años" (Invernizzi y Gociol, 2003: 23), y que por supuesto es parte constituyente del marco que condiciona las iniciativas editoriales que analizaremos.

${ }^{8}$ El proyecto inicial incluía un cuarto objetivo: "Estudiar el uso conmemorativo del espacio público en el caso platense durante la dictadura", que como veremos fue rearticulado en el plan de tesis doctoral.

${ }^{9}$ El desarrollo de una historia social o cultural de la ciudad de La Plata es apenas incipiente. Como sintetiza Vallejo (2005: XI): "Existen numerosos estudios locales que abordan La Plata, aunque en la mayor parte sus perspectivas e instrumentos de análisis aún no han sido alcanzados por la renovación historiográfica de los últimos años. Y existe, a nuestro juicio, una llamativa minimización de la importancia de problemas relacionados con La Plata, como objeto de consideración histórica, en los excelentes trabajos que emblematizan esa renovación historiográfica".
} 
'olvidos' para prestar legitimidad a la realidad presente" (Demasi, 2004: 20). La expresión uso a la que recurren distintos autores (Cuesta, 1993: 59-60; Rousso, 2000: 32; y centralmente en Cattaruzza, 2007) nos resulta sugerente porque implica una agencia activa: "Actores y militantes 'usan' el pasado, colocando en la esfera pública de debate interpretaciones y sentidos del mismo", escribe Jelin (2002: 39). Los usos del pasado, las peleas por la historia -añade Cataruzza- suponen disputas del presente y el futuro en las que intervienen "el Estado, a través de sus funcionarios y sus agencias, los intelectuales, la prensa -desde el boletín barrial hasta los diarios de gran tirada-, los grupos políticos y sociales..." (Cattaruzza, 2007: 16).

Con esa inquietud, además de un análisis endógeno del conjunto de textos que conforman el corpus, la investigación intenta reconstruir las condiciones de elaboración de los principales libros, a partir de entrevistas con autores o colaboradores de las obras en cuestión.

\section{7.}

Sabemos que el concepto de memoria, central en la titulación del grado de maestría al que aspira esta tesis, carga con una polisemia riesgosa -en ocasiones, también, muy productiva- (Badenes, 2010). Usado y abusado, re-usado y rehusado, el término aparece en los discursos de la psicología, la sociología y la historia; también en relación a tecnologías de almacenamiento de información y como bandera de la movilización política que reclama "verdad, justicia y memoria". Desde los estudios sociales sobre la memoria, recurrimos al término para nombrar un proceso activo de elaboración, reelaboración y circulación de sentidos sobre el pasado, en una dimensión colectiva o pública, y por lo tanto socialmente condicionada. En nuestro caso, enfocamos la memoria de un pasado transmitido -que pudo haber existido o no- más que experimentado, y por lo tanto a políticas de memoria más que a procesos de anamnesis o reminiscencias.

Más que una fuente ${ }^{10}$, la memoria emerge aquí como objeto de estudio. Y lo que se estudia no es sólo aquello rememorado sino también "los agentes de elaboración, de transformación y de transmisión, los autores y los transmisores de estos recuerdos" (Valensi, en Cuesta, 1998: 57). Nora (1984) nos da una pauta de la amplitud de este objeto en el primer tomo de su obra, cuando se pregunta: “¿toda gran obra histórica y el género histórico mismo no son acaso una forma de lugar de memoria?". Si pensamos a la historiografía en esos términos, podemos analizarla con categorías y preguntas que suelen usarse en relación a la memoria: lugares, vehículos o depósitos, mediadores, emprendedores o agentes, etcétera. $\mathrm{O}$ como plantea la fenomenología de Ricœur, el qué, el quién y el cómo ${ }^{11}$.

Se trata de comprender de qué manera se construyen sentidos en torno a un pasado: así, efectivamente, entran en el análisis las operaciones de la propia disciplina histórica, y lo que aquel campo de estudios sociales sobre la memoria nombra es una sensibilidad, una nueva

\footnotetext{
${ }^{10}$ Cuando hablamos de la memoria como fuente nos referimos a "la materia prima de la historia" en términos de Jacques Le Goff. Es decir, un recurso que -con el cuidado metodológico necesario- es "útil para reconstruir ciertos datos del pasado a los cuales es imposible acceder a partir de otro tipo de fuentes" (Franco y Levín, 2007: 43). En las entrevistas realizadas, sí, recurrimos a la memoria de los sujetos en esos términos. En ese caso, cabe advertir que las fuentes orales "nos dicen no sólo lo que hizo la gente sino lo que deseaba hacer, lo que creían estar haciendo y lo que ahora piensan que hicieron" (Portelli, 1991: 42).

${ }^{11}$ El filósofo insiste en la necesidad de preguntarse de qué hay recuerdo -en un principio dejando de lado la atribución a alguien- para llegar al quién del acto de acordarse, pasando por el cómo. En términos de Husserl, se trata de la distinción entre el noema -el qué recordado- y la noesis -el acto de acordarse, reflexivo de su quién(Ricœur, 2008: 19-20, 165).
} 
mirada sobre objetos que no son nuevos ni eran desconocidos; en fin, una suerte de historia en segundo grado,

"que se interesa menos por los determinantes que por sus efectos; menos por las acciones memorizadas e incluso conmemoradas que por el rastro de estas acciones y por el juego de estas conmemoraciones; que se interesa menos por los acontecimientos en sí mismos que por su construcción en el tiempo, por su desaparición y por el surgir de sus significaciones; menos por el pasado como ha acontecido que por su reutilización, sus malos usos, su impronta sobre los sucesivos presentes; menos por la tradición que por la manera en la que ha sido formulada y transmitida [...] Una historia que no se interesa por la memoria como recuerdo, sino como economía general del pasado en el presente" (Nora, en Cuesta, 1998: 25-26).

Avanzaremos en esa "historia social de la historia" que sería el análisis de un "trabajo de encuadramiento de la memoria" (Pollak, 2006: 41). Por eso las preguntas no apuntan sólo al qué (qué se recuerda, qué se olvida, qué se silencia), sino también a quiénes, dónde, cómo...

8.

Al igual que el punto de partida, los caminos de esta investigación tampoco encuentran correlato en manuales normativos de metodología. Con ciertas intuiciones y un manojo de preguntas como guía, se desplegó una estrategia plural de construcción y análisis de la información, como se verá a lo largo de la tesis. Por la particularidad de su objeto, un aporte significativo ha sido reunir el material que conforma el corpus estudiado. Ninguna biblioteca o archivo posee la totalidad -ni la mayoría- de los libros y revistas trabajados aquí. La Sala La Plata de la Biblioteca Pública de la Universidad, el Museo y Archivo Dardo Rocha y la Biblioteca Municipal "Francisco López Merino", son acervos importantes, pero lejos están de completar el mapa. Muchos libros fueron obtenidos tras insistentes visitas a librerías de viejo, en los años que maduró esta tesis -en ese punto, el paso del tiempo fue positivo-. Otros aparecieron en la exploración curiosa de bibliotecas populares. Las conversaciones también hicieron lo suyo, incluso en archivos oficiales, donde la confianza construida hizo aparecer papeles que un par de meses antes -ante la consulta del mismo investigador- no existían. En trabajos así, el oficio de investigador nos vuelve cazadores-recolectores, y lo que en contextos con una cultura de la información más desarrollada implicaría unas horas consultando catálogos, se convierte en un trabajo extendido en el tiempo que vale por sí mismo, más allá del análisis.

De todos los textos trabajados -incluso de varios que quedaron fuera del corpus- se produjeron fichas que incluyen datos descriptivos del soporte material, síntesis del contenido y citas significativas en torno a temas que, en el proceso de investigación, fueron identificándose como ejes de problematización cualitativos. De esa labor resultaron más de 500 páginas leídas una y otra vez durante el proceso de análisis y escritura. También se generaron otros insumos, como una base de datos de autores, compiladores y colaboradores de los distintos libros que permitió visualizar cabalmente los cruces personales entre obras, que presentaré en el capítulo IV.

La dimensión que adquirió el "desfile editorial" del centenario relegó a un segundo plano la estrategia de acceso a fuentes orales -autores o editores de las distintas obrasimaginada y en parte concretada durante una primera etapa. Asimismo, algunas personas conectadas eludieron la posibilidad de colaborar con la investigación. No obstante se realizaron seis entrevistas que ampliaron el conocimiento sobre las condiciones de producción 
de algunos de los principales libros y permitieron indagar sobre ciertas decisiones editoriales. También plantearon aspectos significativos sobre la circulación que, sin ser el foco de análisis de las tesis, complementan el panorama y habilitan nuevas reflexiones. Así, por ejemplo, una participante del equipo que preparó el libro coeditado por la UNLP y el Instituto de Estudios de Administración Local de Madrid, que salió a la luz poco antes del regreso de la democracia (Morosi, 1983), recordó que ese volumen tenía un prefacio firmado por el rector de la dictadura, y que esa página fue recortada en cada ejemplar, uno por uno, antes de la visita de los colegas españoles ${ }^{12}$. Advertido de esa situación pude comprobar que los tres ejemplares del libro catalogados en la sala especializada de la Biblioteca Central de la Universidad tienen ese corte sutil que elimina las páginas 5 y 6 . Un dato anecdótico pero ilustrativo de cómo los contextos -que son cambiantes- condicionan la producción y circulación de las publicaciones.

9.

Más allá de los objetivos de análisis y comprensión de la tesis, es probable que una de las contribuciones de la investigación realizada sea ese obstinado trabajo de archivo, que implicó la exploración de bibliotecas públicas, populares y personales, y muchas visitas a librerías de usados durante cinco años. Eso mismo da a nuestro corpus de análisis un carácter singular que condiciona la escritura: es prácticamente imposible que el lector conozca todos los libros citados, incluso que tenga la posibilidad de acceder a ellos, salvo que repita las mismas derivas con idéntica suerte. Escribir sobre "las publicaciones del centenario", entonces, no es equivalente a hacerlo sobre la obra de un escritor conocido o cierta colección de una revista. Ante el previsible desconocimiento de buena parte de mi material empírico y su ausencia en los anaqueles de las bibliotecas, creí conveniente no escatimar el recurso de la cita. Así, la tesis estará plagada de ejemplos que quizás tensionan los límites del derecho de cita y que por otra parte alargan su extensión en páginas.

La autoría del trabajo, en tanto, está comprometida desde antes, por la propia convicción de que toda investigación -aun la más solitaria- es producto de una inteligencia colectiva. Uno siempre piensa con otros. De eso dan cuenta las dos páginas finales de este documento. Por eso mismo, otra decisión en la escritura fue rechazar una regla única para emplear la primera persona en singular o en plural. Recurriré al "nosotros" cuando refiera a reflexiones claramente compartidas con otros o cuando la referencia incluya al lector -por el recorrido ya realizado-, y preferiré el "yo" cuando se trate de asumir un argumento nuevo o sugerir una hipótesis más "personal”.

10.

Sólo resta presentar el camino a recorrer. En el siguiente capítulo revisaremos el panorama de los 54 documentos recopilados: libros, folletos y algunas ediciones especiales de revistas, todos producidos en torno al centenario platense, desde un ciclo de charlas iniciado en 1978 hasta las publicaciones demoradas que vieron la luz el año siguiente de la conmemoración. A continuación pensaremos algunas regularidades de esos textos, cuyos

\footnotetext{
${ }^{12}$ Dicha presentación era un sólo párrafo, puramente formal, que hablaba del impulso de la Universidad y de un “justiciero homenaje a La Plata". En rigor, no tenía definiciones políticas comprometedoras: lo condicionante era el nombre de Guillermo G. Gallo, un emblema de la época dictatorial en la universidad y vinculado a delitos de lesa humanidad (Miguel, 2007). Quitar la página 5 implicó excluir también el texto inicial de la otra institución coeditora, firmado por Luciano Parejo Alfonso, director del Instituto de Estudios de Administración Local.
} 
objetivos mixturan la indagación histórica con escrituras celebratorias y testimonios personales. Analizaremos también las fuentes utilizadas y las formas institucionales de validación de esos relatos locales, a los que creo conveniente pensar en una frontera tensa entre historia y memoria, según las caracterizaciones típicas de esa dicotomía. El capítulo IV refiere a los autores. Advertiremos la presencia de voces reiterativas y de un entramado de vinculaciones entre unos y otros que relaciona a los principales libros a un círculo social muy pequeño que se legitima en relación a un "linaje" producido en los propios relatos.

En los capítulos siguientes analizaremos las disputas y los consensos sobre el pasado platense a partir de algunos ejes problemáticos que atraviesan a la mayor parte de las publicaciones: las ideas sobre el trazado como lugar común de reconocimiento de la ciudad, que se asocia a la reivindicación ideológica de la llamada generación del 80, y la construcción de un imaginario sobre la ciudad cultural y universitaria, con sus propios héroes y mitos de origen. Finalmente, veremos cómo el pasado es usado para instalar la idea de la "unidad nacional" y el "reencuentro de los argentinos", en un proceso donde también emergen voces disidentes, que evidencian la imposibilidad -advertida por Jelin- de "encontrar una memoria, una visión y una interpretación únicas del pasado, compartidas por toda una sociedad [...] Siempre habrá otras historias, otras memorias e interpretaciones alternativas, en la resistencia..." (Jelin, 2002a: 5-6). 


\title{
II. El desfile editorial \\ Libros, revistas y folletos del centenario platense
}

\author{
“...es necesario recordar que una lectura del pasado, por más \\ controlada que esté por el análisis de los documentos, siempre está \\ guiada por una lectura del presente. Una y otra se organizan, en \\ efecto, en función de problemáticas impuestas por una situación [...] \\ es imposible analizar el discurso histórico independientemente de la \\ institución en función de la cual se ha organizado su silencio..."
}

(De Certeau, 1993: 77)

La Plata, 19 de noviembre de 1982. El sol se hace sentir en la Plaza Italia a la hora de inicio de la concentración cívica. Cerca de las seis de la tarde las autoridades -entre ellas el dictador Reynaldo Bignone- toman ubicación en los palcos oficiales, acompañados por una marcha de honor realizada por la Banda del Regimiento $7^{\circ}$. También están presentes las bandas musicales de la Marina, la Policía y el Servicio Penitenciario.

A seis cuadras, tras la autorización solicitada por el mejor alumno -el estudiante con mejor promedio de notas- de las escuelas primarias de la ciudad, comienza el desfile cívico. En la plaza central espera una torta inmensa de 400 metros cuadrados que imita la traza del casco urbano, donada para la celebración por los propietarios de panaderías -Más tarde, a la hora de cortarla, la escena se volverá una batalla campal.

El desfile empieza a marchar por la diagonal 74, desde la Plaza Italia. Al abanderado, sus escoltas y las delegaciones escolares los siguen el Escuadrón Cóndor de la Policía provincial y los Bomberos Voluntarios de Berisso y Ensenada. Detrás vienen las asociaciones de fomento, algunos clubes -hípicos, de patín y otros-, colectividades extranjeras, y grupos de scouts y exploradores. Más atrás marchan las universidades -primero la Católica, luego la Nacional-, seguidas por la Federación Gaucha Bonaerense, la Agrupación Nativista El Alero y finalmente algunas peñas y centros tradicionalistas.

Un grupo de familiares de desaparecidos y algunos ex presos políticos consiguen entrar en la procesión, delante de las universidades. Las madres se colocan sus pañuelos. Entre los asistentes surgen aplausos y algunos gritos de adhesión. Cuando llegan a la plaza Moreno no pueden pasar; el desfile ordenado se trunca y nunca termina.

\section{Una procesión de libros}

La escena es sugerente a la hora de pensar la política local en dictadura y su dinámica de producción de consensos y resistencias. Los grupos que transitan la diagonal 74 esa tarde son, en gran medida, los actores de la política local en tiempos de clausura de la política en términos clásicos. Clubes deportivos, sociedades de fomento, agrupamientos profesionales, colectividades extranjeras, asociaciones tradicionalistas y entidades filantrópicas: ellos constituyen las "fuerzas vivas" a las que interpelaba el discurso municipalista y cuya trayectoria permite dar cuenta de "la producción de consenso y legitimación en estos niveles del gobierno de la dictadura militar" (González Bombal, 1988: 105).

La coyuntura del centenario provoca un desfile similar en el mundo editorial. Todos publican, uno detrás de otro. El relato oficial encuentra eco en algunos sectores universitarios, en colegios profesionales y en vecinos caracterizados que forman parte de aquellos clubes, entidades filantrópicas y organizaciones tradicionalistas. Faltan, igualmente, los partidos y los 
sindicatos. Y el movimiento de derechos humanos es el que tácticamente logra colocar una voz alternativa, disidente.

En este capítulo trazaremos un panorama de esas múltiples publicaciones que analizaremos a lo largo de la tesis. Como ya vimos, el corpus se formó inicialmente con libros fechados en 1982 que proponían aproximaciones a la historia de La Plata -sea en un registro académico o como "crónicas" y escritos más testimoniales- y luego se agregaron otros que, al compartir autores o sellos, forman parte del mismo contexto editorial. Tras esa ampliación del foco quedaron incorporados libros con inscripciones específicas que catalogan su iniciativa "en homenaje al centenario de La Plata". Además tendremos en cuenta algunas revistas -generalmente ediciones especiales-, cuadernillos -que llevan al medio impreso algunas conferencias de la época- y folletos que, sin ser estrictamente libros, forman parte del panorama editorial de la época, y compartieron impulsores, autores, referencias y fuentes de financiamiento con los libros del centenario ${ }^{13}$.

Este pantallazo no se limita a títulos y síntesis de contenidos. Interesa señalar también algunas características materiales de los soportes impresos y, cuando fue posible obtener información al respecto, datos acerca de las tiradas y la circulación. En ese sentido, más allá de la identificación de autores - de quienes analizaremos algunas trayectorias en el capítulo IV - nos ocuparemos también de los editores y organizaciones que impulsaron cada iniciativa. Como advierte Roger Chartier, los autores no escriben libros: "escriben textos que otros transforman en objetos impresos. La separación, que es justamente el espacio en el cual se construye el sentido (o los sentidos) fue olvidada muy a menudo, no sólo por la historia literaria clásica, que piensa la obra en sí misma, como un texto abstracto cuyas formas tipográficas no importan" (Chartier: 1996: 55). "Son los editores quienes los transforman en libros" y eso supone "un proceso de intermediación que no es, de ningún modo, neutro" (De Sagastizábal, 1995: 20), y que no podemos dejar de lado. Como veremos, más allá de algunos emprendimientos particulares, las iniciativas editoriales corresponden a actores sociales significativos: los gobiernos provincial y municipal, la universidad, el diario local tradicional, ciertas corporaciones profesionales y empresas del rubro financiero. Sería entonces un error reducir la mirada sobre las publicaciones a un análisis meramente discursivo: "La memoria como construcción social narrativa implica el estudio de las propiedades de quien narra" pues, siguiendo a Pierre Bourdieu, "la eficacia del discurso performativo es proporcional a la autoridad de quien lo enuncia" (Jelin, 2002a: 35).

\section{Iniciativas gubernamentales}

Si bien se concentran en 1982, las publicaciones sobre La Plata realizadas en torno a su centenario aparecieron desde algunos años antes y en algunos casos se extendieron hasta tiempo después, por demoras en la edición o impresión de libros que no obstante están claramente inspirados por la "fecha redonda"

\footnotetext{
${ }^{13}$ Estas inclusiones, decididas en transcurso del proceso de investigación, implicaron una ampliación del corpus definido tentativamente cuatro años atrás. De los 20 libros previstos en el Plan de Tesis, se retiraron dos que no tenían vinculación directa con el centenario (Laborde, 1979; Seigel, 1980), y se incorporaron 13 libros, 5 revistas y 18 folletos, alcanzando un total de 54 documentos analizados.

${ }_{14}$ Atenderé a las publicaciones posteriores sólo hasta 1983, fecha en que salieron libros proyectados para el año del centenario que se demoraron, y que comprende al mismo período en términos de historia política. Ciertamente, podría afirmar que hay otras ediciones posteriores "inspiradas" por el Centenario, como ocurre con el libro del suizo Alain Garnier, cuya versión en español se publicó en La Plata en 1992, por iniciativa del
} 
Las primeras iniciativas fueron estatales y corresponden al Museo y Archivo Dardo Rocha, que organizó una serie de conferencias luego publicadas en folletos de distribución gratuita que suelen ser citados como libros. Al escudriñar las referencias bibliográficas de textos actuales o revisar listados y catálogos de bibliotecas platenses, es común encontrar publicaciones adjudicadas a la Subsecretaría de Cultura o el Ministerio de Educación bonarenses, órganos de los que el Museo dependió hasta su trasferencia al ámbito municipal en diciembre de 1980. Según pude relevar, la institución realizó publicaciones desde 1954, pero se registran muy pocos títulos -apenas cuatro- hasta 1978, cuando la producción se multiplica. Justamente ese año comienza el ciclo de charlas titulado "Cien años de La Plata. Sus realizaciones, su cultura y su gente” (en adelante, Ciclo Cien años), que tuvo continuidad entre 1978 y $1982^{15}$.

La primera conferencia del ciclo fue el 14 de julio de 1978: José María Prado, miembro de la Asociación de Amigos del Museo y Archivo Dardo Rocha creada poco antes ${ }^{16}$, disertó sobre "Dardo Rocha y Pedro Benoit: el fundador y el artífice de la fundación de la nueva capital”. Enrique Barba, en su carácter de presidente de la Academia Nacional de la Historia, fue invitado a presentar el ciclo que -según auguraba- "despertará gran interés y logrará alta significación"; y certificó "la calidad de los elegidos" para llevarlo a cabo (Barba, en Prado, 1978: 7) ${ }^{17}$. El Ciclo Cien años finalizó en octubre de 1982 en la Caja de la Ingeniería, con una disertación del ingeniero civil y urbanista José Bonilla "sobre el Mensaje y la misión que corresponde cumplir a la generación platense de este centenario". A Prado, el primer conferencista, le tocó en esa ocasión el papel de presentador ${ }^{18}$.

Según detalla la directora del Museo y Archivo en una de las publicaciones de la época, en este ciclo "preparatorio" se trataron "variados aspectos de la ciudad (urbanismo, historia, personajes, teatro, poesía, música, periodismo, instituciones, etc.)" (en Lerange, 1982: 73). En ese marco se elaboraron los textos de Morosi (1978), De Santis (1980), Kilmurray (1980), D’Onofrio (1980), Lahitte (1980), De Gandía (1980), Barba (1980), Moreno Terrero de Benites (1981), Ceriale Costa de Apreda (s/f), Orsi de Herrero Ducloux (1981), Daneri de Rodrigo (1981) y Massimino (1981). También se origina en ese marco el texto de Bernard (1982b) publicado por la Universidad Notarial Argentina, de la que era rector. Su conferencia

arquitecto Julio A. Morosi en un instituto de la Comisión de Investigaciones Científicas de la Provincia de Buenos Aires. La edición en francés, realizada por el Instituto de Investigaciones del Ambiente Construido del Departamento de Arquitectura de la Escuela Politécnica Federal de Lausana, data de 1989 y confirma aquella motivación: "Es necesario reconocer que tras el centenario de la ciudad, celebrado con gran pompa en 1982, una nueva inspiración se ha apoderado de la elite intelectual local. Ahora corresponde a la misma transmitir el mensaje platense a la población”, escribe Garnier (1992: 126)

${ }^{15}$ Una empleada del Museo y Archivo de aquella época aseguró que se hicieron "muchas" conferencias, y que todas o casi todas fueron editadas por el Ministerio, pero no existe una lista sistematizada de la totalidad de las charlas, y los folletos producidos a partir de las mismas no están catalogados en la biblioteca de la institución. Luego accedí a una recopilación realizada por la bibliotecaria del Museo, Silvia Graciela Fajardo, a partir de la cual logré una reconstrucción bastante certera de los temas e invitados del ciclo.

${ }^{16}$ Esta institución fue creada en diciembre de 1976, en una reunión en la que estuvieron presentes Enrique Barba, Francisco Omar Caíno, Eduardo Díaz, Ricardo Pérez Tiribelli, José María Prado, Atanasio Apreda, Patricia Alconada, Nancy T. de Pérez Tiribelli, Eduardo Simonetti, Ana Bond Rocha, María Florencia Apreda de Di Masi, Hebe Rey, Alicia Dupuy, Ana Emilia Lahitte y Haydée Villar de Valsecchi.

${ }^{17}$ En su intervención inicial, Barba insistió en que fue invitado en su "carácter de Presidente de la Academia", pero supone "que también se habrá pensado al hacerlo que soy platense, nacido en esta ciudad hace muchos años de cuyo aumento demográfico, transformación política y desarrollo cultural he sido testigo y en alguna manera protagonista", por lo que repasó algunos recuerdos lejanos de la ciudad, para luego dar "lugar al Sr. Prado que de esto sabe más que yo; de esto y de muchas otras cosas" (Barba, en Prado, 1978: 8)

18 “Quedó clausurado el ciclo Cien años de La Plata”, El Día, 1 de noviembre de 1982, página 8. 
fue el 21 de mayo de 1982 y el rol de presentador lo ocupó el intendente Abel Blas Román, cuyas palabras también se transcriben en el mismo libro-folleto.

En el capítulo IV analizaremos la preeminencia de algunos autores, que son presentados con una legitimidad sobresaliente o participan de varias iniciativas editoriales. Por ahora cabe señalar que de los catorce conferencistas mencionados, ocho participan de uno de los libros "monumentales" publicados en el centenario: La Plata, ciudad milagro (de ahora en más, Ciudad milagro), una co-producción del gobierno bonaerense y la Sociedad de Escritores de la Provincia ${ }^{19}$, que fue coordinada por la titular de esta última, Catalina Lerange, y contó con la participación de un centenar de autores. De hecho, en los casos de De Santis y Kilmurray el aporte al libro colectivo es la transcripción textual de sus charlas en el Ciclo Cien años, ya publicadas en 1980. No son los únicos capítulos de Ciudad milagro que tienen una difusión duplicada: el artículo inicial de Tomás Bernard fue editado además en forma independiente por la Universidad Notarial Argentina (Bernard, 1982a), el del médico Federico Christmann es un extracto de un libro publicado también en homenaje al centenario (Christmann, 1982); en tanto los capítulos de María Cristina Della Croce sobre la vida religiosa local y la institución Cáritas se definen como una síntesis de un libro publicado cuatro años antes en homenaje a las bodas de plata episcopales del arzobispo Antonio Plaza (Sánchez Márquez, $1978)^{20}$. A esto se agrega la coincidencia de autores e instituciones con otras iniciativas editoriales de la época, que analizaremos más adelante.

Ciudad milagro es un libro mayúsculo, el más extenso de los publicados en el centenario: consta de casi 100 artículos $^{21}$, catorce de los cuales están escritos por directivos de la SEP, la entidad que impulsa esta edición consignada como un "Homenaje de la Sociedad de Escritores de la Provincia de Buenos Aires a la Ciudad de La Plata en su Centenario". Formalmente es una edición de Corregidor, y tiene un notorio auspicio del Gobierno de la Provincia de Buenos Aires: la primera página del libro señala esa condición, y a continuación transcribe la nómina de 13 autoridades -gobernador, ministros, fiscal de Estado y algunos secretarios $^{22}$-, todo ello antes de los datos de autoría del libro.

La dirección de la edición está a cargo de Catalina Lerange -presidente de la SEP, mencionada en varios capítulos ${ }^{23}$-, secundada por dos coordinadoras -Patricia Coto y Lilia

\footnotetext{
${ }^{19}$ Según su web actual, la SEP fue creada "con sentido social, cultural y gremial” en 1946, "merced a un grupo de bohemios y soñadores que entendieron la importancia de darle al Escritor la representatividad social como educador, pensador y labriego de la palabra”. Varios de sus socios fundadores, como Tomás Diego Bernard y Ana Emilia Lahitte, escriben en la coyuntura que estamos analizando. La misma fuente señala: "dentro de esos imperecederos hitos culturales se encuentra la publicación de 'La Plata, Ciudad Milagro', que bajo la presidencia e iniciativa, recopilación y dirección de la Prof. Catalina Lerange, alcanzó condigna repercusión, por la notable pléyade de autores allí convocados para evocar la vida social y cultural de nuestra ciudad...”.

${ }^{20}$ Inicialmente el texto apareció por entregas en el Boletín de la Arquidiócesis de La Plata, desde julio-agosto de 1976. En tanto, el capítulo sobre la Policía de la Provincia de Buenos Aires en la Ciudad de La Plata -circunscripto a su origen y centrado en el repaso de datos normativos, edilicios y de dotación de personal- está escrito por el oficial Vicente David Borda Carrera, integrante de la "Comisión Permanente de Asuntos Históricos de la Policía de Buenos Aires", que el año anterior había publicado la Síntesis histórica de la Policía de la Provincia de Buenos Aires 1580-1980 (Richeri y otros, 1981).

${ }^{21} \mathrm{Si}$ se cuentan presentaciones y prólogos, son exactamente 100 textos. Teniendo en cuenta que algunos tienen dos autores, y en especial si se contabiliza la parte final donde se transcriben entrevistas a 19 jóvenes, el libro involucra a más de un centenar de personas.

${ }^{22}$ Es interesante notar que el único militar de esa lista es un coronel retirado que oficia de Secretario de Inteligencia y Comunicaciones.

${ }^{23}$ Esto ocurre pese a una simulada humildad que presenta como seña de "objetividad" de la edición: en el capítulo sobre La ciudad y sus poetas, una nota de la edición afirma: "A solicitud de Catalina Lerange, que tuvo a su cargo la dirección del presente volumen, se ha retirado, por razones fáciles de comprender, el comentario
} 
Guzmán- y varios colaboradores. En la presentación firmada en septiembre de 1982, Lerange remite el origen de la idea a 1977:

“...Julio Anselmino Rica, miembro de la Comisión Directiva de la Sociedad de Escritores de la Provincia de Buenos Aires, propuso que la entidad publicara un libro en torno de la ciudad de La Plata, le respondimos: 'La idea es excelente. Pero nos atrevemos a agregar: en su próximo centenario' $[\ldots]$

A través de los medios de comunicación, invitamos a la ciudadanía a hacer llegar al organismo todos aquellos documentos que fueran considerados realmente de importancia. Constituimos una muy numerosa como calificada Comisión Pro-Libro del Centenario de la Ciudad de La Plata y efectivizamos gestiones de práctica en el Registro de la Propiedad Intelectual" (Lerange, 1982: 11)

La voluminosa obra, que contiene textos de extensiones disímiles y distintos estilos de escritura, trata de "consignar los temas mayores que confieren a nuestra ciudad su particular perfil, acentuado con el contexto de temas menores también contemplados, en el pensamiento de que la 'personalidad' de una ciudad, su idiosincrasia, se conforma -al igual que un prisma-, tanto de sus grandes como de sus pequeñas caras y aristas" (Lerange, 1982: 12). El libro concluye con un apartado titulado "JUVENTUD '82", que contiene 19 entrevistas breves a "hombres y mujeres, representantes de la juventud del último tramo del siglo XX" que contestan dos preguntas: “¿Qué crees haber recibido de tu ciudad? ¿Qué piensas devolverle a ella?" (en Lerange, 1982: 665). A lo largo de la tesis estudiaremos el contenido de esos capítulos en torno a algunos ejes que hacen a la disputa de sentidos sobre el pasado de la llamada "ciudad milagro" 24 .

A propósito de ese título corresponde hacer una observación. Tanto la presentación de Lerange como el capítulo escrito por Morosi ${ }^{25}$ adjudican esa expresión a Martínez Estrada, citando de modo incompleto un fragmento de su Radiografía de la Pampa:

“...Con la concreción de La Plata, Ciudad Milagro, según llamaba a nuestra ciudad Ezequiel Martínez Estada [sic] 'no por la rapidez en que se alzó ni por los edificios magníficos que se levantaron, sino porque como los milagros, va contra las leyes naturales y tienen su realidad en la fe'..." (Lerange, 1982: 12)

En rigor, la expresión fue acuñada por el dirigente político Carlos Pellegrini -presidente argentino entre 1890 y 1892-, tal como reconocía el propio Martínez Estrada en 1933:

“...(La Plata) creció de golpe y luego hubo que llenarla, que sostenerla, que vivirla. La vida le vino por añadidura. Sin misión social, étnica, económica por cumplir, era una creación de orden político que habría que llevar una existencia metafísica. Ciudad milagro, la llamaba Pellegrini, el ingeniero jurídico de puentes económicos. Es la

que, a juicio de sus autores, merece su labor poética. Igual temperamento se aplicó en el resto del libro a otras referencias dirigidas a su persona, a su actuación profesional o a su obra literaria. Únicamente fue aceptada la mención de su nombre en los casos en que, a los efectos de preservar alguna forma de connotación cronológica, ello se ha considerado inevitable" (Lerange, 1982: 123). El nombre reaparece en la reseña sobre escuelas de La Plata, en relación al Instituto 'Carlos N. Vergara': "En 1968 asume la Dirección del Instituto, la profesora Catalina Lerange, hasta setiembre de 1981, cuando (es) requerida para cumplir otras funciones en el ministerio de Educación de la Provincia de Buenos Aires" (Coto y Guzmán, en Lerange, 1982: 351). Luego la directora del volumen es mencionada entre los escritores que participaron de la sección Prosa y verso del diario El Día (Lerange, 1982: 387-388) y, finalmente, el autor del capítulo sobre la bohemia platense, explicita parte de la cocina editorial: "Y para terminar -hay que hacerlo por la simpática dictadora telefónica que es mi talentosa amiga Catalina Lerange, inteligente y ecléctica, que sugirió el tema- ..." (Curuchaga, en Lerange, 1982: 632) ${ }^{24}$ Ese sentido de lo sobrenatural, de la intervención divina, aparece también en Rastros y rostros: "De relatos amarrados al asombro (cuando el asombro era posible) recupero los primeros días de la ciudad, su hospitalario silencio, su inicio de milagro..." (Calvo, 1982: s/n). La autora también participa del volumen de la SEP.

${ }^{25}$ Morosi repite la referencia en otra publicación de la época, de la que es director (Morosi, 1983: 39, 149 y 157). 
ciudad milagro, no por la rapidez con que se alzó ni por los edificios magníficos que se levantaron, sino porque, como los milagros, va contra las leyes naturales y tiene su realidad en la fe..."

No he podido precisar de cuándo data exactamente la afirmación de Pellegrini, que quizá tampoco sea quien acuñó la expresión ${ }^{26}$. Lo que queda claro es que no es una invención de Martínez Estrada. Eso es, sin embargo, lo que los autores citan del ensayista, que en el mismo texto afirmaba que La Plata "no tiene existencia orgánica de ciudad" y la consignaba como "el barrio más apartado de Buenos Aires" (Martínez Estrada, 1991: 224-226).

Entre el centenar de artículos de Ciudad milagro hay referencias al momento de la fundación, sus protagonistas políticos y la acción profesional en la creación de la ciudad; textos sobre algunos edificios y sobre la vegetación platense; evocaciones sobre la vida y obra de Dardo Rocha; algunas notas nostálgicas sobre el pasado urbano -en torno al tranvía, los viejos almacenes, etcétera-; reseñas históricas sobre el desarrollo de las artes plásticas, las "artes del fuego", los coros y la producción musical, el cine, el teatro -con varios capítulos-, la poesía y de modo sobresaliente la obra de Almafuerte. Hay ciertos artículos cuya inclusión no se explica con la intención de construir una historia de la ciudad: "La Cirugía Plástica", por ejemplo, no incluye absolutamente ninguna referencia a La Plata.

Asimismo, la compilación contiene una cantidad importante de textos sobre la institucionalidad platense: establecimientos educativos, culturales, científicos y universitarios; los medios de comunicación y en especial el diario El Día; la Iglesia católica y Cáritas; el Poder Judicial; la Dirección de Impresiones del Estado; la Policía provincial, la Escuela Naval Militar, el Liceo Naval y el Regimiento $7^{\circ}$ de Infantería; también la agrupación Bases, la propia Sociedad de Escritores de la Provincia, el Círculo de Periodistas, el Jockey Club; el Instituto Platense de Cultura Hispánica; el Centro Oncológico de Excelencia; la Asociación Pro Amparo y Defensa del Animal (APADA); el Club Social La Plata (antecedente de Estudiantes) y el Club Universitario.

Dos firmantes de capítulos contenidos en Ciudad milagro, Miguel Blas Szelagowski y Carlos Moncaut, son a su vez los autores de dos publicaciones que llevan el sello de la Municipalidad de La Plata.

Ex intendente radical, Szelagowski fue el encargado de la crónica oficial, una publicación que no trascendió como "el libro del centenario" sino que fue concebida para registrar la conmemoración y ser depositada en la plaza central, junto con nuevos objetos que serian desenterrados cien años más tarde ${ }^{27}$. Es muy sugerente la noticia de su designación:

“[...] Abogado, político, hombre de letras, un testimoniador según sus palabras, tendrá a su cargo la tarea ardua y fascinante de dejar constancia de los pormenores de este acontecimiento. La determinación del intendente Dr. Abel B. Román de nombrar cronista oficial revive una costumbre heredada de España. Fue Fernando el Católico quien instituyó el «Padrón Real» para que se registraran todas las noticias y descubrimientos de estas tierras, con el propósito de «conocer con la mayor precisión y verdad que se pueda». En nuestro país el último gran cronista fue Sarmiento. Según parece desde entonces la tarea perdió individualidad, «se masificó» dijo el cronista del centenario de nuestra ciudad $[\ldots]^{, 28}$.

\footnotetext{
${ }^{26}$ En 1885-1886, De Corvetto escribía: "He aquí una ciudad, La Plata, cuya historia participa del milagro...” (en Barcia, 1982: 73).

${ }^{27}$ Además de los ejemplares para repartir, se imprimieron 5 ejemplares en pergamino vegetal genuino: uno destinado a la redoma y otro al Museo y Archivo. No se explicitó el destino de los otros tres.

28 "Miguel Szelagowski, el hombre que narrará el centenario platense”, El Día, 2 de noviembre de 1982, pág. 7.
} 
La Crónica del centenario es un documento de 46 páginas, de un tamaño inhabitual (33,5 x 22 centímetros), impresas a simple faz y señaladas con números romanos. En la portada sólo figuran título, sello editorial y año, más la imagen pequeña del trazado de la ciudad convertido en símbolo, que como veremos es un recurso reiterado en varios de los libros. En la primera portada interior aparecen los mismos elementos y el nombre de Szelagowski, señalado como "cronista".

La publicación tiene dos partes: la primera es la "crónica" y la segunda es una suerte de anexo documental que incluye los nombres de las autoridades municipales ${ }^{29}$, la nómina de los presentes en la iniciación de las obras de exhumación de la piedra fundamental y la de quienes intervinieron en esas tareas, el decreto de designación del cronista (y más adelante sus antecedentes), la lista de quienes trabajaron en su impresión, la nómina de mensajes que se incluyen en la redoma del año 1982 y la de 232 medallas destinadas a la urna del centenario.

El texto narrativo, en tanto, abarca un relato histórico clásico al inicio, y luego la crónica de la exhumación -en la que se constata el extravío del acta fundacional, "la pieza más importante de este juego histórico" 30 - y de actos centrales del centenario, que llegan hasta diciembre. El autor no oculta ciertos momentos discordantes con el festejo oficial del 19 de noviembre, como "episodios de protesta política consistentes en gritos, despliegue de carteles y volantes arrojados" durante el Tedéum matutino, o la "batalla campal con algunos contusos y trajes y caras llenos de merengue y de dulce de leche" que se produjo a la hora de repartir la torta gigante preparada en la Plaza Moreno.

Szelagowski asume "la responsabilidad de ser vocero para cien años" y le da un tono personal a las crónicas: "Estoy seguro que entre las críticas que se formularán -iy vaya si las habrá!- estará la de los 'solemnes' por algún párrafo donde el humor pudo colarse...", advierte (Szelagowski, 1982b: I). Al cierre del libro destaca el honor que implicó hacer este relato y sostiene que escribió cada palabra "con el pensamiento puesto en ese platense ideal que quisiera interpretar, haciéndolo partícipe del relato” (Szelagowski, 1982b: XXX).

La crónica está enunciada en tiempo real: no hay una narración a posteriori que sintetice, sino un día a día, con una descripción minuciosa de algunos pasos del proceso de exhumación. Incluso intenta, con dificultades, contar sensaciones del momento:

“...curiosidad, el respeto, la emoción, tanto propios como de los demás intervinientes en este apasionante momento, más difícil resulta testimoniarlo por escrito" (Szelagowski, 1982b: XI)

\footnotetext{
${ }^{29}$ Intendente, secretarios, subsecretarios y el presidente del Banco Municipal. Ninguno tiene grado militar.

${ }^{30}$ En la fundación, el 19 de noviembre de 1882, habían sido enterrados en el centro de la ciudad una serie de objetos y documentos, con la consigna de que fueran redescubiertos cien años después. Tal procedimiento se realizó efectivamente en 1982, pero descubrió el material parcialmente arruinado por una filtración de agua, y el faltante de algunos elementos que se esperaba encontrar, entre ellos el acta fundacional. Popularmente se habló también de la desaparición de medallas y botellas de bebidas finas (La expectativa acerca de las botellas de Chateau Cordero que contendría la urna están plasmadas en Soler, 1982: 15). Algunas hipótesis posteriores sobre lo sucedido refieren a la interna entre Roca y Rocha, y señalan que luego del acto de fundación habría habido una profanación y un acto de hechicería (Reynal, 1998). El contenido del documento extraviado no se conoce con fidelidad, ya que existen cinco versiones distintas. Salvadores (1934) las analizó con minuciosidad tempranamente. En la Crónica del centenario, el propio narrador oficial ubica el robo en 1882: “Algo ocurrió aquel 19 de Noviembre que ninguna crónica recogió [...] Al porqué de la desaparición del acta a la que llamativamente se une, al poco tiempo la de su copia destinada al Archivo de la Provincia”. Para Szelagowski, es posible que haya habido "una conjura política alrededor de la oposición a Rocha y no un mero hecho delictivo cometido por interesados en obtener unas cuantas monedas de oro. A lo mejor esta fue la paga a quienes oficiaron de ayudantes de quien o quienes comandaron este gravísimo atentado..." (Szelagowski, 1982b: XXIX).
} 
Luego, el día del hallazgo de la caja:

“...A través del líquido color herrumbre se podía ver un periódico sumergido al lado del recipiente de cristal, y éste aparentemente lleno también de agua.

Por más que estuviéramos preparados para recibir la decepcionante visión, quedamos sobrecogidos. Algún chiste que quiso insinuarse no tuvo acogida..." (Szelagowski, 1982b: XX)

Y finalmente, con los festejos centrales:

“...pese a todas las circunstancias dolorosas y angustiantes que vive el país, el 19 de Noviembre ocurrió como un aflojamiento de tensiones, como una unión advertible y palpable. Se constataba el encuentro en la calle de platenses que no hubieran salido a recorrer algo tan multitudinario como era esta colosal feria; también en algunos invitados a los actos oficiales que por cuestiones políticas no se hacían presentes, pero no podían impedir que fueran sus mujeres o sus hijos, o que les indicaron que fueran [...] Porque cuando la fiesta es de la Ciudad dejamos de lado muchas diferencias que nos separan de quienes conducen el gobierno en esta etapa de la República y nos acercamos a esto tan nuestro, sintiéndonos partícipes y conmovidos ante el acontecimiento" (Szelagowski, 1982b: XXV-XXVI)

En la noticia de El Día ya citada, Szelagowski anticipaba que su misión era "la de narrar pulsaciones del centenario, la de describirlo hasta que adquiera su identidad y para que en lo futuro lo conozcan sin maquillaje" 31 . En ese sentido, su trabajo contempla algunas críticas a los festejos: le disgusta la "cantata del centenario",32 y también se queja de intervenciones del gobierno provincial. Relata que en la cena del 18 de noviembre los 800 presentes eran "lo que el gobierno de la Provincia consideró representativo del quehacer platense" y que, "como siempre ocurre con organismos dirigidos por quienes no conocen a fondo una ciudad, hubo muchas omisiones y no justificadas inclusiones", y en especial un inaceptable "tratamiento secundario" hacia la Municipalidad "en los actos organizados por el gobierno central o difundidos por sus medios..." (Szelagowski, 1982b: XXIV) ${ }^{33}$. Más adelante vuelve a confrontar con los funcionarios provinciales por promover que los documentos y objetos exhumados no volvieran a enterrarse, sino que fueran al Museo: "Creo que en esto se contradice al pensamiento de la gran mayoría de los platenses", sentencia Szelagowski (1982b: XXIX).

No obstante, en lo que hace al sentido político del centenario, su postura acuerda con el festejo oficial y los usos del pasado que analizaremos más adelante:

“...tiene que servir como instrumento convocante y en medio de esta tremenda crisis se advierte una voluntad de unión muy parecida seguramente a la que campeara en aquel 1882. Aquella unión nacional lograda y esta unión nacional anhelada. A cien años estamos como en un nuevo punto de partida..." (Szelagowski, 1982b: I)

\footnotetext{
31 “Miguel Szelagowski, el hombre que narrará el centenario platense”, El Día, 2 de noviembre de 1982, pág. 7.

${ }^{32}$ La cantata oficial había sido compuesta por Pompeyo Camps con versos de Gustavo García Saraví. Fue ejecutada el 18 de noviembre por la Orquesta de Cámara Municipal, con coro, cuatro solistas de canto y un relator, bajo dirección de Carlos Sampedro. Szelagowski escribe: "La velada de gala tradicional [...] dio lugar al estreno de una cantata dedicada a la Ciudad y que fue motivo de concurso. Aparentemente contó con la aprobación del público; mis oídos, posiblemente anquilosados, no aceptan tanta disonancia” (1982b: XXIV). ${ }^{33}$ No es la única ocasión en que hace este planteo protocolar. En su libro Si yo fuera intendente, al que nos referiremos más adelante, Szelagowski evoca una queja similar realizada durante sus años como jefe comunal: "Se trata de un festejo de la ciudad y el primer lugar le corresponde a sus autoridades. El señor gobernador es un distinguido invitado del Intendente por lo que su lugar en los actos corresponde a la derecha que éste [...] Pudo advertirse en la transmisión de los actos del 19 y en la información de prensa, una no disimulada acentuación en dar a la fiesta un carácter de celebración del Gobierno de la Provincia..." (Szelagowski, 1982a: 17).
} 
Otra publicación íntegramente realizada por la Municipalidad es La Plata 1882-1982. Crónicas de un siglo (en adelante, Crónicas de un siglo), del investigador local Carlos Antonio Moncaut, viejo colaborador del diario $E l D_{i ́}{ }^{34}$ y autor de varios libros, que dos años antes había obtenido el Premio Consagración "Roberto Themis Speroni", en la primera entrega de esa distinción por parte de la SEP (1980). El libro, impreso en octubre de 1982 en los talleres gráficos del Estado municipal, incluye algunas fotografías, postales antiguas y grabados que "pertenecen a la colección particular" del autor. Organizado en cinco capítulos, tiene un carácter completamente fragmentario. Se inicia así: "En el mes de noviembre, comienza a pavimentarse con granito el Camino Blanco que une a La Plata con Ensenada" (Moncaut, 1982: 3). A partir de ese momento, año por año presenta distintas informaciones, en su mayoría tomadas en forma textual del diario local, de lo que resulta una sumatoria de datos inconexos, sin ningún hilo conductor ni análisis de procesos. Así, por ejemplo, en distintas fechas indica datos sueltos de "población", en lugar de presentar un cuadro que permita analizarlos. Estas "pastillas” informativas van de la instalación de poderes públicos al clima, del movimiento de trenes a la aparición de publicaciones, la creación de un cementerio, el descubrimiento de un planeta en el Observatorio o la noticia de ahogados en un arroyo. Incluye referencias a prácticas deportivas, viejos cafés, hoteles o restaurantes, instituciones universitarias, colectividades extranjeras, surgimiento de empresas, entre muchas otras. Algunas inclusiones resultan insólitas, como la que alude al "Veraneo en Mar del Plata" (pág. 23) -en un libro sobre historia platense- o a quejas por las lavanderas que usan el césped de calle 51 (pág. 34). También transcribe, en varios tramos, avisos publicitarios: "Hielo. Reparto de hielo cristalino a domicilio. Debía llamarse a 5 entre 49 y 50, hotel de París" (Moncaut, 1982: 29). Así, en algunos años es posible encontrar el precio del ají, la carne o el dólar.

En ese desconcierto informativo es posible advertir la presencia de algunos personajes destacados, a los que se dedican fragmentos más extensos que los demás. No los resalta la voz del autor, pero sí el espacio que dedica a una semblanza o una transcripción, atípico en este libro. El primero de ellos, Almafuerte ("Ejemplo de desinterés"), ocupa poco más de una página. Evocados en el año de su nacimiento o de su muerte, le siguen Nicolás Cúccolo, Florentino Ameghino, Nicodemo Scenna, Agustín Lantero, Carlos Spegazzini, Francisco Piria, Alejandro Korn, Francisco García Cortina, Gerónimo Ingrassia, José María Rey, Rodolfo González Pacheco, Martín García, Atilio Boveri, Víctor de Pol y Noel Sbarra. En el capítulo VI retomaremos esta operación de destacar ciertos personajes, que en varios casos coinciden con otros libros y confirman un panteón de héroes de la capital cultural.

Por último, cabe observar que al final de cada capítulo incluye un apartado con el cintillo "La vida cotidiana en los primeros años de La Plata". Son notas sobre aspectos arquitectónicos, culturales o costumbristas, que resultan mucho más claras, expositivas y con capacidad analítica. La primera refiere a las viejas casonas y alude también a la cocina criolla, la segunda a la "medicina casera", la tercera a los "veraneos de nuestros abuelos" y la última al recuerdo de los tranvías.

\footnotetext{
${ }^{34}$ Moncaut había publicado artículos sobre La Plata desde un cuarto de siglo antes. En la bibliografía de Morosi (1983) aparecen dos: "Miscelánea de los primeros pasos platenses" (El Día, 19/11/58) y "Pobladores afinados en La Plata en 1884” (El Día, 19/11/1966). En 1982 escribió una serie para el tradicional diario que salieron publicados en su Revista Platense. En Ciudad milagro, Becerra los menciona al pasar: “...por último el curioso folleto bilingüe de Arturo Di Castelnuovo, publicado el 19 de noviembre de 1885 en La Plata y cuya amena e inteligente glosa está haciendo actualmente Carlos Antonio Moncaut en la edición dominical de El Día, de La Plata" (en Lerange, 1982: 60). Los artículos en Revista Platense también son citados en el Diccionario de arte.
} 
En suma es un texto caótico, incluso sin una línea editorial clara. Recién al final evoca la inscripción en la caja de piedra fundacional, que alude a la ciudad como "testimonio de amor por la Unión Argentina", y el autor firma un breve mensaje final ${ }^{35}$ : "Pocos días más y La Plata vivirá su jornada histórica más trascendente. Festejará su primer siglo de vida, para lanzarse, inmediatamente, a la conquista de su seguro y próspero porvenir, que todos le auguramos con nuestro más ferviente deseo y esperanza" (Moncaut, 1982: 221).

El tercer libro financiado por el municipio es La Plata, una Creación de la Generación del 80 (en adelante, Creación de la generación del 80) ${ }^{36}$, de la escritora Inés Zuccalá y el profesor de historia Roberto Musmano. En ninguna parte tiene indicada una fecha, pero distintos indicios dan cuenta de que es un libro muy próximo a la fecha del centenario ${ }^{37}$. El currículum público de Zuccalá como "estudiosa de la vida cultural" señala que ha recibido distintos premios por sus obras, entre ellos el "Primer Premio del Centenario de la Ciudad de La Plata otorgado por la Municipalidad de La Plata". En el período de la dictadura ambos autores estuvieron vinculados a la Radio Universidad. En 1982 Zuccalá conducía junto a Perla Villafañe el programa "Tiempo compartido", realizado desde la Universidad Popular Alejandro Korn, que estuvo en el aire durante más de 20 años. En tanto, Musmano comenzó a preparar en 1978 desde la L.R. 11 la colección "Nuestra historia a través de la música" -una historia del país a través de las canciones folklóricas-, presentada luego desde la Asociación Cultural por las Provincias Argentinas. Esta entidad, conocida públicamente como "La Casa de las Provincias de La Plata", fue creada en agosto de 1980 por iniciativa de quien fuera su primera directora, María Cristina Pozzuoli, esposa de Musmano ${ }^{38}$.

El texto es un recorrido clásico por la historia de la ciudad, en el que no se advierte con claridad el énfasis puesto en título del libro. Arranca con el proceso de capitalización de Buenos Aires y los movimientos de los distintos actores políticos hacia 1880, para luego dedicarse a "Dardo Rocha y la nueva capital". Hace una semblanza del fundador y de su idea de una nueva Buenos Aires. Repasa la elección del sitio -marcando la opción una ciudad fluvial-, y al analizar la ubicación elegida se remonta bien atrás en el tiempo: la tesis es que nuestros antepasados, los primeros hombres blancos, fueron los que tuvieron mayor visión para jerarquizar el puerto natural. A continuación narra el proceso de creación de la ciudad y el acto de fundación. El apartado "La Plata y la generación del 80" (Zuccalá y Musmano, s/f: 23), lo más sustantivo según el título del trabajo, lleva menos de una página. Sigue con una mirada sobre los primeros años de la ciudad, reiterando lugares comunes de la bibliografía existente: los primeros edificios, la luz eléctrica, el puerto, los periódicos iniciales de la ciudad, algunas consideraciones sobre el trazado. El relato pone en un lugar destacado a la Universidad y cierra con dos capítulos breves, bastante autónomos: "La ciudad y sus pensadores" y "La Plata y Sarmiento".

\footnotetext{
${ }^{35}$ Acorde al desorden que rige el texto, el libro no termina con este mensaje final. A continuación incluye los versos de "un nostálgico platense, Osvaldo Garriga", a los que queda el peso de concluir este libro municipal. ${ }^{36}$ Es un texto de 61 páginas, con tipografía pequeña. En la Biblioteca Central de la Universidad está catalogado como folleto, pero claramente puede ser considerado un libro.

${ }^{37}$ Según los registros del sitio web http://openlibrary.org/ es un libro de 1981.

${ }^{38}$ Entre las áreas de trabajo de esa entidad, contiene un Instituto de Enseñanza -a mediados de los '80 se identificaba como Universidad popular- que adoptó el nombre "José María Prado", quien fue una personalidad institucional y un autor significativo en la producción del centenario, como detallaremos en el capítulo IV.
} 


\section{Los trabajos de la universidad}

Más allá de Crónica del centenario, Crónicas de un siglo y Creación de la generación del 80 el libro con financiamiento municipal más trascendente fue La Plata, una obra de arte (de ahora en más, Obra de arte), coeditado junto a la Facultad de Humanidades de la Universidad Nacional de La Plata, con una tirada de 3000 ejemplares numerados. En la prensa de la época se puede encontrar una alusión a éste como "el Libro del Centenario"39. Esta expresión, que también aparece en una de sus páginas iniciales (Díaz, 1982: 17), había sido pretendida por la SEP -como vimos- al crear la Comisión Pro-Libro del Centenario.

Obra de arte está indicado como "Edición Oficial de la Municipalidad de La Plata" (Díaz, 1982: 440) y, al igual que Ciudad milagro, es otro producto monumental: es cuadrado, grandote, con tapa dura forrada en tela, y contiene 443 páginas -más algunos pliegos gráficos no numerados. Uno de los autores consultados recordó el "acto protocolar" con que fue presentado el libro en el Salón Dorado de la Municipalidad.

El carácter oficial u oficialista de la edición se lee entre las primeras páginas, cuando el repaso histórico alude el gobierno comunal: "Con el correr del tiempo, la Municipalidad de La Plata ha sufrido importantes modificaciones, siendo hoy el alma de la ciudad. Su moderna organización, fruto de su crecimiento la convierte en un inmejorable administrador para el buen funcionamiento de la misma" (Díaz, 1982: 22).

En rigor, el libro es producto de un convenio entre la Municipalidad, la Facultad de Humanidades de La Plata y una empresa editora llamada Posban SRL \& Saltzmann, que según una de las fuentes consultadas fue quien "le vendió" el proyecto al gobierno comunal y estableció el contacto con la universidad ${ }^{40}$. En la primera página de Obra de arte, se consigna por error un apoyo del Gobierno provincial, en lugar del municipal:

"Este Libro, Testimonio de los Cien Años de La Plata, Capital de la Provincia de Buenos Aires, es el resultado del esfuerzo mancomunado del Gobierno de la Provincia y de la Universidad Nacional de La Plata" (Díaz, 1982: 1982. Negritas y mayúsculas en el original) ${ }^{41}$

La Presentación que viene a continuación, no obstante, aclara las dudas al respecto. Se trata de un texto breve que concentra una gran parte de los núcleos fuertes de sentido que analizaremos en la tesis: la figura de Rocha, la asociación ciudad-universidad, la exaltación de la geometría y el llamado a la unión de los argentinos. Y para completar el cuadro, alude a Dios ( ¡un libro de la Universidad!):

\footnotetext{
39 “«Estamos trabajando aceleradamente en la impresión del Libro del Centenario, que fue compuesto por la Universidad de La Plata», informó el señor Roberto Guillaume, jefe del Archivo Municipal. La edición será de 3.000 ejemplares y los ejemplares tendrán 450 páginas. «Hubo alguna demora en la entrega de los textos y tenemos el problema de los fotocromos»...", en "Trabajando contra el reloj del Centenario", El Día, 1 de noviembre de 1982, página 5. Posteriormente hay una alusión en declaraciones del Intendente, en relación a los costos de la celebración (El Día, 13 de noviembre de 1982)

${ }^{40}$ En el libro sólo se explicita una responsabilidad de la empresa sobre el trabajo gráfico. Aparece recién en la última página, como responsable de la impresión; en tanto algunos de los fotógrafos -José Rafael Andrade y José Carlos Villanueva- trabajaban para Posban. No se han encontrado datos sobre esta empresa, como sí de los talleres gráficos Macchi, Saltzmann y Cía, que imprimieron libros, manuales y guías turísticas durante toda la década de 1970. En ciertas bibliografías o repositorios, Obra de arte suele ser citado como una edición de Posban \& Saltzmann.

${ }^{41}$ En tanto, las páginas que siguen indican la nómina de autoridades de: Provincia de Buenos Aires (aunque no financie ni tenga relación directa con el libro), la Universidad Nacional de La Plata (no así de la Facultad, salvo el decano, concluyendo la lista) y Municipalidad de La Plata.
} 
"La Municipalidad de La Plata, en el umbral de los cien años de la ciudad, ha interpretado como un deber ineludible, precipitar en el libro, la pujanza creadora y fecunda de una ciudad, nacida como capital, que acuñó un impulso de grandeza y que no defraudó el espíritu encerrado en su simiente.

El libro y La Plata conforman una simbiosis particular, tan íntima, que no es nunca ajeno el primero a cualquier simbología de la ciudad que se intente.

El vigor del ser mismo del platense, de sus ideas y de la impronta peculiar que ha conferido a las generaciones de argentinos y latinoamericanos que se formaron en las aulas de su Universidad y que pasearon por la geometría de sus calles sus mejores sueños, sus primeros amores y sus últimas inocencias, requerían insoslayablemente del testimonio del libro.

El Libro para el Centenario y para las generaciones venideras, que recogerán cabalmente el mensaje de Dardo Rocha, que no por casualidad fue ponderado en la dimensión secular porque esa dimensión en su doble desenvolvimiento de mutación y permanencia, dejaría persistentes los valores genuinos.

Y quien llevara de la mano a La Plata hacia el libro, o al libro hacia La Plata, recorriendo el camino cuantas veces fuera necesario, no podía ser otra voz $\mathrm{u}$ otra letra que la de la Universidad Nacional de La Plata, tan cerca de uno y otro término de la simbiosis, que es ciertamente imposible saber si La Plata, es la Universidad, o si ésta es la ciudad, o si una y la otra son el libro, o si finalmente es el libro, la ciudad, la Universidad y ese estilo definitivo de una obra nacida de la inteligencia y para la inteligencia.

Quiera Dios, esta intención, más pureza que especulación, más entusiasmo que cálculo, plasme la iniciativa municipal en este libro, construido por la Universidad para testimoniar los Cien Años de La Plata, ciudad que forjaron los argentinos unidos, para abrirla al mundo" (Díaz, 1982: 9)

Como es previsible, los textos introductorios plantean más explícitamente usos del pasado, y condensan los sentidos político-ideológicos marcados por quienes impulsan y financian las publicaciones. Lo que encontramos luego, en el caso de Obra de arte, es una producción que en partes significativas se corre de ese tono de homenaje a La Plata para dar lugar a exposiciones ordenadas, rigurosas y más afines al campo académico.

El libro, preparado en pocos meses, fue producido desde febrero de 1982 en el marco de la Facultad de Humanidades y Ciencias de la Educación de la UNLP. Al interior de la Facultad, el texto resulta de una iniciativa centrada en el Departamento de Historia y el Departamento de Medios Audiovisuales, con una participación también bastante activa del Departamento de Geografía. La dirección general del trabajo estuvo a cargo del Jefe del Departamento de Historia, el nacionalista de derecha Benito Díaz ${ }^{42}$, y entre los distintos colaboradores hay más de 70 nombres, la gran mayoría de la propia Facultad.

Tras un inicio de carácter institucional (nómina de autoridades, simbología, presentación, prólogo), Obra de arte está dividido en cuatro bloques: Marco espacial (páginas 51 a 86), Marco Histórico (87-158), Marco Actual (159-394) y Hacia el futuro (395-

\footnotetext{
${ }^{42}$ Díaz era un historiador nacionalista que había asumido la dirección del Departamento de Historia durante la gestión peronista, antes del golpe, cuando empezó la persecución a los docentes considerados marxistas. Según su hijo Pablo, víctima de la represión de la dictadura en lo que a posteriori se construyó como la noche de los lápices, estaba "identificado con el rosismo y con el peronismo de derecha, era admirado por la gente del CNU, y dentro de la cárcel me trataban bien porque yo era su hijo" (Seoane y Ruíz Nuñez, 1986: 125). Un entrevistado recordó que "era un tipo que con mucho descaro promocionaba directamente al Ejército. Específicamente al Ejército. Tenía conexiones". A su vez era un hombre de mucha iniciativa: "Tenía cagando y trabajando a todo el mundo". Durante su gestión funcionó una entidad llamada "Mutual de Historia", que organizaba viajes como un recordado Crucero de la Integración al Paraguay.
} 
426). Cada uno tiene subtítulos en distintos niveles. En suma, el volumen trata una gran diversidad de temas: la prehistoria del territorio platense y la zona pampeana en general desde Plioceno, cuestiones geo-estratégicas, el origen y algunas variaciones de los nombres de distintos sitios de la región, la geografía física y natural, la organización administrativa al fundarse la ciudad, el puerto, la vivienda, los usos de la tierra, la historia universitaria, el transporte y las comunicaciones, los servicios públicos, la producción artística y cultural, las distintas instituciones públicas y privadas, las fuerzas de seguridad, las actividades deportivas y recreativas. El recorrido también es ecléctico en sus enfoques y registros de escritura.

La producción del libro integró a una buena cantidad de estudiantes avanzados y graduados recientes, según surge de las entrevistas realizadas:

“...nos dicen que hay una investigación en la cual podemos participar, que tiene que ver con la producción de un libro, que tiene que ver con el centenario. Yo no me acuerdo si estaba en quinto o me había recibido. Entonces bueno, se arma un grupo, en geografía, y ahí esta persona que es la coordinadora de esta parte del libro (Norma Sala), nos dice: bueno, cómo repartimos el trabajo" (Luis Adriani, participante del trabajo en el Departamento de Geografía)

"Participaron varios profes, no sé como fueron seleccionados. Por mi parte, yo era recién recibido y con una compañera, nos dijeron si queríamos colaborar. Creo que nos eligieron porque, a criterio de ellos, fuimos buenos alumnos en las asignaturas de Historia Argentina. Había algunas reuniones por grupos, pero no recuerdo haber asistido a una reunión plenaria de todos los autores. Coordinaba Díaz y un museólogo que, creo que falleció, que era Roberto Crowder. Susana y yo éramos 'pinches' en el trabajo... ya te digo que ni siquiera tengo un ejemplar del libro, pues no nos lo dieron" (Daniel Benavídez ${ }^{43}$, participante del trabajo en el Departamento de Historia)

Aunque el libro está compuesto por fragmentos escritos por distintas personas, tiene la particularidad de no indicar la autoría de cada parte. El resultado es problemático, ya que conviven en el texto distintos tonos de escritura y hasta es posible hallar referencias en primera persona del singular. A fines de 1983, por necesidad de los autores de los capítulos de demostrar su participación en el libro, el Departamento de Historia emitió certificados firmados por su jefe y director general de la obra ${ }^{44}$.

La autoría diversa de los fragmentos de texto se hace evidente también por la especificidad disciplinar del desarrollo de los temas. El Departamento de Geografía, por ejemplo, estuvo a cargo del Marco espacial y de dos partes del subcapítulo económico del Marco actual: "Estructura industrial" y "Puerto La Plata"45.

Según el texto inicial sobre Metodología de trabajo y objetivos, Obra de arte estuvo “dirigido en forma especial, a la población de arraigo en la ciudad, y fundamentalmente a los

\footnotetext{
${ }^{43}$ Benavídez recuerda haber hecho un amplio trabajo de campo, rastreando, visitando y entrevistando a descendientes de familias fundadoras: "quisimos ver si continuaban viviendo en la Plata, si se dedicaban a las mismas profesiones y si habían tenido alguna movilidad social [...] Te imaginás los barrios que recorrimos y el tiempo que nos llevó [...] Finalmente entregamos un informe, pero poco de él apareció en el libro, ya que otra persona, no sé quien fue, hizo una especie de árbol genealógico con quien desciende de quien. No obstante, fue una experiencia que siempre recordamos: era el primer trabajo de campo que hacíamos como profes recibidos". ${ }^{44}$ Por gentileza de uno de los autores tuve acceso a uno de estos certificados, firmado por Benito Díaz el 20 de diciembre de 1983. El papel confirma que fue un libro "publicado por la Municipalidad de La Plata en convenio con esta Facultad...".

${ }^{45}$ En su elaboración, los distintos grupos de trabajo tuvieron una dinámica bastante autónoma. Quienes participaron por Geografía no recuerdan otras directivas que las de su jefa de Departamento, Norma Sala. El 2 de noviembre, dicho Departamento realizó un "ciclo de disertaciones" donde los distintos integrantes expusieron sus aportes al libro (“Ciclo sobre el Centenario”, El Día, 2 de noviembre de 1982, segunda sección, página 2).
} 
sectores educacionales, docentes y alumnos". Se señalan "propósitos de difusión docente" (Díaz, 1982: 16). Cabe advertir, en ese sentido, que el trabajo de investigación tuvo otros soportes, además del libro: "una muestra cartográfica y fotográfica, una guía complementaria de la muestra, una carpeta didáctica orientada a satisfacer los programas escolares y un trabajo audiovisual sobre la vida social y cultural de nuestra ciudad" (Díaz, 1982: 17), lo que explica la presencia significativa del Departamento de Medios Audiovisuales en el equipo. Los integrantes más antiguos de esa área recuerdan hoy que la mayor parte del trabajo de entonces era motorizada por Benito Díaz: "Trabajábamos para el Departamento de Historia".

La muestra consistía en una serie de paneles que fueron expuestos en el Pasaje de Dardo Rocha, que incluían fotografías, genealogías de familias, datos demográficos y mapas, entre otros materiales producidos para el libro. Por su parte, el audiovisual duraba aproximadamente 45 minutos y se basaba en fotografías de "lugares representativos" de la ciudad. Era una serie de diapositivas -alrededor de 140- que se reproducía conjuntamente con un casete que contenía el relato en off de un locutor y varias cortinas musicales. El material se conserva en la Facultad, incompleto ${ }^{46}$. Ese tipo de producciones eran habituales en la época: antes, Audiovisuales había realizado un trabajo sobre la Conquista del Desierto (1979) ${ }^{47}$ y "Berisso, su geografía" (1981), en convenio con la dirección municipal de ese municipio. Además hay registros de "Berisso, un pueblo laborioso", "La ciudad y el poeta" (sobre López Merino) y "Camino a Salinas", y los trabajadores del Departamento recuerdan trabajos similares encargados por otros pueblos como General Lavalle.

Otro aspecto a destacar de Obra de arte es la calidad gráfica. Con tapa dura, impreso en un papel de buen gramaje e incluyendo algunas páginas desplegables, contiene muchos recursos visuales. El libro tiene más de 330 imágenes -entre fotografías, facsímiles, retratos y cuadros ilustrativos-, casi todas a color, incluyendo algunas a página completa.

Ese es un punto en común con otra producción vinculada a la Universidad y también con un ostentoso soporte material: La Plata Ciudad nueva, ciudad antigua. Historia, forma y estructura de un espacio urbano singular (en adelante Ciudad nueva ciudad antigua). Se trata de un libro coeditado por la UNLP junto al Instituto de Estudios de Administración Local de Madrid, que indica a la ciudad española como lugar de la edición, fechada en 1983. Es el producto de una investigación de larga data, iniciada en octubre de 1975 en el seno de la Cátedra de Planeamiento Físico II de la Facultad de Arquitectura, a cargo de Julio A. Morosi, a partir de una idea del urbanista español Fernando de Terán Troyano, que participó como asesor del proyecto. Es un libro grande, realizado en formato A4 apaisado. Tiene 413 páginas gruesas, satinadas, algunas impresas a color, ya que incorpora una cantidad muy significativa de imágenes: 450 en total, de las cuales 197 son fotografías -incluyendo varias panorámicas del casco- y el resto son dibujos, mapas, planos. En muchos casos la ilustración reproduce una imagen del trazado o el plano del casco urbano, convertido en símbolo en la tapa y también en las páginas que separan las partes del libro.

\footnotetext{
${ }^{46}$ Para esta tesis se consultaron las imágenes y el guión, que retomaremos más adelante. No tuve acceso al casete, por lo que ignoramos las características de la musicalización. Según las placas finales, las voces fueron grabadas por Osvaldo Salas Bau -actor y en esa época locutor de Radio Provincia- y Sonia Mabel Salas.

${ }^{47}$ En efecto, la adhesión al aniversario platense no fue la primera conmemoración que movilizó al Departamento: en 1979 se organizó una muestra y un audiovisual -diapositivas, música y una voz en off- sobre la Conquista del Desierto, con los que Díaz recorrió el país y estableció vínculos con jerarquías militares.

"Viajamos de punta a punta del país. ¿Cómo? De este a oeste y de norte a sur", recordó uno de los participantes.
} 
Dividido en tres grandes bloques (Génesis, Desarrollo y Valoración y Conclusiones), el libro incluye 18 capítulos centrados en temas urbanísticos, en lo que predomina un registro académico, con gran erudición. La primera parte repasa el contexto de la fundación, caracteriza el lugar elegido, refiere al Departamento de Ingenieros como actor principal, señala antecedentes urbanísticos internacionales y locales, describe las acciones de la creación de la ciudad, los rasgos principales de la traza y la arquitectura, y cierra con un breve relato de la ceremonia fundacional y los días iniciales de la ciudad. La segunda parte, más analítica, explora la "evolución de la región con posterioridad a la fundación", las "transformaciones formales en la traza" desde una perspectiva micro y macro-morfológica, la "arquitectura y paisaje urbano actual", la "vía pública urbana" y el "elemento vegetal". Además hace una caracterización demográfica-funcional de la población a partir de sus actividades, repasa los principales canales y flujos de la ciudad, y propone un análisis de la "estructura urbana". En la última parte intenta una síntesis del recorrido realizado y dedica un capítulo a "recomendaciones" que incluyen la necesidad de mayor conocimiento sobre La Plata y acciones sobre aspectos formales y estructurales de la ciudad.

El libro suele ser citado como una obra de Morosi y De Terán, pero tiene una autoría colectiva más compleja. Mientras la tapa no indica quiénes son los autores, en la primera página aparece una lista en dos columnas, que incluye: un equipo integrado por nueve arquitectos además de Morosi, reconocido como director y señalado en su condición de profesor titular de la UNLP; el nombre Fernando de Terán -arquitecto y entonces "catedrático de la Universidad Politécnica de Madrid"- como "asesor y autor del proyecto"; y una lista de colaboradores que incluye otros tres arquitectos, un historiador -Fernando E. Barba- y una doctora en Ciencias Naturales, también profesora de la UNLP y a quien ya hemos mencionado como participante del ciclo de charlas: María Cristina Orsi ${ }^{48}$. A continuación viene una doble introducción: mientras la "nota preliminar" la firma "el equipo de investigación"; el prólogo corresponde a De Terán. El texto del reconocido urbanista español está firmado en Madrid, 19 de noviembre de 1982, lo cual confirma el rol del centenario como motivación del libro, más allá de que se trate de una investigación de larga data.

Es importante señalar, a la hora de construir un panorama de las publicaciones sobre La Plata, que producto del mismo proyecto de investigación se editaron seis o siete documentos de avance $^{49}$, identificados con el título general La Plata como ciudad nueva. Historia, forma y estructura, y dedicados a temas específicos: Morfología Urbana Platense (Morosi, 1980a), Micromorfología Urbana Platense. Tejido (Morosi, 1980b), Micromorfología Urbana Platense. Canales Urbanos (Morosi, 1982), Influencia del elemento vegetal (Morosi, 1980c),

\footnotetext{
${ }^{48}$ En la Nota preliminar se detallan los roles cumplidos por estos colaboradores: Barba dirigió la escritura del primer capítulo (sobre El momento histórico de la fundación de la ciudad), los arquitectos "Mabel Margarita Scarone y Jorge Osvaldo Gazaneo, ejecutaron capítulos 6 y 11, junto con arq. Jorge Salvador Mele y Dra. María Cristina Orsi de Herrero Ducloux", y esta última escribió el capítulo 13, "además de haber asesorado en los aspectos vinculados a su especialidad, la Botánica" (Morosi, 1983: 7). En ese mismo introductorio se menciona a Nelly Moranzoni, bibliotecaria de la Escuela Superior de Periodismo de la UNLP, quien trabajó en el "ordenamiento del material", y se agradece "el aporte de quienes se vieron obligados a abandonar la empresa por diferentes razones, y en particular al querido maestro arquitecto Hilario Zalba y a los arquitectos J. M. Valcárcel y A. Liberman, que desde sus cargos propiciaron la gestación de este trabajo".

${ }^{49}$ La numeración de los documentos llega hasta el 7, dedicado a la bibliografía y definido como el "séptimo y último". No se ha podido comprobar la existencia del $N^{\circ} 5$, cuya efectiva publicación fue puesta en duda por los propios investigadores. El grado de independencia de la producción de cada documento de avance permitió, por ejemplo, que el N 4 (Morosi, 1980c) esté fechado dos años antes que el Nº3 (Morosi, 1982); discontinuidad que hace verosímil la posibilidad de que un volumen pautado con el número 5 nunca se haya concretado.
} 
Conclusiones Generales y Recomendaciones (Morosi, 1984a) y Bibliografía sobre La Plata (Morosi, 1984b) $^{50}$. Si bien mantienen el formato, la publicación de estos resultados parciales cambia de sello editorial en los años: mientras los números 1, 2 y 4, datados en 1980, tienen la referencia de "Ramos Americana Editora" -que interviene, como veremos, en otras publicaciones de la época-, los tres restantes están firmados como producciones de la Universidad Nacional de La Plata, publicadas con "fondos acordados por la Secretaría de Estado de Ciencia y Tecnología" (Morosi, 1984b).

El equipo que se puede reconstruir a partir de estos documentos coincide en general con Ciudad nueva ciudad antigua, salvo en tres puntos: 1) De Terán aparece como "asesor del equipo" pero no como autor del proyecto; 2) No se incluyen los colaboradores Fernando Enrique Barba, Mabel M. Scarone, Jorge O. Gazaneo, Jorge S. Mele; y 3) El nombre de Orsi de Herrero Ducloux aparece, junto al de Antonio Valente, bajo el título "participaron además en importantes tramos".

Los textos publicados en los documentos de avance, además de ser parcialidades del trabajo, fueron revisados de cara a la publicación del libro ${ }^{51}$. Concederemos que se trata de una misma producción, y a los fines de esta tesis retomaremos, en los distintos capítulos analíticos, la obra completa y definitiva: Ciudad nueva ciudad antigua, considerada como una de las producciones realizadas desde la universidad local, con la presencia distintiva de Fernando de Terán ${ }^{52}$.

Por su parte, desde la Facultad de Bellas Artes, el Instituto de Historia del Arte Argentino y Americano publica el Diccionario temático de las artes en La Plata (de ahora en más, Diccionario de arte), un libro de 383 páginas con reseñas sobre instituciones de formación artística, bibliotecas, galerías y museos, algunos movimientos y asociaciones de artistas, como así también ciertas instituciones vinculadas a la gestión y medios de comunicación. Las referencias están organizadas alfabéticamente. El foco está puesto en las artes plásticas y en segundo lugar la música, aunque también hay algunas referencias a la arquitectura, al cine, el teatro y la danza. Más allá de la alusión a instituciones tradicionales y la mirada conservadora de algunos artículos, cabe advertir en este diccionario el reconocimiento de ciertos movimientos innovadores. Esto ocurre notoriamente en el campo de la plástica, con artículos elaborados por el compilador Ángel Nessi sobre el Movimiento de

\footnotetext{
${ }^{50}$ Publicado en 1984, el documento dedicado a la bibliografía hace un reconociendo de la profusión editorial incentivada por el centenario.

${ }^{51}$ Guardada en el archivo personal de la arquitecta Vitalone - una de las participantes del equipo-, pude acceder a una carta enviada por De Terán a Morosi, fechada en diciembre de 1981, en el que hace algunas "observaciones y matizaciones" al contenido del documento de trabajo $\mathrm{N}^{\circ} 2$, publicado el año anterior: "no me parece propio del tipo de libro que encaramos, el escoltarse constantemente en definiciones tomadas de diccionarios (páginas 9 y 10). Resulta demasiado escolar y respetuoso con algo que se acepta acríticamente. Por otra parte el diccionario en cuestión no es la Biblia", plantea De Terán, entre otras críticas más específicas. También sugiere diferencias en un plano que implica un posicionamiento político: "Especialmente importante me parece la posible discrepancia en la parte final del documento, en la cual se elogia la normativa vigente (pág. 48) como capaz de encauzar el proceso de 'renovación urbana' (pág. 49). Creo que tal proceso es destructivo de valores reales, necesarios de preservar y que la normativa vigente estimula la desaparición de los elementos valiosos y cambia todo el proceso de generación morfológica a través de la destrucción de la relación parcial-tipo edificatorio, que estaba tan ajustado en la ciudad original y la condicionaba [...] me parece necesario también destacar los destrozos que se siguen cometiendo...”. Más adelante retomaremos otras críticas realizadas por De Terán. 52 Otro producto parcial de esa investigación apareció en la revista madrileña de urbanismo Ciudad y territorio, firmado por Morosi y De Terán (1981). Y Morosi también publica un artículo en Quirón, la publicación de la Fundación Dr. José María Mainetti para el Progreso de la Medicina.
} 
Arte Nuevo, el grupo "Sî" y la carrera universitaria de Pintura Mural, entre otros, o en la convocatoria a Edgardo Antonio Vigo para escribir sobre su revista Diagonal Cero.

Diccionario de arte fue uno de los primeros intentos metódicos de inventariar la vida artística y cultural de la ciudad. Contiene casi cien artículos -además del prólogo y un anexo de documentos-, firmados con iniciales que corresponden a sus autores. Al principio del libro aparece una lista de 45 colaboradores, convocados a escribir sobre una o más referencias del diccionario. Varias entradas están firmadas por el propio director.

Nessi hace su aporte puntual en otros dos libros, los voluminosos Ciudad milagro y Obra de arte, con capítulos en la misma línea -que reconocen movimientos renovadores de los años '60- aunque circunscritos a las artes plásticas. Si bien les confiere un peso menor, el Diccionario de arte incluye otras disciplinas, salvo la literatura, que parece constituir un campo más específico que tiene sus propios capítulos en los libros colectivos y alude a un sujeto específico, los "escritores", cuya organización institucional tuvo un peso relevante en las iniciativas editoriales del centenario platense.

Para completar el panorama de la producción universitaria es necesario explorar algunas publicaciones periódicas, como la Revista de la Universidad, que tiene el aspecto de un libro, por su formato y por sus más de 200 páginas. Fundada en 1957 por Noel Sbarra, que la dirigió durante 17 años, la publicación oficial de la Universidad Nacional de La Plata tuvo una periodicidad interrumpida en distintos momentos históricos. La UNLP intervenida por la dictadura la reeditó después de la primera discontinuidad, ya no dirigida por Sbarra -fallecido cinco años antes-, sino por el arquitecto José María Marquinez ${ }^{53}$, por entonces a cargo de la Secretaría de Extensión Cultural y Difusión, de la que dependía la revista.

Presentada como continuadora de aquella experiencia editorial ${ }^{54}$, durante la gestión de Guillermo Gallo al frente del Rectorado se publicaron tres números de la Revista de la Universidad: uno dedicado del centenario de la denominada Campaña del Desierto $\left(\mathrm{N}^{\circ} 26\right.$, 1979-1980) ${ }^{55}$, donde también se anticipa el aniversario platense; otro abocado al "Centenario de la Generación del 80" ( $\left.\mathrm{N}^{\circ} 27,1981\right)$ y finalmente una edición sobre el centenario de la ciudad ( $\left.\mathrm{N}^{\circ} 28,1982\right)$. Además, la misma gestión realizó dos ediciones extraordinarias: una en torno al $75^{\circ}$ aniversario de la fundación de la universidad nacional, y otra sobre las Islas Malvinas, que se conoció en 1983, dedicada "a dar a conocer los diversos trabajos que, con motivo de la Gesta de las Malvinas, se escribieron o dieron lugar al ciclo que organizó nuestra Universidad a través del valioso concurso aportado por sus diversas Unidades Académicas...”.

\footnotetext{
${ }^{53}$ Es también profesor de UBA y UCA. En el № 28 (1982) Marquínez ya no era Secretario de Extensión Cultural (lo reemplaza Alberto Guillermo Ranea) pero seguía siendo director de la revista -y uno de los diagramadores, según figura en el nuevo staff.

${ }^{54}$ El primer número de la nueva época respeta el diseño original: una tapa sobria, sin información sobre los temas tratados, con el logo de la UNLP en el centro de la portada. No ocurre lo mismo con las publicaciones siguientes. No obstante, las de fines de los '70 y principios de los ' 80 se asemejan a las ediciones históricas, salvo la dedicada el Centenario de La Plata, que adopta otro formato.

${ }^{55}$ Esa efeméride concitó el afán celebratorio del gobierno de facto a nivel nacional (Vezzeti, 2003: 57-58) y también al interior de las universidades. Entre otras actividades, en General Roca se realizó el Congreso Nacional de Historia sobre la Conquista del Desierto (ver Academia Nacional de Historia, 1980) en el que participaron, entre otros, varios de los académicos que tres años después firman trabajos sobre La Plata: Edith Debenedetti, Noemí Girbal, Andrés Allende, José María Prado y Enrique Barba, quien como presidente de la Academia Nacional de Historia inauguró el Congreso junto al Ministro del Interior, general Albano Harguindeguy. Pese a la cantidad de trabajos presentados -cerca de 170-, no hubo ponencias sobre la ciudad, ni siquiera en la comisión sobre "consecuencias de la conquista", que se extendía a períodos históricos posteriores.
} 
Si en todos los libros editados o coeditados por la Universidad aparecía la nómina de autoridades entre las páginas iniciales, es evidente que la Revista de la Universidad es la publicación más institucional. Tal es así que en sus distintos números acostumbra incluir noticias de actividades oficiales. El $\mathrm{N}^{\circ} 27$ es ilustrativo, en ese sentido, de la relación de las autoridades universitarias con los gobiernos de facto nacional y provincial, como así también del vínculo con la jerarquía eclesiástica. La primera fotografía que aparece (página 17) muestra al rector junto al teniente general Jorge Rafael Videla, su ministro Cultura y Educación Juan Rafael Llerena Amadeo, y el general Ibérico Manuel Saint Jean, por entonces gobernador de facto de Buenos Aires. La foto corresponde a la visita del "Presidente de la Nación" en los actos del $75^{\circ}$ aniversario de la UNLP. La siguiente referencia (página 32) será la entrega del título de Doctor Honoris Causa a monseñor Octavio Derisi ${ }^{56}$, ex obispo auxiliar de La Plata y uno de los fundadores de la Universidad Católica Argentina ${ }^{57}$.

La Revista de la Universidad es una de las publicaciones aludidas en el Diccionario de Arte: "La calidad del material de lectura ha seguido manteniéndose interesante e ilustrativo, tanto como oportuno", escribe Miguel Ángel Escalante: "la dirección aproximó atinadamente a destacados colaboradores hacia temas de honda resonancia histórica como la Campaña del Desierto con motivo de su centenario [...] y el 27 dedicado a conmemorar la generación del '80, con despliegue de una bibliografía difícilmente superable" (en Nessi, 1982: 291).

Los números de la revista no tienen, sin embargo, una exclusividad temática. Particularmente en el $\mathrm{N}^{\circ} 26$, más allá de la enunciación editorial, no está clara la centralidad de la campaña del desierto en la edición. La mayoría de los artículos refieren a temas diversos, muy parcialmente vinculados. Entre ellos, Julio A. Morosi escribe con la colaboración de Ricardo P. Prati sobre "Algunos aspectos arquitectónicos y urbanísticos en los orígenes de La Plata". A su vez, el número incluye varios grabados de Francisco A. De Santo, incluso en medio de artículos con los que no tiene relación temática. Se trata de ilustraciones sobre edificios y lugares de la ciudad (Casa de Gobierno, Paseo del Bosque, Rectorado) realizadas para el cincuentenario platense. En el sentido contrario, en los siguientes dos números de la revista pueden encontrarse artículos claramente relacionados con la conmemoración de la operación militar de Roca ${ }^{58}$.

En el $N^{\circ} 27$ la centralidad del "tema de tapa" "59 está mucho más clara en los trece artículos principales; tal es así que buena parte de ellos refiere a la generación del 80 en sus títulos. El tema también es tratado en secciones estables de la revista. A diferencia de lo que ocurrirá en los libros de La Plata, la llamada "Generación del 80" está pensada aquí en un sentido de producción cultural, más que como una generación de dirigentes políticos.

\footnotetext{
${ }^{56}$ Filósofo tomista de profusa producción, fue rector de la UCA entre 1958 y 1980. Ante la visita de la Comisión Interamericana de Derechos Humanos en 1979, declaró que era innecesaria y afectaba la soberanía nacional.

${ }^{57}$ Luego, entre las noticias institucionales aparecen actos de otra índole, organizados por la Secretaría de Extensión Cultural y Difusión, como actuaciones del Cuarteto Zupay, Rodolfo Mederos y Cacho Tirao.

${ }^{58}$ Me refiero a los artículos "La conquista del desierto en una interpretación de Eduardo Gutiérrez", de Juan Carlos Ghiano, en el N 27 (1981), y "Héroes de la Conquista del Desierto. Muerte del Jefe del Regimiento No 5 de Caballería de Línea Gral. Güemes, Don Estanislao Heredia”, de Angel Luis Zappa, en el N 28 (1982). En este último número, además, el capítulo de Exequiel Ortega desarrolla sus últimas dos páginas bajo el subtítulo "Complemento. La Conquista del Desierto" (Ortega, 1982: 78-79)

${ }^{59}$ El título con letras blancas en la tapa anaranjada indica que la edición está dedicada al "Centenario de la Generación del 80". Además incluye seis retratos que corresponden a "prohombres" de esa generación: Roberto J. Payró, Miguel Cané, Paul Groussac, Rafael Obligado, Eduardo Wilde y Estanislao S. Zeballos.
} 
Por otra parte, la edición de 1981 incluye un aporte de Julio Morosi que continúa al publicado en el número anterior. El artículo -ahora en una sección específica, Orígenes de La Plata- refiere a una investigación "actualmente en desarrollo en nuestra Facultad de Arquitectura y Urbanismo", es decir, al proyecto iniciado en 1975 que se plasmó en Ciudad nueva ciudad antigua y en los "Documentos de Avance" ya comentados.

También el $N^{\circ} 28$ incluye otro artículo de Morosi, sobre la "Inserción de La Plata en el contexto urbanístico mundial”. En esta edición de 1982 el tema de tapa no es exclusivo, aunque tiene cierta preeminencia: de los ocho artículos principales, la mitad refieren a la ciudad de La Plata ${ }^{60}$. Y luego, en la sección Revista de libros se dedica a un Aporte para una bibliografía general sobre La Plata. La publicación tiene un nuevo diseño y es presentada por el rector Gallo:

"La Universidad quiere hacerse presente en la conmemoración de esta magna fecha, dedicando el espacio central de su revista con artículos y bibliografías particularizadas, a fin de evidenciar ciertos aspectos desconocidos de nuestra urbe...

Símbolo de constancia y voluntad de ser de aquella legendaria generación que la concibió y edificó...".

Uno de los textos dedicados a La Plata, titulado "Estructura industrial del aglomerado platense", aborda un aspecto que, como veremos en capítulo VI, suele ser ignorado en los principales relatos. Como en el caso de Morosi, aquí también hay un cruce con otra producción editorial: elaborado por Miriam Mónica Prada de Godoy y María Cristina Zilio de Guimaraenz, el artículo coincide con una parte de Obra de arte, la producción realizada por la Facultad de Humanidades y financiada por la Municipalidad platense.

Producido desde la misma Facultad, el artículo firmado por María del Carmen Manes de Della Motta consiste básicamente en un índice cronológico de revistas platenses ${ }^{61}$, que va desde la Revista de La Plata de Larsen (1885) hasta la revista Universidad. Figuran en total 70 títulos, pero es considerado un listado provisorio, que forma parte de "un conjunto de investigaciones hemerográficas" propuesto entre las "tareas planificadas por el Instituto de Literatura Argentina e Iberoamericana [...] bajo la dirección del doctor Pedro Luis Barcia, con motivos del centenario de nuestra ciudad". Si bien la autora da al artículo un carácter de "anticipo", "pues el plan es de mayor amplitud" (Manes, 1982: 95), no hay ninguna publicación posterior que coincida con la descripción. Por el contrario, el trabajo reproducido por Katz (2004) muchos años más tarde coincide con el de la Revista de la Universidad.

Aquellas tareas pueden haber sido parte de un proyecto trunco titulado Paseo histórico. Centenario de La Plata 1882-1982, dirigido por el Dr. Horacio Juan Cuccorese y codirigido por el Dr. Pedro Luis Barcia, y llevado a cabo "por un conjunto de profesores e investigadores de los distintos departamentos de la Facultad de Humanidades y Ciencias de la Educación de nuestra Universidad". Así es mencionado por Carlos Adam, el autor de la "Revista de libros" también publicada en el $\mathrm{N}^{\circ} 28$ de la Revista de la Universidad, que se presenta como "una selección de la 'Contribución a una bibliografía platense', que hemos preparado" para aquella

\footnotetext{
${ }^{60}$ En rigor, la referencia a La Plata no está demasiado presente en el artículo "Último momento poblacional argentino. Inicios de La Plata como capital bonaerense", de Exequiel C. Ortega.

${ }^{61}$ El índice consigna título y subtítulo, año o fecha de iniciación, nombre del director o editor, tamaño, número de páginas (datos tomados del número inicial). Está basado en las colecciones existentes en las bibliotecas de la UNLP, la Legislatura y distintas facultades. El artículo apenas contiene dos o tres párrafos de interpretación o contextualización. El índice, cronológico y luego alfabético, ocupa 32 páginas de la revista.
} 
obra $^{62}$. Otra referencia al mismo proyecto puede encontrarse en el artículo que coordina Cuccorese (1982) para la revista Económica, que sin mencionar a Barcia alude a "una obra de historiografía" con el mismo título, y detalla: "El contenido del primer tomo es el siguiente: Urbanismo, Vida política, Vida económica y Vida militar. El del segundo: Vida cultural y Vida religiosa. Integran el equipo de investigación treinta y nueve científicos", casi todos profesores de la Facultad de Humanidades ${ }^{63}$. "Para ECONÓMICA, hemos seleccionado, de la aún inédita obra general, temas especiales de historia social y económica".

Director del Instituto de Historia Americana, Cuccorese impulsó el proyecto desde 1981, teniendo en cuenta la proximidad del centenario e imaginando una posible publicación. Con la participación de profesores y graduados de distinta formación, se realizaron reuniones coordinadas por Barcia y Cuccorese:

"Se habían dividido en temas de investigación que se nos asignaban a cada uno. Trabajábamos en ellos y en las reuniones charlábamos sobre lo que estábamos haciendo y se hacían los ajustes correspondientes. Nosotros entregamos el borrador final y creo que varios lo hicieron, pero la publicación nunca se hizo pues, al salir el convenio de la Municipalidad con el Departamento de Historia, Díaz decidió hacer otro grupo diferente, que luego produjo el libro La Plata: una obra de arte. Recuerdo haber oído en alguna ocasión a Cuccorese quejarse acerca de cómo se había formado un equipo nuevo, habiendo un trabajo organizado y ya encaminado, que era el de él y Barcia. Lo cierto es que al comenzarse el trabajo de La Plata: una obra de arte, cesaron las reuniones del anterior y aunque se entregaron los borradores, nunca se nos dijo nada qué pasó con ellos" (Entrevista a Daniel Benavidez)

"La obra se dispuso en dos tomos. Se concluyó y cerró. Cuccoresse nunca pudo conseguir dinero para editarla y durmió por años en casa. Cuccoresse padeció, por entonces, una seria persecución ideológica en el CONICET, lo que lo desmoralizó mucho, porque le desaprobaban por sistema sus colaboradores. Gradualmente, los autores comenzaron a pedirme la exclusión de sus capítulos, al ver que la obra no se editaba y los fueron presentando en congresos y jornadas, y así se fue disgregando" (Luis Pedro Barcia) ${ }^{64}$.

Una de esas publicaciones parciales fue la que el propio Cuccorese presentó en Económica. La revista académica de la Facultad de Ciencias Económicas interviene en el

\footnotetext{
${ }^{62}$ La bibliografía publicada en la revista incluiría "solamente libros y folletos de carácter general o de enfoque amplio sobre distintos aspectos que hacen a la ciudad de La Plata y a su historia" (Adam, 1982: 131), aunque al revisar la lista dicho recorte no está tan claro, ya que aparecen reseñas específicas sobre teatro, antecedentes de construcción de un edificio, la gira de un coro universitario, etcétera. Sí es indudable que se trata de una recopilación muy actualizada, ya que contiene referencias muy recientes como los libros de Barcia (1982), De Urraza (1981), Cygan (1979) y Sánchez Márquez (1978), y tres de los documentos del grupo de Morosi (1980). ${ }^{63}$ Se puede reconstruir parte de ese equipo a partir de las notas al pie que adjudican la autoría de los distintos fragmentos: se trata de las historiadoras Silvia Ospital, Noemí Girbal de Blacha -ambas, a su vez, responsables de coordinar la sintesis-, Ana María Acevedo, Marta Valencia de Placente, S. B. Lazzaro, G. Mateo, M. B. Cid de la Paz, E. L. Giuliano y C. L. Durán. Giuliano estudia la historia del Banco Municipal de La Plata y, como veremos adelante, publica también un libro específico, donde dedica "un agradecimiento muy especial" al "Dr. Horacio Juan Cuccorese que en forma espontánea y desinteresada dirigió a la autora..." (Giuliano, 1982: 9). ${ }^{64} \mathrm{La}$ "persecución" a la que alude Barcia corresponde al período de legalidad constitucional, cuando Cuccorese fue cuestionado por su desempeño durante la dictadura. Durante el gobierno de facto Cuccorese se desempeñó como coordinador de la Comisión de Historia y Antropología del CONICET. Según las denuncias públicas de Eduardo Saguier, "practicaba una estrategia premeditada de intimidación pública hacia quienes buscaban ingresar al Programa de Becas o a la Carrera de Investigador [...] Les aclaraba verbalmente a los aspirantes que los formularios se giraban a los organismos de la represión (SIDE y Coordinación Federal), todo lo cual acontecía en el contexto del terrorismo de estado, ahuyentando así a numerosos potenciales postulantes e insinuando en otros a buscar una suerte de certificados de buena conducta".
} 
desfile editorial del centenario con el $\mathrm{N}^{\circ} 3$ de su vigésimo octavo año ${ }^{65}$. En rigor, la revista no está abocada íntegramente a La Plata. Sólo un texto de un total de cuatro artículos y una comunicación, está dedicado a la ciudad centenaria. Pero se trata del primero, está compuesto por varios aportes, y por otra parte la nota editorial sí hace referencia exclusiva al tema, en un texto que condensa en muy pocos párrafos los sentidos más fuertes que se construyen sobre la ciudad en la bibliografía de la época.

A continuación de esa nota editorial viene la "Síntesis esencial de historia socioeconómica", el artículo de 46 páginas elaborado por Cuccorese y su equipo, que hace un prolijo repaso de la evolución del perfil demográfico y el desarrollo de asociación de los inmigrantes, y explora algunas referencias de la historia económica de la región, abarcando el puerto La Plata, las principales industrias, los medios de transporte y la actividad financiera. Este último aspecto tiene un desarrollo importante, que abarca los bancos oficiales, los bancos particulares y la recientemente creada Bolsa de Comercio. En el primer caso, se dedica un apartado específico al Banco Municipal de La Plata, tal como ocurre también en Una obra de arte (Díaz, 1982: 192-195). Se trata de una parte elaborada por Ethel Leonor Giuliano, integrante del equipo dirigido por Cuccorese.

\section{Los bancos}

A su vez, sobre el mismo tema, Giuliano publica Historia del Banco Municipal de La Plata (en las próximas referencias, Historia del Banco Municipal), otro libro que se inscribe entre las publicaciones del centenario ${ }^{66}$. Según la autora,

"la iniciativa surgió como necesidad propia del banco ya que sólo tenía libro de actas y nunca había tenido ningún trabajo estructurado sobre los orígenes, formación y actividades del mismo. Es así que el Directorio decide pedírmelo en función de que yo estaba realizando una pequeña investigación sobre la banca platense. Fue por la propia iniciativa de ellos" (Ethel Giuliano, octubre de 2011)

Más tarde aparecería como folleto -financiado por una Asociación Platense de Abogados de Bancos recientemente creada- otro desprendimiento de la investigación dirigida por Cuccoresse, ya no en la coyuntura del centenario sino en el siguiente aniversario de la ciudad (Girbal, Durán y Giuliano, 1983) ${ }^{67}$.

\footnotetext{
${ }^{65}$ Fundada en 1954 salió prácticamente sin interrupciones. En 1970 discontinuó su numeración y empezó a contar desde el $\mathrm{N}^{\circ} 1$ una vez por año. Trata temas de pensamiento y teoría económica, estudios regionales, sistemas financieros y fiscales, etcétera. El artículo sobre el centenario aparece como una excepción en la agenda habitual de la publicación en tanto sus temarios no están definidos por efemérides.

${ }^{66}$ Cabe advertir que en el libro específico la autora señala que "el estudio de esta documentación permitió realizar una contribución en el libro 'La Plata; una obra de arte', publicada en conmemoración del Centenario de la Ciudad" (Giuliano, 1983: 10). Lo llamativo es que Giuliano no aparece entre los autores o colaboradores de ese libro. Tampoco figura su director, Cuccorese, quien formaba parte del Departamento de Historia que lo editó. ${ }^{67}$ El folleto de 20 páginas era resultado de una conferencia realizada el 5 de agosto de 1983, en la que intervinieron las tres autoras. "Diversas entidades y personas se interesaron antes y después de dicho evento por tener acceso permanente a la valiosa investigación”, explica la institución editora en el prólogo firmado el 19 de noviembre de 1983: "Creemos dar respuesta a esa inquietud con esta publicación, siendo el deseo de la Asociación que la misma constituya un nuevo aporte al acervo historiográfico de La Plata, y un modesto homenaje al nuevo aniversario de su acto fundacional". Por su parte, las autoras aclaran que su exposición "resulta de síntesis esencial de parte de un trabajo de mayor envergadura: Centenario de la ciudad de La Plata 1882-1982. Paseo Histórico, realizado bajo la dirección del Dr. Horacio Juan Cuccorese con el auspicio de la Facultad de Humanidades", con "la participación de más de 30 profesores". Todavía se consideraba a ese libro "en vías de publicación” (Girbal, Durán y Giuliano, 1983: 3). En la contratapa, junto a un breve currículum de cada autora, se desagrega qué parte había desarrollado cada una: Noemí Girbal de Blancha, Bancos Oficiales de La Plata; Claudia Durán, Banca Privada Platense; Ethel Giuliano, Banco Municipal de La Plata.
} 
Historia del Banco Municipal tiene una tapa azul ilustrada con una imagen del Banco y consta de 161 páginas. Si bien podría haber sido mencionado entre los municipales, su institucionalidad más específica -incluye la nómina de autoridades del Banco, no de la Municipalidad, y su prologuista es el presidente de la entidad- nos permite incluirla en otro grupo de iniciativas editoriales, impulsadas por entidades financieras con sede en la ciudad.

Una de ellos es Vida espiritual en La Plata (de ahora en más, Vida espiritual), un libro compilado por Roy Bartholomew ${ }^{68}$ para la colección "Panorama de la Argentina", una serie de libros cortos que impulsaba la Fundación Banco de Boston en 1982, fuera de circulación comercial $^{69}$. Esta edición se pautó para ser repartida gratuitamente "en los colegios primarios platenses y en el Museo Dardo Rocha"70.

Bartholomew reúne una serie de escritos para mostrar "la intensidad espiritual con que La Plata ha brindado escenario propicio para la especulación filosófica, la creación artística, la crítica formadora, con lírica propia y el pensamiento abierto al entero proceso de la cultura", destacando así un puñado de personalidades significativas, como veremos en el capítulo VI. El adjetivo "espiritual" para referir a esos campos de producción de sentidos tiene un antecedente en otro librito previo sobre la ciudad: Historia espiritual de La Plata (Font, 1951; con grabado de Francisco de Santo) ${ }^{71}$.

El compilador de Vida espiritual advierte que "no se trata de escritos sobre La Plata de autores nacidos en La Plata -mi ciudad-, sino de páginas dignas de recordación, de permanente interés y constante docencia, ligadas a la historia de la ciudad" (Bartholomew, 1982: 7). La compilación tiene formato de libro, aunque es un texto breve, de 32 páginas y tapa blanda (como cartulina), ilustrada por Raúl Alonso. Está impreso en julio de 1982 y explicita que se trata de una "publicación dedicada a la ciudad de La Plata, con motivo del Centenario de su fundación". La introducción del autor, que está firmada en Adrogué, el 30 de octubre de 1981, saluda la "feliz iniciativa de la Fundación Banco de Boston de dedicar una de sus publicaciones a La Plata", que "llega en momento oportuno: estamos en vísperas del centenario de la fundación por Dardo Rocha..." (Bartholomew, 1982: 5).

Igual que la edición del Boston, La ciudad de las calles numeradas (en adelante, Calles numeradas) de Ricardo Massa se define como una edición "fuera de comercio", realizada por el Banco Platense "en homenaje al año del Centenario de la Ciudad de La Plata". Está impresa en papel satinado, con fotografías a color del propio autor. Se trata de un libro de poemas -uno de ellos, el del título-, vinculados explícitamente a la ciudad, cuyo análisis exhaustivo como tales excede a esta tesis. Lo incluimos en esta mirada general porque se auto-inscribe en el "Centenario de la ciudad de La Plata / Símbolo de Unidad Nacional" (Massa, 1982: s/n) y

\footnotetext{
${ }^{68}$ Es un profesor de letras que hacia 1980 colaboró con la edición de Siete noches, una serie de conferencias de Borges. Fue director de la Radio Universidad en 1977, después de Pedro Mario Albarracín (1976) y antes de Jaime Sureda (1978) y José María Marquínez (1978-1979), tres personas que también participan en publicaciones del centenario (Katz, 2004: 446).

${ }^{69}$ No he podido confirmar la continuidad de esta colección ni precisar la lista de libros publicados, que incluyó El diario de una mujer en las Malvinas -María Saenz de Vernet- , de Nicolás Cocaro (41 páginas) y Chaco, de Juan Cicco con ilustraciones de Carlos Cañas (31 páginas), ambos en 1982. El libro sobre La Plata disponible para su consulta en la Sala La Plata de la Biblioteca Pública de la UNLP fue donado por el propio Banco.

70 "Un libro sobre La Plata para las escuelas primarias". El Día, 5 de noviembre de 1982, 2ª sección, pág. 5.

${ }^{71}$ Asociado a la idea frustrada de un "Museo Almafuerte", el libro repasa una serie de personalidades de la ciudad cultural/universitaria. Rasgo propio de los relatos locales, incluye muchos nombres, alusiones a las familias platenses y referencias instituciones. En un tono nostálgico evoca la calle 7, carnavales, "las novias fieles", "la ciudad apasible", con notas similares a las que encontraremos en varios libros del centenario.
} 
comparte caracteres que veremos y analizaremos en detalle en los textos principales: un tono patriótico y celebratorio de la ciudad ("No se fundó. La gestaron a caballo de la Historia"), la reivindicación del trazado ("Como el perímetro en Roma / O como Atenas, pensada / entre exacta y luminosa..."), la presencia de referencias religiosas, y una inscripción personal ("tiene el nombre de mi infancia"), propia de un grupo significativo de libros que construyen sentidos sobre el pasado platense a partir de una narración biográfico-testimonial. Es el caso, por ejemplo, de los libros de Jaime Sureda, Miguel Szelagowski y Federico Christmann.

\section{Ramos Americana}

A través de la editorial Ramos Americana, Jaime Sureda publica en 1982 La Plata. La edad de mi infancia (en adelante, Edad de mi infancia). Como sugiere el título, es un texto elaborado con un tono personal, pero fue considerado desde un principio como parte del corpus por abordar - a su modo- la historia platense, y en particular porque incluye la inscripción “Adhesión al Centenario de La Plata. Capital de la Cultura 1882-1982”.

Según el autor, lo personal -que incluye la indagación del origen familiar- es una mediación para hablar de una época: "No he querido destacar nada propio en estas páginas, sino dar cuenta de cosas, costumbres y personas que contribuyeron a hacer la ciudad que es actualmente La Plata. Simplemente viviendo" (Sureda, 1982: 9). Periodista y escritor de larga trayectoria, Sureda aborda centralmente los años '20 a través de semblanzas y anécdotas en las que predomina una mirada nostálgica: "todo el mundo era amigo", "todo el vecindario se conocía" (Sureda, 1982: 11). Dedica el libro a "mis inolvidables amigos de la infancia, aquellos chicos de mi barrio con los que jugué tanto y me hicieron tan feliz".

El testimonio de Sureda abarca el recuerdo de los tranvías y el escaso tránsito vehicular, los juegos en la calle y la vereda, el carnaval, la vigilancia nocturna, las visitas célebres a la ciudad, etcétera. Asimismo produce un mapeo socio-cultural interesante de distintos espacios: cines, teatros, las sastrerías, casas de fotografía, los vendedores ambulantes, las librerías, las casas de remate, las barberías-peluquerías, los prostíbulos o casas de tolerancia, los cafés, las casas de música. Particularmente en algunos de estos capítulos -y a comparación de otros libros de la época- tiene una redacción amena, sencilla, no sobrecargada de adjetivos. Construye relatos a partir de anécdotas pero logra una rica descripción de lo cultural, que dista de la típica enumeración de poetas y orígenes de instituciones.

Debemos dedicar unas líneas de este panorama a Ramos Americana, que además del testimonio de Sureda sella tres de los "Documentos de Avance" del equipo de Morosi y dos libros a los que nos referiremos más adelante: uno de Szelagowski y otro de Estanislao de Urraza, coeditado con el Colegio de Abogados local. Se trata de una empresa familiar ${ }^{72}$, vinculada a la Librería Contemporánea de La Plata, de la que encontramos títulos publicados entre 1980 y 1987, en especial en los primeros años ochenta ${ }^{73}$. Uno de los libros de Cipriano

\footnotetext{
${ }^{72}$ Los hermanos Ramos eran "unos gallegos maravillosos, de Santiago de Compostela, que trabajaban por la cultura como pocos", según recuerda uno de los autores que publicaron en los '80, que pude contactar por correo electrónico. La librería estaba ubicada en 49 N 707 (entre 9 y 10). "Allí conocí a Luis Aguilé, a Cipriano Reyes, a Facundo Cabral, en fin, a algunas docenas de autores y protagonistas del acervo cultural de nuestro país".

${ }^{73}$ Entre ellos identificamos: Mi sermón de la llanura, de Cipriano Reyes; Al badajear del cencerro (1980) y De sangre y pampa (1981), ambos de Carlos Risso; Los incas del Illasuyu, de Rodolfo Raffino (1981), bastante citado en su campo académico; El otro frente de la guerra. Los padres de las Malvinas, de Dalmiro M. Bustos (1982); Un juguete en las manos, de Ricardo Miguel Zuccherino (1983); Ceremonia Diurna, de Osvaldo Ballina y prologado por Gabriel Báñez (1984). Poco más tarde ideará una edición de distribución gratuita también
} 
Reyes, el dirigente sindical partícipe de los inicios del peronismo, lleva ese sello ${ }^{74}$. En 1982, además del libro de Sureda, Ramos Americana publica El otro frente de la guerra. Los padres de las Malvinas, del psicólogo Dalmiro M. Bustos. Con 219 páginas que incluyen cartas y relatos, el libro es producto de reuniones del grupo de padres de soldados de la ciudad de La Plata -Bustos es uno de ellos-. Aunque no es su tema específico, la edición incluye la inscripción "En adhesión al Centenario de La Plata Capital de la cultura, 1882-1982”.

Otro que aparece ese año es Si yo fuera intendente, un libro de semblanzas y anécdotas de Miguel Blas Szelagowski (1982). El título del libro recupera un slogan de la campaña de las elecciones de 1963 en las que el autor fue efectivamente elegido intendente, cargo que ocupó hasta el golpe de junio de 1966. El relato que denomina "suerte de crónica municipal" (Szelagowski, 1982: 8) está centrado en su experiencia al frente de la gestión local, considerada una "etapa excitante", "los mejores años de mi vida, en los que me sentí más a gusto..." (Szelagowski, 1982: 116). El mismo autor había publicado tres años antes otro libro testimonial, La Plata, los años veinte (de ahora en más, Años veinte) ${ }^{75}$, donde la trayectoria política queda de lado. Centrado en su niñez, abarca tópicos de su historia familiar, los trabajos y oficios, vacaciones, los juguetes, la puntualidad, el cimbronazo del ‘30, la vida escolar, la fisonomía de las calles y del barrio, la buena vecindad, los viejos comercios de la ciudad, las festividades, las piletas, la vida social del Jockey Club, los cines, etcétera. La lectura resulta muy similar a la del texto -posterior- de Sureda, por el estilo, la época abarcada y una búsqueda en común: "Este inventario de recuerdos no pretende ser una autobiografía sino que encierra el propósito, seguramente no del todo logrado, de mostrar una época platense a través de la vida de un niño a quien le gustaba, posiblemente más que a otros, mirar su Ciudad", plantea el autor, y en el colofón del libro agrega:

"A las crónicas de las ciudades debieran sumárseles los pequeños episodios de sus habitantes. Que en su conjunto darán explicación a un estilo de vida y sus variaciones en el tiempo. La historia será más vivida, menos fría, comprensible. Servirá, en cierta medida, para que los gobernantes locales sepan qué quieren sus gobernados..." (Szelagowski, 1979: 9, 95).

En la época también se publica ¿Será justicia?, con textos y dibujos de Szelagowski, que no tiene indicaciones precisas de fecha pero, por las referencias del texto, es posterior a $1979^{76}$. Escrito en primera persona y estructurado en quince partes, busca "pintar personajes" del ámbito judicial a partir de su propia experiencia. Dedica el libro "a la memoria de quien me introdujo en ese mundo de la justicia, un juez que conocí bien, mi padre". Retomaremos algunos tramos de este libro en el capítulo VI, a la hora de caracterizar la lectura del autor sobre algunos períodos de la historia política argentina. Esta publicación fue financiada por el

\footnotetext{
dedicada a la ciudad, con la excusa del $75^{\circ}$ aniversario del Banco Crédito Provincial, donde se retoman varios textos del centenario platense (Paladini y Filosso, 1986).

${ }^{74}$ Además del libro publicado en sus tiempos de dirigente político (¿Qué es el laborismo?: Exposición de las ideas que forman la base ideológica, Ediciones R.A., Buenos Aires, 1946), Reyes publica Mi sermón de la llanura (Ramos Americana Editora, 1980), Yo hice el 17 de octubre (Centro Editor de América Latina, 1984) y La farsa del peronismo (Sudamericana/Planeta, 1987). Tras protagonizar el 17 de octubre de 1945, Reyes se volvió un adversario del gobierno peronista y pasó 7 años en prisión, hasta el golpe de 1955. En 1982 encontramos su nombre entre los integrantes de la Comisión Directiva de la SADE La Plata.

${ }^{75}$ En rigor, este libro - que había sido incluido tentativamente en el plan de tesis- no forma parte del grupo más específico de bibliografía del centenario. Es previo y no hace referencia a la proximidad del aniversario. Lo mantendremos en el corpus, no obstante, por la relevancia que adquiere el autor en la coyuntura, designado por la Municipalidad el "cronista oficial del Centenario".

${ }^{76}$ El ejemplar que está en la Biblioteca de la Universidad fue donado por el propio autor en junio de 1982.
} 
Colegio de Abogados (Departamento Judicial La Plata), una de las entidades profesionales que participa del desfile editorial de 1982.

\section{Los grupos profesionales}

Otro libro semejante en el tipo de escritura es Vivencias y testimonios (de mis últimos 80 años) (en adelante, Vivencias y testimonios), escrito por Federico E. Christmann y publicado por la Agremiación Médica Platense. Esta referencia nos introduce a un grupo de libros realizados por iniciativa de corporaciones profesionales, "en adhesión al Centenario de la Fundación de la ciudad de La Plata”, como se explicita en el de Christmann, impreso en los talleres gráficos de la propia agremiación ${ }^{77}$. Escrito entre mediados de 1980 y mediados de 1981, el texto se convierte en libro en el año del centenario, con 363 páginas ${ }^{78}$ y organizado en 17 capítulos relacionados con lugares, personas influyentes y etapas de la vida del autor, que se suceden cronológicamente hasta el "retiro profesional". Como ya dijimos, dos de ellos -los primeros- están integrados en el volumen Ciudad milagro.

Los capítulos arrancan con citas breves que exhiben la sapiencia del autor -Prevost, Ritcher, San Agustín, Coleridge, Fouillée, Quevedo, Montaigne, Hebbel, Lacordaire, Voltaire, Leibnitz, Sarmiento, Wilde y Ortega y Gasset- y están escritos en primera persona. En suma, construyen un relato completamente centrado en el autor: así, la identificación de cada parte no se entiende sino a partir de su vida; por ejemplo, cuando habla del "período europeo". Se trata entonces de un texto sobre vivencias de una persona muy asociada a La Plata -que por lo tanto se permite inscribir su testimonio en el marco del centenario de la ciudad-, pero no una historia de La Plata. De fondo aparecen temas de la historia urbana: los cambios de fisonomía, el desarrollo del transporte, la nevada de 1918, los paseos por el Bosque, la construcción de la Universidad nacional y el origen de la enseñanza médica en la Plata, entre otros. Además, el texto está marcado por la identidad profesional del autor. Las primeras líneas del libro cruzan la condición de libro de memorias con una referencia profesionalmédica: "Dicen los pediatras que el niño comienza a memorizar y fijar sus conocimientos y experiencias a partir de los tres años. Entre los tres y los seis es lo normal. Puedo certificar que la cosa es así analizando mis primeros recuerdos que se remontan hacia fines del año 1902, justo cuando acababa de cumplir cuatro años de edad..." (Christmann, 1982: 1). Del mismo modo, al citar el libro de Florencio Escardó, no dejará de señalar en una nota al pie que el historiador y dramaturgo es "abuelo de nuestro distinguido colega pediatra, neurólogo y escritor” (Christmann, 1982: 5).

El libro producido por una entidad colegiada que más plasma la identidad profesional en sus páginas es el que publica el Consejo Profesional de la Ingeniería de la Provincia de Buenos Aires en adhesión al centenario: La acción profesional en la fundación de La Plata (en adelante, Acción profesional). Con 160 páginas, impresas también en talleres propios, la portada interior afirma que es una edición especial y, según remarca el autor, es iniciativa del Consejo. Claramente es un libro institucional:

“...este Consejo propició la realización de una reseña general de la actividad profesional en los momentos previos a la fundación del 19 de noviembre de 1882 .

\footnotetext{
77 También se indica, que el autor dispuso ceder los derechos correspondientes a la Fundación Pedro Belou para el Apoyo de la Facultad de Ciencias Médicas de la UNLP -institución de la cual Christmann era presidente-.

${ }^{78}$ Además, trae dos hojas sueltas: la primera con un índice titulado Guía para el lector (el libro no traía sumario), y la otra con fe de erratas.
} 
En ella se aprecia algo que debería ser una constante en trabajos de dicha envergadura: la intervención profesional de diversas disciplinas para el logro de una empresa común" (Tartarini, 1982: 7)

Cabe advertir que hay un libro antecedente, realizado por iniciativa estatal en la época del cincuentenario de la ciudad, y que aparece en la bibliografía de Tartarini: Profesionales que intervinieron en la fundación de La Plata (Comisión..., 1935) ${ }^{79}$. No cabe duda que esa publicación fue una fuente fundamental para la del Colegio de Ingenieros.

Por su parte, la Sociedad de Arquitectos ${ }^{80}$ edita para el centenario una Guía Turística titulada La Plata 100. Tiene 75 páginas, un formato cuadrado, de aproximadamente 20 centímetros por 20 , ilustrada con fotos y dibujos. Si bien se presenta como una guía para la recreación, con referencia a "puntos de interés" y "direcciones útiles", también incluye una introducción histórica y, en cada sitio, apartados titulados "Un poco de historia".

Los autores del trabajo de recopilación y textos de La Plata 100 fueron Nelba Benítez, Alfredo Conti y Roberto Cortés. Por otra parte, la guía incluye planos realizados por Fernando Tauber, Andrés Lecich y Américo Gómez Medina, y fotografías de Raúl Bisocoli que también participa como fotógrafo en Crónicas de un siglo.

Además de los "circuitos dentro del Casco Urbano" la guía menciona otros, que incluyen Tolosa, Gonnet, City Bell, Villa Elisa, Parque Pereyra, Melchor Romero, Abasto, Lisandro Olmos, Etcheverry, Los Hornos, el Cementerio, Berisso, la Isla Paulino, el Puerto La Plata, Ensenada, Punta Lara y Magdalena. Como veremos más adelante, tales inclusiones significan un aporte de esta publicación, que está ausente en muchas bibliotecas y que quedó sub-catalogada en la condición de guía útil para el turista.

La Sociedad de Arquitectos, cuya historia se remonta a mediados de los '50, tuvo siempre un perfil menos conservador que el Consejo Profesional de la Ingeniería, al que no obstante debían recurrir para matricularse. Según Hugo Fontana, la Sociedad fue

"muy permeable a lo extra profesional. En particular, en los 60 y los 70, cuando buscábamos la identidad y la autonomía de la profesión, no sólo por autodeterminación sino porque el modelo de organización profesional que pretendíamos se diferenciaba ideológicamente en forma sustancial del modelo burocrático, centralista y conservador como era el Consejo Profesional de la Ingeniería. Nuestra carrera se caracterizó por haber tenido desde siempre mucho debate interno; las repercusiones de la actualidad social y política eran cotidianas y estaban siempre arriba del tablero. El ejercicio de la arquitectura está permanentemente afectado por la problemática social; creo que esto condiciona la mentalidad de los arquitectos y, por ende, el compromiso de sus entidades profesionales" (en Artigas, 2011: 88-89) ${ }^{81}$.

\footnotetext{
${ }^{79}$ Es un libro muy formal, de 358 páginas, que inicia con las “actuaciones del expediente..." que designa una comisión para la elaboración del informe, pocos días después del festejo del cincuentenario. Luego hace una muy detallada lista de los profesionales intervinientes en las distintas tareas, indicando nombre, función y fecha del decreto de designación. El libro contiene luego: Antecedentes; Reseña sobre el trazado de la Ciudad; Indice alfabético de las personas investigadas; Texto de la documentación consultada ordenada cronológicamente. Más allá de la producción propia de la comisión, hay mucha transcripción de decretos y proyectos de ley.

${ }^{80}$ En 1982 aún no se había constituido el Colegio de Arquitectos y el ámbito de matriculación de esos profesionales era compartido con los ingenieros. Tal es así que entre la nómina de autoridades del Consejo de Ingenieros (en Tartarini, 1982), se pueden encontrar algunos profesionales con título de arquitecto. La Sociedad nació en 1956, cuando aún no había graduados de la carrera de Arquitectura local. Algunos años utilizó el nombre Colegio, sin serlo, con la expectativa de obtener la colegiación independiente del Consejo Profesional de Ingeniería, del que logró autonomizarse recién en 1986.

${ }^{81}$ La sede de la Sociedad -comprada con préstamos personales hacia 1978- fue el sitio donde empezaron a reunirse las madres de Plaza de Mayo.
} 
Sin embargo, no por ello la encontramos completamente desvinculada de las publicaciones más próximas al gobierno de facto. Cabe mencionar que además de elaborar la guía turística, la Sociedad de Arquitectos organiza en 1982 el concurso "La Plata Dibujada". El trabajo ganador de ese certamen, realizado por las mismas tres personas a las que se les atribuye los planos de La Plata 100, es publicado en las primeras páginas de Ciudad milagro, después del prólogo y antes del primer capítulo. Titulado "Las puertas de La Plata", sintetiza en una misma imagen los frentes de los principales edificios del eje cívico de la ciudad, a partir de rasgos característicos montados sobre una trama que no es otra cosa que el plano del casco urbano de la ciudad.

Otra asociación que participa de la conmemoración con una producción editorial "en homenaje" 82 es la Sociedad Argentina de Escritores-La Plata, que publica mil ejemplares de 12 personalidades del siglo (en adelante, 12 personalidades), con su sello Ediciones Almafuerte. Ya habíamos apuntado una participación relevante de una entidad corporativa de escritores con Ciudad milagro: en ese caso, la sociedad provincial, aliada al gobierno bonaerense, produjo uno de los libros más voluminosos. SADE es otra entidad, que las historias políticas de la dictadura desde una perspectiva nacional han señalado próxima al régimen de Videla, por la participación de su titular Horacio Ratti en los almuerzos convocados por el presidente de facto en mayo de 1976. Cabe aclarar, no obstante, que la institución tiene una lógica des-centralizada:

"Esta sociedad que agrupa a los escritores de La Plata, Berisso y Ensenada -se apunta en la solapa del libro reseñado- nació como filial de la S.A.D.E. nacional (cuya sede está en la ciudad de Buenos Aires) lo mismo que las demás filiales que existen en el país. Con el transcurso de los años, la experiencia hizo aconsejable dotar a esas unidades dependientes de una autonomía total que favoreciera su desarrollo y les permitiera tener bienes inmuebles a su nombre y consolidar su acción..." (SADE La Plata, 1982) ${ }^{83}$.

El libro es una compilación de biografías, con una estructura clásica: son relatos de vida cronológicos, oficiales, que narran una vida pública intercalada con algunos datos personales y familiares de las figuras en cuestión. Los homenajeados son, siguiendo el orden de aparición en la publicación: el dirigente político Ricardo Balbín -por entonces recientemente fallecido-, el médico y profesor Pedro Belou, el artista plástico Atilio Boveri, el abogado radical Jacinto Calvo, la profesora Juanita Cortelezzi, el bibliotecario y escritor Ismael Dozo, el periodista Ramón García, el ingeniero Enrique Humet, la cantante Lola Julianez Islas, el filósofo Alejandro Korn, el jurista David Lascano y el abogado y escritor Estanislao de Urraza.

Cada texto tiene un autor diferente, y el conjunto no tiene una unidad formal: incluso los títulos tienen distintos estilos -en algunos casos es sólo el nombre del homenajeado, en otros casos están presente expresiones como "semblanza" o "vida y obra", y en otras definiciones personales como "un periodista ejemplar". La edición de la sociedad nacional/local de escritores fue "preparada, coordinada y vigilada por Irene Ene (nombre literario de la Dra.

\footnotetext{
${ }^{82}$ La portada interior indica: “1982. Año del Centenario de la Ciudad de La Plata”, y en otras cuatro líneas: "12 personalidades del siglo / SADE La Plata / En su homenaje al centenario de la ciudad / 1882 noviembre 1982”. ${ }^{83}$ Dichas filiales, convertidas en secciones independientes, se nuclean en una federación de sociedades. En el libro, SADE La Plata asegura tener más de 200 socios. En la época contaba con un espacio radial en Radio Universidad y organizaba diversos actos públicos, uno de los cuales contó con la participación de Borges.
} 
Amalia Alcoba Martínez) ${ }^{\text {,84 }}$, ex directora de la Revista del Colegio de Abogados y autora de trabajos jurídicos, críticas literarias y libros de poesía.

Con 12 personalidades, SADE La Plata entiende que cumple "un deber cordial [...] mediante la evocación de un grupo de personas descollantes, da una imagen aproximativa de los valores humanos que constituyeron los primeros núcleos de la población platense" (SADE La Plata, 1982: 12). Escribe Alcoba Martínez en el breve prólogo:

"[...] Una de las más genuinas formas de celebrar una fecha histórica es, por cierto, evocar a esas personalidades que dejaron claros ejemplos de conducta y descendencia formada en el ambiente del hogar virtuoso, ya que son ellas las destinadas a proseguir siendo las huestes del Bien, en nuestro mundo.

Todo este año se está celebrando en La Plata el centenario de la fundación de esta ciudad, capital de la provincia de Buenos Aires. Con tal motivo, muchos son los homenajes que se están rindiendo y se van a rendir tanto al fundador cuanto a su equipo de gobierno, técnicos y políticos que participaron en tan magna creación, la cual, en su crecimiento a través de la centuria, ha superado las más atrevidas predicciones que se hicieran a su respecto. Es una buena oportunidad, pues, para destacar a hombres extraordinarios que llevaron a cabo empresas relevantes en la ciudad, durante este siglo, propendiendo a su armonioso desarrollo intelectual y moral y dejando una estela brillante en el ámbito de sus actividades. Con este criterio, la Sociedad Argentina de Escritores, SADE, La Plata, se adhiere a los festejos del centenario presentando este libro: 'PERSONALIDADES DEL SIGLO', donde se han reunido estudios y crónicas sobre doce figuras importantes que desenvolvieron su acción, durante los últimos cien años, en nuestra ciudad y cuyas vidas y obras presentan características dignas de ser mostradas, por ejemplo, a las nuevas generaciones" (SADE La Plata, 1982: 10)

En la época también hubo una iniciativa de producir un libro titulado Los cien escritores del centenario, impulsado por la misma SADE La Plata, Peña de las Bellas Artes de la Provincia de Buenos Aires, la Municipalidad de La Plata y la Federación de Instituciones Culturales. El mismo era responsabilidad de Susana Mabel Cantero, secretaria de la editorial, quien colabora con la dirección artística de 12 personalidades. Sin embargo no se encontró ningún registro de esa edición, que debe haber quedado trunca como Paseo histórico.

12 personalidades, en tanto, tiene puntos de contacto con otros libros del centenario. Varios de los autores de capítulos -y también su diagramador- participan de otras publicaciones (especialmente, Ciudad milagro). En el caso de Federico E. Christmann, su homenaje a Pedro Belou ${ }^{85}$ está planteado también en su propio libro, del que ya vimos cómo un fragmento pasa a integrar la compilación impulsada por la SEP y el gobierno provincial.

La publicación está editada por el sello propio de SADE La Plata, Almafuerte, cuyo origen no he podido precisar, pero que encara varias ediciones en los primeros años '80, dos de ellas en explícita adhesión al centenario ${ }^{86}$.

\footnotetext{
${ }^{84}$ Asimismo, se adjudica la responsabilidad por la diagramación y dirección artística al escritor Francisco Guerrero, con la colaboración de la secretaria de la editorial, escritora Susana Mabel Cantero.

${ }^{85}$ La reivindicación de Belou tiene que ver con el origen de la carrera de medicina local. En rigor, el anatomista y profesor de origen uruguayo nunca vivió en La Plata. Entre otras cosas, el artículo señala que su nombre fue elegido para designar a una Fundación destinada a apoyar materialmente las cátedras de la Facultad, de la que Christmann es presidente (SADE La Plata, 1982: 33).

${ }^{86}$ En 1980 edita Treinta mil años con los pies en la tierra, de José Alfonzo, un libro de 97 páginas sobre la figura humana en el arte escultórico, citado en uno de los textos que forman nuestro corpus (Nessi, 1982). De 1983 identificamos dos títulos: El anfora del rey, con poesías de Nélida Carrillo -141 páginas- y Castrenses. Origen, actuación y ocaso del militarismo internacional (Síntesis de 5000 años), de Julio Anselmino Rica, autor que participa en Obra de arte y Ciudad milagro, volumen cuya idea original impulsó. De este último consta una segunda edición en 1984. A posteriori, la iniciativa editorial de Almafuerte parece discontinuada, aunque es
} 
La segunda de ellas es La Plata y su gente. Primeros habitantes (de ahora en más, Primeros habitantes), de Mary Terrasa, que en la portada interior incluye como una suerte de segundo subtítulo, la expresión Homenaje al Centenario. Su sello editorial no es casual: Terrasa integra -como vocal suplente- la comisión directiva de SADE La Plata. El libro tiene un tono igualmente celebratorio: señala que la fundación de la capital "fue una idea de avanzada" (Terrasa, 1982: 23) y se apoya en referencias habituales de la bibliografía platense, como el hecho de haber sido la primera ciudad iluminada con luz eléctrica (Terrasa, 198: 24). "La nueva ciudad significó la transformación económica y cultural de la provincia de Buenos Aires. Erigida en un lugar estratégico, de ella partieron distintos caminos hacia otras zonas de población" (Terraza, 1982: 24). El libro está fragmentado en textos breves, de 2, 4, 8 páginas. El contenido del libro no se corresponde con lo que sugiere el subtítulo. Más bien apunta a caracterizar una ciudad educativa, cultural y sabia, vinculada al arte, de la que exalta algunos personajes históricos y sobre todo una serie de poetas, puestos en el centro de esa "ciudad del arte y la cultura" junto al teatro y la ciencia, como veremos más adelante.

Primeros habitantes está ilustrado con xilografías de Francisco De Santo "en su homenaje" y viñetas del artista Roberto Pinto Álvarez. La primera imagen (reproducida en tapa) representa a la Catedral platense. También hay xilografías del Palacio Municipal, el edificio de la Universidad, el Observatorio, el Teatro Argentino, la Legislatura y el Palacio de Justicia. El prólogo (portal) contiene algunas presentaciones muy breves firmadas por Lázaro Seigel, Héctor Rivera, María Judith A. de Pozzio y Aglaé D’ Sylva. Son reseñas elogiosas, incluso una termina diciendo "Auguro a la escritora un éxito total: muy merecido" (de Pozzio, en Terraza, 1982: 10).

Hay partes escritas en primera persona, donde la autora evoca específicamente su relación o su recuerdo sobre los personajes o instituciones que nombra. En la parte titulada "La Plata Ciudad de arte y cultura" (páginas 41 a 96), dedicada a "escritores, poetas y artistas plásticos en la ciudad de las diagonales", la autora dedica el primer lugar a su madre, Micaela Mestre de Terrasa, de quien transcribe un breve poema inédito ${ }^{87}$.

La última parte del libro, titulada "La Plata y la ciencia", además de sumamente fragmentaria en sus referencias, resulta a su vez muy ilustrativa de los sectores sociales que destaca en su visión sobre la cultura platense. Las primeras cuatro páginas están dedicadas a la Facultad de Ciencias Médicas; son sumamente elogiosas y concluyen mencionando a su decano, el Dr. Manuel Sergio García Mutto, que "es a la vez presidente de la Cruz Roja filial La Plata". Otras cuatro páginas, bajo el subtítulo "Protección y conservación de la naturaleza", son un homenaje al doctor Hosmar Doher Peralta Bergna, egresado de la Facultad de Veterinaria, profesor de la UNLP y oficial veterinario en el Ejército Argentino, dedicado a temas de ecología. Finalmente aparece una larga referencia a la Universidad Notarial Argentina (UNA), universidad privada que inició sus cursos en 1965, "siendo la primera y única Casa de Altos Estudios volcada totalmente a la enseñanza de post-grado en el nivel cuaternario" (citado en Terrasa, 1982: 124).

posible encontrar referencias a libros publicados con ese sello en 1977, 2000 y 2009. En tanto, en 2010 era mencionada en las bases del Certamen Nacional Literario "La UCR, la Fuerza del Pensamiento" como la editorial que publicaría los trabajos ganadores.

${ }^{87}$ Esta evocación aparece en la página 40, entre la portada de esta parte y su inicio. Está firmada, aunque corresponde a la autora. Cabe decir, asimismo, que Terrasa dedica el libro a su hijo fallecido el año anterior. 
Primeros habitantes concluye con esas poco más de seis páginas dedicadas a la universidad creada por el Colegio de Escribanos de la Provincia de Buenos Aires, señalando sus objetivos, los títulos entregados, su "vasto programa de divulgación cultural" y sus principales referentes. Aparece en primer lugar el Dr. Tomás Diego Bernard, quien ocupa el cargo de Rector desde 1978. Su apellido aparece mencionado doce veces en cuatro páginas.

Cabe señalar que dicho Colegio es otro de los grupos profesionales presentes en el panorama editorial del centenario. En general lo hace a través de la Universidad Notarial, de la que hallamos tres publicaciones, dos de ellas firmadas por el propio Bernard.

La primera es una publicación breve, de 25 páginas, titulada Homenaje al Centenario de la Fundación de La Plata (de ahora en más, Homenaje de la Universidad Notarial) que compila presentaciones públicas realizadas el 27 de abril de 1982 en un acto organizado por el Instituto de Historia del Notariado:

"El acto realizado en la sede de la UNA en La Plata, avenida $51 \mathrm{~N}^{\circ} 435$, en homenaje al Centenario de la Fundación de la ciudad, fue presidido por el rector de la casa de altos estudios, Prof. Dr. Tomás Diego Bernard, asistiendo entre otros invitados especiales el Sr. Intendente Municipal de La Plata, Dr. Abel Blas Román, acompañado del Secretario del Departamento Ejecutivo, Dr. Mario Morelli; el Sr. Carlos A. de la Fuente, en representación de la Federación de Instituciones Culturales y Deportivas del Gran La Plata; miembros de número y adscriptos del Instituto oferente y profesionales alumnos de las cátedras de derecho notarial y de técnica notarial del UNA" (VV.AA. ,1982b: 7)

En esa ocasión disertaron el subdirector del instituto, José Armando Seco Villalba ${ }^{88}$; una miembro de número, la Dra. Leonor Frencia de Valiente; y la Directora del Museo y Archivo 'Roberto M. Arata' de la UNA, Dra. Dora C. Tálice de Seco Villalba. La compilación incluye esos tres textos, de 4, 3 y 9 páginas respectivamente. El trabajo de Seco Villalba, "Historia y estética de La Plata", se concentra en la fundación de la ciudad. Sostiene que el acto "se cumplió dentro de un espectáculo grandioso" y transcribe partes del "hermoso discurso que pronunció el Gobernador al colocar la piedra fundamental, lleno de patriotismo, de sabiduría política y de un optimismo fecundo y promisor" (en VV.AA., 1982b: 10). El texto de Frencia es el más breve y refiere al escudo de la ciudad. Finalmente, Tálice plantea una "Crónica retrospectiva de la fundación de La Plata" que recorre tópicos frecuentes en este tipo de relatos: la comisión abocada a definir la ubicación, los trabajos febriles de la fundación, la organización de los actos, el viaje en ferrocarril y una caracterización de la escena de 1882.

Además, la Universidad Notarial realiza las dos publicaciones firmadas por su director Tomás Bernard que ya hemos mencionado. Por un lado, la edición independiente de un texto que -además- está al inicio de Ciudad milagro (Bernard, 1982a). Por otro, su intervención en el Ciclo Cien años, "Una vieja amistad con los Rocha" (de ahora en más, Vieja amistad) organizada en nueve partes y presentada desde un lugar vivencial: hablará de "estampas" de su "terruño natal", en relación a un "pasado cercano" (Bernard, 1982b: 13) ${ }^{89}$.

Por otra parte, en una iniciativa que excede al recorte de nuestro corpus, el Colegio de Escribanos promueve la reedición de la Poesía completa del escritor platense Roberto Themis

\footnotetext{
${ }^{88}$ Años antes, Seco Villalba se había desempeñado como Director del Museo y Archivo Dardo Rocha.

${ }^{89}$ También cabría mencionar a la Revista del Colegio de Escribanos de la Provincia de Buenos Aires. En su número 867 (1983) publica "La Plata en la Exposición Universal de París de 1889", de Julio Morosi, producto de una conferencia realizada en el Colegio el 17 de noviembre de 1981 (reproducida en Morosi, 1999: 51-61).
} 
Speroni, que había salido originalmente en 1975 realizada por el Ministerio de Educación bonaerense, justamente durante la gestión de Tomás Bernard al frente de esa cartera. Con la fecha del centenario y un auspicio económico de la Municipalidad, la corporación profesional imprime 5.000 nuevos ejemplares del libro de 459 páginas cuidado por Ana Emilia Lahitte, incorporando un prólogo del intendente, para quien no es casual el "encuentro de poesía" que se produce entre el Colegio Profesional y el Municipio. En tanto, el escribano Luis María Bordenave escribía como presentación:

"El Colegio de Escribanos de la Provincia de Buenos Aires adhiere, con la presente reedición de la obra poética de Roberto Themis Speroni, a las honras del primer centenario de la fundación de La Plata. Entiende que el mejor homenaje que puede tributarse a la Nueva Capital es dar prevalencia a su espíritu, a la cultura que supo generar desde los días augurales y a la tradición poética que signó su destino. Que no en vano la fundación advino como pacto solidario de reconciliación, paz y progreso, al buscado amparo de las letras, las ciencias y las artes, en su privilegiada condición de urbe universitaria" (en Speroni, 1982: 11-12)

Finalmente, otra corporación profesional que impulsa una publicación en el centenario es el Colegio de Abogados-Departamento Judicial La Plata, con el libro La Plata Ciudad de Mayo (a partir de ahora, Ciudad de mayo), de Estanislao de Urraza. Iniciativa del Colegio, se trata de una coedición junto a Ramos Americana Editora, sello que como vimos participa de otras iniciativas en torno al aniversario platense. En la primera página posterior a la que incluye los datos de edición se puede leer la inscripción: EDICIÓN EN HOMENAJE AL CENTENARIO DE LA FUNDACIÓN DE LA CIUDAD DE LA PLATA 1882-1982, que encontramos también en el texto de Sureda y en el de Los padres de las Malvinas.

Urraza hace un planteo que reitera en su aporte a Ciudad milagro: "Nuestra ciudad es la única del país construida con sentido historicista. Por su destino de paz, como hemos comentado anteriormente, fue consagrada a honrar a los prohombres de la Revolución de Mayo..." (De Urraza, en Lerange, 1982: 58).

Prologado por el presidente de la Academia Nacional de la Historia, Enrique M. Barba, el libro no tiene ninguna especificidad asociada al derecho y la práctica de aquella profesión, más allá de la condición de abogado de su autor. Los artículos rescatan el sentido patriótico de la ciudad, subrayando algunos personajes del ámbito de la cultura y mostrando interés por el arte escultórico y arquitectónico y en particular sobre la influencia de la cultura helenística: "El autor no se ha dispuesto a dar una lección sobre las ideas estéticas que dieron vida y calor a La Plata monumental, ni de las líneas fundamentales que dominaban el ornato y el arte decorativo urbano. Pero arrastrado del ímpetu evocativo que le hace ansioso, llevando de la mano de la Hélade, cuyo espíritu se empeña en revivir, nos habla de la antigüedad dorada que parece encarnarse en la estatuaria y arquitectura que embellecen nuestra ciudad. Todo esto con disquisiciones mitológicas que develan el secreto que tal o cual estatua encierra...", resume elogiosamente Enrique Barba en el prólogo (De Urraza, 1981: 11-12).

\section{Diario El Día}

No es errado relacionar a Ciudad de mayo con el diario El Día, ya que se trata de una compilación de trabajos publicados por De Urraza en ese tradicional medio, entre 1957 y 1978, el primero de los cuales da título al libro ${ }^{90}$. Si bien esto no está advertido en ninguna

\footnotetext{
${ }^{90}$ Uno de los artículos, dedicado a Víctor de Pol, también es reproducido textualmente en Crónicas del siglo.
} 
nota inicial, ni en el prólogo de Barba, tampoco es un dato ocultado: en el índice, ubicado al final, se indica el origen de los textos (diario y fecha de publicación original). Esos mismos datos son explicitados al final de cada capítulo/artículo.

La relación con el diario se hace aún más clara con el último de ellos, referido a "la vida íntima del oficio", que contiene una clara alabanza a El Día, identificado como el diario de la ciudad. Vale la pena transcribir algunos fragmentos:

"Pareciera que una ciudad sin un diario fuera como un niño sin padres. La nuestra, que lo había previsto, se anticipó a este aspecto de posible orfandad, realizando su fundación en dos etapas. En la primera, en 1882, levantó o preparó sus edificios para el funcionamiento administrativo y político de la capital proyectada creando, además, todas las posibilidades para que la habitara el amo de la ciudad: el hombre. En la segunda, en 1884, se instalan en La Plata las autoridades que debían gobernar la Provincia. Cumplido el pensamiento, las familias llegaron y la vida de la urbe se animó a los dos años de su nacimiento. Sin embargo faltaba algo: un diario. Aparece 'El Día', como una mano tendida que buscara otra mano para recorrer juntas el mismo camino".

Nótese que el relato ignora u oculta la existencia de diarios anteriores a El Día, que aparecieron prácticamente con la fundación de la ciudad en 1882. Luego prosigue:

"...la ciudad tenía su diario, testigo de su claro amanecer, que desde entonces y a través de noventa y ocho largos años, sería la imagen de su vida. Dos años más joven que su piedra política de fundación y contemporáneo de su primera infancia, este diario sería, desde aquella aurora, su vocero, su caja de resonancias íntimas, su compañero de ruta, su lazarillo, y en los momentos difíciles, su gran paladín. Y también su archivo, registro fiel de una vida cotidiana jamás interrumpida. Por las páginas de este mentor desfilan los episodios y los hombres de una ciudad incipiente, y los hechos y los actores de todos los tiempos de su hacer ciudadano, como un espejo de su realidad. Leyendo esas páginas, el lector se asoma a un balcón milagroso desde donde ve pasar, en una lenta y continuada procesión, la vida de la ciudad, en una dialéctica de las horas con el hombre, con la piedra, con los crepúsculos. De estos diálogos, que salen siempre a nuestro encuentro, 'El Día' es el taller de imágenes de la vida de la ciudad, su fe de bautismo, su testimonio de trabajo y su libro de recuerdos de tantos años de historia y de amistad. Con tan grata compañía la urbe ha recorrido las transcurridas décadas de su destino y hay consenso que lo ha hecho segura y confiada. Las celebraciones de sus aniversarios han sido un acontecimiento común de La Plata y de su diario, porque ciertamente, la ciudad ha adquirido, por él, la voz de su pujanza y de su grande moral" (De Urraza, 1981: 139)

El Día también es parte de nuestro objeto de estudio: publica en 1982 un libro titulado 100 años de vida platense ${ }^{91}$ (de aquí en adelante, Vida platense), que indudablemente constituye el discurso con mayor circulación entre todos los analizados en esta tesis, ya que a la tirada declarada de 10.000 ejemplares debe sumarse la reproducción del mismo texto en formato tabloide, junto a la edición especial del diario del 19 de noviembre de 1982.

No hay indicios de que haya producido algún libro o folleto especial el otro diario que circulaba en La Plata en la época, el vespertino Gaceta, que por otra parte pertenecía al mismo grupo empresario. En la Sala La Plata de la Biblioteca Pública de la UNLP se conserva

\footnotetext{
${ }^{91}$ Realicé una aproximación a esta publicación en "Medios de comunicación y gestión del pasado: el diario El Día como productor de discurso histórico para la 'transición' en 1982", trabajo final del seminario "Medios de comunicación y memoria social", dictado por Claudia Feld, del que rescato el señalamiento de que los medios de comunicación no sólo construyen la actualidad -como se estudia habitualmente- sino que también cumplen "un rol fundamental en la construcción, la gestión y la circulación de las formas sociales de la memoria" (del Programa del seminario, 2006). En ese sentido es que Thompson (1998) habla de una historicidad mediática y Vattimo reconoce a los mass media como "verdaderos órganos de historización" (Vattimo, 2006: 81-82).
} 
una carpeta de 15 páginas que lleva como título "Centenario de La Plata" y guarda recortes de La Gaceta ${ }^{92}$. Algunas aparecen con el cintillo "GACETA festeja el Centenario". Una, firmada por "Mercurio", se titula "El Día' es la ciudad” y sostiene que "EL DÍA fue el primer diario publicado en la flamante capital bonaerense", que "es el representante auténtico de la capital bonaerense", etcétera. "No extraña, pues, que el homenaje que propios y extraños prodigan a la ciudad centenaria se extienda a EL DÍA, porque atesora las virtudes de su alma y corporiza sus energías creadoras. La Plata se refleja en EL DÍA y EL DÍA es el testimonio más elocuente de 100 años de trabajo inteligente en aras de un común destino de grandeza”.

El Día comenzó a publicarse en marzo 1884, es decir, a menos de un año y medio de la fundación, y muy pocos días después del traslado de los poderes públicos. Cuando la ciudad festejó su centenario llevaba más de 98 años editándose y ocupaba una posición hegemónica en la prensa local, adquirida ocho décadas antes. Usando palabras de Borrat (1989), podemos decir que fue siempre un actor político de la ciudad ${ }^{94}$. La recurrencia de la pintada El Día miente en las paredes de la ciudad es sugerente en ese sentido ${ }^{95}$.

En el período que analizamos la empresa ya estaba manejada por la familia Kraiselburd $^{96}$. En los años previos a la dictadura, El Día -que se caracterizó la mayor parte de

\footnotetext{
${ }^{92}$ La carpeta incluye notas sobre "los hombres-símbolo de la cultura platense" (ver capítulo VI), la obra de los padres salesianos ("La educación en la ciudad que nace"), el club Reconquista ("El más antiguo club de barrio"), la unión de operarios italianos, la Asociación Sarmiento (antes llamada El Cimarrón), la Asociación de Maestros, comercios pioneros como la casa Fígari (negocio de toldos), la casa Macchi (sombrerería), la librería Oitaven y el bazar "X" ("Una vieja peña artística"), y los 96 años de industria harinera en La Plata (en relación a la historia del Molino Campodónico).

${ }^{93}$ Mercurio es el seudónimo de Osvaldo Tomatti, quien durante más de medio siglo escribió en El Día. En 1982 también participa con un capítulo en la compilación Ciudad milagro, al que vincula directamente con su trabajo en el diario: "Paralelamente a la aparición de este volumen, continúo publicando en la Revista Platense de El Día la semblanza de numerosos deportistas de la ciudad. Han aparecido cincuenta y faltan quinientos [...] Por eso ahora, simbólicamente, voy a tomar seis apellidos, tres de cada entidad mayor, y los lanzo como una síntesis del aporte del fútbol al engrandecimiento y popularidad de La Plata en el deporte nacional" (en Lerange, 1982: 577). ${ }^{94}$ El libro publicado por el propio diario reproduce decididas tomas de postura en diferentes coyunturas, como el rechazo al juarismo a principios del siglo XX (Soler, 1982: 28). También se cita, por ejemplo, el "uso de la palabra del entonces director", Juan José Atencio, en los festejos del centenario de la Revolución de Mayo (Soler, 1982: 67) y distintas campañas impulsadas: por el cumplimiento de la ley que obligaba a empleados y funcionarios públicos a residir en La Plata; o en 1925 por el aumento de gravámenes a la importación de películas extranjeras (Soler, 1982: 93). Las consecuencias de su función como actor político se leen entrelíneas en el período del peronismo: como veremos, la sede fue atacada por los obreros el 17 de octubre de 1945 y sus ejemplares fueron quemados antes de que se distribuyeran. Con más detalle indica la toma de posición "sin dudas ni concesiones contra la violencia", en "momentos en que el terrorismo había llegado a constituirse en una fuerza incontrolable" (Soler, 1982: 219). Trataremos este tema en el capítulo VII.

${ }^{95}$ En 1972 el sindicato de trabajadores de la Universidad lo acusó de no dar espacio a sus actividades e incluso de negarse a publicar solicitadas pagas. ATULP imprimió miles de volantes que reproducían el logo del periódico y decían: "El Día miente", inspirados en una campaña realizada en Chile contra El Mercurio (Amato y Boyanovsky, 2008: 154). La Juventud Peronista sostuvo en el tiempo la consigna con afiches y pintadas. Desde entonces, la pintada "El Día miente" se ha reeditado en múltiples oportunidades en las calles de la ciudad. Hace pocos años, la hinchada de Estudiantes promovió esa misma frase para repudiar la postura oficialista del diario en la disputa que ese club mantenía con el intendente en torno a la construcción de su estadio. En la campaña de 1972, los Kraiselburd intentaron una contraofensiva con un panfleto que decía "El Día miente, Gaceta dice la verdad", a lo cual el gremio contestó: "El Día miente, Gaceta miente más". La historia también está relatada en el libro de Alessandro (2011: 133).

${ }^{96}$ David Kraiselburd, que trabajaba allí desde 1929, asumió la dirección de El Día en 1961 tras ser una pieza clave en la ruptura de un conflicto laboral cuyos detalles no han sido historizados y exceden a las posibilidades de esta tesis. Según la entrevista con Soler, "los empleados hicieron una huelga feroz... Kraiselburd se juntó con los amigos y sacó un diarito chiquitito, un día, otro día, otro día, hasta que les rompió la huelga. Y se hizo cargo del diario. La anécdota célebre dice que Stunz, que es el propietario, que era un tipo que andaba en yate por el mundo, un dandy, le pregunta ¿cuánto me va a cobrar por todo esto que hizo?. 'Nada, doctor', le dijo. Y entonces le dio no sé cuántas acciones. Y ahí él y Stunz coparon el diario hasta el día de hoy” (agosto de 2008).
} 
su historia por posicionamientos conservadores- alertaba sobre el "crecimiento de los grupos terroristas" (Katz, 2004: 121) y tras el asesinato del general Aramburu publicó un informe especial titulado "Montoneros: ¿Tacuaras de izquierda?”. La organización política-militar respondió secuestrando en junio de 1974 al director del diario -David Kraiselburd-, quien fue asesinado cuando las fuerzas de seguridad hallaron el sitio de su cautiverio de 22 días. Inmediatamente se hizo cargo de la dirección uno de sus hijos, Raúl, que sigue ocupando ese cargo en la actualidad, y que en ese entonces dirigía el otro diario de la familia. Ya en dictadura sería secuestrado y asesinado también su hijo de 18 meses, en un episodio más confuso en cuanto a su autoría intelectual ${ }^{97}$.

La relación con la dictadura fue de colaboración y apoyo, si bien no pertenece al grupo de empresas periodísticas con mayor compromiso, que se asociaron en el negocio de Papel Prensa $^{98}$. La mañana del 28 de marzo de 1976, cuando asumió la intendencia local el capitán de navío Oscar Macellari, el diario lo saludó con una columna firmada por José del Río: “Tiempo de gobernar". Más tarde llegaría al cargo de intendente Abel Blas Román, abogado de la familia Kraiselburd y padre de un periodista que se desempeñó como secretario de redacción de El Día durante años.

Por otra parte, El Día sostuvo su membresía plena en Asociación de Entidades Periodísticas Argentinas (ADEPA) y la Sociedad Interamericana de Prensa (SIP). Cuando en la reunión anual de esta última realizada en 1980 el director de La Opinión Jacobo Timerman denunció las persecuciones de la dictadura argentina y la existencia de desaparecidos, tanto Kraiselburd como Máximo Gainza -de La Prensa- y Claudio Escribano -de La Nación"replicaron que en la Argentina no había antisemitismo y que el ex director de La Opinión estaba cegado por el rencor personal..." (Novaro y Palermo, 2003: 312-313). Más adelante, según publicó Escribano en 1981, Raúl Kraiselburd colaboró con la edición del libro del general Ramón Camps, quien fuera jefe de la Policía bonaerense y uno de los principales responsables del plan de secuestro, exterminio y desaparición de personas.

En 1982 -tras la derrota en Malvinas- El Día acompañó todas las iniciativas gubernamentales para festejar el centenario de la ciudad. Salvo por la excepción puntual de una carta de lectores ${ }^{99}$ y dos solicitadas ${ }^{100}$, las páginas publicadas a lo largo de noviembre parecen la mitad de un diálogo de sordos: los promotores de los festejos y en particular el

\footnotetext{
${ }^{97}$ Entre los autores materiales estuvo el propio chofer de los Kraiselburd. El episodio ocurrido en agosto de 1976 es mencionado en Vida platense, en el marco de "años sangrientos" donde los secuestros no tenían "nada extraño". Pero se menciona a Montoneros sólo al recordar el secuestro del abuelo, en 1974. En la entrevista realizada, Soler afirma que "al padre (de Raúl) lo mataron los montoneros pero al hijo lo mató la derecha". Díaz agrega que el crimen "aumentó la confusión reinante" y que el represor "Miguel Etchecolatz en su libro (s/f: 85) asigna falsamente la autoría de este hecho a la organización armada Montoneros" (Díaz, 2009: 210) ${ }^{98}$ El historiador César Díaz caracteriza a El Día junto a La Prensa y Buenos Aires Herald con la categoría de “diarios no socios" y analiza su producción editorial con la idea de "periodismo pendular" (Díaz, 2009: 15).

${ }^{99}$ El 18 de noviembre de 1982 publica la carta de un ciudadano que compara la situación del festejo con la antigua Roma. Alejandro Pedernera afirma: "[...] Así también en la Argentina trataron de distraernos con el Mundial en el 78, y ahora, en una versión local, las autoridades tratan de distraer la atención de los platenses con los festejos de los 100 años de su querida ciudad. Y no es mi carta porque La Plata no se merezca estos festejos. Se merece esto y mucho más. Pero pienso que hay tiempos para determinadas cosas". Al caracterizar la situación que no justifica un festejo enumera la desocupación, inundaciones en la periferia, muertes por desnutrición, enfermedades sociales y la deuda externa. No aparecen referencias a los asesinatos y desapariciones.

${ }^{100}$ En la edición del 19 aparecen, entre muchas publicidades que adhieren al Centenario, una solicitada de la Filial La Plata de la Asamblea Permanente por los Derechos Humanos y otra de las Madres de Plaza de Mayo.
} 
intendente Román hacen declaraciones que tienen el tono de respuesta a críticas recibidas, pero esas críticas nunca fueron publicadas en el medio.

El 5 de noviembre, en la misma página donde salió la propaganda del "Eje del Centenario", el diario publicitaba su propia iniciativa. Bajo el contundente titular "Cien años es noticia" anunciaba la edición especial del 19, que venía preparando desde años antes: una "crónica auténtica y vital de los hechos y personajes que conmovieron la ciudad. Con fotos que son reliquias. Y documentos inéditos de incalculable valor testimonial. Para que usted reviva la historia de la ciudad...". La publicidad reapareció el 13 de noviembre, con el mismo diseño pero otra ilustración. Al menos analizado a cierta distancia temporal, el cambio no pasa desapercibido: mientras en el segundo anuncio la imagen anticipa la portada del producto, la primera incluía un paquete de diarios donde el único titular que alcanza a leerse refiere a las Islas Malvinas.

Recién el día 14 un tercer anuncio informó la salida de un libro con el material preparado: "Si el 19 de noviembre no consigue muchos ejemplares de EL DIA", decía, seguido por la imagen de otra portada, "este libro tiene lo mismo. La misma crónica auténtica y vital de un siglo de vida platense [...] Todo está igual, en este libro documento. Para guardar. Para consultar. Para obsequiar. Para tener en la biblioteca". Mientras tanto, en la cuarta sección del diario del 14 de noviembre notificaba que al día siguiente sería inaugurada en el Círculo de Periodistas de la Provincia una muestra fotográfica "sobre la Ciudad de La Plata y en homenaje a su Centenario"101: "La exposición ha sido organizada por la mencionada entidad y cuenta con el auspicio del diario EL DIA y estará realizada en base al material tomado por el mencionado matutino para el ejemplar que imprimirá el 19 del corriente y lleva como título 'Cien años de Vida platense""102.

El 17, una última publicidad emparentaba ambos productos: la edición especial del día del centenario, y el libro. El primero tenía un costo de 40.000 pesos y el segundo, de 200.000.

No tenemos datos certeros acerca de la tirada que tuvo el diario del 19 de noviembre -que se agotó-. En días corrientes, la tirada del diario en la época era de unos 65.000 ejemplares (Getino, 1995: 78). En el caso del libro, editado con la firma de El Día y la Sociedad Impresora Platense, consta el dato de la impresión de 10.000 ejemplares, en tanto el autor difiere y dice que la cifra fue el doble. En cualquier caso, es innegable que se trata del material sobre la historia de la ciudad más difundido hasta la actualidad.

Si bien se publicó bajo su sello, Vida platense no fue producido por periodistas del staff del diario. Ricardo Soler fue el hombre convocado por Kraiselburd para producir la obra, con cierta antelación al centenario que no hemos podido precisar ${ }^{103}$. Trabajó con tres colaboradoras que tenían formación en historia, letras y periodismo. Después se incorporaron dos fotógrafos, de cuya labor surgió la muestra expuesta en el Círculo de Periodistas el mes en que se concentró la actividad conmemorativa.

\footnotetext{
101 "Poliscromías" de Ernesto Eduardo Doménech y Francisco Carrera.

102 El Día, La Plata, 14 de noviembre de 1982; cuarta sección, página 2. Dos jornadas más tarde el diario relata la presentación de la muestra, de la que participó el director del diario con su esposa, el presidente del Círculo Ricardo West Ocampo, quien a su vez se desempeñaba como subdirector de El Día-, el intendente Román, Miguel Szelagowski, "invitados especiales y numeroso público". La crónica transcribe palabras de West Ocampo y de Ricardo Soler, el autor de la edición especial/libro que saldría a la venta tres días más tarde. ${ }^{103}$ El autor estima que la convocatoria "fue más o menos en el 80. Dos años y medio, más o menos, tres años..." (entrevista a Ricardo Soler, agosto de 2008).
} 
En el proceso de realización, según lo cuenta el autor más de 25 años después, no hubo una presencia fuerte de Kraiselburd con directivas:

“Sabés qué pasa? Acá hay una cosa fundamental: él [por Kraiselburd] no sabe un carajo de la historia. Quiere medio que lo hagas vos. El prólogo que está acá, que lo firma él, el prólogo del diario, lo hago yo. Porque el tipo está ocupado, tiene sus cosas. Y yo, a ver, te diría... qué te puedo decir de ese tema, que es un tema interesante... Error hay. Está muy cerquita. Además vos pensá que yo empecé en el ochenta, que además parecía que el Proceso duraba... es distinta la postura" (Entrevista a Ricardo Soler, agosto de 2008)

De todos modos, Soler recuerda que el libro pasó "por el cedazo, mucho por el cedazo, y algunas cosas buenas". Los correctores fueron el ya mencionado Miguel Szelagowski, Osvaldo Tomatti ${ }^{104}$, Juan Francisco Lagomarsino ${ }^{105}$ y Ramiro Casavera ${ }^{106}$.

Tras un prólogo firmado por el director, el libro -igual que la edición publicada en el formato sábana del diario ${ }^{107}$ - sigue un "orden temporal", "para conferir cierta unidad al relato”. Esta cronología parte de una periodización histórica clásica, básicamente establecida en relación a cambios en la política institucional nacional. El título de los dos primeros capítulos lo disimula con referencias a la ciudad, pero los sucesivos esclarecen el criterio prevaleciente: 1) La Plata: desde su fundación hasta la gran crisis del 90;2) La fisonomía platense definitiva; 3) Los años del radicalismo; 4) La vuelta del régimen; 5) Los años del peronismo; 6) Los frustrados ensayos constitucionales, y 7) Los tristes años 70.

La periodización según macroprocesos políticos no implica, sin embargo, una centralidad de los mismos. Al contrario, los temas nacionales -inclusive algunos internacionales- se mencionan a partir de su relación con la vida platense. Casi siempre hay una arista -el paso por la ciudad de un personaje, etcétera- que los vincula directamente con la ciudad. De lo contrario, se lo introduce por su "impacto" local: las referencias al caso Dreyfus, a un duelo protagonizado por Lisandro de la Torre o a la asonada de 1943, que parecieran no tener vinculación específica, están acompañadas por la caracterización de La Plata como centro político y, por lo tanto, "caja de resonancia".

No obstante, cada capítulo tiene un contenido fundamentalmente local, que se constituye a partir de fragmentos -breves subcapítulos-, presentados sucesivamente, que abordan tópicos diversos. Mientras algunos narran escuetamente acontecimientos políticos o caracterizan espacios socioculturales, otros refieren a lo que podríamos llamar "figuras" destacadas (de la política, la "cultura", la ciencia, el deporte) y "personajes" (anónimos o protagonistas de mitos urbanos).

En definitiva, coincide con lo anunciado en el prólogo, donde Kraiselburd afirma que el producto aspira a ser

"una ventana hacia el pasado, por la que los platenses puedan ver desfilar las imágenes de lo que fueron sus luchas, glorias, fracasos, gentes, instituciones, poetas,

\footnotetext{
${ }^{104}$ A Tomatti (Mercurio) corresponden algunas notas históricas que se publicaron en noviembre de 1982, relevadas para este trabajo aunque quedaron fuera del análisis.

${ }^{105}$ Lagomarsino, militante del radicalismo desde sus tiempos de estudiante de la Facultad de Derecho, fue uno de los editorialistas de El Día durante los '70, junto a West Ocampo -que estudió cine y trabajó como periodista desde joven, y sostenía una relación amistosa con Ricardo Balbín (Díaz, 2009: 199).

${ }^{106}$ Según entrevista con Ricardo Soler, agosto de 2008. En el libro impreso no hay agradecimientos a Casavera.

${ }^{107}$ El diario se publicaba en un tamaño de 38 por $60 \mathrm{~cm}$. La edición especial del 19 de noviembre de 1982 tuvo 132 páginas y se dividía en 11 secciones, 9 de las cuales estaban dedicadas a la historia de la ciudad. En relación al libro, la "edición especial" incluyó más imágenes, además de publicidades y dos secciones con noticias del día
} 
artistas, personajes fundamentales y aquellos que, sin serlo, contribuyeron a dar color y vida a la ciudad"; y señala que se "procuró eludir la estructura habitual de los textos enhebrados casi exclusivamente en torno a los hechos políticos. Ha querido ofrecer pantallazos de la vida diaria, el deporte y las costumbres con la visión instantánea característica del periodismo" (Soler, 1982: 7)

\section{Otras ediciones}

Otro libro publicado en el '82 es La Plata vista por los viajeros 1882-1912 (en adelante, Viajeros), una compilación realizada por Pedro Barcia que lleva el sello de Ediciones del 80 asociado a Librerías Juvenilia ${ }^{108}$. Como vimos antes, Barcia codirigió la investigación Paseo histórico... -encabezada por Cuccorese-, cuya publicación quedó trunca. Este libro está dedicado, precisamente, "al doctor Horacio Juan Cuccorese". "El trabajo sobre los viajeros fue simultáneo al de Paseo histórico. Lo empecé en 1979, con el rastreo de los autores. La selección la hice en 1980. Casi todo el trabajo lo adelanté en nuestra Biblioteca Pública de la Universidad y completé los viajeros en la de la Academia de Letras", recordó Barcia en la consulta realizada para esta tesis.

El libro, que ya en su portada se reconoce inspirado por el centenario, reúne 34 escritos de científicos, artistas, periodistas y dirigentes políticos que visitaron la ciudad en sus tres décadas iniciales -la mayoría en el primer decenio-, a saber: Henry Coopin (1884), Arturo Di Castelnuovo (1885), Domingo Faustino Sarmiento (1885), P.M. de Corvetto (1885 y 1886), Santiago Estrada (1886), Florencio Escardó (1886), Emilio Daireaux (1882 y 1886), J. A. Hammerton (1886), Alberto Palomeque (1888), Henry A. Ward (1889), Thomas A. Turner (1890), Theodore Child (1980), F. Resasco (1891), Octavio Velasco del Real (1891), May Crommelin (1891), Angelo Scalabrini (1893), Angelo De Gubernatis (1896), Frederick Alcock (1902). Francesco Scardin (1902 y 1905), Sir Thomas Hungerford Holdich (1903), Federico Rahola (1903), Manuel Bernárdez (1905), W. H. Koebel (1906), Prince Louis D’Orleans-Bragance (1907), François Crastre (1908), Cesarían Lupati Guelfi (1909), Vicente Blasco Ibáñez (1909), Mauricio Honoré (1910), M. Menacho (1910), A. S. Forrest (1912) y Paul Walle (1911-1912). Contiene además un cuidado "estudio preliminar" de 35 páginas elaborado por Barcia y está ilustrado por unas cuarenta imágenes, entre fotografías de los primeros tiempos de la ciudad y facsímiles de diarios o documentos. En las páginas iniciales, además, el libro también incluye un plano inicial del casco urbano de La Plata y retratos de Dardo Rocha y Carlos D’Amico.

Honestamente el libro reconoce como antecedente al trabajo publicado de Alfredo Amaral Insiarte en 1959: La Plata a través de viajeros, que en base al mismo período (18821912) reunía 54 referencias bibliográficas comentadas de relatos de quienes visitaron la ciudad -en su caso, solamente extranjeros-. Este trabajo es retomado también en Ciudad

\footnotetext{
${ }^{108}$ Ediciones del 80 fue una editorial platense surgida dos años antes del centenario, impulsada por Jorge Borean y Eduardo Butti y gerenciada por José Luis Mangieri -quien a mediados de los ' 60 había creado junto a Carlos Brocato la revista de poesía, política y crítica cultural La Rosa Blindada, clausurada en 1966-. Ediciones del 80 empezó su actividad con "Seis personajes en busca de un autor" de Luigi Pirandello. Al momento de la conmemoración platense llevaba publicados 21 libros, todos de "autores consagrados, extranjeros o nacionales: Pirandello, Ibsen, Hebbel, Hudson, Sartre, Heidegger, Lugones, Rilke, Almafuerte, Elliot, son algunos de esos exponentes". La tirada media era 2.000 ejemplares ("El libro en medio de la crisis económica. Una editorial platense peleando por la cultura". El Día, La Plata, 15 de noviembre de 1982). Las ediciones de Lugones, Las fuerzas extrañas y Cuentos desconocidos habían sido cuidadas por el propio Barcia (consulta al autor).
} 
milagro, en un artículo breve -menos de dos páginas-, titulado "Testigos y memorialistas" y firmado por Olegario Becerra, que se limita a sintetizar algunos aportes de Amaral Insiarte ${ }^{109}$.

La compilación de 1959, publicada por el ministerio de Educación bonaerense, no incluía directamente los relatos de los viajeros, salvo algunas citas textuales, sino resúmenes de los mismos y una referencia para consultarlos -la mayoría se encontraban entonces en la Biblioteca de la Universidad-. El trabajo de Barcia, en cambio, recopila varios de los textos citados por Amaral Insiarte, traduce los que están en lenguas extranjeras, e incorpora algunas crónicas de visitantes argentinos, como Sarmiento o Estrada. Según el compilador, este trabajo de documentación responde a una sugerencia de otro texto de antaño, el de Rafael Arrieta (1935). "Así, obtuvimos un caudal de más de medio millar de páginas. De entre ellas seleccionamos -comenta Barcia-, con sentido antológico apoyado en lo testimonial y en la originalidad de la visión [...] menos de la mitad de las originales" (Barcia, 1982: 10).

Como ya advertimos en la introducción, y retomaremos con algunas citas más adelante, el carácter de la compilación de voces externas permite la inclusión de visiones críticas sobre la ciudad. Así, el francés Child considera que la ciudad es un "capricho" que debe su creación a la "industria política, monopolio de los criollos y plaga de la República" (Barcia, 1982: 183), Scardin observa "la grandiosidad de la soberbia iniciativa fallida..." (en Barcia, 1982: 233) y Koebel, entrado el siglo XX, sostiene que "La Plata no es más que una ciudad muerta antes de nacer" (Barcia, 1982: 241), entre otros. Esto sobresale en el marco de un panorama editorial en el que la mayoría de los textos "celebran" la ciudad, glorifican a sus hacedores y destacan sus virtudes, y sólo ejercen la crítica en torno a cuestiones menores o -consolidando lo anterior- sobre el olvido de los orígenes, el descuido del patrimonio, etcétera. El carácter viajero de los autores -y también, la lejanía en el tiempo de las disidencias- da a esos relatos un carácter de curiosidad y facilita su inclusión, aun cuando confrontan con la ciudad reivindicada oficialmente. Por supuesto también hay muchos testimonios favorables a la ciudad -incluido el cambio de opinión de Sarmiento- y construcciones de sentido que sedimentarán en el tiempo, como la que elabora Bernárdez en 1905 postulando a La Plata como ciudad universitaria.

Homenaje de la Universidad Notarial, ya mencionado, también retoma relatos de viajeros: cita a "el conde de Corbeto [sic]" (Seco Villalba, en VV.AA., 1982b: 11) y también recupera textos de Santiago Estrada, Arturo di Castelnuovo, Blasco Ibañez y Albert Einstein (Tálice, en VV.AA., 1982b: 25).

Otra publicación que muestra algún interés por los relatos de viajeros es la edición de la revista "a/mbiente" (de ahora en más, Ambiente) dedicada al centenario platense, que entre sus primeros artículos incluye la transcripción de uno de los textos de Corvetto, "Una excursión a La Plata" [1-1-1885]. A diferencia del publicado por Barcia, incluye un párrafo más (al inicio) y está tanto en castellano como en su idioma original, el francés. La publicación bilingüe de algunos textos es un recurso común en la revista, que publica la editorial del comité directivo en español y en inglés. Ambiente es una publicación sobre "arquitectura, urbanismo y planificación” del Centro de Estudios y Proyectación del

\footnotetext{
${ }^{109}$ También Morosi menciona los testimonios pacientemente recogidos por Amaral Insiarte (en Lerange, 1982: 90), y el artículo de Reynaldo D’Onofrio retoma el folleto "La Plata" de Santiago Estrada, presumiblemente leído en la compilación de Amaral Insiarte. Ciudad milagro incluye además un artículo que da cuenta de visitas de personalidades extranjeras, pero tiene otro sentido, ya que no retoma sus impresiones sobre la ciudad. Tal repaso, que referencia mayoritariamente figuras del arte, no sigue un orden cronológico ni alfabético.
} 
Ambiente (CEPA), una entidad civil encabezada por el arquitecto Rubén Pesci, que tuvo un rol importante en la conmemoración: de ella surgió la idea del "Eje del Centenario", feria pública que incluyó la peatonalización de las calles del Eje Cívico Monumental de la Ciudad durante las semanas previas al festejo. $\mathrm{El} \mathrm{N}^{\circ} 32$ de la revista es un número especial, con su tapa a color ilustrada con la litografía de Quincio Cenni que escenifica el acto fundacional de la ciudad -sobre la que volveremos más adelante- y un único título, en la parte inferior, con letras naranjas: "La Plata, 100 años después". Las ediciones anteriores incluían tres o cuatro títulos por tapa.

"La fundación de la ciudad de La Plata -editorializan en Ambiente- constituye una verdadera gesta argentina, que por sus características y oportunidad, tuvo dimensión americana. Para nuestro país significó la consolidación nacional y el testimonio de la fe americana en la creatividad. Para América toda, fue una acción de vanguardia intelectual y tecnológica, en un continente que recién comenzaba a despertarse.

Como revista genuinamente platense, es un desafío y un orgullo intransferible presentar este número especial de 'a/mbiente'.

Homenaje a un proceso socio-económico-político singular. Y a la capacidad de gestión de un casco urbano excepcional" $" 110$.

El contenido de la revista no se circunscribe a temas urbanísticos o arquitectónicos, aunque varios textos e imágenes están orientados por esa mirada disciplinar. Otros tantos enfocan aspectos de la producción artística, cultural y científica de la ciudad y dos artículos iniciales se dedican a aspectos históricos: "La Plata y su tiempo", de Félix Luna y "Los hechos de la fundación", una entrevista a Fernando Enrique Barba. La vinculación de CEPA con el gobierno municipal queda plasmada en la revista, que en las páginas 66-71 incluye una entrevista al intendente de facto Abel Román. Entre las ilustraciones de esa nota aparece la "Propuesta del Eje Cívico-Monumental (Eje del Centenario), 1982", una idea del Centro "que ha sido elevada a la Subsecretaría de Planeamiento Municipal y asumida por ésta para su posterior desarrollo..." (Ambiente, página 70).

Otro libro de la época sobre la ciudad es Rastros y rostros de La Plata (de ahora en más, Rastros y rostros), de Estela Calvo, quien participa también de Ciudad milagro y 12 personalidades. Consta de 56 páginas -no numeradas- y tiene un diseño muy cuidado, si bien todo indica que se trata de una edición "de autora"111, dedicada a su hermana Martha "que aún habita / la ciudad invisible”.

El libro combina textos breves con fotografías y algunas ilustraciones o facsímiles de materiales históricos ${ }^{112}$ que aluden a lugares públicos y personas destacadas, especialmente vinculados al imaginario de una ciudad cultural-educativa. El libro tiene un tono testimonial $\mathrm{y}$, como veremos, resulta muy coincidente con figuras y sentidos construidos también en otras publicaciones: se centra en los primeros tiempos, destaca aspectos culturales de la ciudad y reivindica las estatuas. Quizá su rasgo distinto sea un mayor énfasis en la Iglesia: entre la

\footnotetext{
110 "Un modelo urbano para la calidad de vida" por el Comité Directivo. En Ambiente, № 32, junio de 1982.

${ }^{111}$ En el ejemplar no figuran datos editoriales. Fue impreso en Artes Gráficas San Miguel (145 esquina 44 bis).

${ }^{112}$ Contiene un total de 25 imágenes que, a diferencia de las páginas, sí están numeradas: “Tapa. Casa de Francisco López Merino; 1. Parque Saavedra; 2. Sala de época; 3. Patio familiar; 4. Postal de época; 5. Profesora María Elena Altube; 6. Conservatorio Chopin; 7. Niña con traje de época; 8. Dr. Estanislao Bejarano; 9. El leñador; 10. Estación F. C. S.; 11. Almafuerte; 12. Carta de Almafuerte a Alfredo Torcelli; 13. Recorte diario 'El Día'; 14. Dardo Rocha y los primeros pobladores; 15. Primera romería platense; 16. Florentino Ameghino; 17. Boleta de época; 18. Arco paseo del bosque; 19. Benito Lynch; 20. Coliseo Podestá; 21. José Podestá; 22. Programa Teatro Olimpo; 23. Teatro Argentino; 24. Teatro Argentino (interior)".
} 
descripción poética que hace de lugares comunes del relato platense (Casa de Gobierno, Plaza San Martín, Teatro Argentino, la "línea perfecta de las diagonales", Zoológico, Observatorio, Museo, los tranvías, etcétera) incluye las campanas de las iglesias, además de sus evocaciones -en otros tramos- de la Iglesia San Benjamín, el Seminario Mayor y del "simbólico Te Deum" de 1883. Guarda, por otra parte, una vinculación familiar con el diario El Día, al que otorga un lugar fundamental al repasar los medios de comunicación de la ciudad. Tres párrafos específicos dedica a su sección Prosa y verso, "que dirigiera durante muchos años Roberto Saraví Cisneros -sensible poeta- (donde) se foguearan los más reconocidos escritores de varias generaciones", dice Calvo y finalmente conecta con otro libro del centenario: "Volver las páginas de los años treinta es reencontrarme con la palabra de mi padre -tan lejana y tan próxima- impresa en cientos de editoriales, con sus desvelos cotidianos compartidos en ese mundo peculiar de anhelos, de vigilias, de camaradería que Estanislao de Urraza describe en su último libro 'La Plata, ciudad de mayo' y en el que vuelca su certero juicio y cálido acento en todo lo relativo a la ciudad por la que tanto hizo" (Calvo, 1982).

El texto tiene una escritura poética, muy melosa en algunos tramos, que celebra una ciudad que fue "impulso de una acción decidida, valiente, vertiginosa que convirtió los proyectos en hechos y el diseño perfecto en una realidad urbanística de excepción" (Calvo, 1982. Las cursivas son mías). Insiste en identificarla como un lugar de serenidad, íntimo y acogedor, y lo hace en un tono nostálgico, buscando rastros de lo que fue una "ciudad de la nobleza y de la abundancia" (Calvo, 1982). Dice en el cierre, presentado con una tipografía manuscrita que enfatiza el carácter personal del texto:

"Ciudad amplia, soleada, adormecida de historias y de otoños. Ciudad sin estridencias, sin fatigas, con un ritmo de promesas y apacibilidad en su pulso de siglo. [...] Ciudad que puede ser legendaria si se la relata en instantes, antigua por la intensidad de su vida, niña si se la analiza en su precoz madurez. Pero siempre joven, templada en su espíritu, en sus rostros inasibles, en la huella de tantos rostros lejanos que aún esperan su homenaje. Desde sus heridas, desde sus glorias, desde sus sellos de altura, desde sus vigilias -insomnes de secreto y leyenda-, desde las calles moradas que el jacarandá enciende en la noche errante. Desde el tiempo... nos presta para el recuerdo nostálgico su pasado que me habita y me acompaña como una sombra entrañable".

Otro libro que se inscribe entre las producciones del centenario -aunque más no sea por su título y su fecha próxima de edición- es La ciudad de La Plata en su centenario. Fundamentos para una nueva Argentina (en adelante, Nueva Argentina), de Gregorio Cygan. Es un caso particular: no es un libro celebratorio de La Plata, si no más bien de España. En ese sentido, intenta situar a la capital bonaerense como expresión última de las corrientes fundacionales españolas. Podría decirse que es un libro que usa a esta ciudad como "excusa", pero en el fondo no es sobre La Plata. Finalmente, cuando la aborda, reiterará tópicos repetidos en los demás libros: la exaltación de Rocha y Benoit como figuras, la reivindicación del trazado (aunque con una interpretación particular), la pacificación nacional y el destino final como ciudad cultural/universitaria.

Es una edición de autor completamente artesanal, mecanografiada en máquina de escribir. Las hojas son utilizadas a simple faz. Tiene 261 páginas numeradas, pero como los números saltan de impar en impar, en rigor tiene unas 130 páginas. La condición de edición del autor de este libro está resaltada en la primera página de información sobre el libro, donde además se indican las fechas de las distintas ediciones: la primera, el 20 de abril de 1979; la 
segunda, ampliada ${ }^{113}$, el 19 de noviembre de ese mismo año, y la tercera, 30 de abril de 1981. No hay datos sobre la tirada de cada una.

El libro está impreso en España ${ }^{114}$. En la portada aparece el título, subtítulo, nombre del autor y también su profesión (ingeniero civil) ${ }^{115}$, número de edición (destacado) y año, y la ilustración de fondo es el contorno de la República Argentina y parte de sus países limítrofes. A diferencia de la mayoría de los libros, donde se recurre al trazado o a una imagen del casco de la ciudad, aquí el referente es la Argentina, lo cual fortalece el sentido del subtítulo. En el interior incluye algunas imágenes, tanto cartográficas como fotográficas, que van desde el Puerto de Buenos Aires hasta Machu Picchu, incluyendo ¡una estatua erigida a Pizarro en una ciudad de España en 1929!

El libro está dedicado “al Dr. Hiram Dairos Haurigot, el amigo de las horas de ilusión” y luego expresa, en un breve texto recuadrado: "Acompañado siempre por el recuerdo de muchos años vividos en la Ciudad de La Plata, ahora veo llegar el Centenario de su fundación como uno de los sueños que, desde la infancia, acostumbraba a forjarme sobre la urbe platense". Pero más allá de un párrafo inicial referido a los primeros años de la ciudad (caracterizados, dice el autor, por un posromanticismo que trascendía al plano político), desde un principio el libro tematiza como problema la cuestión capital de la Argentina, que se vincula con la fundación de La Plata pero va mucho más allá. Así, al primer capítulo titulado "Cuando la República Argentina se formó", le siguen otros sobre "La Ciudad de Buenos Aires y su puerto", "Algunas citas bibliográficas acerca de la fundación de la Ciudad de Buenos Aires y su vinculación con el Virreinato del Río de La Plata y la República Argentina" -este es, notoriamente, el más largo-, para consagrar a "La Ciudad de La Plata" el cuarto capítulo. Éste comienza en la página 187 y va hasta la 201, según la paginación que como ya observamos sólo utiliza números impares: son en total 7 páginas de texto y un gráfico ${ }^{116}$. Es decir, lo específico sobre La Plata ocupa poco más del 5\% del espacio del libro de Cygan.

En rigor y pese a su título, la publicación -incluso por su fecha de edición- es más un libro a propósito del centenario de la federalización de Buenos Aires, que sobre el centenario de La Plata: "Cuando se han de cumplir los 100 años de todo un proceso que hoy reclama mayores apreciaciones -escribe Cygan en la página 213-, cabe un nuevo planteo de las condiciones en que se federalizó la Ciudad de Buenos Aires...”.

Cygan termina analizando demográficamente el territorio argentino, planteando desafíos en torno a la definición de un modelo de país (“ante el año 2000”) y argumentando a favor de un nuevo emplazamiento para la capital federal, en un punto tal como "el encuentro de límites entre las provincias de San Luis, Córdoba y La Pampa”. Otra propuesta de re-localización de

\footnotetext{
113 "La oportunidad de celebrarse próximamente -en el año 1982-, el Centenario de la fundación de la Ciudad de La Plata, en la República Argentina, ciudad en la que he vivido muchos años, me ha impulsado a la publicación de la presente obra, cuya segunda edición aumentada, aparece al poco tiempo de la primera -ya agotada-, con un Capítulo dedicado a la recopilación de referencias acerca de la ciudad de Buenos Aires, por diversos autores que la describen en sus diferentes épocas..." (Cygan, 1981: 30-31. Prólogo a la segunda edición).

${ }^{114} \mathrm{El}$ ejemplar que consta en la biblioteca UNLP tiene una dedicatoria del autor. A partir de ella, se puede deducir que Cygan residía en Granada: "A la biblioteca de la Universidad Nacional de La Plata, Gregorio M. Cygan. Granada, España, 5 de mayo de 1981.

${ }^{115}$ Asimismo, entre las primeras páginas dedicará dos a mencionar las "obras anteriores" del autor, que incluyen 22 libros de "poesía", "historia" y "ciencia y técnica" publicados entre 1959 y 1979. Ninguno está específicamente vinculado a la ciudad de La Plata.

${ }^{116}$ El gráfico incluido en el capítulo es un plano de 1771 de la zona de la Ensenada de Barragán (Archivo de Indias), que se incluye bajo el título "Las tierras de la futura ciudad de La Plata".
} 
las capitales está incluida -pero desvinculada del planteo general del libro- en Obra de arte. Si bien no está firmado, todo indica que ese fragmento de texto fue escrito por José Felipe Marini, un militar retirado que formaba parte del Departamento de Historia ${ }^{117}$.

La coyuntura del centenario debe haber habilitado la producción de otros libros de autor como el de Cygan y diversos folletos o transcripciones de charlas de los que no quedan casi registros. Uno al que hemos podido acceder y tiende a completar el panorama de actores de la conmemoración es la Conferencia sobre el aporte de los italianos a la construcción de la ciudad de La Plata (en adelante, Italianos) realizada el 20 de octubre de 1982 y publicada en un folleto del Hospital Italiano / Asociación Italiana de Socorros Mutuos y Beneficencia Hospital "Humberto 10". Allí, inspirado por el centenario de la ciudad, el cónsul general de Italia Tibor Hoor Tempis Livi se dedica a descubrir "el aporte de mis connacionales llegados un siglo atrás y que constribuyeron [sic] a su construcción", aspecto que considera "quizá descuidado" (Hoor, 1982: 1). El folleto de 12 páginas se organiza en torno a cinco preguntas:

"1) ¿Quiénes y cuántos eran los trabajadores italianos?

2) ¿De cuántas regiones provenían?

3) ¿Cómo vivían en la zona en la cual se levantó la ciudad?

4) ¿Cuáles eran sus respectivas especializaciones?

5) ¿Cuáles monumentos dan testimonio de su participación?” (Hoor, 1982:1)

La exposición "no pretende ser otra cosa que una introducción a un estudio más profundo", que solicita: "Es mi deseo que esta iniciativa inspire a algún estudioso para llevar a cabo el desarrollo de este tema fascinante, y para rendir homenaje sea al Centenario de La Plata, sea a la colectividad italiana y a aquellos esforzados e infatigables inmigrantes que tanto trabajaran en esta ciudad en el siglo pasado y en los primeros años de éste".

El texto nos incorpora al desfile a una colectividad extranjera, la más importante de los tiempos de la fundación, y lo hace a través de la voz autorizada, cuyo título le encarga "proteger las personas e intereses de los individuos de la nación que lo nombra" y lo acredita para representar su voz ${ }^{118}$. En los años 70 , Hoor Tempis Livi solía compartir actos con Tomás Bernard, quien entre sus múltiples títulos portaba también el de cónsul de la República de Ecuador. Sin ir más lejos, ambos figuran entre las siete personas del "Cuerpo Consular acreditado en La Plata" que asistieron a la cena del centenario del 18 de noviembre de 1982, donde se encontraron "autoridades nacionales, provinciales, municipales e invitados especiales, en su mayoría, acompañados por la esposa" $"$.

El último folleto o libro que nos queda por presentar corresponde a un grupo de personas que no estuvieron invitadas a tan magno evento, del que sí participaron autores del centenario como Miguel Szelagowski, José María Prado, Julio Morosi o Catalina Lerange.

\footnotetext{
${ }^{117}$ Aunque no lo hace explícito, su toma de posición implica una confrontación con la visión idealizada que adjudica a los fundadores una mente esclarecida: "Si los hombres hubiesen tenido una visión geopolítica del espacio nacional y las responsabilidades inherentes que asumía la Provincia de Buenos Aires para ocupar su espacio, y por carácter transitivo acelerar el dominio del espacio nacional, es indudable que -para las posibilidades y perspectivas de la época- se debía ubicar en el puerto de Bahía Blanca la nueva capital de la provincia" (Díaz, 1982: 413).

118 Tomado de la definición de la Real Academia Española.

119 "Las personalidades asistentes a la cena del Centenario", en El Día, La Plata, 19 de Noviembre de 1982
} 


\section{La voz disidente: Familiares}

En la atmósfera celebratoria que vivó La Plata en 1982, la intervención opositora con mayor visibilidad fue la de Madres de Plaza de Mayo y "Familiares de Desaparecidos y Detenidos por Razones Políticas" (de ahora en más, Familiares), es decir, parte del movimiento de los derechos humanos que resistió a la dictadura ${ }^{120}$. A las primeras suelen adjudicarse dos acciones significativas en el espacio público, aunque estuvieron junto a Familiares y algunos ex presos políticos. A Familiares corresponde la autoría de una elaborada publicación que, entre otras cosas, discute el discurso oficial del festejo ${ }^{121}$.

En el campo de los derechos humanos, todavía en época de dictadura, la publicación de folletos no era algo que identificara a ese grupo; más bien era una práctica propia del CELS, que por ejemplo en 1982 publicó seis folletos: "El secuestro como método de detención"; "Muertos por la represión", “Adolescentes detenidos-desaparecidos", "Los niños desaparecidos", "Conscriptos detenidos-desaparecidos", "La familia víctima de la represión" y "Uruguay y Argentina: coordinación represiva". Sin embargo, en el contexto de profusión editorial sobre La Plata, Familiares tuvo su propia iniciativa: ¡¡No habrá manto de olvido!! (en adelante, No habrá manto de olvido): una edición casera, distribuida de mano en mano, que si bien circuló hacia el final del año o ya en 1983 (en una larga dedicatoria, se hace referencia a "los caídos en manos de la represión en manifestaciones populares como las del 30 de marzo y el 16 de diciembre de 1982"122), está irrefutablemente producido para la coyuntura de noviembre de 1982, como deja en claro el prólogo al referirse a "este mes que conmemora el centenario de la fundación de la ciudad" y proponer que "el lema de nuestro trabajo sea una antítesis del: ¿Lo festejamos juntos? (respecto al centenario de la ciudad de La Plata)", reemplazándolo por un “ ¡los recordamos juntos!”.

El "libro" es un folleto de 102 páginas producido artesanalmente. En su portada -en coincidencia con otras publicaciones de la época- recurre a la simbología del trazado urbano platense, en este caso sobreimpresa con el texto: “iNo habrá manto de olvido!! La Plata”. Dicho título señala una disidencia hacia una expresión que parece haber tenido fuerza en el espacio público, a juzgar por las respuestas. Además del libro de Familiares, vale recordar el poema de Gelman que habla de un "manto de memoria". No he podido identificar con precisión cuándo aparece la expresión confrontada, "manto de olvido". En noviembre 1980, el general Ibérico Saint-Jean afirmaba que "lo que más conviene a todos los argentinos es echar un cuidadoso manto de silencio" sobre el tema de los desaparecidos, por cuanto "es muy difícil realizar esclarecimientos que no compliquen las cosas" ${ }^{" 23}$.

La mayor parte de las páginas del libro está dedicada a una Nómina de Detenidos Desaparecidos registrados hasta la fecha, con datos recopilados desde el organismo. Además de nombre y fecha de desaparición incluye, intencionadamente, el lugar de trabajo o de estudio de los desaparecidos de la región. Los casos empiezan en 1975. Producto del análisis

\footnotetext{
${ }^{120}$ En La Plata, entre las organizaciones de Familiares, las Madres y la APDH local no sólo hubo múltiples coincidencias de planteos y acciones, sino superposiciones de personas.

${ }^{121}$ Sobre las intervenciones de Familiares escribí una aproximación en "Los familiares en la conmemoración del centenario platense Una disputa de sentidos en torno al pasado de la ciudad (1982)”, presentado como trabajo final del curso de Antropología de la memoria y la identidad dictado por Ludmila Da Silva Catela.

${ }^{122}$ La dedicatoria se refiere también, entre otros, "al pueblo de La Plata que valientemente aplaudió el paso de las Madres de Plaza de Mayo y los Familiares de Desaparecidos y Presos políticos el 19 de noviembre, fecha del Centenario de nuestra ciudad, dando al traste con la intención oficial de acallar nuestras voces" y "a nuestros seres queridos, por quienes no habrá «manto de olvido»".

${ }^{123}$ Clarín, 14 de noviembre de 1980 (citado en Novaro y Palermo, 2003: 317)
} 
de esos datos, los que corresponden a diciembre de 1977 forman un apartado, bajo el título $U n$ mes siniestro.

"Este libro es de consulta permanente. Sobre todo porque están las fechas. Eso sí, la motivación para hacerlo fue el centenario", me dijo la madre de Plaza de Mayo Adelina de Alaye en una entrevista exploratoria que realicé cuando empezaba a estudiar los festejos del centenario. El libro fue un trabajo mentado al interior de Familiares, del que participaron unas 14 personas. El ejemplar que conserva Adelina de Alaye está dedicado y tiene apuntados con lápiz los nombres: Ethel (Ricetti, la hija de Edna), Claudia y Gustavo (Bellingeri), Eduardo (Schaposnik), Ana, Perla (Diez), Reina (Suárez de Diez), Estela, Cacho, Remo (Carlotto), Carmen, Irma (madre de Walter Docters), Micaela, Eva (tía de Cachorro Godoy).

"Reina hacía de directora, y mucho más. Y bueno, nos reunimos, dividimos las tareas que cada uno iba a llevar adelante. Lo más importante era poder construir la lista. Una parte central. Yo creo que el libro nació con la idea de hacer la lista de los desparecidos de La Plata... Para que en esos cien años nadie pudiera decir 'no sabemos nada'. Acá están los desaparecidos. Y no queríamos hacer solamente... porque ya habían circulado algunas listas, había circulado la lista no me acuerdo si era de Madres o de la Asamblea, o Madres y Asamblea que habían trabajado en conjunto, pero con una apreciación un poquito más recortada, si se quiere, que era de los estudiantes desaparecidos en La Plata. Nosotros decíamos, bueno: además de estudiantes hay otros desaparecidos [...] Yo no sé si al principio hablamos de libro. Después yo creo que surgió. Una vez que lo pudimos ver un poco más..." (Entrevista a Claudia Bellingeri, julio de 2007)

Antes de esa lista, a modo introducción, se incluye un escrito breve titulado "1882-1982 La Plata: obreros y estudiantes", que condensa el aporte historiográfico de la publicación, centrada en la denuncia de los crímenes de la dictadura. Una cosa no está disociada de la otra. Un objetivo de Familiares es superar "la casi completa carencia de identificación de los trabajadores desaparecidos" (Familiares, 1983: 42). La recopilación de denuncias sobre desaparecidos obreros se complementa con un repaso histórico que, como veremos, discute la condición de La Plata como mera ciudad universitaria. Por eso el énfasis del título: obreros y estudiantes, ambos constituyen la ciudad y ambos fueron víctimas de la represión estatal.

El libro se completa con una enumeración de las entidades defensoras de los derechos humanos (página 4), el hincapié sobre casos de niños apropiados (página 51) y soldados desaparecidos (página 64) y distintos enfoques sobre las denuncias realizadas: cartas, testimonios, el relato del "encuentro con una madre obrera", las reflexiones de una ex detenida, un informe sobre la Unidad Penal 9 y un análisis sobre la situación jurídica.

\section{Una tipología alternativa}

A lo largo del capítulo hemos presentado poco más de medio centenar de publicaciones que conforman nuestro corpus de análisis. A modo de "desfile", estas fueron ordenadas en función de las organizaciones que las impulsaron, que van desde el Estado hasta un organismo de derechos humanos, pasando por la universidad, colegios profesionales, el diario local y editoriales particulares. Por supuesto, no es la única ordenación posible.

Antes de introducir el análisis de aspectos específicos, podemos reconocer que -a grandes rasgos- entre los títulos reseñados encontramos trabajos de diferente índole:

- Publicaciones que intentan abordar una "historia general", ya sea proponiendo un texto único con una mirada "amplia" (Crónicas de un siglo, Vida platense; y circunscriptos a las 
primeras décadas, Primeros habitantes y Creación de la generación del 80) o una sumatoria de aportes que trabajan diversas dimensiones del pasado (Ciudad milagro, Obra de arte; en menor medida, también la Revista de la Universidad y Ambiente).

- Publicaciones reconocidas como escrituras testimoniales, que con sus semblanzas, anécdotas y definiciones político-culturales sobre la ciudad participan de la disputa por el pasado urbano (Edad de mi infancia; Vivencias y testimonios; Rastros y rostros; Calles numeradas; los textos personales de Szelagowski: Si yo fuera intendente, Años veinte y ¿Será justicia?; y como testimonio familiar, también Vieja amistad).

- Publicaciones que, inspiradas por el aniversario redondo y escritas en homenaje a la ciudad centenaria, enfocan dimensiones específicas: cuestiones de la historia económica (Económica; Historia del Banco Municipal), las artes (Diccionario de arte) y otros aspectos culturales (Ciudad de mayo; Vida espiritual), el reconocimiento de figuras sobresalientes (12 personalidades), la "cuestión capital" (Nueva Argentina), los actos de la fundación y el sentido del escudo (Homenaje de la Universidad Notarial), los aportes en la creación de la ciudad (Acción profesional; Italianos), los relatos de viajeros (Viajeros), las características urbanas y arquitectónicas (Ciudad nueva ciudad antigua) y, mucho más vinculados a un tiempo presente, los circuitos turísticos (La Plata 100), la organización de la conmemoración (Crónica del centenario), la represión estatal y los desaparecidos (No habrá manto de olvido). Por supuesto, estos libros y revistas no están exentos de consideraciones generales sobre La Plata, en especial en sus prólogos o partes introductorias, que condensan aportes significativos en la pugna de sentidos. Y en algunos casos su propio desarrollo abarca distintas dimensiones, como las doce biografías de personalidades o los relatos de viajeros.

Esta clasificación, claro está, tiene fronteras porosas. Si las publicaciones sobre temas específicos también aportan miradas generales y lo mismo sucede con los relatos vivenciales, los más abarcativos no son ajenos a escrituras testimoniales o con marcas muy personales. Hemos visto, de hecho, que la composición de Ciudad milagro incluye fragmentos que también fueron editados independientemente, y que aquí clasificamos por su carácter testimonial o su temática específica. No obstante, esta tipología resultará útil para enunciar reflexiones que abarcan a grupos de libros, sin mencionarlos uno a uno.

En los capítulos que siguen analizaremos distintas cuestiones pensadas a partir de la totalidad del corpus. Por momentos sobresaldrán ejemplos centrados en los libros considerados más significativos -Ciudad milagro, Obra de arte o Vida platense- pero sin abanonar nunca la visión de conjunto, pues es en la profusión editorial y en la afirmación "coral" de ciertas ideas donde advertimos su particular relevancia, como así también el carácter excepcional de algunos matices y la marginalidad de las disidencias. 


\title{
III. Entre historia y memoria El registro de los relatos locales publicados ${ }^{124}$
}

\begin{abstract}
“El combate por la historia (o por el conocimiento histórico) es un combate político ya que si bien la memoria colectiva de un pueblo no está constituida en lo fundamental por el 'saber científico' producido por los historiadores, no cabe duda que este influye en la formación de identidades y tradiciones" (Grez Toso, 2001: 212)

"La historiografía local, como la biografía, parece estar más cerca de la literatura que los otros géneros históricos, quizá porque la vida concreta exige un tratamiento literario, quizá porque la clientela del historiador es alérgica a la aridez acostumbrada por los historiadores contemporáneos” (González, 1999: 24)

“...la escritura de la historia por los historiadores de oficio no es más que uno de los medios de transmitir el recuerdo de los acontecimientos del pasado..." (Valensi, en Cuesta 1998: 68)
\end{abstract}

El carácter "académico" o "no académico" de las publicaciones del centenario no está contemplado en la tipología con la que concluimos el capítulo anterior. Contra lo que pudo preverse, no es una variable significativa para nuestro objeto de estudio. Los textos respetuosos de formalidades del campo académico son escasos y pertenecen -junto a otros- al grupo de trabajos sobre temáticas específicas. Son los trabajos dirigidos por Nessi, Morosi o Cuccorese, que reconocen inscripciones disciplinares, que exhiben un registro de escritura más letrado. Morosi realiza, por ejemplo, exposiciones eruditas donde justifica las denominaciones que utiliza, y recurre a una amplia bibliografía, tanto en español como en inglés. Por su parte, en la síntesis de su investigación publicada en Económica, Cuccorese incluye cuadros analíticos que refuerzan el registro académico en el que presenta su trabajo. También algunos artículos publicados por Ambiente tienen un tono científico-disciplinar, como el de Jorge Gazzaneo sobre el patrimonio urbano.

Del mismo modo, son excepciones Acción profesional -que incluye bibliografía al final de cada capítulo, con un grado importante de exhaustividad- e Historia del Banco Municipal -escrita siguiendo un orden cronológico y con cita de fuentes-. Algunas historias más generales -en especial las dos compilaciones, que se caracterizan por su diversidad internatienen algunos tramos con esas características, pero bajo ningún punto de vista son predominantes. No se definen por eso: su carácter de "homenajes", que las inclina hacia una escritura celebratoria, resulta mucho más determinante.

Explorando el panorama general de libros, revistas y folletos de 1982 atentos a las metas de cada publicación, encontraremos homenajes a la ciudad, testimonios nostálgicos, discursos patrimonialistas, productos con pretensiones científico-académicas y también un texto de denuncia. Algunos entremezclan varias de esas búsquedas. Todos indagan, repasan y usan el pasado de la ciudad, ya sea el transcurso completo de un siglo de historia, la época de la fundación o los años '20 -que aparecen ante algunos autores como una belle époque platense-.

\footnotetext{
${ }^{124}$ Una parte importante de las reflexiones conceptuales de este capítulo fueron ensayadas en dos trabajos finales, "La historiografía local como escritura conmemorativa: análisis de una historia-memoria oficial" e "Historia, memoria y conmemoración: bases teóricas para pensar la disputa del pasado local", entregados para acreditar el seminario "La Odisea de la Memoria" y la materia "Historia y memoria", respectivamente. Agradezco los comentarios realizados por los Josefina Cuesta Bustillo y Daniel Lvovich.
} 
Ahora bien, ¿son textos de historia o son expresiones de una memoria local? ¿están modulados por una búsqueda de conocimiento o más bien determinados por el deber de celebrar a La Plata en su centenario? Para responder tales interrogantes repasaremos primero algunas ideas que opusieron "historia" y "memoria" en forma dicotómica, reconociendo las diferencias y los puntos en común entre tales nociones. Luego indagaremos qué rasgos de cada una tienen las publicaciones del corpus, analizando sus objetivos explícitos, la relación con las fuentes, los estilos de escritura y sus "trabajos" sobre el pasado platense.

\section{Historia / memoria}

“...las oposiciones binarias, de las cuales las discusiones intelectuales hacen gran uso [...] sólo sirven para fines de acusación o de autolegitimación. Creo que es mucho más interesante estudiar las condiciones de posibilidad de esas oposiciones que tomarlas en serio en sí mismas" (Pollak, 2006: 47)

Al explorar los rasgos que separan historia de memoria, veremos que si bien es posible plantear una distinción, ésta no puede sostenerse en forma dicotómica y tajante, y la misma se licua cuando se pone en juego el adjetivo "oficial": la historia pública o la historia oficial se aleja del "tipo ideal" de historia por su grado de condicionamiento -menos controlado por operaciones científicas- y su intencionalidad identitaria; en tanto lo que algunos autores mencionan como memoria oficial se aleja del "tipo ideal" de memoria porque no se asienta en la experiencia vivida y porque recurre a la escritura. Es decir: al alejarse de las definiciones típicas-ideales del concepto básico, la historia oficial se acerca a la memoria, y en tanto la memoria oficial se aproxima a la historia.

En tal sentido, es posible que la mayor parte de las publicaciones del centenario, que hemos pensado asociadas a una gestión oficial de los sentidos del pasado, se ubiquen en una suerte de zona intermedia entre historia y memoria, pues si bien tienen la intención de una reconstrucción escrita del pasado local -y no, salvo los textos testimoniales, la narración de una experiencia vivida y personal- al mismo tiempo están atravesadas por sentidos conmemorativos o políticas de memoria que las alejan del género discursivo que caracteriza a la historia como disciplina científica.

Pero empecemos por la diferenciación ideal. Connerton (1993: 16) plantea la necesidad de distinguir la memoria social de "una práctica más específica", analítica, a la que denomina "actividad de reconstrucción histórica". Halbwachs hablaba de una memoria histórica y una memoria colectiva. La distancia que separa a una -escrita, aprendida, larga, unificada- de la otra -vivida, oral, corta, plural- no difiere de la que muchos autores han trazado entre historia y memoria, a veces presentados como dos conceptos antitéticos. Antes de discutirla, nos abocaremos primero a reconstruir esa visión dicotómica, a partir de distintos aportes, lo cual conlleva (re)construir nociones duras que pueden ser pensadas como "tipos ideales" en términos weberianos, o denunciadas como caricaturas -toda caricatura exalta rasgos, exagera $^{125}$.

\footnotetext{
${ }^{125}$ Esta operación implica ignorar la polisemia de la "memoria" ya mencionada en la introducción, y también la que podría desglosarse para la "historia". Augé (2006: 21), por ejemplo, señala tres acepciones de la palabra: designa una disciplina, el contenido de un acontecimiento y una forma de conciencia colectiva e identitaria.
} 
Desde fines de los '70, cuando la memoria se incorporó como palabra clave y objeto de reflexión socio-histórica, se extendió entre los historiadores el hábito de dividir las aguas entre historia y memoria,

"entre el saber científico de los hechos pasados, la historia entendida como un saber acumulativo con sus improntas de exhaustividad, de rigor, de control de los testimonios, de una parte; y por otra parte, la memoria de estos hechos pasados cultivada por los contemporáneos y sus descendientes. Desde entonces ha corrido mucha tinta [...] Si desde muy pronto se ha podido plantear una distinción de conjunto entre la disciplina científica y la construcción social del recuerdo, ha sido menos fácil precisar sus inevitables relaciones" (Cuesta, 1998: 204)

Para Halbwachs la historia implicaba la muerte de la memoria. En otras palabras: la memoria habla de la experiencia, y es posible hacer historia recién cuando ya no tenemos una relación "orgánica" con el pasado. La historia es entonces la forma de conservarlo. Al oponer esos dos universos, la memoria queda junto a "todo lo que fluctúa, lo concreto, lo vivido, lo múltiple, lo sagrado, la imagen, el afecto, lo mágico; mientras que la historia se caracterizaría por su carácter exclusivamente crítico, conceptual, problemático y laico" (Cuesta, 2007).

Pierre Nora, en su obra de 1984, remarca esa oposición:

“...lejos de ser sinónimos, tenemos conciencia de lo que les opone. La memoria es la vida, arraigada siempre en grupos vivientes y, por ello, está en evolución permanente, abierta a la dialéctica del recuerdo y de la amnesia, inconsciente de sus deformaciones sucesivas, vulnerable a todas las utilizaciones y manipulaciones, susceptible de prolongadas latencias y de frecuentes revitalizaciones. La historia es la reconstrucción siempre problemática e incompleta de lo que ya no existe. La memoria es siempre un fenómeno actual, un vínculo vivido con el presente eterno. La historia es una representación del pasado. La memoria no se acomoda más que a los datos que la confortan, puesto que es afectiva y mágica; se alimenta de recuerdos vagos, telescópicos, globales y flotantes, particulares o simbólicos, y es sensible a todas las transferencias, censuras, pantallas o proyecciones. La historia recurre al análisis y al discurso crítico, puesto que es una operación intelectual y desmitificadora" (citado en Cuesta, 2007)

Otra dimensión de la antítesis es la oposición oralidad/escritura, que para algunos autores marca radicalmente un límite entre historia y memoria. A veces éste se cuela casi como sentido común, por ejemplo cuando Patricia Funes escribe, reflexionando en torno a los relatos sobre hitos fundacionales en nuestras sociedades: "Si de 'historia' se trata, es decir, de registro escrito..." (Funes, 2001: 54).

Un planteo adicional que separó ambos términos, entre muchos que podemos recuperar, corresponde a Martín Broszat, en su correspondencia de 1988 con Saul Friedländer. Allí oponía "una memoria 'mítica' a la aproximación 'científica' y racional del historiador" (citado por Traverso, en Franco y Levín, 2007: 77). De modo similar, la reunión de la American Historical Association de 1996 en la que se debatió quién es dueño de la historia, se enfrentó a las "historias contadas de forma profesional" con "un retorno reflexivo de las memorias" (Britton, en Cuesta, 1998: 148) ${ }^{126}$.

Mencionemos, para concluir este repaso panorámico, el modo en que David Lowenthal diferencia entre memoria e historia:

\footnotetext{
${ }^{126}$ En Zakhor (1996) Yerushalmi también planteó una distinción clara entre memoria e historia, en su caso para subrayar la hipertrofia de la ciencia. Sin refutarla, en Royaumont relativizó esa oposición (Yerushalmi, 2006), o al menos admitió algunas relaciones, como veremos más adelante.
} 
"Por su naturaleza personal y, por tanto, en gran medida no comprobable, la memoria se remonta sólo hasta la infancia, aunque a nuestros recuerdos añadimos los que nos cuentan nuestros antepasados. En contraste, la historia, cuyos datos y conclusiones compartidos han de estar abiertos al escrutinio público, se remonta hasta o más allá de las primeras manifestaciones de la civilización. La muerte de cada individuo conlleva la extinción total de un sinnúmero de recuerdos, mientras la historia (al menos la impresa) es potencialmente inmortal"127.

Lowenthal agrega luego que "sin embargo, toda historia depende de la memoria y muchos recuerdos incorporan la historia" y atenúa la oposición reconociendo que ambas tienen deformaciones originadas en una "percepción selectiva". Pero tomemos la parte inicial de esa cita, junto a las referencias anteriores, para reconocer cómo se ha construido una dicotomía que persiste en muchos textos y debates:

\begin{tabular}{|c|c|}
\hline Memoria & Historia \\
\hline $\begin{array}{l}\text { Experiencia. Relación orgánica (viva) La } \\
\text { vida, lo vivido. }\end{array}$ & $\begin{array}{l}\text { Muerte de la experiencia (conservación) } \\
\text { Reconstrucción de lo que ya no existe. }\end{array}$ \\
\hline Fenómeno actual & Representación del pasado \\
\hline Se extingue con la muerte & Acumulativa. Potencialmente inmortal \\
\hline $\begin{array}{l}\text { Comprende la vida de una persona y } \\
\text { recuerdos familiares }\end{array}$ & $\begin{array}{l}\text { Se extiende a los orígenes de la } \\
\text { civilización }\end{array}$ \\
\hline $\begin{array}{l}\text { Mítica. Lo sagrado. Es afectiva, mágica. } \\
\text { Se acomoda a los datos que la confortan. }\end{array}$ & $\begin{array}{l}\text { Aproximación científica, racional, } \\
\text { rigurosa. Laica. Es conceptual, }\end{array}$ \\
\hline $\begin{array}{l}\text { Fluctuante o discontinua. Abierta a la } \\
\text { dialéctica de recuerdo y el olvido. } \\
\text { Inconsciente de sus deformaciones. }\end{array}$ & $\begin{array}{l}\text { problemática. Recurre al análisis y el } \\
\text { discurso crítico. Es una operación } \\
\text { intelectual y desmitificadora }\end{array}$ \\
\hline Personal & Profesional (supone distanciamiento) \\
\hline No comprobable. & Tiene "pruebas". \\
\hline $\begin{array}{l}\text { Vulnerables a todas las utilizaciones y } \\
\text { manipulaciones }\end{array}$ & $\begin{array}{l}\text { Datos y conclusiones sometidas a } \\
\text { escrutinio público. }\end{array}$ \\
\hline Aspira a la fidelidad & Aspira a la exactitud \\
\hline Se expresa en la oralidad & $\begin{array}{l}\text { Tiende a estar escrita (impresa) Es un } \\
\text { relato duradero. Emplea la prosa. }\end{array}$ \\
\hline Parte de la rememoración & Se investiga en archivos. \\
\hline
\end{tabular}

(Elaboración propia a partir de las lecturas realizadas)

Podríamos retomar otras dimensiones -más complejas y menos recurrentes- en las que se ha señalado la distancia entre historia y memoria. La noción de tiempo, presente en Ricœur $^{128}$, es una de ellas. De las "cuatro maneras de visualizar el tiempo, de traducirlo en signos" planteadas por Pomian -cronometría, cronología, cronografía, cronosofía- la cronología es la más próxima a las operaciones de la historia, que ordena acontecimientos en una serie de fechas/nombres y en la sucesión de eras/épocas. También está vinculada a una

\footnotetext{
${ }^{127}$ De su trabajo incluido en la compilación de Gillis: Conmemoration: The Politics of National Identity, Princeton University Press, 1994. Tomamos la traducción de una cita de Diane Britton (en Cuesta 1998: 158)

${ }^{128}$ Tema abordado en Tiempo y narración, vuelve sobre él en la obra que seguimos aquí (Ricœur, 2008), retomando una obra de Krzysztof Pomian: El orden del tiempo.
} 
forma de cronosofía -al construir grandes periodizaciones- pero en un sentido político más que religioso. En tanto, la memoria sería más cronográfica, ya que puede prescindir del calendario: "Los episodios anotados se definen por su posición respecto a otros: sucesión de acontecimientos únicos, buenos o malos, alegrantes o afligentes" (Ricœur, 2008: 201-202).

Digamos, finalmente, que la oposición tajante suele asentarse en un supuesto positivista según el cual el pasado al que refiere la historia está epistemológicamente desvinculado del presente. Desde esa perspectiva, la historia reciente o historia del presente no sería historia sino periodismo o una forma de crónica no-científica. De este modo, el positivismo incorporaría al cuadro anterior la idea de objetividad ${ }^{129}$, y al referirnos a una "aproximación científica" estaríamos hablando de un conocimiento objetivo, mientras que la memoria es eminentemente subjetiva.

En suma, los caracteres que definen a la historia y a la memoria como antagónicas se tornan hoy inadmisibles. Sin embargo, cuestionarlos no supone fundir ambos conceptos en uno, sino procurar una definición más apropiada de sus diferencias.

La distinción no se asienta en la "objetividad" de la historia versus la "subjetividad" de la memoria. La reconocida intervención del sujeto en las investigaciones sobre la historia reciente ha permitido tematizar una subjetividad; al tiempo que un avance más general de la epistemología acierta al plantear que ninguna de las otras parcelas del saber es ajena a ella. Como advierte Traverso,

“...El historiador no trabaja encerrado en la clásica torre de marfil, al abrigo del mundanal ruido y tampoco vive en una cámara refrigerada, al abrigo de las pasiones del mundo. Sufre los condicionamientos de un contexto social, cultural, y nacional; no escapa a las influencias de sus recuerdos personales ni a un saber heredado condicionamientos e influencias de los cuales puede intentar librarse a través de un esfuerzo de distanciamiento crítico, pero nunca a partir de la negación- [...] Su tarea no consiste en tratar de suprimir la memoria [...] sino en inscribirla en un conjunto histórico más vasto" (Traverso, en Franco y Levín, 2007: 77)

También Raymond Aron -cuya tesis doctoral llevaba por subtítulo "Ensayo sobre los límites de la objetividad histórica"- señalaba que la comprensión "compromete siempre al intérprete" y que el historiador "nunca es comparable con un físico; sigue siendo hombre al mismo tiempo que científico. No quiere devenir en científico puro, ya que la comprensión, más allá del saber, apunta a la apropiación del pasado" (en Ricœur, 2008: 436).

Tampoco convence la asociación directa entre memoria y experiencia. No siempre el objeto de la memoria es algo vivido personalmente, como bien advierte Yerushalmi: "cuando decimos que un pueblo 'recuerda', en realidad decimos primero que un pasado fue activamente transmitido a las generaciones contemporáneas..." (Yerushalmi, 2006: 17-18)

Menos aún la antítesis podría sostenerse afirmando que la historia se relaciona exclusivamente con el pasado -un pasado pasado- mientras que la memoria refiere a un pasado que aún no ha cristalizado. La historia, incluso la historia de la antigüedad, guarda

\footnotetext{
${ }^{129}$ Contra lo que indica una idea bastante difundida, cabe advertir que los primeros historiadores no eran tan ingenuos al respecto: "No es extraño encontrar en las declaraciones de intenciones de las primeras revistas de historia, surgidas en el siglo XIX, alusiones al 'lazo vital con la vida del presente', a que 'el pasado es todavía contemporáneo', a la 'importancia nacional' del estudio del pasado, o a que 'la historia puede arrojar luz sobre problemas prácticos’. Desde entonces, los historiadores siempre han mantenido una compleja tensión entre su deseo de objetividad y su voluntad de responder a ese 'uso públicó...” (Berenzon Gorn, 2004: 90).
} 
relación con el presente: "se escribe siempre en presente, aunque pase por otras mediaciones" (Traverso, en Franco y Levín, 2007: 74).

Por último, la división también es precaria cuando se habla de oralidad y escritura. Sin duda, la historia está estrechamente vinculada a las grafías: la escritura suele ser su forma de expresión y, a menudo, también su fuente. Esto último deviene de una herencia positivista que fetichizó el documento e identificó el oficio del historiador con el archivo. No obstante, el trabajo con fuentes orales en los últimos tiempos resquebraja esa identificación. A su vez, la proliferación del género autobiográfico discute la necesaria "oralidad" de la memoria. Las cosas son más complejas.

Debemos repensar, entonces, los conceptos de historia y memoria. Un buen ejercicio, antes de plantear las diferencias, es escrutar lo que tienen en común, que no es poco. Por ejemplo:

1) Son elaboraciones y reelaboraciones del pasado. Ambas, historia y memoria, son construcciones de sentido sobre algo pretérito. Comparten ese objeto, si vale la palabra. Por eso están relacionadas y "se entrecruzan constantemente" (Nora, 1984: XIX).

2) Ambas son narrativas. Aquí seguimos a Chartier y rechazamos la simplista oposición que contrasta "las explicaciones sin el relato y los relatos sin explicación: la comprensión histórica está construida, en efecto, en y por el relato en sí, por sus disposiciones y sus composiciones" (Chartier, 1996: 74-75). También Ricoeur insiste en que la historia siempre es narrativa, "en todas sus formas, incluso las que menos describen los hechos, o las más estructurales [...] Cualquier escrito propiamente histórico se construye, en efecto, a partir de fórmulas que pertenecen al relato o a la intriga" (Chartier, 1996: 73-74).

3) Operan desde un presente. Desde la lejana expresión de San Agustín, suele estar claro que "cuando hablamos de 'memoria' no hablamos sólo del pasado, sino de la lectura, interpretación y sentidos de ese pasado desde y en el presente" (Catela, en Franco y Levín, 2007: 217). No está tan asumido que lo mismo ocurre con la historia; pero como vimos, también las preguntas de la historia, sus presupuestos, su terminología y sus hipótesis de explicación están condicionados por el presente en que es o fue producida. Es decir, tanto la historia como la memoria son presente del pasado.

4) Tienen anclajes socio-políticos. De los puntos anteriores se desprende que el objetivo de "exactitud de la representación" (Candau, 2001: 127), apuntado del lado de la historia en el modelo ideal, no tiene asidero. Como plantea Didi-Huberman (2005), no hay un "pasado exacto". Más o menos reconocidos, tanto la historia como la memoria tienen bases, horizontes y usos, que son sociales y políticos. Eso se expresa, por ejemplo, en su vinculación con la construcción de identidades, si bien la forma en que la asumen es distinta: "mientras la primera se desembaraza de su papel legitimador de identidades, la segunda se vincula precisamente con su búsqueda y su construcción" (Sábato, en Franco y Levín, 2007: 224). En el caso de la memoria, ningún autor discute ese vínculo estrecho al conceptualizarla. De hecho, teóricos de la identidad social como Gilberto Gimenez (1997) señalan la construcción de una memoria común como un elemento constitutivo.

En el caso de la historiografía, su conformación como tal -igual que la mayoría de las ciencias sociales- está relacionada con el período de consolidación de los Estados-nación, y tuvo el sentido que Williams le otorga a la tradición. La historia sirvió a la necesidad de 
construir un pasado que legitimase la unidad nacional. "Si bien con frecuencia desde la propia disciplina se buscó definir pautas para funcionar con independencia de las demandas políticas e ideológicas formuladas desde el Estado (o desde quienes pretendían impugnarlo), eran esas mismas demandas las que le otorgaban prestigio y poder institucional en la era de las naciones" (Sábato, en Franco y Levín, 2007: 222). Ocluida a veces en la investigación, esa condición quedó siempre manifiesta en la enseñanza escolar ${ }^{130}$.

5) Son "selectivas" e implican "trabajos intelectuales". Los términos propuestos no son desconocidos, pero han estado asociados al planteo dicotómico. Hemos leído y escuchado recurrentemente que la memoria es selectiva y parcial. Pero la historia también lo es: en principio por el simple hecho de que es imposible abarcar todo; luego, por su propia función.

Por otra parte, la historia se asocia a un trabajo intelectual y está bien que así sea: hay sujetos -los profesionales de la disciplina- que desarrollan operaciones con su intelecto para producirla. Lo que solía perderse de vista es que la memoria también implica un ejercicio activo -los trabajos de memoria- que pone en juego capacidades intelectuales. En "procesos de transformación simbólica y de elaboración de sentidos del pasado", los seres humanos “'trabajan' sobre y con las memorias del pasado" (Jelin, 2002a: 14). Veremos, claro, que las actividades cognitivas de la historia y la memoria son distintas. Pero ese es el siguiente paso.

Efectivamente, siendo ambas elaboraciones subjetivas sobre el pasado que se construyen desde un presente, el modo en que son usadas, el sentido de sus selecciones y la forma en que desarrollan sus trabajos, varían y tienden a separar a la historia de la memoria. Analicemos ahora en qué consiste esa separación, sin perder de vista que es una frontera porosa, delicada, acaso movediza, que no impide los cruces y los puntos de encuentro.

Rescatemos un punto del planteo inicial: la historia supone una actividad profesional, científica. Eso no le quita completamente su carácter subjetivo y político, pero anuncia que tiene ciertas reglas específicas de construcción -las que permitieron, durante algún tiempo, sostener que su conocimiento era objetivo-. En otras palabras: la historia se caracterizaría por un proceso de producción controlado, que depende de criterios y convenciones por las cuales se le requieren pruebas y argumentos. En otras palabras, implica "una escritura del pasado según las modalidades y las reglas de un oficio...” (Traverso, en Franco y Levín, 2007: 72).

Pero ¿en qué consisten esas reglas o procedimientos que autonomizan a la historia? Según el análisis de Ricoeur -que sigue planteos de Michel de Certeau- la operación historiográfica ${ }^{131}$ se estructura en tres momentos:

- La fase documental, que incluye el trabajo con las fuentes (sean escritas u orales, archivos o testimonios), que en ningún caso se tratan de algo dado.

En esta fase se establece la prueba documental, una preocupación que -con objetivos distintos- comparten juez e historiador ${ }^{132}$. Evocando a Bloch como "el historiador que mejor

\footnotetext{
${ }^{130}$ Sobre la función de la historia escolarizada son muy interesantes los planteos de Silvia Finocchio en un artículo compilado por Franco y Levín (2007), titulado "Entradas educativas en los lugares de la memoria". ${ }^{131}$ La caracterización de esa "operación” fue la contribución que De Certeau hizo al proyecto de Nora y Le Goff, Hacer la historia. Allí aparece nombrada como "operación histórica", pero el propio De Certeau (1993) la redefinió como "operación historiográfica”. Ricœur (2008) retoma esa expresión y, a grandes rasgos, la estructura triádica propuesta, dotándola en algunas dimensiones de contenidos diferentes. La referencia al concepto original está mediada, también, por la lectura de Barthes.

${ }^{132}$ Igual que Carlo Ginzburg, Ricœur se interesa bastante por caracterizar el juicio histórico en relación al juicio judicial (Ricœur, 2008: 416-421). También Habermas (1999), Connerton (1993: 16) y Traverso (2003: 83).
} 
ha delimitado el lugar del testimonio en la construcción del hecho histórico" Ricœur insiste en que "no todo comienza en los archivos, sino con el testimonio, y que, cualquiera que sea la falta originaria de fiabilidad del testimonio" no hay en última instancia nada mejor "para asegurarnos de que algo ocurrió". Tanto el relato oral como el archivo implican una búsqueda, guiada por ciertas preguntas. Se entiende por documento, entonces, "todo cuanto puede ser interrogado por un historiador con la idea de encontrar en él una información sobre el pasado" (Ricœur, 2008: 220, 190, 232).

Hay no obstante una idea extendida de que "ir a los archivos es una ley del trabajo histórico" (González, 2009: 85); está asociada a una concepción que supone que la distancia temporal habilita la objetividad del historiador.

- La fase explicativo-comprensiva, vinculada a objetivos de conocimiento, donde la práctica entra en su momento crítico e intenta responder a un por qué. Como dice Luis González, "sin interrogatorio inteligente no hay documentación que valga" (2009: 85).

En este punto radica el mayor reto epistemológico para el historiador, aunque su intención se declara plenamente en la tercera fase. Es aquí donde la distancia entre la historia y la memoria se amplía, pues el conocimiento histórico incorpora la "articulación entre acontecimientos, estructuras y coyunturas, multiplicación de escalas de duración extendidas a las escalas de normas y de evaluaciones, distribución de los objetos pertinentes de la historia según múltiples planos..." (Ricœur, 2008: 637).

La doble denominación de esta fase pretende rechazar la oposición entre explicación y comprensión, que podría impedir el reconocimiento de la amplitud de la búsqueda del por qué histórico. Hay que reconocer que este momento está imbricado con el anterior, ya que "no existe documento sin pregunta ni pregunta sin explicación..." (Ricœur, 2008: 237). Hay interpretación en todos los niveles de la operación historiográfica: también en lo que De Certeau llamó "representación-escenificación literaria", es decir,

- la fase representativa, que implica su formalización mediante la escritura ${ }^{133}$, la puesta en discurso. La configuración literaria-narrativa que ha adoptado la historia introduce una cuestión que no profundizaremos aquí: la de cómo la historia logra distinguirse de la ficción (Ricœur, 2008: 245). El autor se aboca al tema en Historia y narratividad, donde -igual que De Certeau y Augé- retoma los aportes Paul Veyne en Cómo se escribe la historia. En la concepción de las tramas -señala- "la imaginación histórica y la novelística se encuentran unidas. La demostración es palpable si consideramos el siglo XIX, en el que coinciden el momento de máximo esplendor de la novela y el de la historia" (Ricœur, 1999: 179). En su diferenciación se plantea la cuestión de la voz -el historiador es un narrador distinto al autory reaparece la pretensión de verdad de la historia. Finalmente, la distinción en esta fase está dada por lo que aportan las anteriores: la fidelidad hacia la documentación y su búsqueda explicativa-comprensiva.

Con las tres fases hablamos de "niveles de programa que únicamente la mirada distanciada de la epistemología distingue". Del concepto de fase no debe deducirse la idea de estadios cronológicamente distintos: se trata de "momentos metodológicos imbricados entre sî" (Ricœur, 2008: 189, 177). Cada uno de ellos tiene sus reglas. El trabajo documental ciertamente es selectivo, pero no del modo en que lo es la memoria, sino por "principios de

${ }^{133}$ Ricœur evita esta expresión en la denominación, ya que toda la práctica implica la escritura. 
selección" que "son internos a la disciplina". La escritura tiene modalidades características para la construcción de un "verosímil" que ha sido bien caracterizado por Barthes (1984) y De Certeau (1993), entre otros.

Advirtamos además que lo implicado en cada fase se trasforma con el tiempo: así como mencionamos cambios referidos a las fuentes, también ha variado la relación con esas pruebas -o indicios-, los criterios analíticos, el vocabulario y las gramáticas de escritura.

No obstante, de un modo general vemos que la historia se produce a partir de un conjunto de reglas que tienen cierto consenso entre su "comunidad académica". Muchos rasgos señalados por quienes marcan la separación entre la memoria y la historia, como su expresión escrita y su carácter conceptual y laico, son precisamente el producto de esos acuerdos disciplinares.

La historia es, entonces, producto de una tarea profesional que se vincula a un objetivo de conocimiento, al ejercicio de un análisis crítico y a ciertas operaciones que, si bien no producen neutralidad, la caracterizan como actividad intelectual. Como nos recuerda Sábato, existe "un campo reconocible y reconocido de producción historiográfica, donde se generan, discuten, cambian y difunden las reglas del oficio" (en Franco y Levín, 2007: 229). La historia se procura una base empírica, documental, fáctica, y busca la verificación de sus postulados. Estas operaciones le permiten "poner distancia" respecto de la memoria. Pero se trata de emanciparse y no de oponerse, porque como ya dijimos no hay antagonismo sino relación. La disciplina, en tanto científica, tiene una búsqueda específica, que radica en aquel carácter explicativo-comprensivo.

La memoria, por su parte, ha sido definida como "una reconstrucción psíquica e intelectual que comporta, de hecho, una representación selectiva del pasado" (Rousso, citado en Cuesta, 1993: 41-42). Esta caracterización nos resulta insuficiente. Al hablar de una representación del pasado, selectiva y -agreguemos- forjada en el presente, también podemos estar refiriéndonos a la historia. Aquí, lo que nos aleja de la frontera porosa es el adjetivo psíquico. Podríamos admitir además cierto carácter espontáneo (Cuesta, 1993: 41-42) y afirmar que la memoria es más subjetiva. O mejor dicho, que tiene menos control sobre esa subjetividad, en el sentido de que es "singular, poco cuidadosa de las comparaciones, de la contextualización, de las generalizaciones; no tiene necesidad de pruebas para quien la transporta" (Traverso, en Franco y Levín, 2007: 73). La memoria carece de pretensiones de universalidad -presentes en algunas corrientes historiográficas- o de demostración.

En su primera aproximación, en 1978, Nora planteaba que la memoria colectiva es "el conjunto de recuerdos, conscientes o no, de una experiencia vivida y/o mitificada por una colectividad, alimentada por una identidad de la que el sentimiento del pasado es parte integrante" (citado en Cuesta, 2007). Como tal se presenta más sensible a los silencios, los cambios, las proyecciones. Es decir, sus operaciones no son las mismas que las del oficio histórico. Suponen una actividad que a veces es inconsciente: no hablamos de búsqueda, generalización, contextualización, verificación; los trabajos de la memoria más bien refieren al recuerdo y al olvido, la nostalgia, la mitificación, la sustitución, la restitución, la fusión, etcétera (Cuesta). Con esto no queremos decir que la memoria sea pura invención. Eso sería correcto sólo si quitáramos al término todo sentido peyorativo y le diéramos un sentido amplio; en tal caso, también la historia es invención. Lo que si observamos es una fuerte relación con lo concreto, lo afectivo y lo fragmentario, que no perturba su pretensión de fidelidad (Ricoeur, 2000), pues esa es la forma en que construye su verosímil. 


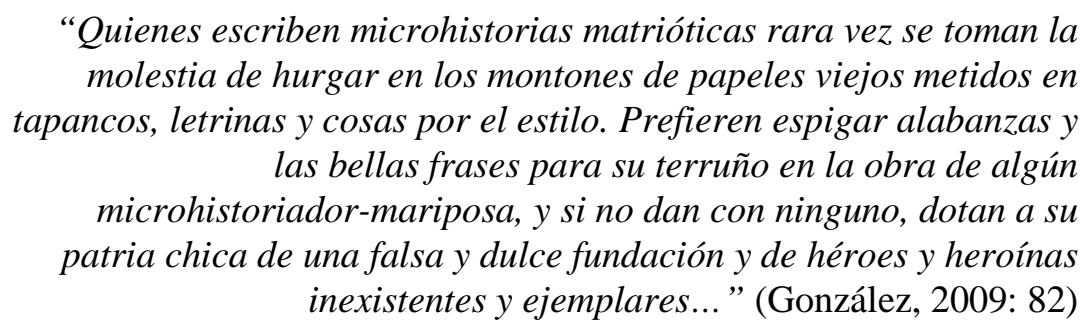

Desde un principio advertimos que la historia de La Plata -como en general todas las historias locales- aparecía desatendida por el ejercicio "profesional" de la historia científica. Es por eso que casi la totalidad de los textos que la revisan fueron realizados en el marco de celebraciones (cincuentenario, $75^{\circ}$ aniversario, centenario), lo que les da una impronta particular. Consideramos que tales publicaciones se ubican en una zona intermedia entre historia y memoria, pues si bien tienen la intención de una reconstrucción escrita del pasado local -más que la narración de una experiencia personal- al mismo tiempo están atravesados por políticas conmemorativas, sentidos nostálgicos y marcas testimoniales que cargan de afectividad al relato y lo alejan del género discursivo que caracteriza a la historia como disciplina científica.

Como sugerimos al principio, la propia bibliografía citada hasta recién presenta términos que tematizan una intersección, como el de historia oficial, una historia que no sería tan conceptual ni tan crítica como definimos a la disciplina académica, cuyo objetivo es la construcción de identidades y, muchas veces, la legitimación de un orden. Si bien no todas las publicaciones del corpus son "oficiales", el término nos ayuda a pensar el desfile de textos en el que, como vimos, predomina una mirada celebratoria sobre la ciudad. Eso sin contar que buena parte de los trabajos fueron encuadrados en la actividad de instituciones del Estado u organizaciones que tenían fluidas relaciones con el gobierno de facto, por lo que están estrechamente vinculados a los sentidos de la celebración oficial.

En general, cuando se introduce el adjetivo oficial, queda diluida la diferencia entre historia y memoria. En su repaso de la obra de Halbwachs, luego de utilizar la expresión memoria escrita oficial, Namer escribe: "la historia oficial se encarna en una historia imperativa, se plasma bajo el concepto de racionalidad dominante de los poderes ideológicos establecidos...". Memoria oficial e historia oficial tienden a nombrar lo mismo.

Algo similar ocurre en la obra Ricœur. En un mismo capítulo, a pocas páginas de distancia, habla de una "memoria obligada, impuesta" y de una "historia autorizada, impuesta, celebrada, conmemorada -de la historia oficial-". Así, el abuso de la memoria es también el abuso de la historia: la imposición de "poderes superiores" que puede tramarse sobre las identidades comunitarias que estructuran vínculos de pertenencia y que establece un "relato canónico mediante la intimidación o la seducción, el miedo o el halago" (Ricœur, 2008: 572, 577). "La memoria impuesta está equipada por una historia `autorizada', la historia oficial, la historia aprendida y celebrada públicamente” (Ricœur, 2008: 116). Por su parte, al tratar el contexto nacional "en el que la Historia había sido la principal formadora de la conciencia nacional", Nora utiliza la denominación "historia-memoria".

Sucede que la calificación oficial opera matizando cada uno de los conceptos, y acercando uno al otro. Si la memoria, al ser oficial, es escrita y ya no refiere a algo vivido personalmente; la historia, por su parte, se aleja de sus "reglas" y su contenido crítico, y 
asume un compromiso mucho más explícito con la formación de identidades. La cita de Sergio Grez Toso con la que iniciamos este capítulo alude, precisamente, a esa trascendencia que tiene la historia más allá del plano estrictamente académico o historiográfico.

En la bibliografía pueden rastrearse otros conceptos que suponen una interacción entre historia y memoria como la "memoria académica" (Baroseck) o una "memoria culta o especializada, la recogida y transmitida por los historiadores" (Cuesta, 1993: 44), que en una dicotomía conceptual estricta resultarían un oxímoron. En una situación similar encontramos a la noción de memoria histórica, que muchas veces se confunde con la memoria oficial.

En todos los casos nos estamos refiriendo a memorias que no parecen implicar el relato de una experiencia vivida en carne propia, sino la transmisión de acontecimientos generalmente protagonizados por otros grupos y en otros tiempos. A su vez, las memorias cultas o las memorias oficiales, al no ser narraciones personales, están más asociadas a la escritura que al registro oral.

Al fin y al cabo, hablamos de un tipo de historia, esa historia-homenaje "que Marco Tulio Cicerón llamó 'maestra de la vida'; historia reverencial, Friedrich Nietzsche; historia pragmática, no se quién; historia edificante o didáctica, no sé cuántos, y los irreverentes, historia de bronce". Una historia de monumentos, adoctrinante, pragmático-poética o pragmático-ética, que "aspira a la recuperación de los valores del pasado en provecho del aquí y ahora; busca en adultos de otras épocas la lección para los menores de hoy; añade adrede la moraleja a la descripción de obras y al relato de vidas pasadas; quiere dotarnos de un proyecto vital por medio de un repertorio de exempla de grandes hombres y de hechos hazañosos...." (González, 2009: 100). Conservadora y moralizante, reverencial y panegírica, construye un relato que recoge acontecimientos celebrados institucionalmente, es proclive a las "biografías de santos, héroes, próceres y gobernantes", gusta "de la descripción de los momentos estelares de la patria y de la matria"134 y "practica también el culto a los orígenes" (González, 2009: 317, 82) ${ }^{135}$.

Como veremos, hay una serie de rasgos que se reiteran en las publicaciones sobre el pasado local: la composición a partir de fragmentos heterogéneos -a veces escritos por distintos autores- y sin una ilación clara, cierta preferencia por "anécdotas y curiosidades" y la glorificación a-crítica de sucesos y personajes destacados de la historia, propia de aquella historia de bronce, didáctica y reverencial que caracteriza Luis González. En fin: una despreocupación por definir un objeto de conocimiento, que pone en cuestión el status historiográfico de estas publicaciones.

Para ser más claros, examinemos los textos presentados en el capítulo a la luz de las tres fases de la operación historiográfica que caracterizamos antes.

\footnotetext{
${ }^{134}$ El término matria, característico en la obra de este referente de la microhistoria mexicana y latinoamericana, refiere justamente a la escala local de la que venimos hablando. La matria es la "patria chica", la minisociedad del pueblo, el municipio o la aldea, que plantea la convivencia de un espacio corto con un tiempo largo. En la Antigüedad, la palabra se usaba para referir a la tierra de nacimiento y donde radicaba el sentimiento de pertenencia. También ha sido utilizada en la literatura, con distintos sentidos.

${ }^{135}$ González la opone -entre otras- a una historia académica, erudita y crítica, realizada por profesionales en ámbitos universitarios (2009: 83-104). No obstante, veremos que muchos de esos rasgos están presentes en la historia producida desde la universidad, y esto no es exclusivo de la historia platense: la llamada Nueva Escuela Histórica, que impulsó la profesionalización de la disciplina en Argentina, fue al mismo tiempo promotora de una historia de próceres.
} 


\section{La debilidad de las fuentes}

En el orden de lo documental encontramos una característica muy relevante del corpus analizado: muchos libros históricos del centenario carecen de cualquier referencia a fuentes. A eso se suman los descuidos de ciertas ediciones, que producen que haya citas sin referencia bibliográfica (por ejemplo en Díaz, 1982: 212).

En su aporte al Homenaje de la Universidad Notarial, Dora Tálice retoma las palabras de "un cronista de la época" (Tálice, en VV.AA., 1982b: 20), pero sus distintas citas de diarios aparecen sin referencias que permitan ubicarlas.

Bill Kovach decía que el periodismo es la primera versión de la historia. El problema es cuando las siguientes versiones reiteran la primera sin revisarla, completarla ni contextualizarla. Así, según una tendencia que parece muy habitual en las historias locales, el periódico del lugar cumple una función central como fuente, en general utilizada acríticamente, sin ejercer controles epistemológicos sobre el documento ni detenerse a pensar al enunciador como actor político. En varios de los trabajos, El Día es prácticamente la única fuente utilizada.

“...me fui al archivo, me fui a las librerías, me fui acá, allá, allá. Fui a ver un tipo, otro tipo. Lo ví a don (Enrique) Mariano Barba, que es el presidente de la Academia de Historia. Que falleció diez años después, en el noventa, por ahí. Y me dio buenos consejos [...] Trabajé archivo. Creo que leí la totalidad de los diarios. 360.000 diarios ¿viste? Creo. Entre yo y los colaboradores fuimos buscando, buscando, buscando.

-Básicamente trabajaron con el archivo de El Día, digamos

- Si. ¡Es que no hay otra cosa!

- Ajá. Libros tomaban el Salvadores y el de Rey... ${ }^{136}$

- Hasta los 50 años andaba bastante bien. Porque hubo un 25 años que fue bastante más débil, creo que vivía Dardo Rocha, por el 20, por ahí...” (Entrevista a Ricardo Soler, agosto de 2008)

Así cuenta el autor de Vida platense el proceso de producción del libro publicado por El Día. El equipo trabajó a partir de la recopilación de las crónicas de un medio que, a diferencia de la "vida efímera" de muchas experiencias periodísticas platenses, ha sobrellevado "avatares políticos y económicos", por lo que "los ejemplares de EL DIA brindan el hilo que enhebra 98 de los 100 años platenses y permite reconstruir el pasado de la ciudad" (Soler, 1982: 42). En algunos tramos, Vida platense elogia explícitamente las coberturas de El Día.

Pero la utilización predominante de esa fuente está lejos de ser exclusiva del libro publicado por el propio diario. Por ejemplo, en su artículo en Ciudad milagro Lucrecia Amelia Silva Noseda advierte que "los párrafos entre comillas son transcripción textual de artículos aparecidos en el diario 'El Día' de La Plata en las fechas indicadas" (en Lerange, 1982: 355). En tanto, el texto de Moncaut no deja dudas:

“...una de las principales fuentes de consulta resultó la prensa periódica, que día a día fue consignando hechos y sucesos tal vez menudos, pero valiosos hoy, y que de otro modo se hubieran perdido para siempre. Entre esas fuentes hay que destacar, en verdad, la de un antiguo órgano periodístico que nació casi con la ciudad, el diario El Día’" (Moncaut, 1982: VIII)

\footnotetext{
${ }^{136}$ La pregunta partía de la lectura del libro, donde esos autores aparecen como el estado del arte reconocido: "La tarea de investigación y selección de los temas incluyó, además, la consulta a los ancianos y hombres maduros que conservan vivas las experiencias de la niñez platense y recogió valiosos aportes de las tradiciones populares y de libros ya clásicos, como los de José María Rey y Antonino Salvadores...” (Soler, 1982: 7)
} 
Ya hemos mencionado la pobreza de contenido de ese trabajo, que más de una vez transcribe avisos publicitarios, y hasta repite noticias. Hasta tal punto es un libro de transcripciones hemerográficas que llega a repetir eufemismos de la prensa de antaño: un título, por ejemplo, habla de "gente de vida alegre" (Moncaut, 1982: 35). Sólo excepcionalmente aparecen citas de autoridad referidas a otras fuentes, como un Diccionario Geográfico Argentino de 1899. Crónicas de un siglo coincide de un modo palmario con la caracterización de Luis González según la cual "los cronistas municipales tienden a las narraciones atiborradas de datos. Cuentan cosas sin importancia; refieren sucedidos sin relaciones con el tema central; plagan su discurso de basura, y en definitiva, deforman la forma clásica de la narración de los buenos narradores" (González, 2009: 270) ${ }^{137}$.

Las demás fuentes de los trabajos analizados son secundarias respecto a la preeminencia de El Día, y excepcionales en tanto la mayoría se desentiende de cualquier alusión al origen de la información publicada.

Entre esas excepciones están dos notas culturales consecutivas incluidas hacia el final de Ciudad milagro: "La moda en La Plata" de Alicia Dupuy y "El 'tango' en La Plata" de Oscar Bozzarelli. El primero, uno de los artículos mejor armados, hace mención explícita de sus fuentes: cinco diarios, seis revistas, y seis familias consultadas (en Lerange, 1982: 614). El segundo, por su parte, incluye una reflexión epistemológica que reivindica la fuente oral:

"Esta historia es el testimonio oral de los mismos protagonistas que hicieron el tango en La Plata, o de sus familiares. Incluso también mi testimonio, porque yo toqué tangos en bandoneón de 1937 a 1951. Por lo tanto no tiene bibliografía. Es un trabajo original de investigación, en el que, si bien no se ha aplicado la metodología que utilizan los historiadores, tiene sin embargo el valor de la comunicación verbal de los protagonistas. Cuando pude, corroboré la veracidad de los relatos con programas, contratos de actuaciones, piezas musicales y viejas fotografías, la mayoría fechadas. Se transcribieron también fragmentos de dos notas publicadas por el diario 'El Día' en 1896 y 1899, que no hicieron más que confirmar lo expuesto por los relatores" (en Lerange, 1982: 615)

También Bernard hace referencia a las fuentes orales:

"Como se trata de un pasado cercano, de un ayer no tan remoto, utilizaremos y nos valdremos no sólo de la tradición oral, por otra parte primigenia fuente de la historia, del testimonio recibido por boca de los ancestros, sino -y principalmente- de las probanzas documentales, de la fuente escrita, a fin de que la crónica doméstica, familiar, se inserte en la gran historia, brindándole sustancias vitales" (Bernard, 1982b: 19-20)

Otro recurso utilizado por algunos autores son los relatos de viajeros, cuya aparición fue comentada en el capítulo anterior a propósito del libro específico de Barcia (1982). En un sentido similar, como "información cultural", Raquel Sajón de Cuello y Alcides De Giusseppe, reivindicarán la producción poética:

"Si la historia documental es una fuente viva de conocimientos para seguir el desarrollo de un pueblo, las palabras de sus poetas es el mejor testimonio para pulsar el latido de su corazón y las cuerdas de su alma. Uno de ellos, precisamente, maestro de varias generaciones daría ese testimonio en La ciudad del bosque" (en Lerange, 1982: 113)

Finalmente, cabe decir que Obra de arte -que por su procedencia universitaria es quizá uno de los libros con mayor necesidad de validarse en el campo profesional- menciona una

\footnotetext{
${ }^{137}$ Este tipo de productos difiere de la crónica o historia narrativa que González defiende como un formato posible, modelizada por Rebeldes primitivos de Hobsbawm o A sangre fría de Capote (González, 2009: 94).
} 
"exhaustiva investigación en Archivos, Bibliotecas y Museos, complementada con una gran cantidad de documentación gráfica", en un texto que reivindica "una nueva metodología de trabajo basada en la coordinación de equipos y con el apoyo de especialistas de disciplinas afines con la investigación en marcha" para "análisis y una interpretación más integral de los hechos o acontecimientos objeto de estudio" (Díaz, 1982: 17). Más allá de su mención como fuentes, en dicha publicación hay una parte importante dedicada a los archivos, bibliotecas y museos en tanto instituciones de la ciudad (Díaz, 1982: 307-310).

Estos casos son excepcionales y no contradicen la caracterización general: los relatos locales publicados son débiles en su fundamentación y su trabajo con fuentes. De hecho, buena parte de los libros analizados no incluyen referencias bibliográficas. El más erudito en ese sentido es Ciudad nueva ciudad antigua, que culmina con 28 páginas de bibliografía también publicada por separado como un Documento de Avance- que constituye un interesante material de trabajo, preparado especialmente por una bibliotecaria, donde incluso se remite a qué instituciones conservan cada publicación. El listado bibliográfico de esta coedición argentino-española incluye artículos periodísticos, álbumes fotográficos, ediciones de discursos, informes técnicos, censos, reglamentaciones. Hay reseñas biográficas, historias de instituciones, obras de "prohombres", estatutos, libros de arquitectura, etcétera.

La bibliografía de otros libros, en tanto, suele recaer en un estado del arte "canónico" al que me referiré en el capítulo siguiente. El desarticulado artículo de Valdovinos que ya hemos mencionado incluye ese tipo de referencias, en un listado que no sigue una norma de cita y donde faltan datos de edición. La lista concluye con una línea que dice "Rastreo personal (negocios, casas, edificios)", ilustrativa de la débil relación de estos trabajos con sus fuentes. Por su parte, en Vivencias y testimonios todos los libros están citados en el texto, sin notas al pie ni bibliografía al final.

Referencias más específicas pueden encontrarse en el capítulo de Horacio Alberto Urbañsky sobre Berisso (en Lerange, 1982) o en el libro Nueva Argentina ${ }^{138}$.

Aunque puede resultar paradójico, simultáneamente a esta relación débil con las fuentes, la mayoría de los textos recurren a ciertos documentos a los que incluyen con facsímiles o transcripciones completas. Hay así una cierta "necesidad de documentar" que finalmente adquiere una función meramente ilustrativa y que recurre a algunos documentos en particular, en especial de carácter legal. Es un recurso reiterado y su principal fuente es el trabajo precedente de Salvadores, al que nos referiremos en el próximo capítulo. Aunque implica adelantar un aspecto vinculado a la fase representativa, cabe señalar algunos ejemplos.

En algunos casos están previstas secciones específicas o apéndices documentales. La Crónica del centenario, como ya vimos, consagra una parte importante a documentos. Acción profesional tiene un apéndice que contiene una memoria del Departamento de Ingenieros, un significativo debate legislativo ocurrido momentos previos a la elección del sitio, el programa de edificios para el Concurso Internacional -incluidas las planillas de evaluación utilizadas por el jurado- y la memoria del proyecto presentado por J. M. Burgos (ver capítulo V). Se trata de un caso especial porque es una publicación que tiende a la compilación de información: toda vez que puede, transcribe nóminas de profesionales,

\footnotetext{
${ }^{138}$ Su capítulo 3, titulado "Algunas citas bibliográficas acerca de la fundación de la Ciudad de Buenos Aires y su vinculación con el Virreinato del Río de La Plata y la República Argentina”, está basado en largas citas que ocupan varias páginas. Retoma más de una decena de libros de historia, la mayoría editados en España.
} 
autoridades de organismos, programas de estudios, integrantes de comisiones, tareas asignadas, detalles técnicos, montos, evaluaciones de proyectos, etcétera ${ }^{139}$.

El Diccionario de arte, en tanto, incluye una parte final con seis documentos vinculados a su temática ${ }^{140}$. También Creación de la generación del 80, pese a su brevedad -61 páginas, incluye un apéndice documental en el que transcribe el acta fundacional (una de sus versiones) y los mensajes enunciados el 19 de noviembre de 1882 por Dardo Rocha y el delegado del Poder Ejecutivo. Un acta fundacional también está incluida ilustrativamente en Ciudad de mayo, ubicada después del prólogo y antes de los artículos compilados (Urraza: 1981: 15). En Obra de arte se transcriben los considerandos del decreto que creó la comisión de trabajo para una nueva capital -además de nombrar, lógicamente, a sus integrantes- (Díaz, 1982: 129-130), como también la ley de creación promulgada el $1^{\circ}$ de mayo de 1882.

En Vieja amistad, a la foto-retrato de Rocha que aparece inicialmente le sigue un facsímil de la ley y el decreto sobre autoridades provisorias para la capital de la Provincia. El decreto, firmado por Rocha y D’Amico, incluye a Joaquín Bernard (hijo) como escribiente (ayudante y asistente del Escribano) y a Joaquín Bernard ${ }^{141}$ como subcomisario.

Historia del Banco Municipal, por su parte, apela frecuentemente al recurso de la transcripción de documentos: leyes, debates legislativos, etcétera. También incluye fotos de los distintos edificios.

En Ciudad nueva ciudad antigua hay notas al pie con transcripciones completas de decretos (1983: 92-97). También se utiliza la transcripción textual de documentos legales en varios capítulos de Ciudad milagro, como los de Rica o Douglas Morgan. El artículo de Menucci en ese volumen, dedicado al Palacio D’Amico, es bien ilustrativo: tras relatar -con detalle de montos pagados en remate- las operaciones de cambio de propiedad del palacio fundacional que hoy es sede de la Curia Eclesiástica, reproduce el acuerdo y el decreto correspondiente a esa transferencia. No es el único en acudir a la transcripción de documentos específicos que van más allá de la ciudad y sus normas fundacionales: Canestri y Canestri incluyen el acta Fundacional del Jockey Club; Massuco y Outon el acta-convenio de fusión entre el Club Estudiantes y el Club Social La Plata (ambos en Lerange, 1982), y el artículo de Morosi en la Revista de la Universidad, la única transcripción del trazado realizada por Benoit, tomada de la reseña de Coni.

\section{Entre el conocimiento y el homenaje}

En relación a la segunda fase de la operación historiográfica, podemos advertir en general un limitado trabajo explicativo-comprensivo sobre procesos históricos, que tiene como punto de partida la indefinición de un "problema de conocimiento" y tiende a expresarse finalmente en el desarrollo de crónicas no exhaustivas, el interés por curiosidades, y la alabanza hacia ciertas individualidades.

\footnotetext{
${ }^{139}$ La búsqueda de documentar también recurre al uso de imágenes. Por ejemplo: el título de agrimensor extendido por el Departamento Topográfico a Pedro Benoit en 1861 (página 27); plantas y fachadas de proyectos (61-68), el plano elevado por el Departamento de Ingenieros en mayo de 1882 (85), el repartido en la fundación (87) y el que aparece en la Reseña de Coni (89), y finalmente fotos de edificios públicos (91-94)

${ }^{140}$ I. Monumento a la Junta de 1810 / II. Contrato y presupuesto para la obra de pintura y decoración de la Cámara de Diputados de la provincia. / III. Pintor de la provincia / IV. Programa de dibujo intuitivo en la escuela argentina / V. El salón oficial y las sociedades de arte / VI. Supuestos formativos de la formación plástica.

${ }^{141}$ Es el padre del escribiente. Era hermano mayor del abuelo del autor, Tomás Bernard, que vino a la ciudad un tiempo más tarde y trabajó custodiando títulos y papeles del Estado en el Ministerio de Hacienda. Ambos hijos de Juan Joaquín Bernard, llegado de Francia para integrar las dotaciones de la escuadra del almirante Brown.
} 
Predominan en la bibliografía sobre la ciudad las miradas celebratorias, tomando un término utilizado por Gorelik al caracterizar ciertas narrativas sobre Buenos Aires. El referente de la historia cultural urbana afirma que este tipo de producciones "coinciden todas en una visión reconciliada y en un circuito, de hechos y lugares, que no se arma muy diferente de un circuito turístico: como un manojo de postales se reúnen en el relato monumentos al progreso y arrabales pintorescos" (Gorelik, 2004: 114-115). Es lógico que esta inclinación hacia el homenaje relegue cualquier trabajo de comprensión o explicación. Es excepcional encontrar notas epistemológicas en las publicaciones que integran nuestro corpus. En ese sentido, si bien no ubicamos a los textos analizados en el universo de la memoria -con sus sentidos asociados a lo vivido-, sí afirmamos que están inscriptos en un uso conmemorativo de la lectura del pasado, que los corre del registro más sistemático de la historia profesional.

Como anticipamos al inicio del capítulo, al explorar los objetivos planteados por los distintos textos del centenario, hallamos discursos de homenaje o celebratorios -que son predominantes-, nostálgicos y de "lucha contra el olvido""142 -asociados a los textos de vivencias y testimonios-, patrimonialistas y algunos, sí, guiados por una búsqueda de conocimiento en un sentido científico-académico. Finalmente, con una meta que también implica el conocimiento pero con intenciones contrahegemónicas o de denuncia, encontramos la publicación de Familiares sobre los desaparecidos de la región.

La clasificación anterior no es taxativa: las búsquedas se solapan; hay textos testimoniales que reclaman el cuidado del patrimonio urbano y obras "académicas" tensionadas por pasajes que demandan homenajear la ciudad y festejar sus cien años.

Las miradas celebratorias destacan de La Plata un carácter de "ciudad inédita, atípica", por su "diseño original, estudiado", una "condición de ciudad rectora" (Bernard, 1982a; también en Lerange, 1982: 21-22). Aquí aparecen las comparaciones con las grandes ciudades europeas y norteamericanas, y también alusiones al pensamiento griego:

"Como Minerva de la cabeza de Zeus, La Plata nace adulta" (Bernard, en Lerange, 1982: 22)

"La fundación de La Plata nos recuerda la concepción Homérica de la sociedad fundada en la justicia. Cuando Ulises desembarca en un país desconocido...." (Douglas Morgan, en Lerange, 1982: 209)

Rica, en otro texto introductorio de Ciudad milagro, destaca el carácter planificado de La Plata, donde primó una "perspectiva de conjunto", "todo fue prolijamente calculado", "se proyectó así una ciudad moderna" (en Lerange, 1982: 42). Asimismo, como muchos otros textos, aporta referencias que resaltan el carácter moderno y progresista de la ciudad:

"En La Plata de inmediato se adoptó el alumbrado público a electricidad; fue una de las primeras ciudades del mundo que aplicó el alumbrado en casas, negocios, talleres, industrias, en calles y parques" (en Lerange, 1982: 43)

Además del trazado perfecto y el carácter ex novo de la ciudad, el otro tópico recurrente de los discursos celebratorios es su consideración como "ciudad del saber" o "capital de cultura", que lleva a la exaltación de la presencia universitaria que problematizaremos en el capítulo VI.

Las miradas nostálgicas son más propias de los textos testimoniales, ya que tienen un fuerte anclaje en las vivencias, en la añoranza de una socialidad perdida:

142 "Este es un libro que trata sobre cosas sencillas sin otro propósito que el de evitar la desaparición u olvido de todo eso que fue síntoma y consecuencia de un proceso social hoy ya inexistente" (Sureda, 1982: 9). 


\begin{abstract}
"De alguna manera, las palabras precedentes -escriben Sara y Graziela Canestri en una evocación sobre el Jockey Club- son el testimonio nostálgico de una época que no ha de volver, la de romanticismos y bohemias perdidas, que estimulaban el placer de la 'charla', enhebrándose amistades y estableciéndose compromisos recíprocos de verdadera solidaridad social.

El materialismo y la urgencia, pusieron fin a un tiempo en que se vivía 'el club' como parte de la vida de cada uno, con sus implicancias en las actividades deportivas y sociales y como caja de resonancia de los acontecimientos políticos. En definitiva, no se lo podía ignorar, si se quería vivir con intensidad, la vida toda de la ciudad" (en Lerange, 1982: 445)
\end{abstract}

La nostalgia se construye siempre sobre una ausencia. El recuerdo del tranvía o el carnaval, por ejemplo, son referencias fuertes y habituales en estos relatos sobre "todas costumbres que se han ido y que es grato recordar" (Moncaut, 1982). El recuerdo feliz de una vida de antaño se asocia especialmente a las décadas previas al peronismo, los años '20 y ‘30, cuando vivieron su infancia o adolescencia los autores de los libros más vivenciales.

"En La Plata anterior a los años 20 no había casi tránsito vehicular [...] Será tal vez por eso que ahora, cuando la ciudad es ya populosa y con denso tránsito vehicular, me aflige comprobar que en ninguna calle hay chicos jugando. ¿Dónde está el piberío ahora? ¿Dónde juega? ¿Cómo entretiene su infancia?” (Sureda, 1982: 27)

"Mi madre me dejaba jugar todo el día con los chicos del barrio porque la gente de aquel tiempo, hacía más vida vecinal" (Sureda, 1982: 29)

Ya vimos que los '20 son una época añorada por Sureda y Szelagowski; también por Rogelio Yáñez, que sintetiza una visión negativa sobre el presente de la escritura:

"Estamos en el comienzo de la década de los años ochenta, como estuvimos, al principio de estas líneas, en la de los años veinte. En su centenario, la ciudad ha bordeado las plazas y avenidas centrales, con innumerables torres de cementos, no mиy atractivas. Sonidos estridores, estrépito de escapes abiertos, sin cesar, taladran los oídos y hacen la noche inepta para reposar. La juventud, prácticamente, está uniformada en atuendo y en hábitos. El tabaco es una pandemia total..." (SADE La Plata, 1982: 87-88)

Por su parte, Estela Calvo (1982) se reconoce "demorada en los años treinta" y desde su nota preliminar asume el carácter de su libro: "Siempre pensé que vivir en la nostalgia era un derroche o un riesgo. Hoy, al ofrecer estas palabras de recuerdo encaro lo segundo. Conmemoro el pasado y reconozco que quedó tan prendido a mi vida que ya no tiene forma pretérita..." (Las cursivas son mías). Y en su tiempo presente, advierte una ciudad "invadida por construcciones que enturbian su cielo de placidez inicial, atacada por el ruido del progreso, por el trajinar indiferente del platense que sin embargo la quiere y el domingo brumoso la reencuentra en alguna nostalgia...".

Como se advierte en las últimas citas, la mirada nostálgica conecta con un discurso patrimonialista, al lamentar las torres de cemento y las invasivas construcciones que enturbian el cielo, o como plantea Seiguel en el prólogo de Primeros habitantes, "el aluvión edilicio impelido por la podadora del progreso que ha trocado en urbe ululante su quietud campesina" (en Terraza, 1982: 9).

Cabe aclarar que llamamos patrimonialismo a un discurso que exige la preservación de ciertos bienes urbanos considerados de valor-esculturas, edificios históricos y en ocasiones el patrimonio vegetal-, que suele dar por obvio o natural el origen de esa valoración, cuando en rigor es producto de disputas, políticas de lugares o políticas de memoria, que definen ciertos 
objetos como patrimonio en detrimento de otros (Carman, 2006: 24-27). En el fragmentario Crónicas de un siglo, Moncaut señala al 13 de junio de 1913, cuando se procede a la demolición del monumento a la Primera Junta, como "fecha fatídica" (Moncaut, 1982: 96). Rastros y rostros, por su parte, evoca “'El leñador' que fuera retirado de su sitio en la antigua 53 por la desorientante costumbre de innovar que, con igual indiferencia desplazara la estatua de Moreno de la plaza que lleva su nombre o destruyera en 1915 el romántico arco que emplazado en el bosque fuera para los platenses de fines de siglo un símbolo de fraternidad" (Calvo, 1982). Cabe sospechar que en este conservacionismo hay también una cuota de conservadurismo, y que tanto la mirada nostálgica como el discurso patrimonial tienen un sentido decisivamente político.

La prédica patrimonialista es marcada en los textos específicamente dedicados al arte escultórico, como Ciudad de mayo o el artículo "Mi ciudad y sus esculturas" en Ciudad milagro:

"La demolición de monumentos conmemorativos en nuestra ciudad constituye un episodio más de la época legendaria del conocimiento artístico e histórico por parte de las autoridades responsables de tales hechos. Según Jean Cocteau, las estatuas de los grandes hombres se hicieron con las piedras que les fueron arrojadas cuando ellos vivían, y lo justo parece ser que los hombres de poder obliguen a las estatuas a devolver esas piedras" (De Urraza, 1981: 43)

"El objetivo que tiene esta publicación, es alertar a las autoridades comunales y provinciales, a preservar el patrimonio histórico-cultural. Algunas esculturas han sido destruidas por la negligencia y la desidia: otras por la piqueta 'modernizadora' en un afán de 'progreso' deshumanizado y en gran medida todas se han perjudicado con una actitud de la población en general que no ha exigido el mantenimiento que merece, ni ha cuidado, como suyas, las obras que unen nuestro pasado orgulloso y señero, con los días que hoy transcurren" (Canestri, en Lerange, 1982: 249. Las cursivas son mías)

La figura de la piqueta como sujeto impersonal de esos flagelos es reiterativa. Al referirse al viejo arco de entrada a la ciudad Urraza afirma que "fue arrasado y demolido por la piqueta de la improvisación y la ignorancia" (De Urraza, 1981: 41). La expresión aparece también en textos de Szelagowski (1979: 13), Christmann (1982: 209), Terry (en Lerange, 1982: 335) y Bernard (1982b: 36), en estos dos últimos sobreadjetivada: es la piqueta demoledora o la piqueta destructora de un despiadado e incomprensible progreso.

Según la Crónica del centenario "la profusión de trabajos de investigación, de conferencias, de artículos, exposiciones o libros que el Centenario ha alentado, está creando, era hora, una conciencia platense sobre la verdadera tradición a exaltar y preservar. Es el tiempo que terminemos de demoler y comencemos a construir sin destruir".

El patrimonialismo está presente también en textos orientados a temas urbanísticosarquitectónicos como el dirigido por Morosi (1983). En el intercambio epistolar entre el director y el asesor de la investigación, el español De Terán afirmaba que Ciudad nueva ciudad antigua "debería tratar de crear una conciencia de valoración de ese patrimonio cultural, hacer nacer una actitud administrativa más conservadora" ${ }^{\text {143 }}$. En el libro se plasman críticas a una modernización engañosa que degrada el patrimonio urbano:

“...ejemplos de caminos dudosos recorridos por la senda de una falsa modernidad y la frivolidad de una banal, artificiosa y superficial concepción pretendidamente democrática del uso de los espacios urbanos..." (Morosi, 1983: 249)

${ }^{143}$ Fernando de Terán, correspondencia con Julio A. Morosi, 22 de diciembre de 1981. 
La ciudad en 1982 generaba un planteo dual, de celebración y queja, como sintetiza De Terán en el prólogo:

"La realidad urbana actual de La Plata suscita dos tipos de reacciones contrapuestas. Por una parte, produce la complacencia y satisfacción admirativas de lo hermoso y singular. Por otra, la indiferencia despectiva que se siente ante la vulgaridad y la falta de interés" (Morosi, 1983: 8)

En algunos textos, como la Crónica del centenario, el llamado de atención abarca también a los espacios verdes:

"También su patrimonio arbóreo y vegetal ha sido descuidado o directamente agredido muchas veces por un falso sentido del progreso. Su fama como 'ciudad de los tilos' que tendría sus inicios alrededor de 1914, tiene que ser preservada mediante la intensificación de adecuadas forestaciones; y cuando pensamos en el 2082 nos preguntamos sobre la supervivencia de esa hermosa especie" (Szelagowski, 1982b: VII)

A propósito de esta cita, notemos que otra de las motivaciones que aparecen en las publicaciones es la de dejar un mensaje para el futuro. Esto está particularmente marcado en la crónica de Szelagowski, escrita para ser incluida en la cripta que se desenterrará en el bicentenario de la ciudad, y por lo tanto con un destinatario "que resulta lejano, etéreo; que podrán ser nuestros bisnietos, parientes innominados, y conciudadanos que allá lejos leerán un mensaje que pretendemos los pueda ubicar en una ciudad, frente a sus antepasados, remontarlos 100 años atrás y hacerles conocer cuáles fueron sus pensamientos, sus problemas y su legado" (Szelagowski, 1982b: I). Pero no es la única publicación con ese impulso. En la presentación de Crónicas de un siglo, firmada por el gabinete municipal, las autoridades interpretan al centenario como "un llamado cierto y compromisorio para las generaciones venideras" y por eso "han querido entregar este libro dirigido fundamentalmente a los jóvenes, porque en sus manos y sus mentes está el futuro de la ciudad y no tenemos miedo al futuro" (Moncaut, 1982: V). Catalina Lerange, por su parte, señala que los capítulos de Ciudad milagro permiten "volver a nuestras raíces por el silencioso y no obstante docente camino de nuestros muertos amados y, desde allí, extender la mirada a la esperanza de una futuridad mejor" (en Lerange, 1982: 12).

Por último, hay obras que remarcan una búsqueda vinculada al conocimiento, si bien como venimos observando el carácter académico-disciplinar no es un aspecto significativo en la caracterización de estos textos.

El más preocupado por el carácter científico de su aporte es presentado en Económica, producto parcial de la investigación intitulada Paseo histórico que nunca llegó a ser publicada $^{144}$. El artículo incluido en la revista presenta unas "síntesis esenciales originales" como "colaboraciones interdependientes que han seguido, dentro de lo posible, la construcción de un orden científico, propio de las ciencias humanas, que se sintetiza en la frase: 'unidad en la variedad y mutua afinidad en la diversidad' (León XIII)". La idea de síntesis esencial viene a advertir que "no es una historia integral de la ciudad de La Plata. Es, simplemente, el conocimiento de algunas vertientes de un inmenso caudal. Sugerimos, pues, no conformarse con un sector de la variedad y procurar adentrarse en la unidad" (Cuccorese,

\footnotetext{
${ }^{144}$ Esto no implica que desconozca la coyuntura celebratoria como motivación. En la misma presentación, Cuccorese plantea: "El Centenario de La Plata resulta ocasión propicia para volver sobre la historia, origen y desarrollo de la ciudad..." (Cuccorese, 1982: 139)
} 
1982: 139). Al mismo tiempo, el texto señala la dificultad que implica producir la historia de una ciudad, hasta sugerir la imposibilidad académica de una historia local:

"Hacer 'vivir la historia' integral de una ciudad centenaria es sumamente difícil. ¿Por qué? Puesto que la historia de una ciudad es parte de la historia regional, y de la historia nacional, y hasta de la historia universal" (Cuccorese, 1982: 137-138)

"Al abordar la historia de las ciudades se vislumbran problemas [...] Respetando religiosamente la teoría e historia de la historiografía tendríamos que decidir, ante la realización de la historia de las ciudades, por... no hacer nada. Porque una microhistoria de una ciudad no resiste a los embates de la crítica" (Cuccorese, 1982: 138)

Otro que incursiona en reflexiones epistemológicas es Bernard, en su conferencia inspirada en la amistad de su propia familia con los Rocha. Además de evocar a Mitre como "padre de nuestra historiografía erudita" (Bernard, 1982b: 20) y señalar un papel protagónico del paso del tiempo en la producción histórica ${ }^{145}$, el autor defiende la idea de una "pequeña historia" o "microhistoria"146, que terminará siendo identificada con el vocablo "crónica", recurrente en la bibliografía analizada:

"La 'pequeña historia' está hecha de aconteceres varios, de un conjunto por veces inorgánico de sutilezas, cuyas fuentes simples y espontáneas, dan frescura y colorido al friso de la gran historia y permiten esclarecer la entretela del cañamazo en que se bordan los sucesos relevantes, las manifestaciones sobresalientes y las actitudes de los personajes que caracterizan -a la postre-, tipificándolos, los ciclos, los períodos y los aconteceres propiamente históricos.

Esa gran historia, sea universal, continental o nacional, es el macro cosmos, el espejo que devuelve, por la investigación y el estudio, la imagen integral e integrada del pasado, ubicándola, con precisión, o por lo menos con la mayor aproximación posible, según un estricto sentido de verdad, en el tiempo y en el espacio, condicionantes de todo proceso histórico. Pero la intelección, la comprensión acuciosa de ese pretérito que se desea recrear, cobra su fuerza vital, expansiva y suasoria, en el micro cosmos, en la 'petite histoire', cuando el investigador ilumina los detalles reveladores de la realidad coetánea, los rasgos indelebles de circunstancias, hechos y figuras que bajo la escrutadora lupa pondera los ingredientes sazonadores de lo que aparece revestido finalmente de perennidad".

La referencia a la petite histoire, la historia menuda tan adorada por los franceses (González, 2009: 94) nos da un indicio de la inclinación europeísta del autor. La cita vale también para advertir la prosa anticuada de los escritores del centenario, que analizaremos más adelante. Bernard prosigue:

"La micro historia, con suma pormenorizada de datos, visualiza la macro historia desde todos los ángulos y perspectivas y hace a una más correcta, completa y compleja hermenéutica, vale decir, favorece el proceso de interpretación vital del pasado en que se pone a prueba la capacidad e intuición del auténtico historiógrafo.

Pretendemos, por nuestra parte, en esta fiesta centenaria de la Nueva Capital, urgar [sic] en esa crónica menuda, casi diría hogareña, que da sentido trascendente al empeño fundacional, mostrando la raigambre de un ideal constructivo, creador y dinámico, que afincó su éxito en fuerzas cívicas y morales de depurado linaje espiritual" (Bernard, 1982b: 13-14)

\footnotetext{
145 "He afirmado con reiteración que el tiempo es a la historia lo que la proyección a la pintura. Debemos alejarnos lo suficiente del origen para enfocar debidamente el cuadro y apreciarlo en todos matices y detalles. El tiempo juega un papel protagónico en la historia" (Bernard, 1982b: 37)

${ }^{146}$ Bernard utiliza el término microhistoria sin la carga semántica de la tradición intelectual italiana que tiene como referentes a Giovanni Levi, Carlo Ginzburg o Carlo María Cipolla.
} 
En los trabajos que señalan búsquedas vinculadas a la ampliación y circulación del saber histórico, lo científico suele aparecer mezclado o tensionado por la celebración, la nostalgia o el "mensaje a las generaciones venideras". Así, por ejemplo, Historia del Banco Municipal se presenta como un "trabajo de investigación" (Giuliano, 1983: 9) pero en su prólogo, el presidente del banco resalta que "la decisión de escribir y publicar este libro, nace de la necesidad de brindar un homenaje más al Primer Centenario de la Fundación de La Plata. Es por lo tanto un momento propicio para recordar y dimensionar a todos aquellos hombres que la engrandecieron" (Ripa Krause, en Giuliano, 1983: 7). Encontramos una doble justificación similar en Ciudad nueva ciudad antigua:

"Esta obra procura cubrir parte del vacío que significa la carencia de estudios referentes a la ciudad de La Plata considerada como fenómeno urbanístico y, al propio tiempo, pretende rendir justo homenaje a ese singularísimo espacio urbano, en ocasión de cumplirse el primer centenario de su fundación" (en Morosi, 1983: 7)

Además, el saber producido, relacionado con una "necesaria generalización de la educación histórica", se asocia con las metas de preservación patrimonial mencionadas antes:

"En este libro se trata de hacer una profundización en el conocimiento de los valores de La Plata, con énfasis fundamental en el proceso de su creación y evolución histórica. Como producto académico y costoso que es, difícilmente podrá actuar en forma directa como estímulo de la sensibilidad histórica colectiva que es necesario potenciar. Pero sí puede jugar el papel de desencadenante de un proceso de divulgación que habrá de ser instrumentado, con apoyo en la existente sensibilidad pública, cuando se den las condiciones políticas para ello. También en esto manda la historia que hacen los hombres" (Morosi, 1983: 13)

“...es ese conocimiento el que puede actuar de antídoto contra tentaciones desarrollistas que, amparadas en excusas de modernización, lo que hacen es continuar el proceso de destrucción de los más altos valores de la ciudad que constituyen, y así deben ser considerados, un verdadero patrimonio social" (Morosi, 1983: 12)

Los dos ejemplos presentados corresponden a publicaciones sobre dimensiones específicas, escritas precisamente en homenaje a la ciudad. Veamos cómo las mismas tensiones aparecen -con mayor complejidad- en el grupo de obras que intentan abordar una "historia general". Obra de arte y la Crónicas de un siglo son ejemplos elocuentes.

En el primer caso, una edición preparada desde la Universidad, el prólogo del decano de la Facultad de Humanidades invoca la ciencia histórica, asociándola a "una de las necesidades más básicas del ser humano": la de saber quiénes somos.

"Hay una ciencia que se ocupa de responder estos interrogantes: La Historia, que -lejos de ser la mera narración de lo que pasó, incluso más que ser el recuento de lo que nos pasó- tiene como propósito dar cuenta de cómo y por qué hemos llegado a ser lo que somos hoy. El relato de lo que hicieron en el pasado innumerables hombres y mujeres no pasaría de ser un ejercicio intelectual de investigación paciente y memoriosa, un promotor de gratitudes y rencores, homenajes y denuestos (finalmente estéril como toda entelequia) si no sirviera para darnos ese sentido de pertenencia a la enorme familia de la Humanidad y al grupo más reducido de nuestra comunidad que, así como tiene una dimensión especial dentro de los límites de nuestro partido, tiene una dimensión temporal en estos primeros cien años que celebramos" (Elder Daniel Evans, en Díaz, 1982: 10)

El libro se presenta respondiendo a una necesidad o un derecho, del que serían portadores los platenses, destinatarios del libro: "Usted, habitante de La Plata, tiene el derecho de saber de dónde viene. Usted tiene la obligación de explicarle a sus hijos de dónde vienen y 
hacia dónde van”. La narración histórica está asociada entonces a derechos y deberes. La historia que relatará Obra de arte "nos pertenece, y a esta historia pertenecemos, o perteneceremos si tenemos la entereza y el coraje necesarios para estar a la altura de las demandas de esta hora que nada nos permite suponer sea sustancialmente más difícil que la que le tocó vivir a nuestro fundador y a los que junto a él se atrevieron a soñar este sueño en el que hoy vivimos" (en Díaz, 1982: 10).

Luego, la precisión o el rigor de la historia se mixtura con la afectividad de la memoria: "Este libro es un intento de presentar al lector un análisis detallado y afectuoso de por qué aquí, por qué entonces, por qué de esa y no de otra manera, junto al afán esperanzado de contribuir a iluminar hacia dónde" (Díaz, 1982: 10. Las cursivas son mías)

Más adelante, en un capítulo sobre la metodología de investigación, los autores de Obra de arte puntualizan una serie de objetivos, que sin dudas son atípicos para una investigación académica y exceden la idea de "objetivo de conocimiento". Estos son:

“- Rendir un justo homenaje a su población fundadora;

- Destacar su aporte en el orden artístico, literario y deportivo;

- Resaltar la formación económica y social de la ciudad;

- Colocar en manos de los educadores, hombres de empresa, funcionarios provinciales y municipales, trabajadores y estudiantes de todos los niveles, una obra didáctica, clara y accesible, que sirviera de instrumento de enseñanza y de difusión general;

- Proyectar la ciudad centenaria, sus hombres y sus obras, hacia el futuro" (Díaz, 1982: 17)

En varios de los libros analizados, la mixtura entre investigación histórica y homenaje define cabalmente el carácter de obras que afirman un objetivo de conocimiento, pero se ubican fuera del campo académico-científico de la historia. Esto es bien característico en Crónicas de un siglo, que también alude a la ciencia histórica pero lo hace para desmarcarse desde un principio:

"Cuando en nuestro transcurrir por las aulas debíamos adentrarnos en la disciplina de la historia, los textos que se nos ofrecían eran todos tradicionalmente uniformes: hechos políticos y militares. Pero la pequeña historia, la de la vida cotidiana, con sus aspectos sociales y económicos, difícilmente tienen cabida en sus páginas.

Por ello es que decimos que este libro es distinto. Pretendemos, a través de las crónicas menudas, deshilvanar la madeja de nuestro pasado lugareño" (Moncaut, 1982: VII)

La opción está marcada desde el título mismo de la obra: busca ser una crónica y no una historia de un siglo platense. No obstante, la noción de crónica presente en las publicaciones del centenario es ambigua. Los textos tienden a un ordenamiento cronológico, pero no ofrecen la narrativa "por definición informativa" a la que "se le agradece la ausencia de vituperios y alabanzas que en algunos casos suple el lector", sino que adquieren rasgos propios de la historia pragmático-ética que expide constantemente juicios de valor (González, 2009: 9697). Pero aunque podamos discutir el estatuto de estos textos como crónicas, la expresión evidencia una búsqueda específica que no se referencia en el campo científico:

"Con este enfoque de crónicas y hechos cotidianos, seguramente de menor cientificismo, aun cuando de difícil sencillez, pretendemos revivir el pasado platense con amenidad levantando lenta y casi imperceptiblemente el velo de nuestro pasado" (Moncaut, 1982: VIII)

"El toque anecdótico, aunque aparentemente pueril, logra, con más posibilidades que otros medios, conmover, deleitar, atraer e informar" (Moncaut, 1982: VIII) 
Así, las partes narrativas del libro adoptan tonos de semblanza y rememoración, y contienen una mirada nostálgica sobre el pasado de la ciudad. En el caso de Crónicas de un siglo, como vemos, es el propio autor quien reitera la expresión y reivindica la nostalgia.

"Pretendemos con este libro brindar a los lectores un álbum de recuerdos, como aquéllos que no faltaban en ningún hogar de antaño, forrados de terciopelo rojo, azul o verde, cerrado con un broche de plata, donde se colocaban los retratos rígidos como sus cartones, hechos sobre fondos de telones pintados en la 'Fotografía Artística' del pueblo, con motivo de acontecimientos importantes: bodas, bautizos, comuniones, etcétera. Y en estos días de puro pragmatismo, hojeándolo, recuperaremos el romanticismo, el fluido amor al terruño. Sus páginas exhalarán un tenue aroma de nostalgia y, a través de la noche estrellada del recuerdo, esos seres inanimados tomarán vida en nuestra imaginación, y a su conjuro, veremos desfilar la vida íntima de nuestra ciudad querida" (Moncaut, 1982: VIII)

Varios de los textos analizados reivindican la idea de recuerdo y rememoración, aún conscientes de las posibles "inexactitudes, porque nuestra memoria puede traicionarnos y haber ido reformando, con el tiempo, nombres y lugares" (Szelagowski, en Lerange, 1982: 603). Las nociones semánticamente próximas al término memoria se utilizan también para nombrar una suerte de historia-homenaje que caracteriza a los libros, más que en el sentido de testimonio de una experiencia vivida. Como plantea Lerange al presentar Ciudad milagro:

“...no creemos haber logrado 'el libro ideal de la centuria platense', como afirmara alguien al conocer su temario. Simplemente intentamos una forma de memoración, de las tantas que ha suscitado y habrá de continuar suscitando dicho acontecimiento" (en Lerange, 1982: 12. Las cursivas son mías)

\section{El formato misceláneo y los descuidos editoriales}

La operación historiográfica culmina con la configuración literaria de un texto y su presentación editorial, sobre la que ya hemos adelantado algunas caracterizaciones. Dado aquel cóctel de objetivos que rebasa el de explicación-comprensión, es lógico que los relatos locales publicados también presenten particularidades en su fase representativa.

El primer aspecto a destacar es que la mayoría de las publicaciones incluyen imágenes, tanto en sus portadas como en algunas páginas interiores. Como veremos más adelante, hay motivos reiterativos como la simbolización del trazado o retratos de personajes fundadores, que enfatizan sentidos que ya están presentes en los textos. También hay imágenes del arte escultórica, no sólo en textos centrados en ese tema como Ciudad de mayo, sino también en publicaciones como 12 personalidades, que en su portada tiene a El pensador de Rodin.

En el caso de los trabajos más voluminosos, ya hemos señalado una presencia muy significativa del recurso gráfico en Ciudad nueva ciudad antigua y en Obra de arte; no así en Ciudad milagro. En el caso de la publicación realizada desde la Facultad de Humanidades, cabe recordar que su producción estuvo acompañada de un audiovisual y una muestra gráfica presentada en el marco de la celebración del centenario.

No obstante, el uso de imágenes no es un recurso de la totalidad de los libros ni la característica más sobresaliente en esta fase.

Retomando una expresión que vimos utilizada por Bernard y Moncaut, las historias presentadas son menudas en los distintos sentidos de la palabra: en efecto, presentan hechos con detalle y pormenor, pero también cargan con una escritura endeble, de baja calidad. 
El formato de los libros, la organización del material y sus estilos de escritura también alejan a las producciones del centenario de la historia académica o disciplinar.

Si tomamos las publicaciones más voluminosas, la única que tiene unidad narrativa o argumentativa es Ciudad nueva ciudad antigua: la indagación arquitectónica-urbanística establece un hilo conductor, hay ciertas preguntas recurrentes, unos capítulos refieren a otros, y hasta cierra con una "síntesis" que efectivamente propone un repaso de lo visto.

No pasa lo mismo, por ejemplo, con Ciudad milagro, donde textos sobre instituciones de la ciudad o sobre aspectos específicos de la historia platense conviven con una semblanza sobre las campanas de la ciudad que entremezcla prosa y poesía ("Las campanas de La Plata", de Lina Husson), un artículo que busca "hacer justicia" con una persona ("Ernestina Rivademar y la fundación del Museo de Bellas Artes", de Horacio Ponce de León") ${ }^{147}$ y otro que se presenta como un homenaje de la primera promoción de bachilleres egresadas en 1910 del Colegio Secundario de Señoritas ("Dos Centenarios y rosas por doquier", de Lucrecia Amelia Silva Noseda). En "El Almacén”, Carlos Moncaut pretende "rendir un homenaje a los primeros almaceneros que se establecieron en nuestra ciudad al tiempo de su fundación" (en Lerange, 1982: 594) en un artículo extenso que, tras una larga presentación de citas desvinculadas de La Plata, presenta datos tan concretos como el nombre de cada negocio, su dueño y su dirección. Un caso extremo es "Jardín Zoológico de La Plata" -la primera nota institucional de la compilación-, que acumula datos como pesos y cantidades de comida consumida por los animales, y señala el horario de atención al público del Zoo en esa época, en un texto escrito como una memoria anual de la institución y firmado por el jefe de su División Técnica.

Algunos capítulos de la compilación contienen en sí mismos esa heterogeneidad temática: ni "La Plata hacia una nueva armonía" de Conrado Bauer ni "Ramos Generales" de Dora Valdovinos tienen un tema claro, sino que proponen recorridos amplios. El segundo artículo es paradigmático: el título alude a su contenido, pues a "semejanza" de los llamados comercios de ramos generales,

"aspiro que la esencia de este trabajo de rastreo y síntesis -intencionalmente sin cronología en sus datos- ofrezca al lector aquello que su curiosidad estaba buscando y que, por la disparidad de los acontecimiento señalados, logre incentivar su interés y sea punto de partida para ampliarlo. Será un breviario -así lo exige la justeza de sus páginas- que solamente pretende rescatar 'algo' del acontecer del pasado, esbozando casos verídicos de la ciudad ya centenaria" (en Lerange, 1982: 633)

Valdovinos habla de "recuerdos" y de "restaurar con orgullo hechos y nombres quizá desvanecidos" (en Lerange, 1982: 633). Pero lo que el artículo expresa, en rigor, es una lógica de sumatoria de datos llevada al extremo. Al igual que la Crónicas de un siglo, es una mixtura de informaciones diversas: nombres, primeras veces, construcción de edificios, instalación de comercios, designaciones en cargos, etcétera, que en buena medida son lugares comunes, referencias muy conocidas de la historia de La Plata y muchas de las cuales ya habían aparecido en otros capítulos del mismo libro. La autora intercala un párrafo en cursiva con otro normal, y con ese recurso tipográfico salta de un tema a otro. Escribe: "Al senador

\footnotetext{
${ }^{147}$ Hay que decir que el artículo va más allá del Museo de Bellas Artes y presenta datos interesantes, no sugeridos por el artículo. Por ejemplo, Rivademar es presentada también como "precursora local en el campo del arte cinematográfico" (en Lerange, 1982: 190).
} 
José Hernández -autor del libro gauchesco 'Martín Fierro' se le atribuye el nombre de la ciudad: La Plata" (en Lerange, 1982: 633), y pasa al siguiente tema. Y así sucesivamente:

"Fundador y primer Director de la Escuela Industrial de la Nación fue el profesor José Miguel Sagastuma".

"'La ciudad de las ranas', llamaban a La Plata los enemigos porteños".

"El doctor Enrique Rivarola que vivía en 47 entre 8 y 9 (actual Cruz Roja) además de ser notable jurista y destacado catedrático, se lo considera el primer escritor y poeta de La Plata".

"El primer Vicecónsul de España en La Plata fue el señor Idelfonso Medina" (en Lerange, 1982: 633-636)

Todo es una suma de acontecimientos sin proceso, de datos sin contexto. Llega a incluir un párrafo que dice:

"El día que se fundó La Plata era domingo y llovía" (en Lerange, 1982: 636)

Por otra parte, la mayoría de las menciones son previas a 1930. Hay muy pocas referencias posteriores ${ }^{148}$. El caso de Valdovinos es extremo, pero el carácter de la información presentada y su escritura están lejos de ser una excepción en la bibliografía analizada. También en Vida platense se incluyen párrafos aislados que aluden -por ejemploa los primeros farmacéuticos (Soler, 1982: 24), y en la edición universitaria Obra de arte, en un apartado sobre escuelas y bajo el título "Hechos peculiares", se relata que en 1960 egresaron de la escuela 7 alumnos no videntes.

Ese carácter misceláneo -evidenciado en extremo en los últimos ejemplos- es característico de distintas publicaciones, sobre todo aquellas que procuran construir una mirada amplia, una "historia general" sobre la ciudad. En algunos casos se defiende como una decisión consciente, como lo hace Kraiselburd en el prólogo a Vida platense:

“...procuró eludir la estructura habitual de los textos enhebrados casi exclusivamente en torno a los hechos políticos. Ha querido ofrecer pantallazos de la vida diaria, el deporte y las costumbres con la visión instantánea característica del periodismo" (en Soler, 1982: 7)

O como plantea la contratapa del libro:

"100 años de vida platense intenta, en apretada síntesis, resumir aquello que los habitantes de la ciudad han vivido con mayor intensidad, a lo largo de un siglo. Se destacan así, los sucesos políticos, los vaivenes de la economía, los acontecimientos artísticos, el deporte, las enfermedades, las costumbres y la estela que dejan en la vida, por una razón u otra, los hombres destacados o los genios. Por rara decantación del tiempo hubo casos que quedaron en la memoria de los platenses, como personajes y hechos cotidianos que también se intentó registrar. El texto tiene un poco de historia, otro de ensayo, algo de periodismo y por eso no tuvo el atrevimiento de llamarse historia o crónica, sino simplemente, quiso ser una ventana al pasado de la ciudad" (Soler, 1982. Las cursivas son mías)

De ese modo, se intercala información sobre la evolución del transporte, celebraciones realizadas (fundación, centenario nacional, aniversarios de la ciudad), actividad de instituciones, colectividades extranjeras y espacios culturales (los primeros teatros, la

\footnotetext{
${ }^{148}$ Básicamente son las referencias al coro universitario -1941-, la fundación de APRILP -1957- y el incendio del Teatro Argentino -1977-. Ninguna de las fechas corresponde al período peronista, ni hay referencias a fábricas. Volveremos sobre esto más adelante.
} 
formación de cine-clubes, etcétera). Algunas temáticas aparecen en ciertas épocas y en otras no, dejando dudas sobre el criterio con que se construyó el conjunto de relatos ${ }^{149}$.

En un sentido similar plantea Bernard su "pequeña historia", definida como "una 'causserie', 'entre nous', petite histoire teñida de afectividad que narra episodios concatenados de una 'vieja amistad', robustecida en la comunidad de empeños antes de la época de la fundación, según veremos, y proyectada en fraternal secuencia de abuelos a padres, de padres a hijos y de hijos a nietos, formando esa raigambre de oro de la historia que se denomina tradición" (Bernard, 1982b: 20).

Todo ello organiza de un modo particular la representación temporal. Producto de una lectura no procesual de la historia, es excepcional encontrar periodizaciones, como las que estructuran Vida platense o las que aparecen en algunos capítulos de Obra de arte y Ciudad nueva ciudad antigua. En tanto, la presencia de relatos testimoniales y vivenciales hace coexistir dos temporalidades, la cronológica y la cronográfica.

Pasando a otra característica de los textos, la presencia de reseñas institucionales es muy común en las obras más voluminosas, como Ciudad milagro y Obra de arte. Esta última tiene un capítulo dedicado a instituciones públicas y privadas, que básicamente es una lista de entidades (en el caso de los hospitales con sus direcciones; en el caso de parroquias con fecha de fundación) con alguna presentación inicial. Más adelante, al dedicarse a los clubes, se concentra en una historia bien institucional: no señala copas obtenidas en campeonatos deportivos, sino fechas de fundación, primeros referentes, actividades iniciales, lemas, ubicaciones, etcétera.

Algunos capítulos institucionales de Ciudad milagro, en tanto, siguen una lógica de transcripción indiscriminada que llaman la atención en un libro al cuidado de una Sociedad de Escritores. En "Dirección de Impresiones del Estado y Boletín Oficial (Ministerio de Gobierno de la Provincia de Buenos Aires)", por ejemplo, se incluye la dotación inicial de personal que tuvo la entidad. Un estilo similar tiene el capítulo sobre "Dirección de Bibliotecas de la Provincia de Buenos Aires".

De "Instituciones Culturales", firmado Héctor M. Rivera, corresponde llamar la atención sobre la no explicitación de la lógica con que se seleccionaron las cinco entidades aludidas. El artículo dedica tres páginas y media a una institución desaparecida y en especial a la persona que la lideró ${ }^{150}$, y recién la última página y media, a las cuatro restantes.

Otro rasgo peculiar de las publicaciones analizadas es la proliferación de nombres propios, asociados a la trayectoria de instituciones y a la historia política local: la primera comisión municipal, el primer intendente, los primeros concejales, los directores de escuela, las comisiones fundadoras de clubes y demás. Están asociados a la lógica de sumatoria de datos sin contexto ni comprensión de un proceso que mencionamos antes. Así, por ejemplo, en la parte dedicada a las escuelas en Obra de arte, al repaso sobre la Escuela Nacional Superior de Comercio le corresponde información como el número de ley que la creó, la

\footnotetext{
${ }^{149}$ Por ejemplo, entre la escasa información deportiva, un subcapítulo evoca la convocatoria de un jugador de fútbol de Gimnasia para jugar en Chile (Soler, 1982: 115), pero nunca se menciona el campeonato obtenido en 1929 por ese club.

${ }^{150}$ Se trata de "Don Vicente Albamonte", de quien se destaca, entre otras cuestiones, su condición de precursor de la parapsicología: "creía en la Ley Palinigenésica y en las premisas de Allan Kardec, que dieron jerarquía científica a los fenómenos metapsíquicos, hoy estudiados y reconocidos por la parapsicología [...] Por ello, cuando con un núcleo de amigos creó la Biblioteca Inspiración, la orientó en el sentido de la vanguardia espiritualista" (en Lerange, 1982: 544).
} 
autoría del proyecto, el presupuesto inicial, etcétera; de la Escuela Nacional de Educación Técnica $\mathrm{N}^{\circ} 1$ se señala su primer director, el primer curso, las estadísticas sobre la población escolar desde su fundación; y así sucesivamente (Díaz, 1982). En Ciudad milagro, podemos conocer antecedentes del inmueble del Colegio Podestá: números de inscripción de dominio, declaratoria de herederos, etcétera; o la dotación inicial de la Policía de la Provincia, además de las normas que la regían; o el mobiliario que integra el Patrimonio del Jockey Club: "2 sillas y juego de sillones esterillados estilo victoriano. Araña inglesa. Cuadros" (en Lerange, 1982: 319, 433, 443).

La inclusión de nombres parece tener una lógica también en un sentido de "reconocimiento", un posible uso de la historia local: buscar el propio apellido, reconocer trayectorias familiares, construir el linaje, saber quién es quién en La Plata. Hay algunos artículos, como "Biblioteca Musical Verdi", "El teatro que fue. Para una historia del teatro argentino", "Club Universitario de La Plata" o el dedicado a la sección Prosa y Verso de El Día, en Ciudad milagro, que son puro nombre. En su fragmentario artículo, Rica incluirá una nómina de funcionarios -sólo los nombres: sin datos de gestión, sin referencia a orientación política- desde la Comisión Municipal de 1884 y ¡sólo hasta 1932! (en Lerange, 1982: 55). Y por el texto dedicado a la Radio Universidad podemos saber el nombre de los consejeros presentes en una reunión ordinaria del Consejo Superior. En suma, tenemos comisiones fundadoras de bibliotecas, comisiones directivas del clubes y de una asociación pro amparo y defensa del animal, educadores y gremialistas de la Asociación de Maestros, autoridades y miembros del Círculo de Periodistas, de la Sociedad de Escritores de la Provincia, del Instituto Platense de Cultura Hispánica, participantes del grupo "GARS", de la Agrupación Bases, la nómina de jefes del Regimiento 7, una lista de directores, periodistas y colaboradores del diario El Día y de El Argentino, y muchos más.

En Crónicas de un siglo, por su parte, volvemos a encontrar la comisión directiva del Jockey Club, una nómina de profesores que forman mesas examinadoras en el Colegio Nacional, los socios fundadores del Banco Crédito Municipal y muchos otros nombres.

Los ejemplos podrían ser interminables. Los nombres proliferan incluso en los trabajos más breves. En Italianos, la parte dedicada a caracterizar especializaciones laborales termina con una lista y breves biografías de "mis más distinguidos compatriotas platenses de esa gloriosa época" (Hoor, 1982: 7-10).

Esto se vincula con una tendencia propia de las antiguas historias locales, según observa el mexicano González: "La mayoría de los microhistoriadores de la vieja guardia cierran sus libros con una nómina de emigrados ilustres de la localidad en cuestión. Los de la nueva ola prescinden de los nombres propios, no creen que los individuos cuenten en las pequeñas comunidades" (González, 1999: 18)

Otra característica sobresaliente en los textos analizados, sobre la que volveremos en siguientes capítulos, es la ponderación de ciertas "personalidades", al modo de Thomas Carlyle, el británico que a mediados del siglo XIX defendía una lectura de la historia basada en la acción de grandes hombres, los héroes. Para este autor, al igual que para muchos narradores del pasado platense, la vida social y sus condiciones son producto de la acción de personalidades excepcionales y enérgicas, y se mantienen hasta que un nuevo héroe inicia una nueva época. De allí que las obras históricas incluyen fragmentos biográficos de grandes individuos y una prosa que ensalza constantemente la voluntad del hombre y su fuerza 
creativa. Esto es propio de la historia didáctica o educativa, que es "desde la antigüedad glorificadora del heroísmo" (Rojas, 1909: 30).

Así, por ejemplo, SADE La Plata "adhiere a los festejos del centenario" presentando un libro sobre esos "hombres extraordinarios que llevaron a cabo empresas relevantes en la ciudad, durante este siglo, propendiendo a su armonioso desarrollo intelectual y moral y dejando una estela brillante en el ámbito de sus actividades". Como explica Irene Ene en "Centenario" el texto breve que introduce a 12 personalidades,

"La historia grande de los países se escribe, generalmente, sobre gobernantes, aconteceres políticos o económicos o hechos de armas; y en mucho menor medida, sobre descubridores, sabios o artistas. Pero en la compleja vida de los pueblos hay, también, otra historia que es el sustento de aquella, donde existen personajes dignos de mayor admiración, que son los héroes de todos los días, quienes aplicados a un quehacer específico ponen en él tal impulso del ánimo, tal fuerza constructiva, tales empeños bienhechores, tan altos ideales de pureza y tan honradas convicciones que, a través de los años de esa tesonera labor, logran dejar obras que se proyectan más allá de sus vidas y merecen el recuerdo conmovido de sus coetáneos y generaciones subsiguientes" (SADE La Plata, 1982: 9)

"Una de las más genuinas formas de celebrar una fecha histórica es, por cierto, evocar a esas personalidades que dejaron claros ejemplos de conducta y descendencia formada en el ambiente del hogar virtuoso, ya que son ellas las destinadas a proseguir siendo las huestes del Bien, en nuestro mundo" (SADE La Plata, 1982: 10)

Los relatos resultantes se ajustan a la precisa definición de González: "se trata de textos que no sólo desprenden de su contexto histórico los hombres y las hazañas edificantes para hacer patriotas a carta cabal, sino que embellecen o afean a los personajes y los hechos históricos con embustes literarios" (González, 2009: 100). Más adelante veremos cómo esto ocurre en relación a la figura de Pedro Benoit (Capítulo V) y una serie de próceres cuya ponderación sostiene el imaginario de La Plata como ciudad artística, científica y universitaria (Capítulo VI).

Por otra parte, como observamos en el marco del planteo misceláneo de varios relatos locales, la referencia a figuras paradigmáticas no termina con las personas conocidas por su labor artística, científica o política, sino que se extiende a personajes urbanos curiosos, simpáticos.

La presentación de esos otros personajes, ligados al "toque anecdótico" al que refería Moncaut, puede rastrearse en Vida platense, en el artículo "Dos nombres" aportado por Estela Calvo a Ciudad milagro o en el libro testimonial de Jaime Sureda.

En la publicación del diario El Día, cuyo carácter misceláneo incluye una serie de relatos de episodios curiosos a lo largo del libro, se evoca una "galería de personajes típicos de La Plata": Chichilo, Ayacucho, Medicinale y Rico Tipo (Soler, 1982: 119) ${ }^{151}$. Son referencias repetidas. Tanto Chichilo, el hombre de la bolsa, como Rico Tipo (José La Fusa), con su edad sin tiempo de los desposeídos, aparecen también en el relato de Calvo, entre otras figuras urbanas pintorescas. Rico Tipo, Ayacucho y Medicinale son mencionados también en el capítulo "Los tipos raros" de Edad de mi infancia, junto a otros "tipos pintorescos de La

\footnotetext{
${ }^{151}$ En relación a los objetivos de esta publicación, Kraiselburd planteaba en el prólogo que aspiraba a ser "una ventana hacia el pasado, por la que los platenses puedan ver desfilar las imágenes de lo que fueron sus luchas, glorias, fracasos, gentes, instituciones, poetas, artistas, personajes fundamentales y aquellos que, sin serlo, contribuyeron a dar color y vida a la ciudad" (Soler, 1982: 7).
} 
Plata" (Sureda, 1982: 28): cocheros, solterones, vagabundos solitarios; todos varones hasta el párrafo final:

"Después estaba la Reina del Bosque. En nuestra misteriosa fauna de seres pavorosos que nos amenazaban cuando éramos niños desde la oscuridad o lo desconocido, no sé como se engendró la Reina del Bosque, una bruja poco menos que mitológica que habitaba por las noches la vieja gruta junto al lago. Robaba chicos y los vendía. Era maligna, había que escaparle porque sus manos destrozaban como garras. Era inútil que dijeran lo contrario en mi casa, que me aseguraran que no existía. La Reina del Bosque estaba allí, frente al Jardín Zoológico de noche. Yo lo sabía, lo sabíamos todos los chicos del barrio. Al menos a eso sí que le tuvimos miedo..." (Sureda,1982: 65).

Otra cuestión significativa en parte del corpus es el recurso de la primera persona en la escritura. Esto es lógico y esperable en los textos testimoniales, pero también ocurre en los libros generales, como Ciudad milagro. El breve artículo de Carlos Vallina sobre cine y la evocación de Reynaldo D’Onofrio sobre el tranvía, por ejemplo, están escritos en primera persona del singular. Escribe D’Onofrio:

“...me apoyaré en una nota oportuna que escribí para el diario 'La Nación' como corresponsal de ese diario en La Plata [...] personalmente cuidada por el entonces Subdirector y maestro de periodistas Dr. Juan Santos Valmaggia, de mi recuerdo grato y permanente" (en Lerange, 1982: 600)

Sin embargo, no hay una regla clara en relación a la persona de la escritura. Así, en un artículo sobre "Institutos de enseñanza de idiomas", su autora habla de sí misma en tercera persona, al señalar que el Instituto de Lengua Francesa Paroles "fue creado en 1978 por la Profesora Susana María Moretti de Mallol...” (en Lerange, 1982: 530). También es posible encontrar artículos donde el autor se referencia a veces en primera persona y otras en tercera, como "Instituto Platense de Cultura Hispánica" de Ovidio A. Valenciano y "Evocación de una revista platense" de Alfredo Ves Lozada.

En Obra de arte, un libro donde la autoría de cada parte ha sido escondida tras la adjudicación de toda la obra a un equipo numeroso, encontramos sin embargo varios pasajes escritos en primera persona del singular. Es bien ilustrativo un tramo final -además de la descuidada repetición de algunos verbos-: "Cuando hablo de ciudad me refiero a su aspecto formal..."; "me estoy refiriendo a una ciudad estructurada sobre una sintaxis atemporal..."; "Cuando me refiero a ciudades superpuestas [...] no describo una fantasía..."; "Me refiero a las ciudades invisibles..."; "He rescatado..."; "Al hablar de los recintos me refiero..."; "Propongo revitalizar..."; "Propongo conservar..." (Díaz, 1982: 422-425).

En relación a esto y antes de caracterizar más detenidamente los estilos de escritura, debemos advertir que los trabajos analizados presentan notorios descuidos formales, que revelan cierta incapacidad o cierta improvisación de las ediciones, acaso nunca pensadas estrictamente como obras para ser leídas. La desprolijidad está lejos de ser una excepción de algunos libros secundarios: la encontramos inclusive en los principales libros, elaborados por instituciones legitimadas y con financiamiento. Veamos algunos ejemplos a partir de dos de los volúmenes que hemos considerado más significativos, Ciudad milagro y Obra de arte:

- Algunos títulos de capítulos en Ciudad milagro aparecen en mayúscula, otros en mayúsculas y minúsculas. En algunos casos aislados también hay leves variaciones tipográficas. Además del descuido en la diagramación, la identificación de los capítulos no está cuidada en el trabajo de edición. Aparecen títulos muy dispares. Algunos son cuestionables por inespecíficos ("Apuntes en el 1er. centenario de La Plata", "En 
agradecimiento"), pero además hay una gran dispersión en el estilo de la titulación. El artículo de Jerónimo Carol sobre la sección Prosa y Verso del diario El Día, por ejemplo, más que título tiene un sumario:

"Otros aspectos de la vida cultural platense. Cómo surgió y se mantuvo durante tres décadas la selección Prosa y Verso en EL DÍA. Trescientos mil lectores por jornada. Material como para llenar un centenar de volúmenes. El estímulo a los jóvenes con vocación literaria. Nómina de colaboradores. Algo más del mundo periodístico local. Anécdotas y otras cosas y aconteceres en nuestra querida ciudad" (Lerange, 1982: 383)

Asimismo, hay titulaciones poco informativas, que no se corresponden con los contenidos. Por ejemplo, el encabezado "Los eucaliptos: nombre para una pasión", puede sugerir que el artículo se refiere a la construcción de una ciudad verde o ciudad jardín; sin embargo, el texto se aboca a una historia del hipódromo y del Jockey Club platense.

Los propios artículos son, como ya vimos, muy dispares en su contenido, en su estilo y también en su extensión: algunos tienen menos de una página y otros superan las 25.

Similares críticas caben a la composición de Obra de arte. En el aspecto vinculado a la diagramación, hay que advertir que las partes en las cuales está estructurado el volumen (que ya mencionamos: Marco espacial, Marco Histórico, Marco Actual y Hacia el futuro) no son evidentes a una lectura sin consultar el índice, ni está claro el estatuto de los distintos subtítulos que ordenan los textos. Si nos atenemos al diseño, la portada interior con el título "EL ARTE EN LA PLATA" pareciera marcar el inicio de una parte estructural del libro, cuando en rigor se trata de un subtítulo del Marco actual. Entrando ya en el cuidado del contenido, cabe decir que esa sección refiere exclusivamente a artes plásticas (aunque el título no lo explicite claramente), siendo que ese título viene después de las referencias a la literatura platense -que parece no quedar contenida en el "El arte en La Plata"- y es continuada por referencias a la música, donde el jazz cuenta con una sección por separado.

Cabe advertir, además, que la mayoría de los capítulos o las secciones de la parte titulada "Marco actual" tienen una mirada histórica que en muchos casos no va más allá de la década de 1940.

- También hay omisiones y descuidos no advertidos en la corrección. Por ejemplo, en Ciudad milagro el artículo de José María Mainetti incluye llamadas a notas ampliatorias que no están incluidas, ni a pie de página ni al final. En Obra de arte, al referir al Museo y Archivo Dardo Rocha, se afirma que "fue inaugurado el 19 de noviembre de 1952 al cumplirse el 50 aniversario de la fundación de la ciudad de La Plata" (Díaz, 1982: 320), en lugar del 70 aniversario. El mismo error de cálculo reaparece dos páginas después, cuando afirma que el Museo Policial, creado en 1951, corresponde al "49 aniversario de la fundación de la ciudad de La Plata".

- Entre las páginas 546-548 de Ciudad milagro aparece un "índice alfabético de entidades", que remite a las páginas en que distintas instituciones son mencionadas en el volumen. Lo llamativo es que el índice no está en las páginas finales del libro, sino antes de los últimos dieciocho capítulos, y las instituciones que vienen a continuación no están indizadas. Es como si el proyecto original hubiese sido más reducido y la parte final se agregó a último momento.

- En algunos capítulos o fragmentos de los libros aparecen desarrollos sobre temas generales -como la historia del ferrocarril, entre otros-, sin ninguna referencia, aunque sea mínima, a la historia de La Plata. En el libro de la Sociedad de Escritores de la Provincia es 
particularmente llamativa la inclusión de un artículo sobre cirugía plástica, que no hace ninguna alusión a la ciudad.

De un modo similar, un capítulo presentado como "Trayectoria y misión de la Universidad de La Plata" (Casey, en Lerange, 1982) deriva en una "historia legislativa" -tal es así que los subtítulos que ordenan el texto son referencias a leyes- y, más que repasar la trayectoria de la UNLP, es una historia de las universidades nacionales, a partir de su normativa.

- Como sabemos, esa compilación está conformada por una sumatoria de capítulos. La falta de diálogo de los distintos aportes entre sí provoca ciertas reiteraciones innecesarias. Las referencias a la Biblioteca Musical Verdi en el texto sobre el Teatro Argentino, por ejemplo, resultan repetitivas dado que ya hubo uno específico dedicado a esa institución. Lo mismo sucede cuando el referido al Círculo de Periodistas reitera la historia de la Escuela de Periodistas, contada en otro texto del mismo libro.

Esto sucede también en Obra de arte. Pues aunque no distinga autorías por capítulo, también este libro compila distintos aportes, y la suma termina presentando un carácter fragmentario. Así, en varias oportunidades define qué entiende por "Gran La Plata” y reitera acontecimientos de los orígenes de la ciudad.

Por otra parte, el libro coeditado por la Municipalidad y la Facultad de Humanidades se torna fragmentario al incluir referencias a bibliografía y fuentes documentales en partes intermedias del libro, y en especial en el tramo dedicado a la estructura industrial que culmina con "conclusiones", como si fuera un texto independiente (Díaz, 1982: 187).

- Ciudad milagro incluye cuatro artículos sin firma. Tres de ellos corresponden a reseñas de instituciones militares: "Escuela Naval Militar", "Liceo Naval Militar 'ALMIRANTE GUILLERMO BROWN'. Un aporte positivo de nuestra Armada en la preparación y formación de la juventud argentina" y "Regimiento $7^{\circ}$ de Infantería". El cuarto corresponde a un capítulo brevísimo sobre "Canal 2".

- El capítulo "Cien años del Museo de La Plata", adjudicado a Luis de Santis y Jorge O. Kilmurray, es en realidad la suma de dos textos de autoría individual, transcriptos en continuo. Se trata de las exposiciones de De Santis y Kilmurray en el ciclo Cien años de La Plata. Así, la primera termina diciendo: "La historia de la Institución, después su incorporación a la Universidad, va ser tratada en otra conferencia de este ciclo que estará a cargo del Decano de la Facultad de Ciencias Naturales y Museo, doctor Jorge O. Kilmurray, por lo que pongo, aquí, punto final a la mía”, y sigue con dicho texto a vuelta de página, sin distinción de autor (en Lerange, 1982: 475-476).

- Hay un trato diverso en la presentación de los autores. En general no se incluyen referencias al pie del nombre indicando quién es. Esto puede resultar problemático a la lectura: un artículo como el de Federico Christmann, titulado "Algunas vivencias y testimonios platenses" y con una escritura personal, requeriría alguna referencia sobre el enunciador. La editora opta por obviarla, pero no es una regla seguida a rajatabla: en el mencionado capítulo sobre cirugía plástica, se indica que su autor Leonardo Barletta es "Profesor Adjunto de Cirugía. Miembro Correspondiente Nacional de la Academia Argentina de Cirugía".

Otros se presentan de un modo más solapado. El artículo "Jardín Zoológico de La Plata", firmado por "el Dr. Pablo D. Videla" (nótese la inclusión del grado de doctor), 
contiene una lista de autoridades que incluye al autor en segundo lugar: “...Jefe de División Técnica, Dr. Pablo D. Videla...” (en Lerange, 1982: 197).

Hemos tomado ejemplos de dos de los libros más significativos y con mayores recursos de producción, pero cabe advertir que los descuidos del trabajo editorial son extendidos. En La Plata 100, por ejemplo, advertimos una serie de diferencias entre el índice y el contenido de la guía turística. De los circuitos fuera del casco urbano, Los Hornos está contemplado pero no figura en el índice, "Berisso e Isla Paulino" son un sólo capítulo y en el índice aparecen por separado, contrariamente a lo que pasa con "Ensenada y Punta Lara", que están unidos en el índice y desarrollados por separado en la guía. Esto provoca, lógicamente, incongruencias en la numeración de los capítulos.

\section{Tonos de la escritura}

"La narración edificante, o de bronce, o pragmático-ética, suele ser nauseabunda" (González, 2009: 87)

El movimiento pendular entre conocimiento histórico y formas de la memoria asociadas al recuerdo nostálgico y el acto conmemorativo, habilita diversos estilos o tonos de escritura. Hay algunos textos poéticos -con una escritura generalmente sobreadjetivada- y otros que más allá de sus objetivos celebratorios- recurren a escrituras más académicas, tanto en su jerga como en su sintaxis.

En compilaciones amplias como Ciudad milagro esos estilos conviven al interior de una misma obra. Entre los literarios encontramos "La ciudad de Dardo (Fundación Humorística de La Plata)”, el artículo de Luis Patricio Saraví estructurado en quince partes breves identificadas con números romanos. El relato, que recurre a figuras de la mitología griega, arranca en 1520 (con Magallanes) y abarca la fundación de La Plata, enfocando especialmente la figura de Rocha. Saraví propone párrafos como el que sigue:

"Fue la época en que a la curiosidad y al talento les nació el hijo. Lo bautizaron Progreso. De una diabólica belleza, inquietó a todos desde el vamos. Era primo hermano, por parte de padre, de su compinche, la Civilización.

Los dos recorrieron el mundo acuciando a las buenas gentes" (en Lerange, 1982: 643)

El mismo volumen incluye un artículo como el de Sara A. Canestri sobre esculturas, que se presenta de este modo:

"Este trabajo, realizado durante el desarrollo de mis estudios de Museología en La Plata

(Cátedra Historia del Arte) representa un intento por documentar gráficamente las obras escultóricas de la ciudad, las existentes y aún las que desaparecieron por diversas causas" (en Lerange, 1982: 249)

Ambos registros, por otra parte, deben ser pensados como polos de un continuum que contiene diversas expresiones intermedias. El capítulo sobre "La moda en La Plata", por ejemplo, no exalta una búsqueda académica: simplemente repasa la historia de distintas tiendas -sastrerías, sombrererías, romerías, etcétera-, siguiendo un orden cronológico. Al referir distintos contextos y cambios en el consumo resulta -sobre todo en el marco de Ciudad milagro- una aceptable contribución de historia cultural, que sin embargo no recurre a una jerga académica.

En un extremo de esa línea, cuando refiero a escrituras excesivamente adjetivadas, barrocas, pienso en artículos como "La Ciudad y sus poetas" (de Raquel Sajón de Cuello y Alcides De Giusseppe), "El teatro que fue. Para una historia del teatro argentino" (de Pedro 
Albarracín) o "Club Universitario de La Plata" (de Carlos Pacheco), por citar algunos ejemplos contenidos en Ciudad milagro:

"Inconsolablemente lírica, empecinadamente soñadora, brumosa de sueños y lejanías, sin razón de ser, su ritmo de sangre, su carne renacida, su tibieza de pulso, se entrelazan en el canto de sus poetas" (Sajón y De Giusseppe, en Lerange, 1982: 113)

"Ya no alumbra la luz del crepúsculo la majestuosa fachada del Coloso. Ni reflejan los rayos postreros el sol irisados matices en los vidrios de sus ventanales. Aquella majestuosa mole..." (Albarracín, en Lerange, 1982: 291)

“...cimentar, tesonera y entusiásticamente, el mampuesto de una idea que es hoy orgullo y regocijo de la ciudad..." (Pacheco, en Lerange, 1982: 453)

Abundamos en ejemplos para certificar una caracterización que, enunciada de golpe y sin rodeos, podría resultar exagerada: los escritos del centenario con pretensiones literarias son cursis y anacrónicos. Cursis porque pretenden en vano mostrar refinamiento expresivo y porque aparentan elegancia y riqueza narrativa pero resultan de mal gusto, excedidos en sus epítetos. Anacrónicos porque están fuera de tiempo: ese estilo barroco es decimonónico y resulta anticuado en su tiempo, lo que nos da una pauta de quiénes escriben en 1982 -asunto que retomamos en el siguiente capítulo-. Es posible encontrar otra intelectualidad y otra escritura, antes incluso del centenario. Hacia los años '80 Ricardo Piglia y Juan José Saer habían consolidado su lugar dominante en el campo literario argentino (De Diego, 2003: 193). Piglia estudió en La Plata. También escritores como Rodolfo Walsh y Enrique Anderson Imbert habitaron la ciudad. Entre los historiadores, Tulio Halperin Donghi y José Luis Romero enseñaron en la UNLP ${ }^{152}$. La cursilería de aquellos textos expresa entonces, más que las formas literarias alcanzadas en la época, el vaciamiento que produjeron los regímenes instaurados en 1966 y 1976 al perseguir y asesinar a ciertos intelectuales y promover y habilitar a otros. Sin ir más lejos, encontramos textos en prosa o verso mucho más "legibles" entre las cartas y mensajes incluidos en No habrá manto de olvido.

El tono más académico, en tanto, podemos encontrarlo especialmente en los trabajos mencionados al principio del capítulo, que tienen inscripciones disciplinares y corresponden a publicaciones llevadas a cabo desde la universidad. El caso más claro es el de Ciudad nueva ciudad antigua, que tiene una exposición ordenada y erudita, elabora sus categorías de análisis e incluye una importante bibliografía. La ciudad es definida, por ejemplo, como "un sistema formal cuya lógica estructural está determinada por el proceso histórico de su construcción" (Morosi, 1983: 121). Asimismo se recurre a cuadros y gráficos que complementan los textos descriptivos y analíticos.

Cabe decir que sólo dos libros, Ciudad nueva ciudad antigua y Obra de arte, ambos realizados desde facultades, incluyen algún apartado con definiciones de orden metodológico en relación al proceso de elaboración. En ese plano, ambos defienden concepciones abiertas, no estrictas, sobre el camino de la investigación. Según el prólogo de Fernando de Terán, la investigación que impulsó y asesoró no propone "ninguna especie de panacea metodológica",

"[...] Desde esa actitud de pluralismo metodológico y de escepticismo doctrinal, está planteada y desarrollada la labor que se presenta en este libro. Es esperable que esa misma falta de adscripción a una tendencia, sincera y abiertamente confesada, pueda contribuir a facilitar la consecución más generalizada de los objetivos que persigue, poniendo en movimiento mecanismos variados de comprensión y de valoración e

${ }^{152}$ Romero es, de hecho, uno de los autores compilados en Vida espiritual. También es citada una carta suya en uno de los capítulos de 12 personalidades. 
incluso reacciones emocionales que conduzcan a la creación del clima social que la ciudad merece y necesita... (en Morosi, 1983: 13)

La parte final de Obra de arte incluye un informe que "pretende ser una conclusión de los temas tratados precedentemente sobre el aspecto geográfico de La Plata y su evolución a través de cien años, así como también un diagnóstico y un pronóstico sobre la ciudad en el momento actual y su futuro, y una evaluación de los propósitos y expectativas que guiaron a sus fundadores", basado en la comparación de La Plata "con los partidos de la conurbación de Buenos Aires y las principales ciudades provinciales". El análisis está ilustrado con cuatro gráficos basados en estadísticas sobre industrias, servicios, comercios, bancos, que compara los distintos "partidos de la conurbación y principales de la provincia" (Díaz, 1982: entre 398 y 399). También hay un gráfico de "Área de influencia de La Plata determinada por la fórmula de Reilly". Hay una apelación erudita a las estadísticas presentadas que refiere a "variables" y "correlaciones". Más tarde, al proponer una periodización histórica, habla de un "campo interpretativo", de "modelos" de análisis, y hace explícitas decisiones epistemológicas.

"La construcción de un modelo de periodización, tal como se inserta en este libro, proyectado y llevado a cabo para dar mayor claridad a los hechos históricos, constituyó una labor bastante compleja y hasta árida. Nos dimos cuenta que necesariamente deberíamos acompañar al modelo con un material cartográfico que expresara visualmente las modificaciones territoriales y, a la vez, pudiera contener otras informaciones aclaratorias del modelo..." (Díaz, 1982: 114)

Varios tramos de Obra de arte recurren a terminología especializada e incluyen su propia bibliografía. Otros adquieren un tono estrictamente informativo, sin jergas académicas. No obstante, es un buen ejemplo de un libro que pivotea entre distintos registros o estilos de escritura, del mismo modo que conviven en él informaciones de muy distinta índole, algo característico en las publicaciones que forman nuestro corpus.

Es interesante advertir, por otra parte, que hemos reconocido la escritura más académica en textos con orientaciones disciplinares específicas: el urbanismo y la geografía -ya que los fragmentos de Obra de arte más eruditos corresponden a ese campo.

¿Qué pasa con el abordaje de la historia? En la correspondencia entre De Terán y Morosi encontramos una preocupación del primero en ese sentido, que le cabe al texto que más claramente hemos identificado con un registro académico. A propósito de los borradores del capítulo histórico sobre la fundación de la ciudad, el asesor español demanda no rehuir "los aspectos sociales y económicos":

"Si eludimos estas cuestiones y todo se queda en una secuencia histórica descriptiva perdemos credibilidad y se nos criticará como 'ocultadores' de la realidad. Hay preguntas que yo todavía no tengo contestadas, a pesar de haberlas formulado varias veces: ¿dónde vivían los italianos que construían el puerto y la ciudad? ¿Dónde salió todo el dinero necesario para el formidable proceso? Creo que (Fernando) Barba debería profundizar un poco en el aspecto económico y relacionarlo con la política general argentina del momento y tratar de manifestar los intereses que hicieron posible todo, ya que es evidente que al lado de los idealismos hay siempre factores de otro tipo más prosaico. ¿Se podría relacionar con toda la crítica que se hace del proceso político de la generación del 80 , junto con sus aciertos? [...] mi deseo es evitar fáciles críticas que preveo aparecer, que desautorizarían profundamente al libro".

Los relatos con pretensiones académicas-profesionales tienen características propias de la llamada Nueva Escuela Histórica, encabezada por Emilio Ravignani y Ricardo Levene, 
quienes impulsaron la creación de las primeras instituciones destinadas a la formación e investigación, la organización de archivos y la edición de fuentes documentales, inspirados en planteos historiográficos positivistas de Charles Seignobos y Charles Victor Langlois. Desde el Instituto de Investigaciones Históricas de la Facultad de Filosofía y Letras (hoy Instituto de Historia Argentina y Americana "Dr. Emilio Ravignani") y la Junta de Historia y Numismática Americana (luego Academia Nacional de la Historia), respectivamente, Ravignani y Levene trabajaron una historia predominantemente política ${ }^{153}$-semejante a la de los positivistas europeos- basada en grandes figuras, y propiciaron la intervención del Estado en la creación de archivos y otras políticas de memoria histórica. Levene fue promotor, además, de una historia patriótica que articulaba sus fines con los del Estado, cuya máxima expresión fue su Historia de la Nación Argentina (1936) prologada por el entonces presidente Agustín Justo. Esa versión "oficial” de la historia sería cuestionada desde la década del ‘30 y en particular en los '60 por el denominado revisionismo, que también propuso un relato fundamentalmente político que se consideraba portador de la verdadera identidad nacional.

En los años '20 y '30, Levene se desempeñó como profesor ${ }^{154}$ y funcionario de la Universidad Nacional de La Plata -que llegó a presidir-, e impulsó el Archivo Histórico de la Provincia de Buenos Aires, creado en 1925, al que dirigió en simultáneo a su tarea como Decano de la Facultad de Humanidades (Bisso, 2010).

En 1932, ya siendo presidente de la UNLP, creó y presidió el Centro de Estudios Históricos, que contó con Antonino Salvadores y Enrique Barba entre sus miembros. Salvadores presentó allí su trabajo sobre El acta de fundación de La Plata y se convertiría luego uno en los autores precedentes más retomados y adulados en el centenario.

Desde el Archivo, Levene publicó su Historia de la Provincia de Buenos Aires y la fundación de sus pueblos (1941) e impulsó la indagación de historias locales. En noviembre 1950 -durante el gobierno peronista al que se opuso- se realizó el Primer Congreso de Historia de los Pueblos de la Provincia de Buenos Aires, que lo tuvo como presidente. Es interesante reparar en nombres y cargos de los participantes de ese Congreso para pensar las continuidades que implican las producciones de 1982. Los miembros titulares por la ciudad de La Plata incluían delegados del arzobispado, las cámaras legislativas provinciales, la Base Naval y la segunda división del Ejército y la Policía, un juez de cámara y representantes del Instituto de la Tradición de la Provincia, el Archivo Histórico, el Instituto Sanmartiniano, la Dirección de Museos Históricos, el Círculo de Periodistas y la Sociedad de Escritores. Por la UNLP participaba Andrés R. Allende; en tanto el delegado enviado por la comuna platense era Tomás Diego Bernard.

\section{Sellos de validación}

Dado el arcaísmo de las pretensiones literarias de algunos textos y la concepción histórica que subyace en otros, no sorprenden los títulos y las instituciones que aparecen a la hora de poner en juego mecanismos de "validación" o "valorización". Encontramos dos grandes entidades que operan en ese sentido en el panorama amplio de las publicaciones del

\footnotetext{
${ }^{153}$ Las investigaciones de Levene acerca de la historia económica del Virreynato del Río de la Plata constituyen una excepción en el marco de un planteo historiográfico centrado en lo político-institucional.

${ }^{154}$ Autores de los textos analizados se formaron con él. Esto es explícito en el caso de Terrasa, quien afirma el "privilegio" de haber sido su alumna y recuerda sus palabras sabias. Esta escritora escribe Historiador con mayúscula y alude a una tarea agotadora y paciente, que es "imparcial, busca de la verdad" (Terrasa, 1982: 34).
} 
centenario: la Academia Nacional de la Historia y la Sociedad Argentina de Escritores. La primera aparece en los propios textos, a través de prólogos, y la segunda actúa a posteriori, premiando a varios libros publicados.

El doctor Enrique M. Barba escribe varias presentaciones para libros de la época ${ }^{155}$ en las que, aun cuando argumenta desde sus recuerdos como platense o alude a la amistad con los autores, siempre firma con su cargo de Presidente de la Academia Nacional de Historia.

Este recurso a un título académico nos remarca una cuestión interesante: más allá de las características señaladas, sigue adjudicándose a los textos un carácter histórico, como puede leerse en la solapa de Primeros habitantes:

"Mary Terrasa, observadora, sensible, amante de su ciudad ha posibilitado un ramillete de personajes y hechos, que exhalan el genuino aroma de la civilidad platense. Y su tarea de investigación, plasmada en esta obra, representa un documento fidedigno, noble, valioso y encomiable, para las generaciones venideras. Es un libro de Historia Platense, desde sus orígenes; historia lo de antes, documenta sus frutos y menciona su actualidad vigente" (Terrasa, 1982. Las cursivas son mías)

Enrique Barba escribe la apertura de Ciudad milagro, prologa Ciudad de mayo y, como vimos anteriormente, actúa como primer presentador del Ciclo Cien años, certificando la calidad de los invitados.

En otros libros el historiador está presente como una personalidad de La Plata: "En los últimos años no son muchos los platenses que se han proyectado como figuras nacionales", dice Vida platense y junto a cuatro grandes cirujanos que "trascendieron las fronteras de la ciudad y en ocasiones del país" ubica "la figura del Dr. Enrique M. Barba por su tarea específica de custodiar la memoria nacional desde la Academia Nacional de Historia de la que es presidente casi perpetuo". Tras repasar su trayectoria, el texto remata: "Sin abandonar la ciudad que lo vio nacer y con la que se siente consustanciado, ha hecho pasar a un primer plano la historiografía platense, de la que es uno de sus más empinados representantes" (Soler, 1982: 250).

Barba también es citado como autoridad en el artículo sobre "Cien años del Museo de La Plata" publicado en Ciudad milagro -y antes concebido para el ciclo organizado por el Museo y Archivo Dardo Rocha-. Allí, De Santis explora la controversia sobre las fechas de creación de aquella institución, glorificada en la abrumadora mayoría de los relatos: "Los historiadores del Museo de La Plata no se han puesto de acuerdo en lo referente a la fecha de la fundación" (en Lerange, 1982: 471). Aunque autoriza otras voces -cita, por ejemplo, a Estanislao de Urraza con otra forma de pensar la fecha-, De Santis ratifica la autoridad de Barba y recuerda su título: "El profesor doctor Enrique M. Barba, actual presidente de la Academia Nacional de la Historia, ha dejado establecido, a mi entender con todo acierto, que es esa la fecha de fundación del Museo de La Plata" (en Lerange, 1982: 472).

Se trata, recordemos, del prologuista del libro que contiene a ese artículo, y que cumple esa función con una intervención completamente personal:

"Debo manifestar que como platense de nacimiento, profesor de historia por vocación y profesión, nada que se refiera a esta ciudad que amo me es extraño [...]

\footnotetext{
${ }^{155}$ Además de los mencionados en el capítulo precedente, en 1979 prologa la Breve historia de Tolosa de Francisco Laborde, centrado en una querella sobre la fecha de fundación de ese pueblo. El prólogo concluye comentando que "después de largo debate", el 16 de junio de 1977, el gobernador -general Saint Jean- "puso las cosas en su lugar" fijando oficialmente la fecha correcta.
} 
Muchas cosas que en él se dicen las he vivido; he conocido a muchos de los personajes que se mencionan, he formado parte de instituciones que se recuerdan, he participado en la tarea de sociedades que se memoran. ¿Qué podré decir de los autores? Conozco a muchos de ellos a quienes respeto y admiro. Está de más decir que, en muchas de las materias que aquí se abordan soy profano, no siendo autoridad en ninguna de las otras" (Barba, en Lerange, 1982: 13)

La ambivalencia es significativa: Barba alude a su condición de platense y al recuerdo de lo vivido, pero firma el prólogo con su título institucional. Siempre, en todas sus intervenciones, es el titular de la Academia. El sello está en tensión con el texto y eso expresa también una tensión constitutiva de los textos: aunque no pretenden hacer historia, en el sentido profesional-académico, recurren al presidente de la Academia de Historia para validarse.

La Academia es la institución "tradicional" ligada a la práctica de la investigación histórica, de un tinte conservador y rituales muy protocolares. Su origen se remonta a la Junta Numismática creada por Bartolomé Mitre, que se convirtió en Academia en 1938 con el impulso de Levene, quien la presidió durante casi treinta años -con interrupciones-, además de colocar como presidente honorario a Agustín P. Justo.

Está integrada por un número reducido de académicos, que reúne historiadores de las universidades y también militares. En rigor, esa presencia militar no es propia del período de la dictadura: venía de antes y -con una presencia más reducida- se extiende hasta hoy. En la mesa directiva 1979-1981, en la que Enrique Barba era presidente, Andrés R. Allende, prosecretario y Horacio Cuccorese, protesorero; un capitán de navío -Humberto F. Burzio ${ }^{156}$ se desempeñaba como vicepresidente $2^{\circ}$ y un contraalmirante -Laurio H. Destéfani- como secretario. En tanto, entre los 35 "académicos de número" había otros militares: el Cnel. Augusto G. Rodríguez (ingresado en 1955, igual que Barba), el contraalmirante Laurio H. Destéfani (1971) y el Gral. Gustavo Martínez Zuviría (1977) ${ }^{157}$.

$\mathrm{Su}$ carácter conservador está signado por la trayectoria institucional y las formas de admisión y se reitera en otras academias, acaso especialmente en la de Ciencias Morales y Políticas. El tema excede los alcances de esta tesis, pero basta la sugerencia de consultar en la web quiénes son sus integrantes y los nombres de algunos de sus sitiales, o evocar el Medio pelo de Arturo Jauretche, quien describía a las academias como "el coronamiento del status de la 'intelligentzia'. Para acceder a ellas no hay que dar examen de aptitud [...] Más bien el examen es al revés. Hay que acreditar una continuada vida marginada de los fines y aspiraciones nacionales sin que importen las ideologías ni los antecedentes sociales de procedencia" (Jauretche, 1966: 249).

La SADE también es una organización de larga data, surgida en 1928 con la participación de Leopoldo Lugones, Horacio Quiroga, Manuel Gálvez, Ezequiel Martínez Estrada, Ricardo Rojas, entre otros, incluso algunos vinculados a la ciudad de La Plata como Rafael Arrieta y Arturo Capdevilla. Su creación precede al Primer Congreso Nacional de

\footnotetext{
${ }^{156}$ Cabe advertir que el año de la sesión en que fue admitido como académico no era reciente, sino 1946

${ }^{157}$ Salvo cuatro, el resto de los académicos habían ingresado en ese mismo período, entre 1955 y 1977. Andrés Allende, por ejemplo, fue admitido en octubre de 1970 "para ocupar el sitial N 39 que correspondía al profesor Carlos Heras" y se incorporó efectivamente en la sesión pública de la academia realizada el 9 de noviembre de 1971. El discurso de recepción correspondió al entonces académico de número Enrique M. Barba. En esa ocasión Allende dio lectura a su conferencia "Julia A. Roca y Dardo Rocha. Una amistad y una enemistad históricas", publicada luego en una separata del Boletín de la Academia (Allende, 1971).
} 
Escritores e Impresores Argentinos (1938) y al nacimiento de la Cámara Argentina del Libro, antesala de lo que se considera la "época de oro" de la industria editorial, comprendida por el período que va de 1938 a 1955 (De Diego, 2006). Más tarde desarrolló la estrategia de regionalización que mencionamos en el capítulo anterior, ya que SADE La Plata y su sello Almafuerte tienen sus propias iniciativas editoriales en el contexto del centenario.

La filial platense de SADE otorga el "sello de Honor" a una serie de publicaciones de la época, cuya lista completa no conocemos con certeza, ya que la distinción se otorga una vez publicado el libro y por lo tanto no figura necesariamente en su soporte material.

Sabemos que Vida platense, la publicación de El Día, obtuvo el "sello de honor extraordinario"158, al igual que Obra de arte, el libro editado por la Municipalidad en adhesión al centenario de la ciudad. Ante la "autoría diluida" de este último, SADE La Plata en contacto con la Facultad de Humanidades se encarga de emitir un certificado por autor, alusivo al premio. También recibieron un Sello de Honor de esa institución dos libros de Szelagowski: Años veinte (en 1980) y Si yo fuera Intendente (en 1982), y el No27 Revista de la Universidad.

${ }^{158}$ Así se hizo constar con un sello de tinta en el ejemplar consultado, donde del mismo modo se agregó la inscripción "EJEMPLAR OBSEQUIO". 


\section{Ciudad de sabios y poetas Los autores, sus títulos y sus círculos sociales}

"La ciudad es el nombre de una mirada que abre mundos, es una gran pregunta cuya respuesta no tiene un único camino. No importa tanto el qué pueda ser dicho en relación con la ciudad sino desde dónde se dice" (Rossana Reguillo, El laberinto, el conjuro y la ventana)

“...Buenos Aires es una perturbadora presencia que nos recuerda que no somos los mejores. Allá los teatros, las conferencias, la calle Corrientes, el tango. Y aquí nosotros, provincianos sin ganas, varados en un barro que apenas alcanza para que unos japoneses colonicen claveles y unos italianos cosechen la lechuga y el tomate que consumirá la ciudad. Lo que brilla. El centeno azulado. El trigo que muele Campodónico.

La invernada de bifes ampulosos. Llegan de lejos. A los apellidos ilustres tuvimos que inventarlos. La fundación monumental nos rescató de la llanura sin nombre y dictó el linaje, pero igual nos carcome una envidia...” (Bernazza, 1997: 113)

Arribamos ahora a la pregunta por quiénes son los agentes de elaboración y transformación del pasado de la ciudad. Partimos de la sospecha de que hay líneas de continuidad entre los círculos sociales de esos autores y los ámbitos, prácticas y sentidos que sus narraciones celebran. En otras palabras, el trabajo selectivo que toda historia implica pone el foco sobre una parte de la sociedad platense, la misma que constituyó una trama civil de adhesiones y consensos pasivos para la última dictadura y otros gobiernos conservadores, la misma que desfila despreocupada y sin cuestionamientos en la escena del 19 de noviembre de 1982, marchando al encuentro del "presidente" Bignone.

Las clases medias tiene un peso importante en la demografía de La Plata y una parte de ese sector social es el que aparece autorizado y en condiciones de tomar la palabra para narrar la ciudad en la coyuntura del centenario, para dotar de un sentido al pasado urbano. En ese proceso se vislumbra una suerte de nobleza local, una aristocracia de barrio al decir del cantautor español Joan Manuel Serrat, o acaso la versión platense del medio pelo, entendido como aquel "sector que dentro de la sociedad construye su status sobre una ficción en que las pautas vigentes son las que corresponden a una situación superior a la suya, que es la que se quiere simular" (Jauretche, 1966: 19). Obtenido ese status por vía de títulos profesionales, cargos sostenidos en el Estado y cátedras en la universidad, esa parte sana de la población autoproclama su decencia y también su derecho a la voz, participa insistentemente de la escena pública y a la hora de escribir la historia se cuenta a sí misma, se instituye como narradora y protagonista del relato urbano.

Como vimos en el capítulo anterior, varios de los textos que analizamos recurren a la primera persona en la escritura. Otros no utilizan ese recurso, pero el autor tiene una presencia fuerte en casi todos los libros. Sólo dos de ellos -ambos de origen universitario- intentan diluir la autoría, pero lo hacen sin demasiado éxito: Obra de arte, que compila todos los aportes y adjudica la totalidad de la obra a un amplio equipo de trabajo, y el Diccionario de 
arte, donde las entradas están firmadas con iniciales ${ }^{159}$. No obstante, la autoría se cuela en la escritura. En el de la Facultad de Humanidades lo hace con narradores que escriben en primera persona y refieren a sus propios libros; en el de Bellas Artes, con textos que tienen fuertes marcas personales como el de Romualdo Brughetti, que escribe sobre su padre.

A su vez, como ya vimos, hay presencias reiterativas y son evidentes algunas vinculaciones entre los autores, que se nombran unos a otros. Por eso cobra particular interés la pregunta por los agentes: ¿quiénes son los cronistas de la ciudad?, ¿quiénes escriben sobre el pasado platense?

El corpus analizado incluye nominalmente a 296 autores, que en una división binaria de sexos son $55 \%$ varones y $45 \%$ mujeres. De ese total, 37 participan de más de una publicación analizada. Y hay doce que intervienen en tres o más ${ }^{160}$.

Observaremos particularmente estos últimos dos grupos, dado que el rastreo y la reconstrucción de la trayectoria personal de los casi trescientos autores excede a nuestros alcances. Además, la mirada sobre firmas recurrentes de los textos del centenario nos conduce hacia las voces más autorizadas y/o con más recursos para escribir sobre la ciudad.

Si la distribución por sexo no exhibe una desigualdad muy marcada entre el total de autores, la misma se amplía en los conjuntos más chicos. De los 37 autores que participan de más de una publicación, 29 son varones y 8 son mujeres. Y de los 12 más reiterados, 10 son varones y sólo 2, mujeres.

Otro aspecto significativo es el de las profesiones, pues nos confirma el tenor de la historia local que señalábamos en el capítulo anterior: desatendida por la academia, se trata de una historia amateur, hecha por aficionados.

Detengámonos en los 37 autores que participan de más de una publicación. Si atendemos a una única identificación profesional por persona -esto es, tomamos la definición predominante, más allá de que algunos abogados se definen también como escritores, etcétera-, en ese universo tenemos: 7 escritores/as, 5 abogados o escribanos, 4 periodistas, 4 historiadores académicos, 4 profesionales de las ciencias naturales, 3 arquitectos, 2 aficionados a la historia, 2 geógrafos, 3 personas vinculadas al arte, 1 profesor de filosofía, 1 museóloga y 1 médico.

Es decir que los historiadores académicos representan apenas el 10,8\% del grupo de autores más significativos del corpus analizado. Si a ellos sumáramos la museóloga y los dos aficionados a la historia $^{161}$, el número ascendería al $18,9 \%$, pero sigue siendo minoritario frente a los escritores y periodistas (entre ambos representan un 29,7\%) o las profesiones liberales (que suman el 24,3\%).

\footnotetext{
${ }^{159}$ Una tercera publicación que no señala explícitamente la autoría es No habrá manto de olvido (Familiares, 1982), donde la operación es exitosa: en la materialidad del libro no hay otra alusión que a la organización, y la autoría en términos personales recién pudo reconstruirse a partir de fuentes orales.

${ }^{160} \mathrm{Al}$ final del capítulo incluimos una infografía que muestra la complejidad de relaciones entre los libros. Cada círculo representa una publicación, dependiendo de la cantidad de autores la variación de sus tamaños. Las líneas que conectan a las publicaciones entre sí -y el grosor de las mismas- indican que éstas comparten autores o editores. El gráfico puede consultarse y manipularse en forma dinámica en: www.unpasadoparalaplata.com.ar ${ }^{161}$ Catalogamos como historiadores aficionados a José María Prado, definido siempre como "investigador en historia" pero cuya carrera se desarrolla fuera del ámbito académico disciplinar, y a Carlos Moncaut, escritor costumbrista y aficionado a la historia, quien finalmente en 2003 -pocos años antes de su muerte- fue incorporado a la Academia Nacional de Historia.
} 


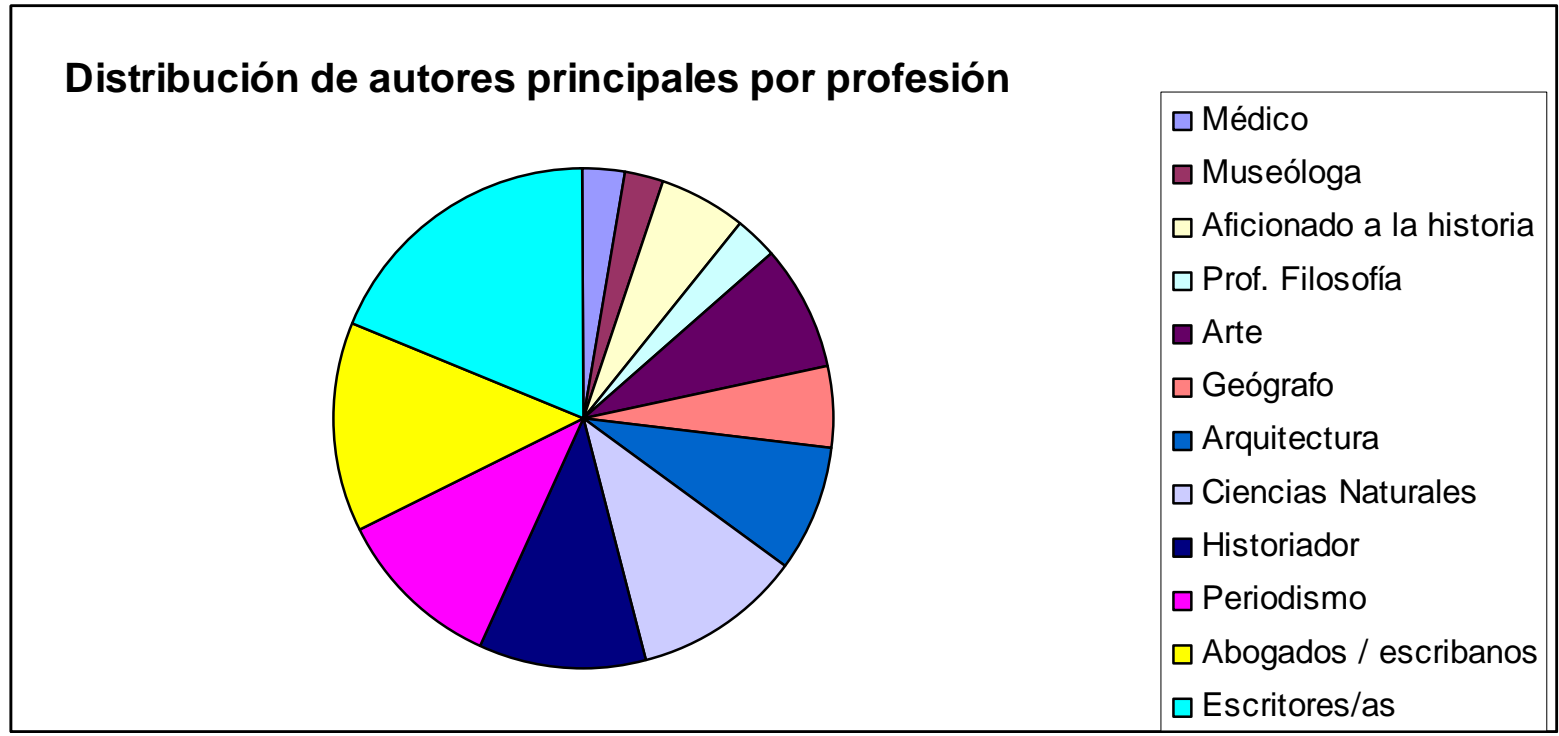

La presencia de arquitectos puede estar vinculada a que la ciudad es precisamente su objeto de estudio y trabajo profesional, y como veremos en el capítulo siguiente, La Plata ha sido fuertemente identificada con sus rasgos urbano-arquitectónicos. La identificación de la ciudad con su "trazado perfecto" habilita la voz profesional de los arquitectos e ingenieros. El peso de otras profesionales liberales como médicos, abogados y escribanos, en cambio, estaría ligado con el propio prestigio social de esos títulos. Asimismo, se vincula a la intervención de las asociaciones profesionales como emprendedores editoriales, comentada en el capítulo II: la Asociación Médica Platense, el Colegio de Abogados y la Universidad Notarial dependiente del Colegio de Escribanos hacen sus propias publicaciones, producidas por un médico, un abogado y escribanos, respectivamente.

La mayoría de los autores nacieron en la ciudad, se criaron en ella y explicitan una fuerte vinculación laboral y afecto personal en sus testimonios. Este es otro rasgo que acerca la historia local a la memoria: quienes emprenden la producción de relatos forman parte de la comunidad que pretenden historizar. Cuentan $s u$ aldea.

\section{"Sangre azul"}

"Los sinónimos de linaje son ilustrativos. $O$, al menos, ilustremos algunos. Estirpe, alcurnia, prosapia, abolengo. Nos detendremos (aunque, no olvidar esto, son todos sinónimos) en abolengo y sangre. El abolengo indica algo cerrado, algo vuelto sobre sí. De aquí que entre sus sinónimos figure cuna. 'Pertenecemos a la misma cuna."”

(Feinmann, 2010: 173)

"El 'nuevo rico', el pequeño comerciante afortunado, el empleado eficaz, el obrero habilidoso, se abrieron paso entre los recovecos del

armazón social y consiguieron dislocarlo [...] Con todos ellos se encontraba ahora el viejo patriciado en los clubes -nuevos, muchos de ellos, a imitación de los ingleses- y hasta en las reuniones exclusivas de su clase, que se abría poco a poco ante el prestigio de la nueva riqueza" (Romero, 2009: 245)

En algunos textos esa pertenencia es ostensiblemente objeto de disputa. Queda clara la importancia de ser "nacido y criado". Y si es en el seno de una familia fundadora, mejor aún: más legitimidad para contar la ciudad. 
En el texto sobre el deporte platense incluido en Ciudad milagro, Osvaldo Tomatti deja en claro el valor simbólico de algunos apellidos. Tras listar los firmantes del acta de fundación del club Gimnasia y Esgrima, el periodista concluye con la expresión "¡Qué apellidos!" (en Lerange, 1982: 575). Al párrafo siguiente refiere a "58 caracterizados vecinos" que asistieron a una reunión.

Ahora bien, ¿cómo se conforma ese linaje platense?

En sus aproximaciones a la historia socio-cultural urbana, Luis Alberto Romero planteaba que La Plata, Rosario y Bahía Blanca son "típicas ciudades de inmigración y comercio, con una determinada estructura social en la que nunca existió el tipo de aristocracia tradicional que había en Córdoba" (Romero, 2009: 108). Es decir, no hay herederos de la corona ni familias nobles. En la síntesis de su obra más amplia nunca publicada, el equipo dirigido por Cuccorese plantea: "No hay una ciudad rígidamente estratificada, las distancias entre unos y otros son apenas notables. La clase alta no existe, se formará en el trabajo, en el sacrificio, en el esmero" (Cuccorese, 1982: 141) ${ }^{162}$. Y escribe Calvo en sus Rastros y rostros:

"[...] nuestra ciudad no está atada a prestigios o a heredades de sombríos orígenes, como los que suelen detornar con fatuidad otras sociedades [...] No ostentó la capital nueva -claustro de ciencia, arte y trabajo- esa falencia que se reemplaza con blasones transmitidos, las más de las veces sin fundamento valedero.

La Plata puede jactarse de haber fundado la casta espiritual que enriquece su historia.

Profesores, maestros, comerciantes, artistas, industriales, profesionales que recorrieron los eslabones administrativos o aportaron a las instituciones su juventud, quienes desempeñaron cargos de responsabilidad para otorgarles con su apoyo la dimensión precisa, quienes hicieron producir las quintas aledañas, rememoran con gratitud el tiempo de sus mayores" (Calvo, 1982)

Por su parte, Szelagowski apunta en la Crónica del centenario que la sociedad platense de la época fundacional "fue una sociedad más bien pobre, con hábitos de rico. Esta será un poco la constante durante toda la vida de la ciudad" (Szelagowski, 1982b: VIII). La Plata se nutrió de inmigrantes que formaron colectividades, y las principales vías de ascenso social fueron las carreras profesionales (Szelagowski, 1982b: VIII-IX), otra razón explicativa de la presencia de médicos y abogados entre las personas que asumen la tarea de narrar su ciudad. Más adelante, Szelagowski señala el peso que fue adquiriendo la burocracia provincial, que unida "al desenvolvimiento del Poder Judicial y al de la Legislatura en épocas de normalidad institucional, formó cientos de hombres que constituyeron grupos importantes dentro de la sociedad", al igual que el desempeño en cátedras universitarias, medios periodísticos, academias de arte y clubes (Szelagowski, 1982b: IX). La legitimidad se basa entonces en haber sido (o ser descendiente de) uno de los primeros médicos, escribanos, jueces, catedráticos.

Esa construcción de las alcurnias, de familias destacadas y protagonismos ciudadanos, no empieza ni termina con el centenario. Entre platenses de una generación es muy recordada una edición titulada Quién es quién en La Plata, de casi 900 páginas, que a modo de guía ofrecía un resumen sobre la formación, trayectoria, producción, vida institucional y distinciones de centenares de "figuras notables en distintos órdenes que contribuyen con su

\footnotetext{
${ }^{162}$ La inexistencia de una clase alta puede corroborarse en el estudio de Bejarano (1967), que plantea que La Plata constituyó "un centro urbano cuya característica más significativa se halla en la falta de 'clase alta', en el predominio de los estratos medios y la existencia de una pequeña clase obrera asalariada. Este rasgo proviene de su origen inmigratorio, pero también de las peculiares circunstancias en que ella surge...".
} 
dedicación, al engrandecimiento de la Patria" (Napolitano, 1972: 5-6) ${ }^{163}$. El libro editado por Américo Napolitano y elaborado durante diez meses por un equipo de "casi un centenar de colaboradores" salió a la luz en 1972 con el auspicio de la Asociación Pro Rehabilitación Infantil La Plata (APRILP).

Ese "esfuerzo periodístico" producido diez años antes del centenario, y con gran impacto en un sector de clases medias y altas de la sociedad local, nos permite aproximar algunas ideas sobre quiénes producen y escriben las publicaciones de 1982. Al cruzar la base de datos de autores con el contenido del Quién es quién... surge que 52 de los 296 que participan de nuestro corpus, aparecen en aquel tomo orientado al reconocimiento de figuras destacadas del orden local. Es decir, un 17,6\%. Y si tenemos en cuenta las referencias -en esa guía- a padres o madres de esos autores, el número asciende a 64 (21,6\% del total de autores). La proporción no es claramente significativa, pero cobra un sentido interesante cuando analizamos el caso de las firmas más reiteradas. De aquellos que participan en al menos 2 publicaciones, 20 (el 54\%) están incluidos -ellos y/o alguno de sus progenitores- en Quién es quién en La Plata. Y si se contabilizan los que participan en tres o más, la proporción asciende al 75\% (9 de 12 autores), es decir, una amplia mayoría.

En otras palabras: aquellos autores que gozan de mayor legitimidad o al menos de una presencia institucional que promueve y valida su voz en la coyuntura del centenario, pertenecen a una franja "destacada" de la sociedad, a una suerte de aristocracia localmente construida con pertenencias institucionales significativas, que como veremos se relacionan entre sí y forman un círculo social distinguido.

\section{Los doce destacados}

Repasemos quiénes son los doce autores con mayor presencia en el amplio corpus de textos analizados. Dos tercios nacieron en La Plata. En 1982 tenían un promedio de 63 años.

Al historiador Enrique Mariano Barba (La Plata, 1909) ya nos hemos referido en el capítulo anterior, pues interviene legitimando algunos textos: es autor de prólogos o presentaciones de libros, además de realizar una conferencia en el marco del Ciclo Cien años. Es el único historiador académico de esta lista. A juzgar por sus cargos se nos presenta como un "heredero de Levene": Director Honorario del Archivo Histórico de la Provincia de Buenos Aires y decano de la Facultad de Humanidades de la UNLP (Barba, 1980), lo que lo emparienta con la tradición de la Nueva Escuela Histórica mencionada en el capítulo anterior.

Doctorado en España, inició su carrera docente en 1934 en la universidad platense, y también se desempeñó en la Universidad de Buenos Aires. En 1976 fue consagrado Presidente de la Academia de la Historia, cargo que desempeñó hasta 1988 y desde el cual tuvo intervenciones significativas en conmemoraciones de la época, que no se circunscriben al centenario de La Plata. Así, por ejemplo, en 1979 inauguró junto al Ministro del Interior,

\footnotetext{
${ }^{163}$ En términos más recientes podemos mencionar el libro Familias platenses, publicado tres décadas después del Quién es quién..., prologado por el ex intendente Hipólito Frangi, contador al que podemos encontrar referenciado y elogiado en los libros de Szelagowski. Si bien pertenecieron a escisiones distintas del radicalismo, Frangi y Szelagowski se dispensan respeto entre sí, se validan mutuamente. Según el libro de 2002, Frangi es "miembro de una familia de hondo arraigo en La Plata que mereció el honor de ser elegido por el voto popular para ejercer el cargo de Intendente Municipal (1958-1962), desempeñándose también como Subsecretario de Industria y Comercio (1970-1972), Subsecretario de Trabajo (1971-1972) y Presidente del Banco Municipal de La Plata (1983)" (De Luca, 2002: 4). Es notoria la ausencia casi total de familias con alguna vinculación al peronismo en dicho libro. Todos o casi todos los funcionarios mencionados, lo fueron en gobiernos de facto o en administraciones radicales post-yrigoyenistas.
} 
general Albano Harguindeguy, el Congreso Nacional de Historia sobre la Conquista del Desierto realizado en General Roca.

Por su parte, el doctor en letras Pedro Luis Barcia (Gualeguaychú, 1939) -también académico con pertenencia a la Facultad de Humanidades local- compila Viajeros, participa del $\mathrm{N}^{\circ} 27$ de la Revista de la Universidad, y formalmente figura como uno de los coautores de Obra de arte -aunque consultado sobre el tema minimizó su participación: "No creo que yo haya hecho mucho porque estaba con otras labores en mano" "164-. Sí participó activamente como co-director de la investigación Paseo histórico. Centenario de La Plata 1882-1982, impulsada por Horacio Cuccorese, que como ya vimos quedó inédita.

Barcia exhibía una trayectoria universitaria importante -doctorado a los 32 años en la UNLP- que consagraría en el año 2000 al ser designado académico de número de la Academia Nacional de Letras, que actualmente preside. A principios de los '70, según señala el Quién es quién..., había "dictado cursos y conferencias en: Instituto Platense de Cultura Hispánica, Facultad de Humanidades, Jockey Club de la Provincia de Buenos Aires e Instituto de Filosofía de la Universidad Provincial de Mar del Plata" (Napolitano, 1972: 77).

Angel Osvaldo Nessi (Chivilcoy, 1915), además de ser compilador y coautor del Diccionario de arte, publica en la Revista de la Universidad ( $\mathrm{N}^{\circ} 26$ y 27) y en Ambiente, participa de la elaboración de Obra de arte y aporta un capítulo a Ciudad milagro. Graduado en la Facultad de Humanidades en 1948 con una tesis sobre Fernando Fader y la pintura argentina, a lo largo de su vida desempeñó diversos cargos de gestión en instituciones públicas académicas y artísticas de distintas disciplinas. Indudablemente es un autor convocado por su trayectoria. Dos décadas antes, había sido uno de los participantes de Universidad nueva y ámbitos culturales platenses (VV.AA., 1963), con un capítulo sobre "Las amistades literarias de Emilio Pettoruti". Antes aún, escribió en el suplemento especial de El Día para el $76^{\circ}$ aniversario de la ciudad un artículo titulado "La Plata, ciudad de grandes artistas".

Nessi fue un referente importante de la crítica de arte, con una formación teórica importante y muy actualizado. Entre 1964 y 1966 dirigió el Museo Provincial de Bellas Artes, donde promovió muestras innovadoras, en sintonía con la vanguardia porteña y siempre en diálogo con los artistas locales. En ese marco convocó al "Movimiento Arte Nuevo" (MAN), una exposición colectiva de la que participaron Edgardo Antonio Vigo, César López Osornio, César Paternosto, Alejandro Puente, Hugo Soubielle, Pablo Suárez, Jorge de la Vega, entre varios otros. Al celebrarse el centenario platense era director del Instituto de Historia del Arte Argentino y Americano de la Facultad de Bellas Artes -desde donde emprende el Diccionario de arte- con una trayectoria muy reconocida por su rigurosidad y la apertura al reconocimiento de nuevos grupos y corrientes.

El otro autor de mayor presencia con un perfil académico es el arquitecto Julio Ángel Morosi (La Plata, 1926). Director del trabajo de investigación plasmado en Ciudad nueva ciudad antigua y en seis documentos de avance que hemos comentado, además da una charla en el ciclo del Museo y Archivo Dardo Rocha, escribe en los tres números publicados por la Revista de la Universidad durante el período y también en Ambiente.

\footnotetext{
${ }^{164}$ En nuestro intercambio afirmó que creía que fue Delia Zaccardi, entonces secretaria del Departamento de Letras, quien se ocupó del tema. No obstante, el nombre de Zaccardi no figura en el libro, lo que sí ocurre en el caso de Barcia, único participante indicado por el área de Letras.
} 
Nacido en la ciudad, fue a la Escuela Anexa y al Colegio Nacional, y estudió en la Facultad de Ciencias Fisicomatemáticas -cuando aún no existían las facultades de Arquitectura e Ingeniería-, donde obtuvo los títulos de Ingeniero Hidráulico (1951), Ingeniero Civil (1952) y Arquitecto (1958), con un total de 53 materias rendidas. Luego realizó estudios de posgrado en Suecia entre 1959 y 1966. Este autor cultiva una identidad netamente académica, con sus estudios de grado y posgrado, dominio de idiomas y estancias de investigación en el extranjero. Su trayectoria se concentra en la Facultad de Arquitectura de la UNLP, donde ocupó cargos de gestión y asumió diversas responsabilidades, sobre todo durante el período de dictaduras 1966-1973. En la misma etapa fue Subsecretario de Obras Públicas y Planeamiento de la Municipalidad (1966-1969) y asesor de distintos entes gubernamentales.

Se inició en la docencia en 1953. En 1967 era Profesor Titular en la Facultad de Arquitectura y Urbanismo. Desde 1975 su cátedra fue Planeamiento Físico II (Microescala), con dedicación exclusiva, cátedra desde la cual impulsó la investigación con De Terán y en la que es confirmado por resolución del Rectorado en 1981. En el currículum de ese año figura que en su legajo personal de la FAU aparece su condición de "Decano Sustituto de la Facultad" (1968-1973). En 1968-1969 participó de la comisión que redactó el plan de estudios vigente entre 1969 y 1974, años en los cuales se desempeñó como jefe del área de planeamiento físico.

Durante la siguiente dictadura también cumplió roles institucionales en la UNLP: integró la Comisión de Becas (1975-1980), coordinó las tareas de investigación de la facultad (1975-1978), fue miembro de la "comisión asesora", de la "comisión de incumbencias" (1976-1980) y de otra designada en 1976 para "reunir antecedentes y efectuar proposiciones para cubrir cargos docentes en la Facultad" (Res. 662/1976 del Rectorado), entre otras.

Otro arquitecto, Alfredo Conti (1948?) es uno de los responsables de la recopilación y textos de La Plata 100; además interviene en la elaboración de Crónicas de un siglo y escribe en el Diccionario de arte. Es el más joven de este grupo de autores. Hoy reconocido como referente en temas de patrimonio, en 1982 llevaba apenas cinco años graduado como arquitecto. En 1977 se integró a la Dirección de Planeamiento municipal, organismo en el que trabajó hasta 1991, cuando inició su carrera académica en la Comisión de Investigaciones Científicas. No era un "nombre reconocido" en la época ${ }^{165}$, si bien participa en tres textos. Su mayor trabajo está en La Plata 100, guía turística producida desde el órgano gremialprofesional de los arquitectos, mientras que su intervención en las otras dos publicaciones es secundaria.

Siguiendo con el repaso, la docena autores más reiterados incluye tres auto-identificados como escritores y vinculados a la SADE y/o la SEP. En este subgrupo están las únicas dos mujeres de los "doce destacados".

Héctor Marcelino Rivera (Chascomús, 1927) participa de tres libros impulsados o publicados por las asociaciones de escritores: tiene un capítulo en Ciudad milagro y otro en 12 personalidades. Además, es uno de los presentadores de Primeros habitantes. Estos dos últimos corresponden a la editorial Almafuerte, de SADE La Plata, cuya Comisión Directiva integra. Mucho tiempo antes había ocupado el cargo de secretario en la Sociedad Provincial

\footnotetext{
${ }^{165}$ Hoy es presidente del comité argentino del Consejo Internacional de Monumentos y Sitios (ICOMOS) y vicepresidente de su comité ejecutivo internacional.
} 
de Escritores (SEP), en 1954-1955, época en que publicó su Oda al poeta Almafuerte (1954). La misma SEP premió con la "Faja de Honor" a su libro Edad de Buenos Aires (1960). Definido como “escritor" en el Quién es quién en La Plata (Napolitano, 1972: 700), era maestro normal, cursó en las facultades de Derecho y Humanidades y fue bibliotecario de la Cámara de Senadores provincial. También se lo identifica como miembro del Instituto Almafuerteano y Belgraniano (1952)

La escritora Ana Emilia Lahitte (La Plata, 1921) por su parte, fue una de las conferencistas del Ciclo cien años. Escribe un capítulo de Ciudad milagro y un artículo en la revista Ambiente, donde además es entrevistada como personalidad de la cultura local. Cabe indicar, también, que elaboró la antología del poeta Speroni publicada en 1975 por el Ministerio de Educación bonaerense, durante la gestión de Bernard, reeditada en el centenario por iniciativa del Colegio de Escribanos.

Con título de maestra normal de la Escuela $\mathrm{N}^{\circ} 1$ "Mary O’Graham", se la reconoce como "escritora", "educadora" y "periodista" (Napolitano, 1974: 446), tiene libros publicados desde 1947 y también exhibe su pertenencia a ambas sociedades de escritores:

"Es miembro de la Sociedad Argentina de Escritores, de la Sociedad de Escritores de la Provincia de Buenos Aires, del PEN Club en la Argentina, del Círculo de Periodistas de la Provincia de Buenos Aires, de la Asociación de Escritores y Periodistas de México y de la Asociación de Periodistas y Escritores de Turismo asociada a la F.I.J.E.T. de París. En 1970 fue nombrada presidente de AMMPE (Asociación Mundial de Mujeres Periodistas y Escritoras) en la Argentina" (Napolitano, 1972: 446)

La SADE - de cuya filial platense fue secretaria- la premió en varias oportunidades. En 1980 creó un taller literario dependiente de la Dirección de Cultura de la Municipalidad de La Plata y en 1982 la Fundación Argentina para la Poesía le otorgó el premio "Pluma de Oro 1982" por "su obra total".

La tercera escritora es Estela Calvo (La Plata, 1931), autora de capítulos en los dos libros promovidos por sociedades de escritores, Ciudad milagro y 12 personalidades, además de publicar su propio trabajo: Rastros y rostros. Es sobrina del poeta Francisco López Merino e hija de un recordado editorialista de El Día, Jacinto Calvo ${ }^{166}$, y ese linaje parece ser su mayor mérito. Además del trabajo del '82 sólo publicó un pequeño libro de poesía, Terapia intensiva, que saldría en 1988 editado por Almafuerte. Más tarde sería subdirectora de Promoción de la Municipalidad y organizadora de distintos actos culturales desde el Salón Cultural Bernardino Rivadavia.

Los cuatro autores restantes sobresalen en lo que hace a la exaltación de su figura: tanto en sus propios libros como en producciones ajenas aparecen aludidas sus trayectorias, lo que refuerza su legitimidad para hablar de la ciudad. Todos hombres, la mayoría nacidos en la ciudad, exhiben un linaje, vida social, títulos y reconocimientos que los colocan como figuras destacadas.

Federico E. Christmann (La Plata, 1898) es, según lo presenta uno de los libros que integra nuestro corpus:

\footnotetext{
166 "Fueron sus padres el doctor Jacinto Calvo y doña Néstar López Merino. Jacinto, abogado, periodista del diario EL DIA, donde redactaba artículos de fondo, Fiscal de Cámara y Asesor de Minoridad. Néstar nació en el palacio López Merino, calle 49 no 835, donde hoy funciona el Complejo Bibliotecario Francisco López Merino, siendo sus padres, Toribio López y América Merino. De este matrimonio nacieron varios hijos, entre ellos, el poeta" (Venturini, 2010)
} 
"Profesor honorario de la Universidad Nacional de La Plata. Profesor honoris causa de la Universidad Católica de Córdoba. Miembro de honor de la Fundación José María Mainetti (La Plata) Presidente de la Fundación Pedro Belou (La Plata) Guardasellos de la Universidad Nacional de La Plata. Socio honorario del Rotary Club de La Plata. Orden del Buen Vecino, otorgada por la Municipalidad de La Plata (1980) Autor de trabajos científicos de índole médica de observación, casuística, investigación clínica o quirúrgica y de divulgación: en total ciento treinta" (SADE La Plata, 1982: 35 ) ${ }^{167}$

Igual que Calvo, Christmann participa de aquellas dos compilaciones y tiene un libro con su autoría individual: Vivencias y testimonios.

Hijo de una familia radicada en los primeros años de la ciudad, fue a la Escuela Anexa ("una escuela modelo") desde segundo grado y obtuvo el título de Bachiller en el Colegio Nacional. Su destacada biografía podemos leerla en el libro testimonial que publica para el centenario: tras un viaje de estudios en Europa, ganó un concurso en una cátedra de Medicina Operatoria/Técnica Quirúrgica de la UBA. En esa época escribió un libro para la enseñanza del tema, del que en 1979 se celebró el cincuentenario de su aparición (Christmann, 1982: 236-239). En la década del '30 se incorporó a la UNLP, donde pronto obtuvo un cargo de Profesor Titular. En 1960 fue decano de la facultad ${ }^{168}$. Era intendente el contador Hipólito Frangi, de quien se dice amigo personal (Christmann, 1982: 10). En 1962 recibió el diploma de Profesor Honorario de la Universidad ${ }^{169}$.

Su vinculación con la Facultad no concluyó en los ‘60: “en 1978 -cuenta- fui invitado por el Dr. Manuel Sergio García Mutto, para integrar un grupo de personas dispuestas a crear una Fundación de apoyo económico a la infraestructura de la Facultad" (Christmann, 1982: 288). La fundación recibió el nombre de Pedro Belou. Menciona los integrantes de la misma: tres abogados, dos médicos, alguien señalado como "de Ciencias Económicas", un integrante de la industria maderera, otro de la frigorífica, un contador del Banco Platense y un integrante del Banco Crédito Provincial (Christmann, 1982: 289). Precisamente a esa Fundación dona los beneficios de su libro.

Además, detalla una amplia "vida social" que incluye la participación en la Asociación Cristiana de Jóvenes, su integración a la Sociedad Médica de La Plata ${ }^{170}$ y al Rotary Club donde fue electo presidente en 1943-. También sus distinciones: en 1975 la Sociedad Argentina de Cirujanos lo reconoció como "cirujano maestro"171 y en noviembre de 1980 recibió la "Orden del Buen Vecino".

\footnotetext{
${ }^{167}$ La condición de Guardasellos también está señalada en los datos institucionales del Diccionario de arte y en la Revista de la Universidad. En los números 26 y 27 de esta última, Christmann aparece entre los siete nombres de autoridades de la UNLP. Para el 28 ya no cumple ese rol y ha sido reemplazado por José María Mainetti.

${ }^{168}$ El anteúltimo capítulo de su libro testimonial está dedicado a la política universitaria. Relata que llegó a ser Consejero Académico en la Facultad de Química y Farmacia casi contra su voluntad (Christmann, 1982: 331). Reconoce que allí se iniciaba en "tareas de gobierno". Diez años después, en 1946, el delegado interventor con funciones de Decano de la Facultad de Ciencias Médicas organizó un nuevo consejo académico y lo invitó a integrarlo. Aceptó - dice- "ingenuamente" (Christmann, 1982: 333). Trabajó en un nuevo plan que fue desestimado y renunció, en lo que define como un "clima poco grato". Diez años después, en noviembre de 1957, fue elegido consejero superior (Christmann, 1982: 333) y luego decano.

${ }^{169}$ En su libro destaca que cuando recibió esa distinción todavía estaba vigente el Estatuto que disponía que debía ser otorgada por unanimidad.

${ }^{170}$ Fundada en 1910, la primera comisión provisoria fue presidida por Alejandro Korn (Christmann, 1982: 307). Es una de las últimas referencias del libro: le dedica un capítulo a la Sociedad Médica y los siguientes a Alejandro Korn y Giordano Burno Cavazutti, sus fundadores.

${ }^{171}$ En el capítulo sobre cirugía plástica incluido en Ciudad Milagro, Leonardo Barletta -presidente de la Sociedad Argentina de Cirugía Plástica entre 1980 y 1981- menciona inicialmente a "mi maestro, el doctor
} 
Siete personas obtuvieron tal distinción en ese año. Entre ellas estaba José María Prado $^{172}$ (Rioaveso, España, 1896), otro de los autores que interviene en más de dos publicaciones: además de su conferencia en Ciclo Cien años, participa de dos de los volúmenes más importantes: Obra de arte y Ciudad milagro. Investigador -aunque sin formación en ámbito formal- y autor de numerosas conferencias,

"Ha estudiado los orígenes y antecedentes de la federalización y la fundación de nuestra capital. Desde el Archivo Público de la Dirección de Geodesia (ex Archivo del Departamento Topográfico) ha investigado y estudiado las luchas por la conquista del desierto. Ha indagado en profundidad el historial de las pampas de Buenos Aires y organizado por primera vez, desde la fundación de La Plata, una exposición de cartografía histórica y más de medio centenar, en la ciudad y en el interior, desde 1950 hasta la actualidad" (Napolitano, 1972: 669; idem Prado, 1978: 5) ${ }^{173}$

Prado es reconocido como responsable de distintas iniciativas en el ámbito local, como el señalamiento del centro geográfico y la piedra fundamental ubicada en la Plaza Moreno. Además exhibe múltiples membresías: es Presidente de la Federación de Instituciones Culturales y Deportivas, miembro de los Institutos Belgraniano y Sarmientino y del Centro de Historia Argentina de la Capital Federal, "integrante de la Comisión de Homenaje al historiador Manuel Ricardo Trelles" (Prado, 1978: 5), Presidente Honorario del Centro Argentino de Cartografía y Presidente de la Peña Cultural de la Institución Cultural HispanoArgentino. También se desempeña como jefe de la Asesoría Histórica de la Dirección de Geodesia. En 1976, al cumplirse el Sesquicentenario de la creación del Departamento Topográfico, el gobernador Saint Jean "lo distinguió con medalla de oro y un pergamino, por los importantes servicios extraordinarios prestados a la Administración de la Provincia" (Prado, 1978: 6). En la proliferación de trabajo en instituciones, Prado sintetiza la figura del dirigente caracterizada por Garguin:

“...Las diferencias sociales y económicas entre ellos no escaseaban y algunos sobresalían del resto; sin embargo, la distinción explícita se basaba en cuestiones morales y de conducta. Los dirigentes no aparecen como 'sectores medios', sino como los más abnegados, altruistas y sacrificados 'hijos del pueblo' y su accionar estaba indisolublemente ligado al prestigio, la honra y progreso colectivos, tanto económico y edilicio como social y cultural" (Garguin, 2009: 11)

No es aquí una tradición familiar sino la inserción en una institución la que tiende a "hacer de sus dirigentes miembros destacados de sus respectivas comunidades. 'Vecinos caracterizados', los llama de Privitellio; 'elite bienintencionada', los denomina Jumar; como 'gente destacada', los describe Troisi; 'vecino dilecto', se autodenominaba Contarelli"' (Garguin, 2009: 12)

Por su parte, Miguel B. Szelagowski (La Plata, 1920), quien como ya hemos visto fue designado cronista del centenario, es autor de varios libros en la época y aporta un capítulo a Ciudad milagro, además de colaborar como corrector de la publicación del diario El Día, Vida platense. Abogado y además integrante de la Comisión Directiva de la Sociedad

Federico Christmann" y dice que en el "Servicio de Cirugía del Prof. Christmann nació la Cirugía Plástica como especialidad bien definida, en nuestra ciudad" (en Lerange, 1982: 153). Cabe decir que Christmann es el autor del artículo inmediatamente antecedente.

${ }^{172}$ Los restantes son: la doctora Matilde K. de Creimer (Matilde Alba Swann), César Gatti, monseñor Roberto P. Lodigiani, Nello Principi y Manuel Vega Segovia (Christmann, 1982: 290).

${ }^{173}$ Es interesante notar que la reseña presentación de Prado -más extensa, de la que aquí sólo transcribimos un párrafo-incluida en el Ciclo Cien años, está tomada textualmente del Quién es quién en La Plata. 
Argentina de Escritores (SADE La Plata) -que premió dos de sus libros-, es una figura del ámbito político y judicial de la ciudad. Militante de la Unión Cívica Radical, integró el poder judicial entre 1934 y 1947, fue secretario Obras Públicas de la Municipalidad en 1956, secretario general del Ministerio del Interior (1957), subsecretario de Justicia de la Nación (1957) y secretario legislativo del Bloque de Senadores provinciales de la UCR -presidido por Arturo Mor Roig-. En 1963 fue electo intendente de la ciudad por la UCRP -experiencia a la que dedica uno de los libros del centenario (Szelagowski, 1982a)- y más tarde se desempeñó como Jefe de Asesores de Gabinete del Ministro del Interior (1971) y Subsecretario General del Ministerio del Interior (1973).

Además de en sus libros, el apellido de la familia Szelagowski es citado en varias publicaciones del centenario: Ladislao entre jóvenes de familias acomodadas que viajaron al Viejo Mundo (Soler, 1982: 79), su tío Honorio como amigo del viejo director de El Día Juan Atencio cuando éste fue batido a duelo (Soler, 1982: 80). El propio Miguel Blas es mencionado en publicaciones del centenario: en Obra de arte se alude a su participación como caricaturista en el periódico radical Adelante (Díaz, 1982: 329), y Sureda menciona "su hermoso libro La Plata de los años 20" (Sureda, 1982: 79).

Como vimos en el segundo capítulo, Szelagowski fue nombrado por la Municipalidad como cronista del centenario: "Honor y responsabilidad que me toca como pudo tocarle a muchos otros platenses posiblemente mejor dotados que yo para hacerlo" (Szelagowski, 1982b: I). El decreto que lo designa -por pedido suyo, con carácter ad-honorem- considera "que las relevantes condiciones de escritor del señor ex Intendente Municipal don Miguel Blas Szelagowski, así como su ejemplar conducta ciudadana, su acendrado amor a la Ciudad y su singular conocimiento de la historia de La Plata, amalgamado con su experiencia municipal, lo configuran con específicas aptitudes para la labor". Al ser presentado en esa función, su condición platense de familia fundadora aparece como una justificación de peso:

“...Szelagowski señaló ante una pregunta que conocía bien a la ciudad, por propia visión. «Soy de 1920 -confiesa- y tengo recuerdos de esa década y de más atrás que me llegaron por testimonio oral. Tuve la suerte de tener una buena relación con mi abuelo. El vio nacer a esta ciudad y me pudo relatar muchas cosas. Mi padre, que es de 1890, hizo algo parecido, y sus hermanos también dejaron rastros en mi memoria de hechos que ocurrieron». También recuerda a muchos personajes de la primera época y las remezones de la época brillante de la ciudad, con los grandes poetas y pintores, como Petorutti, Boveri, Delfor Méndez, Benito Lynch, etc". ${ }^{174}$

En Años veinte deja en claro su cabal conocimiento de un círculo de la sociabilidad local relacionado con clubes selectos:

"La vida social se desarrollaba alrededor del Jockey Club. Era fundamentalmente un club para hombres, donde las mujeres tenían acceso en contadas ocasiones; alguna comida o un baile en las fechas patrias o aniversario de la fundación de la Ciudad. Un grupo se reunía diariamente en lo que llamaban 'El tambo'. Desconozco el origen del nombre. Allí estaban Francisco Alconada, 'el apóstol'; Julio Aramburú, 'Beto'; Amílcar Mercader, 'Parrita'; Honorio Szelagowski, 'el buda'; Isidoro Aramburú, 'el soto'; Benito Lynch, Ramón Iramain, 'Shalaco'; Lucio Florio, 'el ratón'; Juan Carlos Mena, etc, etc..." (Szelagowski, 1979: 69)

En Crónica del centenario se presenta como "perteneciente a la tercera generación de una familia platense" y en Si yo fuera intendente menciona el paso de su abuelo por el

174 "Miguel Szelagowski, el hombre que narrará el centenario platense”, El Día, 2 de noviembre de 1982, pág. 7. 
gobierno comunal, en 1884: un polaco que había llegado desde París en agosto de 1878 y se instaló en La Plata poco después de la mudanza de los poderes provinciales a la ciudad. Era sastre y a su negocio concurría "gente importante", según afirma Szelagowski en otro libro, donde también menciona "su amistad con el fundador, Dardo Rocha, que continuó hasta la muerte de éste y prosiguió con sus hijas". Asimismo comenta que su abuelo instaló una fábrica de hielo, la primera la ciudad (Szelagowski, 1979: 13-15). La trayectoria de la familia es, finalmente, representativa de esas clases medias que crecieron con La Plata y se consolidaron a partir del acceso a profesiones liberales. Su padre -cuenta- obtuvo su título "con gran sacrificio": "Había trabajado desde su adolescencia en variadas tareas. Su primer trabajo había sido de lavacopas en un almacén que había tenido mi abuelo en diagonal 80, creo que esquina 47..." (Szelagowski, 1979: 12).

Como otros de los autores a los que nos hemos referido, Miguel Szelagowski fue a la Escuela Anexa y al Colegio Nacional. En la primera, de la que señala su tendencia "aristocratizante" (Szelagowski, 1979: 44-48) ${ }^{175}$ y su "aspecto clasista" (Szelagowski, 1979: 46), recuerda entre otros compañeros al autor que nos queda por mencionar: Tomás Diego Bernard (La Plata, 1919).

De profesión escribano, hijo de otro matrimonio que se instaló en La Plata poco después del traslado de la administración pública, en la coyuntura del centenario Bernard escribe un texto que sale en una separata de la Revista del Notariado, que a su vez es un capítulo fundamental de Ciudad milagro, y realiza la conferencia basada en la amistad de su familia con los Rocha. Ostenta múltiples identificaciones, como puede leerse en Quién es quién en La Plata: "Doctor en Jurisprudencia. Profesor Universitario. Escribano. Investigador de Historia y Museología Diplomática" (Napolitano, 1972: 95). Fundador de la Escuela Superior de Policía de la Provincia, también fue profesor -en la primera mitad de los '50- del Liceo Naval y de la Escuela Naval. Tuvo un paso por Córdoba a mediados de los años '40, donde fue intendente de la ciudad capital. Entre 1947 y 1951, además, se desempeñó por concurso en la cátedra de "Historia Sanmartiniana". En el mismo sentido, fue presidente del Instituto Nacional Sanmartiniano, filial provincia de Buenos Aires, en el período 1936-1950. Y al momento del centenario es presidente del Círculo Sanmartiniano de La Plata (Marcovich, en Lerange, 1982: 518) ${ }^{176}$.

Entre sus adscripciones docentes aparecen varias instituciones privadas: Universidad del Salvador, Universidad Católica y especialmente $s u$ Universidad Notarial.

Frente a una marcada presencia de varios autores y referencias propias del radicalismo como Szelagowski-, Bernard es junto a Estanislao de Urraza uno de los nombres del centenario que podemos asociar al peronismo, con la diferencia significativa de que esta identidad no deja huellas en sus textos. De origen nacionalista y católico, Bernard se desempeñó como ministro durante la gestión de Victorio Calabró. En línea con ese perfil

\footnotetext{
${ }^{175}$ El hermano del padre, Eduardo Szelagowski, fue entre otras cosas profesor de la escuela Anexa, donde en 1916 inició una experiencia de taller de manualidades, por la que "en la primera época fue tildado de izquierdista" (Szelagowski, 1979: 44). Si bien no era radical, el autor lo ubica entre quienes sufrieron las represalias del régimen del 30 en la escuela, "profesores que hicieron esfuerzos para democratizar" una escuela "aristocratizante" (Szelagowski, 1979: 23, 44)

${ }^{176}$ Cabe recordar que San Martín fue objeto de una de las principales políticas de memoria de la dictadura. "Una de las instituciones que ocupaba un lugar privilegiado en la gestión de la memoria del héroe máximo era el Instituto Sanmartiniano, creado el 5 de abril de 1933, fecha del aniversario de la batalla de Maipú, en la sede del Círculo Militar", señala Philip (2006)
} 
ideológico, su hijo y uno de los hijos de Urraza se vincularon con el grupo derechista denominado Concentración Nacionalista Universitaria $(\mathrm{CNU})^{177}$.

Bernard se desempeñó en tareas diplomáticas -como Cónsul General Honorario de la República de Ecuador durante más de medio siglo- y políticas: fue Director del Museo Histórico Nacional (1954-1955); Escribano General de Gobierno (1973) y, como ya vimos, Ministro de Educación bonaerense (1974-1975) (De Luca, 2002: 103). Por otra parte, entre 1959 y 1966 presidió la Sociedad de Escritores de la Provincia de Buenos Aires (luego continúa en su Comisión Directiva y su Tribunal de Honor), la institución editora de Ciudad milagro, donde escribe el primer capítulo, con un fuerte sentido editorial.

Sus escritos sobre la historia platense empiezan, no obstante, más de dos décadas antes. Así, por ejemplo, en 1960 -"para las honras del Sesquicentenario de la Revolución en Mayo"el Colegio de Escribanos y la editorial Omega publicaron "Los Rocha, un linaje porteño de fundadores", sobre el notariado en la colonia, donde vinculaba aquel apellido con la revolución de mayo que cumplía 150 años. Bernard es uno de los autores que más insiste en el linaje de fundadores, y la validación de su voz, anclada en el reconocimiento de su apellido, se basa justamente en la "amistad" que unía a los Bernard con la familia Rocha.

Ser fundador

"La condición sine qua non para pertenecer a la 'gente decente'se vincula esencialmente a un elemento cultural: el linaje, cuya única exigencia es la filiación legítima transmitida familiarmente. El individuo antes que por sus hechos significa por su correcta situación de familia..." (Jauretche, 1966: 64)

“En la última reunión de la Asociación de Amigos del Museo y Archivo Dardo Rocha se adoptaron diversas resoluciones relacionadas con la mejor contribución a las fiestas del Centenario, entre ellas la realización de una jornada de museología, con participación de la Federación de Museología de la República Argentina. Por su parte el señor José María Prado propuso en nombre de la Federación de Instituciones Culturales y Deportivas, la apertura de un Libro Registro de familias o vecinos residentes en La

Plata que desciendan directamente de fundadores y que haya permanecido en esta ciudad de la unión nacional. Tras un cambio de ideas, se resolvió abrir el citado registro, en la sede del Museo, calle

$50 N^{\circ} 933$, que funcionará de 9 a 18, todos los días hábiles, por la cual desciende de una familia fundadora, en cualquier nivel que haya actuado, durante la fundación y hasta el 19 de noviembre de 1883"

(Diario El Día, 10 de noviembre de 1982. Los errores de sintaxis vienen del original)

La identificación de los pioneros es recurrente; aparece en varios de los libros analizados. En Vida platense, por ejemplo, podemos encontrar como apéndice una lista de primeros abogados, escribanos, procuradores comisionistas, rematadores, médicos comerciantes, industriales y también familias. (Soler, 1982: 251).

Obra de arte encara esta cuestión como objeto de investigación, al punto que se detiene en explicitar qué consideran "primeras familias" -"las que habitaron nuestra ciudad en los

\footnotetext{
${ }^{177}$ Así surge de la denuncia realizada por las autoridades de la UNLP en agosto de 1970, que incluye entre otros a Gonzalo De Urraza, Tomás Diego Bernard (h) y Juan Cristian Herrero Doucloux (Alessandro, 2011: 109).
} 
primeros años de su fundación"- (Díaz, 1982: 143) y se preocupa por explicar "el método de investigación utilizado para rastrearlas", que incluye búsquedas hemerográficas, consulta de libros de socios de entidades y búsqueda de descendientes. Además, antes de listar las familias y sus genealogías, propone algunas conclusiones que "se desprenden" de las "encuestas realizadas". Vale la pena mencionar algunas de ellas, coincidentes con cuestiones apuntadas en el apartado anterior:

“a) Con excepción de algunos casos de troncos de familia con hondas raíces en suelo argentino o de linajes aristocráticos europeos, el resto posee un origen común: la masa de trabajadores y extranjeros que con su trabajo contribuyeron al engrandecimiento de la ciudad y al bienestar de sus hijos y descendientes muchos de los cuales hoy han logrado una sólida posición económica y ocupan sitios relevantes en la sociedad platense" (Díaz, 1982: 143)

También menciona el predominio de la población italiana, adulta y de sexo masculino en los primeros años, y apunta:

"g) $[\ldots]$ los descendientes han optado por profesiones liberales que pocas veces coinciden con las de sus ascendientes; sin embargo, en el ramo comercial, la continuidad es más acentuada" (Díaz, 1982: 143)"

A continuación, de modo similar a Soler, Obra de arte presenta los primeros profesionales, obreros calificados, comerciantes e industriales (Diaz, 1982: 144), y finalmente dedica trece páginas enteras a listar apellidos, dando cuenta de los descendientes de unas 118 "primeras familias" (Díaz, 1982: 145-158). Entre esos apellidos están Apreda, Bernard, Szelagowski y Urraza. Curiosa resulta la ilustración de esas páginas: los editores la resuelven con fotos incrustadas - $¿$ al azar?- en dos partes de la lista: una muestra el interior de una casa señorial antigua ubicada en el centro de la ciudad y otra, un comité radical.

Dado ese interés por los fundadores, haberlos conocido o tratado o pertenecer a sus familiares aparece como un factor legitimador. Escribe Szelagowski en Crónica del centenario:

"Mi amistad con esa familia (Rocha) tiene dos orígenes. Por un lado la de mi abuelo con el fundador quien, según me relatara María Celia Rocha, cada aniversario, ya cesado su mandato, cuando éste llegaba a la estación del ferrocarril, lo esperaba con sus ocho hijos para saludarlo. Por otra parte mi vinculación con la familia Arana anudaba esa amistad y con ellos y los familiares más cercanos del fundador, cada 6 de septiembre, fecha de su muerte, íbamos a rezar un responso a la cripta de la catedral.

La última vez que estuve con María Celia Rocha fue el 19 de noviembre de 1965 en el Tedéum celebrado en la Iglesia San Ponciano. Conservo la esquela que me enviara anunciando su venida y las fotografías de ese día, postrera visita a la ciudad de su padre" (Szelagowski, 1982b: XVIII)

En el texto que escribe Héctor Rivera en homenaje a Lola Juliánez Islas, es llamativo lo poco que el autor dice sobre su vida y obra, y lo mucho que se explaya sobre sus relaciones, que parecen lo más importante: Lola y Rocha, Lola y Joaquín V. González, Lola y muchas otras figuras: “...Lola Juliánez Islas era una de las pocas platenses que pudo tutearse con el fundador predestinado" (Rivera, en SADE La Plata, 1982: 154).

Sin duda, el texto donde la relación con el linaje de fundadores aparece más acentuada es Vieja amistad, publicado por la Universidad Notarial Argentina:

"En ese calidoscopio de los primeros tiempos de La Plata, del esfuerzo solidario hecho mandato de conciencia para dar plenitud de vida a la ciudad nueva, se ubican los primeros gratos, imborrables recuerdos de nuestra 'vieja amistad con los Rocha'. Me 
propongo relatar, hilvanar sucesos, que jalonan, a través del tiempo y de sucesivas generaciones de una y otra familia, esa antigua, fecunda, verdadera amistad. Una amistad nacida antaño, y por tanto, firme, sólida, leal, como lo fueron las consolidadas en un tiempo de dificultades y luchas, pero también de fe y de nobleza, donde los sentimientos privaban sobre el interés y cuando la generosidad, el espíritu solidario y el mutuo respeto daban a la vida el mayor aliciente para ser vivida, jerarquizándola y enalteciéndola con una escala de valores imprescriptibles e inalienables, más allá y más arriba de todo cálculo o de cualquier especulación" (Bernard, 1982b: 19)

A lo largo de la publicación, Bernard insiste en hablar de una antigua estirpe platense y remarcar el común trato refinado, señorial, culto y afectivo de familia, de linaje patricio de los Rocha ${ }^{178}$, linaje que se cortó por la ausencia de descendientes varones (Bernard, 1982b: 34-36). A lo largo de todo el libro da cuenta de la amistad entre las familias Bernard y Rocha. Cuando habla de los hijos del fundador sostiene que "eran tres hermanos: dos mujeres y un varón", sin mencionar nunca a los dos fallecidos tempranamente. Carlos Dardo fue el último en heredar ese "abolengo patricio" y "apellido prócer" (Bernard, 1982: 29, 31).

En síntesis, la pertenencia a una alta sociedad desde la que se produce el discurso de estos autores no se define por una condición de clase pensada sólo en términos económicos ${ }^{179}$, sino por un capital simbólico vinculado a las trayectorias familiares. Antes de producir la información que hemos repasado hasta aquí y también antes de advertir las marcas de ese auto-reconocimiento en los propios textos, fue el autor del libro de El Día quien me señaló esa fuente de legitimidad. Durante el proceso de producción de Vida platense, Soler ${ }^{180}$ se vio impugnado o presionado por no tener esa "sangre azul":

"El diario te da más enemigos que amigos [...] Por ejemplo, me acuerdo que una mina me dejó de saludar... Porque el padre había sido presidente del Jockey... En los eventos platenses no figura. Ni en un diario ni en una revista. Almafuerte figura en todos lados [...] Hay gente que me ha venido a ver, y te aprietan por ahí. Kraiselburd dijo: 'no, no les des bola, a los artistas y todos esos que te vienen a apretar...' No le des pelota, me dijo.

- ¿Era público que el diario estaba haciendo el libro?

- Si, acá se entera la gente. Esa gente está en esas. Para colmo, ¿viste? no sé... Es medio choto... Kraiselburd hubiera buscado un sangre azul... Un Alconada Sempé, un Alconada Aramburu, un Berisso Rocha, qué sé yo... Y aparece un plebeyo de mierda como soy yo, que no tiene ni sabe, ni al abuelo llego de antecedente, Soler, que es un peluquero... Y es medio pelo, es medio fulero, ¿viste? Yo creo que ellos no se la tragan del todo [Hace una pausa para buscar algo en la cocina]. De todas maneras, eso... capaz, ¿viste cómo es la cosa? Vos estás escribiendo algo y estás muy al borde. Lo que vos preguntás está muy bien preguntado porque tiene eso ahí dando vueltas [...] Hay gente, supongamos, un tipo... El abuelo fue juez, en la época de Rocha, y el padre fue

\footnotetext{
178 “EEsos inolvidables tés de la casa de la calle Lavalle frente al impecable mantel bordado, de fina lencería, junto a las matronas que cumplían el rito del servicio acompañando la tibia infusión con las mil tentaciones de una pastelería casera que olía a delicia!" (Bernard, 1982b: 34-35)

${ }^{179}$ Por otra parte, esa posición económica excede las posibilidades de nuestra indagación sobre los autores.

${ }^{180}$ Originario de Daireaux, instalado desde 1958 en La Plata, donde estudió las carreras de Letras y Filosofía, Ricardo Soler tuvo cierta militancia estudiantil en Impulso, una agrupación de tinte reformista donde confluían militantes del Partido Socialista, anarquistas, independientes y algunos radicales, antes de la existencia de Franja Morada. También se vinculó a ciertos espacios del teatro independiente. En el 1968, en la Universidad, participó de los homenajes por los 50 años de la reforma universitaria que significaron una confrontación con la dictadura de Juan Carlos Onganía. A esos ámbitos fueron cercanos los Kraiselburd, sobre todo por Antonia Suñol -la esposa de David Kraiselburd desde 1942-, una mujer vinculada al teatro universitario y también al socialismo a través de la Universidad Popular Alejandro Korn. En los '70 Soler no tenía trato cotidiano, pero se volvió a acercar a la familia cuando sufrieron el segundo secuestro, ya en la última dictadura.
} 
fiscal, y el otro fue coso, y el otro fue... todo tu, tu, tu, tu, siguen así... igual aparecen en el libro [...] Para que una mina te deje de saludar es terrible, terrible. Hay tipos que ya te digo, que figuran ahí, por ejemplo... Y tipos que son, hasta son pesados, tienen peso. $\mathrm{Y}$ yo hice muchas cosas con Miguelito Szelagowski, que es bastante sangre azul...

- Del que fue intendente estamos hablando, ¿no?

- Sí, sí, sí, pero hubo Szelagowskis en... todavía hay Szelagowskis dando vueltas. [Vuelve de la cocina]. Te digo más, Miguel Szelagowski me dio muchos datos, de la vida cotidiana... algunas anécdotas son de él, propias de él, más de él... Del ambiente, digamos.

- Él escribió la crónica del centenario...

- Sí, sí, sí. Pero un hombre muy metido, muy consustanciado, muy platense. Hay una elite en La Plata. No sé si vos la habrás notado. A vos te jode, tenés que usar el segundo apellido. ¿No?... Pero sabés dónde la encontré yo: en los nombres de la justicia. Se repiten sistemáticamente. Peralta Calvo, Sal Llargués. ¿Los jueces? Parece que no hubiera transcurrido el tiempo. Son Cien años de soledad... Está el mismo Aureliano Buendía" (Entrevista a Ricardo Soler, agosto de 2008)

\section{El estado de la cuestión: dos autores indiscutidos}

En el corpus analizado encontramos además dos voces indiscutidas para hablar de la ciudad: José María Rey y Antonino Salvadores. Ambos fallecidos, son particularmente citados y bien valorados en la mayor parte de las publicaciones, en las que como vimos las referencias bibliográficas suelen ser escasas.

En rigor, un puñado de libros aparecen con cierta recurrencia formando una suerte de "estado del arte" sobre la historia de La Plata. Un texto temprano es la reseña estadística y descriptiva sobre La Plata editada en 1885 por Emilio R. Coni. Asimismo aparecen Loores platenses de Arturo Capdevila (1932), La ciudad del Bosque de Rafael Arrieta (1935), la compilación de relatos de viajeros de Amaral Insiarte (1959) y La Plata, ciudad ideal, de Alberto Oitaven (1941). El texto específico sobre Ochenta años de tango platense, publicado por Oscar Bozzarelli en 1972, es mencionado en varias oportunidades -Bozzarelli escribe sobre ese tema en Ciudad milagro-; al igual que Medio siglo de farándula, de Pepe Podestá, fuente principal para dar cuenta de la historia teatral y la labor cultural de la familia Podestá.

Pero no caben dudas que entre todos los trabajos antecedentes sobresalen los de Rey y Salvadores, citados frecuentemente -en algunos casos con largas transcripciones- y además evocados como figuras platenses. Hay un consenso unánime en torno a sus aportes: son las "voces autorizadas" que, de estar vivas, no hubiesen faltado en el centenario. Enrique Barba escribe al prologar Ciudad milagro: "Quien de existir el cargo hubiese sido, por derecho propio y por general aprobación, el Cronista mayor de la ciudad, nuestro inolvidable y querido amigo el profesor José M. Rey, que pasó la mayor parte de su vida escribiendo sobre las personas y las cosas de La Plata, vería en este libro el mejor homenaje que podía brindarse a la ciudad de sus amores" (en Lerange, 1982: 16). La misma idea había planteado dos años antes en el Ciclo Cien años, donde dedicó una conferencia entera -transcripta en 17 páginasa homenajearlo: "De haber existido el cargo y dominado la justicia, el profesor Rey hubiese sido el cronista oficial de La Plata" (Barba, 1980: 7). Por su parte, uno de los artículos de Julio Morosi en la Revista de la Universidad, cierra incitando a nuevas inquietudes e investigaciones, "adormecidas desde la interrupción de la gran labor de Antonino Salvadores y de José María Rey” (Morosi, 1981a: 278). Estos constituyen el estado de la cuestión reconocido por Kraiselburd en el prólogo a Vida platense, que refiere a "aportes de las 
tradiciones populares y de libros ya clásicos, como los de José María Rey y Antonino Salvadores..." (en Soler, 1982: 7). Y sus trabajos también son reconocidos por Bernard (1982a y 1982b), quien dirá que la obra de Rey "ha pasado a ser clásica" y que Salvadores "mucho urgó [sic] sobre los orígenes de La Plata..." (en Lerange, 1982: 29).

Las referencias a Rey incluyen básicamente tres libros, publicados en años importantes en términos conmemorativos: La nueva capital (Rey, 1932), en el cincuentenario; Ciudad armoniosa (Rey, 1939), en el centenario del nacimiento de Rocha, y finalmente Tiempo y fama de La Plata (Rey, 1957), publicado por la Municipalidad de La Plata en el año del $75^{\circ}$ aniversario de la ciudad y prologado por Enrique M. Barba. Durante la década de 1940, en tanto, tiene una multiplicidad de artículos y participaciones en otras publicaciones.

En el caso de Salvadores hay centralmente tres libros vinculados al cincuentenario (Salvadores, 1932, 1933 y 1934) y una serie de colaboraciones posteriores, también en los años cuarenta. El primero de ellos, centrado en una compilación de documentos de la fundación y publicado por el Archivo Histórico de la Provincia de Buenos Aires, es una fuente citada recurrentemente por los libros de 1982.

Algunas de las publicaciones de nuestro corpus incluyen transcripciones parciales de sus textos. En Ambiente, por ejemplo, encontramos un texto de una página y una columna titulado La nueva ciudad, firmado por Antonio [sic] Salvadores, que está tomado de su libro de 1932. Más adelante, la sección a/personajes dedicada a "Los 5 sabios" se resuelve con un texto tomado de Tiempos y fama de La Plata (Rey, 1957). Breves fragmentos de ambos libros aparecen también en pequeños recuadros incluidos en otras páginas de la misma edición.

Por su parte el libro de Estela Calvo, luego de una dedicatoria a su hermana, comienza con una cita de Rey (1939): "Al caer la tarde / el alma sencilla y comunicativa / de La Plata, / se viste / y sale de casa".

En Ciudad nueva ciudad antigua Rey y Salvadores son referencias bibliográficas frecuentes y, cuando se registra la tendencia ya señalada a transcribir documentos, Fundación de la ciudad de La Plata. Documentos éditos e inéditos (Salvadores, 1932) es una de las principales fuentes. Asimismo, Morosi utiliza a Rey como cita de autoridad para resolver la disputa por la autoría del trazado: “...Como bien señala Rey, existen indicios que permiten atribuir esa responsabilidad al ingeniero Pedro Benoit, quien encabezaba un equipo de destacados técnicos en dicho departamento" (Morosi, 1983: 99).

También se retoma a estos autores en Obra de arte, Ciudad Milagro, Vida platense, Crónicas de un siglo, Creación de la generación del 80 y Diccionario de Arte, además de algunos artículos publicados en revistas.

Por otra parte, los mismos autores son aludidos en los textos. Rey es una de las figuras destacadas en Crónicas de un siglo, con una reseña biográfica que aparece en el año de su muerte: 1945 (Moncaut, 1982: 173). En los años anteriores de la fragmentaria cronología ya habían aparecido seis referencias al autor "que tanto investigó sobre los primeros años de La Plata", como lo caracteriza Moncaut (1982: 101) al citar su interpretación sobre la inspiración francesa del arco de entrada al Bosque. La primera mención es en 1906, a propósito de la revista del Centro de Estudiantes del Museo de la que Rey es director (Moncaut, 1982: 80). En 1909 es por el círculo Ars y la revista homónima, de orientación artística y literaria, dirigida por la misma figura. Más tarde, las noticias de 1932 incluyen la salida de La nueva capital: 
"En el mes de agosto aparece editado por la Casa Peuser, el libro del profesor José María Rey 'La nueva capital', donde se reúnen los primeros cinco años de su construcción. Cincuenta notas e ilustraciones con 74 grabados que reproducen fotos de la época -se decía- interesa por igual a los viejos y a los nuevos platenses; a los primeros, como animadora de recuerdos; a los otros, como revelación. Tapa ilustrada con xilografías de Francisco De Santo. Se vende el ejemplar a 3,50.” (Moncaut, 1982: 139-140)

En 1934 la aparición de Letras Platenses cuenta a Rey entre sus redactores, además de Ricardo Levene, Benito Lynch, Alberto Palcos, Délfor B. Méndez, Dalmiro Corti y otros (Moncaut, 1982: 142). En 1936 y sin más datos, se menciona el dictado de una conferencia sobre El Ratón Mickey en el arte, la moral y el buen humor (¡!) (Moncaut, 1982: 146). Finalmente, a posteriori de su muerte, se cita el Premio José María Rey, creado por la Municipalidad "en homenaje a quien fuera un destacado profesional y un ciudadano ejemplar, que amaba entrañablemente a su ciudad y que estaba atento a todas las manifestaciones del quehacer artístico y cultural de la urbe”, y adjudicado por primera vez en 1970. En tercera persona se detalla que "en la categoría 'Artículos o series de artículos periodísticos' el premio fue acordado al señor Carlos Antonio Moncaut por la serie de artículos evocativos e históricos de la ciudad [...] Entregó personalmente los premios el Intendente Municipal, coronel Franco Icazatti” (Moncaut, 1982: 207-208).

El reconocido cronista de la ciudad también es aludido en varios tramos de Ciudad milagro. Menucci cita Ciudad armoniosa, del "incansable investigador que fue don José María Rey” (en Lerange, 1982: 78); en tanto Apreda de Di Masi lo señala como inspirador del Museo Dardo Rocha: "En 1943, el profesor José María Rey, a quien se le deben tantos estudios e investigaciones para el mejor conocimiento de La Plata, elaboró un proyecto de creación..." (en Lerange, 1982: 70) ${ }^{181}$. En el homenaje del Ciclo Cien años Barba destaca a Rey como un estudioso de la faceta artística de la ciudad, que maduró sus aportes durante dos décadas hasta darlos a conocer, a partir de 1930. "Nuestro personaje es algo más que el historiador urbanista de nuestra ciudad. Es diría yo, el historiador incipiente de nuestra cultura y muy en especial de nuestra cultura artística", plantea. Y en otro tramo sintetiza:

“...amó intensamente a su ciudad. Fue el suyo un amor ahincado y fervoroso. La historia que él escribió, más que la narración fría y circunstanciada de los hechos es una verdadera confesión dictada al oído. Es también, en cierta manera, una autobiografía. Nació con la ciudad -apenas un año después de fundada-, vivió en ella, sufrió sus quiebres y se alegró de sus triunfos. Desde muy joven ejerció la docencia y fue, por encima de todas las cosas, profesor. Hubiérase quebrado la eufonía si a alguien se le hubiese ocurrido llamarlo por su nombre, o decir el señor Rey o don José María Reyera para todos, el profesor Rey. En su largo magisterio, ejercido en la docencia, en la tribuna política, en el artículo periodístico o en el libro, dejó la huella imborrable de su espíritu dilecto preparado sólo para las cosas nobles" (Barba, 1980: 14)

Asimismo, deja establecida la influencia del otro historiador:

\footnotetext{
${ }^{181}$ Desde el Centro de Estudios Históricos de la UNLP, Rey impulsó la creación de un museo de esas características. Antes habían existido iniciativas en el mismo sentido de parte del concejal Ballbé, en 1938, y del ingeniero Oitaven, en 1941. En la conferencia de Barba, organizada precisamente por el Museo y Archivo, reconoce que la iniciativa de Rey en 1943 fue contemporánea a la propuesta del diputado José Antonio Berges para declarar monumento público la casa de Rocha y montar una biblioteca y un museo referido a la ciudad y su fundador. El proyecto "difería en parte del de Rey", porque "instituía una comisión no platense para la organización y administración del museo", por lo que tuvieron "una respetuosa polémica” (Barba, 1980: 16-17).
} 
"Sin tanteos previos visibles, su entrada decidida y decisiva en el terreno de la historia le valió ser ungido historiador de la ciudad. Otros lo habían sido antes que él. No podremos olvidar, los platenses, a Antonino Salvadores que estimuló al profesor Rey. Orientados ambos en tareas similares y en los mismos nobles afanes, merecen nuestro recuerdo agradecido y cariñoso" (Barba, 1980: 13)

Las alusiones a la persona de Salvadores son menos frecuentes, pero no inexistentes. Aparecen dos en Moncaut: primero como miembro de la añorada Universidad Integralista, "una singular y fallida empresa de cultura que ocurrió en La Plata, por 1918" (Moncaut, 1982: 106) y luego como redactor de la revista Don Segundo Sombra aparecida en 1928 bajo la dirección de Juan Manuel Villarreal: "Esta publicación platense se cerrará con el número 3, en el mes de setiembre de 1929. Escriben, entre nosotros, en ella, Antonino Salvadores, Luis Aznar, Héctor Ripa Alberdi y Ezequiel Martínez Estrada” (Moncaut, 1982: 131).

Autores consagrados y reiteradamente citados en las publicaciones del '82, encontramos juntos a Rey y Salvadores en una publicación institucional realizada por el Jockey Club: $L a$ Plata. 1882-19 de noviembre 1944. Homenaje a la nueva capital. Se trata de un folleto institucional de 20 páginas, con una portada color que incluye la litografía del acto de fundación (sin aclaraciones acerca de su montaje). Además de la exaltación de Rocha, D’Amico y Benoit ${ }^{182}$, el folleto incluye dos artículos de cinco páginas, uno de cada autor: "Fundación de una Nueva Capital" (Salvadores) y "El monumento al fundador" (Rey), y una reproducción facsimilar de la versión oficial del Acta de fundación de La Plata. El artículo de Rey, referido al monumento a Rocha erigido en los festejos del Cincuentenario, es retomado por Canestri en Ciudad milagro al comentar las esculturas de la ciudad.

\section{Círculos sociales interconectados}

La universidad, las sociedades de escritores, el Rotary y el Jockey Club, algunas instituciones consagradas a la exaltación de próceres: un puñado de entidades se repiten y se vinculan en la trayectoria de los autores más reiterados en el centenario. A su vez, esas instituciones son impulsoras de publicaciones y/o están presentes en sus relatos. En suma dan el panorama de un ámbito de sociabilidad específico, propio de alta sociedad platense que pretende para sí un reconocimiento ${ }^{183}$, tanto por pertenecer a familias fundadoras como por llevar una vida profesional e institucional destacada. Una estima que constituiría el fundamento para hablar sobre la ciudad y escribir su pasado.

Con trayectorias formativas habitualmente vinculadas a la Escuela Anexa, el Colegio Nacional y el paso por carreras universitarias, los autores exhiben profesiones liberales o un desempeño destacado en carreras humanísticas -ratificado por las academias de Letras e Historia y las sociedades de escritores-, una vida pública activa y labores filantrópicas que van desde el Rotary hasta fundaciones vinculadas a la medicina (Belou y Mainetti), incluyendo tareas de preservación de cierto legado cultural en ámbitos como la Institución Cultural Hispano-Argentino.

\footnotetext{
${ }^{182}$ En la primera página la publicación incluye un retrato de Rocha y otro de D’Amico, y sus breves reseñas biográficas, firmadas por Salvadores. Al final del libro, en tanto, habrá un retrato y una reseña -más extensasobre Pedro Benoit, rubricada por José María Rey.

${ }^{183}$ La distinción entre esa "sociedad tradicional" y las clases populares aparece explícitamente planteada en el texto con el que Héctor Rivera homenajea a Vicente Albamonte: "Su muerte, producida el 10 de junio de 1955, produjo hondo pesar en todos los sectores de nuestra sociedad tradicional, en todos los círculos de la cultura y también en conglomerados populares que supieron de su apoyo material” (en Lerange, 1982: 544).
} 
También resulta importante la participación y la presencia en los medios periodísticos locales, centralmente en El Día. Así, por ejemplo, el padre de Tomás Bernard, además de "decano de los notarios platenses" y funcionario público, ejerció el periodismo en las redacciones de El Día y El Argentino -del que fue fundador-, "donde tuvo a cargo la sección de noticias sociales, lo que le permitió acercarse aún más a la frecuentación y trato de la tradicional sociedad platense a la que pertenecía por múltiples lazos de parentesco y amistad" (Bernard, 1982b: 17, 28) ${ }^{184}$. La tarea periodística puede ser un medio de sustento económico o bien una participación de carácter honorífico, como colaboradores en secciones puntuales. Entre quienes corresponden al primer caso, se agrega como ámbito de sociabilidad y reconocimiento el Círculo de Periodistas ${ }^{185}$.

Así como muchas de esas instituciones aparecen en la escena del desfile del centenario y forman parte de las "fuerzas vivas" a las que apela el discurso político oficial en un contexto de negación de la actividad política partidaria y sindical, también es interesante advertir cómo ese círculo social formado por un entramado de entidades profesionales, sociales, culturales, académicas y filantrópicas aparece en la textura de los propios relatos publicados.

Como es esperable, a estos círculos de sociabilidad pertenecieron los homenajeados en 12 personalidades. El ingeniero civil Don Enrique Humet integró el Jockey Club, al igual que Jacinto Calvo -padre de Estela y cuñado de Francisco López Merino- quien además participó del Club Estudiantes, la Sociedad "La Protectora" y la Comisión Directiva del Círculo de Periodistas, entre otras instituciones.

El Círculo de Periodistas fue presidido en tres oportunidades por Ramón García, la personalidad celebrada por la compiladora del libro. Para Irene Ene, García fue "un arquetipo humano de primera categoría", un "eximio periodista y cumplido caballero, (que) se presenta en mi memoria, reclamando su justo lugar en las celebraciones del centenario"; "un ejemplo resplandeciente para su familia, para sus allegados y amigos; así como en su conducta social y en cuanta actividad debió actuar, en su múltiple y diverso hacer cotidiano" (SADE La Plata, 1982: 125-127). Además, estuvo entre quienes fundaron en 1925 el Rotary platense, caracterizado como el "primero de una serie de clubes similares, en esta ciudad", con una selección rigurosa de sus socios (SADE La Plata, 1982: 127-128).

En un libro como Diccionario de Arte, académicamente valorado todavía hoy, aparecen entre las entradas sobre artistas y grupos, referencias a instituciones como el Jockey Club, el Museo y Archivo Dardo Rocha y la Fundación Dr. José María Mainetti para el Progreso de la Medicina. De esta última, tras una pequeña reseña de la organización, se transcribe "una síntesis de las actividades culturales realizadas por el Departamento de Relaciones Culturales, dirigido por el Dr. Estanislao de Urraza y la Brigada de Voluntarios” (Nessi, 1982: 182). Cabe recordar que el abogado y escritor De Urraza, fallecido meses antes de la salida de las publicaciones, es autor del libro impulsado por el Colegio de Abogados -que compendia artículos suyos en El Día- y hace un aporte a la compilación confeccionada desde la Sociedad

\footnotetext{
${ }^{184}$ Su madre, por su parte, integró el claustro fundador del Liceo Secundario de Señoritas: "Su obra filantrópica perdura en el recuerdo", dice en una nota al pie y menciona una lista de instituciones (Bernard, 1982b: 17). Sobre Bernard padre cabe mencionar que medio siglo antes de 1982 se desempeñó como secretario de la Comisión Ejecutiva del Cincuentenario.

${ }^{185}$ En el año del centenario, el Círculo de Periodistas inauguró "un natatorio de dimensiones olímpicas a cuya realización contribuyó en generosa medida el Estado bonaerense con oportunos subsidios” (Katz, 2004: 507).
} 
de Escritores de la Provincia ${ }^{186}$. En cuanto a la Fundación Mainetti, cabe consignar también que su revista Quirón publica uno de los artículos de divulgación realizados por Morosi (1981b). En tanto, Ciudad milagro incluye un artículo de José María Mainetti sobre la creación del "Centro Oncológico de Excelencia", cuya inauguración parcial se pautó para el centenario de la ciudad. (en Lerange, 1982: 217).

El recorrido de esa compilación por distintas instituciones es ilustrativo de lo que venimos comentando. La propia Sociedad de Escritores de Provincia, institución editora del libro, aparece referenciada en varias oportunidades. Además del capítulo sobre esa entidad (Delfino, en Lerange, 1982: 465), con muchos nombres propios, el capítulo dedicado a "revistas de la ciudad nueva" menciona:

"Hacia 1950 irrumpe una revista de significación, pulcra en su estructura. Es Letras, órgano de difusión cultural de la Sociedad de Escritores de la Provincia de Buenos Aires (S.E.P.) Allí escribieron: Antonio Herrero, David Krainseldburd [sic], Lázaro Seigel, Jaime Sureda, Tomás D. Bernard, Raúl Touceda, Ismael Dozo, Eduardo Zapiola, entre otros. En ella, la generación del 40 tuvo una fundamental acogida: Roberto T. Speroni, Aurora Venturini, Ana Emilia Lahitte, Alfredo Casey, Alberto y Horacio Ponce de León, Gustavo García Saraví, dieron a conocer su pensamiento poético" (Alcaraz, en Lerange, 1982: 424)

Varios de esos mismos nombres se repiten formando otras organizaciones, como la agrupación Bases o incluso el "Grupo de Amigos de Ricardo Sánchez" al que Ana Emilia Lahitte -una de las autoras destacadas- dedica un artículo en Ciudad milagro, titulado "Algo distinto: EL GARS". En la lista de asistentes a ese taller del artista hay seis autores de textos del centenario, entre ellos Bernard.

Particular atención recibe el Jockey Club. En la compilación de la SEP, el capítulo de Sara Alicia Canestri ${ }^{187}$ y Graziela Canestri titulado simplemente "El Jockey" es una de las notas institucionales más extensas y está acompañada por varias páginas de fotos (Lerange, 1982. 447-551), exclusivamente de esa institución. Más adelante aparece el artículo de Enrique Alarcón, "Los eucaliptos: nombre para una pasión", que asocia el aroma de ese fruto con "una cita semanal con la pasión popular", la de la "reunión turfística en el hipódromo del Bosque..." (en Lerange, 1982: 621).

Durante los primeros años de la ciudad existen dos jockeys, el Jockey Club de la Provincia y el "Jockey Club", que hacia 1904 se funden en una única institución ${ }^{188}$. El primero surge para "propiciar las actividades sociales, culturales y deportivas, como así también fomentar el desarrollo y estímulo en la producción del pura-sangre de carrera, organizando su hipódromo" (en Lerange, 1982: 439). Por esto último tuvo una tensión muy

\footnotetext{
${ }^{186}$ Integrante de la comisión que funda el Colegio de Abogados de la Provincia de Buenos Aires, De Urraza es otro de los homenajeados en 12 personalidades (SADE La Plata, 1982). Como es esperable, es también otro apellido que podemos encontrar en la guía Quién es quién en La Plata (Napolitano, 1972).

${ }^{187}$ También es autora de otro capítulo en el mismo libro, "Mi ciudad y sus esculturas", donde usa además el apellido de casada (Sara A. Canestri de Alvarez Gelves).

${ }^{188}$ La historia institucional es compleja, según surge de los textos analizados. El Jockey Club bonaerense no tenía apoyo de su par porteño, "que incluso llegó a prohibir la actuación en Palermo de todo aquel ejemplar o jinete que viniera a La Plata. Esa situación se superó recién en 1935..." (Alarcón, en Lerange, 1982: 623). 1904 es también el año en que el Jockey Club adquiere la concesión del hipódromo. Según uno de los autores de Ciudad milagro, se inicia entonces "el período que se diera en llamar 'la época romántica' del turf platense" (Alarcón, en Lerange, 1982: 622). Más tarde, hacia 1956 vuelve a quedar bajo la órbita oficial, hasta que en 1978 el Poder Ejecutivo provincial lo entrega nuevamente al Jockey Club (Díaz, 1982: 359). En Vida platense, en tanto, se señala 1904 como la fecha de fundación del Jockey Club de la Provincia (Soler, 1982: 40).
} 
grande durante el gobierno de Hipólito Yrigoyen, ya que en 1927 una ley provincial prohibió la actividad, restituida cinco años más tarde:

"El 50 aniversario de la fundación de La Plata, halla en el Jockey Club digno auspicio a su alto significado, prestando un marco brillante a su conmemoración.

Con una concurrencia selecta y numerosa, se lleva a cabo la reunión de carreras en el hipódromo local, cuya prueba máxima, el clásico 'Cincuentenario' había logrado suscitar considerable interés.

La jornada hípica fue honrada con la presencia del Presidente de la Nación, general Agustín P. Justo; el Gobernador de la Provincia, don Federico Martínez de Hoz; los ministros de Gobierno, Hacienda y Obras Públicas, autoridades provinciales, legislativas y judiciales, delegados de las instituciones hípicas del interior" (en Lerange, 1982: 440)

Cada aniversario de la ciudad, los 19 de noviembre, se realiza una actividad hípica conmemorativa de La Plata y de Dardo Rocha, que fue socio fundador del Jockey local.

Es interesante detenerse también en la parte de Obra de arte dedicada al deporte, donde se repasan diecinueve actividades deportivas y recreativas: 1) Hipódromo, 2) Esgrima, 3) Fútbol, 4) Remo, 5) Pelota paleta, 6) Tenis, 7) Hockey, 8) Rugby, 9) Ajedrez, 10) Waterpolo, 11) Atletismo, 12) Básquetbol, 13) Natación, 14) Hipismo, 14’) Aeroclub, 15) Sóftbol, 16) Pelota al cesto, 17) Saltos ornamentales, 18) Yachting. Las referencias aparecen en ese orden, y los primeros tres son los que reciben mayor espacio -también el atletismo-. No obstante, se aclara que "el platense no es particularmente 'burrero'; la concurrencia al hipódromo está constituida fundamentalmente por porteños y habitués, variando esta composición el 19 de noviembre, fiesta popular que asume características hasta de familiar cuando se corre el premio Dardo Rocha” (Díaz, 1982: 390).

El hipódromo es evocado directamente como una iniciativa del fundador de la ciudad, que funcionó "hasta que un día, el circo platense pareció llamado a desaparecer. Fue a mediados de 1927, [...] por razones políticas". Luego su reapertura significa un "proceso de engrandecimiento" (Díaz, 1982: 358-359).

En otras publicaciones analizadas la mención del Jockey refiere a su actividad social, cultural y/o filantrópica. En el texto misceláneo de Moncaut, por ejemplo, se evoca una fiesta realizada en 1906, con una "concurrencia muy selecta", ocasión en la que "se inauguran en esta oportunidad varias canchas, entre ellas las de 'lawn tenis"” (Moncaut, 1982: 79). Por su parte, Soler apunta que durante algunos meses de 1933 el club costeó una olla popular para 700 personas en el Hipódromo: "Así comenzó la mendicidad, por obligación, y para muchos se transformó en profesión..." (Soler, 1982: 114).

Finalmente, la mención institucional llega también por el lado de la arquitectura. En la revista Ambiente, un texto de su director Rubén Pesci -incluido en la sección La Plata, su arquitectura- destaca al complejo del Jockey Club de Punta Lara como "una obra maestra del período (los años 30), que aún hoy se exhibe preclara y sensata" (Presci, 1982: 55).

La posición social de los autores parece expresarse también en las referencias multiplicadas sobre ciertos espacios e instituciones. Hay ciertos lugares comunes de la ciudad que se repiten libro a libro. El Teatro Argentino, que "cae años más tarde víctima del fuego" (Soler, 1982: 18), es un ejemplo paradigmático. Está presente en casi todas las publicaciones. Calvo le dedica seis páginas enteras y prácticamente termina su libro con esa referencia. Como veremos en el capítulo VI, forma parte del imaginario de una ciudad ilustrada, capital de la cultura. 
Los espacios verdes son otro tópico frecuente, sobre todo algunas plazas -Moreno, San Martín y Rocha- y muy en particular el Bosque, vinculados a "ideas europeas acerca de la ciudad progresista o la ciudad higiénica, quedará sentado que los que planearon la ciudad con árboles [...], con amplias plazas y con jardines en torno a los edificios..." (Orsi, en Morosi, 1983: 290). Analizaremos los alcances de este higienismo progresista en el próximo capítulo.

En la ciudad homenajeada también se destacan la escuelas, las estatuas, el diario El Día, el Museo de Ciencias Naturales, la arquitectura monumental -en torno a la cual se construye un relato repetido una y otra vez sobre los llamados a concurso, los proyectos presentados, la acción del Departamento de Ingenieros, etcétera- y también algunos hitos como el hecho de haber sido la primera ciudad sudamericana alumbrada con luz eléctrica. Finalmente, el principal rasgo destacado de la ciudad es su trazado, ese que la convierte en una ciudad "geométrica" o "perfecta". En el capítulo siguiente nos concentraremos en este tópico, en torno al cual podemos ver algunas disputas académicas, la construcción de un prócer local como Pedro Benoit y, sobre todo, la plasmación de una mirada que pone el foco en el centro de la ciudad y tiende a ocluir otro motivo fundacional: el río.

\section{La otra cara}

“[La Plata] fue una de las más golpeadas en el país con éstos métodos, siendo miles los vecinos que los han sufrido directamente;

los que han sido desaparecidos tras un secuestro perpetrado por agentes pertenecientes a organismos de seguridad; o los que sufrieron por largo tiempo -y aún lo son muchos- el proceso de las arbitrarias e inhumanas detenciones" (Familiares, 1983: 85)

Si como dijimos al principio hay una parte de la sociedad platense, de sus clases medias profesionales, que interviene en la escena pública y en las operaciones de la escritura histórica, es tan interesante saber quiénes son esos narradores narrados como identificar a aquellos que permanecen en silencio o marginados. En este punto vale la pena volver sobre la publicación de Familiares, No habrá manto de olvido ${ }^{189}$, donde también predominan los nombres propios, listados uno detrás de otro.

La nómina de apellidos adquiere allí otro sentido. No se trata de distinguir a una élite sino de identificar víctimas. Sin embargo, también en esas líneas hay una parte de la clase ilustrada platense. En los listados de Familiares podemos encontrar otros apellidos con cierto linaje: hay Sánchez Viamonte y Alconada Moreira, hay Carriquiriborde, García Cappanini y Fonrouge, hay Mercader, Bettini, Calcagno, Moura y Ramírez Abella. Dicho con otras palabras, en la producción editorial del 82 podemos encontrar distintas listas de apellidos: tenemos las "familias fundadoras" pero también las familias diezmadas por la represión política, y si se hila fino en sus genealogías, unas y otras están conectadas ${ }^{190}$.

\footnotetext{
${ }^{189}$ En relación a la autoría, en la producción de este libro hay que reconocer a una emprendedora al interior de Familiares: Reina Suárez Diez, quien había sido decana de la Facultad de Humanidades durante el gobierno de Cámpora, y su familia resultó diezmada por la represión. Cuenta Claudia Bellingeri: "Ella era un cuadro, una militante, mucho más que una familiar. Era... no sé como decirlo, pero creo que era un cuadro político, y mucho más que un cuadro también. Bueno, fue muy importante para nosotros contar con ella. Y creo que acá [mirando los volantes], esta idea de plantear el centenario y de plantear la ciudad, de plantear como lo opuesto a lo que estaba ocurriendo o a lo que la dictadura quería mostrar, una ciudad tan prolija, sin duda fue una idea de Reina. Que nosotros supimos o tratamos de acompañar, sobre todo en la acción. Seguramente la idea central de la redacción, del concepto del volante, lo puso Reina..." (Entrevista realizada en julio de 2007)

${ }^{190}$ A su modo, el libro que termina expresando esa contradicción que atraviesa a la clase media local es Vida platense, ya que incluye una y otra lista. Según esta publicación, la "hora trágica" que vivió el país y "de modo
} 
No toda la aristocracia platense -si existe tal cosa- escribe libros: por el contrario, una parte está entre los silencios de esas publicaciones, en los no-dichos de la ciudad festejada.

Los otros ausentes en esos relatos serán los sectores populares. A veces ignorados, otras tratados con desdén o aludidos como parte del "toque anecdótico" de las crónicas menudas del centenario, las barriadas populares que habitan las zonas periféricas, los albañiles que construyeron la ciudad o los trabajadores que protagonizaron momentos históricos como el 17 de octubre de 1945, quedarán opacados por las dos significaciones fuertes que identifican a la ciudad: el trazado perfecto, que circunscribe La Plata a su casco urbano y pone el foco en la acción ideológico-profesional de la fundación, y la ciudad universitaria, que reinventa el origen de la ciudad para enaltecerla como capital ilustrada de la cual los autores más destacados del centenario se enorgullecen por ser parte.

especial la ciudad” incluyó a “casi todos sus sectores, la mayoría de sus habitantes, estaban inmersos, enredados en la maraña de esa lucha por ser unos funcionarios, otros parientes de alguien involucrado en un hecho irregular o investigado, o políticos, o amigos, compañeros de trabajo o conocidos de un extremista de izquierda o de derecha; y otros, a la inversa, por tener esta misma relación con miembros de las Fuerzas Armadas o la policía" (Soler, 1982: 230). Volveremos sobre este discurso en el capítulo VII. 


\section{Gráfico. La red de relaciones entre libros}

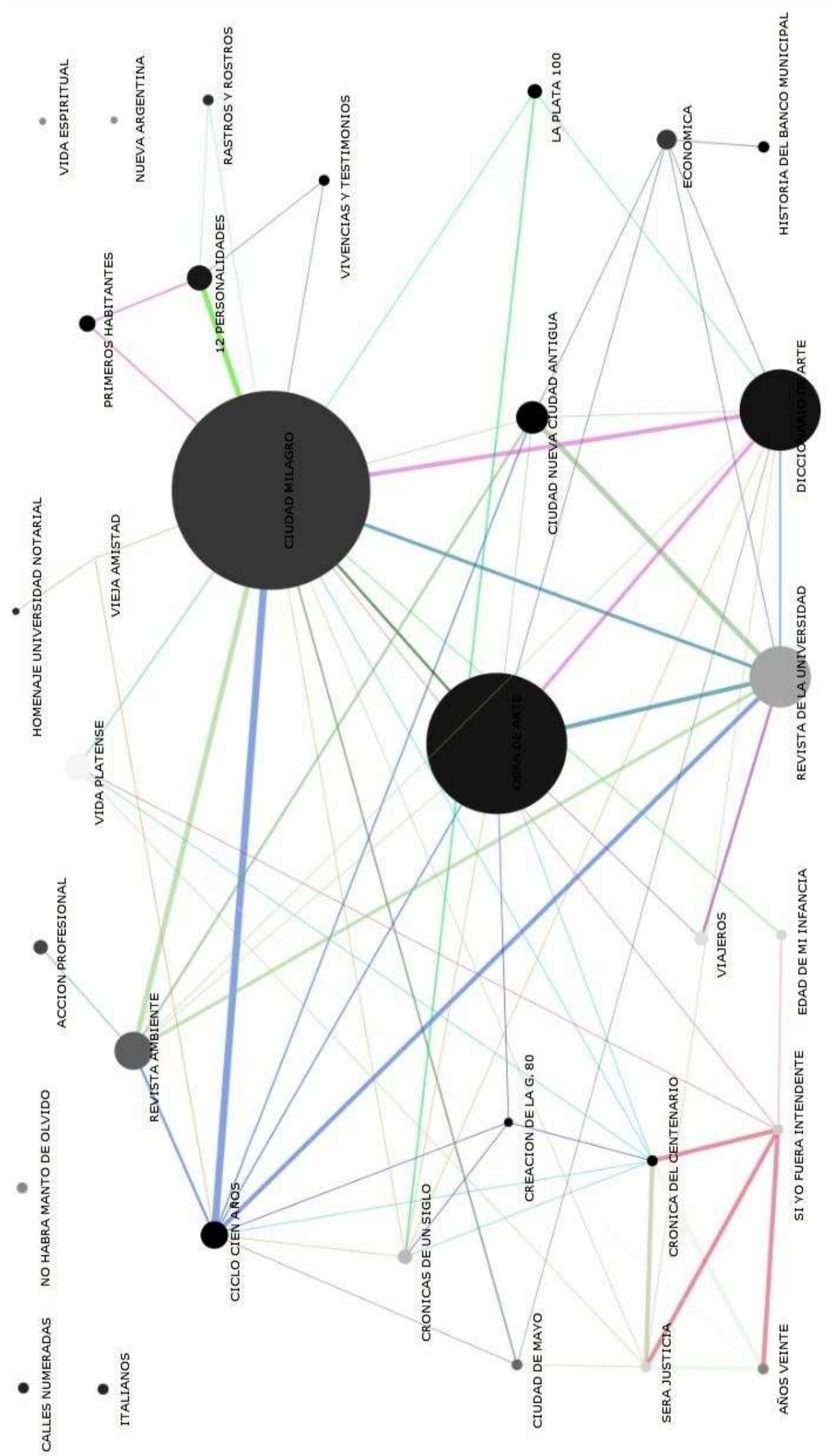

Elaboración propia. El cuadro expresa la presencia de autores y editores en los distintos libros y sus relaciones. Se sugiere utilizarlo en forma dinámica (Disponible en: www.unpasadoparalaplata.com.ar) 


\title{
V. Ciudad perfecta \\ La celebración del trazado, el orden y sus límites
}

\author{
"Lo expuesto nos habilita para sostener que, en el marco del \\ contexto urbanístico mundial, el trazado de La Plata se caracteriza \\ por la profundidad de su raigambre; por la singularidad del modelo \\ urbano, de muy escasos ejemplos, que representa; por la intensidad \\ del esfuerzo consciente por ligarla al ámbito regional en que se la \\ implantaba y, finalmente, por lo indeclinable del vigor y \\ consecuencia aplicados a su ejecución material” (Morosi, 1982b: 66)
}

La Plata es emblemática por su planificación y su trazado. En esto coinciden la totalidad de las publicaciones. La guía turística editada por la Sociedad de Arquitectos plantea en sus primeras líneas: "es la capital de la Provincia de Buenos Aires. Su característica principal es haber sido fundada especialmente para tal fin y diseñada integralmente según las teorías urbanísticas más avanzadas para su época" (VV.AA., 1982a: 5). Agrega Conrado Bauer, en Ciudad Milagro: "Otra característica que hizo famosa a La Plata fue la de 'Ciudad Jardín', bella, sana y agradable para vivir, como sus fundadores lo quisieron, lo posibilitaron al diseñar su trazado y elegir su emplazamiento, y lo fueron concretando con sus realizaciones" (en Lerange, 1982: 568). Obra de arte asegura que la ciudad "se identifica por el orden geométrico de su trazado y la contribución de las ideas urbanísticas que estaban presentes en los que formularon el proyecto" y que "La Plata, aliada al orden, recibe la belleza con naturalidad, sus reglas son simples, tiene dentro de sí una experiencia histórica que nos posibilita interpretar su lenguaje" (Díaz, 1982: 31, 33). También son ejemplares las primeras palabras en off del documental realizado junto a esa publicación:

"Es una ciudad modelo por su trazado y su concepción urbanística. En sus orígenes, quizá, fue sólo un sueño inspirado que logró concretar su fundador, después fue creciendo como resultado de otros sueños y la suma de otras voluntades. Y desde su diseño geométrico, que posibilita un crecimiento racional, se extiende y se proyecta hacia zonas suburbanas enlazando a otras poblaciones nacidas a su amparo..." (Guión del documental "La Plata", Departamento de Medios Audiovisuales, FAHCE, 1982)

La entrada sobre la ciudad en el Diccionario de Arte remarca su singularidad: "Desde el punto de vista del diseño urbano, la ciudad de La Plata posee como particularidad esencial, la de ser el único ejemplo en Latinoamérica de ciudad proyectada y construida en el siglo XIX" (Nessi, 1982: 224). Morosi, en tanto, la define como "el producto del esfuerzo urbanístico y arquitectónico más completo y ambicioso que el país haya conocido", en un artículo dedicado específicamente a la génesis de la traza de lo que considera una "ciudad de avanzada" (Morosi, 1980d: 109-111). En un número posterior de la misma Revista de la Universidad destaca la "importancia excepcional" de esta urbe, "que nació como ciudad nueva, es decir, como resultado de una idea preconcebida y ejecutada como un todo en un momento histórico determinado" (Morosi, 1982b: 57). El desarrollo ordenado de la ciudad, que según se afirma fue sostenido hasta la década del 50, es atribuido a la capacidad de la generación del 80. Ambos artículos están ilustrados por facsímiles de diversas versiones del plano, dibujos del trazado y una foto panorámica del casco visto desde arriba.

La imagen del trazado, convertida en un emblema identificatorio, es recurrente en las publicaciones del centenario. El trazado -simplificado, convertido en símbolo- es mucho más frecuente que el propio escudo de la ciudad. De hecho, en la programación de los festejos de 
1982 se utiliza como logo identificatorio de la Municipalidad ${ }^{191}$. Y lejos de ser algo propio de los libros de arquitectos y urbanistas, caracteriza transversalmente a las distintas publicaciones.

La Revista de la Universidad, a la que veníamos aludiendo, adopta en su edición dedicada a este centenario, junto a ciertas mejoras de diseño, un formato distinto: pasa a ser cuadrada. "A través de esta nueva propuesta gráfica, encontramos la posibilidad de brindarnos para este primer centenario a estrenar por nuestra ciudad", afirma el rector en la presentación. Con un fondo gris, la tapa está ilustrada por la imagen superpuesta del trazado de la ciudad -en blanco, a partir de una trama de puntos- y un retrato de Dardo Rocha -en negro-.

Sobre la presencia simbólica del trazado en los libros más voluminosos, ya sugerimos algo en el capítulo II: en Ciudad nueva ciudad antigua esa figura es utilizada como separador entre partes, y se suman otras imágenes que reproducen la traza o el plano del casco urbano. Y el cuadrado con sus diagonales es la imagen de tapa. Lo mismo sucede con Obra de arte: en la portada no figura el título del libro, sino aquella figura del trazado simplificado, y la inscripción "1882-1982"192. El símbolo vuelve repetirse en la primera página (o tapa interior), ahora sí junto al título La Plata / una obra de arte / 1882-1982. El trazado vuelve a aparecer a página completa -pero sin ser el mismo diseño de tapa- en la página 5, tras la presentación y el prólogo, y luego en más páginas posteriores. Entre las 300 imágenes incluidas en el libro, el trazado simplificado o el mapa circunscripto al casco, aparece una docena de veces. El escudo de la ciudad aparece sólo en la página 8.

Tal emblema, elaborado en los primeros años de la ciudad, ocupa un lugar importante sólo en casos excepcionales: la portada de Ciudad de mayo está ilustrada con esa imagen del sol, el río, la llanura, los barcos y el ganado, incluido con un sutil recurso de diseño: el paisaje se sale del óvalo que demarca al emblema oficial y se extiende sobre el resto de la tapa y también la contratapa, ambas impresas sobre un fondo anaranjado ${ }^{193}$. La otra tapa con ese recurso es la del libro de poesía Calles numeradas, que contiene una imagen -no muy grande- que parece ser la del escudo en relieve, en color dorado. No obstante, ya en la primera página, junto a la inscripción "Centenario de la ciudad de La Plata / Símbolo de Unidad Nacional” encontramos una vez más el símbolo del trazado, dibujado en líneas blancas sobre celeste.

Acción profesional es otra excepción, en tanto las imágenes predominantes son fotografías de los primeros años de la ciudad. Tapa y contratapa están ilustradas con fotos del álbum de Thomas Bradley (vistas de la Plata desde su fundación hasta junio de 1884) que dan cuenta de "un grupo de ingenieros en el comienzo de la construcción del edificio de la casa de gobierno". La portada de color amarillo-crema no incluye el nombre del autor, sino sólo título y subtítulo/motivo. Además de la foto, sobre el margen superior derecho de la tapa incluye el esquema del trazado y la inscripción de los años del aniversario: 1882-1982.

Con sus variantes de diseño ésa es, sin duda, la imagen más frecuente en los libros: también aparece en Diccionario de arte, construida a partir de puntos (cuadrados) grandes y

\footnotetext{
${ }^{191}$ Nótese que esa identificación hoy está instalada en la ciudad. La imagen que uno encuentra en principales entradas a La Plata -en 7 y 32, o en la bajada de la autopista- es justamente esa representación de la ciudad geométrica atravesada por diagonales.

${ }_{192}$ El título figura en la solapa del libro, junto al escudo de la Universidad.

${ }^{193}$ Los créditos de la imagen se incluyen en la contratapa: "TAPA: Escudo de la Ciudad de La Plata. Proyecto: Pedro Benoit. Dibujo: Ernesto Meyer".
} 
chicos, como píxeles ${ }^{194}$. En el libro de Familiares, en tanto, el trazado también identifica la ciudad, sobreescrito con la expresión ;No habrá manto de olvido!

\section{La ciudad planificada y sus profesionales}

“...es el resultado del esfuerzo urbanístico y arquitectónico más ambicioso y coherente que, hasta nuestros días, se haya emprendido en nuestro país" (en Lerange, 1982: 83)

La exaltación del trazado contiene un elogio a la planificación de antemano, como rasgo platense sobresaliente: "Con el proyecto aprobado -escribe Soler- triunfó la concepción cartesiana, es decir, la más racionalista, para una ciudad sin historia, contrariamente a como se fueron haciendo muchos centros urbanos en el devenir del tiempo" (Soler, 1982: 13). El trabajo dirigido por Morosi, en tanto, recuerda que "la mayor parte de los nuevos poblados formados en la Argentina continuaron siendo obras como aquellas de las que se quejaba Mallo en 1879 y en las que no se podía hacer sentir a los gobernantes la conveniencia y la necesidad de consultar a los hombres de ciencia para la erección de los nuevos pueblos', y, por lo tanto, eran, en la práctica, parcelaciones elementales ejecutadas por 'un simple agrimensor"” (Morosi, 1983: 152).

Varios autores mencionan y Morosi estudia especialmente la presentación de La Plata en la Exposición Universal de París en 1889 - “el magno evento organizado para conmemorar el centenario de la Revolución Francesa"-, cuando una litografía del plano fue exhibida en el pabellón argentino, además de fotografías, estadísticas y diagramas de la ciudad, y "la obra de sus habitantes, fundamentalmente expresada bajo la forma de libros, revistas y periódicos" (en Lerange, 1982: 88-90). En esa ocasión la traza de la ciudad obtuvo una medalla de oro. Para Morosi, que considera al proceso de ejecución de La Plata como una proeza técnica, el análisis urbanístico resulta entonces una de las facetas más ricas de su estudio: La Plata "no tiene parangón en el país" por su carácter de "ciudad nueva" (en Lerange, 1982: 83).

Estas valoraciones conducen a una atención particular sobre la arquitectura y el urbanismo. Desde Ambiente sostienen que "la ciudad de La Plata fue fundada en 1882 como un subproducto directo de las teorías urbanísticas de los siglos XVIII y XIX” y repasan la suma de conceptos higienistas, el arte de la simetría, la búsqueda de ritmo espacial, etcétera. Por otra parte, uno de los lugares comunes de los relatos sobre el origen de la ciudad es la referencia detallada al concurso de proyectos para los principales edificios públicos. Aquel interés se observa incluso en textos "institucionales" como el que dedica Juan Douglas Mogan en Ciudad milagro a El Poder Judicial de la Provincia de Buenos Aires, un capítulo completamente atravesado por la cuestión arquitectónica: da cuenta de la historia institucional a partir de los edificios, ocupándose de mencionar las distintas obras y traslados. En la misma compilación, también es ilustrativo el aporte de Carmen Krumpotic y Raúl Antonio Rumi, directamente dedicado al Edificio del Banco de la Provincia de Buenos Aires -no al banco, sino al edificio de su casa matriz, a cuya descripción dedican el artículo.

La inquietud sobre lo urbanístico-arquitectónico también apunta a los profesionales de esas ramas: no sólo los arquitectos sino también, y especialmente en la época, los ingenieros. No casualmente el libro que reivindica la acción profesional en la fundación es producido por

${ }^{194}$ Además de la figura básica del casco urbano se forma la leyenda “1882-1982” y “ARTES”. En el interior se adjudica a Patricia Sambartolomé la autoría del diseño de tapa. 
el Consejo Profesional de la Ingeniería (Tartarini, 1982). El mismo contiene un fuerte elogio a la planificación urbana:

"Muy pocas veces en la historia de una nación, la fundación de una ciudad hecha a nuevo, como es el caso de La Plata, congrega a un mismo tiempo y en distintas disciplinas, el enorme número de profesionales locales y extranjeros, que intervinieron en las distintas etapas de su concepción y ejecución.

Hablar de planificación y trabajo interdisciplinario, en la acepción moderna de ambos términos, sería a todas luces erróneo; pero si aún hoy, a casi cien años de ese acontecimiento, todavía nos asombra la calidad del resultado obtenido, cabría reflexionar sobre la coyuntura que hizo posible en un momento histórico determinado, llevar adelante una empresa tan ambiciosa y coherente que permanecería como hecho aislado e irrepetible a través del tiempo, a pesar de los avances que la ciencia y la tecnología introdujeron en distintas disciplinas" (Tartarini, 1982: 31)

El objetivo declarado de Acción profesional es destacar los "aportes intelectuales y materiales" de los profesionales que intervinieron en los pasos previos a la fundación y "valorar sus gestiones y tareas de diseño, trazado, replanteo, mensura y organización" de la obra pública. Asimismo, "antes de considerar el tema central que nos ocupa [...] se ha juzgado oportuno efectuar una reseña general sobre la evolución de las profesiones de ingeniero, arquitecto y agrimensor en nuestro país" (Tartarini, 1982: 9).

La publicación del Consejo Profesional no es la única que se ocupa del tema. El segundo capítulo de Ciudad milagro, elaborado por un autor destacado como José María Prado, se titula "La trilogía fundadora y los profesionales y urbanistas de la fundación de la nueva capital de la provincia" "195. En rigor, el interés está puesto en una trilogía formada "por el Dr. Dardo Rocha, el Dr. Carlos D’Amico y el ingeniero y urbanista don Pedro Simón del Corazón de Jesús Benoit, las dos personas que gozaban de su confianza. Benoit pertenecía al Departamento de Ingenieros, como antes había actuado, desde los 14 años, en el Departamento Topográfico" (en Lerange, 1982: 32).

Alude también a otras figuras como Carlos Glade, de origen alemán; el agrimensor Luis Monteverde, que luego fue intendente; o el agrimensor y diputado Rafael Hernández, que "no sólo intervino en los trabajos técnicos, urbanísticos y catastrales de La Plata, en el período de su fundación, sino también en el trazado de otros pueblos del interior de la provincia" (en Lerange, 1982: 34). De igual modo rescata antecedentes del agrimensor José Antonio Lagos, autor de un plan de saneamiento de la ciudad de Buenos Aires presentado en 1871 después de la fiebre amarilla, en cuyo plano incluía diagonales y una ancha avenida de circunvalación: "Vale la pena citarle, para demostrar cómo el sistema urbanístico de las diagonales, que tanto preocuparon al Dr. Dardo Rocha como a Benoit, en 1882, ya venía de muy lejos, como se observa en los tratados de la historia urbanística, para otras ciudades del viejo mundo" (en Lerange, 1982: 33-34).

Prado también hace una vaga mención de "otros profesionales" y evoca dos homenajes que se les rindió en conjunto durante el cincuentenario: un monumento erigido en 6 y 50 por iniciativa del Colegio de Ingenieros ${ }^{196}$ y el volumen Profesionales que intervinieron en la

\footnotetext{
${ }^{195}$ Morosi también se detiene en algunos aportes profesionales. Por ejemplo, señala una decisiva presencia de los sanitaristas: "forman parte de la Comisión tres sanitaristas destacados: Eduardo Wilde, Manuel Porcel de Peralta y José María Ramos Mejía, este último en calidad de Secretario”, y además los presidentes de los Departamentos de Ingenieros de la Nación y de la Provincia, Guillermo White y Francisco Lavalle..." (en Lerange, 1982: 84)

${ }^{196}$ Menos conocido, también en el centenario se levantó un Monumento a la Ingeniería, promovido por el Centro de Ingenieros de la Provincia de Buenos Aires y ubicado en 7 y 528.
} 
fundación de La Plata, al que ya aludimos en el capítulo II. Un dato interesante es que esa publicación antecedente (Comisión..., 1935) ya ponía en un lugar central a Pedro Benoit, al menos simbólicamente: la primera imagen incluida en aquel libro es un retrato suyo. La inflación de su figura se retoma y profundiza en varios textos del centenario, aun cuando algunos ponen en discusión su condición de autor de la traza urbana platense.

\section{El talento de Benoit}

Escriben los autores de La Plata 100 bajo en el ítem trazado urbano:

"Al hablar del trazado de La Plata no se puede dejar de mencionar a su artífice, el Ing. Pedro Benoit. Era hijo del ingeniero francés Pierre Benoit, en torno de quien existe una curiosa leyenda, pues se dice que era hijo del mismísimo Luis XVI, rey de Francia. Leyendas aparte, Pedro Benoit es, en el campo de la arquitectura y la construcción, uno de los personajes más importantes de fines del siglo XIX; su obra, la más voluminosa de la época, oscila alrededor de los mil ochocientos proyectos.

Poseedor de una sólida formación, basada en la tradición cultural francesa, su obra refleja la corriente ecléctica vigente en el momento, abarcando desde edificios civiles de corte clásico hasta arquitectura religiosa, en la que era partidario acérrimo del neogótico" (VV.AA., 1982a: 5-6)

La exaltación de la figura de Pedro Benoit (1836-1897) es frecuente en varios de los textos que integran el corpus y se basa en su rol fundamental durante la planificación de la ciudad y el diseño de sus primeros y principales edificios. Es el ingeniero y arquitecto de la fundación, más allá de que nunca obtuvo esos títulos en una graduación universitaria. Si Rocha era el previsor, Benoit fue el gran ejecutor de la ciudad (Soler, 1982: 18).

Los escritos destacan su "talento" (Calvo, 1982), señalan su condición de "intérprete fiel de las ideas del Dr. Rocha” (Frencia de Valiente, en VV.AA., 1982b: 13) y lo califican como "una de las figuras más extraordinarias de la arquitectura argentina de la segunda mitad del siglo XIX, por la fecundidad y variedad de sus obras, [que] dominó, juntamente con su padre, Pierre Benoit, la escena de dicha arquitectura durante más de cincuenta años" (Morosi, 1983: 40) ${ }^{197}$. En Obra de arte su nombre aparece incluso en el tramo dedicado a las colectividades: "Los franceses -sostiene- constituyeron uno de los grupos más importantes en la vida social y en la construcción de la ciudad. Uno de sus representantes más conspicuos, el ingeniero Benoit, argentino de padres franceses, jugó un papel fundamental en el diseño del plano..." (Díaz, 1982: 344). Acaso el texto que más relativiza su figura es el dedicado a la acción profesional de los ingenieros (Tartarini, 1982), donde su trayectoria aparece junto a la de los demás participantes de las comisiones, no híper-exaltada como en los otros libros.

En tanto, su posible relación con el último monarca francés es aludida también por el texto de Prado, que sostiene que "el presunto nieto de Luis XVI y María Antonieta es el autor de la avanzada y moderna trama de esta Ciudad de la Unión Nacional"' (en Lerange, 1982: 36. Las cursivas son mías). La idea, planteada en dos textos del centenario, proviene de un libro publicado en Buenos Aires en 1941 por un bisnieto del ingeniero, que sembraba la duda sobre el destino del hijo del último rey de Francia y planteaba la posibilidad de que no hubiera muerto mientras estaba prisionero en Temple (Zapiola, 1941). Retomada esporádicamente en

\footnotetext{
${ }^{197}$ En total se le atribuyen los proyectos de más de 1800 edificios públicos y privados, entre ellos 25 dedicados al culto, por los que usualmente se negaba a percibir remuneración. Además de sus trabajos de índole más profesional, Benoit fue concejal de la primera municipalidad elegida por voto popular (1890) y luego intendente municipal (1893). También acompañó la fundación de la Universidad provincial: "otro adalid de la Fundación que se volvía a unir a Rocha", escribe Conrado Bauer (en Lerange, 1982: 567).
} 
artículos periodísticos, el tema será tratado también por Raúl Eduardo Marne (1984: 6-7), en un texto abiertamente celebratorio de la figura de Benoit, publicado poco después del centenario y repleto de adjetivaciones sobre su labor magistral, visionaria, relevante.

Sin embargo, más que aquella presunta condición, lo que se disputa en algunos textos es su autoría sobre el trazado platense, tema no saldado al día de hoy. Algunos de los que relativizan su participación lo hacen reconociendo un trabajo más generalizado al Departamento de Ingenieros. En un tramo de Obra de arte, por ejemplo, se afirmará que el plano fue "proyectado por el Departamento de Ingenieros bajo la dirección de su jefe de Obras Públicas, don Pedro Benoit...” (Díaz, 1982: 133) ${ }^{198}$. Por otro lado, hay una corriente que será reimpulsada años más tarde por Alberto De Paula- que insiste en un papel central cumplido por Juan Martín Burgos, quien entrega y hace pública una propuesta de plano en abril de 1882, que podría haber inspirado la forma que adoptó la ciudad ${ }^{199}$. Aunque varios textos del centenario mencionan este planteo previo (véase, por ejemplo, Díaz, 1982: 69) ${ }^{200}$, es Acción profesional el que se destaca en este planteo. Al dar cuenta de la "concepción y materialización del trazado" relata:

"Luego de un año de arduo trabajo, en el que el Departamento elabora varios anteproyectos, e incluso se registran colaboraciones espontáneas como la del arquitecto Juan Martín Burgos -no valorada en su exacta dimensión hasta la fecha (...)- se eleva finalmente el plano del trazado junto a una breve memoria..." (Tartarini, 1982: 73)

Efectivamente, el último apéndice del libro incluye, no sólo el gráfico sino la Memoria completa presentada por Burgos (Tartarini, 1982: 143-157) ${ }^{201}$.

Estos planteos son minoritarios en la bibliografía del centenario. Lo que predomina es la apreciación de la figura de Benoit, que "dio forma a los planos de esta ciudad que, hoy centenaria, es aún un ejemplo de funcionalidad en el mundo entero", según afirma Alfredo Luis Delfino en el capítulo de Ciudad Milagro dedicado a la Sociedad de Escritores de la Provincia de Buenos Aires. Vale esta cita y otras para advertir que el asunto excede a los textos abocados específicamente a temas urbanísticos. En la publicación de la Universidad Notarial, Seco Villalba apunta:

"Hoy celebramos a La Plata centenaria. Ciudad nacida en primavera. Un estadista concibió la aventura de su fundación y un enjambre de hombres orquestó la proporción

\footnotetext{
${ }^{198}$ En otra página plantea: "La traza de la ciudad de La Plata habría sido realizada, según documentos y versiones familiares, por el ingeniero Pedro S. Benoit..." (Díaz, 1982: 69)

${ }^{199}$ En esa línea se inscribe, por ejemplo, la edición artesanal del ingeniero Antonio Corrado (2000) archivada en la Sala La Plata de la Biblioteca Central de la Universidad. Sin querer "menoscabar la imagen del ing. Pedro Benoit, quien sin lugar a deudas fue uno de los actores importantes", su propósito es "rescatar del olvido, tanto más ingrato teniendo en cuenta que su aporte fue espontáneo y desinteresado, el nombre y la figura" de Juan Martín Burgos, que debe ser "reconocido y recordado como el inspirador del diseño de la Ciudad de La Plata" (Corrado, 2000: 20-12). El folleto da cuenta de las gestiones para que el Concejo Deliberante local reconociera a Burgos en esos términos. Corrado adjudica el "descubrimiento" al arquitecto De Paula.

${ }^{200}$ También Morosi transcribe extensamente la propuesta de Burgos en una nota al final de capítulo y comenta: "Como podemos observar, las bases teóricas de este programa, como el esquema formal propuesto, coinciden casi totalmente con los adoptados finalmente para La Plata" (Morosi, 1983: 74). No obstante, veinticinco páginas más adelante reafirmará la autoría de Benoit.

${ }^{201}$ El trabajo de Burgos se titula "La nueva capital de la provincia" y abarca los temas: "Su situación. Orientación. Trazado de sus calles. Boca-calles. Calles diagonales. Avenidas. División de las manzanas por lotes. Pasajes interiores. Porticados. Plazas públicas. Jardines. Paseos. Plano general de la traza de la ciudad". Cita diversas experiencias internacionales pero predominan los casos norteamericanos. Hace un diagnóstico, ofrece recomendaciones para "una ciudad moderna, llamada a ser un gran emporio comercial, el asiento de las autoridades de la primer provincia", analiza el modo de articular el interés del gobierno y el de los particulares, y concluye evocando el procedimiento seguido en la fundación de Washington (Tartarini, 1982: 155).
} 
de sus volúmenes y su trazado. Recordemos que el plano de la futura metrópoli fue minuciosamente estudiado por Dardo Rocha y diseñado con prolijo y entusiasta empeño por el ingeniero Benoit..." (en VV.AA., 1982b: 11)

Aunque no siempre señalado explícitamente como autor de la traza, Benoit es destacado por su "enorme responsabilidad de dirigir las obras del trazado de la ciudad" (Terraza, 1982: 24), por haber estado "al frente del grupo de proyectistas, ingenieros, agrimensores y topógrafos" (Cygan, 1981: 193) o por su tarea "ardua y abundante, destacándose como urbanista, proyectista y director de obra, a la que imprimió un ritmo que no se conocería en los años que van de la fundación al centenario, caracterizada por la velocidad y eficiencia con que se realizaban los proyectos, en una verdadera tarea de equipo" (Soler, 1982: 17).

Quienes sí lo reivindican como responsable del trazado y más insistentemente colocan su figura son dos de los autores más reiterados en nuestro corpus: el arquitecto Morosi y el historiador aficionado José María Prado.

El primero afirma que los Benoit -padre e hijo- "ostentaron, durante más de medio siglo, un lugar de preeminencia en el campo de la arquitectura, la ingeniería y el urbanismo en nuestro país, pero recordaremos que su obra más completa, trascendente y de mayor envergadura fue la concepción de La Plata y de una serie de proyectos arquitectónicos vinculados a la misma" (en Lerange, 1982: 87). Además, en su artículo publicado en el $\mathrm{N}^{\circ} 28$ de la Revista de la Universidad transcribe la única descripción realizada por Benoit de la traza (Morosi, 1982b: 61-62). El mismo documento, que pone en un lugar importante a Benoit, es incluido en tres páginas de Ambiente -en la que también participa Morosi.

Para este autor la mayor evidencia de autoría es un plano impreso por el Departamento de Ingenieros, cuya fuente es el catálogo de la Exposición Universal de París (en Lerange, 1982: 87-88). Finalmente, el urbanista apoya su afirmación en la voz autorizada de José María Rey:

"Frente al plano fundacional cabe preguntarnos, en primer término, quién fue, dentro del Departamento de Ingenieros de la Provincia, el responsable principal de su trazado. Como bien señala Rey, existen indicios que permiten atribuir esa responsabilidad al ingeniero Pedro Benoit, quien encabezaba un equipo de destacados técnicos en dicho departamento" (Morosi, 1983: 99)

En segundo lugar es significativa la conferencia de Prado (1978) en el Ciclo Cien años. Es una intervención breve, que ocupa ocho páginas en el cuadernillo publicado, donde no desarrolla nada en profundidad y se ocupa, especialmente, de la figura de Benoit. Según el dirigente de la Federación de Instituciones, "la fundación de la Nueva Capital para la provincia de Buenos Aires, tiene dos autores ejecutivos: el Dr. Dardo Rocha, en la faz política e institucional, y el ingeniero Pedro Benoit, como el urbanista, planificador y arquitecto". Por eso instala la fórmula que refiere a "el fundador y el artífice" (Prado, 1978: 9).

“...a esta altura del partido y del Mundial 78, nos preguntamos ¿fue el Dr. Dardo Rocha el que trazó y construyó, él solo, la ciudad? No. Tan ingenuos no somos.

Rocha necesitó del artífice. ¿Y quién fue el elegido?, pues el ingeniero Pedro Simón del

Corazón de Jesús Benoit; Pedro Benoit a secas, como se hizo llamar y como firmó siempre, toda la documentación privada y pública, como profesional" (Prado, 1978: 12)

Además de considerarlo "amigo y confidente" o "brazo derecho y confidente del Dr. Rocha” -sin contemplar nunca a D’Amico-, Prado claramente identifica a Benoit como autor del trazado de La Plata (Prado, 1978: 12-16). 


\section{Continuidad o ruptura con la tradición española}

“...sería aventurado afirmar [...que] abrevaron en esta o aquella fuente histórica para determinar la traza de La Plata. No podría tratarse más que de especulaciones..." (Garnier, 1992: 32)

Otra cuestión que aparece en pugna al revisar el conjunto de publicaciones realizadas en 1982 es la caracterización de las corrientes urbanísticas que inspiran al trazado. Si bien esto no es presentado como una discusión o un objeto de debate en cada texto, las conceptualizaciones son divergentes: hay textos que piensan la traza a partir de la cuadrícula propia de las Leyes de Indias- y otros que acentúan sus rasgos más modernos y progresistas. Ciudad nueva ciudad antigua, el libro con mayor desarrollo sobre el tema y producido por urbanistas, es el que aporta la mirada más compleja.

En Obra de arte se afirma:

"La ciudad de La Plata fue diseñada en la clásica traza de 'Damero' en el que se conjugan los conceptos de geometría y simetría, más las posturas higienistas de los urbanistas del siglo pasado. Estas teorías tenían por objeto superar los problemas que acarreaba la ciudad industrial.

Tal sistema se ve trastrocado con la incorporación al plano de avenidas diagonales y de un eje que corre directamente hacia el puerto. Este eje es cortado en forma perpendicular por otro que al coincidir con el primero, termina el punto central de la traza...." (Díaz, 1982: 69)

Según dónde se pone el énfasis -si en el clásico damero o en el higienismo y las diagonales-, La Plata será tradición o modernidad, ciudad antigua o ciudad nueva.

La primera idea es sostenida fuertemente por Cygan, quien piensa a la ciudad como "una expresión última de las antiguas corrientes fundacionales españolas", que "cerraba el ciclo histórico de la ruta afanosamente transitada del norte, en una situación geográfica tras de la Ciudad de Buenos Aires y su puerto, con el nombre de uno de los metales preciosos que la Conquista por allí exportó: La Plata" (Cygan, 1981: 201). Si bien reconoce que el diseño puede haber sido "influenciado por el trazado de la ciudad de Washington, surcada por calles rectas, cruzadas, como un damero, al que la Ciudad platense ha agregado también diagonales", aclara que ese trazado "es típico de las fundaciones coloniales en América y respondía a un esquema regulado por la corona" (Cygan, 1981: 195).

Otros textos, en cambio, tienden a pensar el trazado en ruptura con la tradición hispánica: "El gobernador Dardo Rocha y su equipo político intentaron contraponer a la cuadrícula indiana de la ciudad de Buenos Aires una traza que, sin alcanzar emocionantes efectos espaciales, resultaba novedosa con sus diagonales y con sus calles y avenidas anchas y bien arboladas", escribe en Ambiente Alberto De Paula (1982: 47). Por su parte, Bernard identifica a la nueva capital como algo distinto a las ciudades del urbanismo indiano:

"Bien sabido es que La Plata nació de la nada, en medio del desierto, como un desafío al espíritu creador e imaginativo, con ansias de futuro, del hombre argentino. Las capitales tradicionales de las provincias que en 1853 crearon la Nación políticamente organizada, eran obra de un plan fundacional hispánico basado en la necesidad del doblamiento y la colonización del Nuevo Mundo.

Ideadas y levantadas en el arduo trajín de la conquista, el sello peninsular quedó estereotipado en la cruz sobre los campanarios, en las arcadas y balcones de los cabildos y ayuntamientos y en la entronización del árbol o rollo de la justicia, la célebre 'picota', proclamando el imperio de la ley" (Bernard, 1982b: 14) 
Aun con su plaza mayor y el damero, La Plata "abrirá paso a la ciudad moderna, bien llamada por ello, 'la nueva capital' [...] En Argentina no existían para fines de siglo, ciudades modernas, en la acepción que hoy da a estos vocablos la ciencia del urbanismo" (en Lerange, 1982: 22-23).

Son los trabajos de Morosi y su equipo los que presentan una lectura más compleja acerca de las corrientes inspiradoras del trazado platense. La ciudad "sintetiza, fundiéndolas en una obra revelante, las tradicionales experiencias fundacionales hispanas con los novedosos aportes europeos que empezaron a insinuarse a partir de mediados del siglo pasado" (Morosi, 1980d, 109). En otras palabras, el repertorio barroco y clásico se funde con las ideas más avanzadas de la época:

“...el Departamento de Ingenieros, creado en tiempos de Rivadavia, atesoraba una larga y amplia tradición urbanística. Su base la constituía la activísima experiencia colonial, regida por las leyes de Indias, que preconizaban el damero, cuyos antecedentes son bien identificables en el mundo clásico y, en especial, en la civitas romana [...] A pesar de todo ello, ya hemos señalado que La Plata, en el contexto urbanístico, ha sido ubicada generalmente en el casillero de las creaciones postbarrocas. Tal calificación es superficial, ya que no atiende siquiera a los aspectos meramente formales del problema. Hallamos, por cierto, la simetría, la cuadrícula y las diagonales del repertorio formal clásico y barroco, pero aquí se las ha insuflado de un nuevo espíritu que surge de las ideas del siglo pasado acerca de la ciudad progresista en su variante higienicista. La cuadrícula y la rigurosa simetría se han ablandado por la introducción de ciertas licencias justificadas mediante impecables argumentos racionales" (Morosi, 1982b: 59. La negrita es del original) ${ }^{202}$

La visión de estos investigadores es sumamente erudita. Los distintos textos publicados por el grupo hacen un repaso amplio de las influencias intelectuales sobre el trazado ${ }^{203}$. Entre ellas está el damero clásico, la ciudad ideal renacentista, la ciudad barroca, la ciudad industrial -incluyendo las reformas de Haussmann en París-, el proyecto de nueva capital del reino de Italia ejecutado por Tettamanzi en 1863 -según los autores, el antecedente formalmente más emparentado con la traza platense-, el movimiento de revalorización del espacio verde urbano (Morosi, 1983: 42-57). También hay referencias literarias y en particular a la posible inspiración de Rocha en la obra de Julio Verne, cuya Franceville -la ciudad imaginada de la novela Los 500 millones de la Begum- contiene "la descripción que más se aproxima a la traza que se dio a La Plata" (Morosi, 1983: 60-61).

\section{Una obra de la voluntad del 80}

“...la conquista del desierto era un hecho y el país había oblado [sic] su 'cuota de ingreso' al club de la civilización... ¡Como para no sentirse orgullosos, estos argentinos que veían crecer su país día a día, llenar los espacios vacíos de su mapa, poblar de ciudades lo que habían sido conspicuos claros! La Argentina había ingresado, de pleno derecho, al núcleo de naciones civilizadas. Podía codearse con Inglaterra y Francia. Podía mirar con compasivo desdén a la pobre

\footnotetext{
${ }^{202}$ El prólogo a Ciudad nueva ciudad antigua, De Terán también cuestiona la "inadecuada caracterización" de La Plata como "un producto posbarroco" (Morosi, 1983: 9) y caracteriza un "sistema" con distintos elementos.

203 También explorarán las "resonancias" posteriores: el trazado de Belo Horizonte (1897) -denominada por Afrasio de Mellos Franco como La Plata de Brasil-, la propuesta de diagonales convergentes en Estados Unidos de Daniel Hudson Burnham -exponente del movimiento de la City Beautil- (1909), los planos de Nueva Delhi y Canberra, y a nivel local el proyecto para la ciudad y puerto de Samborombón (Morosi, 1983: 146-152).
} 


\begin{abstract}
España, decadente y empobrecida. Y con indisimulado desprecio a sus hermanas latinoamericanas, con sus guerras civiles, sus dictaduras, su barbarie y su pintoresquismo...” (Luna, 1982)

"[La Plata] representa la obra de una generación política argentina vinculada al desarrollo económico y cultural de Europa...” (Díaz,
\end{abstract}

1982: 15)

La capacidad de planificación y el impulso a la creación de la ciudad son asociados en buena parte de los textos a una caracterización de la llamada "Generación del 80", que como vimos había sido objeto de conmemoración a nivel nacional tiempo antes, algo que está presente en la trayectoria de los departamentos universitarios que realizan Obra de arte como así también en las páginas de la Revista de la Universidad, entre otros. Cabe recordar, desde ya, que uno de los libros que integra el corpus identifica desde su título a La Plata como una creación de la generación del 80.

Las caracterizaciones elogiosas no se limitan a esa publicación municipal sino que están presentes en un grupo importante de publicaciones. El capítulo sobre la fundación en Primeros habitantes es un buen ejemplo de las palabras dirigidas hacia esa "generación del ochenta positivista y previsora", que "fue idealista en sus proyectos apoyando obras que llevaron al país a un nivel superior" y "trabajó incansablemente hasta encauzar al país hacia un futuro promisor". Al igual que otros autores, reproduce la mirada orientada a Europa:

“...Representantes argentinos en el extranjero fueron portadores de mensajes de amistad y de anhelos para estrechos vínculos de colaboración en obras que concurran al bienestar general.

Se afianzaba un estrecho acercamiento con la Madre Patria. Inmigrantes italianos y españoles llegaban periódicamente a la República argentina..." (Terrasa, 1982: 21)

Se habla de una "Argentina de las grandes realizaciones, del refinamiento y de la cultura" orientada por una "política de grandeza", según las palabras utilizadas por Canestri y Canestri en su artículo dedicado al Jockey Club: "Ese mismo principio de siglo asistía, a su vez, a los albores del funcionamiento de la nueva Capital, ciudad levantada en el desierto, resultado de la política del 'acuerdo' y la 'concordancia' instaurada precisamente por aquella generación”. Esa ciudad prestigiosa y respetada, donde crecían instituciones científicas y artísticas y clubes como el Jockey, "nació así como producto espontáneo de una eclosión de fuerzas superiores que sólo trasuntan las mentalidades ilustradas de las clases dirigentes" (en Lerange, 1982: 439). El adjetivo espontáneo suena contradictorio con la idea de una ciudad planificada, pero más que a un fenómeno sin causa o sin una intervención humana, aludiría al producto de una voluntad, característica de la época donde -como plantea Vida platense- la consigna orden y progreso "se tradujo en los hechos en una actividad casi febril" (Soler, 1982: 11). Así, por ejemplo, Vida espiritual señala a la ciudad como "uno de los actos de voluntad creadora más trascendentes de la generación del 80" y de la fe de quienes gobernaban en la época (Bartholomew, 1982: 5).

Una ciudad surgida de la nada, como se la nombra, es un hecho "asombroso, pero se corresponde con el espíritu de la época. Más aún: lo traduce", escribe para Ambiente el historiador Félix Luna, en uno de los artículos que más consecuentemente encumbra a la dirigencia política de fines del siglo XIX: "Si algo caracterizó a la Argentina de esos años, fue la profunda, inalterable, casi sagrada fe, en sus propias posibilidades”. Según Luna, La Plata es más que una ciudad: 
"Es la expresión urbana de un impulso de progreso, de un sentido optimista, triunfalista, que era el meridiano de la época y daba el aire usual a los argentinos de entonces. $\mathrm{Y}$ así debemos celebrarla, en sus primeros cien años de vida: como la realización del espíritu que dominó una etapa de la existencia del país, que hoy quisiéramos revivificar" (Luna, 1982: 18)

Ese espíritu de su tiempo se expresaría de un modo emblemático en la planificación, en la obra pública acelerada y en la capacidad de generar un crecimiento que cien años más tarde parece febril pero "era el ritmo normal, era el movimiento con que todo se ponía en marcha":

"El día que se instalaron las autoridades bonaerenses en La Plata (abril de 1884), se sirvió un refrigerio en el galpón de la estación ferroviaria, único recinto con suficiente capacidad como para albergar a los numerosos invitados. En las paredes se habían fijado, vis a vis, dos croquis: uno era el de La Plata, tal como estaba en ese momento en relación con los planes previstos. El otro croquis era el de la ciudad de Buenos Aires, tal como había sido a doscientos años de su fundación, es decir, en 1780.

La diferencia saltaba a la vista: la actual Capital Federal, dos siglos después de su erección, era un caserío. La nueva capital bonaerense, en cambio, dos años más tarde de su fundación, constituía una pujante y concreta realidad.

Podemos imaginar el orgullo de los gobernantes de la primera provincia argentina, al reflejar gráficamente la diferencia de crecimiento de ambos centros urbanos. Pero este orgullo era común a los hombres del 80: un orgullo no basado en lugares comunes o estereotipos banales, sino en la realidad que estaban viviendo $\mathrm{y}$, en gran medida, modelando" (Luna, 1982: 16)

Para Morosi, aquella "capacidad de la generación del 80 es más sorprendente aún si se considera la manera ordenada en que se llevó a cabo la radicación, a pesar del proceso expeculativo [sic] que toda empresa de este tipo y magnitud implica y del que La Plata no estuvo ausente". El comentario del urbanista intenta trazar una diferencia incluso con otras experiencias de ciudades planificadas, como Brasilia: sólo en La Plata, sugiere, "la radicación de toda la población en sus diferentes grupos sociales se cumplió en forma aceptablemente ordenada y sin la aparición de fenómenos de urbanificación que implicaran desarrollos espontáneos de vivienda", y las primeras viviendas tipo villa, producto de una migración "masiva y desordenada", aparecieron recién en la década de 1950 (Morosi, 1982b: 66).

\section{Prever el orden}

"1882, ab urbe condita. En el pajonal agreste se edifica una ciudad neoclásica. La más rigurosa forma, basada en la geometría, instaura el damero con diagonales. El país se halla en la euforia del positivismo que sucede a la anarquía romántica. Organizar es la consigna. La plataforma y el damero señalan la afirmación y la seguridad frente al desorden topográfico: nivelar, canalizar, pavimentar, urbanizar, cultivar, educar...."(Nessi, 1982: I-III)

"Con una minuciosidad realmente llamativa, nada quedó librado al azar, por lo que todo lo relacionado con el orden público fue previsto

y organizado convenientemente" (Of. Insp. Vicente Borda Barrera, "La Policía de la Provincia de Buenos Aires en la Ciudad de La Plata", en Lerange, 1982: 431)

Una cuestión interesante para analizar en la bibliografía estudiada es el reconocimiento de la influencia del ideario haussmaniano. Son pocos los autores que se detienen en él, y lo hacen sin señalar el carácter de embellecimiento estratégico de sus reformas, cuya "verdadera finalidad" era "asegurar a la ciudad contra la guerra civil" (Buck-Morss, 1995: 107). 
El equipo de Morosi, como vimos, menciona a Haussmann en el marco de múltiples influencias. Lo mismo ocurre en la entrada "La Plata" del Diccionario de arte, elaborada por los arquitectos Alfredo Conti y Norberto de la Torre:

"Los elementos básicos del planteo urbano provienen de las ciudades ideales proyectadas a partir del Renacimiento [...] incorporando elementos del período barroco y reelaborados por las teorías urbanísticas de la propia Academia. Asimismo fueron tenidos en cuenta los principios higienicistas [...]

Premisas similares habían sido tenidas en cuenta por L’Enfant para el plan de Washington (1793), por Haussmann para París (1853) y por Cerdá para Barcelona (1859)..." (en Nessi, 1982: 226)

En Ciudad Milagro -en el capítulo del mismo Morosi- el carácter haussmaniano se admite en relación al principal parque público. En otros textos, la referencia está ausente. El artículo de Exequiel Ortega en la Revista de la Universidad, por ejemplo, se concentra en la influencia norteamericana sobre la traza, y en particular la inspiración en Washington (Ortega, 1982: 76-78).

En ninguno de los textos del centenario encontramos planteos como el que hará Fernández: que el "magnífico trazado" es "excelente para reprimir -objetivo de diseñadores amparados en el espíritu de una época convulsionada aquí y allende los mares-, placentero para vivir -segundo objetivo, también alcanzado-"; es decir, que "la movilidad policial es más sencilla en La Plata que en cualquier otro lugar" (Fernández, s/f). El único actor que tiende a ese enfoque, es decir, que revisa el sentido de trazado tan elogiado, es Familiares. Pero esa lectura crítica no está plasmada en la publicación que forma nuestro corpus sino que podemos encontrarla en un volante repartido en el acto del 19 de noviembre de 1982. Allí afirmaban:

\section{"Centenario}

Hoy nos encontramos conmemorando el centenario de nuestra ciudad. Ciudad de prolijo trazado.

Y hoy sentimos desde muy dentro el sabor amargo de no tenerte con nosotros, de tu ausencia.

Porque te conocimos, trabajador, hermano, hijo, estudiante, vecino solidario. Te conocimos y supimos como eras.

Porque no sólo fuiste estudiante, padre, hermano, trabajador, vecino.

Supiste ver en los demás a tus hermanos, y entonces no fuiste sólo vos, no fue sólo tu hogar, tu puesto en el trabajo o tu carrera, sino que fue tu País y por él te preocupaste.

Y quisiste hacer de él un país grande y justo, un país de todos.

Y por eso alzaste tu voz, y te silenciaron de la manera más cruel.

Utilizando el trazado tan prolijo de nuestra ciudad, la represión actuó de tal manera que no quedó una sola de sus manzanas sin su marca.

Calles, diagonales, esquinas, ramblas, casas, oficinas, fábricas. Todas ellas tienen su dolorosa huella.

Por eso hoy tenemos tu presencia. Porque no te encontramos o te vemos detrás de un paredón o de unas rejas.

Por eso hoy no callamos: PORQUE ESTÁS CON NOSOTROS.

Aparición con vida de los detenidos-desaparecidos.

Restitución a sus legítimos hogares de los niños secuestrados y los nacidos en cautiverio.

Libertad a todos los presos políticos.

Desmantelamiento del aparato represivo-castigo a los responsables". 
Según recuerda una de las militantes de Familiares, "repartir ese volante era como la tarea específica que se había propuesto Familiares. Además la hechura del libro, pero ese día en particular la acción era esa [...] El objetivo era aprovechar este acto tan masivo" (Entrevista a Claudia Bellingeri, julio de 2007).

El texto distribuido tiene mucho para analizar, desde la riqueza de su redacción hasta sus planteos políticos, "avanzados" para el momento en el campo de los derechos humanos. Aquí nos interesa, en relación a lo que venimos trabajando, cómo asume en términos críticos uno de los lugares comunes de la historia de la ciudad. Familiares interpreta que la ordenación urbana no está pensada para alcanzar una ciudad saludable, como dice el relato dominante, sino para permitir el control y la movilidad policial. Así es que "utilizando el trazado tan prolijo de nuestra ciudad, la represión actuó de tal manera que no quedó una sola de sus manzanas sin su marca".

En rigor, los autores de No habrá manto de olvido no hacen otra cosa que reconocer la contracara del higienismo progresista: el control de sujetos indeseables en el cuerpo social, la represión de la multitud sublevada (Sennett, 1997: 351). No olvidemos que el "progreso" de la generación del 80 venía con "orden", al igual que la "organización nacional" -idea revindicada por el Proceso- traía una idea particular de nación e implicó la campaña militar de sometimiento y exterminio que Luna cita como la carta de ingreso al "club de la civilización". Como veremos en el capítulo siguiente, los obreros en Berisso y Ensenada, identificados a mediados del siglo XX con el peronismo, fueron una expresión de esa presencia no deseada por aquel progresismo excluyente, que culminó con la escisión administrativa de una parte de la ciudad que había sido vital para el proyecto y que ocupa un espacio marginal en los relatos del centenario.

La ciudad-puerto, del fracaso al olvido

"(Berisso era) una creciente comunidad de trabajadores que brindó escasas oportunidades a las sutilezas de la planificación urbana" (James, 2004: 17)

“...fuera del cuadrado original de La Plata, la traza que heredó del urbanismo francés decimonónico cede a los azares de la pobreza y la necesidad. Las calles, de tierra despareja o asfalto electoral, bordadas por zanjas, se enciman y doblan, se cruzan, se interrumpen. No hay amplias diagonales, no hay plazas cada siete cuadras, casi no hay árboles. Los números, muchas veces garabateados con una brocha sobre puertas o paredes, se entreveran, suben, bajan, se contradicen. La matemática sufre...” (Duizeide, 2010: 89)

“...De acuerdo con el plan original, La Plata apuntaba a dos polos: uno, el interior de la provincia de Buenos Aires, y el otro, el puerto de ultramar que conducía a Europa" (Soler, 1982: 13)

El trazado en cuadrícula caracteriza al casco urbano de la ciudad y los primeros cordones periféricos. Las diagonales y la distribución relativamente pareja de plazas es propia del cuadrado central, de 38 por 38 cuadras. Una consecuencia del encomio de la planificación cuidadosa y geométrica es la invisibilización de vastas zonas que también forman o formaron parte de la ciudad y quedan fuera de ese trazado con diagonales convertido en símbolo. 
Los criterios higienistas y modernos que pautaron el centro de la ciudad no se extendieron más allá de las calles 122, 31, 32 y 72, tal como asume la Crónica del centenario en un registro afín al patrimonialista que caracterizamos en el capítulo III:

“...la ciudad ha sufrido otra alteración que consiste en su dispersión incontrolada hacia la periferia sin haberse seguido con el respeto de la traza original en sus prolongaciones, en especial omitiendo las reservas de espacios verdes que hicieron a la naturaleza de su creación. Ejemplo típico de ese crecimiento sin reservas verdes es el barrio de Los Hornos y en cuanto a otro lugar de la ciudad con características singulares es el que comienza a través del cruce de las vías del ferrocarril en diagonal 80 que se desarrolló alrededor de la actividad hípica y que recién hace pocos años se está integrando al resto urbano" (Szelagowski, 1982b: VI)

También en Obra de arte se asume la marcada diferencia entre el casco urbano y las periferias: "El cuadrado original de La Plata constituye una unidad en sí misma, difiriendo notablemente en algunos casos de los barrios vecinos. La Avenida Circunvalación actúa como una muralla, constituyendo la división entre categorías de viviendas diferentes..." (Díaz, 1982: 76. Los destacados son míos). Esto también nos habla de la faceta menos contada del higienismo de la generación progresista: el lugar para los sectores populares y los "malos olores" de la producción estaba previsto fuera del casco, lejos de la "ciudad perfecta" a la que no debían invadir.

Por lo tanto, la centralidad adjudicada al trazado con diagonales y espacios verdes, que los convierte en emblema de la ciudad, deja afuera a zonas que formaron parte del proyecto original. Recordemos que al pensar la nueva capital provincial se descartaron las zonas mediterráneas y que la ubicación definitiva se eligió por el puerto natural de Lomas de la Ensenada. Imaginada como ciudad portuaria, La Plata se pensó de cara al río. El viejo arco de entrada, cuya demolición a principios del siglo XX aparece cuestionada por el discurso patrimonialista, estaba precisamente en 1 y 52, el contacto entre el centro urbano y el camino hacia el puerto.

Cabe observar cómo varios de los textos del centenario tratan esa idea original. El fracaso de la ciudad portuaria -que es, en parte, una derrota de la planificación- es asumido abiertamente, y el error de haberla imaginado así resulta objeto de crítica en un tono inhabitual para textos donde predomina un discurso celebratorio. Acción profesional, por ejemplo, se permite incluir un interesante fragmento de un debate legislativo previo a la creación de la ciudad, sostenido entre los senadores Ortiz de Rosas, Hueyo y ministros del gobierno, donde el primero cuestionaba la elección del sitio y terminaba augurando el fracaso del puerto (Tartarini, 1982: 124-125):

"[...] No considero, pues, inconveniente un puerto para el establecimiento de una gran ciudad, lejos de eso!, pero creo imposible levantar una gran ciudad a las puertas de otra gran ciudad. Y si el hecho fuese posible, llega que una de las dos tiene que perecer.

Sr. Hueyo.- Yo no tengo miedo.

Sr. Ortiz de Rosas.- Como no es posible distribuir en un corto espacio las corrientes de comercio de una manera tal que alimenten la prosperidad de esas dos localidades, una de las dos ofrecerá más ventajas, y a ella se inclinará todo el comercio. Entonces la ciudad abandonada tendrá que sufrir las consecuencias de esta desviación de las corrientes comerciales.

Esto es lo que yo he dicho, siempre conjeturando, porque no podemos hacer en esta cuestión otra cosa que conjeturar, aplicando soluciones, hechos conocidos, a los hechos a producirse" (Tartarini, 1982: 124-125) 
Hay algunos relatos que disculpan a los fundadores, que no habrían tenido "ni la más leve percepción del error cometido al haber elegido para la ubicación de la ciudad de La Plata", según se afirma en Creación de la generación del 80 -sin tomar en cuenta, por ejemplo, las oportunas críticas de Ortiz de Rosas-. Según este planteo, "lo que hoy nos parece un error, en realidad puede haber sido un desconocimiento del avance del hombre en las comunicaciones. Esa distancia que hoy nos parece tan irrisoria, tal vez en aquellos tiempos" fue considerada "suficiente para evitar ser absorbida por la Capital del país" (Zuccalá y Musmano, s/f: 28).

"La idea básica era convertir a La Plata en una gran ciudad portuaria", afirma Rica, uno de los ideólogos de Ciudad milagro, y asume: "En realidad, el proyectado y ejecutado Puerto La Plata consumió durante casi diez años la economía de la Provincia, hasta que finalmente en 1905 fue vendido a la Nación como obra frustrada y endeudada. Quedaron truncas las ilusiones y esperanzas" (Rica, en Lerange, 1982: 53-54).

La mayoría de los relatos abocados a los primeros años de la fundación se detienen en las obras del puerto, que buscó ser superior al de Buenos Aires, sin prever que éste también sería mejorado y luego reemplazado. Las características del puerto natural, el proyecto del ingeniero holandés Juan Abel Adrián Waldorp, las grandes obras y la inauguración oficial en 1890 son algunos de los tópicos tratados.

"El plan general del puerto fue concebido bajo las ideas de las prácticas modernas, en boga en ciertos pueblos europeos, particularmente en los de Holanda. El proyecto incluía la instalación de un elevador de granos, hecho digno de destacarse para la época" (Díaz, 1982: 201)

"Podríamos decir que se invirtió en la obra del Puerto de La Plata tanto o más dinero que en la construcción de todos los edificios públicos, incluyendo las edificaciones escolares de La Plata" (Rica, en Lerange, 1982: 54)

"Aunque la Provincia siguió construyendo el puerto de La Plata la batalla ya estaba perdida" (Bauer, en Lerange, 1982: 566)

"[La obra] completamente terminada, no recibió, sin embargo, la importancia que se buscaba originalmente para el desarrollo de la Ciudad, ya sea por su proximidad al de Buenos Aires, por las consecuencias de la crisis de 1890, o por las presiones e influencias políticas, que fueron apagando también la estrella del Dr. Rocha, el caso es que el Puerto de La Plata nunca fue exigido en la verdadera dimensión de su proyecto" (Cygan, 1981: 199-201)

Los relatos incluyen referencias al atraso en las obras, los obstáculos enfrentados y a la desatención que sufrió el puerto hasta su transferencia a la Nación, que lo relegó a un carácter secundario. Luego, el puerto tiende a desaparecer de la historia de La Plata. Obra de arte es uno de los pocos trabajos que siguen la cronología, caracterizándolo desde la instalación de la destilería en 1925 como dedicado a actividades petrolíferas, y señalando una paralización total desde 1968, seguida de reiteradas promesas de reactivación. En la coyuntura de 1982, la publicación asume una postura política favorable a su retorno a la provincia con el objetivo de privatizarlo: "Se abre así una nueva esperanza" (Díaz, 1982: 202). Más allá de esta declaración política explícita, cabe destacar de este libro un análisis técnico de la estructura y el movimiento portuario, la propuesta de una periodización a partir de la lectura de distintas variables y la comparación con otros puertos (Díaz, 1982: 202-209). El trabajo dedica a este asunto un número considerable de páginas con textos e imágenes, en un registro académico que al igual que la parte dedicada a la industria cierra con "conclusiones". 
El otro trabajo que propone un abordaje más analítico sobre el puerto es el publicado en Económica, que también se origina en la Facultad de Humanidades:

"La síntesis se inicia con el estudio del puerto de La Plata, uno de los elementos decisivos en la elección del lugar donde se asentará la capital bonaerense; seguidamente y merced a la necesidad de vincular la nueva urbe con la Capital Federal, el estudio deriva hacia los medios de transporte; el ferrocarril, tranvías y automotores; para culminar con una referencia a las actividades industriales y comerciales platenses, reflejo del dinamismo productivo de este medio urbano y sus adyacencias. Como complemento y corolario de este breve estudio, la actividad financiera -en estrecha vinculación con la evolución económica local- cierra esta síntesis valorativa..." (Cuccorese, 1982: 152. Las cursivas vienen del original) $^{204}$.

Lo más valorable es que propone un relato de historia económica, es decir, se corre de los tópicos más repetidos en referencia al puerto -la figura de Waldorp y el desarrollo de las obras- que tienen una impronta arquitectónica muy fuerte. Por otra parte, el texto descarga a los fundadores de toda responsabilidad por el fracaso del puerto: afirma que el centralismo hará "fracasar el propósito -satisfactorio en su formulación pero difícil de alcanzar en la práctica- de hacer del puerto de La Plata un vigoroso centro comercial [...] A pocos años de su inauguración, comienzan a evidenciarse una serie de obstáculos que se oponen a una dinámica actividad portuaria..." (Cuccorese, 1982: 153)

A la frustración de la ciudad-puerto y su proyección económica también se refieren libros como Primeros habitantes, centrado en la caracterización de La Plata como ciudad artística y cultural. En el tercer capítulo Terrasa alude al proyecto fundacional:

"Dardo Rocha había ideado una ciudad proyectada a una vida intensa y activa. Pensó en un emporio comercial e industrial. Esto podemos confirmarlo por las medidas urgentes que tomó: habilitación de un puerto de ultramar. Ensenada estaba destinada a iniciar un vasto intercambio comercial con la construcción de un canal para recibir barcos del exterior. Proyecto fantástico y previsor, sin alcanzar el destino que su creador quiso darle" (Terrasa, 1982: 25)

En el siguiente capítulo, dedicado a la Universidad nacional, hace otra mención breve del poderío industrial y comercial previsto por Rocha para la ciudad, concluyendo: "El empuje económico es importante; pero aventaja a esta actividad otra que gravita con caracteres bien definidos: el alto nivel cultural que hoy tiene la ciudad de La Plata..." (Terrasa, 1982: 31). Esta puesta en primer plano de la actividad cultural-universitaria, que analizaremos en el siguiente capítulo, junto a la celebración del trazado, terminan circunscribiendo La Plata a su casco urbano. Así, el relato posterga a los barrios periféricos y especialmente clausura un sentido original, condensado en su escudo: la ciudad pensada mirando al río.

\section{La pérdida del sentido de región}

De ese modo se consolida, en la mayoría de los relatos publicados en el centenario, el abandono de la mirada regional que incluya a Ensenada y Berisso, zonas con una actividad industrial importante que tienden a ser nombradas como meros partidos limítrofes.

\footnotetext{
${ }^{204}$ El tren aparecerá asociado al puerto La Plata, ya que el Ferrocarril Provincial buscó ser una línea de fomento, con tarifas reducidas, para trasladar los productos agropecuarios hacia allí (Cuccorese, 1982: 158).
} 
Cabe recordar que Ensenada y Berisso fueron autonomizados como municipios en $1957^{205}$. Las publicaciones que excluyen a estos distritos de su relato posiblemente lo hacen teniendo en cuenta esa decisión administrativa; sin embargo, también es cierto que fueron parte de la ciudad capital durante los primeros 75 años de 100, y que territorialmente forman una unidad.

No es casual que el puñado de trabajos que sí tienden a un reconocimiento de la región son aquellos producidos por arquitectos o geógrafos -además del libro de Familiares, cuya mirada integral se orientará al reconocimiento de una población obrera que también fue víctima de la represión estatal reciente- ${ }^{206}$.

El que expone con mayor claridad el carácter de la región como un complejo orgánico por encima de las divisiones jurisdiccionales es Ciudad nueva ciudad antigua, que al dar cuenta de la evolución platense incluye las comunidades de Berisso y Ensenada, que "configuran una unidad coherente y definida con la ciudad y resultan parte de la región de manera orgánica" (Morosi, 1983: 177, 372).

La conciencia regional, de hecho, es parte de lo que estos autores elogian a la planificación platense:

“...Esta circunstancia no ha sido destacada por quienes se han ocupado de La Plata, aunque posee indudable importancia, ya que el plan se extiende a las seis leguas cuadradas y veintidós centésimos que se expropiaron según dicha ley, más las tierras afectadas por la construcción del puerto, todo lo que totaliza una superficie de más de veinticinco mil hectáreas [...] constituyendo en cierto modo un antecedente del análisis regional, que algunas décadas después habría de desarrollar el escocés Geddes.

Si bien el concepto de región había sido manejado por los geógrafos europeos desde mediados del siglo, no son abundantes los ejemplos en los que las relaciones entre una ciudad y su región se hayan ilustrado cuantificadamente en un documento gráfico que traduce espacialmente las directrices que un equipo de planificadores recibe del poder político a fin de cumplir su misión [...] Se identifican así, aparte de las trazas de la ciudad y del pueblo preexistente de Ensenada, las áreas destinadas a las quintas y chacras de diferente tamaño, dimensionadas a partir del módulo básico de la manzana de 120 metros de lado; el emplazamiento del cementerio junto al ángulo sur de la ciudad y el del hospital regional de Melchor Romero; las superficies aplicadas a la construcción del puerto, terrenos para radicación de almacenes, depósitos e industrias junto al mismo, así como los necesarios para futuras expansiones; el sistema ferroviario de comunicación con la capital federal, el resto de la provincia y el país, y el planteo de los accesos carreteros, así como del camino Blanco de enlace entre La Plata y la Ensenada" (Morosi, 1983: 110)

Partiendo de esa noción regional, su relato histórico no sólo da cuenta de la construcción del puerto sino también de la aparición de los frigoríficos y la instalación de la Destilería YPF (Morosi, 1983: 178). A la decisión jurisdiccional de 1957 la califica como un “desmembramiento" (Morosi, 1983: 355, 372). Luego, la región pierde identidad:

\footnotetext{
${ }^{205}$ Esta autonomía, ciertamente reclamada por grupos de vecinos de esas localidades, cargaría también con una intencionalidad política del régimen instaurado en 1955, que vuelve a confirmar el higienismo progresista excluyente. Esta cuestión sólo es sugerida al pasar en Vida platense, donde se afirma que "el peso del peronismo se había hecho sentir en Berisso y Ensenada, constituyendo éste un factor preponderante, en opinión de algunos, para decidir, después del 55, separarlas de la capital bonaerense” (Soler, 1982: 230-231). Volveremos sobre este tema en el siguiente capítulo.

${ }^{206}$ Económica, en tanto, planteará una idea de región en otro sentido: "Los estudios socioeconómicos más modernos consideran que este aglomerado integra ya, junto con los partidos que tradicionalmente formaron el Gran Buenos Aires, un gran Eje Metropolitano" (Cuccorese, 1982: 151). Como veremos, la referencia al sistema metropolitano aparece también en Pesci y Morea (1982).
} 
“...presenta hoy un esquema de localización y relaciones que difiere sensiblemente de ese planteo fundacional y en el que se expresan las consecuencias de la distorsión y el fracaso parcial de los objetivos que lo sustentaban y le otorgaban su claridad conceptual [...] La ciudad y el puerto sufren, a partir de su desactivación, una pérdida cierta de identidad con esos objetivos y consecuentes posibilidades de desarrollo que no consiguen restituirle las posteriores instalaciones industriales de escala nacional radicadas en el área ni el propio funcionamiento de la ciudad, limitada a su rol de centro administrativo y de servicios, y en el cual aún el carácter de cultura que le otorgara la Universidad se ve fuertemente disminuido. La actividad del medio rural se desequilibra por la ocupación de las áreas de explotación por parte de otros usos (residencial, industrial, etcétera)" (Morosi, 1983: 351-353)

Otro de los aportes del urbanismo es la revista Ambiente, que incluye una síntesis de un breve estudio realizado entre 1979 y 1981 por CEPA y Consultora del Plata, que lamenta que la ciudad no haya "adquirido el rol nacional previsto y el modelo urbanístico ha sido descuidado y tergiversado, en particular, de su circunvalación hacia fuera”. En su hipótesis central, el estudio propone:

"asumir que en la unidad 'Gran La Plata' están contenidos los principios propios de la solución de este sistema ambiental. Hasta que no sea considerado como tal, superando sus fracturas jurisdiccionales, reproduciendo su rol original (con su gran puerto) e insuflándole uno nuevo y trascendente: el de subsistencia del sistema metropolitano de Buenos Aires, el vehemente sueño de sus fundadores será sólo una quimera irresuelta" (Morea y Pesci, 1982: 23)

En la misma edición, el propio intendente de facto llama a recuperar un sentido de región, incitado por preguntas de la revista sobre la relación con Berisso, Ensenada y el Puerto: plantea que "La Plata ha sido una historia de desintegración" y "no es concebible una gran capital sin puerto”. Según Abel Román, la conformación autónoma de Berisso y Ensenada "atentó contra la voluntad de la gran capital de reemplazo, como fue pensada por Dardo Rocha; no en vano el escudo oficial tiene, ocupando gran parte de su campo, la idea del puerto e incluso, La Plata se funda aquí por el puerto".

La tercera excepción en cuanto a la mirada amplia sobre la región es la guía turística La Plata 100, que como ya vimos incluye una serie de "circuitos fuera del casco" entre los que están Berisso y la Isla Paulino, el Puerto La Plata, Ensenada y Punta Lara.

De un modo similar, al repasar circuitos turísticos, Obra de arte también incluye la costa del Río de La Plata y un "circuito industrial" que mantiene -con ciertas contradicciones- un sentido de región. Esto podemos advertirlo sobre todo en los capítulos producidos desde el Departamento de Geografía. Inicialmente, el libro define el "Gran La Plata, ex municipio de Ensenada (1821-1882)" como

"formado por tres Partidos: La Plata, Ensenada y Berisso. Podemos sintetizar en un cuadro general, escrito y cartográfico, en lo territorial y económico, el espacio donde se iba a insertar la nueva capital:

\footnotetext{
${ }^{207}$ La sección Turismo y recreación (Díaz, 1982: 384-389), que se inicia con la aclaración de que "La Plata no representa hasta el momento un polo turístico importante en la Provincia de Buenos Aires", está dedicada a señalar "sitios de mayor interés" y "puntos de visita imprescindibles". En muchos casos reitera datos que ya fueron presentados en otras partes del libro. El registro de esta parte no difiere de una guía turística. Aquí hay un punto de contacto con la publicación de la Sociedad de Arquitectos, con la que coincide en el uso de la expresión "circuitos", si bien no refiere exactamente a los mismos. En Obra de arte ese término aparece explícitamente asociado a la política municipal: "Entre los circuitos proyectados por la Subsecretaría de Turismo de la Municipalidad, se ha pensado incluir uno de tipo industrial, que comprendería la visita a establecimientos fabriles de la zona, especialmente los situados en Berisso y Ensenada” (Díaz, 1982: 389).
} 
- En una zona portuaria a construirse, en relación directa con la nueva ciudad;

- Con una cadena industrial (saladeril) en pleno funcionamiento: Ensenada, Berisso y Atalaya (Magdalena);

- Con una comunicación ferroviaria (Buenos Aires Ensenada) inaugurada en 1872;

- Con una zona rural con posibilidades óptimas para el desarrollo agropecuario" (Díaz, 1982: 19$)^{208}$

La consideración conjunta de los tres distritos pareciera ser una decisión consciente sostenida por el origen disciplinar de una parte del grupo realizador:

“...desde esa perspectiva que teníamos en ese momento en la cabeza -y hoy también, con otra perspectiva- hubiera sido imposible dividirlo. Es una unidad física, tanto natural como económica y social, funcional... entonces hubiera sido imposible dividirlo. No sé si Norma Sala tuvo que discutir con los otros con relación a la imposibilidad de cortar La Plata y no incluir Berisso y Ensenada. Ahora que me lo decís me resuena algo de eso, me parece que se discutió. Me viene a la cabeza una cosa de este tipo, como 'nos dicen que tenemos que hablar sólo de La Plata y nosotros decimos que es imposible', una cosa así. Hubiera sido imposible. Teóricamente y empíricamente" (Entrevista a Luis Adriani, julio de 2011)

Además del interés por Berisso y Ensenada, Obra de arte da cuenta de la expansión de la ciudad más allá del cuadrado original. "A comienzos del presente siglo, y con la finalidad de orientar el crecimiento de La Plata hacia otras direcciones, son creadas varias villas mediante expropiación y loteo de tierras" (Díaz, 1982: 72). Incluye a Villa Garibaldi, Rufino Elizalde, Melchor Romero, Gonnet y City Bell -además de algunos loteos que no prosperaron-, sobre los que hace una ordenada y rigurosa descripción del crecimiento. Pero la caracterización de la zona de La Plata, Berisso y Ensenada como una unidad geográfica está tensionada por otras partes del libro que ocluyen la mirada sobre la zona industrial. En las conclusiones de Obra de arte se afirma que la ciudad homenajeada "cumple fundamentalmente, el rol de centro administrativo, financiero y de servicios" y que "entre sus funciones especiales se destacada el rol de ciudad universitaria” (Díaz, 1982: 398, 400).

Esa mirada es la que predomina en la mayoría de las publicaciones del centenario. Si observamos Ciudad Milagro, Berisso y Ensenada aparecen con dos capítulos específicos, ubicados casi al final del libro: "Berisso y el desarrollo del Partido de La Plata", de Horacio Alberto Urbañsky, y "Aporte de Ensenada a la Ciudad de La Plata", Carlos Antonio Asnaghi. Dos artículos entre cien, que están dedicados -más que a la región- a los partidos limítrofes que reivindican su propia personalidad. Y Asnaghi nos recuerda que La Plata nació en Ensenada, que la preexiste y es parte necesaria de su historia: ese partido "hoy mira con sincera admiración e íntima alegría la opulencia cultural y edilicia de su hija dilecta" (Asnaghi, en Lerange, 1982: 661).

Más allá de las excepciones señaladas, la operación simbólica de buena parte de la bibliografía platense hace desaparecer Ensenada y Berisso. Podríamos decir que las convierte

\footnotetext{
${ }^{208}$ Poco después afirma que en el centenario el Gran La Plata presenta tres sectores básicamente diferenciados:

“- El municipio de La Plata y sus Delegaciones, sede del gobierno provincial, destacándose esencialmente como centro cultural, deportivo y recreativo, con una intensa vida universitaria;

- El municipio de Ensenada, caracterizado por su zona industrial y turística;

- El municipio de Berisso, distinguido como capital provincial del Inmigrante, definida por sus numerosas colectividades extranjeras, que constituyen un pueblo laborioso y de iniciativas.

El Gran La Plata tiende a extender su influencia más allá de los límites de los Partidos de Magdalena, Chascomús y Brandsen, hasta alcanzar los ríos Samborombón y Salado; o sea más o menos la antigua jurisdicción del Pago de la Magdalena..." (Díaz, 1982: 20). La división de Ensenada y Berisso en 1957 será señalada como "una consecuencia de la evolución" (Díaz, 1982: 72).
} 
en ciudades sin historia -como dice el epíteto cuestionado que identifica a La Plata-, pero no por carecer de un pasado, sino por la ausencia de historias escritas, como las que proliferan en el caso platense, más allá de sus repeticiones y "baja calidad" de su escritura. Ciertamente, son escasos los textos que las cuentan. Como apunta James (2004: 17), el libro de Lía Sanucci, "Berisso, un reflejo de la evolución argentina (La Plata, sin mención de editorial, 1983), es la única historia formal de la comunidad". En el caso de Ensenada, son los aportes de Asnaghi, el historiador de Ensenada, los que reponen parte de esa historia ${ }^{209}$.

Así, en el mismo movimiento, La Plata se reduce a aquello que contiene su casco central, la actividad que ocurre sobre su trazado perfecto, las personas que recorren sus diagonales. Se convierte entonces en ciudad universitaria, deja atrás el río y reinventa el sentido de su propio nombre, como veremos a continuación.

\footnotetext{
${ }^{209}$ Hay no obstante otros trabajos que permiten aproximarse a la historia de esas comunidades. Para el caso de Berisso, además del propio James (2004), es fundamental el aporte de Lobato (2001). Sobre la presencia y la movilización obrera en Ensenada se suman trabajos recientes como el de Ivonne Barragán (2011) sobre el Astillero Río Santiago.
} 


\section{Ciudad universitaria, capital de cultura La invención de una razón de ser}

“...queremos una ciudad con los gérmenes prolíficos de un crecimiento indefinido, hija robusta del trabajo y el comercio, que si bien no se divorcie de los gustos artísticos, que revelan la civilización, se vean a la par los signos de un comercio activo, de una riqueza útil y la industria poderosa [...] Que al descubrirse desde lejos no sólo se distingan las altas y bellas construcciones del lujo, sino también las elevadas chimeneas de las usinas y las vastas edificaciones comerciales, que llame la atención el tráfico ruidoso y continuo..." (Mensaje de Rocha a la Legislatura, 14 de marzo de 1882, citado en Tartarini, 1982: 36-37)

“La Plata nació con la calma de su espaciada geometría. Un orden físico para un orden de pensamiento. Una pulcritud integrada. Convocatoria para la intensa vida espiritual. 'Ciudad de silencios', llamada por algunos. Pero silencios significantes, expresivos, custodios de palabras..." (Cipriano, en Lerange, 1982: 664)

“...determinados proyectos urbanos pueden comprenderse no sólo fundados y anclados únicamente en lo físico, arquitectónico y urbanístico, sino también a partir de la imposición de un relato que procura unir espacios y prácticas espaciales, exaltando algunos puntos de la ciudad en detrimento de otros, y legitimando ciertos recorridos..." (Carman, 2006: 139)

La identificación de La Plata como "ciudad universitaria" y "capital de la cultura" es el punto de encuentro de casi la totalidad de las publicaciones analizadas. Ese sentido construido sobre el muncipio, que tiene una base real en la presencia que adquirió la Universidad Nacional y su impacto sobre la vida urbana, confronta con el proyecto original de La Plata, que en su elogiada planificación de antemano no preveía albergar una universidad y que no la tuvo durante muchos años. La construcción de este potente imaginario de una "ciudad universitaria", entonces, tiende a borrar esa realidad de los primeros años, y opera a su vez en detrimento de la mirada sobre otras actividades y actores: la capital del saber, de las artes y la cultura, ocluye el reconocimiento de la presencia obrera o la producción frutihortícola, mencionadas sólo en algunos de los textos y a veces como meras curiosidades. También tiende a colocar en un plano secundario el carácter de ciudad burocrática-administrativa, sede de los tres poderes públicos provinciales.

Las producciones editoriales del centenario exaltan un epíteto que tiene una gestación previa, iniciada a proponerse la nacionalización de la universidad en 1905. El escrito de Bernárdez, compilado por Barcia, testimonia esa construcción temprana de la noción de ciudad universitaria. Ya entrada la década del '30 podemos leer a Arrieta en La ciudad del bosque: "La ciudad universitaria salvará, en cierto modo, el sueño frustrado de la ciudad desencantada" (Arrieta, 1935: 60).

El proyecto universitario dio una razón de ser a La Plata tras el fracaso del puerto que aspiraba a convertirla en la gran capital. Acaso tampoco adquirió el peso político anhelado por sus fundadores y también por eso se buscaron funciones sustitutas.

Rastros y rostros evoca aquella crisis: 


\begin{abstract}
"Factores políticos, crisis económica, decepciones, quisieron dejarla inconclusa. Sola. Inmensa en la grandiosidad edilicia que no podía sostener el pulso originario.

Aníbal Sánchez Reulet en el prólogo del libro de homenaje a Dardo Rocha, describe con acierto ese período crucial que paraliza sus vibraciones como si un gran cansancio hubiera cedido la ilusión a la desesperanza.

Sin embargo, en el destierro de la luz quedaron los que artesanaron la penumbra. Los que creyeron. Los que sostuvieron su fe con mucho temple. Los que recogieron para el alma la plegaria de aquel primer Te Deum de San Ponciano..." (Calvo, 1982)
\end{abstract}

Sobre esa adversidad aparece el nuevo proyecto, que hará crecer tras el Paseo del Bosque "una soleada ciudad universitaria" (Calvo, 1982). En un fragmento de ese libro, organizado en torno a la recurrente pregunta por dónde está la ciudad, Calvo escribe: "Está en el testimonio de su pasado y en la certeza de su incomparable significación y está sin duda fundamentalmente erguida sobre la aristocracia de pensamiento, en la epopeya de un humanismo que la enaltece" (Calvo, 1982).

En su aporte a 12 personalidades, Elsa Hounie de Mondolfo escribe: "La ciudad tuvo un trazado geométrico. Y una Universidad. Una Universidad moderna, sin togas, donde pudo darse la Reforma Universitaria" (SADE La Plata, 1982: 95). Así contextualiza a su biografiada, Juanita Cortelezzi, quien fue profesora titular de la cátedra de Mineralogía y Geología del Museo y llegó a directora del Colegio Secundario de Señoritas.

Cuando se asocia el "orden físico" al "orden de pensamiento", como propone Néstor Cipriano al definir la "Personalidad de La Plata" en Ciudad milagro, el trazado perfecto se convierte en la base de la ciudad del saber. En la misma compilación, Canestri afirma que "el cultivo de las bellas artes y el humanismo quizá pueden definir el entorno dentro del cual se desenvuelve la actividad de la ciudad". Y los escritores Sajón de Cuello y De Giusseppe definen a La Plata como una pequeña Atenas (Lerange, 1982: 250, 114).

Hacia el final del libro, por su parte, Conrado Bauer destaca de la armoniosa ciudad a "su Bosque y su Universidad, que le inyectaron a la joven urbe savia y saber vivificantes y le imprimieron, junto con su primigenia capitalidad, genio y carácter" (en Lerange, 1982: 561). Para el ingeniero y ex funcionario, que durante la dictadura se desempeñó como ministro de Obras Públicas y además presidió la Fundación del Museo de La Plata,

"La instrucción, la sanidad, la belleza, la ciencia y la cultura aparecieron, como vemos, en un rango privilegiado de preocupación de los conductores para integrarlas a la nueva ciudad desde el mismo inicio de su proceso gestatorio, antes de la fundación [...] Así fue como La Plata atrajo luego a sabios, pensadores, artistas, maestros y estudiantes que encontraron en ella ámbito propicio para su formación, sus enseñanzas y su labor creadora. Tal fue un rasgo distintivo que configuraría con el andar del tiempo uno de sus títulos sobresalientes, quizás el más glorioso" (en Lerange, 1982: 564)

En el Diccionario de Arte, Conti y de la Torre sostienen que "a cien años de su fundación, La Plata se ha convertido en uno de los centros urbanos más importantes del país. Su Universidad la define como foco cultural de primer orden" (en Nessi, 1982: 227).

Educadores, artistas y científicos

"La Plata está en sí misma y más allá de sí misma [...]

El progreso la respeta [...] Las ciencias y las artes encuentran en la ciudad de Rocha un fértil anidar. La Universidad le dio un tono docto. Prudentemente docto" (en Lerange, 1982: 664) 
"La ciudad y la cultura constituyen una simbiosis cuya significación tiene tal entidad que requiere insoslayablemente la una de la otra para su interpretación genuina. La poesía como parte de las dos ha tenido también sus apariciones intermitentes y dolorosas. No podía pues, dejar de manifestarse en la conmemoración que ha precipitado una fuerza espiritual en el platense que está más allá de puntos de vista o desencuentros" (Abel

Román, en el prólogo a Themis Speroni, 1982: 9)

La idea de ciudad universitaria se construye sobre un imaginario más amplio, el de La Plata como capital cultural, que también se expresa en las identificaciones de una ciudad educativa, de artistas y poetas, de científicos y sabios. La definición "universitaria" es la que penetra más profundamente en los relatos sobre el pasado de la ciudad, aunque asociada a esos otros sentidos próximos que la alimentan.

Obra de arte, el libro realizado desde la universidad por encargo del Estado municipal, plantea que "el clima intelectual" de La Plata, "propicio para el surgimiento de una sensibilidad estética especialmente inclinada hacia las letras, acompaña a la ciudad desde sus comienzos..." (Díaz, 1982: 262)

La asociación de La Plata con la educación está muy marcada en Ciudad milagro, entre otros libros. Las coordinadoras Patricia Coto y Lilia Guzmán dedican su capítulo, subtitulado "Páginas de estudiantina platense", a las escuelas. Se trata de un largo texto que recorre distintas instituciones locales -el otro libro voluminoso, Obra de arte, incluye un apartado similar-. Casi a continuación viene el aporte de María Dolores Corro abocado a la Asociación de Maestros de la Provincia de Buenos Aires -creada en 1900- y más adelante capítulos sobre la enseñanza de periodismo y los estudios lingüísticos en la ciudad.

También Primeros habitantes insiste en esta ciudad educativa, sabia, detallando instituciones y nombres. En su tercer capítulo menciona al primer Director de Escuelas, a los colegios pioneros -incluyendo el "recuerdo" del primer director/a, los primeros docentes, los primeros alumnos-. Lo arquitectónico -como vimos en el capítulo anterior- es otra dimensión atendida: Terrasa destaca la "majestuosa construcción" del edificio de la Dirección General de Escuelas y también de las sedes escolares. Con todo, dice, "la instrucción primaria va adquiriendo esa jerarquía que hoy destaca a La Plata en el concierto de las grandes ciudades modernas" (Terrasa, 1982: 27).

En su totalidad, el libro editado por el sello Almafuerte pone enfáticamente su mirada sobre aspectos culturales y artísticos de La Plata. Tras dos capítulos iniciales dedicados a los "primitivos habitantes" y a la fundación, el índice se concentra en instituciones, figuras y definiciones culturales sobre la ciudad:

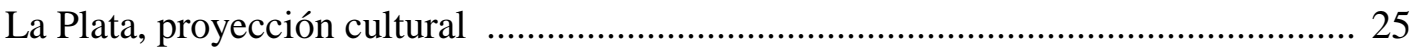

Fundación de la Universidad Nacional de La Plata ................................................. 31

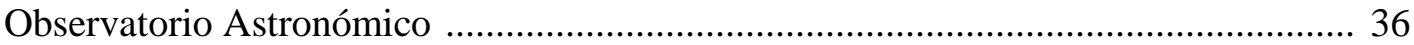

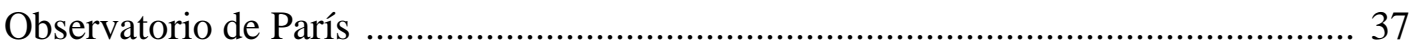

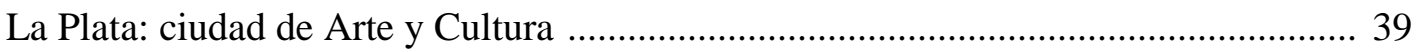

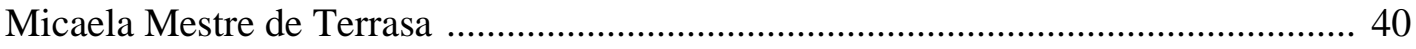

Escritores, poetas y artistas plásticos, en la Ciudad de las Diagonales ........................ 41

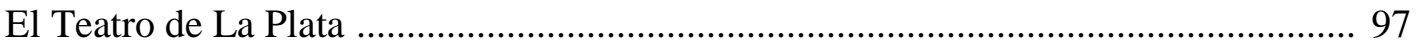

Héctor M. Rivera (Un hijo adoptivo de La Plata) ...................................................... 99

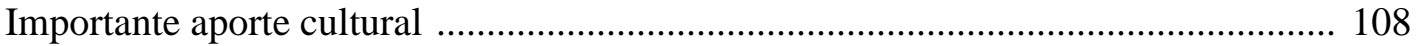

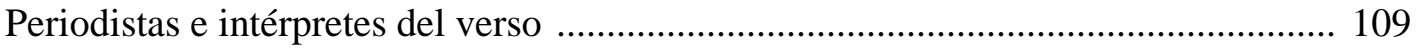

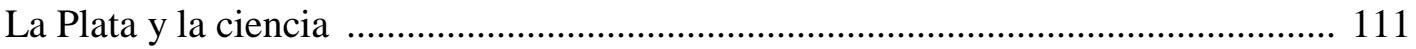


Protección y conservación de la Naturaleza

Universidad Notarial Argentina

Todo el tiempo está presente la imagen de una capital del saber: "El cielo platense da albergue a una permanente cultura, cuyos protagonistas no abandonan su obra en su afán de alcanzar el más alto nivel de progreso". La metáfora del cielo también aparece en el prólogo de Barba a Ciudad milagro, donde recorre distintos motivos culturales, entre los cuales señala al Observatorio Astronómico: "Pocas ciudades en el mundo a poco más de un par de años de su fundación o de sus orígenes, si se quiere, pueden mostrar una constelación tan brillante como el [sic] que iluminó el cielo cultural de La Plata" (en Lerange, 1982: 14).

Terrasa sostiene que ese "vergel de sabiduría y belleza" surge desde distintas "ramas del saber, del buen decir y de la imagen plasmada en colores" (Terrasa, 1982: 41). Ya en una de las solapas del libro, aquel imaginario emerge con contundencia:

"El planteo de los educadores más prominentes, sabios, políticos, escritores de fuste, entre los que se destacan los poetas, escribanos, abogados, médicos, astrónomos, antropólogos, veterinarios, arquitectos, etc., han sido, desde su fundación, los que han dado brillo de inteligencia y sabiduría a esta hermosa ciudad de clásicos palacios, diagonales y perfumados tilos... De sus claustros provienen la más alta formación humanística y profesional, y llamarla 'ciudad de sabios y poetas', 'la cuna de la sabiduría', 'la docta' es expresar la más ajustada verdad. Los hombres y mujeres que aquí bebieron su conocimiento, esparcidos por el país y el mundo, llevan un sello que los distingue: su preclara intelectualidad, su acendrado amor por saber, su condición de almas de cuño" (Terrasa, 1982. Las cursivas son mías)

Además de las instituciones educativas y en particular la universidad una vez nacionalizada, la actividad editorial, los grupos e instituciones culturales y la producción artística se presentan como expresiones de esa ciudad letrada. También los teatros y muy especialmente la presencia de poetas.

Las expresiones son diversas, sobre todo en los libros formados a partir de la compilación de aportes de distintos autores. En Ciudad milagro, por ejemplo, podemos encontrar un artículo dedicado a una edición platense de El ingenioso Hidalgo Don Quijote de la Mancha, reivindicada como la "primera edición argentina del Quijote [...] en el año 1904, hecho poco conocido, que merece ser recordado como una de las mayores glorias literarias de la ciudad" (Guzmán, en Lerange, 1982: 364).

Más adelante encontramos otros capítulos que destacan la producción editorial, en particular la creación de revistas. Alcaraz aporta un texto abarcativo sobre las "Revistas de la ciudad nueva", en cuyo inicio hace una caracterización de la población que vale retomar:

"La Plata, aunque nació por obra de una política descentralizadora, está muy cerca de Buenos Aires, y respira casi su mismo aire. Se consolida sólo en dos facetas que con los años la tipificarán: la burocrática y la universitaria. Entre las dos fluctúa una especie de provincianismo comunal que cuenta por cierto, con hombres de progresistas iniciativas. Estas tres facetas contribuyen con sus materiales diversos, debilitados o enriquecidos por variantes de época, a la contextura ciudadana que se manifiesta a diario en el movimiento cultural..." (en Lerange, 1982: 419)

Luego, se aboca a un índice de revistas que en lo sustantivo no es un aporte original, ya que retoma un trabajo elaborado veinte años antes para el libro sobre la ciudad realizado en 
homenaje al centenario de Joaquín González (VV.AA., 1963) ${ }^{210}$. En la página final intenta actualizar ese relevamiento:

"Durante la primera parte de la década del 60 (de signo ascendente en nuestra cultura) dos revistas literarias reunieron a poetas, narradores y pintores de vanguardia: Espacios y Diagonal Cero" (en Lerange, 1982: 424)

En el marco de una breve referencia a la producción reciente, cabe destacar el reconocimiento de esta última revista -también realizado por Nessi-, producida por un artista innovador cuyo hijo, militante del peronismo de izquierda, fue desaparecido durante la dictadura. "Diagonal Cero, alcanzó los 28 números, con el hecho insólito de que el $\mathrm{N}^{\circ} 25$ no salió porque su editor, el plástico Edgardo Antonio Vigo, lo dedicó a la Nada", comenta Alcaraz (en Lerange, 1982: 424) ${ }^{211}$.

El capítulo que le sigue en Ciudad milagro es la "Evocación de una revista platense" y está dedicado a Cuaderno de la Costa, que "nació en 1950 y su tercer y último número apareció en 1951 [...] su gestión fue casi tan larga como su vida" (en Lerange, 1982: 427). El autor es Alfredo Ves Lozada, que había sido director de esa publicación, y durante la última dictadura se desempeñó como decano de la Facultad de Derecho de la UNLP.

El texto sobre el Cuaderno de la Costa nos permite advertir el carácter antojadizo y sesgado de la compilación, que dedica uno de sus artículos a una revista prácticamente desconocida que sólo publicó tres números, mientras que publicaciones significativas para la historia platense apenas son mencionadas, o ni siquiera.

Por otra parte, hay capítulos dedicados a medios radiales y televisivos. El abocado al Canal 2, brevísimo, es uno de los que no indican autor. Sostiene que la señal "siempre trató de ofrecer, más allá de las necesidades operativas de un medio de comunicación masiva, una imagen platense acorde con el estilo de vida propio a la Ciudad Universitaria" (en Lerange, 1982: 539). El que reseña la historia de la LR11 -la "primera emisora universitaria argentina"también destaca esa característica de la ciudad: “[En 1923] La Plata, ciudad provincial que contaba apenas con unas 300 cuadras adoquinadas, poseía en cambio, una universidad pujante [...] Un cierto ángel parecía caminar por entre los tilos, contagiando a sus habitantes una inquietud espacio-temporal" (en Lerange, 1982: 537).

Otro capítulo, "La Plata coral", refiere al surgimiento del canto de coros en la ciudad, hacia 1941, calificado como un "milagro de la paz, del amor, de la confraternidad". Uno de los destacados es el Coro Universitario, "hijo dilecto de la ciudad". La referencia permite aludir a la "alegre estudiantina" (en Lerange, 1982: 523-524).

Entre las instituciones culturales aludidas en Ciudad milagro está el Museo de Bellas Artes. Ponce de León se encarga de destacar que, pese a su carácter provincial, su decreto de creación en 1922 refiere a La Plata, "con lo cual impuso la obligatoria residencia del naciente Instituto en nuestra ciudad, y abrió el camino para que con el tiempo se convirtiese en otro motivo de orgullo para los platenses" (en Lerange, 1982: 187).

\footnotetext{
${ }^{210}$ Encontramos otro índice en el $N^{\circ} 28$ de la Revista de la Universidad. El artículo consiste en un listado cronológico de 270 revistas platenses y apenas contiene dos o tres párrafos de interpretación o contextualización en los que intenta reconocer períodos. Se concentra en las primeras décadas: "Una rápida mirada a estos cien años transcurridos muestra a una ciudad preocupada por su vida cultural..." (Manes de Della Motta, 1982: 96) ${ }^{211}$ La que no es mencionada en ningún caso es Hexágono/71, la publicación experimental que Vigo realizó entre 1971 y 1975, con trece números editados. Heredera de experiencias previas como la mencionada Diagonal Cero (1962-1969) y otras anteriores, fue la primera que aludió explícitamente a asuntos políticos nacionales e internacionales, mixturando su mirada artística con un discurso contra la represión y el imperialismo.
} 
En un tono más "íntimo", Lahitte dedica un capítulo al "GARS", sigla que significa el Grupo Amigos de Ricardo Sánchez ${ }^{212}$, una suerte de taller-escuela que funcionó en 19711972. Según indica, es uno de los "cientos de artículos" que la escritora publicó en la década del "70: "elijo este que se vincula estrechamente con una época de nuestra ciudad y con algo que, en su momento, significó un acontecimiento sociocultural" (en Lerange, 1982: 469)

En tanto, el texto de Pacheco dedicado al Club Universitario relata su actividad cultural:

"Aún son recordadas las notables presencias del profesor Américo Ghioldi; el escritor, periodista e historiador Félix Luna; el doctor Enrique M. Barba, presidente de la Academia Argentina de Historia; el concertista Cacho Tirao; el doctor Pedro Badanelli, y tantos otros que gracias a su reconocida actividad artística, supieron engalanar la programación cultural de Universitario" (en Lerange, 1982: 456)

Cabe notar la reiteración de nombres y la confluencia de signos ideológicos. Como vimos, Enrique Barba es uno de los autores más recurrentes del corpus analizado, cuya presencia aporta a varias publicaciones el sello de "validación" de la Academia de Historia. Félix Luna también participa de los relatos del centenario, con un artículo en Ambiente. Años más tarde, en 1989, publicaría su libro más emblemático, Soy Roca, la biografía de quien comandó el exterminio indígena de la "Conquista del Desierto". El historiador y divulgador de filiación radical se oponía al revisionismo que comenzó a cuestionar la figura del militar y ex presidente. Durante la dictadura, Luna fue titular de la cátedra de Historia Contemporánea en la Universidad de Belgrano, condujo un programa de radio entre 1977 y 1982, y participó de la película apologética del Mundial de Fútbol titulada La fiesta de todos. Por su parte, el dirigente del Partido Socialista Américo Ghioldi, que representó el más férreo antiperonismo al interior de ese partido, fue partícipe del gobierno golpista aceptando un cargo de embajador en Portugal. Ingresado a la Academia de Ciencias Morales y Políticas en 1966, es el autor de la expresión que identificó a los trabajadores peronistas con la oposición alpargatas versus libros. El obispo de origen español Pedro Badanelli, en cambio, tuvo una fuerte identificación con el justicialismo, sostenida desde su filiación católica y con un profundo sentimiento anticomunista $^{213}$.

Otro grupo de aportes incluidos en la compilación de la SEP valora la actividad teatral, señala a La Plata como "ciudad de poetas" y más genéricamente destaca a la ciudad por su actividad artística.

Albarracín dedica un capítulo al Teatro Argentino, primer teatro lírico de Sudamérica, "legítimo orgullo de una ciudad pujante y segura de su destino luminoso": “...casi podría afirmarse que no debe haber ningún teatro en el mundo que, en un período de tiempo igual, haya visto desfilar por su escena tantos artistas y compañías de celebridad mundial" (en Lerange, 1982: 302, 296). La exaltación de ese espacio se registra en muchos textos de la época, más allá de su historia plagada de litigios que lo hizo estar "más tiempo cerrado que abierto" (Sureda, 1982: 57) y del incendio que llevó a su destrucción en 1977. Una de las

\footnotetext{
${ }^{212}$ Ricardo Sánchez fue un artista plástico local. Entre otras cosas, cultor de la Escuela Clásica de Mosaistas del Vaticano. "Orientador de generaciones vocacionales cuya cuantiosa obra de pintor, decorador, constructor de sus propios hornos, etc., desde el taller y la cátedra, le han valido ese bien ganado reconocimiento. La ciudad le debe su monumento al igual que a Boveri, entre otros", considera Francisco Guerrero (en Lerange, 1982: 222)

${ }^{213}$ Abogado y profesor de literatura, durante el primer peronismo Badanelli ofreció al líder encabezar una Iglesia Justicialista al margen de la Iglesia Católica Romana, proyecto clausurado por el golpe de 1955. Tras la vuelta de Perón en 1973, apoyado por José "El Brujo" López Rega, concretó su "Iglesia Católica Apostólica Argentina" (ICAA) -no romana-, de filiación justicialista.
} 
promesas del presente, en los textos del '82, era la construcción de un nuevo teatro, desistiendo de la posibilidad de reconstruir el anterior. Varias de las publicaciones aplauden y alaban ese proyecto de la dictadura, lo que implica cierta contradicción con el discurso patrimonialista que plantean en otros momentos.

Otro artículo de Ciudad milagro, "El teatro que vivimos... el teatro que queremos", amplía la mirada hacia otros ámbitos y experiencias teatrales, resaltando un movimiento independiente que llevaría a la creación de la Comedia de la Provincia de Buenos Aires" (Sobreiro y Girotti, en Lerange, 1982: 330).

La preeminencia de la poesía, en tanto, es señalada en uno de los capítulos iniciales, "La Ciudad y sus poetas". Sajón de Cuello y De Giusseppe -dos integrantes de la entidad que impulsa la compilación- intentan caracterizar una presunta "Escuela Platense" a la que pertenecieron Rafael Arrieta, Héctor Ripa Alberdi y Francisco López Merino, entre otros, y que se habría caracterizado por una "poesía crepuscular, de desvaídas sombras, hondamente intimista (no ha perdido ese rasgo); hecha para la lectura silenciosa o a media voz; fugaz, efímera, apenas un aliento, líricamente vivenciada en el instante inasido del tiempo" (en Lerange, 1982: 114).

Según los autores, "cada vez que se habla de La Plata se conjugan, por extraño designio, dos notas que la definen, sin mentarla: tilos y poetas" (en Lerange, 1982: 113). Ciertamente, la tipificación como ciudad de poetas no es exclusiva de la publicación de la SEP. Cabe recordar la reedición de la poesía completa de Speroni que realizan en 1982 el Colegio de Escribanos y la Municipalidad. Al introducir este libro, Lahitte apunta:

"La trayectoria avasallante de su existencia, su pasión creadora; aquello que podríamos llamar su luminosa ferocidad intelectual, la llamarada de su talento, nos habilitan para aseverar que la ciudad de La Plata confirma una vez más su casi secular derecho adquirido a ser considerada Ciudad de los poetas, al enraizar en su misterio y en su tradición humanística la voz de Roberto Themis Speroni” (Lahitte, en Themis Speroni, 1982: 14)

En Ciudad de Mayo Urraza se refiere a diez poetas y entre ellos recuerda a Arturo Capdevilla, quien "evocando los primeros tiempos de soledad de La Plata, advirtió que después vinieron los poetas a consolarla" (De Urraza, 1981: 47).

En Primeros habitantes, el primer apartado, titulado "La Plata ciudad de arte y cultura" está dedicado a poetas. Se listan 52 platenses de los cuales, en general, se transcribe un poema más una alusión breve al autor y/o a su obra, de uno a cuatro párrafos. Entre ellos están Aglae D’Sylva y Lázaro Seigel -dos de los que prologan el mismo libro, elogiándolo-, Alcides Degiuseppe -identificado como un estudioso de "los inicios literarios de la ciudad fundada por Rocha"-, Matilde Alba Swann -presidente de la Sociedad Argentina de Escritores y también presidente de la Comisión de Minoridad del Colegio de Abogados de La Plata- e Irene Ene -la compiladora de 12 personalidades, publicado por la misma editorial-. La mayoría de las poesías transcriptas de las que se indica fecha son recientes, escritas o publicadas hacia 1980-1981. Un rasgo llamativo es el tono religioso de varias de ellas, alusivas a los designios de Dios, etcétera.

En aquella lista se "cuelan" también unos pocos que no son poetas. Odin Gómez Lucero es identificado como creador de una institución cultural indigenista abierta a todo público en La Plata, el Museo Yana Kuntur. María Carmen Negri, artista plástica, aparece en medio de las poesías, sin párrafo de presentación. Del ámbito del teatro se referencia a Alberto M. 
Oteiza. También se incluye al investigador y dirigente institucional José María Prado, del que hay una presentación pero no se trascribe ningún escrito. Lo mismo sucede con Carlos Mario Terraz, diseñador industrial y joven artista, vinculado al Club Universitario. El libro continúa con una parte dedicada al teatro que repasa autores, obras y algunos lugares a través de la transcripción de un texto de Héctor Rivera, quien también participa de otras publicaciones ${ }^{214}$.

Volviendo a Ciudad milagro, encontramos también otros capítulos sobre teatro y dos dedicados a conservatorios musicales, entre otros espacios de producción cultural. Y es Nessi quien define a La Plata como una "ciudad madura en las artes, con un acervo que no sólo posee resonancia nacional, sino internacional". El director del Instituto de Historia del Arte Argentino y Americano reclama que los platenses reconozcan "estas realidades y desborden el cerco localista para proyectarse, mediante un consenso digno de la ciudad universitaria y culta, hacia más altos destinos" (en Lerange, 1982: 127. Idem en Díaz, 1982: 281-283). Los planteos de este historiador y crítico de arte, que incluyen una periodización de la trayectoria del arte plástico local, también están incluidos -sin firma- en Obra de arte, y se desarrollan más ampliamente en la obra que dirige:

"Si hubiésemos de buscar una clave que explique el éxito de tantos artistas platenses más allá de las fronteras nacionales encontraríamos, como es lógico, una forma nueva de existencia, una constante diacronía ligada al contexto social, a la vez agredido y consagrado por la expresión del misterio, de la forma que ordena el caos primordial o del 'desorden creador' que aspira a rescatar al hombre enajenado de la sociedad de masas. La Plata ha sido fiel caja de resonancia; ha sido capaz de compensar el decalage con que los movimientos estéticos se recibían en el país antes de 1924..." (Nessi, 1982: I-III)

El aspecto artístico también conjuga con la ciudad universitaria. La Plata lo es "aún en el sentido artístico" -según plantea el fragmento dedicado a la plástica en Obra de arte- "ya que la propia Universidad asumió -desde hace tres cuartos de siglo- la educación artística por intermedio de su hoy Facultad de Bellas Artes. Ello ha configurado el perfil, no sólo de sus graduados, sino además el de los autodidactos, quienes, de alguna manera, se sienten íntimamente confortados" (en Díaz, 1982: 281).

Por su parte, varias páginas de Ambiente están dedicadas a siete entrevistas con referentes culturales de La Plata ${ }^{215}$. En una nueva muestra de los cruces entre las distintas publicaciones, cabe advertir que cinco de esos entrevistados participan como autores en

\section{Ciudad milagro.}

Finalmente, además de la ciudad educativa, la ciudad de los poetas y esta ciudad madura en artes, una presencia que caracteriza a la ciudad universitaria es la producción científica, encarnada por el trabajo de sabios que se constituyen como personalidades platenses. El Museo de Ciencias Naturales y el Observatorio Astronómico - previstos desde el primer día de

\footnotetext{
${ }^{214}$ El capítulo se completa con tres referencias muy fragmentarias: una, bajo el título "Un importante aporte cultural", menciona a Susana Coradazzi como "excelente cultora" de la danza española y clásica; otro más breve, titulada "Prof. Sarita del Carmen Ugazi", brinda reconocimiento a esa escritora. Finalmente hay una página dedicada a "Periodistas e intérpretes del verso".

${ }^{215}$ En ningún caso está indicado el entrevistador. Los diálogos están presentados en una tipografía reducida -más pequeña que el resto de la revista-. Mantiene la diagramación con fragmentos de textos en el margen superior: arranca con "Lección de optimismo" de González, sigue con un verso de Almafuerte y un fragmento de Borges sobre ese escritor; una cita de López Merino, una ilustración de Carlos Pacheco (Urbus, 1981), un artículo de Pettorutti y varios textos extraídos de El Día: uno sobre la "triste soledad de las estatuas", otro sobre el Museo (firmado por Luis De Santis, su director, en febrero de 1982) y otro sobre la Sala La Plata de la Biblioteca de la UNLP (son declaraciones que hizo en 1981 el director de esa entidad, entrevistado en la misma página).
} 
la ciudad y un cuarto de siglo más tarde incorporados a la Universidad Nacional- aparecen como lugares de referencia; en tanto figuras como Vucetich, Spegazzini y Ameghino se suman al panteón de próceres que analizaremos más adelante.

Los libros ya citados contienen capítulos que incorporan esta dimensión. Primeros habitantes, luego de referirse al Archivo Histórico (;del que transcribe los nombres del personal!), menciona al Observatorio y dedica palabras elogiosas a sus "grandes directores".

En tanto, la referencia al Museo como escenario de la labor científica resulta ineludible para la mayoría de los libros. Generalmente se cuenta una historia color de rosas, que glorifica a su fundador Francisco Pascasio Moreno y no tematiza el rol cumplido en las campañas de exterminio de los pueblos originarios, el origen de sus colecciones de restos humanos y la presencia de indígenas cautivos y en exposición durante los primeros años de la institución (Badenes, 2006). Esa otra historia sólo se advierte en algunos pasajes de los relatos compilados en Viajeros, tales como el de Federico Rahola en 1903 (en Barcia, 1982: 230231) o el de A. S. Forrest, que en 1912 escribió: "El museo de La Plata es un magnífico edificio, con muchas cosas de interés para el antropólogo, pero resulta más bien horripilante para el visitante común, a quien impresiona la enorme colección de cráneos y esqueletos de indios americanos que ocupa muchas salas y cientos de vitrinas" (Barcia, 1982: 269).

Entre los artículos compilados en Ciudad de mayo, varios versan también sobre aquel museo. Urraza alude a la fundación en 1887, sobre el final de la gobernación D’Amico, y repasa una polémica historiográfica acerca de la fecha de origen del Museo, cuyas colecciones datan de antes de la creación de La Plata. Además de su aporte antropológico, el autor apunta a resaltar los valores artísticos del Museo, vinculado a las obras de Coutaret y De Pol (De Urraza, 1981: 99-108). El texto incluye una reivindicación institucional: "al servicio de los intereses nacionales comprometidos, [el Museo de La Plata] ha demostrado así, que los establecimientos de su género no son solo custodios de vidas extinguidas, sino también una escuela formativa de científicos, centinelas de la patria”, escribe Urraza (1981: 109).

El investigador del Museo y ex decano de la Facultad de Ciencias Naturales Mario Egidio Teruggi es el principal encargado de dar cuenta de la ciudad científica en la compilación publicada por la SEP. Según este autor,

"Los epítetos que La Plata, como centro intelectual, ha merecido a través del tiempo, provienen de humanistas. Así, en 1914, el periodista español Enrique Gómez Carrillo la llama 'El Oxford argentino', denominación que reconoce haberle sido sugerida por Leopoldo Lugones. Más cerca de nosotros, el Profesor Luis M. Lunazzi [sic] aludía frecuentemente a la capital provincial llamándola 'La Atenas de la Argentina" (en Lerange, 1982: 103)

Teruggi reconoce a La Plata como un centro del saber pero propone un matiz al distinguir los aportes de las humanidades y los de "las ciencias", que muchos abordan en conjunto. Esto implica cierta crítica a aquel relato -muy presente en la época-, dado que para Teruggi la identificación genérica de una "capital intelectual" tiende a dejar en un segundo plano a la producción científica:

"Por lo general, los homenajes, tributos e historias escritas sobre la ciudad se han ocupado de sus aspectos 'culturales', quedando fuera de ellos los científicos. La disyuntiva de C.P. Snow -humanismo frente a ciencia, las dos culturas del mundo actual- parece haberse planteado desde temprano en la misma vida de la ciudad, en cuyo ámbito universitario suele a veces contraponerse 'El Centro' a 'El Bosque', dos símbolos urbanos que marcan, las dos culturas. En esa dicotomía, las humanidades y las 
artes se han llevado las palmas de la publicidad, como lo atestiguan, frente a los pocos sobre La Plata Centro de Ciencias, la gran cantidad de notas, artículos, ensayos, folletos y libros sobre La Plata Centro de Cultura. Escapan un poco a esta situación el Museo, en primer lugar, y el Observatorio Astronómico después. Pero un grueso número de institutos, centros, laboratorios y, por supuesto, las personas que se han ocupado del quehacer científico platense, apenas son reconocidos y menos aún recordados. Esto no fue siempre así, pues hubo períodos en que La Plata conocía a sus prohombres científicos" (Teruggi, en Lerange, 1982: 103)

Así, el objetivo -ciertamente inabarcable- de su aporte a Ciudad milagro es componer un panorama integral de la evolución de las ciencias en La Plata. Por su especialización como naturalista, dice, se limitará a algunos aspectos de las "ciencias puras". Su recorrido abarca menciones a notables del cuerpo docente-investigativo de la Universidad Nacional, publicaciones y lugares de reunión de científicos -como lo fue el Hotel Sportman-, y visitas ilustres como la del físico Alberto Einstein (Lerange, 1982: 103-106).

Teruggi destaca al Museo de Ciencias Naturales como un "lujo científico", pero su relato no reproduce el planteo clásico y más reiterado, dado que resalta a la institución pero no a la figura de Moreno, como hacen la mayoría de los textos. Por el contrario, a la hora de destacar figuras que "concitaron la admiración ciudadana", elige otras tres personalidades: Florentino Ameghino, Carlos Spegazzini y Enrique Herrero Ducloux, "tres hombres símbolos de la cultura científica" que según el autor tuvieron muchas características en común: "no fueron ricos ni ganaron mucho dinero", tuvieron "laboriosidad y dedicación" y "representaron modelos para imitar" (Teruggi, en Lerange, 1982: 106-108) ${ }^{216}$.

Sobre el Museo de La Plata hay un capítulo específico en Ciudad milagro, formado por las conferencias de Luis de Santis y Jorge Kilmurray en el Ciclo Cien años, donde sí encontramos la habitual exaltación del "perito". En el texto que corresponde al primero, abocado a un recorrido histórico, el cautiverio del cacique Inacayal en el Museo es presentado como una estadía casi placentera:

“...Clemente Onelli, en alguno de sus escritos, recuerda afectuosamente que vivió en el Museo y también se alojaron allí, los caciques Inacayal y Foyel con sus respectivas familias, unas 15 personas en total [...] Foyel y también Saihueque pudieron regresar pero Inacayal, a quien Bertomeu considera como el precursor auténtico de Bariloche, murió en el Museo en 1891 [...] Mientras estuvo viviendo en el Museo, Víctor De Pol esculpió del natural, la cabeza y la figura del cacique" (en Lerange, 1982: 473) ) $^{217}$

Otro libro que se ocupa de esa entidad es Vivencias y testimonios. En este caso, el repaso de algunos personajes de la institución tiende a mencionar acontecimientos vinculados a la institución médica. Cabe recordar que el Museo fue el marco institucional donde se originó la primera propuesta de lo que luego sería la Facultad de Medicina platense.

\footnotetext{
${ }^{216}$ Teruggi escribe también que "aún hoy, en estos momentos brumosos del país y del mundo, los tres siguen siendo faros lejanos que no se extinguen" (Teruggi, en Lerange, 1982: 108). La alusión al momento presente es enigmática y no va más allá. Cabe señalar que la hija del autor, Diana Esmeralda Teruggi de Mariani, fue ejecutada por las fuerzas conjuntas de la dictadura el 24 de noviembre 1976 en el marco de un episodio represivo emblemático para la ciudad - conocido como el ataque a la casa Mariani-Teruggi-, ocasión en la que además fue secuestrada y privada de su identidad la beba Clara Anahí Mariani. Resulta llamativo entonces el elogio a la situación presente: "En cien años de la ciudad, es ahora que se lleva a cabo el máximo de investigación científica" (Teruggi, en Lerange, 1982: 109)

${ }^{217}$ El paso de Inacayal por el Museo también es mencionado en Vida platense, donde tampoco es considerado un cautiverio: "En el Museo vio morir a un querido amigo que vivió allí sus últimos días, el cacique Inacayan [sic], cuya amistad cultivó en el desierto y a quien liberó del cautiverio" (Soler, 1982: 49).
} 
Christmann utiliza en más de una oportunidad la expresión "grupo selecto de sabios" en relación a los científicos del Museo (Christmann, 1982: 62, 73). Como los conoció, propone una semblanza de los diez que más le impresionaron, que comienza con "el fundador" Moreno y luego sigue en orden alfabético ${ }^{218}$. Con el tono personal de un libro de memorias, de Herrero Ducloux señala que fue su padrino en el Rotary Club (Christmann, 1982: 79).

Luego se aboca a reseñar la trayectoria de los estudios de medicina en La Plata, tópico fundamental en su libro editado por la Agremiación Médica. Aquí la figura más destacada es la de Pedro Belou, sobre quien también escribe en 12 personalidades.

La referencia al campo de la medicina como parte de la capital ilustrada también está presente en Ciudad milagro, donde podemos encontrar -además de un texto de Agradecimiento firmado por René Favaloro- el aporte específico de José María Mainetti, quien valora especialmente la creación de la Escuela de Ciencias Médicas en 1934 -más tarde convertida en Facultad- y finalmente llega a una auto-referencia:

"Inmersos en ese clima cultural, ciudadano y universitario de La Plata, un grupo de hombres resolvieron en el año 1969 constituirse en persona jurídica, sin espíritu de lucro, y nació la 'Fundación Dr. José María Mainetti para el Progreso de la Medicina"” (en Lerange, 1982: 215)

Dicha Fundación, a la que ya hemos aludido en el capítulo IV, fue el punto de partida del Centro Oncológico de Excelencia, el primero "de nuestra ciudad joven y universitaria" (en Lerange, 1982: 216), cuya inauguración se previó para el año del centenario platense.

\section{La ciudad universitaria}

Mainetti reitera la expresión y no es el único: la ciudad universitaria prolifera -con matices- en las distintas producciones del centenario. Por ejemplo, el guión del audiovisual realizado desde la Facultad de Humanidades junto a la publicación Obra de arte plantea:

"Con posterioridad a la década del 30 la importancia que adquirió la Universidad convirtió a La Plata en una ciudad universitaria, un centro de estudios donde concurrirían y concurren una gran cantidad de estudiantes del interior y del extranjero" 219 .

En marzo de 1935, El Día ya hablaba de La Plata como una "ciudad universitaria por antonomasia", según se cita en el libro promovido por el mismo periódico (Soler, 1982: 234).

En tanto, para Bernard, La Plata no sólo es "modelo o arquetipo de modernidad, sino de ciudad con alma, urbe universitaria, apta igual para los logros del trabajo y de la inteligencia" (Bernard, 1982b: 15). Según escribe al inicio de Ciudad Milagro, "La Plata apareció plena de adelantos técnicos, con una infraestructura envidiable, pero a la vez, apoyada en un espíritu

\footnotetext{
${ }^{218}$ La lista incluye a Florentino Ameghino, Carlos Bruch, Miguel Fernández, Enrique Herrero Ducloux, Samuel Lafone Quevedo, Roberto Lehmann-Nietsche, Santiago Roth, Walter Schiler y Carlos Spegazzini.

${ }^{219}$ Algunos textos del corpus dan cuenta de la llegada de jóvenes de otros países para estudiar en la UNLP.

Donde más claramente se describe este proceso es en No habrá manto de olvido: “...poco a poco, se transformará la composición social del estudiantado platense. Ya no se incorporarán a la Universidad los provincianos de buena familia, inteligentes y ambiciosos, sino los jóvenes de clase media baja, llegados de los pueblos bonaerenses en su mayoría. También de dos naciones sudamericanas limítrofes: Bolivia y Perú. Es decir, jóvenes con una mayor percepción de la realidad que de ajustada va haciéndose estrecha. Ansiosos de participación aparecen en los Centros de Estudiantes promoviendo debates sobre aranceles, cursos y exámenes. Asumen algunos la posición nacional e internacional sobre el margen de una cultura libresca..." (Familiares, 1982: 2). Por otra parte, un capítulo de Ciudad milagro está dedicado a los "Estudiantes no platenses en la Universidad Nacional de La Plata" (en rigor, se aboca al caso de los peruanos). Finalmente, Obra de arte ofrece un panorama actual expresado en un gráfico que muestra la estadística de estudiantes por región de origen.
} 
capaz de asegurarle vida propia, de convertirla -como a poco lo fue- en un centro cultural y universitario de jerarquizada solvencia" (en Lerange, 1982: 23).

La presencia movilizadora y el impacto de la universidad sobre la ciudad son innegables. No obstante, es interesante reconocer un período inicial en que el proyecto urbano tenía otras bases, cuestión olvidada por varias publicaciones de 1982. En otras palabras, el imaginario de "ciudad universitaria" adquiere tal significación que minimiza o relega cierta identidad o búsqueda fundacional de la ciudad reconocible, por ejemplo, en el discurso de Rocha que abre este capítulo.

Ya hemos visto que La Plata nació como capital con el objetivo de articular y ser la puerta de salida de la actividad productiva del interior bonaerense. El escudo de la ciudad es ilustrativo al respecto: un labrador, las tierras cultivables, el curso del agua. Sin embargo, como se observa en Nueva Argentina,

“...su destino, diremos que ha sido más bien de aporte cultural y científico, trayectoria que, inicialmente tuviera al Museo de Ciencias Naturales como claro exponente también de la aludida monumentalidad, y luego a su reputada Universidad, curiosamente, agreguemos, elevada desde su categoría de Provincial a la de Nacional, décadas después de la Fundación platense. Esta significación agraria y fluvial del escudo platense se desvió por caminos distintos..." (Cygan, 1981: 199)

O como plantean los autores de Creación de la generación del 80:

“...los grandes proyectos iniciados en 1882 tardaron años en llevarse a cabo, y otros que si bien en un principio tuvieron el apoyo buscado, quedaron desarticulados a la brevedad, prontamente perdieron vigencia y el impulso inicial quedó estancado [...]

Esta ciudad, soñada por Dardo Rocha, por D’Amico, de avasallante poderío económico $^{220}$, que debió ser populosamente industrial y comercial, se tornó con el correr del tiempo en un relevante centro burocrático de la Provincia, de crecimiento letargoso, que a cien años de su fundación sobrevive económicamente por el aporte de las destilerías, de algunas industrias, y fundamentalmente del prestigio que aún le queda-bastante menguado- como ciudad universitaria.

El prestigio que ganó en los tiempos la ciudad no fue por el dinamismo de su puerto, ni por sus edificios públicos, ni por su particular trazado... ese valimiento lo salvó la Universidad Nacional de La Plata, que por el tesón del Dr. Joaquín V. González, dotó al mundo entero de médicos, ingenieros, abogados, profesores...." (Zuccalá y Musmano, 1981: 29. Las cursivas son mías)

Por su parte, Fernando Barba -el hijo del historiador consagrado, que aporta el capítulo histórico inicial de Ciudad nueva ciudad antigua- reconoce que, por la cercanía con Buenos Aires, "La Plata nunca pudo descollar" en el orden económico: su puerto entró en decadencia y se convirtó en un puerto petrolero, que en el tiempo de su escritura estaba prácticamente inactivo. "A pesar de ello -concluye Barba su texto- la joven ciudad se convirtió bien pronto en un importante centro de estudios universitarios e importante difusor de cultura, orgullo de un pueblo que estaba formando su propio destino" (Barba, en Morosi, 1983: 25).

\section{Las dos fundaciones}

Los distintos textos que integran el corpus analizado esbozan una historia de la institución académica. Hay dos orígenes: el de la universidad provincial, efímera y de escasa relevancia, creada a fines del siglo XIX, y el de la nacionalización proyectada por González, a

\footnotetext{
${ }^{220}$ El libro incluye ilustrativas citas textuales de Rocha y D’Amico en torno a la meta de constituir a La Plata como uno de los principales mercados del mundo (Zuccalá y Musmano, 1981: 30-31).
} 
partir de la cual empieza a utilizarse la expresión ciudad universitaria ${ }^{221}$, no para nombrar un espacio aislado del espacio urbano donde se concentran los institutos académicos, sino una identidad que abarca a la totalidad de la urbe.

Algunas publicaciones directamente omiten la etapa provincial: la aparición de la UNLP se presenta como una suerte de "refundación" de la ciudad, y de la etapa previa sólo se destacan las dos instituciones más prestigiosas: el Museo y el Observatorio.

En Primeros habitantes, por ejemplo, la mención de la Universidad empieza directamente en la Universidad Nacional, en 1905: "Joaquín V. González concibió a la nueva ciudad con el título que hoy la define: Gran Ciudad Universitaria Argentina" (Terrasa, 1982: 32). Recién después menciona como "base" la universidad provincial que se había fundado en 1897 y las otras instituciones preexistentes, como el museo del "perito" Moreno.

En el mismo sentido, el prólogo de Enrique Barba a Ciudad milagro plantea:

"La creación o transformación en 1905 de la Universidad provincial en nacional determinó un giro copernicano en la vida física y cultural de la ciudad. Los cursos se iniciaron en 1906 con una matrícula de 1000 alumnos. Llegados de distintos puntos del país y aún de las repúblicas vecinas, como dice Arrieta, 'aquella invasión juvenil, reanimó todos los barrios, todos los centros sociales, todos los ambientes de la citta morta'. Volvió el optimismo de los primeros años de la fundación y La Plata fue para toda la república la ciudad universitaria" (en Lerange, 1982: 15)

Para Zuccalá y Musmano (1981: 33), González emerge como un “ángel salvador”. Soler recurre al mismo adjetivo en Vida platense y habla del "proyecto salvador del ministro González" que "revivió las esperanzas de la ciudad" (Soler, 1982: 60).

La creación de la Universidad Provincial había surgido propuesta por el senador Rafael Hernández y otros tres legisladores, a siete años de la fundación de la ciudad. "Estamos haciendo puertos, construyendo ferrocarriles, proyectando canales, levantando pueblos y colonias por todas partes, en una palabra, cuanto es necesario para la vida material -planteó en la cámara legislativa en junio de 1889- pero la vida intelectual, la que prepara a los hombres para los grandes movimientos, para los grandes progresos del país, está un poco olvidada”. La ley se promulgó en 1890, pero la universidad tardó siete años en concretarse. Rocha la presidió. Tuvo pocos estudiantes y un presupuesto escaso y cuestionado.

Obra de arte es uno de los libros que incluye la narración de esa etapa. La parte dedicada a la historia universitaria tiene un desarrollo cronológico $^{222}$, iniciado con la ley promovida por Hernández. Afirma que "en sus nueve años de vida, la Universidad Provincial de La Plata, fue dignamente dirigida por el Dr. Dardo Rocha”, y reconoce la coexistencia de

\footnotetext{
${ }^{221}$ En 1905, el escritor nacido en España y criado en Uruguay Manuel Bernárdez presentó sus impresiones sobre la ciudad en unas "Jornadas del progreso argentino". Los trabajos se compilaron en el libro "Hacia las cumbres" (Editorial F. Escaris Méndez, Talleres Tipográficos de Ortega y Radaelli, Buenos Aires, 1905) y son retomados en Viajeros. El mismo año de la re-fundación universitaria, Bernández desarrollaba la idea de "ciudad universitaria" citando el discurso con el que González anunció el proyecto de la "Universidad nueva". En él contraponía la afiebrada Capital Federal con la sosegada y serena La Plata, para considerar a esta última como el ambiente ideal para el desarrollo de actividades académicas. Por su "medium insuperable de aclimatación y florecimiento", La Plata formaría -según los presagios de Bernárdez- "un gran centro universitario". Por eso, el escritor la emparienta a las ciudades universitarias de Estados Unidos ( allí de cuarenta las ciudades que no tienen más razón de ser, ni más objeto, ni más pasión, ni más vida, que la razón, el objeto, la pasión y la vida de sus grandes instituciones de enseñanza. Lo aprendieron de Oxford, de Cambridge, de Hilderberg, pero ¡cómo aventajaron a los ejemplos!” (en Barcia, 1982: 237-239).

${ }^{222}$ El recorrido es cronológico, mas no completo. Por ejemplo, al dar cuenta del crecimiento de la Universidad nacional, no enumera ninguna novedad entre 1936 y 1956.
} 
otros institutos que, lejos de potenciar la actividad, "estaban en un estado de casi total abandono". Finalmente llega la reivindicación del ministro nacionalizador: "Una ardua labor se planteaba; un infatigable luchador estaba dispuesto, sin embargo, a realizarla: el doctor Joaquín V. González". Éste termina identificado como el fundador (Díaz, 1982: 252-257).

También Vida platense reconoce un claro cambio de etapa. La Universidad Provincial tenía pocos estudiantes y le faltaban recursos de todo tipo. "Al ser nacionalizada, se revitalizó y tomó el espíritu universalista y experimental de Joaquín V. González" (Soler, 1982: 42). Así, "entraría La Plata en la historia cultural nacional y sería reconocida, a partir de 1905, como ciudad universitaria" (Soler, 1982: 61)

El primer artículo dedicado específicamente a la institución en Ciudad milagro corresponde a Alfredo Casey y aparece en décimo orden. "Trayectoria y misión de la Universidad de La Plata" considera la etapa provincial pero presta especial atención al proyecto de González, de quien toma varias citas para iniciar el texto. Como repasan distintos textos, propuso una "Universidad nueva", científica y experimental, que incorporó nuevas disciplinas y articuló los distintos niveles educativos, en especial con la incorporación de un colegio secundario con "internado".

Buena parte de los autores, graduados de ese colegio, reivindican el modelo. Christmann escribe sobre el proyecto gonzaliano y afirma que "el plan de estudios del Colegio Nacional fue a mi juicio actual, perfecto, pues hizo lo posible para hacer de cada uno de nosotros una persona culta e ilustrada...". Define al Internado como un "grupo aparte de la Universidad, formando una especie de isla o lugar reservado". El autor no participó de esa experiencia, pero convivió con ella: "El internado venía a ser una especie de quiste dentro del Colegio Nacional, por supuesto no maligno, sino todo lo contrario, pues el programa integral proyectado por el Dr. González se cumplió siempre muy bien [...] En 1918, cuando se produjo la Reforma Universitaria, se cometió el error grosero de suprimirlo sin más, en lugar de perfeccionarlo como correspondía a una magnífica tarea" (Christmann, 1982: 36-37)

Según Casey, "debemos ser honestos y leales a las legítimas razones que inspiraron a J. V. González" y asumir que su plan "no se ha cumplido porque fue alterado fundamentalmente a partir de 1918".

"La universidad tipo, que aspiraba a ser distinta y a cumplir una misión excepcional para el país, pasó a ser una más a semejanza de las de Córdoba y Buenos Aires; su sistema y forma de enseñanza se desvirtuaron" (en Lerange, 1982: 101) ${ }^{223}$.

Más allá de alusiones a la etapa provincial, casi la totalidad de la bibliografía del centenario coincide en la identificación de González como "fundador", en detrimento de la figura de Hernández. Este es un dato a tener en cuenta sobre la producción del '82, ya que en épocas anteriores había existido una disputa historiográfica en torno a ese reconocimiento. Dos décadas antes, Ataulfo Pérez Aznar publicó en El Día -en la edición del aniversario de la ciudad- un artículo titulado “QQuién fue el fundador de nuestra universidad?”, que reconocía que "Máximo Paz, Manuel B. Gonnet, Rafael Hernández, Guillermo Udaondo y Dardo Rocha" podían "disputar con derecho ese título" (Pérez Aznar, 1962). En rigor, la principal tensión se dio siempre entre Hernández y González, y se resolvía según la valoración realizada sobre la experiencia de la Universidad Provincial.

${ }^{223}$ El texto de Emilio Estiú en 12 personalidades hace un planteo similar, retomando las críticas que realizara Korn sobre los ideales no concretados del proyecto gonzaliano (en SADE La Plata, 1982: 184). 
Hacia una ponderación de González intervino históricamente el dirigente del Partido Socialista Alfredo Palacios. Como recuerda Rivera en 1982, por su tarea como nacionalizador de la Universidad "muchas figuras importantes del país" consideran "al prominente riojano, como el fundador del claustro universitario":

"El tema daría para mucho [...] Pero no puedo dejar de señalar que en un debate sostenido al respecto en el Senado de la Nación por el Dr. José Nicolás Matienzo y el Dr. Alfredo Palacios, el día 31-7-34, el Dr. Palacios señaló que la Universidad de La Plata fue fundada por el Dr. Joaquín V. González. Y esa afirmación de Palacios-sin restarle bajo ningún concepto méritos al esclarecido Rafael Hernández- es compartida por muchos argentinos" (en SADE La Plata, 1982: 155)

Dicha valoración fue cuestionada fundamentalmente por el peronismo. En 1953, durante la gestión de Marcos Anglada en el rectorado, al tiempo que se adoptaba el nombre de "Universidad Nacional de Eva Perón" se encaró un proceso de "redescubrimiento de figuras del pasado universitario, descuidados por la historia oficial". En ese marco, Hernández fue reivindicado como "verdadero fundador", mientras González pasaba al status de mero "nacionalizador" (Barba, 2005: 85). Como reparación histórica, en diciembre de 1954 se impuso su nombre al ex Colegio Nacional, denominado entonces Instituto Modelo de Enseñanza Secundaria para Varones "Rafael Hernández",224.

Tras el golpe del 1955 esa resolución quedó en suspenso, hasta que en 1973 el nuevo interventor de la UNLP ratificó el nombre del colegio y ordenó la colocación de un busto en sus jardines y una fotografía en el despacho del rector.

Sin retirarle el nombre a esa institución, el período iniciado en marzo de 1976 significó un nuevo retorno sobre la figura de González como fundador de la Universidad. Una resolución de ese año estableció como Día de la Universidad Nacional de La Plata al 12 de agosto, que corresponde con la firma del convenio de nacionalización: a partir de entonces, cada año debía celebrarse la fecha de la creación y la memoria del Dr. Joaquín V. González. La opción por esa versión, además, generó la proximidad de una fecha redonda: así, en agosto de 1980 la Universidad cumplía el 75ªniversario de la fundación, por lo que el rector Gallo creó una Comisión Especial para celebrar ese "trascendente acontecimiento". Los homenajes incluyeron la visita del dictador Videla, que fue designado Huésped de Honor Extraordinario. En las noticias institucionales del $\mathrm{N}^{\circ} 27$ de la Revista de la Universidad -dedicada a la generación del 80-, hay fotos del acto que encabezó en la Facultad de Ciencias Médicas el 12 de agosto de 1980, a sala llena.

No es casual que el único que en el corpus analizado objeta la figura de González como fundador es Bernard, uno de los pocos autores que proviene de una tradición peronista, y que se había desempeñado como Ministro de Educación provincial en el período 1974-1975: “en realidad solo fue el primer Presidente de la Universidad nacionalizada, que tenía para entonces ocho años de vida como organismo provincial y había realizado 3 colaciones de grados" (en Lerange, 1982: 27).

\footnotetext{
${ }^{224}$ Ese mismo año apareció la primera edición del libro de Osvaldo Guglielmino Rafael Hernández, el hermano de Martín Fierro, que apunta a reponer su biografía "olvidada" como militante federal no rosista. Se lo reivindica como un impulsor del desarrollo industrial en tiempos en que se imponía el modelo agroexportador dependiente y limitado. El autor también se ocupa de señalarlo como fundador de la institución platense: "La fundación de la Universidad de La Plata ha sido atribuida, y todavía lo es, al doctor Joaquín V. González... La verdad es muy otra y las cosas ocurrieron de la siguiente manera: el 12 de junio de 1889 presenta Rafael Hernández en el Senado el proyecto de creación de la Universidad..."
} 


\section{El énfasis en la cultura y los "hombres del 80"}

Al acento puesto -con sus distintos matices- en la producción cultural y la actividad universitaria viene asociada la insistente reivindicación de la generación del 80: "Reseñar la historia del pensamiento argentino a través de la Universidad de La Plata, parece una tarea absurda, pero sin embargo, de esta Universidad ha salido la columna vertebral de un pensamiento que por primera vez podríamos decir auténticamente argentino", escriben Zuccalá y Musmano: "Los hombres del 80 pusieron gran énfasis a la cultura, porque era el medio idóneo para transformar el País pastoril en un País que se integrara al consenso universal" (Zuccalá y Musmano, 1981: 31).

Cuando Primeros habitantes menciona al Observatorio Astronómico se afirma que tanto Rocha como Mitre, Sarmiento y Avellaneda pusieron "especial empeño en dar a la Universidad, la categoría de un alto nivel científico y cultural". En definitiva, "la generación del 80 se empeñó en profundizar los estudios de las Artes y las Ciencias; su condición de argentinos, impulsábamos a ser reconocidos en el exterior como gente culta y emprendedora" (Terrasa, 1982: 36).

Resulta interesante, en este marco, la operación que hace Carlos Vallina en su texto sobre la carrera de cine de la UNLP, en Ciudad Milagro, al colocar ese espacio de formación propio del siglo XX en la tradición de aquellos hombres, en su caso con una generación del 80 leída en clave progresista:

“...esta nueva carrera creada, y que reconocía el siglo XX en estas comarcas. Tal como la generación del 80, había convalidado los mejores aportes culturales sobre el filo del siglo XIX.

El Colegio de la Universidad, el famoso Nacional, ya proponía en sus actas de gestación, la puesta en funciones de un laboratorio fotográfico a fin de desarrollar las nuevas técnicas de reproducción de la imagen" (en Lerange, 1982: 341)

Según Vallina, "el sueño positivista y progresivo de Rocha, González, contaba con un aire popular y tecnológico, que no entusiasmaba por igual a artistas e intelectuales de la época". El lugar ganado por el teatro -que no iba a resignarlo fácilmente-, la falta de una industria nacional sólida y los trabajos de construcción de la capital, dice, "influyeron en que el séptimo arte sólo ocupara el papel de diversión" (en Lerange, 1982: 341). Pareciera entonces que, si no fuera por esos datos de coyuntura, el desarrollo cinematográfico formaba parte de los aportes culturales de la generación de dirigentes glorificada cien años más tarde.

No habrá manto de olvido es prácticamente el único libro que desliza -en su breve introducción- una crítica al ensalzamiento a-crítico a aquella dirigencia. Los autores también asocian a La Plata con un "proyecto global", el de "la famosa generación del '80, hoy sujeta al revisionismo crítico, como saludable reacción a la apoteosis que le ofrendan los epígonos del liberalismo argentino..." (Familiares, 1983: 1).

\section{La ciudad relegada}

“...tiene uno de los mejores puertos argentinos, con docks hasta las mismas puertas de la ciudad, y en su Puerto se hallan la Base Naval, Astilleros, Arsenal Naval, Escuela Naval y, en construcción, los Astilleros del Ministerio de Marina; los dos frigoríficos: Swift y Armour, los más grandes de Sud América, donde trabajan cerca de 10.000 obreros; la Destilería de Petróleo de los Yacimientos 
Petrolíferos Fiscales, la planta más importante de Sud América, donde trabajan cerca de 1.500 obreros, se hallan dentro del 'Centro Industrial'..." (Oitaven, 1941: 15)

La cita precedente está tomada del libro La Plata, ciudad ideal, publicado en 1941. En ese entonces, Alberto Oitaven reonocía un "centro universitario de primer orden" pero también una ciudad "pujante, de intensa actividad comercial e industrial" (Oitaven, 1941: 13).

En el centenario, en cambio, el difundido imaginario de La Plata como ciudad universitaria tendió a soslayar otras referencias de la vida urbana, como el puerto -pensado originalmente como vector de desarrollo-, las fábricas aledañas, el comercio e incluso la actividad político-administrativa.

Así, la actividad productiva de la región quedaba en un claro plano secundario: tanto la industria -referida sólo a partir de hitos puntuales- como el sector hortícola, sobre el que prácticamente no hay referencias, si bien se trata de uno de los partidos bonaerenses más importantes en esa actividad ${ }^{225}$. De igual modo, la mayoría de los textos ignoran o desatienden la vida obrera, en lo que refiere a la vivienda, los espacios culturales, las organizaciones gremiales, etcétera.

En buena medida, esa relegación se realiza a partir de una operación que analizamos en el capítulo anterior: el desmembramiento de Berisso y Ensenada, que ocurre efectivamente en términos administrativos pero que además se consolida en la producción simbólica.

Dichas localidades fueron, históricamente, los principales núcleos obreros de la región. Hacia mediados del '30, cuando Berisso era parte del distrito platense, alrededor de 8000 personas trabajaban en los dos grandes frigoríficos de esa zona, ubicados entre los más importantes de América Latina. Como bien describe Vallejo,

"Berisso era un conglomerado cultural de aventureros, jornaleros atraídos por el trabajo y exiliados de la guerra, y donde una importante presencia ácrata trató de ser enfáticamente controlada tras desatarse la revolución rusa. Era una especie de company town hablada en su mayor parte por los trabajadores de los frigoríficos, que componían casi un tercio de la población, y por quienes se desempeñaban en la Hilandería de capitales ingleses, The Pattent Knitting -compuesta por unos 600 obreros-, o cruzaban a diario el canal del puerto para dirigirse en Ensenada a la más grande refinería del país montada por la empresa de Yacimientos Petrolíferos Fiscales que contaba con más de 1.000 obreros" (Vallejo, 2005: 262)

Ensenada también es el enclave del Astillero Río Santiago (ARS), creado para proveer de buques a la marina mercante, que empleó inicialmente a 900 personas y a mediados de los '60 contaba con una planta aproximada de 5000 empleados a los que se sumaban 3000 de empresas subcontratistas afectados en la producción directa (Barragán, 2011: 289). Salvo la guía turística La Plata 100, fragmentos específicos de Obra de arte y una aproximación de No habrá manto de olvido, las publicaciones del centenario no dan cuenta de la relevancia del astillero más grande de Sudamérica, inaugurado cuando Ensenada era parte de La Plata (en ese tiempo llamada Ciudad Eva Perón), ni mucho menos de la magnitud de la represión y el desguace productivo que sufrió en la dictadura ${ }^{226}$.

\footnotetext{
${ }^{225}$ La Plata, por ejemplo, es el principal productor de alcaucil. Concentra cerca del $97 \%$ de la superficie provincial destinada a ese cultivo, introducido por inmigrantes italianos en la década del ' 50 .

${ }^{226}$ Se estima que en la dictadura 11 trabajadores de ARS fueron asesinados y 42, desaparecidos. Además, 135 trabajadores fueron despedidos por la Ley 21.274 de Prescindibilidad y 299 por la Ley 21.260 de bajas de Personal por Seguridad Nacional. Por otra parte se registra la renuncia de 1016 trabajadores en los primeros años de la dictadura (Barragán, 2011: 301). Sobre el declive productivo, relata Duizeide: "En 1975 había 8.500
} 
Ensenada fue además una zona de concentración industrial por la Destilería de YPF y la Propulsora Siderúrgica. En 1974 se inauguró la planta de Petroquímica General Mosconi, empresa mixta integrada por YPF y la Dirección Nacional de Fabricaciones Militares. En suma, como apunta Barragán,

"la zona de Ensenada, Berisso y La Plata presentaba gran cantidad de establecimientos fabriles de importante envergadura, con un significativo grado de sindicalización y organización de los trabajadores, presencia de juntas internas y de sindicatos de relevancia en la estructura sindical tradicional. Al promediar la década la región presentaba el desarrollo de una nueva experiencia en la organización sindical: la aparición de las coordinadoras interfabriles de delegados" (Barragán, 2011: 290)

Otro sitio relegado en la historiografía del centenario es la Isla Paulino -sólo mencionada en La Plata 100-, que en las primeras décadas del siglo XX llegó a producir 500.000 litros del llamado vino de la costa, proveía de verdura y de fruta a Berisso, Ensenada y La Plata, y era un lugar frecuente de recreación. A esa isla dedicó el último escrito que publicó con su firma Haroldo Conti: Tristezas del vino de la costa, que intenta desmontar el mito que señala en una inundación de los años '40 la causa del declive de la isla.

Por otra parte, todas esas zonas y en particular Berisso fueron puntos de partida de un acontecimiento fundante del peronismo: la movilización del 17 de octubre de 1945. Como reconstruye Vallejo, ese día

"amaneció con piquetes formados frente a los frigoríficos y la fábrica textil, como también en todos los puntos de acceso de Berisso, donde camiones y tranvías procedentes de La Plata fueron volcados. Los vehículos de reparto de los diarios platenses fueron interceptados y todos sus ejemplares quemados ritualmente. La ciudad obrera estaba aislada, las escuelas suspendieron sus actividades debido a que los maestros procedentes de La Plata no pudieron trasladarse, y prácticamente todos los comercios cerraron. Todo estaba preparado para iniciar la marcha hacia la ciudad universitaria" (Vallejo, 2005: 286. Las cursivas son mías)

Daniel James (1987) dio cuenta del carácter profundamente iconoclasta que tuvo la movilización que llegó atravesando el paseo del Bosque. A su paso, los manifestantes atacaron el diario El Día, el Jockey Club y algunos grandes negocios. Fue en el Rectorado de la Universidad donde se detuvieron para entontar el Himno Nacional y cantar irónicamente “¡Alpargatas sí, libros no!”. Y un grupo de manifestantes concluyó la jornada de violencia callejera atacando la casa particular del entonces presidente de la UNLP, Alfredo Calcagno, "una residencia señorial urbana con los rasgos afrancesados a los que habitualmente recurría un sector acomodado de la ciudad para transmitir su status, especialmente en el centro de la ciudad" (Vallejo, 2005: 286-287). También hubo asaltos contra pensiones estudiantiles. Al día siguiente, los negocios de la ciudad cerraron, los periódicos no se publicaron y hubo asueto obligado en la universidad y las escuelas. Además, se produjeron nuevos ataques sobre los símbolos de la ciudad. Con las fuerzas militares y policiales ausentes, la disputa por la ciudad se daba con particular transparencia:

"Era una contienda por el acceso a la esfera pública, en la que la ciudad universitaria recordaba en forma particularmente intensa a los obreros la desigual distribución del poder cultural que existía en el centro y el bosque de La Plata frente al postergado enclave portuario" (Vallejo, 2005: 288)

trabajadores. En los 34 meses de gestión peronista previa al golpe de 1976 se habían contratado 225.000 toneladas de porte bruto, la cifra máxima en toda su historia. Durante el Proceso, en más del doble de tiempo se contrataron 182.000 toneladas y los trabajadores disminuyeron a 3.600...” (Duizeide, 2010: 35). 
"Más que tratarse de una manifestación en reclamo por la ampliación de sus derechos, como muchas veces se ha señalado, los obreros irrumpían [...] para poner en cuestión un status quo en el que identificaban el motivo de su propia exclusión sociocultural [...] Es decir que los episodios de octubre vinieron, por sobre todas las cosas, a negar el poder simbólico de la Universidad en La Plata" (Vallejo, 2005: 287).

Ninguno de los textos del centenario relata estos hechos, con excepción del publicado por el diario El Día, que lo hace desde la perspectiva de uno de los íconos atacados en esa irrupción obrera. "EL DÍA publicó una larga lista de comercios dañados, saqueados y de instituciones perjudicadas" (Soler, 1982; 149). En Vida platense, lo central es que en dichas jornadas los órganos de prensa locales fueron censurados, y que en la UNLP "el ataque sufrido" en octubre "engendró una mística en la lucha por la libertad y la Reforma, la democracia y la autonomía universitaria, que los universitarios platenses recordarían por años". Soler cita un poema de Gustavo García Saraví, que "se convirtió en símbolo y bandera de la resistencia" del estudiantado.

Cabe destacar que el relato asume que "si tenemos en cuenta que el partido de La Plata comprendía a Berisso y Ensenada, el 17 de octubre fue en gran medida un hecho platense". Por otra parte, el personaje que recupera de esos días es una figura trágica, Cipriano Reyes:

“...quien organizara los grupos que concentraron el 17 de octubre. A pesar de ese triunfo, Reyes sufriría luego persecución y cárcel por parte del mismo gobierno que contribuyó a encumbrar [....] Como rara paradoja, Cipriano Reyes recuperó su libertad por obra de la Revolución que en 1955 derrocó a Perón” (Soler, 1982: 150)

Después de octubre, "el peronismo manejó los resortes fundamentales del poder" (Soler, 1982: 149). En varias oportunidades el libro reitera el término "fórmulas adictas a Perón", adjetivo utilizado casi exclusivamente al referirse a ese gobierno.

El quinto capítulo de Vida platense está dedicado a "los años del peronismo". Se trata de una excepción en el conjunto de textos del centenario, entre los cuales la década que va de 1945-1955 aparece como un bache, un período inexistente. En la mayoría de los textos, el 17 de octubre nunca existió, el Astillero Río Santiago, el Parque de los Derechos de la Ancianidad y la República de los Niños carecen de relevancia como obras locales o regionales, y la ciudad parece no haber sido rebautizada nunca ${ }^{227}$.

Los autores identificables con el peronismo -como Bernard- no escriben sobre el período; en tanto muchas alusiones a la época que aparecen en el corpus son claramente adversas a ese movimiento político. Los escritos testimoniales de Christmann y Szelagowski son paradigmáticos en ese sentido. Recordemos que en los textos caracterizados en el capítulo III por su tono nostálgico, los tiempos perdidos de vida feliz se asociaban a las dos décadas anteriores al ascenso de Perón al poder.

En el libro de memorias del médico hay escasas referencias a la política más allá de la política universitaria. Sólo aparecen en relación a algunas épocas, y centralmente encontramos una caracterización muy negativa del peronismo. Lo advertimos ya en el primer capítulo de Vivencias y testimonios, cuando habla de la vinculación entre las estancias Iraola y Pereyra:

\footnotetext{
${ }^{227}$ Desde julio de 1952 y hasta el 27 de septiembre de 1955 la ciudad tuvo el nombre Eva Perón. En ese período, el gobierno también modificó el escudo de la ciudad por uno que tenía la silueta de Evita con el símbolo peronista de fondo. En los años '70, la organización político-militar Montoneros retomaría esa denominación en sus acciones platenses, desconociendo el decreto-ley de la denominada "Revolución Libertadora" que restituyó el nombre original. En los comunicados escritos en la zona la fecha era antecedida por la expresión "Ciudad Eva Perón”. En tanto, Anguita y Caparrós recuerdan un cántico que decía "La Plata, La Plata,/ ciudad Eva Perón,/ ciudad de montoneros/ para la liberación!” (Anguita y Caparrós, 2010: 126).
} 
“...los campos privados que perduraron integrando las estancias San Juan y Santa Rosa eran de la familia Pereyra Iraola y fueron expropiadas más o menos en el año 1948, para crear el entonces llamado Parque de la Ancianidad. Después de 1955 se le puso con justicia el de Parque Pereyra. Este parque había sido diseñado por Prilidiano P. Pueyrredón..." (Christmann, 1982: 3; también en Lerange, 1982: 146)

La calificación del período se torna más explícita hacia el final del libro, cuando Christmann se refiere a un médico al que admiró, Ricardo Finochietto, y alude -sin mencionarlo- al "papel que le tocó desempeñar durante la dictadura finalizada en 1955" y concluye que "su vida se vio amargada por su inoportuna adhesión a la política del momento" (Christmann, 1982: 253). Luego, en el tramo referido a su actividad de cátedra, escribe:

“...Estábamos en 1947, y todos los integrantes de la cátedra participábamos del mismo malestar de ánimo que el resto del país culto. Progresiva y sucesivamente se iban dando hechos y episodios negativos para la Cultura y para las Ciencias, todo lo cual nos disminuía el entusiasmo, tan acentuado desde años atrás y tan venido a menos ahora. Cumplíamos [...]nuestras obligaciones [...] pero con evidente apatía..." (Christmann, 1982: 280. Las cursivas son mías) ${ }^{228}$.

Por su parte, en Si yo fuera intendente Szelagowski recuerda "lo tremendo que fue para los platenses el cambio de nombre de la Ciudad en 1952" (Szelagowski, 1982a: 112). "Uno se olvida, pero el miedo se palpaba". Sin embargo, es su texto dedicado a la experiencia en el Poder Judicial el más explícito sobre asuntos de historia política. En el capítulo V, "Los profesionales", propone repasar los factores que provocaron la "degradación" del Poder Judicial, a partir del primer "sacudón" ocurrido en 1930:

"...no fue tan estremecedor como los que se sucedieron desde entonces [...] Puede decirse que el primer remezón significativo después del 30 fue el producido en 1943 donde se alentaron muchas esperanzas ya que en un primer momento se comenzaron por reparar las postergaciones existentes en la carrera judicial en 15 o 20 años anteriores y así fueron destinatarios de ascensos antiguos funcionarios de la justicia. Ese criterio sano y reparador duró menos de tres años porque en 1946 el remezón benéfico se transformó en terremoto asolador cuyas secuelas seguimos soportando. Casi todos aquellos ascendidos fueron dejados en la calle. De ahí en más hemos venido asistiendo a cambios donde desafortunadamente pareciera que la revancha estuvo por sobre las decisiones cuerdas y ecuánimes" (Szelagowski, s/f: 23-25)

Más adelante afirma que "a partir del período político que irrumpe en 1946 ocurrió el primer terremoto en la justicia" y que enuncia esa idea sin dejarse "llevar por impulsos sentimentales sino que me afirmo en hechos concretos y conocidos". Szelagowski apunta a "situaciones tremendas e insoslayables", contando anecdóticamente episodios de atropellos y obsecuencia. La indignación alcanza especialmente al último gobierno peronista:

"Los últimos cambios más o menos violentos sufridos por la justicia fueron en 1973 y 1976 [...] Cada movimiento triunfante puso sus piezas claves, favoreció amigos, cometió injusticias y arrasó con la carrera judicial. No niego que personalmente me resultó saludable la actitud de la Corte de 1955 o la del gobierno de 1976, aquella barriendo con los 'renunciantes' y éste con quienes nunca debieron ocupar un estrado de la justicia. Fresca está la memoria como para olvidar a los jueces que concurrían a sus despachos con chomba o campera. No caeré en la tilinguería de creer que la ropa mejorará al magistrado pero cierto decoro es indispensable para integrar los conceptos de majestad y respeto" (Szelagowski, s/f: 23-25. Las cursivas son mías)

\footnotetext{
${ }^{228} \mathrm{Al}$ dedicarle unas páginas a Bernardo Houssay, refiere al conflicto de éste con el peronismo y la indignación que provocó: "Con motivo del atropello a la gente de ciencia que enaltecía a nuestro país, numerosos argentinos sentimos la necesidad de visitar al Maestro y expresarle nuestra total solidaridad..." (Christmann, 1982: 123).
} 
No son los únicos altercados con el peronismo narrados en los textos de la época. En su artículos sobre la bohemia en La Plata, el periodista Marcelo Curuchaga cuenta en Ciudad milagro un cruce con el gobernador Aloé, cuando "el gobierno había 'participado' en casi todas las empresas periodísticas libres" (en Lerange, 1982: 630). Por su parte, el ingeniero Enrique Humet, homenajeado en 12 personalidades, habría sido corrido de su cargo en 1952, aunque el episodio es contado confusamente (Ortales, SADE La Plata, 1982: 146)

En general, encontramos en el corpus analizado muchos textos que evitan las referencias explícitas, como si todavía rigiera el decreto que en 1955 prohibió nombrar a Perón y sus derivados. Veamos por ejemplo el aporte de Casey -sobre la historia universitaria- en Ciudad Milagro: "Producida la revolución de 1943 y los hechos del mes de octubre de 1945 en la Universidad de La Plata que culminan con las escenas callejeras de los días 3 y 4 la toma de la Universidad por las fuerzas policiales, se transforma el ámbito universitario y se producen cambios de profesores..." (en Lerange, 1982: 100. Las cursivas son mías). En el capítulo sobre el Jockey Club, los dos momentos de conflicto señalados ocurren durante los gobiernos de Yrigoyen y Perón, pero ninguno de los dos es aludido con nombres propios, como sí lo es por ejemplo el presidente de facto Agustín Justo.

En tanto, el golpe que derroca a Perón es corrientemente mencionado como "la revolución de setiembre de 1955..." (en Lerange, 1982: 307, 405) o como un "movimiento cívico militar" (Moncaut, 1982: 186). O en el caso del capítulo -sin firma- sobre la Escuela Naval Militar en Ciudad milagro:

“...El 16 de setiembre de 1955, se inició en el país un movimiento armado que concluyó, días más tarde, con la instalación de un nuevo gobierno. En esa emergencia, la Escuela Naval, identificada estrechamente con los cuadros de la Institución, participó -incluso con el invalorable tributo de su sangre joven- de parte de las fuerzas revolucionarias. Fue ese episodio, el más cruento de su historia, una demostración palmaria del ideal de libertad que anida en cada marino, el cual encuentra un nuevo motivo para exaltar este sentimiento, con sólo otear, desde la borda de su buque, la inmensidad azul del mar [...] Normalizada la vida del establecimiento y del país se retornó a la labor creadora" (Lerange, 1982: 491)

Otra cuestión interesante en la relación de los textos del centenario y el peronismo es que algunos incluyen realizaciones del período, pero eludiendo cualquier mención de la iniciativa o la responsabilidad política, algo que sí suele advertirse en relación a otras épocas. Así, por ejemplo, se dedica un capítulo de Ciudad milagro a la Dirección de Bibliotecas de la Provincia de Buenos Aires, creada en 1950, pero no hay ninguna alusión al peronismo ${ }^{229}$. O en la parte deportiva de Obra de arte, la historia del Instituto de Educación Física de la UNLP registra mucha actividad en los años 1946-1953, pero no se nombra al peronismo ni mucho menos en relación a la universidad (Díaz, 1982: 352-353). Este libro es, junto a La Plata 100, uno de los que señala a la República de los Niños como uno de los espacios de recreación de la región (Díaz, 1982: 357 y 383) ${ }^{230}$. Se trata de "un predio de 52 hectáreas, donde alternan praderas, bosques, un lago y una ciudad infantil, proyectada en 1949 por los arquitectos Lima, Cuenca y Gallo. El recreo fue habilitado en 1951" (VV.AA., 1982a: 59) ${ }^{231}$.

\footnotetext{
${ }^{229}$ Como vimos en el capítulo II, también el Museo y Archivo Dardo Rocha fue creado en ese período.

${ }^{230}$ Obra de arte también señala la expropiación que da lugar al Centro Cívico de Berisso, en 1947, otro dato histórico que da cuenta del impacto del peronismo en la región (Díaz, 1982. 173).

${ }^{231}$ Cabe mencionar que en 1979 la Provincia de Buenos Aires se había desprendido de la República de los Niños, transfiriéndola a la Municipalidad de La Plata, quien la cedió para su explotación privada por parte de
} 
La guía elaborada por la Sociedad de Arquitectos también incluye al Parque Pereyra llamado entre 1949 y 1955 Derechos de la Ancianidad-, pero no menciona su origen, y el relato transcurre con un evidente salto temporal:

“...Esta estancia pertenecía, desde 1850, a don Simón Pereyra; en 1857 se hizo cargo su hijo Leonardo, quien le dio gran impulso como cabaña de cría de ganado vacuno, caballar y porcino. Verecke fue quien se hizo cargo del diseño del parque. El suntuoso casco pertenece, desde 1959, a la Escuela de Policía 'Juan Vucetich', la que comenzó a funcionar allí un año más tarde [...] Sobre Camino Centenario, a $25 \mathrm{Km}$. de La Plata, se encuentra la Estación de Cría de Animales Salvajes [...] Fue creada en 1971 con la idea de exhibir animales autóctonos y éxitos en ambientes naturales y a la vez perpetuar algunas especies en vías de extinción. Constituye la primera experiencia de su tipo en América Latina..." (VV.AA., 1982a: 61)

La referencia es completamente diferente en Vida platense, cuyo capítulo sobre el peronismo se destaca por un claro reconocimiento de la obra pública ${ }^{232}$ :

“...las más importantes para la ciudad fueron la expropiación de las tierras destinadas al Estadio Provincial y, más aún, la de la estancia Pereyra Iraola, emplazada en una extensa superficie arbolada con una gran cantidad y variedad de especies. Se la convirtió en un lugar de libre ingreso. El aspecto del parque, al que no tenía acceso el público, era imponente por los óptimos cuidados que había recibido durante años. Paulatinamente se ha ido deteriorando este magnífico paseo.

Fue abierto al público con el nombre de «Parque de los Derechos de la Ancianidad», el 24 de febrero de 1950, en conmemoración de los comicios de 1946. Se calculó que concurrieron 20.000 personas a la inauguración. Por la tarde, y organizado por la Confederación General del Trabajo de La Plata, se declaró un paro en adhesión a los festejos. A partir de las 12 la ciudad ofreció un aspecto de total inactividad, ya que sólo trabajaban las farmacias de turno" (Soler, 1982: 162)

El capítulo sobre el peronismo en el libro editado por El Día versa además sobre el problema de la inflación y la regulación de precios, la cultura oficial, "el control absoluto de los medios de comunicación, el adoctrinamiento partidario en las escuelas y otras formas de penetración" (Soler, 1982: 165), el exilio de opositores, el fallecimiento de la primera dama y las distintas críticas al peronismo. Ya en el capítulo siguiente, los hechos de septiembre de 1955 son mencionados como "el movimiento armado que desalojó a Perón de la Presidencia de la República" y se destaca que "La Plata constituyó otro foco rebelde al sublevarse la Base Naval de Río Santiago bajo el mando del contraalmirante Isaac F. Rojas...” (Soler, 1982: 173). Al término de las hostilidades, dice, "se vivió en la calle un clima de euforia" (Soler, 1982: 174) aunque reconoce que "los grandes núcleos que apoyaban al peronismo, sin embargo, no podían suprimirse por decreto" y da cuenta de la sublevación que intentó el retorno del presidente derrocado, que terminó con la ejecución sumaria de Oscar Lorenzo Cogorno y Alberto Juan Abadie (Soler, 1982: 175-177).

En general, los textos que se explayan con más claridad y menos eufemismos sobre cuestiones de la década peronista son los que tienen una inspiración académica y trabajan temas específicos, centralmente Ciudad nueva ciudad antigua y el Diccionario de $\operatorname{arte}^{233}$.

Luis Zanón (Clarke, 2006). El empresario, que por entonces también manejaba el parque de diversiones Italpark, es otro de los presentes en la cena de gala platense del 18 de noviembre de 1982.

${ }^{232}$ Se reconoce el notable cambio de "orientación de la obra pública", que "intentó atender a los aspectos sociales, y se plasmó en La Plata con la construcción de barrios obreros y la expropiación del Parque Pereyra Iraola, la construcción del Hotel Provincial, el Estado Provincial y la República de los Niños" (Soler, 1982: 158)

${ }^{233}$ Desde la arquitectura, Morosi habla de una época "dominada por el nacionalismo popular" (Morosi, 1983:

251). Por su parte, Nessi señala que "la década peronista, compleja y versátil en todas sus trabajadas direcciones, 
Como sugerimos antes, la dificultad para tematizar al peronismo y su intencionada exclusión de relato histórico, está vinculada a la también dificultosa inclusión de la realidad obrera de la región. Ésta es relegada por el fuerte imaginario de la ciudad universitaria, que ocluye la mirada sobre las zonas de producción industrial y hortícola, las condiciones de vida de los trabajadores y también la organización gremial.

En la mayoría de los libros, las referencias a la actividad productiva son concretas y puntuales, es decir, sin contexto ni descripción estructural. Por ejemplo, Crónicas de un siglo, que como vimos es el texto más fragmentario, menciona en su recorrido cronológico la aparición de la $40^{\mathrm{a}}$ edición de Nociones de Geografía, del autor platense Francisco Guerrini. De ese libro retoma algunos datos como su división de La Plata en "siete parroquias", y también que "tiene dos grandes frigoríficos donde se faenan novillos de muchísimo precio y la más importante destilería de América del Sur, donde se elaboran más de 2.000 toneladas diarias de petróleo crudo" (Guerrini, citado en Moncaut, 1982: 131-133).

En Rastros y rostros, libro claramente centrado en la ciudad cultural y universitaria, hay no obstante algunas breves referencias a comercios y establecimientos industriales, los considerados fundacionales: el Molino Campodónico, La Julia, la primera fábrica de cal y mosaicos, y algunas caballerizas, talabarterías, tambos, fondas y cafés.

En los relatos de Viajeros, concentrados en los primeros años de la ciudad -cuando La Plata no era ciudad universitaria-, los artículos de P.M. de Corvetto fechados en 1885 y 1886 hacen referencia a una "vitalidad industrial" de la nueva capital y mencionan varios establecimientos fabriles. En el paraje de Arroyo del Gato -agrega- "atraen la mirada y excitan la curiosidad dos altas chimeneas, una de $40 \mathrm{~ms}$., otra de más de $37 \mathrm{~ms} . . . ”$. El texto alude también a un proyecto de ley en discusión que acordaría un subsidio a la instalación de frigoríficos, promovido por el ministro de Obras Públicas Gonnet (Barcia, 1982: 92, 100).

Del mismo período, el escrito de Santiago Estrada se dedica a los grandes talleres ferroviarios de Tolosa y menciona la introducción de casas para los obreros, de inspiración sajona (Barcia, 1982: 110). Por su parte, Emilio Daireaux retoma datos censales sobre los trabajadores, en esa época en que la ciudad apenas superaba los 10.000 habitantes: "había 3 médicos, 1802 albañiles, 337 carpinteros, 128 empedradores, 2.451 peones, 57 lavanderas o tituladas tales, 87 panaderos, 53 pintores, 112 serenos o policíacos, sin contar las profesiones no caracterizadas...", escribe. Los datos vienen acompañados por un reconocimiento de la población inmigrante, mayoritariamente italiana (en Barcia, 1982: 148).

En ese sentido, la publicación que hace una lógica referencia a los obreros que construyeron la ciudad es Italianos:

"Es indudable que, mientras el trazado de la ciudad fue obra de Pedro Benoit a quien la iluminada personalidad de Dardo Rocha confió su realización, la construcción de los monumentos y edificios más representativos no se hubiera podido llevar a cabo sin la contribución de la mano de obra de los inmigrantes que en un número de 4.200 llegaron a esta zona hasta entonces casi desierta y la poblaron" (Hoor, 1982: 1)

se opuso al arte nuevo. Como todas las revoluciones fue conservadora en materia cultural, hizo prevalecer una actitud seudotradicionalista y normativa. En arte se tomó el rábano por las hojas; de modo que en 1955 fue preciso comenzar de nuevo" (Nessi, 1982: I-III).

El artículo en Económica, en tanto, es ambivalente y su escritura difiere en los distintos fragmentos, cuya autoría varía. Hay un claro reconocimiento de los cambios impuestos en el sistema financiero (Cuccorese, 1982: 166-168) pero en las referencias políticas aparecen expresiones esquivas, como la alusión a "los sucesos políticos de 1955”, en la parte escrita por Girbal (en Cuccorese, 1982: 168). 
Según destaca Hoor, los italianos, que fueron mayoría en los primeros años de la ciudad, eran una población joven, con una mayoría absoluta de varones y con distintos oficios: "En el siglo pasado, el $65 \%$ de los italianos recién llegados eran agricultores, braceros y peones; un $15 \%$ obreros de la construcción y un $9 \%$ obreros especializados, siendo también notable la multitud de actividades industriales, comerciales, financieras y de todo tipo que desde antiguo han brotado y florecido en esta ciudad por obra suya" (Hoor, 1982: 7).

En Edad de mi infancia, Sureda también evoca a los primeros trabajadores, los que construyeron la ciudad: albañiles, herreros, plomeros, carpinteros, yeseros, pintores, decoradores, dibujantes y "peones para todo servicio" (Sureda, 1982: 14).

Por su parte, cabe mencionar a Vida espiritual, que si bien está dedicado a alentar la noción de ciudad universitaria, no deja de mencionar "el primer barrio obrero que tuvo el país (las 'mil casas')"234 e incluye referencias laborales como el puerto o YPF:

“...El puerto, suficiente para la mayoría de los calados de la época, alcanzó tráfico constante y surgieron los astilleros y la Escuela Naval. Vino también la refinería de Yacimientos Petrolíferos Fiscales. Pero La Plata fue fundamentalmente, y es, la ciudad universitaria que bajo la sabia orientación de Joaquín V. González desde el despacho de la rectoría (o presidencia, como el prefirió), pronto alcanzó fama y merecido respeto entre la intelectualidad y el estudiantado de toda América..." (Bartholomew, 1982: 6)

En Ciudad milagro, las alusiones más claras al mundo del trabajo están dadas por el ensayo fotográfico de Alberto Rossi con textos de Carlos Vallina, que va de la página 234 a la 247. "La Plata: Herencia y Proyecto" incluye imágenes de la ciudad-puerto y también de la ciudad industrial, además por supuesto de los lugares comunes como la catedral o la universidad. En tanto, el artículo de Bauer da cuenta de una ciudad con industrias -aunque sin peronismo-, con menciones que van dese el primer frigorífico hasta la instalación en 1925 de la destilería de YPF en la zona del puerto (en Lerange, 1982: 568). Otros capítulos hacen otras referencias puntuales ${ }^{235}$.

Buena parte del desarrollo sobre ese tema y sobre la vida de los trabajadores incluido en Ciudad milagro podemos encontrarlo en el capítulo casi final que la compilación concede a Berisso, pues el repaso de la historia de esa ciudad liga la trayectoria obrero-industrial excluida o silenciada en el planteo general. Tras el afincamiento de los trabajadores, Urbañsky evoca también el desarrollo de recursos primarios, en quintas, montes y viñedos: "El sauce y el álamo originaron la leña y la madera. La producción agrícola se enriqueció con tomates y ajíes morrones [...] La 'uva chinche' fermentó 'vino de la costa', de interesante producción en 1960, que luego se estabilizó en Palo Blanco, Balneario Bagliardi, La Balandra y camino a la Isla de Armour y que muchos platenses acuden a saborear" (en Lerange, 1982: 654).

El relato menciona además un "importante movimiento cooperativo" en la comunidad y da cuenta de "fervorosas huelgas" (en Lerange, 1982: 654), un tema completamente ausente en el resto de la compilación: la cuestión sindical está tibiamente sugerida en el capítulo sobre

\footnotetext{
${ }^{234}$ En el corpus analizado son escasas las menciones de esta experiencia de vivienda obrera considerada pionera en Latinoamérica y que en 1939 Sánchez Reulet consideraba "famosa". En Vida platense hay una alusión al "barrio temido" en que se convierte la zona cuando ya es un proyecto frustrado (Soler, 1982: 84).

${ }^{235}$ En un texto sobre el Palacio D’Amico que se demora en hablar de su tema específico, Menucci menciona los talleres ferroviarios de Tolosa como "los más importantes de América del Sur" (en Lerange, 1982: 76). Bernard, por su parte, alude a la industria frigorífica, "continuadora de la más cerril de los saladeros que, al establecerse después en el barrio platense de Berisso, convertirá a éste en populoso centro fabril” (en Lerange, 1982: 29).
} 
la Asociación de Maestros de la Provincia, pero no se desarrolla sino hasta que aparece el artículo sobre el partido limítrofe a la ciudad ilustrada.

El que presenta cierta aproximación a "conflictos obreros" es Vida platense, el libro publicado por El Día. Esta aparece en relación a los primeros años de la ciudad, época de anarquistas y socialistas, cuando surgieron las primeras asociaciones de trabajadores. Algunos juicios del autor dan un carácter particular al tema: "Huelgas casi románticas, conflictos de tono menor, dan la tónica de estos primeros reclamos gremiales que, con el tiempo, se harían masivos" (Soler, 1982: 26). Esta formulación es claramente discutible. Cabe recordar que en agosto de 1896, cerca de setecientos obreros de los talleres ferroviarios de Tolosa iniciaron una de las huelgas más importantes de la época.

Soler también afirma que "el gremialismo no tenía entonces el enorme poder económico y político que alcanzó después. El sindicalista se sentía representante y no dirigente, y cumplía con su militancia sindical con verdadero sacrificio" (Soler, 1982: 50). Pero las páginas que siguen no retoman los conflictos masivos ni el poder que alcanzó después el sindicalismo. Finalmente, sólo el libro de Familiares, abocado a la denuncia de la represión desatada por la dictadura, reconoce abiertamente que "aquí se habían librado luchas obreras, protagonizadas por las fábricas petroquímicas, siderúrgicas, frigoríficas, astilleros, etc., que, junto a otros sectores populares, hicieron escuchar sus justos reclamos y despertaron solidaridad en barriadas y villas..." (Familiares, 1983: 57)

Acaso en aquella recuperación romántica del conflicto obrero se juega la dicotomía que divide a los trabajadores entre "obreros y 'negros", que Jauretche había descubierto en Beatriz Guido y consideraba constitutiva del medio pelo: "El obrero es un ente imaginario de piel blanca y apellido preferentemente italiano, más concretamente, ocupado en los servicios públicos, y con una cultura media que lo pone al margen de los movimientos multitudinarios. Su característica no es su ideología que supone comunista, socialista o anarquista, posiciones repudiables pero cultas" (Jauretche, 1966: 321)

En cuanto a la estructura industrial, las mejores caracterizaciones podemos encontrarlas en trabajos universitarios: Obra de arte y el aporte del equipo de Cuccorese a Económica.

La cuestión productiva aparece en varios tramos de la publicación de la Facultad de Humanidades: al recorrer las distintas localidades del Partido ${ }^{236}$, al dar cuenta de los "usos de la tierra" y con un capítulo específicamente dedicado a la "estructura industrial". Es el único texto de la época que destaca la importancia de la producción hortícola, frutícola y florícola de la región. También se detiene en la existencia de zonas de residencia de familias obreras.

Estamos ante partes del libro desarrolladas en un tono académico, con datos precisos, cita de fuentes y sin adjetivaciones exageradas. Su redacción correspondió a integrantes del Departamento de Geografía de la Facultad. La mirada incluye a la zona de Berisso y Ensenada: se menciona la Destilería YPF, la Petroquímica y Propulsora Siderúrgica, el Astillero Río Santiago, la Fábrica Militar de Ácido Sulfúrico, la Sociedad Industrial de Aparatos de Precisión (SIAP), la industria alimenticia -molinos y empresas productoras de bebidas y chacinados- y la metalurgia liviana. Además, en un recorrido histórico se incluyen los saladeros de Antonio Cambaceres y Juan Berisso -que llegaron a emplear 2.000 obreros- y

\footnotetext{
${ }^{236}$ En Gonnet menciona, además de clubes e instituciones deportivas y el Hospital San Roque, que es "asiento de industrias: INDECO, papelera San Jorge y en Ringuelet SNIAFA y SIAP, y de emprendimientos tales como Micro-ómnibus 518, La Plata refrescos, SED, etc”. Señalamientos similares hace en otras localidades. De Romero destaca la "floricultura" como "motor económico de la zona".
} 
los frigoríficos que los reemplazaron, llegando a ocupar a más de 10.000 trabajadores. Al analizar la evolución industrial se reconoce un particular crecimiento en la década del ' 40 .

En total hay 18 páginas continuas dedicadas a la actividad industrial -incluso con imágenes significativas, como un esquema sobre la complementación de industrias del área (Díaz, 1982: 170-187). Apartados como el dedicado a la Comparación del aglomerado con la conurbación de Buenos Aires, General Pueyrredón y Bahía Blanca dan cuenta de una intención claramente analítica, no celebratoria, propia del tono académico de una parte significativa del libro. Otra versión del mismo trabajo se publica en el $\mathrm{N}^{\circ} 28$ de la Revista de la Universidad, firmado por Miriam Prada y María Cristina Zilio (1982), las investigadoras de Geografía que elaboraron ese fragmento de Obra de arte.

El otro texto que destaca al menos algunos hitos de la evolución industrial y comercial es el del equipo dirigido por Cuccorese, concentrado en la historia económica de la ciudad. En el espectro industrial incluye frigoríficos, destilería, hilandería y fábricas de tejidos, astilleros y otras pequeñas y medianas industrias. Una referencia importante es a la Petroquímica Sudamericana en Lisandro Olmos, surgida hacia 1962, que "conforma un complejo industrial con las hilanderías Olmos". De un modo análogo al otro libro, también señala que "con las reformas económico-financieras de 1946/55, el comercio y la industria se ven beneficiados; fundamentalmente esta última que se transforma en meta de las planificaciones estatales" y que en "1949-50 se evidencia un crecimiento de la industria..." (Cuccorese, 1982: 164) ${ }^{237}$.

Por último, retomemos el prólogo de No habrá manto de olvido, donde concentra su reflexión histórica, titulado "1882-1982 La Plata: Obreros y estudiantes”. El señalamiento desde el título de esa coexistencia es importante y encierra una gran lucidez: no refuta la presencia protagónica de los universitarios, sino su consideración como única realidad de la ciudad. Así, como proceso contemporáneo al desarrollo del movimiento reformista en los claustros universitarios locales (1919-1920), señala:

“...Lejos de los centros de la vida estudiantil, en los barrios periféricos, en las márgenes apenas delimitadas con el campo, va desarrollando su vida autónoma el mundo obrero, el mundo del trabajo fabril y manual" (Familiares, 1983)

La conclusión tácita es que La Plata no es una ciudad exclusivamente universitaria. El libro habla de una urbe "obrera y estudiantil", que en ese sentido "fue una de las más golpeadas en el país" por el accionar represivo de la dictadura, que "miles de los vecinos [...] han sufrido directamente..." (Familiares, 1983: 85).

El esfuerzo central de No habrá manto de olvido está dedicado a construir una lista de detenidos-desaparecidos de la región, donde "predominan los estudiantes, pero también ha crecido el número de obreros", de los que se tiene poca información: "La denuncia de secuestro de los estudiantes es total, completa y generalizada; y la de los obreros muy incompleta, cuando existe..." (Familiares, 1983: 3). Esta idea resulta significativa, sobre todo por su temprana enunciación. Desde las primeras denuncias públicas sobre el terrorismo de

\footnotetext{
${ }^{237}$ En la caracterización general de la ciudad, ambos trabajos coinciden finalmente en que la actividad productiva, aunque importante, es secundaria: "La Plata ha sido siempre una ciudad de 'servicios', de neto predominio de la actividad terciaria (...) La industria nunca ocupó un lugar destacado en la evolución de la ciudad, dedicada casi exclusivamente a satisfacer necesidades del mercado local, mostrando escasa diversificación y complejidad. No obstante, tomando globalmente el Gran La Plata puede observarse un considerable desarrollo industrial, debido esencialmente al sector fabril de Berisso y Ensenada. En la actualidad el Gran La Plata, tiende a ser absorbido por el Eje Metropolitano, formando una zona económicamente homogénea y dinámica.." (Cuccorese, 1982: 165)
} 
Estado en Argentina, la representación de las víctimas obreras -que según el informe de CONADEP son el $30 \%$ de los desaparecidos- ha sido ocluida por la imagen dominante del joven universitario, o las figuras paradigmáticas de intelectuales, periodistas y religiosos, que pertenecen a grupos "menos" afectados, proporcionalmente. La escasa visibilidad de los trabajadores está vinculada a una "desigual distribución de los medios culturales y simbólicos" entre los allegados de cada víctima, "para hacerlos reconocer, individualizarlos y convocar la adhesión de otros" (Da Silva Catela, 2001: 175). Su consecuencia fue la sobrerepresentación de facciones de la pequeña burguesía acomodada y de asalariados no obreros (Maneiro, 2005: 48).

Con gran perspicacia al respecto, Familiares señala "la casi completa carencia de identificación de los trabajadores desaparecidos, aún de aquellos que integraban empresas estatales o privadas de primera categoría" (Familiares, 1983: 42), y se preocupa por incluir en su texto de denuncia la represión a los obreros, iniciada el mismo día del golpe:

"El 24 de marzo de 1976, a las 2 de la mañana, Infantería de Marina ocupa la Planta (de Propulsora Siderúrgica) Lleva listas de «sospechosos» y detiene alrededor de 20 obreros. Se cierra la fábrica por dos días. Cuando los trabajadores vuelven a trabajar, continúa ocupada por la Marina. Piden documentos a la entrada y a la salida, requisan, palpan, violan los armarios de los operarios y ante la menor sospecha, detienen [...] En Y.P.F., el 24 de marzo de 1976, la Marina ya controla la entrada pidiendo documentos durante una semana. Detiene a seis obreros en Destilería. Buscan los más destacados dentro del S.U.P.E. [...] En SWIFT el 24 a las 3 de la madrugada Prefectura y Marina controlan la zona y el Frigorífico. A punta de bayoneta, sacan los obreros del turno noche. Cierran la fábrica durante todo el día [...] En SIAP el Ejército se llevó detenidos a 7 delegados, la mayoría mujeres. Fueron brutalmente golpeadas y violadas..." (Familiares, 1983: 59-60)

Así, si bien hallamos varios textos que incorporan referencias a la actividad industrial de la zona, No habrá manto de olvido es el único que emprende cierta impugnación -que es, en rigor, una relativización- del potente imaginario de la ciudad universitaria:

“...los obreros y los estudiantes permanecerán unidos a través de nuestra acción para recuperar la vida y libertad [...] Unidos como el país lo necesita y La Plata-ciudad universitaria y obrera- lo reclama" (Familiares, 1983: 3, 4. Las cursivas son mías)

\section{Una reinvención del origen}

En los principales textos del '82, la identidad universitaria de la ciudad adquiere tal peso que aplasta cualquier reconocimiento como el que promueve el libro de Familiares. Una muestra elocuente de la fortaleza de ese imaginario está dada por las operaciones simbólicas que lo llevan hasta el origen mismo de la ciudad, que como vimos nació sin universidad y no tuvo una sino hasta varios años después de la fundación.

"La Plata fue creada, programada para la Cultura", afirma Ana Emilia Lahitte (1982: 81). En el prólogo de la antología completa de Speroni preparada por esa escritora, el notario Luis María Bordenave ratifica la idea: "la fundación advino como pacto solidario de reconciliación, paz y progreso, al buscado amparo de las letras, las ciencias y las artes, en su privilegiada condición de urbe universitaria" (Speroni, 1982: 11-12). Análogo planteo hace el intendente de facto entrevistado en Ambiente: "En la fundación, el rol de La Plata estuvo 
claro. El rol de 'nueva Salamanca' de Latinoamérica, el rol de ciudad universitaria, que fue cumplido y con creces" -esa identidad, dice, se presenta desdibujada hacia el centenario- ${ }^{238}$.

Bernard, por su parte, afirma que La Plata fue diagramada "como urbe universitaria, destinada a albergar estudiantes de todo el continente, en su preciada condición de nueva Chuquisaca ..." (en Lerange, 1982: 23). Detengámonos en los textos de este autor, que es el responsable de una llamativa operación de reinvención del pasado, a partir de una singular forma de explicar la denominación de la ciudad.

El nombre de La Plata, vale recordar, suele adjudicarse al autor del Martín Fierro, José Hernández, quien al proponerse la ciudad era senador provincial (Garnier, 1992: 27; VV.AA., 1982a: 5). La denominación apareció agregada entre líneas con tinta, en el proyecto de creación de la nueva capital tratado el 20 de abril de $1882^{239}$. A su vez, algunos trabajos recuerdan que en el concurso para proyectar el edificio de la Municipalidad la propuesta ganadora se titulaba La Plata, y se había presentado antes de la elección del nombre en el Senado (Morosi, 1981a: 275-277; Morosi, 1983. 79, 87) ${ }^{240}$.

Pero la querella que nos interesa se produce en torno a cuál es el sentido de ese nombre, sobre lo cual hay dos grandes relatos ${ }^{241}$ :

1) El que relaciona a la ciudad con el río -que a su vez deviene del metal buscado por los conquistadores-. Esta asociación con la geografía patria se constata con la lectura del discurso de Rocha en el acto de colocación de la piedra fundamental, que resalta "la alta significación nacional de la ciudad que vamos a fundar, que se liga directamente a la historia de la Nación, y que será recordada en ella, no como un acto de la vida de provincia, sino como un acontecimiento argentino, y así con justo título, tomamos el nombre del gran río, para designarla con él, confiando que este nombre será el augurio de su riqueza y de su rápido acrecentamiento" (citado en Barba, 1995: 146. Las cursivas son mías).

\footnotetext{
${ }^{238}$ Según Román, si hubo un proyecto productivo para La Plata corresponde a la década del 60: "Dos décadas atrás surge un proyecto nacional, que imaginaba la formación de un gran eje industrial que terminaba en Rosario (...) Pero La Plata hoy, no tiene definida su personalidad porque es mucho menos universitaria de lo que era; es sólo un poco y no plenamente universitaria, un poco industrial, y un poco comercial. Es decir, es un poco distintas personalidades, sin ser total y definitivamente algo" ("Entrevista al Dr. Abel Román Intendente de La Plata”, en revista Ambiente, $\mathrm{N}^{\circ}$ 32, junio de 1982, página 67).

${ }^{239}$ Según Soler, por esa razón no se puede "determinar fehacientemente a cuál de los legisladores de entonces se debe el nombre de la ciudad” (Soler, 1982: 12). Es Hernández, no obstante, el miembro informante que defiende el nombre en la sesión del Senado: "No queda, señor, sino decir algunas palabras respecto a la razón que ha tenido la Comisión para denominar a esa ciudad con el nombre de 'La Plata'. Ella ha querido evitarse las divagaciones consiguientes si entraba ya en la designación de nombres propios, ya en otras divagaciones, e inspirándose en los antecedentes de la República, inspirándose en la geografía patria, ha dado el nombre de 'La Plata' porque estos territorios fueron primero: Gobernación del Río de La Plata, en tiempo de la Metrópoli; fueron más tarde: Virreynato del Río de La Plata; más tarde: Provincias Unidas del Río de La Plata..." (citado en Morosi, 1981a: 277).

${ }^{240}$ En la Comisión del senado estaba Belisario Hueyo, miembro también del jurado del concurso. Para una revisión más completa de este tema, véase Vallejo (2005: 32).

${ }^{241}$ Nos referimos a las publicaciones de 1982 analizadas. En el libro -posterior- de Troisi se menciona adicionalmente una posible inspiración familiar: "Se barajan antes varias denominaciones. Carlos Pellegrini propone 'Rivadavia', en tanto Rocha -sin ocultar los objetivos de la nueva ciudad- sugiere Nueva Buenos Aires'. Finalmente, es la propuesta de José Hernández la que prospera. El río, la histórica ciudad del Alto Perú actual Sucre- o incluso, el apellido de algún pariente de Hernández, parecen haber sido las posibles fuentes de inspiración del autor del Martín Fierro..." (Troisi, 2006: 70). No obstante, la eventual referencia al abuelo de Rafael y José Hernández (José Gregorio Hernández Plata) no aparece en ninguno de los textos del corpus.
} 
2) El que relaciona a la ciudad con un supuesto destino de "ciudad universitaria". Esta última interpretación resulta curiosa, ya que La Plata -reconocida por su planificación previanació sin universidad, y fue recién entrado el siglo XX cuando logró un proyecto sólido.

Vida platense admite ambas significaciones: "Es sabido que se la quiso llamar Rivadavia o Moreno, en recordación de los propulsores del puerto de Ensenada. Sobre el origen del nombre recogemos dos versiones: el gran río, o la Universidad de Chuquisaca, que también se llamaba La Plata" (Soler, 1982: 12). También el artículo de Douglas Morgan sobre el poder judicial, incluido en Ciudad milagro, sugiere las dos posibilidades: “¿Por qué ese nombre colonial y boliviano?, preguntaron los periódicos, recordando que La Plata, era una de las viejas designaciones de Sucre. Debe reconocerse que era una designación armoniosa y evocativa para una ciudad argentina junto al Río de la Plata” (en Lerange, 1982: 209)

Entre los que toman partido por el primer relato, Ciudad nueva ciudad antigua sostiene que el nombre refiere al "Río de La Plata, que daría su nombre a la ciudad..." (Morosi, 1983: 28), y pone en palabras de Hernández la asociación con el río y la forma en que se denominó a la región (Morosi, 1983: 79). En La Plata 100, en tanto, se dice que "Hernández propone la denominación de La Plata basándose en consideraciones históricas, ya que la región se había llamado Virreynato del Río de La Plata y posteriormente Provincias Unidas del Río de La Plata" (VV.AA., 1982a: 5)

En el mismo sentido interviene Conrado Bauer, con otras palabras, en Ciudad milagro:

“...La Plata, el nombre de la nueva capital, tenía resonancia nacional y americana. Estaba profundamente enraizado con la tradición histórica de nuestras Provincias Unidas, desde que se bautizara con ese sustantivo mágico al río-océano que descubrió Solís. Es que el tintineo del metal noble convocó durante siglos los sueños de aventureros y conquistadores; la naturaleza que aquí negó la recompensa mineral retribuyó más tarde con la alquimia dorada de los vegetales el esfuerzo laborioso regado con el sudor humano. El nombre de La Plata renovaba el viejo sueño; posiblemente quiso ser estímulo para la ilusión creadora y no incentivo de rapiña voraz" (en Lerange, 1982: 562) 242 $^{2}$

También en Obra de arte La Plata se vincula a esa denominación que ya portaba el territorio, y que se asocia directamente a la conquista: “....así nació La Plata, cuyo nombre simbolizó las ancestrales aspiraciones de los conquistadores y colonizadores hispánicos al llegar a estas tierras en busca del codiciado metal, penetrando en el corazón mismo del continente sudamericano; ilusión cuya persistencia en el tiempo hizo surgir el nombre genérico de Argentina a un dilatado territorio, hoy consolidado en nación" (Díaz, 1982: 15). En la misma dirección, Cygan describe a la ciudad como "una expresión última de las antiguas corrientes fundacionales españolas [...] en una situación geográfica tras de la Ciudad de Buenos Aires y su puerto, con el nombre de uno de los metales preciosos que la Conquista por allí exportó: La Plata" (Cygan, 1981: 201).

Aunque estas explicaciones del nombre parecen convincentes, un segundo relato las contradice. Es el propuesto por Tomás Bernard, quien como vimos en el capítulo IV lejos está de ser un autor marginal en el desfile de textos del centenario: publica varios textos y además

\footnotetext{
${ }^{242}$ Esto es así aún cuando Bauer es uno de los que fomenta el imaginario de ciudad universitaria, cuando escribe: "Las aulas, las pensiones estudiantiles, el comedor universitario, los campos de deporte, las reuniones culturales y sociales fueron ámbitos de una confraternidad que, al par que forjadora de ciencia y cultura, arraigó firmes vínculos humanos, confiriendo a La Plata el matiz de 'ciudad universitaria' que irradiaba su influjo y su estilo en misión trascendente para Argentina y América" (en Lerange, 1982: 568)
} 
es un miembro relevante de instituciones con iniciativas editoriales en torno a la celebración. La idea sostenida por este autor, que coloca la autoría en los dos hermanos Hernández, confirma y refuerza el imaginario de la ciudad universitaria:

"Dejó al espíritu sagaz de José Hernández -el más grande clásico de la literatura argentina, la honra de bautizar La Plata. Y Hernández, con el consejo de su ilustre hermano Rafael, nominaron, con certeza de destino la ciudad de Rocha, como la Nueva Chuquisaca, la Nueva Charcas, centro inaugural de la cultura universitaria sudamericana, foco luminoso de las ideas revolucionarias que debían saciar el hambre y la sed de justicia de los hombres nuevos del Nuevo Mundo" (Bernard, 1982b: 21)

En el mismo folleto, al inicio del siguiente capítulo ratifica la analogía: "La urbe siguió creciendo con ritmo vertiginoso ganando su propia capitalidad [...] el Museo y la Universidad proclamaban el señorío cultural de la Nueva Chuquisaca, Charcas o La Plata" (Bernard, 1982b: 26). Es llamativa la mención a la universidad en este punto, cuando se está refiriendo a los años 1884-1891, etapa en que todavía no existía una institución de ese tipo en la ciudad.

La teoría aparece aún más desarrollada en su aporte a Ciudad milagro, que es ni más ni menos que el capítulo inicial de la monumental compilación. Bernard es consciente que está refutando otra idea, pues escribe: "el nombre de La Plata no era dado por el Río de La Plata". Y explica:

“...José Hernández, no obstante señaló el nombre de La Plata, con una intención y un significado mucho más profundos y trascendentes. Lo hizo porque la Nueva Capital iba a ser una ciudad universitaria, un centro de alta cultura verdadero faro del espíritu americano. Si en lo arquitectónico, en lo edilicio, en su traza, La Plata era una creación inédita, singular, representativa del nuevo mundo en sus valores revolucionarios, en lo espiritual estaba llamada a ser, también, una Capital del pensamiento. De ahí que el nombre de La Plata lo inspirara la lejana ciudad alto peruana de Chuquisaca. 'Chuquisaca' -Puente de oro-, Charcas o La Plata, sede de la celebre Universidad de la Colonia donde se formaron gran parte de nuestros próceres. Chuquisaca, Charcas o La Plata, fundada por don Pedro de Anzures, en 1538, por orden de Pizarro, resultó la Capital de la intelectualidad rioplatense [...] La Universidad que se llamó de La Plata fue creada por Real Cédula de Carlos V en 1552 [...] La Nueva Capital debía ser la Nueva Chuquisaca, la Nueva Charcas, modeladora del espíritu renovador americano. $Y$ no se equivocaba tampoco en esto, La Plata se caracterizaría por ser ciudad universitaria” (en Lerange, 1982: 26-27. Las cursivas son mías)

\section{El panteón de héroes}

El peso excluyente del imaginario de la ciudad de artistas y sabios, de la capital de cultura, de la consagrada ciudad universitaria, se confirma al conocer sus próceres. Más allá de Rocha y Benoit como fundadores, el panteón se construye a partir de figuras de la ciencia, el arte y el pensamiento. Es una operación que antecede al centenario, pero que en 1982 se multiplica y se expresa en casi todos los textos.

La tendencia a enaltecer figuras no es atípica para la actividad historiográfica, mucho menos en el tipo de historia que González identifica como pragmático-ética, adoctrinante o de bronce, ese relato que "recupera valores del pasado para venderlos a los hombres del presente; se especializa en la resurrección de gloriosos ejemplos que emular", de la que -como vimos en el capítulo III- estos textos tienen mucho (González, 2009: 82). La tendencia a enaltecer ciertas figuras se asocia a la búsqueda de crear identidad, que generalmente se ha pensado en términos nacionales, pero también se produce en la escala local. 
Los relatos sobre el pasado platense analizados destacan entonces a personajes ejemplares, "prohombres que sustituyeron su falta de tradición con el cimiento de mentalidades únicas" (Díaz, 1982: 279), héroes de la ciudad que "comprendieron que los bienes del espíritu son riquezas centrípetas, que a diferencia de las materiales, cuanto más se dan más se acrecientan, y en estas riquezas asentaron toda la existencia, legándonos el imborrable legado de su ejemplo excepcional" (Hortel, en Lerange, 1982: 165).

Las referencias se repiten una y otra vez, de publicación en publicación, con escasas variaciones, y están estrechamente vinculadas al imaginario de la capital cultural o intelectual, definida con ciertos sesgos específicos. En buena medida, la gestación del "panteón de héroes" tiene una historia previa. El investigador de la policía Juan Vucetich, el poeta Almafuerte, el médico y filósofo Alejandro Korn y los científicos naturalistas Carlos Spegazzini y Florentino Ameghino son reconocidos como los "cinco sabios" desde varias décadas antes. Como podemos advertir en la lectura de Crónicas de un siglo, el hemiciclo con sus bustos que está frente al Museo de Ciencias Naturales fue realizado para el 19 de noviembre de 1941, por iniciativa del entonces presidente de la UNLP Alfredo Palacios.

Aquellos nombres se repiten una y otra vez en la bibliografía analizada, y vienen de textos previos. Ambiente, que dedica su sección "a/personajes" a "Los 5 sabios", lo hace retomando un fragmento del texto Tiempos y Fama de La Plata, de José María Rey (1957), publicado por la Municipalidad en el $75^{\circ}$ aniversario de la ciudad ${ }^{243}$. Encontramos otra referencia breve al hemiciclo en Vida platense:

"Los quintillizos.

Así son conocidos popularmente los cinco bustos que se levantan en el Bosque, entre el Zoológico y el Museo de Ciencias Naturales...” (Soler, 1982: 136)

En el capítulo sobre esculturas de Ciudad milagro, Canestri se ocupa de esa representación de los cinco genios (en Lerange, 1982: 256). También Rica menciona, al referirse al Bosque, el "rincón con los bustos de cinco personalidades que vivieron en La Plata, y con su genio e inteligencia dieron renombre universal a la ciudad, por su laboriosidad, arte y ciencia" (en Lerange, 1982: 48). Tres años antes, el mismo autor había publicado en Letras, la revista de la SEP, un artículo titulado "Cinco personalidades: Ameghino, Almafuerte, Spegazzini, Korn, Vucetich”.

No son los únicos héroes culturales de la ciudad. Como ya vimos, Joaquín González -consagrado como "fundador" de la Universidad- también ocupa un lugar importante. Algo

\footnotetext{
${ }^{243}$ Un excelente ejemplo de una publicación previa que construye una lista próceres, más amplia pero siempre vinculada a un modelo de ciudad, es la Historia espiritual de La Plata de Ricardo Font: “...cuando aún se leía con vivo interés 'Mis montañas'; Ameghino empezaba a ser comprendido más allá de los círculos intelectuales; el perito Moreno, sin descuidar sus actividades internacionales, enriquecía las colecciones paleontológicas del Gran Museo platense; Spegazzini incorporaba importantes estudios originales a la botánica; Ricaldoni llevaba nuevas y brillantes luces a las ciencias matemáticas; Berra elevaba a gran altura la educación común; Vucetich atraía también las primeras miradas del Continente; Beuf, genio de la Astronomía, el Flamarión platense, organizó y dirigió el Gran Observatorio, el mayor existente en América latina, lo propio que nuestro museo; Korn, la más alta personalidad del espíritu que fue dado contemplar de cerca, sentaba los sólidos principios de una filosofía americana; Olivera, eminencia intelectual y legislativa, iluminaba con fuertes relámpagos Kantianos el nublado cielo intelectual de las almas; Agustín Alvarez y Rodolo Rivarola, representaban con González la sabiduría Universitaria; Saldías daba clima a su fecunda obra histórica y literaria; Rocha presidía personalmente las fiestas de aniversario de su gran formación; en las profesiones, en la cátedra, en el Gobierno, daban altas lecciones de ética, de ciencia y de patriotismo". La lista continúa con una selección de abogados, músicos, escritores, filósofos, etcétera, todos "prohombres que impulsaron el progreso y la cultura de la ciudad y de la provincia" (Font, 1951: 9-11)
} 
similar ocurre con el creador del Museo, Francisco Moreno. Y otros de los textos analizados -en especial los promovidos por las sociedades de escritores- incorporan nombres propios de "la ciudad de los poetas", ampliando una lista que por supuesto empieza con Almafuerte.

Podemos ver entonces cómo el panteón se amplía, pero siempre en torno a un imaginario de ciudad letrada, científica, artística y universitaria.

Uno de los trabajos de Bernard incorpora a Lynch y a González: "Se honraba con haber albergado talentos de la talla de Almafuerte, Ameghino, Joaquín V. González (que aunque no vivió, aquí enseñó y educó), Alejandro Korn, Vucetich, Benito Lynch y tantos otros" (Bernard, 1982b: 17). En el tono propio de su texto, todas las referencias se vinculan a su familia: esos sabios fueron su médico, sus maestros, sus amigos.

En el artículo de Carol en Ciudad milagro hallamos una lista más completa, asociada a la afirmación de un imaginario de ciudad:

"[...] La ciudad era ya famosa no sólo por su trazado, su Universidad, su Museo, Observatorio Astronómico, palacios, Catedral, Teatro Argentino, etc., sino también por la amplitud y la jerarquía de su actividad cultural, destacándose entre otras, las figuras de Ameghino, Spegazzini, Korn, Vucetich, Moreno (Francisco P.), Joaquín V. González, Almafuerte y Lynch, que desarrollaron en ella. 'Como se sabe -escribió Pedro Miguel Obligado-, La Plata es, desde su fundación, una ciudad especialmente meditativa, una capital universitaria, de ambiente propicio al estudio, que ha tenido la fortuna de contribuir a la cultura de nuestro país con el talento y la labor de hombres excepcionales."' (en Lerange, 1982: 384-385)

Otra lista ampliada de héroes culturales podemos encontrar en uno de los capítulos de $\mathbf{1 2}$ personalidades:

"¡Las sombras tutelares la protegen! Dardo Rocha, el fundador, siempre presente; Juan Vucetich, Fiorentino [sic] Ameghino, Carlos Spegazzini, Samuel Lafone Quevedo, sabios de trascendencia ecuménica, transitaron sus calles desiertas; Carlos Vega Belgrano, también, pero acarreando libros preciosos que donó a la Biblioteca; Joaquín $V$. González, el patriarca; y el tonante Almafuerte, que se arraigó con fuerza; el maestro Pedro Ruta; el humanista Angel Licitra; Emilio Pettoruti, el pintor por antonomasia; el exquisito Rafael Alberto Arrieta y la caravana homogénea de sombras -si cabe- más leves: Abigail Lozano, Pedro Mario Delheye, Héctor Ripa Alberdi, Alberto Mendióroz y el amigo querido, Francisco López Merino. Y Jacinto E. Calvo, el orador eximio" (Yañez, en SADE La Plata, 1982: 88)

\section{O en la Crónica del centenario de Szelagowski:}

"Pocas veces el reconocimiento ciudadano alcanzó a valorar y exaltar las figuras en su época. Recién pasados los años, y casi siempre después de la muerte de los personajes, surgieron como figuras de platenses ilustres.

Pocos convecinos del poeta Almafuerte reconocían sus méritos, o tenían interés en un cuadro de Pettoruti o de Brughetti. Veían pasar a Florentino Ameghino, como un hombre más, con sus rarezas de juntador de huesos. O a Alejandro Korn o a Rafael Arrieta, ocupados de esas cosas extrañas de la filosofía y de la literatura. O más adelante, cuando concurríamos al Colegio Nacional de los años treinta, no nos admiraba que eminentes escritores o científicos fueran sencillos profesores con los que teníamos diario contacto" (Szelagowski, 1982b: X) ${ }^{244}$

\footnotetext{
${ }^{244}$ El Colegio Nacional es un punto de encuentro de muchas de las figuras culturales exaltadas, como puede verse en el artículo de Coto y Guzmán dedicado a las escuelas platenses. Unido a "la historia de dirigentes y protagonistas de la historia local y nacional”, se caracterizó "por tener los mejores profesores e investigadores del ámbito ciudadano y nacional”. Entre otros mencionan a Henríquez Ureña, Martínez Estrada, Spegazzini, José
} 
En Rastros y rostros, cuando Estela Salvo indaga si la ciudad dejó de ser elegida por los soñadores, se pregunta:

“¿Dejó de ser taller de Perito Moreno, Víctor de Pol, de Korn, de Vucetich, de Spegazzini, de Ameghino? Ellos supieron que más que un proyecto sería una constante de evidencias y sobre los surcos de la historia inicial, la ciudad dormida recibió la siembra que dio frutos permanentes" (Calvo, 1982)

La autora hace luego una mención específica a los poetas, en especial a la "creadora fuerza vital" de Almafuerte y de su tío: "Francisco López Merino, el poeta de la ciudad...".

Cabe recordar también a Vida espiritual, que constituye específicamente una compilación de seis referentes de la cultura local: Korn, Henríquez Ureña, López Merino, Emilio Pettoruti, José Luis Romero y Baldomero Fernández Moreno. Otro libro que se estructura en torno a figuras relevantes es 12 personalidades, donde como ya vimos también predominan referentes de una ciudad letrada.

Los citados son sólo algunos ejemplos ilustrativos entre muchos de la bibliografía analizada, que como vimos está plagada de nombres propios.

Veamos, finalmente, cómo los textos del centenario construyen coralmente la heroicidad de los más destacados, a partir de sobreadjetivaciones y narraciones recurrentes. En suma, sobresalen un puñado de personalidades científicas -Ameghino, Spegazzini y especialmente Moreno-, universitarias -González y Korn- y artísticas -entre los plásticos Boveri y Petorutti; Podestá en el teatro; y entre los poetas Lynch y principalmente Almafuerte-.

Ameghino es evocado por Urraza -entre otros- en el cuarto artículo consecutivo vinculado al Museo en Ciudad de mayo, que elogia y retoma una "trascendental biografía" trazada por Joaquín Frenguelli y publicada en 1936 (De Urraza, 1981: 122). Christmann, en tanto, construye una imagen suya a partir de múltiples citas: de Arrieta, Ingenieros, Mercante y Ambrosetti. También ensalzan su figura De Santis, Calvo y Soler, quien lo considera un "sabio" y "autodidacto" (1982: 63).

Spegazzini, por su parte, es citado como "sabio" en Ciudad nueva ciudad antigua, precisamente en la parte dedicada a El paisaje y la flora en la época de la fundación, donde se cita el testimonio del naturalista. Soler suma su condición de "políglota y filósofo", que "sintió una particular inclinación por el estudio y contemplación de la naturaleza..." (Soler, 1982: 64). Italianos, por su parte, lo destaca entre los "más distinguidos compatriotas platenses de esa gloriosa época" (Hoor, 1982: 7). Y Vivencias y testimonios aporta a su consagración a partir de citas de Arrieta y, sobre todo, de José F. Molfino -su yerno, discípulo preferido y continuador de su obra-, quien en 1951 estuvo a cargo de un "homenaje al sabio" en el $25^{\circ}$ aniversario de su muerte.

El prócer platense del plano científico sobre el que vale detenerse es Francisco Pascasio Moreno, quien no integraba el panteón construido a principios de los ' 40 y sin embargo lo encontramos evocado en forma reiterada en la bibliografía del centenario.

También Moreno es un "sabio", "conocido explorador, geógrafo y antropólogo argentino" (Terrasa, 1982: 32-33):

“A Joaquín V. González y al perito Moreno la ciudad de La Plata recordará siempre con admiración y respeto por su importante aporte a la cultura; ellos formaron la base del acervo cultural que une a la Universidad Nacional de La Plata con todas las

Luis Romero y Enrique Barba. También a los poetas Arrieta y Seigel, ambos alumnos, luego profesores y finalmente rectores del Colegio (en Lerange, 1982: 343-344). 
ciencias del saber, ampliándose día a día con el aporte de estudiosos platenses; del interior del país; y de gente de otras naciones..." (Terrasa, 1982: 33) ${ }^{245}$

Elogian a Moreno y sus colecciones Bartholomew (1982: 6), Zuccalá y Musmano (1981: 31) y Christmann (1982: 63), además de los principales libros del centenario, que retomamos a continuación.

En Obra de arte se plantea que "el Museo de La Plata es la mejor pieza que se puede exhibir" en "el contexto de la cultura científica argentina" y antes de esbozar la trayectoria institucional dice que "la historia del Museo es la de la vida misma de quien lo concibió, lo fundó y lo organizó, el Perito Francisco P. Moreno" (Díaz, 1982: 318).

En Ciudad milagro, De Santis afirma que la "magna empresa" que fue la fundación el Museo "tuvo como único inspirador a ese gran argentino" del que destaca una "vigorosa personalidad". Es un texto marcadamente adjetivado: el Museo y su fundador son excepcionales, magníficos, etcétera. También alude al busto de Moreno realizado a partir de donaciones durante el rectorado de Benito Nazar Anchorena (en Lerange, 1982: 473-474).

Conrado Bauer agrega que Moreno "fue un argentino admirable y cabal, valiente explorador de la Patagonia, delineador convincente de nuestros límites con Chile, iniciador de nuestros Parques Nacionales, naturalista, científico y maestro; sus veintiún años en la Plata honraron nuestra ciudad..." (en Lerange, 1982: 565). Y agrega:

"Aún en plena crisis los hombres de cultura insuflaban nuevos sueños; es elocuente recordar que mientras la ciudad languidecía en lo económico, en 1895 Francisco Moreno expresaba: 'uno de los fines que persigue el Museo, es llegar a ser un centro de investigaciones que sirva al país y a la ciencia y que algún día sea núcleo de las instituciones que convertirán a esta ciudad muerta en un Cambridge o en un Oxford sudamericano", (en Lerange, 1982: 567)

Por último, Vida platense también hace alusiones a un "sesudo" trabajo de Moreno y a sus "indudables méritos personales". Lo describe como "un joven de apenas 21 años (que) exploró, en pleno dominio del salvaje, los vastos territorios de Chascomús y de Carmen de Patagones", y que hacia 1898 ya "había llegado al pináculo de la gloria" (Soler, 1982: 49). Después, agrega Soler,

“...todos sus bienes los ofrendó, ya anciano, a la niñez argentina, a la que brindó pan y educación. Sus últimos años estuvieron signados por el desencuentro con el régimen radical, que tenía a Moreno por un elemento conservador" (Soler, 1982: 49)

Y cita a Manuel Carlés, quien "lo despidió con esta palabras: 'Esta es la leyenda de la patria y Francisco P. Moreno fue el último protagonista de esa tradición sentimental"' (Soler, 1982: 50). La referencia es significativa: aunque el autor no lo indica, Carlés fue el líder de la derechista Liga Patriótica Argentina que en la década del '20, con la meta de estimular el patriotismo, promovió el culto a ciertos "héroes" nacionales, entre los que ubicó a Moreno, que había sido uno de los integrantes iniciales de esa organización (López, 2003). Al igual

\footnotetext{
${ }^{245}$ Cabe notar lo forzado de la asociación de Moreno con la Universidad nacional. El creaor del Museo -que al llevar su propuesta a la flamante ciudad había negociado su designación como director vitalicio- no fue un promotor del proyecto gonzaliano. Por el contrario, se alejó de la institución que había fundado cuando ésta pasó a la órbita de la Universidad, nacionalizada en 1906. Entre los textos del centenario, podemos encontrar un relato al respecto en el texto de De Santis en Ciudad milagro, originalmente preparado como conferencia para el Ciclo Cien años. Finalmente, el entonces director del Museo intenta conciliar historias: "Estoy seguro, sin embargo, de que si el fundador pudiese contemplar hoy, la trayectoria seguida por la institución después de su incorporación a una Universidad bien nacida, bien cimentada y de prestigio bien ganado, como lo es la Universidad Nacional de La Plata, no consentiría jamás que el Museo se desligase de la misma” (en Lerange, 1982: 475).
} 
que los textos producidos en el período 1979-1982 que venimos analizando, la Liga Patriótica reivindicaba a la generación del '80 y alababa la llamada "Conquista del Desierto", en cuyos crímenes y saqueos se originaron buena parte de las colecciones del museo platense.

El paso del tiempo -y las operaciones sobre la historia que trae aparejado- permiten que Moreno comparta el podio de próceres platenses con Joaquín V. González, a cuyo proyecto se había opuesto duramente. Como ya vimos, hacia 1982 hay una difundida tendencia a identificar en esa figura al fundador de la Universidad, en detrimento de Hernández. Junto con Korn -que ya formaba parte de los cinco sabios consagrados décadas antes-, González resulta la personalidad universitaria más destacada de los textos analizados.

Vale la pena detenerse otra vez en el texto de Bauer, que lo identifica como un Mesías de la ciudad, al mismo tiempo que mantiene en un lugar destacado a Moreno:

"La Plata esperaba su Mesías y éste llegó a través de una personalidad que, como antes la de Rocha, combinó con raro equilibrio calidades de estadista, soñador y realizador, a las que agregó además sus dotes de escritor y poeta: se trataba de Joaquín V. González, riojano descollante en el ámbito nacional, por entonces ministro de Justicia e Instrucción Pública.

Resumiendo orgánicamente las concepciones de Rocha, D’Amico y Moreno, González, con experiencia política y visión de largo alcance, interpretó que el país necesitaba una nueva mentalidad y ritmo realizador..." (en Lerange, 1982: 567)

González, que "creyó en la ciudad de La Plata" (Bauer, en Lerange, 1982), fue "baluarte del conocimiento y el progreso", un "iluminado progresista" y una "figura señera" (Calvo, 1982). Tuvo una "profunda y clara visión del problema argentino" y un "ideario valiente y necesario para el destino de las generaciones jóvenes argentinas" (Casey, en Lerange, 1982: 101). Fue un "estadista prominente, que fuera senador nacional, ministro de Roca, tratadista de derecho, escritor de envergadura, presidente de nuestra Universidad y, por sobre todas las cosas, una columna moral de la República" (Rivera, SADE La Plata, 1982: 155). Evocan al prócer una y otra vez los artículos relacionados con la actividad universitaria local, lo cual tiende a fijar una visión limitada de su figura. Ningún texto menciona, por ejemplo, su labor en torno a la primera ley nacional de regulación del trabajo -producida luego de encargar a Juan Bialet Massé un relevamiento sobre la situación de la clase obrera en la Argentina-, acaso la faceta más progresista de quien aparece aquí como el Mesías que llevó a La Plata su razón de ser: la consagración como la Oxford o la Heidelberg de América Latina.

De un modo similar, también se iluminan sólo algunas partes de la trayectoria de Korn, en detrimento de otras: un filósofo brillante antes que un militante político; un hombre de la generación del '80 antes que un referente de los universitarios reformistas movilizados en La Plata hacia 1919-1920. Su condición de médico, en tanto, es destacada -como era esperableen el libro testimonial editado por la Agremiación Médica Platense, donde Christmann dedica los capítulos finales a dos colegas, Alejandro Korn y Giordano Cavazzutti, recurriendo a la transcripción de homenajes que le tocó realizar oportunamente.

Al principal texto que exalta a Korn lo encontramos en 12 personalidades, elaborado por Emilio Estiú, en aquel entonces director del Instituto de Filosofía Sistemática de la Facultad de Humanidades de la UNLP. Este capítulo -igual que el que le sigue en el libro, dedicado a un especialista en derecho procesal- no apunta a la reconstrucción de la biografía del personaje sino al repaso de sus ideas; en este caso, los planteos de su sistema filosófico. Estiú destaca dos aspectos fundamentales: "el predominio del problema del devenir, de la evolución, sobre el del ser, objeto de metafísicas tradicionales" y "la constante presencia de 
intereses gnoseológicos..." Además lo reconoce como creador de la Facultad de Ciencias de la Educación -donde ocupó la cátedra de Historia de la Filosofía- y elogia su "noble sencillez" y su "rigor y claridad" (Estiú, SADE La Plata, 1982: 170-173)

También Narcisco Pousa, en el capítulo de Ciudad milagro abocado a "La Filosofía en La Plata", afirma que "la gran figura del campo filosófico de la ciudad de La Plata es, sin dudas, D. Alejandro Korn" (en Lerange, 1982: 157). En Pousa encontramos la conexión entre personaje y ciudad, esa ciudad destacada constantemente en su condición ilustrada:

"Alejandro Korn fue una personalidad convocante. La cultura de la ciudad y del país le debe, además, una gran actividad suscitadora [sic]. La Plata ha sido tradicionalmente una ciudad de encuentro por la que han pasado personalidades filosóficas [...] La Plata ha sido sede de unas Jornadas de Filosofía organizadas por la Asociación Argentina de Filosofía, que convocaron a lo más importante del pensamiento argentino de 15 al 19 de noviembre de 1966 [...] Estas jornadas marcan un hito en la evolución de las ideas dominantes en la Ciudad. Fundada en el auge del cientificismo positivista preponderante en la llamada 'generación del 80’”' (en Lerange, 1982: 157)

Como vemos Korn permite, además, una nueva mención de aquella generación. Lo comprueba el apartado publicado en Vida platense con el título "El último del 80". Soler, que lo considera un mecenas y lo recuerda como un asiduo visitante del Jockey Club, parafrasea al propio Korn, que se habría definido como "el último de la generación del 80 que se retira del magisterio".

Finalmente, en el panteón de héroes de la capital de la cultura encontramos una serie de figuras del ámbito artístico: del teatro, de la plástica y especialmente de la poesía -no olvidemos que uno de los epítetos extendidos sobre La Plata es el de la ciudad de los poetas.

En rigor, la presencia del teatro es más recurrente como espacio social que en relación a figuras individuales. No obstante, cuando la referencia se vuelca hacia nombres propios el más frecuente es el de José Podestá, un uruguayo que vivió en La Plata hasta sus últimos días y sostuvo el teatro Politeama Olimpo. Autor de un libro citado en varias oportunidades como fuente (Medio siglo de farándula, 1930), es distinguido especialmente en Ciudad milagro, donde se le dedican dos capítulos presentados en forma consecutiva: "JOSÉ J. PODESTÁ. Creador del teatro criollo rioplatense. Su labor pionera. Su actuación en La Plata", de Juan José Terry, que incluye una foto del homenajeado, y "Evocación de los Podestá", escrito en primera persona del singular por Eduardo Horacio Giorello.

Según se advierte en el primero de los capítulos, su figura ya había sido objeto de conmemoración hacia fines de los '50, al cumplirse el centenario de su nacimiento, cuando la Provincia instituyó al 6 de octubre como el "Día del Teatro Criollo Rioplatense"246.

Para Terry, "existe hoy pleno acuerdo en reconocer a don José J. Podestá, con su 'Juan Moreira', de Eduardo Gutiérrez, el carácter de fundador del teatro criollo rioplatense, denominación comprensiva de la actividad escéptica en ambas márgenes del Plata". El autor agrega que fue un "verdadero patriarca de la escena nacional", de "una estirpe tan noble y tan consecuente", "un gaucho cabal, altivo y generoso..." (en Lerange, 1982: 333-334).

Giorello, en tanto, destaca que el teatro y circo de los Podestá fue el "preferido sobre todo por las clases más numerosas" y que los hermanos constituyeron "un hecho único dentro de la historia de la cultura de nuestro país" (en Lerange, 1982: 337).

\footnotetext{
${ }^{246}$ Con un estilo propio de estos libros, Terry transcribe el decreto y además menciona a todos los integrantes de la Comisión de Homenaje formada entonces (en Lerange, 1982: 335-336).
} 
El teatro también aparece como un ámbito de referencia para el artista plástico Atilio Boveri, mencionado en el capítulo sobre "La escenografía teatral" de Ciudad milagro que precede a los recién recitados. Boveri se destaca por polifacético. Lo encontramos en la Revista de la Universidad en un artículo del director de la publicación, sobre la obra en torno al Parque Saavedra y el Jardín Científico de Punta Lara (Marquínez, 1980), y también en las páginas dedicadas a las artes del fuego en la compilación de la SEP:

“...una de las figuras más prestigiosas del arte nacional, a quien La Plata tanto le debe. Nos referimos al hombre que supo sobrevolar como el águila y el cóndor toda la dimensión del espacio y dar prestigio, desde nuestra Ciudad, al país: don Atilio Boveri" (en Lerange, 1982: 221)

Sin duda, el principal texto que enaltece la figura de Boveri es el que repasa su vida y obra en 12 personalidades. Profesor de filosofía y crítico de arte del diario El Día, Amílcar Ganuza considera a este artista como una "personalidad singular y excepcionalmente dotada de talento, que abarcó con la misma pasión constructiva tanto las artes y las letras, como las ciencias", y afirma que con justicia se lo llamaba "el Leonardo argentino" (en SADE La Plata, 1982: 50). Nacido en Rauch y fallecido en Gonnet, se formó en Europa, pintó escenas bíblicas para catedrales y vivió en la Isla de Mallorca, donde fundó el primer colegio, gestionó el uso de la luz eléctrica y el teléfono, y hasta ofreció funciones de títeres.

Encontramos en Boveri -y en el relato de Ganuza sobre él- el personaje más interesante y complejo del panteón que venimos revisando, en el sentido de que no calza perfectamente en el canon que tiende a construirse, y más: por momentos tensiona al imaginario de ciudad que intenta olvidar al peronismo o que, concentrado en el casco urbano, abandona la mirada hacia el río. Boveri entra y sale del relato oficial: su figura contiene a la ciudad higiénica -con sus campañas de forestación- y a la ciudad de los poetas -con Almafuerte y el tradicionalismo que indagaremos más adelante-, pero también a la ciudad industrial -al pintar en los ‘30 un mural alusivo al petróleo, con la sigla YPF, o promover la creación de Escuelas-Taller de Artes Aplicadas a la Industria- y a una zona relegada como Punta Lara -con su proyecto de jardín científico-. Boveri levantó casas de señorío con espléndida concepción, trabajó con Ameghino y fue un profesor de Bellas Artes formado en Europa, pero su evocación trae además un monolito de piedra que rememora la resistencia civil al invasor inglés, convoca a la valoración de los pueblos originarios con su obra del Dios inca vivo, y referencia a la gestión pública ni más ni menos que durante el yrigoyenismo y el peronismo.

Sin ir más lejos, fue el tercer peronismo, con el intendente municipal Jorge Falcone, el que organizó los dos homenajes mencionados por Ganuza, que incluyeron la colocación de una placa recordatoria en su casa de Gonnet. Pero la consagración de su figura también habilitó la exposición de obras durante la dictadura, en 1980 y 1982.

La otra personalidad de las artes plásticas que adquiere relevancia en la producción editorial del centenario platense ${ }^{247}$ es Emilio Pettorutti, destacado por Ganuza -ahora en Ciudad milagro- como uno de los artistas que con "clara independencia de criterio se animaban a buscar nuevos caminos y a proponerse nuevas experiencias en el arte" (en Lerange, 1982: 191). Rogelio Yáñez menciona a Petorutti como "el más notable pintor de todos los tiempos de la ciudad" (en SADE La Plata, 1982: 74) y Vida platense también le dedica su espacio (Soler, 1982: 180). En otras ocasiones, su figura aparece vinculada al

\footnotetext{
${ }^{247}$ Sin el mismo nivel de reiteración y exaltación, también son significativas en algunos textos las figuras de Emilio Coutaret y Víctor de Pol, ambas vinculadas a la etapa fundacional de la ciudad.
} 
diarismo platense, a partir de su amistad con Ramón García, quien le cedió el último piso de El Argentino para que instalara su taller y lo respaldó cuando quisieron echarlo de la dirección del Archivo de Arte de la Provincia (Sureda, en Lerange, 1982: 397).

La lista de personalidades destacadas la completan escritores. Son varios los artículos sobre la literatura platense y proliferan los nombres propios, desde el legendario Matías Behety -de cuya producción no quedan rastros- hasta López Merino -homenajeado con un nuevo busto en el Bosque (Soler, 1982: 102)- o Roberto Themis Speroni. De esa "Escuela de La Plata" que algunos autores caracterizan, sobresalen Benito Lynch y Almafuerte.

El autor de Los caranchos de la Florida es considerado como "el escritor más importante que ha dado la ciudad de La Plata" (Díaz, 1982: 264) y "nuestro máximo novelista", del que se destaca su "fina personalidad, la de un caballero a la antigua, educado y sensible" (Soler, 1982: 164). Más allá de su carácter solitario, se presenta como una figura muy asociada al Jockey Club, del que llegó a ser socio vitalicio. Por otra parte, Lynch tenía once acciones en la sociedad anónima "El Día” constituida en 1890, según señala Urraza (1981: 131), que lo recuerda como "amigo" y "compañero", y concluye así el capítulo final de su libro, dedicado al ejercicio de periodismo:

"no quiero dar nombres por temor de olvidar algunos, pero haré una excepción con alguien que ya no está entre nosotros, que fue nuestro guía, nuestro hermano mayor, camarada y maestro en la edad feliz de los sueños, con alguien que iluminó nuestro camino y nos entregó el oro de su amistad: Benito Lynch” (De Urraza, 1981: 142)

Pero la figura de mayor realce en el conjunto de la bibliografía analizada es la del autor de La Inmortal, Pedro Bonifacio Palacios, más conocido como Almafuerte, el apodo retomado por SADE La Plata a la hora de bautizar su sello editorial, que como vimos publica dos libros en el marco del centenario.

Palacios es el poeta en Vida platense (Soler, 1982: 76-77); en tanto Obra de arte lo destaca como "un caso aislado en nuestra literatura: toda su obra se expresa como una transcripción directa de su yo: apasionado, profético, solidario a la vez, son aspectos contradictorios que no resuelve nunca en su obra..." (Díaz, 1982: 263).

$\mathrm{Su}$ presencia en la compilación de la SEP, en tanto, es más que notoria: además de múltiples menciones en otros artículos, hay tres específicamente dedicados a Almafuerte. Los antecede y los anuncia el texto dedicado a "La Ciudad y sus poetas":

“...Otras plumas inspiradas le dedican en este mismo libro, un fecundo estudio. Son tres figuras platenses encargadas de la vida y obra del poeta, ya que el autor de $\mathrm{La}$ Sombra de la Patria y El misionero es patrono de la Sociedad de Escritores de la Provincia (SEP); grandioso, dilatado, incendiario..." (en Lerange, 1982: 116)

La singularidad de su escritura, su militancia en el radicalismo, su tarea como periodista y los trastornos de su personalidad son algunos de los temas repasados en esos trabajos.

El primero de ellos, "Almafuerte: el poeta, el maestro", de la profesora de letras Marita Minellono, tiene un tono bastante analítico: da cuenta de los gustos de la época y analiza etapas de su producción poética. Finalmente, sí, pasa del análisis literario a la semblanza de la persona, que presta atención a sus ideas pedagógicas. Llama la atención, en este artículo, que la ciudad de La Plata no aparece en todo el recorrido.

El siguiente capítulo de Ciudad Milagro está dedicado a Almafuerte como "periodista político". En esa trayectoria explorada por Horacio Alfaro, su paso por el periódico platense El Pueblo (1891-1892) resulta incuestionablemente lo más notorio. 
Una cuestión significativa de ambos capítulos es que tematizan explícitamente las opciones políticas del poeta, vinculado a la Unión Cívica y luego a la Unión Cívica Radical $^{248}$. De algún modo, la figura de Almafuerte, que ingresa fluidamente en el libro por ser prácticamente sinónimo de la Sociedad de Escritores -la institución editora-, habilita a introducir referencias sobre revueltas políticas. Alfaro, por ejemplo, transcribe fragmentos de la proclama del levantamiento de 1890 (en Lerange, 1982: 178).

Minellono, en tanto, analiza el poema dedicado a la derrota de 1890 -Antífona Roja- y caracteriza una "poesía comprometida". Sin embargo, y pese a la manifiesta referencia a su militancia, afirma que "Almafuerte no está comprometido o al servicio de una ideología o fin político" sino que "su compromiso está establecido con su propia persona; es la fidelidad con lo que él piensa, siente y mira" (Minellono, en Lerange, 1982: 170-171). Por otra parte, la autora hace una singular lectura sobre un posterior abuso de aquella línea o tradición en la que coloca al escritor:

"Después de Almafuerte, aparecieron tanto en Oriente como en Occidente literaturas que hicieron denuncia. Por ejemplo: Nicolás Guillén, Nicanor Parra (en la poesía) y en la novela Miguel Angel Asturias, Vargas Llosa y casi todos los escritores del movimiento denominado realismo mágico.

Inclusive, en la década del 60 al 70, se cometieron abusos, con abundancia de obras y poemas panfletarios" (Minellono, en Lerange, 1982: 171)

El tercer capítulo dedicado específicamente a esta figura es "Almafuerte: un destino cíclico", de Juan Carlos Secchi. Su vinculación con La Plata es mucho más explícita: la ciudad es donde recala en cierto momento de su vida y el lugar de su "muerte casi silenciosa" en 1917. La exposición está organizada en torno a "interrogantes" que plantea su vida:

" 1 - El porqué de sus seudónimos.

2 - El porqué de su agresividad.

3 - El porqué de sus depresiones.

4 - El porqué de su poesía fustigante.

El suma: el porqué de su personalidad ególatra, de su hipertrofia del yo, de su pedantería, de su generosidad, de su proclividad a la humillación, de sus delirios, de su celibato, de su amor por lo que él llamó 'la chusma"” (Secchi, en Lerange, 1982: 181)

El desarrollo de esos tópicos, que incluye ciertos giros psicoanalíticos, da cuenta de una vida signada por diversos trastornos mentales -caracterizados en detalle- que derivan en problemas de alcoholismo, en "frecuentes conflictos con la policía" y la autoridad en general, y finalmente en una tendencia al ostracismo (Secchi, en Lerange, 1982: 183-185).

Pero no son éstos los únicos tres artículos de Ciudad milagro que aluden a Almafuerte. Las referencias proliferan en todo el libro. Por ejemplo, en el texto de Urbañsky se menciona el monumento levantado al poeta como uno de los que "interrelacionan a La Plata con Berisso". En el texto sobre la bohemia platense Curuchaga define a Almafuerte como "el clásico bohemio" y alude a la agrupación Bases. Y Héctor Rivera, al elogiar la trayectoria del mecenas platense Vicente Albamonte, recuerda sus contactos con Pedro Palacios (en Lerange, 1982: 657, 626, 542-543)

Como era esperable, también aparece en un capítulo dedicado a la SEP, de la cual como ya vimos es considerado "patrono". Alfredo Delfino asegura que esa Sociedad "desde siempre y en forma permanente, honra su memoria" y pone como ejemplo "haber instituido como 'Día

${ }^{248}$ Sus opciones políticas también incluían admiración por Alsina y una distancia con Roca (Minellono, en Lerange, 1982: 175). 
del Escritor Bonaerense' el 13 de mayo, aniversario del nacimiento del poeta" (en Lerange, 1982: 466). Por otra parte, la principal distinción entregada por la institución es el Gran Premio Almafuerte. Asimismo, menciona las tratativas para que su casa de calle 66 fuera declarada Monumento Histórico. Aquello se concretó durante la gestión al frente de la SEP de Tomás Bernard, el mismo que en 1974, durante su gestión como Ministro de Educación bonaerense, le devolvió el título de maestro ${ }^{249}$.

El último conectado con la figura enaltecida del poeta es el texto dedicado a la Agrupación Bases, mencionada en varios libros de 1982. Este grupo cultural, inspirado en una proposición lírica de Almafuerte -“cuando se ha roto la Traición / se ha conurbado el presente / y oscurecido el porvenir”- (Seigel, en Lerange, 1982: 462), nos liga con una tendencia traicionalista que forma parte de la matriz cultural de la conmemoración del centenario.

\section{Tradición y organización nacional}

El interés por "la tradición" trae aparejado el apellido Hernández, pero no precisamente al fundador de la Universidad provincial -deslucido por la figura sobresaliente del ministro nacionalizador González- sino a José, el creador del Martín Fierro, a quien tiende a adjudicarse la denominación de la ciudad. Más aún: la cuestión tradicionalista permite aproximar a los apellidos de Hernández y González, al recuperarse de éste último una de sus primeras obras, mucho menos conocida pero quizá más sustantiva que Mis montañas (1893): La Tradición nacional (1888).

La evocada trayectoria de la agrupación Bases permite entonces conectar a Almafuerte, Hernández y González en una matriz que se revela activa en la escena del desfile comentado al inicio del capítulo II, cuando las universidades marchan seguidas de cerca por la Federación Gaucha y otras agrupaciones tradicionalistas.

Aquella tríada -Almafuerte-Hernández-González- se construye explícitamente en el libro realizado desde la Universidad por encargo del gobierno municipal, que llega a difundirlo como el libro del centenario. Bajo el título "Raíces de la Tradición: Agrupación 'Bases", podemos leer en Obra de arte:

"Al hacer referencia a los orígenes de aquellas instituciones que bregaron y bregan por el culto del acervo nativo, se torna un deber ineludible dirigir una ojeada retrospectiva a la labor desarrollada por la Agrupación 'Bases', por cuya iniciativa se instituyera el Día de la Tradición -en el ámbito provincial- en homenaje a Don José Hernández, figura señera de las letras argentinas.

Quizá, siguiendo la ruta trazada por el espíritu culto e inquieto de don Joaquín V. González - de notable influencia en nuestros círculos artísticos y literarios de la época-, a través de su conocida obra La tradición argentina [sic], considerada entre los primeros ensayos de investigación folklórica y en la que estudia con ahínco los problemas inherentes a la tradición de los pueblos, es que la citada agrupación procura llevar a buen término su iniciativa.

\footnotetext{
${ }^{249}$ En 1896 Palacios había sido destituido de su cargo docente, por razones claramente políticas, alegando que no tenía un título habilitante. Bernard "reparó una injusticia histórica (...) devolvió al Maestro su título de tal, poniéndolo a la cabeza del Magisterio Bonaerense y proclamándolo benemérito hijo de Buenos Aires y paradigma del docente" (Delfino, en Lerange, 1982: 466). El asunto también es mencionado por Minellono, aunque indica erróneamente el cargo de Bernard como ministro de Gobierno (en Lerange, 1982: 175).
} 
Destacada institución de nuestra querida ciudad, la agrupación 'Bases', estuvo integrada por artistas locales, guardadora de la casa de don Pedro B. Palacios (Almafuerte)..." (Díaz, 1982: 299)

Las gestiones para establecer el Día de la Tradición ocurrieron a fines de la década del '30 y son contadas en el mismo libro, donde se transcribe la ley sancionada en 1939 (Díaz, 1982: 299-300). Al detallar quienes participaron de la propuesta, Obra de arte sostiene que la idea surgió en una reunión "presidida por el propio Almafuerte", lo que resulta una metáfora poco clara, o directamente un error, puesto que el escritor falleció en 1917 y la agrupación fue fundada en marzo de 1929, justamente para "exhumar, en primer término, y enaltecer, de seguro, la integridad humana de Pedro B. Palacios" (Seigel, en Lerange, 1981: 461).

En rigor, Bases fue constituida por una serie vecinos comprometidos con su obra, motivados por "el deseo de incrementar la expansión poética de Almafuerte, mantenimiento vivo en el pueblo del culto a su recuerdo..." (Seigel, en Lerange, 1982: 460). Como afirma Calvo, sus integrantes -a los que menciona- estaban "enamorados del acto de entrega que es hacer poesía". Por eso Bases fue, entre otras cosas, un sello editorial. Además tuvo y concretó la iniciativa de convertir la casa de Almafuerte en un Museo, que estuvo a cargo de ese grupo hasta que en 1945 pasó a la órbita municipal.

El nombre de la agrupación era un homenaje a Juan Bautista Alberdi, el mentor de la Constitución, lo que nos enlaza con otro tópico recurrente de la coyuntura conmemorativa que analizamos: las loas a los dirigentes del proceso de organización nacional. En el libro cuyo título asocia explícitamente La Plata a la generación del 80, los autores afirman: "El triunfo definitivo del 80 fue el ideal de Juan Bautista Alberdi” (Zuccalá y Musmano, 1981: 9).

Además, cabe advertir la existencia de una tesis que adjudica a Alberdi haber lanzado la idea de fundar una nueva ciudad para ser capital de la Provincia. Dicho planteo fue desarrollado en un artículo publicado en marzo-abril de 1961 en la Revista de Educación por José C. Picone, que había sido años antes uno de los integrantes de Bases.

Entre los textos del centenario, Obra de arte cita el escrito de 1881 titulado " $L a$ República Argentina consolidada con la ciudad de Buenos Aires por capital" y sugiere una posible influencia de Alberdi sobre la decisión: hay "una gran coincidencia -dice- con el lugar señalado por Alberdi en su obra ya citada, pues señalaba al puerto de Ensenada, considerado en ese entonces el mejor puerto del país, como el lugar donde debía funcionar la nueva capital de la Provincia" (Díaz, 1981: 412).

En cuanto al establecimiento del 10 de noviembre -día del nacimiento de José Hernández- como Día de la Tradición, se considera como uno de los promotores a Mario Sureda, socio de Bases, que publicó un artículo en El Argentino titulado "Día de la tradición". Se trata del hermano de Jaime, quien participa de la producción editorial del centenario con un libro y un capítulo de libro, y que también fue miembro de Bases.

Seigel dedica su artículo de Ciudad milagro a la "Vida, pasión y vigencia" de la agrupación Bases, a la que él mismo perteneció y considera un "verdadero hito en el devenir cultural de la ciudad" durante quince años, cuya "trascendencia" estaría dicha "apodícticamente" 250 en "el desfile por su tribuna de personalidades de toda índole, literarias, historicistas, docentes, periodísticas, artísticas, políticas” (en Lerange, 1982: 461). Su texto

\footnotetext{
${ }^{250}$ La expresión viene de la filosofía y refiere a algo "incondicionalmente cierto, necesariamente válido" (Real Académica Española, 2011). En la lógica aristotélica, lo apodíctico es contrario de lo dialéctico y refiere a una proposición indispensable y prácticamente obvia, que en caso contrario deviene imposible.
} 
está escrito en primera persona, con un tono vetusto que se manifiesta especialmente en algunos tramos:

"¿Qué mejor buenaventuranza que la de la evocación? [...] Toda idea ha menester de un amor que la fecunde, una fe que la frutezca, una voluntad que la anime. Fueron estos atributos los fundamentos que sirvieran de sólido mampuesto a la Agrupación Bases..." (en Lerange, 1982: 459)

Es a su vez uno de los artículos atestados de nombres propios. La revisión de éstos nos permite encontrar en Bases -con su acción centrada en los años '40- un punto de conexión entre aquellos que escriben en el centenario y otros que son "escritos" en esa coyuntura conmemorativa. En otras palabras: Bases reunió a Seigel, Sureda y un autor prominente de 1982 como Bernard, con personalidades como la de Antonino Salvadores o Atilio Boveri ${ }^{251}$.

En la evocación de Ganuza sobre Boveri podemos leer que "promocionó y apoyó fervorosamente la fundación del Museo Almafuerte, poeta al que en vida siempre le guardó especial consideración y trato asiduo", que "fue uno de los factores determinantes de la oficialización del Día de la Tradición en la Provincia" y que "participó decididamente en el proceso de implementación del Monumento al Gaucho en los pagos de San Antonio de Areco" $^{252}$ (Ganuza, en SADE La Plata, 1982: 54). La matriz tradicionalista construye sobre un gaucho idealizado y disciplinado al soldado anónimo de la independencia, símbolo épico de la argentinidad.

Los mismos textos que venimos analizando nos llevan luego a la Federación Gaucha Bonaerense, "nacida del seno de Bases" según palabras de Seigel, que "sería quien salvaguardara el patrimonio de la autoctonía gaucha, fundamento esencial de la República" (en Lerange, 1982: 462). Dicha federación, participante del desfile cívico de 1982, quedó encargada a partir de los años '40, de promover los festejos de cada 10 de noviembre ${ }^{253}$.

El tradicionalismo nos conecta también con otro autor del centenario, Carlos Moncaut, quien además de producir uno de los libros financiados por la Municipalidad, aporta un artículo sobre los almacenes en Ciudad milagro, que en su genealogía remite a las pulperías de campaña de principios del siglo XIX. Casi dos décadas más tarde Moncaut el mismo autor publicaría un libro específico sobre el tema: Pulperías, esquinas y almacenes. Actualmente lleva su nombre la biblioteca popular de la Asociación Argentina de Escritores Tradicionalistas, fundada en 1984, con sede en La Plata y vinculaciones con la Sociedad de Escritores de la Provincia.

Como bien describe Cattaruzza, el recurso a la figura del gaucho y la obra de José Hernández, que registraba iniciativas desde la década del '10, se fortaleció a partir de mediados de los años '30. Según Ricardo Rojas, el Martín Fierro resultaba para la nación argentina el análogo del Cantar del Mío Cid para la nación española y la Chanson de Roland

\footnotetext{
${ }^{251}$ Sureda le dedica un capítulo de sus memorias al artista, a quien conoció por su hermano y reencontró en la agrupación Bases (Sureda, 1982: 189-191)

${ }^{252}$ Aunque se registra algún intento de nominar a La Plata como "capital de la tradición" -actualmente hay una pintada que así la identifica, sobre 122 y 52-, ha sido San Antonio de Areco la sede del tradicionalismo, promocionada incluso por los platenses de Bases, que eligieron ese lugar para la primera celebración del Día de la Tradición (en 1939), por ser el pago de Ricardo Güiraldes, autor de Don Segundo Sombra.

${ }^{253}$ Desde esa entidad se impulsó el monumento al gaucho concretado en 1947 y el estudio y desarrollo de actividades folklóricas. Obra de arte asocia a la lista de sus logros la creación de la Escuela de Danzas Tradicionales, posteriormente bautizada José Hernández, creada en tiempos del primer peronismo, que convertiría al Día de la Tradición en una efeméride extendida a todo el país (Cattaruzza, 2007: 132). Fue aquella Federación, por otra parte, la que convocó el Congreso Nacional de la Tradición realizado a fines de 1968.
} 
para la francesa. Con el tiempo, "la nación gauchesca vino de este modo a cohabitar el imaginario social con la nación de Mayo sin demasiadas tensiones, y a mezclarse con ella" (Cattaruzza, 2007: 113-131, 195). Duizeide cuestiona del género gauchesco que "toma una parte del país por el todo" pues sólo "llega hasta la orilla", algo que sucede también con el cancionero (Duizeide, 2010: 209). Es interesante pensar esta característica teniendo en cuenta que la historiografía del centenario, que retoma el ideario tradicionalista de Bases, tiende a omitir la ciudad con río, pensada de cara a él, como vimos en el capítulo anterior.

\section{El laicismo tensionado}

Conviven entonces, entre las rasgos sobresalientes de la bibliografía del centenario, una pretendida vuelta a los orígenes -con el planteo tradicionalista- y la reinvención de un origen -el de La Plata como ciudad universitaria más que portuaria o productiva-, ambas vinculadas a un énfasis puesto en la cultura y coherentes -o al menos compatibles- con la reivindicación de los hombres que condujeron la Organización Nacional en el siglo XX.

Lo que de algún modo tensa el lazo histórico con ese período es la presencia de un discurso religioso. Esta contradicción podría señalarse igualmente a la gestión estatal de la época, que también despliega un relato laudatorio hacia la generación del 80: la proximidad/complicidad del Proceso de Reorganización Nacional con la Iglesia Católica, reflejada en la defensa de los valores cristianos en sus discursos, contradice ese planteo. Si la búsqueda de orden y la negación de un otro a través del exterminio los emparentaba, debe recordarse que el conflicto más fuerte de la presidencia de Julio Argentino Roca (1880-1884) tuvo que ver con la sanción de las leyes laicas: la adminitración de cementerios, en 1881; la ley 1420 que estableció un sistema educativo "gratuito y obligatorio" y quitó a la Iglesia el monopolio de la educación -sin bien en su texto no consigna el carácter laico-, y la creación del registro civil en 1884 -paso previo a la sanción de una ley de matrimonio, cuatro años más tarde-; todo lo cual llevó a una ruptura de relaciones con el Vaticano ${ }^{254}$.

Los textos que vimos al inicio de este capítulo, que construyen el imaginario de una ciudad focalizada en lo educativo, lejos están de un planteo favorable a la educación pública laica. Así, leemos en el artículo sobre "La Filosofía en La Plata" de Ciudad milagro que el Seminario Mayor es un lugar de referencia, que desarrolló "una verdadera acción formadora" (Pousa, en Lerange, 1982: 156).

Por su parte, el capítulo de la misma compilación dedicado a las escuelas de la ciudad, si bien advierte limitaciones de espacio para ocuparse de todas, incluye colegios católicos y destaca "en particular al colegio Nuestra Señora de la Misericordia", que surgió en 1888 en respuesta a la demanda de enseñanza religiosa. Se menciona también la Escuela Nuestra Señora del Carmen y la fundación del Seminario Catequístico en 1973. El tono religioso de esta parte es notable:

\footnotetext{
${ }^{254}$ Por supuesto, las relaciones entre Iglesia y Estado son complejas y exceden a la referencia simple acerca de la laicidad de esa generación. Según afirma Bauer en uno de los textos analizados, tras la ruptura de Roca y Rocha, que ocurre próxima al debate de la ley de educación común, el fundador de La Plata recibió el apoyo del grupo católico a su candidatura. Encontramos también un sesgo religioso en el discurso del 19 de noviembre de 1882, cuando el entonces gobernador concluye pidiendo al Arzobispo la bendición a la piedra fundamental.

Con posterioridad se han publicado textos que intentan señalar un vínculo estrecho entre impulsores de la ciudad -como Rocha y Benoit- y la masonería (fundamentalmente Reynal, 1998). Corresponde señalar que ese planteo está completamente ausente en la bibliografía del centenario.
} 


\begin{abstract}
"Antes de finalizar deseamos recordar en lo más íntimo la obra de los padres vicentinos y salesianos, que en humildad y alegría han formado a tantos jóvenes para el sacrificio y el servicio a todos los hombres, como continuación de las huellas de Cristo" (en Lerange, 1982: 351)
\end{abstract}

Aunque no es la única, la compilación impulsada por la SEP -marcada desde ya por su título- es la publicación con mayor presencia de este componente religioso. No sólo encontramos capítulos que evocan a "Dios": además, dos de ellos incluyen citas del papa Pío XII. Esto ocurre en el artículo sobre la Asociación pro amparo y defensa del animal (APADA) y en el dedicado a la cirugía plástica (Lerange, 1982: 574 y 154).

Cabe recordar también los dos capítulos de María Cristina Della Croce, "La vida religiosa y espiritual de la ciudad" y "Caritas", presentados en forma consecutiva. El primero tiene un título engañoso, ya que la vida religiosa y espiritual se reduce prácticamente a la Iglesia Católica -algo similar a lo que ocurre en Obra de $\operatorname{arte}^{255}$-. Ambos son resúmenes de las publicaciones de Sánchez Márquez (1978) que, como los demás textos de la época, tiene un registro basado en acumulación de datos (nombres, años de asunción, resoluciones). Por supuesto, ninguna selección de ese tipo de material es inocente. Un planteo político explícito aparece en relación a lo educativo, con una fuerte reivindicación de la educación religiosa ${ }^{256}$. El autor nos recuerda que el homenajeado arzobispo Plaza fundó en 1957 el Instituto Pro Universidad Católica de La Plata, que obtuvo su aprobación definitiva en 1971 (Sánchez Marquez, 1978: 67). Recordemos que varios planteos del centenario colocan a la UCA en un lugar central. Volvamos, por ejemplo, sobre el texto de Pousa:

"Hoy, la ciudad nuestra, privilegiada por su ubicación, la lejana cercanía de Buenos Aires, le permite participar selectivamente en los grandes movimientos culturales, y preservar su propia geografía y toponimia. La Universidad Nacional, y últimamente la Universidad Católica, el importante Seminario Mayor, el joven e infrecuente Instituto de Teología, otrora la Universidad Popular Alejandro Korn ${ }^{257}$, son las instituciones más importantes como centros de estudio y difusión del pensamiento en la Ciudad. En la

\footnotetext{
${ }^{255} \mathrm{El}$ apartado de este libro dedicado a la vida religiosa ocupa seis páginas -incluyendo fotos-. El apartado "Vida Religiosa: Otros Cultos" ocupa el párrafo final de la última de esas páginas: el resto está dedicado al catolicismo. Incluye una lista de parroquias, menciona los alcances de la diócesis, el primer obispo y algunas leyes y bulas papales que la organizan. A monseñor Espinosa -el primer obispo- lo define como " un incansable misionero" y destaca su "labor evangelizadora" acompañando a Roca como capellán en la "Campaña del Desierto". También comenta cuáles son las principales comunidades religiosas: franciscanos, salesianos, hijas de María Auxiliadora, otras (Díaz, 1982: 337-342).

${ }^{256}$ El último capítulo de la Historia de la arquidiócesis de La Plata está dedicado a las decenas de instituciones educativas y para-educativas que funcionan bajo la órbita de la Iglesia Católica. Se resalta -caso por caso- el papel de Plaza en su consolidación. También el trabajo previo de Chimento. Entre otras acciones, se recuerda que Plaza creó en 1957 la Fundación de Escuelas Libres Argentinas (FELA), "con el ánimo de contrarrestar las campañas Pro Escuela Laica de esos años y fundar diversos colegios, los que recibieron un gran impulso en la Arquidiócesis a partir de la década del 60" (Sánchez Márquez, 1978: 178).

${ }^{257}$ Corresponde destacar también de esta cita la mención de la Universidad Popular vinculada desde sus orígenes al Partido Socialista local y que fuera un refugio de los reformistas universitarios durante el primer peronismo (Graciano, 2008). Como reconstruye Florencia Bossié, en la última dictadura a la UPAK y su Biblioteca Popular "Francisco Romero Delgado" sólo se les prohibió funcionar en un primer momento. Luego, por el contrario, la entidad fue una de las pocas habilitadas para realizar conferencias. Según el testimonio de Antonio Cóccaro, integrante de la Comisión Directiva de la UPAK, asistían policías para registrarlas: “...inclusive llegaron a hacerse amigos de los oficiales y con el tiempo los integrantes mismos del Partido confeccionaban cartillas informativas con resúmenes sobre lo conversado en la conferencia que enviaban al diario y que entregaban a los oficiales, ahorrándoles el trabajo. La explicación que Cóccaro da a todas estas excepciones es que Américo Ghioldi (a quien caracterizó como un 'destacado dirigente del partido') fue nombrado embajador en Portugal por la dictadura, hecho que generó grandes controversias en el Partido y divisiones internas" (Bossié, 2006: 86-87). En 1982 participaba de la UPAK Inés Zuccalá, coautora de Creación de la generación del 80.
} 
evolución de las Ideas, esos centros han ido conjugando una suerte de trama de influencias mutuas, diálogos que se siguen por encima de los atavares [sic] políticos del Estado" (en Lerange, 1982: 155)

La ciudad universitaria no es sólo la ciudad de la Universidad Nacional de La Plata: también lo es de la Universidad Notarial Argentina -que promueve varias publicaciones- ${ }^{258}$ y de la Universidad Católica, que como vimos estuvo convocada al desfile del 19 de noviembre de 1982 en pie de igualdad con la institución que debate su fundación entre las figuras de Hernández y González. Esas dos referencias están incluso en Obra de arte, el libro elaborado desde la Facultad de Humanidades de la universidad pública (Díaz, 1982: 328).

En el número analizado de Ambiente, la sección Documentos aborda la iniciativa de la Universidad Católica de La Plata de crear un Doctorado en Arquitectura, que por supuesto incluye en su plan un curso de Teología. La revista presenta una entrevista al decano de la Facultad que promueve el nuevo posgrado. En otra parte de la revista, para dar cuenta de la música platense, el entrevistado es el compositor y director Enrique Gerardi, que exhibe el título de "profesor titular ordinario de la Facultad de Artes y Ciencias Musicales de la Universidad Católica Argentina de la cual ha sido profesor fundador y miembro de su primer Consejo Académico". También La Plata 100 le da entidad a la UCALP, al incluir su Facultad de Ciencias Económicas entre los hitos del Eje Cívico Monumental.

Asimismo, entre las citas breves que se incluyen en el margen superior, es interesante advertir el tono de uno de los párrafos que los editores de Ambiente eligen de las clásicas viñetas platenses de Arrieta:

"Poco tiempo después de fundada La Plata, Dios, que había concurrido a la fundación, volvió a visitarla, y al pasear por la calle 7 , notó sorprendido -porque Dios también sabe sorprenderse- que a la ciudad mágica, le faltaba lo mejor. Entonces Dios, expeditivo, como siempre, sin más trámite, tomó una estrella, una rosa y un versículo del cantar de los cantares, y dijo: 'Sea. Por los tiempos de los tiempos. Amén'. Y se produjo el milagro. Nació la mujer platense...” (en Ambiente, $\mathrm{N}^{\circ} 32$, 1982, pág. 40)

El catolicismo también está presente en varias lecturas sobre la producción escultórica y arquitectónica de la ciudad. Canestri sostiene que "nuestra tradición católica apostólica romana también está simbolizada en monumentos de la ciudad" (en Lerange, 1982: 250). Urraza dedica un artículo a la Iglesia San Ponciano, "uno de los primeros edificios que

\footnotetext{
${ }^{258}$ Cabe recordar el lugar privilegiado que Terrasa le otorga en su libro a la Universidad Notarial, en la parte dedicada a "La Plata y su ciencia". Además de una reivindicación de la educación privada, la alusión al instituto universitario perteneciente al Colegio de Escribanos provincial y dirigido por Bernard, nos aproxima a un pensamiento hispanista que, sin ser una regularidad, encontramos presente en varios textos. Como se cita en Primeros habitantes, un propósito de la Universidad Notarial es "promover el intercambio internacional intensificando las relaciones culturales y profesionales con todos los países y principalmente con la Madre Patria (España) y las naciones hispanoamericanas" (en Terrasa, 1982: 123). En Vieja amistad, el titular esa institución escribe que La Plata "se inserta, ab-initio, en la gran historia de la nacionalidad, en el meollo mismo de la epopeya del pueblo argentino. Y va en pos de las raíces, para encontrar su ombligo, hasta la gesta misma del período hispánico cuando se echaron las bases de la 'nueva y gloriosa Nación'.(Bernard, 1982b: 15). En Ciudad milagro se dedica un capítulo al Instituto Platense de Cultura Hispánica, entre cuyos fundadores está uno de los autores trabajados: Jaime Sureda. Se menciona la celebración, desde 1957, de la Semana de la Hispanidad. Entre otras refiere a un busto que "fuera bendecido por el Sr. Arzobispo de La Plata y Miembro Honorario del Instituto, Monseñor Dr. Antonio J. Plaza” (en Lerange, 1982: 501). Otro autor vinculado a una postura hispanista es Enrique De Gandía, participante del Ciclo Cien años, promovido como "autor de unos cien libros y dos mil artículos", especializado "en historia del descubrimiento de América, de la conquista, de la independencia y tiempos modernos" (De Gandía, 1980: 7). De Gandía es miembro de las academias nacionales de Historia y de Ciencias Morales y Políticas. Entre sus cargos universitarios destaca su condición de profesor emérito de la Universidad de Morón y honorario de la de Belgrano, ambas privadas.
} 
lucieron en la nueva ciudad, donde se construía también pensando en Dios" (De Urraza, 1981: 79). De Paula, por su parte, remarca que la catedral proyectada por Benoit es el edificio más grandioso de la época (De Paula, 1982: 48); algo en lo que coinciden otros autores:

"Todo estuvo previsto en esta ciudad signada por la paz para los argentinos. Y merece capítulo aparte lo referente a la Catedral, porque toca muy profundamente la esencia católica del pueblo y simboliza la alta búsqueda de Dios por sobre las mezquindades humanas" (Zuccalá y Musmano, 1981: 35)

"Si retomamos el orden del desarrollo inicial vemos que dando culminación al eje monumental de la ciudad aparece la mayor escenografía urbana: la Catedral. En este templo del Dr. Dardo Rocha dedicó personalmente su tiempo para enfatizar lo que debía representar en la ciudad, así lo certifica su capacidad de 12 mil personas y 7000 metros cuadrados cubiertos" (Díaz, 1982: 40)

La catedral se destaca en este tramo de Obra de arte también por la cantidad de fotos. Ilustra la tapa de Rastros y rostros, y Ciudad milagro incluye su imagen en la sobre-tapa que trae para forrar la edición. Además, la publicación de la SEP incluye una página dedicada a "La catedral vista por los ojos de una artista plástica", firmada por Lucila Bautista. La reproducción en blanco y negro de la obra dificulta su comprensión (Lerange, 1982: 182). Páginas más adelante encontramos el lírico capítulo sobre "Las campanas de La Plata", donde Lina Husson escribe:

"La Catedral está en la calle invisible de los fantasmas, de los miradines y las sombras. En la 52 escamoteada. La calle del milagro. Tiene torres soñadas, y en ellas invisibles campanas..." (en Lerange, 1982: 229)

En Bernard, las trabas y demoras que tuvo la construcción son resemantizadas en términos positivos:

"La Catedral, la obra más ambiciosa, sería, según se corresponde con la mejor tradición, paciente labor de varias generaciones, verdadera plegaria hecha material elevándose poco a poco..." (Bernard, 1982b: 26-27. Las cursivas son mías)

Finalmente, es interesante detenerse en uno de los escritos de este autor, donde esta matriz religiosa se convierte además en un recurso narrativo, dotador de metáforas:

"La ciudad padeció el suplicio de Adán de nacer sin ombligo, de ser Capital antes que ciudad y ciudad antes que pueblo, fue, en un duro comienzo, pueblo sin habitantes, situación tanto más conflictiva cuanto que entonces no se hablaba de habitantes en los centros poblados, sino de 'almas', siguiendo la acertada tradición cristiana. Es decir, que empezó, como el primer hombre, según el relato evangélico, siendo tierra, polvo, para adquirir gradual y progresivamente, en titánico esfuerzo, cuerpo y alma. Y modeló esa tierra con probidad de alfarero, creando el hábitat, con profundidad de ánfora, al rescoldo de los hogares, verdaderos hogares, de los hombres y de las familias de la época, casi legendaria, de la fundación" (Bernard, 1982b: 15-16)

Más adelante habla del "milagro contra toda adversidad y contra toda desesperanza" y recurre a una cita del papa Juan Pablo II: "Reflexionar en el pasado es cargar con la responsabilidad del futuro" (Bernard, 1982b: 16, 37)

\section{La capital cultural en tiempo presente}

La definición de La Plata como ciudad cultural y universitaria tiene plena vigencia en las referencias que las publicaciones hacen a su actualidad y en sus proyecciones de futuro.

Esa identidad se expresa por ejemplo en datos demográficos incluidos en Obra de arte, que afirman el volumen importante del escalón etáreo de 20 a 29 años en la pirámide de 1970, 
originado por "la presencia de la Universidad en la zona, ya que afluyen a ella jóvenes procedentes del interior y exterior del país" (Díaz, 1982: 62). En este plano, son pocos los textos que dan cuenta de las políticas restrictivas al ingreso adoptadas por el régimen iniciado en $1976^{259}$. El más claro al respecto es el libro del diario El Día, posiblemente influido por la antigua militancia de su autor y de la familia Kraiselburd en el reformismo universitario:

"La de La Plata siguió siendo por un tiempo una universidad latinoamericana; hay hitos que marcan el término de esta solidaridad dentro de la historia de nuestra casa de estudios: 1966, con su intervención, y los violentos años 70, época en que los latinoamericanos fueron hostigados, a lo que se agregó el dictado de normas restrictivas, por las autoridades universitarias posteriores al $76[\ldots]$

Muchos que manifestaron su coincidencia con la política restrictiva, revieron sus conceptos años después, luego del 2 de abril, cuando el único respaldo para la lucha del país por su soberanía en las islas Malvinas, provino de las naciones cuyos hijos durante tanto tiempo había recibido, con los brazos abiertos, la Universidad de La Plata..." (Soler, 1982: 189)

El otro que alude al tema es Vivencias y testimonios, con una postura completamente favorable a los cupos implementados. De su efímera gestión como decano de Medicina, en 1960, Christmann recuerda un conflicto con la oposición estudiantil, a propósito de las restricciones al ingreso, que llevó a una toma de la facultad y su posterior renuncia. El médico considera que "los estudiantes habían desoído la advertencia de Osvaldo Loudet: 'En la Universidad, no seáis otra cosa que estudiantes' (Política del espíritu, pág. 123)". En su condición de guardasellos de la UNLP considera "disparatada" la cifra de 980 títulos de Medicina que debió firmar en 1980, y agrega:

“...con el placer imaginable, he visto en estos últimos años, implantar el examen de ingreso y la reducción sustancial del número de aspirantes, basándose en las calificaciones obtenidas. Pienso que su reducción actual de 350 es todavía excesiva ${ }^{260}$, pues es imposible dar a ese número de alumnos, la suficiente preparación práctica para alcanzar el nivel mínimo requerido para su habilitación profesional" (Christmann, 1982: 338-340)

Pero las limitaciones al ingreso no llegan a afectar, en los relatos publicados, la identificación de La Plata como ciudad universitaria. Cuando Cuccorese intenta sintetizar "el papel (actual) de La Plata en el plano social", afirma que "se ha convertido en importante centro urbano, de gran significación político-institucional y de considerable peso educativo y cultural", que ejerce el "magisterio cultural de su Universidad sobre toda la provincia" (Cuccorese, 1982: 151).

Por último, hemos apuntado que la voluminosa edición de Ciudad milagro concluye con un apartado denominado "JUVENTUD 82", donde incluye diecinueve entrevistas a jóvenes de la época, en un claro intento de dar cuenta de una ciudad con futuro. No está explicitado cómo fueron seleccionados los jóvenes que exponen sus opiniones. A grandes rasgos, se puede decir que refieren a una clase media universitaria, con cierta presencia de empleados del sector terciario. Considerando una identificación por persona, contabilizamos 9 profesionales -abogados, profesores, ingenieros y locutores-, 5 estudiantes y 5 comerciantes o empleados. Una vez más, no hay obreros en la ciudad letrada. Por otra parte, en cinco casos

${ }^{259}$ Según Obra de arte, para el ciclo lectivo 1982 fueron asignados un total de 4.392 cupos (Díaz, 1982: 258).

${ }^{260}$ Cabe señalar que en 1974, antes de las restricciones al ingreso, habían ingresado a Medicina 3018 estudiantes. 
-un profesional, tres comerciantes/empleados y un estudiante- se indica también la condición de "poeta", "escritor" o "letrista y editor".

Cada uno está identificado con una foto. Los textos son breves y responden a dos preguntas básicas acerca de la ciudad. En varios aparecen alusiones a la formación académica, el colegio nacional, el acceso a las "fuentes de información" y, en general, un reconocimiento de la tradición universitaria platense. Como ejemplo valga citar algunas palabras del joven profesor de historia Ricardo Juan Klala Domian, en las últimas páginas del libro:

"...la ciudad de La Plata me ha brindado el cálido abrigo de una ciudad que ha surgido como 'símbolo de unidad'; donde he aprendido a desarrollarme espiritualmente; a recibir su calor humano y su abrazo amigo (... ) Quizás para reafirmar lo expuesto, es preciso recordar aquella frase de Domingo Faustino Sarmiento donde manifiesta:

'Es una ciudad ideal... que se ve que no es para el presente sino para una generación venidera..." (en Lerange, 1982: 677)

En las páginas que siguen retomaremos esa apelación a la "unidad" o la "conciliación nacional", frecuentemente utilizada en los textos del 1982, e intentaremos cerrar el recorrido de reflexiones acerca de la disputa de sentidos por la ciudad y los usos del pasado platense en el contexto de su centenario. 


\title{
VII. Ciudad de la conciliación La historia reciente y los usos del pasado
}

\author{
“...el pasado que se rememora y se olvida es activado en un presente \\ y en función de expectativas futuras" (Jelin, 2002a: 18) \\ "Hace poco la municipalidad ha adoptado como lema el de la Unidad \\ Nacional y creo que es un acierto que señala el camino que debe \\ transitarse” (Szelagowski, 1982a: 44)
}

Un aspecto delicado al que sólo hicimos algunas referencias en los capítulos anteriores es el modo en que los textos del centenario tematizan su historia reciente, es decir, los años inmediatamente previos a 1982. Es ahí donde hallamos más frescas las políticas de memoria de la época, donde podemos observar cómo los años de la dictadura empiezan a ser narrados -todavía durante el régimen- y advertir algunas marcas propias de una "transición negociada", como los llamados a la unidad nacional y la reconciliación que analizaremos aquí.

No todas las publicaciones abordan los tiempos recientes. Al practicar el "culto a los orígenes" propio de la historia didáctica, muchas se limitan a los primeros años de la ciudad y se concentran en los relatos de la fundación. Los textos testimoniales, por su parte, ponen el foco en el tiempo feliz de la infancia de sus autores y construyen a los años '20 y '30 como una suerte de belle epoque platense.

Ni siquiera todos los textos que en teoría proponen un recorrido completo por el siglo de la ciudad se animan a la historia reciente. Crónicas de un siglo es un claro ejemplo. Está dividido en cinco partes a partir de una periodización en etapas de aproximadamente veinte años: 1882-1899 -“Los primeros años de una idea que se concreta"-, 1900-1919 -“Comienza el nuevo siglo”, 1920-1939 -“El próspero Cincuentenario-, 1940-1959 -“La ciudad cambia su fisonomía"- y 1960-1982 -"Donde el ayer se fue volviendo hoy"-. El último capítulo, que en la división temporal es el que abarca más tiempo, resulta sin embargo el más acotado: desde 1973 en adelante hay, con suerte, una referencia breve por año, y la cronología elude varias fechas. Así, por ejemplo, el único párrafo sobre 1973 dice: "Historietas. Aparecen en las páginas de historietas del diario 'El Día', como tiras cómicas y de aventuras, el Pato Donald, Mandrake y el Ratón Mickey”. 1974, en tanto, está dedicado a evocar la figura de Noel Sbarra, retomando una nota publicada ese año sobre el pediatra y escritor ya fallecido. $1975 \mathrm{ni}$ siquiera aparece; en tanto, de 1976 el único -y largo- texto que se incluye es... ¡ iel testimonio de un vendedor ambulante de 1913!. En el recorrido también faltan 1978 y $1981^{261}$.

No es el único libro que esquiva el pasado reciente. En Historia del Banco Municipal, por ejemplo, se afirma que "el período comprendido entre los años 1976-1982, por sus características, merece un estudio particular y pormenorizado dentro del contexto histórico de la institución" que "no se ha realizado por ser ésta una obra general" (Giuliano, 1983: 9).

Vida platense es, finalmente, la publicación que más claramente abarca todas las épocas de la historia política. De hecho, el capítulo sobre los años '70 presenta el desarrollo más "lento", con menos narración de anécdotas sueltas y mayor contenido político. Resulta

\footnotetext{
${ }^{261}$ Las últimas referencias de Crónicas de un siglo alimentan el imaginario de la ciudad cultural que caracterizamos en el último capítulo. La noticia de 1977 es el incendio del Teatro Argentino, en tanto la de 1980 es una bibliográfica: la aparición de Nuestra Juvenilia, una "obra de evocación del viejo Colegio Nacional" (Moncaut, 1982: 218) realizada por otro de los autores del centenario: Lázaro Seigel.
} 
interesante observar el modo diferente en que construye una mirada sobre los ' 60 -años en que tanto el autor, Soler, como parte de la familia editora de El Día, militaron en el reformismo universitario- y sobre los ' 70 -con la radicalización política que el diario impugna y de la que la familia propietaria fue víctima-.

En primer lugar cabe reconocer una caracterización relativamente sensata y abierta sobre la década de 1960. Al igual que señalamos a propósito de los textos de $\mathrm{Nessi}^{262}$, no hallamos una mirada conservadora sobre esta etapa, sobre todo en lo que refiere al plano cultural. Vida platense menciona a los jóvenes pintores del grupo Sí, reconoce cierta influencia de la cultura beat y hippie, y cita la experiencia de la Cofradía de la Flor Solar, una comunidad de artistas fundada hacia 1967 en la ciudad. En el ámbito universitario menciona que La Plata vivió episodios equivalentes a "la noche de los bastones largos" y cuestiona la supresión de la organización estudiantil (Soler, 1982: 189-194). Y en relación a la dictadura encabezada por Juan Carlos Onganía, el autor refleja la confrontativa opinión editorial de $E l$ Día, en ese entonces contraria a la interrupción del mandato constitucional.

También hace alusión a cierto proceso de liberación "sexual y de las costumbres" -que incluye el desarrollo del "hotel alojamiento o por horas, en donde se permitía el ingreso de parejas sin presentar documentos" (Soler, 1982: 208)-, aunque finaliza con un comentario de moderación:

"La informalidad había ganado todo, educación, matrimonio, vida cotidiana, sexo, modas, política, negocios, etc. De todos modos, la mayoría de los platenses, menos exhibicionista, seguía estudiando y trabajando como siempre" (Soler, 1982: 208).

A partir de este punto comienza a desplegar una mirada condenatoria sobre la radicalización de la juventud, asociada centralmente a una universidad que albergó "docentes ultras, situados más allá del bolchevismo e inclusive del maoísmo..." (Soler, 1982: 213). Una alusión al "desaliño" de los jóvenes de la época, en este tramo, presenta un parecido de familia con la indignación de Szelagowski por los jueces que llegaban a su despacho con chomba o campera. Soler habla además de una moda ideológica:

“Así como había modas en las ropas, en los vehículos, en las casas, también las había ideológicas. Parte de la juventud miraba con simpatía al peronismo o era peronista, gustaba del cine liberación, la literatura del Tercer Mundo, el movimiento hippie y algún movimiento místico como Silo. Eran los epígonos del estructuralismo y de alguna escuela nueva del psicoanálisis, cuya exégesis proveía los temas de esa generación. Aparecieron así en el horizonte tratadistas como Darcy Ribeiro, Paulo Freire, el argelino Franz Fanon, y esta juventud entendía que lo que no estaba en esta línea era perimido, burgués, decadente, superado; es decir, malo" (Soler, 1982: 213)

La violencia política, generalmente caracterizada con los mismos términos de los responsables de la represión ilegal, aparece casi súbitamente y adquiere centralidad en el capítulo dedicado a "Los tristes años 70"263. El autor habla del asesinato del general

\footnotetext{
${ }^{262}$ El historiador y crítico participa de Ciudad milagro y Obra de arte, y dirige el Diccionario de arte. En su recorrido Nessi menciona "el grupo del 'Barrilete' (1951/54) disidente en arte y en política; 'Los elefantes' (1958/60) ya consagrados a la antipoesía y a una pintura que niega la forma natural; y el grupo Sí (1961/63) de gravitación decisiva en la ruptura" (en Lerange, 1982: 127). Luego observa: "los acontecimientos históricos a partir de 1966 desalentaron la creatividad artística: La Plata, en mayor medida que Buenos Aires, pierde su imagen; los artistas se quedan en casa, los centros como Bellas artes y el museo deponen su liderazgo" (Nessi, 1982: I-III). Tampoco es conservadora la mirada de Ganuza sobre la "Problemática del arte actual a través de la plástica platense", donde cita a los informalistas, a Rollié y a Vigo, entre otros (en Lerange, 1982: 192-194).

${ }^{263}$ Tramos anteriores del libro dan la sensación de un ocultamiento intencionado de la conflictividad social y la violencia política. Como vimos en el capítulo anterior, las primeras acciones gremiales se evocan como "huelgas
} 
Aramburu, el "baño de sangre con el que surgió la nefasta organización Montoneros, definida en aquella época por un cronista de EL DIA como «Tacuara de izquierda»..." (Soler, 1982: 209). También aparecen en el libro expresiones como peronismo izquierdizado, acólitos de Firmenich, grupos asesinos autotitulados izquierda, bajas a manos del terrorismo y una larga serie de sindicalistas muertos por la subversión. Al mismo tiempo que enfatiza la cotidianidad de la violencia, le resulta posible mencionar el acto de recibimiento a Perón en Ezeiza sin nombrar la masacre ocurrida ese 20 de junio de 1973 ni mencionar muertes (Soler, 1982: 218). Según Vida platense,

"Dos hechos resonantes y nuevos para la ciudad irrumpieron con los años 70. Por un lado, parte del movimiento estudiantil hizo su entrada en el peronismo; por otro la subversión, que ya había comenzado a ganar adeptos en los claustros universitarios, emprendió su etapa más trágica y sofisticada: la de «la guerrilla urbana», como se la denominaba en los manuales de entrenamiento que llegaban desde Cuba o China, logrando gran difusión entre los estudiantes.

A poco de andar, el accionar de estos grupos dio origen a la formación de otros de signo contrario que salieron a combatirlos, generándose así una guerra despiadada que sacudió a la sociedad en su conjunto. Por sus características de ciudad universitaria La Plata fue una de las más castigadas por ese capítulo de horror, que no sólo cobró víctimas entre las dos bandas en pugna, sino que, desgraciadamente, en numerosos casos lo hizo entre personas ajenas a las parcialidades enfrentadas" (Soler, 1982: 205-206)

El autor enfatiza que "La Plata fue una de las ciudades «cuna»" de las "bandas subversivas" y que "la guerrilla se fue incorporando -como un cáncer- a la vida cotidiana platense..." (Soler, 1982: 208, 214). Merecería un trabajo aparte el análisis detallado de la lectura sobre este proceso, dado el espacio dedicado al tema, los hechos retomados y la proliferación de caracterizaciones sobre los grupos involucrados, incluido el reconocimiento de algunos "originarios de la ciudad", que hace de Vida platense una excepción en cuanto al tratamiento de la historia reciente. Incluso arriesga un análisis de "causas del fenómeno guerrillero", vinculadas tanto a una frustración de la democracia argentina como a los "coletazos de la aventura marxista en América Latina" (Soler, 1982: 211) ${ }^{264}$. El libro plantea, por otra parte, la imposibilidad de "reconstruir la formación de un movimiento clandestino como fue el subversivo ya que un bar, una pensión estudiantil, un internado universitario, una plaza, eran lugares apropiados para la formación de una célula” (Soler, 1982: 210).

Ese estado de "La Plata al rojo" se revirtió a partir de 1976 con "el gobierno de las Fuerzas Armadas", que "se juramentó a la eliminación de la subversión, atacándola en todos los frentes, en especial en los ámbitos que más la generaron, como la Universidad, y en modo especial la de La Plata" (Soler, 1982: 234).

casi románticas", de "tono menor", que suenan prácticamente anecdóticas: porque el reclamo de los trabajadores refería a la prohibición de "usar ladrillo sin mojarlo", o bien a la orden de un vigilante que no permitió que un grupo de carpinteros pernoctaran en el Ministerio de Hacienda para poder cuidar la obra y sus instrumentos de trabajo (Soler, 1982: 26). Basta observar la vaguedad del sujeto de la acción en la siguiente frase: "los sucesos políticos de la toma y posterior desalojo de los talleres Vasena produjeron cuatro muertos..." (Soler, 1982: 78).

${ }^{264}$ En la Crónica del centenario -otro de los pocos textos que aluden a la guerrilla-, el fenómeno es desestimado: "Hoy existen conflictos armados en más de una veintena de lugares con guerras que se vienen sucediendo desde la última conflagración mundial. A las libradas entre países se han sumado las desatadas por movimientos internos mediante las guerrillas, constituidas en su mayoría por civiles pertenecientes a grupos ideológicos de extrema izquierda. Todos estos conflictos si bien trascienden de la primera significación local por la interrelación de factores, intereses, políticas o creencias religiosas, no han afectado a nuestro país con la intensidad producida por los otros conflictos citados" (Szelagowski, 1982b: IV). 
En términos generales, el libro sigue la línea editorial de El Día durante el período 19741982, que consistió en "construir el sentido de otredad asignado a las organizaciones armadas, de ambos signos como las calificaba a las de derecha e izquierda" (Díaz, 2009: 252) y así reforzar la llamada teoría de los dos demonios, que leía los hechos de los últimos años como el enfrentamiento de extremismos de distintos signos políticos, eximiendo a la sociedad civil de toda responsabilidad. Contra lo que sugiere la usual adjudicación de ese relato al gobierno de Alfonsín y al primer prólogo del Nunca más, la condena del terrorismo "de ambos signos" fue una fórmula habitual desde la aparición del grupo represivo para-estatal conocido como la Triple A. Por otra parte, las páginas del diario daban escasa jerarquía a la responsabilidad de las Fuerzas Armadas en su implementación del terrorismo de Estado ${ }^{265}$.

Al igual que ocurre con las alusiones a 1955, los textos que abarcan los años de la última dictadura utilizan distintos eufemismos para hablar de ella. En Crónica del centenario, Szelagowski refiere a "períodos de 'veda política" y, si bien en otros tramos y en particular en el libro dedicado a su experiencia de gestión reivindica la legalidad constitucional, admite que aquellos "impulsan un mayor diálogo entre las fuerzas políticas ajenas a la conducción del gobierno y vinculan personalidades de distintos sectores" (Szelagowski, 1982a: 51).

En su texto sobre los estudios de periodismo, Elsa Bustos escribe que "luego de las alteraciones en los planes de estudios y cambios propios de los avatares políticos de la época, que resintieron la estructura académica de la Escuela, en 1976 se aprobó un nuevo plan de estudios, que es el que actualmente rige..."266 (en Lerange, 1982: 406). Por su parte, Albarracín alude a un "año de profundas transformaciones en el panorama político del país" (en Lerange, 1982: 310). No hay, en libros como Ciudad milagro, ninguna alusión a los desaparecidos. Por el contrario, la expresión se utiliza en varias oportunidades sin la carga de sentido que alude a una víctima del terrorismo de Estado: se habla de un artista desaparecido en plena juventud, de la "desaparición” de Roque Sáenz Peña, etcétera. Con distintas concepciones, las únicas publicaciones que dan cuenta de la represión estatal son Crónica del centenario, Vida platense y, por supuesto, No habrá manto de olvido.

Szelagowski escribe:

"El gobierno actual, que actúa desde 1976, a través de distintos titulares y compartido el poder con una Junta Militar integrada por las tres fuerzas, y que asumiera en medio de una tremenda crisis política y económica, no ha logrado cumplir con los objetivos que se habían propuesto, salvo el de la eliminación de la subversión desatada en toda su intensidad, que comienza a preocupar alrededor de 1970. Fue una guerra despiadada, que dejó miles de muertos y desaparecidos. La violencia llegó a límites inimaginables. Trágicos atentados cobraron víctimas en todos los sectores. La Ciudad de La Plata fue, por momentos, la más castigada y vivió horas de terror. Las secuelas de esa tragedia tan reciente, que tocó a tantas familias, hoy continúan y pasará mucho tiempo antes de que las heridas sean restañadas" (Szelagowski, 1982b: IV)

De este último párrafo, entre otras cosas, cabe advertir la coincidencia de la expresión "guerra despiadada" con la anterior cita, que correspondía al libro de El Día. Con un enfoque

\footnotetext{
${ }^{265}$ Otras muestras de la postura del diario en esa época encontramos en Ciudad milagro, donde Carlos Fragueiro y Marcelo Ortale escriben un capítulo sobre El Día. Allí, bajo el subtítulo "línea editorial” incluyen algunas citas que corresponden a la época de la dictadura. En tanto, en el capítulo sobre la bohemia se menciona que "David Kraiselbud" [sic] fue "muerto trágicamente víctima de la subversión" (en Lerange, 1982: 632).

${ }^{266}$ Entre las materias del Plan de Estudios aprobado se incluía Seguridad Nacional y Comunicación Social.
} 
bien distinto -que denuncia la ilegalidad de la represión y, además, inclina la balanza hacia un énfasis en los trabajadores que fueron víctimas-, el libro Familiares planteará:

"Nuestras calles, las de siempre, conocieron por las noches o a plena luz del día, los gritos desgarradores de los trabajadores, el ulular crispante de sirenas, el sonido de los autos sin patente que huían llevando en sus baúles, secuestrados, que irían a engrosar los Campos de Concentración y 'chupaderos' de la zona.

Las aceras y cordones sintieron con dolor la roja y caliente sangre de nuestros trabajadores" (Familiares, 1983: 58)

En el caso de Vida platense, si bien la escritura mantiene el léxico de la dictadura en cuanto habla de "extremistas", "subversivos" y "terroristas", relata:

"Se iniciaba el año 75 con una mención que en los tres años siguientes sería cotidiana: el operativo rastrillo. Consistía en el cerco de una manzana o zona tendido por las fuerzas conjuntas (Fuerzas Armadas y Policía) y el registro concienzudo del lugar aislado en busca de extremistas o de elementos abandonados por éstos" (Soler, 1982: 230)

Por supuesto, no habla de centros clandestinos, sino que "en los enfrentamientos, la superioridad de las fuerzas conjuntas era notoria..." (Soler, 1982: 235) ${ }^{267}$. Contradictoriamente, hacia el final del libro reproduce una solicitada con nombres de desaparecidos, del 21 de noviembre de 1978, como las que las madres y familiares empezaron a promover desde 1977. El Día se jacta de haber sido "el primer diario en el país en publicar una solicitada de este tipo" (Soler, 1982: 243). En la entrevista que realicé al autor tuve oportunidad de tratar el tema:

“- En una de las últimas páginas... Es cierto que es el '82, pero una de las últimas páginas del libro tiene transcripta la lista de desaparecidos de entonces...

[hace silencio y arranca hablando bajito]- Pero... no pensés idealísticamente, no vas a entender nada. Kraiselburd quería la próxima etapa. ¿O vos te creés que el tipo la iba a sacar por idealista?" (Entrevista con Ricardo Soler, agosto de 2008)

\section{Unidad nacional y reencuentro pacífico}

"Desde aquella primavera [...] en que La Plata fruteciera como un anhelo de unidad política del país contó con almas que le dieran vida, envolvieran con desvelos su puericia. Con gracia su pubertad. Y hoy, en su mayoría de edad, continúan amparándola desde las estrellas" (Terrasa, 1982: 9)

"Hoy, a los cien años, rebasada la peligrosa curva de las grandes desgracias y desencuentros de la segunda mitad del siglo XX, renace como 'ave fénix' a su deber ser, consolidada en los valores fuerza que le dieron origen, con blasones ganados en las lides republicanas, tras las pruebas de fuego...” (Bernard, en Lerange, 1982: 29)

La Crónica del centenario, colocada en la cripta y legada a la generación del $200^{\circ}$ aniversario, sostiene que la derrota en Malvinas y una deuda externa "que supera toda razonabilidad" han llevado a "la crisis más espantosa de nuestra historia, ha causado un

\footnotetext{
${ }^{267}$ Es más evidente la existencia de represión de Estado en tramos que refieren a otras épocas. Por ejemplo, recuerda a "la policía ugartista", tal como denominaba EL DÍA a la policía de la Provincia de Buenos Aires, de la que denunciaba abusos de poder, arbitrariedades y atropellos. Citaba, por ejemplo, el procedimiento realizado frente al frigorífico Swift, del Puerto de La Plata, en enero de 1915 (Soler, 1982: 74). O refiere las denuncias de 1933 sobre "la jauría vacuna con los Martínez de Hoz a la cabeza (...que) persiguen ciudadanos honorables, torturan hombres indefensos en el fondo oscuro de los calabozos" (Soler, 1982: 119).
} 
revulsivo dentro de la vida política argentina, alcanzando todos los niveles, desde los de conducción hasta los de oposición" (Szelagowski, 1982b: V). Es uno de los pocos textos que se hace eco de la promesa de una salida electoral ("a la brevedad posible, no más allá de marzo de 1984"). Además expresa un deseo de que "éste sea el inicio de una era de estabilidad institucional" y llama a convencerse "de la bondad de la democracia como forma de gobierno y mantenernos férreamente en la decisión de respetar el orden jurídico" (Szelagowski, 1982b: V). Si tenemos en cuenta que esta publicación fue promovida por la Municipalidad y pensada como el documento oficial de la celebración, queda claro que estamos ante una etapa de transición. En ese contexto, el pasado platense -cuya revisión es activada por la coyuntura del centenario- es "usado" para postular intereses y delinear los sentidos de ese proceso, que no pocos actores conciben como una transición negociada.

En esa dirección, Vida platense recuerda que la ciudad fue "fundada como prenda para el logro de la unión nacional" (Soler, 1982: 248) y lleva esa idea al tiempo presente en el último subcapítulo, titulado "El reencuentro pacífico":

“...Digamos para concluir que La Plata fue en el momento de su creación, la ciudad del reencuentro de los argentinos. Que quizá en la década de 1970 fue la cuna de la guerra civil. Pero que muy probablemente pueda aspirar a superar el pasado reciente para conseguir que toda la pluralidad de su compleja amalgama de sectores sociales la lance, en esta nueva época de la década del '80, al liderazgo, en el reencuentro pacífico de los argentinos..." (Soler, 1982: 250)

Reparemos otra vez en la utilización del término guerra, aludiendo aquí a una guerra civil, que vuelve a colocar la responsabilidad de las muertes y desapariciones sobre un "enfrentamiento entre bandos" con ideologías o intereses distintos, aunque en este caso hace partícipe a una sociedad que ahora debe reencontrarse y "aprender del pasado" para salir de la crisis. Con ese planteo, por otra parte, se piensa al proceso de violencia política y represión del siglo XX como equivalente a los conflictos entre Buenos Aires y las demás provincias en torno a la "cuestión capital" en el XIX ${ }^{268}$. La consigna es terminar con los odios fratricidas que llevaron a esa guerra y volver a encontrarse en la concordia.

El día del aniversario, la edición de El Día publicó además una nota editorial alusiva, que desarrolla ideas similares:

"La Plata envuelta en una de las más graves crisis de su historia amanece hoy, en el día de su Centenario, preparada para vivir la conmemoración en un clima de emocionada reflexión, en el que las preocupaciones del presente deben declinarse en el recuerdo del pasado y la esperanza en el futuro. La imagen de aquella planicie desolada de 1882 otorga un brillo renovado al panorama de este 19 de noviembre y propone a los platenses un nuevo metro para evaluar las dificultades de esta hora. Esto no significa que queden olvidados ni dejen de sentirse los complejos problemas de una realidad

\footnotetext{
${ }^{268}$ Nos referimos a la resolución de "la cuestión capital", que fue un tópico conflictivo de la historia del país desde sus orígenes y produjo enfrentamientos durante décadas. En 1826 Rivadavia intentó declarar a Buenos Aires como capital federal pero fue objetado. El problema seguía abierto cuando en la década del 1870 se enfrentaban el Partido Nacional liderado por Bartolomé Mitre y el Partido Autonomista, encabezado por Adolfo Alsina. Entre ellos se produjo, con la intervención de Nicolás Avellaneda, un pacto que se conoció como la conciliación y que permitiría saldar la "cuestión capital" con la federalización de Buenos Aires en 1880, paso previo a la propuesta de Rocha de crear una nueva Buenos Aires como capital de la Provincia, que se plasmaría en la fundación de La Plata en noviembre de 1882. Ese pacto de conciliación del siglo XIX, no obstante, tuvo resistencias. Dentro del autonomismo, un sector liderado por Sarmiento se opuso y formó un nuevo partido. Al referirse a la propuesta de Avellaneda, el ex presidente escribió: "Las ideas no se concilian; las conciliaciones alrededor del poder público no tienen más resultado que suprimir la voluntad del pueblo para sustituirla por la voluntad de los que mandan"”.
} 
conflictiva, pero la magnitud de la gesta de los fundadores brinda un ejemplo de cómo es posible realizar las grandes empresas que esa realidad exige [...]

La Plata, que brotó de una guerra civil, puede ser un ejemplo para salir de la crisis después de un período aún más doloroso y sangriento. Para eso se requiere ciudadanos que encuentren en el pasado una fuente de aprendizaje y no de resentimiento y que reserven su apasionamiento para crear la unidad -concebida a partir del pluralismobase de toda realización económica, cultural y social. Pocas familias han sufrido durante la reciente guerra civil como la de EL DIA. Pero, sin olvidar nuestros muertos, nuestras heridas y nuestras cicatrices, queremos mirar $-\mathrm{y}$ esperamos que todos los ciudadanos miren- hacia el futuro [...]

Se necesita la creación de puestos de trabajo y para ello, la radicación de industrias capaces de aprovechar las cualidades de los trabajadores platenses. Trabajadores a la vez aptos y generosos, como lo demuestra su actitud de hoy, al deponer los planteos que las urgencias presentes justifican para conmemorar la gesta de los fundadores y manifestar [...] su deseo de vivir en paz y libertad, como sólo puede lograrse mediante la vigencia plena del sistema democrático" ("El centenario", en El Día, 19 de noviembre de 1982. Las cursivas son mías)

Encontramos así, en los discursos históricos producidos durante el centenario, una intencionada producción de sentidos, a partir de las ideas de unidad y conciliación traídas de la historia del siglo XIX pero ahora para sustentar una lectura sobre una época que tiende a percibirse como el final de la dictadura.

Para entonces esas ideas portan el sentido del manto de olvido o de silencio al que se oponen los organismos de derechos humanos. Es posible trazar cierta genealogía de esos "discursos rituales sobre la 'reconciliación"” (Groppo, 2001: 37) ${ }^{269}$, que fueron promovidos por los militares prácticamente desde el inicio de la dictadura. Al cumplirse el primer aniversario de la toma del poder, por ejemplo, Videla definió a 1977 como "el año de la conciliación" (Novaro y Palermo, 2003: 172). Ya el año siguiente, al iniciarse el Ciclo Cien años, el término aparecería vinculado a los discursos celebratorios de La Plata:

"El próximo centenario, de esta ciudad de la conciliación nacional, para el que sólo faltan cuatro años, sin que nadie dé señales de vida, es la gran oportunidad, para que fundador y artífice, allá en la eternidad, puedan darse un abrazo y decir ahora estamos mano a mano, como lo estuvimos en 1882. NADA MÁs" (Prado, 1978: 16)

Luego, en 1979, Nueva Argentina recordaría que la ciudad nació "del deseo de pacificación nacional" y pretendió representar "una esperanza de unión y una señal de fe" (Cygan, 1981: 197).

Entrada la década del '80, los lemas de unidad nacional y reconciliación fueron notoriamente impulsados por la Iglesia y durante cierto tiempo sellaron también el discurso de la Multipartidaria, que surgió en 1981 e intentó negociar una transición sin grandes conflictos ni movilización popular ${ }^{270}$. En 12 personalidades dicho agrupamiento es identificado como

\footnotetext{
${ }^{269}$ Según Bruno Groppo (2001: 37-38), esos discursos “operan sólo como ejercicios retóricos, al menos por dos razones: primero, porque la verdad sobre los crímenes de la dictadura" no fue totalmente develada ni sancionada por la justicia, y porque sus responsables "no han manifestado ninguna intención de pedir perdón a las víctimas o a sus familias" y por lo tanto "la idea misma de una reconciliación parece un poco surrealista".

${ }^{270}$ Como caracterizan Novaro y Palermo, "uno de los rasgos recurrentes de los primeros documentos de la Multipartidaria es la ausencia de una voluntad de revisar el pasado. Se pronuncian por la vigencia de los derechos humanos en el futuro, pero en lo que se refiere a las violaciones perpetradas, los políticos no obstaculizan un acuerdo. La preferencia entonces mayoritaria era que el gobierno diese a conocer una lista de víctimas y su estado jurídico para dar por finalizada la 'guerra antisubversiva', y se reinstituyera el monopolio legal de la violencia, a cambio de un más o menos expreso compromiso de no revisar ni investigar" (Novaro y
} 
una obra "ciclópea" de Ricardo Balbín, "nacida bajo el impulso de la generosidad de la U.C.R.":

"Con el lema de la Iglesia de la reconcialización [sic], se dirige a todos los sectores de la vida nacional sin exclusiones, sean políticos, sociales, de los trabajadores, empresariales, espirituales, culturales, profesionales y militares, inspirada en la necesidad perentoria de elaborar, en conjunto, con espíritu de grandeza y auténtica generosidad, una estrategia global que aglutine a todas las fuerzas e ideas de la nación, con raigambre nacional, democrática y humanista..." (Alfaro, en SADE La Plata, 1982: 29)

La pretensión multipartidaria de evitar confrontaciones con la dictadura se asemeja al clima de participación que adquiere el centenario platense, en cuyo festejo la Municipalidad recibe el apoyo de múltiples entidades civiles. No obstante, los partidos están ausentes en las distintas escenas del centenario. El único que alude a estas instituciones -y a las elecciones previstas para 1983- es Szelagowski. En Crónica del centenario escribe que "los partidos tienen a la vista y sus aspiraciones puestas en los cinco millones de nuevos votantes que se incorporarán a los padrones para las elecciones del año próximo" (Szelagowski, 1982b: IV); mientras que sobre su experiencia como intendente afirma: "a mi retiro salí revitalizado en mi fe en los valores de la democracia, en la inexcusable existencia de los partidos políticos, en la bondad de nuestra organización institucional..." (Szelagowski, 1982a: 116).

Esta promoción de unidad nacional ligada a los partidos se asocia con otra operación de la época que consistió en la "reinvención" de la figura de Balbín (Novaro y Palermo, 2003: 384), producida a partir de su muerte en septiembre de 1981, cuando las exequias canalizaron en la calle cierto descontento propio de la época y fue posible escuchar algunos cánticos antimilitaristas. En rigor, las consignas no eran muy acordes a la trayectoria del viejo líder radical, que había sido uno de los más convencidos promotores de los proyectos de convergencia cívico-militar. Cabe recordar sus definiciones de Videla como un "gran general para la democracia" en 1978 y las declaraciones que hizo a Clarín en noviembre de 1979: "le decimos al gobierno militar que no se vaya hoy, sino que se quede a buscar con nosotros el milagro de una democracia argentina que salve la democracia de todo el continente americano". Su fallecimiento, no obstante, habilitaría esa operación que lo construyó como un gran defensor de la democracia. En esos términos aparece como el primer homenajeado en 12 personalidades, donde se destaca su carácter de "paladín de la democracia y de la unidad nacional", tal como indica el título del capítulo abocado a su figura, que contiene una gran ponderación del radicalismo (SADE La Plata, 1982: 16-18). También Vida platense reivindica a Balbín, al dedicarle un subcapítulo bastante extenso - dos páginas y media- a raíz de su muerte: "Fundada como prenda para el logro de la unión nacional, la ciudad honraba, al borde de su centenario, a un platense que había luchado, hasta su último suspiro, al pie de esa misma bandera" (Soler, 1982: 248).

La idea de la reconciliación, en tanto, venía siendo planteada desde la Iglesia católica. Como detalla Quiroga (1994: 319), el Episcopado Argentino había hecho un llamado en esos términos en junio de 1981, mientras que la junta interpartidaria adoptó la misma fórmula el mes siguiente. La expresión siguió circulando y está presente en el "Documento Final sobre la Lucha contra la Subversión y el Terrorismo" que la dictadura presentó en abril de 1983. 
Como señala Groppo, en países como Argentina, Chile y Uruguay, los discursos sobre la reconciliación estuvieron "regularmente utilizados para legitimar el olvido impuesto a una sociedad poco dispuesta a aceptarlo" (Groppo, 2001: 37-38). Cobra gran significación, entonces, advertir la frecuencia con que esta expresión se utiliza en la producción editorial surgida en torno al centenario de La Plata. En la propia conmemoración del 19 de noviembre de 1882, fue enunciada en el discurso del presidente de facto, Reynaldo Bignone:

"Quieran los argentinos interpretar en ella [la fundación de la ciudad] la imperiosa necesidad de que todos juntos seamos activos protagonistas del proceso de transición que nos toca vivir para cimentar la definitiva unión y el lanzamiento del país. Permita el Señor que se iluminen nuestras mentes, se apacigüen los ánimos y disminuyan los rencores con cristiana resignación, para que la reconciliación de la familia argentina sea muy pronto una realidad concreta..." (citado en Bernazza, 1997: 94)

En tanto, el Programa de Festejos del Centenario señalaba en su primera página la invitación de la ciudad "a reformular los votos de grandeza y Unidad Nacional".

Coincidentemente, buena parte los textos producidos por distintos actores de la sociedad civil en el centenario insisten en identificar a La Plata con estos epítetos.

Al igual que el dictador, Bernard alude a la familia argentina cuando escribe en el capítulo inicial de Ciudad milagro: "Es la Nueva Capital' provinciana la que consolidará la 'unión nacional', reuniendo la familia argentina en gesto fraterno. Por eso La Plata es símbolo de unidad, de paz, de confraternidad" y mientras ella no existió "no hubo, no podía haber, verdadera integración ni unión nacional...” (en Lerange, 1982: 25). Además, en Vieja amistad señala que la nueva capital vino "a cumplir un destino de concordia y pacificación, cerrando un largo ciclo histórico en nuestra vida independiente". Curiosamente, al mismo tiempo que la define como "ciudad sin historia" afirma que "su fundación es resumen y clave de la historia patria" (Bernard, 1982b: 15). El mismo sentido otorga Urraza a esta "ciudad predestinada" en Ciudad de mayo:

"[los fundadores] operaban con un sentimiento de hondo arraigo nacional, que ceñía sus actos a una sola voluntad de filiación patriótica. Para ellos, la fundación tenía un sentido patriótico y otro urbano. Se trataba del nacimiento de una ciudad que se levantaba como bandera de paz para una solución conciliadora y, por lo tanto, estaba predestinada a servir los más altos fines del interés nacional..." (De Urraza, 1981: 21)

Eso explica, según el autor, por qué la ciudad "se engalana" con "nombres patricios" y destina sus calles ${ }^{271}$, plazas y monumentos a "un éxtasis patriótico" (De Urraza, 1981: 21-22).

En Ciudad milagro, varias de estas alusiones a la pacificación se relacionan con la celebración de la generación hacedora de la organización nacional:

“...ciudad de la reconciliación nacional, fue la hija dilecta del progreso argentino. Es una síntesis del pensamiento y la acción de los hombres de la Generación del 80, y debe ser, porque así parece imponerse su especialísima condición, la urbe del presente para el futuro" (Albarracín, en Lerange, 1982: 291)

\footnotetext{
${ }^{271}$ Urraza le da una importancia vital sin aclarar que la denominación conocida de las calles es la numérica. Los miembros de la primera junta recibieron los nombres de las calles que corren de 2 a 14. En tanto, al mencionar la calle 1, que antes había sido el Camino Real, señala: "Carretera de la conciliación nacional en tiempos de la fundación, que unía inolvidables y comunes recuerdos, entre la nueva y la antigua capital de la Provincia. Su trayecto, de tránsito renovado, hizo de esta larga calle, un símbolo de la unión definitiva, entre la misma provincia y la Nación, y una mano cordial tendida en la llanura, inundada de sol, como prenda de total solidaridad y sentido común" (De Urraza, 1981: 22). También destaca el nombre de la 13, que "asume la responsabilidad de simbolizar un hecho institucional” y se denomina Avenida de la Unión Argentina.
} 
"La Plata, ciudad de la Paz y la Concordia, ligada directamente a la consolidación institucional de la República, es el producto de hombres preclaros que integraron una generación que construyó la Nación, la 'Generación del 80'...” (Canestri, Lerange, 1982: 250)

Este último texto, preludio de algunas líneas sobre las esculturas, afirma que La Plata "usa su pasado como plataforma para lanzarse al porvenir" y por ello "habría de materializar circunstancias históricas y protagonistas de nuestras principales gestas”. Entre las figuras representadas retoma distintos próceres y también "héroes anónimos, los policías muertos en servicio" (en Lerange, 1982: 250).

Rastros y rostros se suma al coro: "La realidad histórica que aspiraban los argentinos para la conciliación nacional, se gestó en la pampa de Hernández, cuando a los relámpagos sólo los sostenían los pastos" (Calvo, 1982). Y el cronista oficial del centenario escribe:

"Nunca resultará excesivo repetir lo que representó la fundación de La Plata como símbolo de la unidad nacional largamente buscada y alcanzada después de tensos desencuentros y sangre hermana derramada" (Szelagowski, 1982b: I)

\section{Rocha y una generación en armonía}

"Rinde al esclarecido ciudadano y eminente patriota, Dr. Dardo Rocha, fundador de la Ciudad, el homenaje que merece, quien con clara visión del porvenir, concibiera y creara una nueva capital para la Provincia de Buenos Aires, consolidando de ese modo, la unidad de la Nación y la paz entre los argentinos” (Editorial de Económica)

"Si de algo pecaron, fue de un exceso de grandeza cuya herencia anhelamos" (en Lerange, 1982: 564)

La unidad de la familia argentina supuestamente alcanzada en el siglo XIX con la fundación de La Plata no es atribuida a una obra del destino sino a una generación y concretamente a algunos "prohombres". Como venimos viendo, el tipo de relatos que analizamos tiende a construir y enaltecer ciertas figuras heroicas, como ocurre en este punto con Dardo Rocha, "convencido partidario de la conciliación nacional" que había apoyado la idea de Avellaneda y consideraba que "como fruto de esa unión nacional debía nacer la nueva Capital” (Bauer, en Lerange, 1982: 561). Rocha es "el padre de La Plata", un "patriarca", "moldeado en la guerra del Paraguay" y que "en las luchas civiles supo participar con coraje e hidalguía en las no menos difíciles lides políticas en las que fue gran contenedor" (Soler, 1982: 11, 89). El fundador constituye una figura casi mítica, como vemos en la frase inicial del texto brevísimo que Becerra publica en Ciudad milagro: "Si decimos que La Plata la hizo un hombre parece una demasía, un disparate. Pero así fue" (en Lerange, 1982: 60).

Los atributos de Rocha son claros: "es un ejemplo de lo que puede ser la capacidad creadora del hombre", es incansable y "no pierde un detalle" (Terrasa, 1982: 24). Es un "hombre de métodos, asido a las disciplinas, incapaz de avanzar más allá de lo que señala un claro y exhaustivo razonamiento" (Bernard, en Lerange, 1982: 26). "La silueta y su rostro de patriarca provocaban la simpatía y movían al saludo de los platenses", agrega Cygan: "El artífice velaba por su obra, serenamente" (1981: 187). Para los autores de Creación de la generación del 80, "Dardo Rocha probó que los ideales son los que arrastran las acciones. Y en la soledad de la pampa el mundo vio surgir la obra prodigiosa de los hombres tenaces, la magnífica obra del trabajo humano sostenido” (Zuccalá y Musmano, 1981: 51). 
Los recursos para la ponderación de este personaje son abundantes y abarcan casi la totalidad de las publicaciones analizadas. Aquí apenas retomamos algunos ejemplos para dar cuenta de esa diversidad de imágenes y textos sobre el fundador.

Al inicio de Obra de arte, además del trazado de la ciudad encontramos un retrato suyo. La imagen es seguida por un texto sin firma titulado "Dardo Rocha" que propone una biografía familiar y pública del ex gobernador (Díaz, 1982: 14). Luego viene una página desplegable con la "Genealogía Dr. Dardo Rocha", que incluye más de 200 nombres.

Ciudad milagro, por su parte, al proponer el nombre de Rocha casi como un sinónimo de La Plata, explora otras facetas de su figura, incluso algunas que no tienen que ver con la ciudad. Así, por ejemplo, Amelia Sánchez Garrido explora su trabajo como autor teatral ${ }^{272}$. Por otra parte, Rocha es mencionado entre los primeros presidentes del Club Social de La Plata y como promotor de la práctica de turf en uno de los artículos dedicados al Jockey: "No puede extrañar demasiado, entonces, que apenas 22 días después de la fundación, el gobernador Rocha designara una comisión [...] encargada de planear la instalación del hipódromo" (Alarcón, en Lerange: 622). Finalmente, en el tramo final de la compilación nos encontramos con el texto de Luis Saraví titulado "La ciudad de Dardo", que abarca la fundación de La Plata y especialmente su figura. Cabe transcribir algunos tramos para ver su composición literaria:

"Llegaba al mundo, Dardo.

Gordito.

Macizo.

Ojitos de un profundo azul y pelito colorado.

Todo un fundador" (en Lerange, 1982: 643)

Y más adelante:

"La cuna obliga.

Dardo fue el alumno que todo fundador debe ser.

Fue el heroico guerrero que todo fundador debe ser.

Fue el periodista y buen hombre público que todo fundador debe ser.

El marido y padre que todo fundador debe ser.

Gobernando Buenos Aires, recibió el mandato para el cual había nacido: funde una

Capital [...]

En el umbral de la primavera.

En el sexto día de septiembre.

Más que un mes, un estado del alma.

Se iba de este mundo Dardo.

Viejito.

Ojos muy azules.

Pelo colorado entreverado con plata.

Todo un fundador" (en Lerange, 1982: 646, 649)

Otro texto que constituye una demostración acabada de la glorificación de Rocha es Vieja amistad. Allí Bernard evoca su "vida excepcional" y su "nombre inmortal en la onomástica de la proceridad americana" y destaca una "alongada prosapia", la "herencia cabalmente fundacional" que anida en su sangre, pues la trayectoria familiar entronca "con los hacedores de la 'patria vieja', con sabor colonial y con constructores de la 'patria nueva', de

\footnotetext{
${ }^{272}$ Comenta su drama El sitio de Buenos Aires, 1852-1853 -un relato histórico antirrosista originalmente dado a conocer sin autor- y su obra inédita Amor heroico (en Lerange, 1982: 62-66).
} 
acento revolucionario y transformador, su linaje corporiza en las instituciones republicanas que caracterizaron el siglo XIX" (Bernard, 1982b: 27, 20).

"Este hombre pequeño y grande, prototipo del repúblico y del ciudadano, cuya figura menuda de armoniosos perfiles, se agiganta en la acción y en el pensamiento. Puede decirse de él, sin ambages, que alcanzó el raro equilibrio interior necesario para actuar como hombre de pensamiento y pensar como hombre de acción. Fue el acabado exponente de una generación de constructores, de hacedores de cosas. Y en tal dimensión le correspondió el mérito - tan singular para los argentinos- de ser hacedor, constructor de ciudades. A su impronta personal se debe no sólo La Plata; Pehuajó y Necochea se gestan en la misma ubérrima matriz" (Bernard, 1982b: 20)

Pero entre tantos dichos sobre Rocha hay también muchos no-dichos. El problema se extiende hasta nuestros días, pues si bien hay abundantes escritos en torno a él, "muy pocos han sido los trabajos que realmente han intentado un análisis profundo de la figura social y política, más allá de las anécdotas relacionadas con la fundación de La Plata”. Como advierte Troisi, "esto no constituiría un problema en sí mismo, si no fuera porque en el afán de destacar la figura de Rocha como prócer de la ciudad, los autores han olvidado, por lo general, todo intento de espíritu crítico" (Troisi, 2006: 120). Sin ir más lejos, es probable que la exaltación de Rocha exclusivamente asociada a la creación de La Plata sea algo con lo que ni siquiera él estaría de acuerdo:

"Asociado historiográficamente con La Plata, nunca dejó, sin embargo, de sentirse identificado con la ciudad que lo vio morir y también nacer. Rocha fue un auténtico miembro de la élite porteña, reconocido paradójicamente por haber fundado una ciudad concebida para ser su rival. Tal contradicción resultaría un sustancial condicionante de su carrera política" (Troisi, 2006: 13)

Tal es así que Rocha dejó un pedido expreso de que sus restos fueran depositados en el cementerio de la Recoleta. Como el relato del pasado, también su cadáver fue usado políticamente: en 1940 se gestionó su traslado a La Plata y hoy los restos del fundador tienen una cripta en la catedral local.

Entre los tópicos no abordados en la bibliografía del centenario están la negativa de Rocha al sufragio secreto y la asociación a la Liga Patriótica Argentina, constituida en 1919 por sectores conservadores de la élite argentina. Como vimos, también Francisco Moreno promovido por Carlés como héroe civil- había formado parte de este grupo que se planteó reprimir con sus propios recursos la creciente conflictividad obrera.

Los relatos platenses que ensalzan al ex gobernador tampoco dan cuenta de su participación en conspiraciones, como la que preparó con el apoyo de algunos generales en 1885 para derrocar a Roca ${ }^{273}$. Finalmente, ofrecen una versión idealizada de la generación de fundadores que no da cuenta de las disputas que ocurrieron en su seno y que pondrían en duda las ideas de "conciliación" y "unidad" asociadas a La Plata.

En ese sentido, es notable que pocos textos del centenario dan entidad a la figura de Carlos D’Amico, quien primero fue ministro de gobierno de Rocha y estuvo a cargo de muchos de los acelerados trabajos de la creación de la ciudad, y luego lo sucedió en el cargo

\footnotetext{
${ }^{273}$ Como explica Troisi (2006: 49), "tanto su participación en la trunca revolución argentina como en la fallida uruguaya harán incuestionable el desempeño político de Rocha, que de alguna manera tratará posteriormente de remediar. En un intento de limpiar ese pasado, décadas más tarde, totalmente alejado de las disputas políticas partidarias, escribirá en una de sus notas: 'Jamás he tomado parte en una revolución”".
} 
de gobernador hasta $1888^{274}$. A juzgar por algunos gestos, como la construcción de su mansión frente a la plaza central o la posterior disposición de que sus restos fueran sepultados en La Plata ${ }^{275}$, D’Amico parece ser una figura más compenetrada con la ciudad que el propio Rocha. Sin embargo, su figura carece de relevancia en muchos de los textos analizados, y si salimos del corpus para observar el espacio urbano veremos que no hay ninguna estatua en su homenaje -como tampoco la hay para Roca, que había sido designado "padrino" de la fundación pero se ausentó tanto en el acto del 19 de noviembre de 1882 como en el de traslado de los poderes públicos provinciales.

A poco de dejar la gobernación D’Amico se instaló en México. Desde allí en 1890 publicó con seudónimo un libro titulado Buenos Aires, sus hombres, su política, donde daba cuenta de elecciones fraudulentas y negociados ${ }^{276}$ de un gobierno reducido a una clase social aristocrática y ponía en evidencia pugnas y disputas al interior de la llamada generación del $80^{277}$. La creación de La Plata, pues, no parece haber sido prenda de paz tal como lo plantean los relatos publicados. Es interesante recordar, en ese sentido, que las principales figuras políticas de la época faltaron al festejo de la fundación: Julio Roca, Nicolás Avellaneda, Domingo Sarmiento, Carlos Pellegrini, Francisco Madero, Leandro Alem y Bernardo de Irigoyen, entre otros, estuvieron ausentes el 19 de noviembre de 1882 cuando Rocha colocó la piedra fundamental de la "ciudad de la unidad nacional".

\section{La invención del pasado}

A propósito de ese acto, debemos advertir que la invención de la historia platense no empezó en 1982, sino en el mismo momento de creación de la ciudad. La litografía que representa la ceremonia fundacional es paradigmática. Podemos verla en varias de las publicaciones del centenario: allí están Roca, Sarmiento, Avellaneda y Pellegrini ${ }^{278}$ acompañando el nacimiento de la nueva capital.

\footnotetext{
${ }^{274}$ Una excepción es el fragmentario artículo de Dora Valdovinos en Ciudad milagro, donde apunta que "junto a Dardo Rocha y Pedro Benoit constituye el triángulo fundamental en la concreción de la ciudad". Allí, la propia autora considera que D’Amico ha sido "una figura olvidada" (en Lerange, 1982: 640).

${ }^{275}$ Según Reynal, los restos de D’Amico están en un nicho común del cementerio y es el único ex gobernador de la Provincia de Buenos Aires que descansa en el cementerio local (Reynal, 1998: 91). El Palacio que le había pertenecido es actualmente la sede del Arzobispado local, dato significativo teniendo en cuenta que se habría tratado de un líder masón. Según sintetiza Vallejo en su tesis doctoral, "D’Amico fue un referente central de la Masonería en la región. Tras perder su palacio de La Plata en la crisis económica, viajó a México donde Porfirio Díaz le ofreció la ciudadanía de ese país, que rechazó aún cuando se esperaba que ese paso lo habilitara para convertirse en Ministro de Relaciones Exteriores y posible sucesor en la Presidencia de la Nación. A su regreso a la Argentina, D’Amico fue electo en 1904 Gran Maestre del Gran Oriente del Rito Argentino, cargo máximo de la Masonería argentina que hasta entonces detentaba Carlos Pellegrini” (Vallejo, 2005: 110).

${ }^{276}$ Por ejemplo, el trabajo de D’Amico sería retomado más tarde por Scalabrini Ortíz para denunciar la extranjerización de los ferrocarriles. "Los ferrocarriles de la provincia se llaman ahora "New Western Railway of Buenos Aires" ¿No se parece eso a la sombra de la bandera inglesa flameando sobre otro pedazo de territorio argentino con más derecho del que tiene para flamear sobre las Islas Malvinas", escribía el ex gobernador con seudónimo Carlos Martínez, en 1890.

${ }^{277}$ Entre los planteos conspirativos de su Historia Oculta de la Ciudad de La Plata, Reynal afirma que "ese libro, en 1982, estuvo prohibido en esta ciudad que celebraba su centenario, para no lastimar-supongo- a la generación del 80" (Reynal, 1998: 79). No he podido confirmar esa prohibición, aunque sí es interesante advertir que el libro no está disponible en bibliotecas especializadas en la ciudad, como la sala sobre La Plata de la biblioteca de la UNLP o la Biblioteca López Merino. En esta última el libro aún figura en su fichero pero, tras buscarlo, los empleados confirman que está extraviado y "alguien lo debe haber robado".

${ }^{278}$ Sobre las imágenes de los primeros años y el "planeamiento iconográfico" de la fundación es interesante la reciente tesis de Pereira de Arruda (2011), que compara los casos de La Plata y Belo Horizonte, otra ciudad creada por una elite política para ser capital política-administrativa de un Estado, a fines del siglo XIX en Brasil.
} 
La escena, en rigor, nunca existió. El acto del 19 de noviembre se realizó en un contexto de fuertes internas políticas y, como vimos recién, muchos se ausentaron. La cromolitografía fue realizada por el grabador milanés Quincio Cenni por encargo de Rocha, a partir de un montaje solicitado al fotógrafo que se ocupó de retratar los inicios de la ciudad, Thomas Bradley. En otras palabras, el mismo gobierno que impulsó la fundación de La Plata mentó y reprodujo la imagen de una escena conciliadora que nunca existió.

Con el tiempo esa obra tendría efectos de verdad. Así, acompañó los festejos del cincuentenario -en los que se encontraron los hijos de Roca y Rocha convalidando el montaje- y aparece en la portada color del folleto del Jockey Club que reunió aportes de José María Rey y Antonino Salvadores (1944). Para entonces la historia de la imagen creada ya había sido explícitamente contada ${ }^{279}$.

Entre las publicaciones que estamos analizando, Vieja amistad y Ambiente incluyen esa escena sin ninguna aclaración al respecto. En la revista de urbanismo la litografía a color ocupa toda la portada ${ }^{280}$. La historia sí es aclarada en varios libros impulsados por el gobierno y la universidad: Crónicas de un siglo, Ciudad nueva ciudad antigua, Ciudad milagro, Crónica del centenario y Diccionario de arte. Moncaut señala que "la litografía fue mandada confeccionar por el doctor Dardo Rocha agregando los invitados que por discrepancias políticas sobre los problemas de la fundación" no habían concurrido, y que el objetivo era "conciliar a los hombres de la época, en un cuadro de trascendencia histórica" (Moncaut, 1982: 7). No cuenta demasiado detalle, pero es interesante que un libro oficial mencione el montaje -como así también la frustración del asado criollo previsto en el acto fundacional-, sobre todo teniendo en cuenta que otras publicaciones lo incluyen sin ninguna advertencia al respecto.

En Ciudad nueva ciudad antigua, que desarrolla un relato clásico y bastante detallado sobre la ceremonia fundacional (Morosi, 1983: 157-160), la litografía está reproducida a color, con un epígrafe aclaratorio: "Oleografía oficial del Acto Fundacional. Ejecutada en base a una fotografía que mandó trucar el propio Gobernador. Este quería conferir a la misma un carácter alegórico, haciendo incluir a los personajes importantes de la política argentina que habían estado ausentes, para demostrar que había sido una verdadera fiesta de la conciliación nacional" (Morosi, 1983: 158. Las cursivas son mías). También lo comenta en el texto principal:

"En una litografía en color que mandó ejecutar en Italia, basada en la fotografía oficial del acto, [Rocha] ordenó adulterar los hechos registrados por la cámara con el objeto de incluir a todos los personajes y aun al presidente, que habían estado ausentes. Quería, y así lo hizo, registrar en ese documento gráfico, aunque no fuere más que mediante un

\footnotetext{
279 El encargado de des-montarla fue el socialista Guillermo Korn. Su estudio apareció en el número inicial de Libertad Creadora (1943), apoyado por la colaboración de José Fontana -conocedor de las técnicas de las artes gráficas- y Grete Stern -esposa del fotógrafo Horacio Cóppola-, que realizó ampliaciones para precisar los detalles de la obra. Años antes, en 1939, Korn había dirigido la publicación La Plata a su fundador, impulsada por la Municipalidad de La Plata para celebrar el centenario del nacimiento de Rocha. Allí estaba incluida la imagen sin aclaraciones, salvo la sugerencia de compararla con la foto original.

El trabajo se editó en forma individual en un folleto de 20 páginas, con el título La litografía de la fundación de La Plata (Korn, 1948). El tema fue retomado en 1961 por Prado, que publicó en El Día un artículo sobre "El espíritu conciliador de Dardo Rocha y la litografía de la Fundación”. Sin embargo, la cromolitografía siguió reproduciéndose muchas veces sin ninguna aclaración, como ocurre en Ambiente o en Vieja Amistad.

${ }^{280}$ Sin recurrir a la imagen, Primeros habitantes también consolida el montaje mentado por Rocha, ya que al aludir a la ceremonia fundacional dice que "fue padrino el presidente de la República: Teniente General Julio A. Roca" -lo cual es formalmente cierto-, sin señalar la ausencia del presidente en el acto (Terrasa, 1982: 24).
} 
truco fotográfico, el instante que había soñado y que entendía constituía la imagen misma de la ansiada conciliación nacional" (Morosi, 1983: 158)

En Ciudad milagro, la referencia se reduce a una nota al pie en el artículo de la directora del Museo y Archivo Dardo Rocha. Por su parte, el cronista del centenario, tras comentar el "tremendo episodio histórico" que significó la desaparición del acta fundacional -hecho que ubica en 1882-, escribe: "Nos preguntamos por último si Rocha pudo sospechar que existió una conjura y que se cometió tamaño delito. Y vuelve a nuestro pensamiento la oleografía de la fotografía fraguada que seguramente contiene, por decisión de aquel, el rostro de los responsables" (Szelagowski, 1982b: XXIX).

La descripción más detallada aparece en Diccionario de arte, en una entrada redactada por el propio director de la publicación, que examina detalles de la obra:

“...al fondo, entre arcos de triunfo que ostentaban una proliferación de banderas y escudos, los pendones de la Societá Stella d. Italia, de la Societé de S.M. des Résidents de France, del Centro Gallego de Bs. As. Representaban la adhesión de las colectividades. Damas con sombrillas y trajes de la época impresionista, parece evocar, de lejos, la fiesta popular del Moulin de la galette, de Renoir. Para la versión cromática del acontecimiento se eligió una paleta de azul celeste y amarillo, con acentos rojos en las banderas de Italia, Francia y España; en los kepis de los oficiales elementos iconográficos que Cenni conocía muy bien por ser pintor de batallas [...]

Quizá por razones de fotomontaje, Sarmiento vino a quedar un poco lejos, a la izquierda, en segunda fila; Roca, detrás del sacerdote, casi en el centro de la escena, más próximo al espectador; también se advierte la presencia de dos niños en la escena del centro: son los hijos de Rocha y de Roca. Las firmas abundan, por parte de los realizadores de la cromolitografía [...] Se hizo una tirada de 500 copias. El Dr. Dardo Rocha podía estar satisfecho: la Fundación quedaba documentada en sus menores detalles. No contó, sin embargo, con la vanidad de los hombres que agregaría un truco final: cuando vio las oleografías llegadas de Italia tuvo un gran disgusto: entre los asistentes, señalado por las puntas de las enes y el trazo de la i en la firma, en el primer término de la escena, estaba el mismísimo Quincio Cenni...” (Nessi, 1982: 224)

Además, Nessi explica sin vueltas el motivo político del montaje: "dar a la fundación de La Plata el carácter de una conciliación nacional que de hecho no tenía".

Será esa conciliación imaginada la bandera levantada un siglo más tarde, en la celebración del centenario, cuando las imágenes y los textos producidos ocultan otras ausencias. 


\section{Ciudad de los silencios Reflexiones finales}

Es raro encontrar investigaciones rigurosas sobre la historia de las ciudades. Como dijimos desde un principio, el pasado local ha sido un objeto de estudio desestimado por los historiadores profesionales, lo que coloca a ese tipo de historia en la condición de un "género menor" que la academia delega en literatos y aficionados. La consecuencia es que la mayor parte de las producciones sobre el tema son textos panegíricos inspirados por "fechas redondas", como en nuestro caso el centenario.

Las celebraciones jalonan los tiempos de producción y circulación de este tipo de relatos. En broma, Luis González sugería a los aspirantes a historiadores asegurarse "publicidad y buen salario" escogiendo como objeto de estudio alguno vinculado a una “celebración centenaria en puerta” (González, 2009: 178).

A lo largo de esta tesis hemos analizado más de cincuenta publicaciones sobre La Plata producidas en torno a 1982, lo que confirma el peso que esa coyuntura tuvo como incentivo de la producción editorial sobre el pasado local. No es algo nuevo ni propio de la capital bonaerense. Por citar otros ejemplos, la historia de Quilmes a través de los años fue publicada por la Municipalidad "en homenaje al Tricentenario de la Fundación de Santa Cruz de Los Quilmes" (Craviotto, 1966) y es un texto que su autor escribió en 1960, estimulado por el sesquicentenario de la revolución de mayo. Por su parte, el Manual de Historia de Bahía Blanca, todavía la obra más accesible sobre el tema, fue iniciativa de la Universidad Nacional del Sur para la celebración del $150^{\circ}$ aniversario de la fundación de esa localidad (Weinberg, 1978). De un modo análogo a la historia platense, se concentra en la etapa 1880-1930. Su capítulo final, "Las últimas décadas", prácticamente salta de los años '30 a los actuales "70.

Un interrogante irresuelto -y quizá irresoluble- es el enigma de los lectores. No sabemos a ciencia cierta quiénes consumen historia local. En cuanto a la distribución, las iniciativas exploradas dan cuenta de libros hechos para ser obsequiados más que vendidos, pero eso no nos dice demasiado acerca del público. Por otra parte, atentos a los descuidos advertidos en las distintas ediciones, hemos arriesgado la idea de que tales publicaciones no parecen escritas para ser leídas, sino para "cumplir" con la celebración. En este plano, igual que en otros, No habrá manto de olvido parece ser la excepción: está signado por la urgencia de ser leído y reproducido, más que por la motivación del "efecto político" que implica existir, como objeto, en homenaje a la ciudad letrada.

En aquella incógnita radica también una dificultad para definir la relevancia de cada libro analizado. A tientas hemos pensado y mixturado varios criterios. Uno es la accesibilidad en bibliotecas. Libros como Obra de arte o Ciudad milagro aparecen en distintos catálogos, en tanto Vida platense es una de las lecturas más factibles de encontrar en una biblioteca personal o familiar. Otro criterio es el reconocimiento de la cita posterior. Aunque no encaramos un análisis bibliométrico al respecto, es frecuente hallar en textos posteriores sobre La Plata citas tomadas de libros como Viajeros o Ciudad de mayo, además de los ya mencionados. En la valoración de cada libro también pusimos en juego el reconocimiento de los actores involucrados en la edición: el gobierno, las asociaciones profesionales o la voz disidente de un organismo de derechos humanos, por ejemplo. En suma, no fue fácil precisar la importancia de cada publicación a la hora de organizar el análisis. 
Por otra parte, no dejaron de interesarnos algunas ediciones poco accesibles y apenas conocidas, que nos ayudan a completar una visión de conjunto sobre la multiplicidad de iniciativas editoriales del centenario y sus relaciones, tanto en lo que hace a los autores compartidos como a los sentidos de la ciudad que se reiteran en los distintos textos.

En el capítulo III hemos visto que los relatos publicados sobre la historia de La Plata, con sus matices, tienen rasgos que los colocan en una zona de frontera entre la historia y la memoria. Presentan el registro escrito de un pasado transmitido más que vivido -salvo los textos testimoniales-, pero sus operaciones, su prosa y el motivo mismo de su publicación los alejan del estudio académico y los aproximan a la lógica de la conmemoración.

Coexisten en las publicaciones la pretensión de homenajear a la ciudad centenaria, testimonios nostálgicos de ciertas vivencias personales, discursos conservacionistas sobre el patrimonio y algunas búsquedas de conocimiento en un sentido más académico. Varias mixturan distintos objetivos en textos que tienen una composición fragmentaria y dan cuenta del pasado local con repasos misceláneos de sucesos fundacionales, instituciones destacadas, grandes personalidades y otras "pinceladas" de una ciudad en las que proliferan los nombres propios. Algunos textos nos recuerdan al borgiano Manual de Zoología Fantástica: enumeraciones de personas u organizaciones en torno a algún tema o actividad específica, terminan sufriendo alteraciones, excepciones y desvíos. Todos quieren entrar en la historia de la ciudad.

Esa forma de representación constituye la fase final de una operación histórica peculiar, que comienza con una débil relación con las fuentes en el plano documental y un trabajo limitado en términos de explicación y comprensión de procesos históricos, determinado por el peso dominante que lo celebratorio tiene por sobre lo cognoscitivo.

Se forma así un relato con una entidad singular, afín a lo que González llama historia didáctica, de bronce, reverencial, un género histórico que "pretende dotarnos de un proyecto para toda la vida por medio de un repertorio de exempla distraídos de personajes y hechos hazañosos" (González, 2009: 81-82). En el caso de La Plata, el engrandecimiento de grandes hombres al estilo de Thomas Carlyle, alcanza a la figura de Benoit -como vimos en el capítulo V-, a un panteón de próceres artísticos y científicos de la ciudad universitaria -revisado en el VI- y al fundador Dardo Rocha -como vimos en el VII-. En todos los casos, son incluidos y valorados algunos aspectos de cada personalidad y cada trayectoria en detrimento de otros, y esa selección resulta coherente con los sentidos construidos en torno a la ciudad, su razón de ser, su historia política, etcétera.

Esta historia autorizada, como la llamaba Ricœur, transmitida y celebrada públicamente, suele presentar una retórica "nauseabunda". Afirmarlo así conlleva el riesgo propio de cualquier generalización y sabemos que en el corpus de 54 publicaciones hay matices y casos excepcionales; pero a grandes rasgos hemos encontrado textos con una prosa antigua, pueblerina, que lejos están de evidenciar una ciudad madura en artes en el plano literario. Adrede, esta tesis recurrió a la transcripción de párrafos enteros que sirven como muestra de esas oraciones largas, con palabras añejas y expresiones sobreadjetivadas. Al volver sobre las fichas elaboradas durante el trabajo de archivo me encontré con una anotación sarcástica bien ilustrativa. Después de copiar parte del prólogo que el presidente del colegio de notarios incorporó a la antología de Speroni, apunté: "1982 es el año que los escribanos se creyeron buenos escritores”. En los textos de origen académico, en tanto, 
advertimos una redacción más sobria, pero no obstante caracterizada por un tono decimonónico.

Al titular a los capítulos más analíticos con algunos de los epítetos que han identificado a La Plata, otra carga de ironía denominó al que dedicamos a los autores y sus círculos sociales como "Ciudad de sabios y poetas". Cuando indagamos quiénes escriben encontramos la reiteración de ciertos nombres e identidades profesionales propias de una clase media que se arroga el derecho de narrar la ciudad y produce textos auto-celebratorios de su propio sector social. Podríamos haber llamado al capítulo con una expresión que aparece en Rastros y rostros: ciudad de la nobleza. Esa nobleza, igual que la sabiduría, es una construcción de los propios relatos. Así como el linaje es una invención, son los mismos autores los que se declaran unos a otros poetas, sabios y genios de la ciudad, y son las instituciones a las que están afiliados las que premian sus obras. Además, se consideran herederos de una tradición cultural particular, a la que reivindican, pero cuya trascendencia real es bien discutible. En cierto modo, la "cultura platense" que intentan legitimar es -al igual que la ciudad portuaria o la gran capital política- un proyecto frustado. Las expresiones literarias parroquiales $-\mathrm{y}$ para 1982, anacrónicas- que glorifican la mayoría de los textos analizados no tuvieron mucho más reconocimiento que el de los pares en la escala local, tragedia que se repite como farsa entre los escritores del centenario.

Lo que nos plantea el recorrido del capítulo III es la existencia de un estrato social bien dotado de recursos materiales y simbólicos que se auto-instituye como narrador y protagonista del relato urbano. Los sentidos del pasado que producen sus libros están articulados en torno a sus lugares de pertenencia: la universidad -pública o privada-, las sociedades de escritores, el Jockey Club, las corporaciones profesionales y algunas fundaciones e instituciones filantrópicas donde completan una vida social activa que los confirma como ciudadanos platenses.

Escritos desde ese lugar, estos relatos ubicados en la frontera entre historia y memoria construyen o reproducen sentidos muy fuertes sobre la ciudad, que analizamos de la mitad de la tesis en adelante. La exaltación de una "ciudad perfecta", que alude a la cuidadosa planificación del trazado del casco urbano céntrico, expresa la reivindicación de un higienismo progresista. Esto se hace, claro, sin tematizar el carácter excluyente y represivo de esa corriente que implicó desde siempre el control de las "presencias no deseadas".

La valoración de la ciudad en ese aspecto tiene varias consecuencias. Una es habilitar una mirada centrada en lo urbanístico-arquitectónico, que se expresa en un interés por la ciudad física y una valoración de la acción de los profesionales vinculados a su construcción. Este énfasis en el aspecto material de la ciudad, a su vez, da cabida a la prédica patrimonialista que advertimos en algunos textos - cuya definición de qué cosa es considerada como patrimonio y cuál no, depende de una mirada particular sobre la historia-.

Otra consecuencia es cierta pérdida de un sentido de región y del reconocimiento sobre el proyecto original de la nueva capital, que se pensó de cara al río y su mayor inversión inicial fue para desarrollar un gran puerto. Como vimos, sólo tres publicaciones sostienen un enfoque más regional. En el resto, la mirada centrada en el casco urbano de la ciudad deja afuera a los barrios periféricos y a los partidos autonomizados de Berisso y Ensenada, y facilita la construcción del imaginario más fuerte: el que identifica a La Plata como una ciudad universitaria, capital cultural, sitio privilegiado de las ciencias y las artes. 
Esto opera en detrimento de la posibilidad de reconocer otras actividades o actores urbanos, que aparecen sólo en algunos textos y tienden a adquirir el carácter de anécdotas o curiosidades. La significación de la ciudad universitaria aplasta a la producción industrial o frutihortícola, al movimiento obrero de la región e incluso a la función administrativa de la capital provincial. La Plata aparece, sobre todo, como un foco de cultura, y esa definición es la que filtra la atención sobre instituciones y personalidades. Los héroes que hicieron la ciudad son entonces Francisco Moreno y Joaquín González, Alejandro Korn y Almafuerte. Como analizamos en el capítulo VI, aquella razón de ser llega a motivar en uno de los autores más significativos de la época una operación de reinvención del sentido del nombre de la ciudad.

Si otrora el gobierno peronista le había quitado su bautismo fundacional para llamarla Eva Perón, esta nueva intervención le quita el sentido original que tenía su nombre histórico, que refería a una ciudad pensada de cara al río. Curiosamente, el escritor que explica la denominación de La Plata por "el señorío cultural de la Nueva Chuquisaca" tiene una trayectoria personal cercana al peronismo, al que se vincula a partir de un ideario nacionalista y católico. No obstante, y a diferencia de los autores que provienen del radicalismo conservador -como el cronista oficial del centenario- en los textos de Bernard no hay alusiones al movimiento político que integró sino una insistente reivindicación del linaje de fundadores en el que se inscribe, mientras que en el panorama general de libros del '82 el peronismo aparece silenciado o impugnado.

A fin de cuentas, en este desfile editorial pasa lo mismo que observamos a propósito de la programación cultural del Club Universitario: parecen encontarse distintas tradiciones políticas -peronistas, radicales, socialistas- pero se trata de la versión más conservadora de cada una de ellas, todas con una inclinación aristocratizante.

Identificamos en Bernard a uno de los autores más relevantes del centenario, no sólo por su participación en distintas publicaciones, sino también por su membresía en varias de las entidades que nutren la profusión editorial de esa coyuntura y por la densidad de las operaciones de sentido que advertimos en sus textos. Su participación en el Ciclo Cien años es justamente la que convoca como presentador al intendente de facto Abel Román, cuyas palabras -también trascriptas- son significativas:

"En este ya prestigiado ciclo en que los platenses meditan acerca de la cultura, de las realizaciones, y de la gente de la ciudad, abrimos el año 1982, etapa singular en la vida de La Plata y de sus habitantes, porque La Plata alcanza los cien años de su fundación. Hemos dicho más de una vez y queremos repetirlo aquí que el centenario de la fundación de La Plata, no es solamente el festejo de un cumpleaños, sino que debe ser la plataforma de lanzamiento definitivo de una ciudad que por capital de la provincia de Buenos Aires, y por la peculiar dotación de recursos humanos y culturales que ha detentado a lo largo de esta centuria, puede ejercer realmente una función gravitante y de ejemplo para los argentinos que en momentos tan especiales, como los que estamos transitando necesitamos realmente de ese alimento espiritual e inteligente que La Plata ha sabido darle a la historia nacional. Y no podríamos abrir mejor este ciclo del centenario, que con la palabra inteligente del doctor Tomás Diego Bernard, un platense de quien si tuviera que resumir su curriculum, le robaría yo el tiempo de su conferencia. Basta decir que desde sus años juveniles ha transitado comprometida y apasionadamente todas las ramas del quehacer social y cultural. Ha sido funcionario, ha sido escritor, ha sido maestro, yo creo que fundamentalmente y eso es un atrevimiento, su vocación es esencialmente universitaria...” (Román, en Bernard, 1982b: 11-12) 
El tema de la charla pública, como ya sabemos, fue la vinculación entre la familia Bernard y la del fundador Dardo Rocha; en palabras de Román, "la evocación de quien fuera de algún modo el numen de la grandeza que se precipitó en el trazado urbanístico y en la concepción de esta ciudad modelo del mundo civilizado". El jefe comunal define a La Plata como una "ciudad inteligente" que deberá "acompañar este momento histórico del país, mediando con inteligencia, sobre aquellos que nos dieron un ejemplo de grandeza, que seguramente vamos a necesitar retemplar, para enfrentar los acontecimientos a los que estamos ya enfrentados" (en Bernard, 1982b: 11-12). Es entonces en la ciudad docta donde el discurso oficial deposita las esperanzas de unidad y concordia. En la entrevista con Ambiente, Román insiste con que el centenario es la oportunidad para "darle un perfil" a la ciudad: "Esto significa tomar un partido y, a veces, es difícil tomar partido porque si uno dice 'debemos recuperar nuestra gravitación cultural', parece que nos olvidáramos de nuestro incipiente perfil industrial. Creo que el destino de La Plata es gravitar fundamentalmente en lo cultural; lo cual no quiere decir que estemos olvidando otras cosas..." (pp. 68-69. Las cursivas son mías).

Por otra parte, en los escritos de varios autores relevantes del centenario reconocimos ciertas matrices ideológicas que atraviesan la conmemoración. Aunque no se puede hablar de un discurso único y homogéneo, hay definiciones y referencias institucionales que se reiteran y adquieren gran relevancia en el "coro" de 1982. En suma, la ciudad cultural no es la capital de cualquier cultura. Al final del capítulo VI vimos cómo ciertos escritos e imágenes preñan al relato de la historia platense con ideas tradicionalistas, católicas y en algunos casos ancladas en una reivindicación de la cultura hispánica. No es tampoco cualquier ciudad universitaria, sino una que entiende el conocimiento como signo de distinción y promueve una institución académica incapaz de convivir y crecer con las expresiones de la ciudad obrera -como pretendería esa otra idea de unidad que reclama el llamado de Familiares, distinta de la unidad nacional a la que apuestan las consignas de conciliación-.

La ciudad higiénica e ilustrada que se proclama heredera de la generación del 80 -al fin y al cabo, de una élite minoritaria que organizó el país sobre una matriz liberal-conservadorase reserva el derecho de admisión.

En esa clave se entienden los silencios y las ausencias que señalamos en los relatos predominantes. La aristocracia platense, sobre-representada en sus textos, no habla de los desaparecidos que tiene en sus propias filas. Apenas Vida platense -con sus contradiccionesy No habrá manto de olvido introducen el tema. Sólo el último caracteriza cabalmente al aparato represivo y sus víctimas, obreros y estudiantes. Entre los marginados en los relatos del centenario también señalamos a los sectores populares: unas veces ignorados, otras menospreciados o nombrados entre las curiosidades de las crónicas menudas, los trabajadores quedan ensombrecidos por las ideas fuertes de la ciudad perfecta y la capital de cultura.

Finalmente, el propio imaginario de la ciudad ilustrada tiene sus propios ausentes y marginados. Las figuras destacadas son cuidadosamente seleccionadas: una y otra vez, Moreno, González y Korn, Almafuerte, Lynch, López Merino o Speroni. No están contemplados Alvaro Yunque o Rodolfo Walsh en la ciudad de escritores, ni John William Cooke o René Orsi entre los pensadores políticos, ni Javier Villafañe animando la vida 
teatral $^{281}$. Tampoco aparece el rock, movimiento musical que llevaba algunos años como ámbito privilegiado de sociabilidad de actores juveniles y tenía sus propias expresiones locales -como Virus, que para 1982 ya había presentado su segundo LP-. Y mucho menos prácticas culturales barriales como la construcción y quema de muñecos, tradición que se inició en Ensenada en los '50 y que fue vedada durante la dictadura ${ }^{282}$. En el plano de la arquitectura -que concita gran interés- hay escasas referencias a la Casa Curutchet, el único proyecto de Le Corbusier construido en América Latina y quizá la obra de arquitectura moderna más importante del país. Y el reconocido cirujano que encargó esta vivienda unifamiliar, edificada durante los años de peronismo, no es mencionado por sus colegas Mainetti o Christmann, que se instituyen como la voz de la profesión médica.

\section{La exacerbación de ideas de larga data}

Una de las ventajas de haber desarrollado la tesis sobre un corpus de análisis amplio -decisión que, por supuesto, también tiene sus aspectos desfavorables- fue evidenciar cuán reiterativos y coincidentes resultan ciertos discursos que, sin haber sido necesariamente financiados y dirigidos desde el Estado, constituyen la trama de una historia oficial.

Citemos a modo de ejemplo un fragmento de Mainetti, que sintetiza la mayor parte de los tópicos que hemos recorrido:

"Los platenses somos hombres orgullosos de nuestro acervo institucional, intelectual y cultural. La Nueva Capital de la Provincia de Buenos Aires surgió el 19 de noviembre de 1882 como símbolo de unidad y paz nacional. El genio inspirado de su fundador, Dardo Rocha, planeó una obra perfecta, serena y armoniosa, como una creación de Atenas. Artistas y artesanos forjaron febrilmente en los primeros pocos años la fisonomía física y social de la ciudad; sus calles y plazas recibieron el bautismo cívico bajo la advocación de los hombres de Mayo, con Joaquín V. González surgió la Universidad Nacional bajo el lema 'por la Ciencia y por la Patria' y ocupó uno de los primeros lugares en el prestigio científico humanístico internacional. La Universidad polarizó la juventud de gran parte del país y de naciones de Sudamérica, e hizo crecer una ciudad pujante en ideas y en valores culturales que preservaron la acción ciudadana del crudo materialismo" (Mainetti, en Lerange, 1982: 215)

La Plata es, entonces: una capital culta, ilustrada, universitaria; un símbolo de unidad nacional; una ciudad perfecta; una obra de grandes hombres como Rocha y González. Muchas de estas construcciones de sentido vienen de textos previos al centenario, la mayoría elaborados también en torno a conmemoraciones.

\footnotetext{
${ }^{281}$ Estas figuras son sólo algunos ejemplos ilustrativos. Algunas no aparecen en ninguna de las miles de páginas escritas en el centenario, otras son mencionadas al pasar. Alvaro Yunque aparece antepenúltimo en una larga lista de colaboradores del suplemento Prosa y Verso (en Lerange, 388) y es aludido en un artículo sobre el Club Universitario que cita una "conferencia dictada por el escritor Alvaro Yunque, recientemente desaparecido, dando inicio con su tema 'Poetas sociales de la Argentina..." (en Lerange, 1982: 454). Rodolfo Walsh aparece también al pasar en una lista, como colaborador de Cuadernos de la Costa, revista que se editaba cuando el escritor tenía 23 años y todavía no había comenzado a publicar su obra literaria y periodística. En tanto, a Javier Villafañe lo menciona Szelagowski al testimoniar su gestión como intendente: “A Javier lo contratábamos con frecuencia y circulaba por todas las plazas con su valija conteniendo el teatro El Gallo Pinto. Todo cabía en ella, desde el recinto del teatrillo hasta los títeres y sus trajes..." (Szelagowski, 1982: 26).

${ }^{282} \mathrm{Si}$ bien su auge ocurre a fines de los '80, el ritual de los muñecos ya era reconocido para la época del centenario. Comenzó en 1951 con un muñeco realizado frente al bar y Almacén Los Obreros por el presidente del Club Cambaceres para homenajear a un jugador y se reiteró los años siguientes. En los '70 la práctica ya se extendía a distintos barrios platenses.
} 
En el capítulo IV advertimos el reconocimiento de un "estado de la cuestión" que se reduce a un puñado de autores, entre los que se destacan especialmente Rey y Salvadores. La revisión de esas producciones antecedentes nos permite advertir que ciertos discursos característicos en el centenario tienen desarrollos previos, y en el contexto de 1982 se multiplican y exacerban: Rey hablaba de una "ciudad de los poetas y de los espíritus de la fe" y centraba su mirada en los palacios de la ciudad; Salvadores la definía como una "gran ciudad moderna", un "milagro surgido en medio del desierto" y "el más alto exponente de la capacidad constructiva de la república"; y la prosa poética de Capdevilla enaltecía las figuras de Rocha, Almafuerte, Ameghino y González. En este último autor, igual que en Arrieta, encontramos el registro adjetivado que imitarán algunos escritores del centenario. No ocurre lo mismo con Salvadores, minucioso en los datos de cada relato y más preocupado por la recopilación de documentos. Cada uno a su modo, todos exaltaban la idea de una ciudad moderna y enaltecían a los ilustres fundadores.

Entre los textos de una y otra época hay, no obstante, algunas diferencias. Desarrollarlas en detalle excede a los alcances de esta tesis, pero cabe mencionar algunas. En primer lugar, los autores de la década de 1930 no hablan de la "generación del 80" como tal, sino que circunscriben sus textos laudatorios a figuras individuales -entre ellas, D’Amico está mucho más presente que en los relatos del centenario-. Por otra parte, hay un mayor reconocimiento de que el proyecto de la gran ciudad moderna se pensó de cara el río. La meticulosa narración de Salvadores sobre la elección del lugar enfatiza que se descartó la opción de una ciudad mediterránea y se detiene en las discusiones sobre la ubicación ribereña y la construcción del puerto. En La Plata a su fundador (Korn, 1939), tanto el texto como las imágenes dan un lugar importante a la actividad industrial. El recorrido fotográfico sobre la ciudad de Horacio Cóppola incluye el frigorífico Swift, la destilería de YPF, la playa de Punta Lara, el arroyo Doña Flora en Cambaceres, el puerto y otros espacios de Berisso y Ensenada -además de otras zonas de la periferia-. Loores platenses también dedica varias páginas a esas localidades (Capdevilla, 1932: 59-64), que como vimos en el capítulo $\mathrm{V}$ tienden a ser olvidadas por el discurso centrado en el casco fundacional. Otro punto muy interesante de este libro es la alusión al uso de bicicletas en la ciudad: "Eres, no sé desde cuándo, la ciudad de los ciclistas", escribe Capdevilla (1932: 15): "Los ciclistas te aman, se diría que nacieron para ti, y tú para ellos"283.

Por otra parte, en los textos antecedentes las arengas patrimonialistas carecen de peso y nos revelan que toda definición en ese sentido es una construcción histórico-política. Salvadores, que insiste en identificar a La Plata como "ciudad monumental", lejos de escandalizarse por la quita del arco de entrada a la ciudad en 1913 -como vimos en varios autores del centenario-, asegura que fue "felizmente demolido", ya que era "un verdadero adefesio" que "no llenaba ningún requisito de perspectiva ni de estética" (Salvadores, 1932: LIII).

\footnotetext{
${ }^{283}$ El texto prosigue hablando de los soñadores ciclistas. Publicados poco más tarde, también refieren a las bicicletas los libros de Arrieta (1935: 170) y Oitaven (1941). Este último precisa que La Plata estaba entonces en el segundo puesto -después de Buenos Aires- entre las ciudades con mayor número de bicicletas, y que en proporción era la primera: "le corresponde 1 bicicleta por cada 8 habitantes, mientras que a Rosario 1 por cada 28 habitantes y a Buenos Aires, 1 por cada 50 habitantes" (Oitaven, 1941: 64). Llamativamente, nada acerca de esta ciudad de ciclistas es retomado en las publicaciones del centenario.
} 
Tampoco encontramos en el estado del arte canonizado la insistencia en la conciliación que advertimos en el capítulo VII. La idea sólo aparece al pasar en algunos textos:

"Naciste porque te necesitaba la historia. Te levantaste como palma de paz y como ramo de olivo. Cerrabas el tiempo ominoso de los odios fratricidas. Para cerrarlos, te alzaste por la puerta de tiempos nuevos" (Capdevilla, 1932: 12)

Explícitamente, el epíteto de ciudad de la conciliación nacional lo encontramos utilizado en el aporte de Emilio Azzarini al libro-homenaje al creador de la Universidad nacional (VV.AA., 1963) pero nunca con la fuerza que adquiere en 1982, cuando adopta el sentido particular del llamado a un nuevo "reencuentro de los argentinos".

\section{Algunas preguntas abiertas}

Si bien el foco estuvo puesto en la producción editorial, un interrogante que movilizó el planteo inicial de esta tesis apuntaba a las políticas conmemorativas de la dictadura.

La aproximación al centenario de La Plata nos muestra que los actores del régimen actuaron explícitamente sobre las lecturas de la historia y la organización de sus efemérides. Esos usos del pasado se advierten en conmemoraciones de carácter nacional como el bicentenario del nacimiento de San Martín -resignificado como un héroe militar, eminentemente guerrero- o el centenario de la "epopeya" de la Conquista del Desierto -que tuvo una fuerte expresión a nivel local, a partir de la iniciativa de Benito Díaz en la Facultad de Humanidades y con la nueva época de la Revista de la Universidad-. Esta última conectó, además, con una serie de homenajes a la llamada "Generación del 80", la élite que llevó a cabo la Organización Nacional. No por casualidad, el régimen instaurado con el golpe de estado de 1976 fue denominado por sus responsables Proceso de Reorganización Nacional. Como apunta Jelin (2002b: 245), "en el mismo momento de las intervenciones militares, los vencedores interpretan su accionar y el acontecimiento producido en términos de su inserción en un proceso de larga duración, haciendo referencias a los momentos fundacionales de la nación y declarando su papel de continuidad".

El centenario platense se inscribe en esa zaga pero incorpora, a nuestro entender, dos nuevas inquietudes. Una es la pregunta por las conmemoraciones en una escala local, por la disputa de sentidos en torno a la ciudad, que podría ser observada también en las celebraciones del sesquicentenario de Bahía Blanca (1978), el bicentenario de Carmen de Patagones (1979) o el centenario de Victorica (1982), entre otras ${ }^{284}$.

La segunda, propia de la celebración platense, es el interrogante acerca de la capacidad de convocatoria de la dictadura después de la guerra de Malvinas, es decir, en el período que suele sintetizarse con la idea del "ocaso" o la "descomposición" del régimen. La participación de actores civiles que se observa en el desfile comentado al inicio del capítulo II, entre otras adhesiones de las "fuerzas vivas" interpeladas por el discurso municipalista, nos llama la atención sobre cómo el gobierno de facto sigue produciendo hegemonía en esa etapa en que la bibliografía dominante sólo ve una retirada veloz.

\footnotetext{
${ }^{284}$ También podemos pensar una micro-escala local, más allá de los aniversarios. La referencia a distintos museos que Apreda hace en Ciudad milagro es sugerente, ya que menciona una serie de instituciones dedicadas al pasado que fueron creadas durante la dictadura: el Museo de la Catedral (1977), el Museo Fra Angélico (1980), el Museo de la Historia de la Medicina (1981) y también un “pequeño Museo del Ser Nacional, de la Escuela 102, montado por alumnos del Instituto Superior de Museología en 1979” (en Lerange, 1982: 69).
} 
Al limitarse a las publicaciones realizadas en esa coyuntura, el presente trabajo sólo es una aproximación a ese problema que seguiré trabajando en mi tesis doctoral ${ }^{285}$, donde ya no se trata sólo de problematizar los sentidos sobre el pasado disputados en la celebración, sino también de comprender en ella la dinámica de consensos sociales y resistencias en la última dictadura. En otras palabras, la conmemoración puede ser la puerta de acceso para identificar y analizar los actores, espacios y prácticas de la política a nivel municipal, en un período particular. El recorrido realizado aquí nos deja algunas pistas acerca de cuáles son esos actores: corporaciones profesionales, asociaciones tradicionalistas, colectividades extranjeras, clubes deportivos, sociedades de fomento, universidades o institutos de enseñanza privados y ciertas entidades filantrópicas forman una trama civil significativa para pensar los espacios de participación en tiempos de una pretendida clausura de la política y problematizar los procesos de búsqueda de consensos (logrados o no), con sus negociaciones y resistencias.

No por casualidad, en la entrevista con Ambiente el intendente destaca el rol de las entidades intermedias: "los colegios profesionales, los centros de fomento, los clubes, etc. y todos han alcanzado un grado de elaboración y organización muy particular. En la planificación del Centenario, hemos ido convocando sectorialmente a las entidades platenses, profesionales, financieras, deportivas, bancarias, etc. y nos hemos encontrado en cada una de esas reuniones con representaciones multitudinarias pero a la vez formales..." (p. 71).

Muchos de ellos desfilan en noviembre de 1982 y contribuyen a los festejos sin críticas explícitas a la gestión oficial. Más aún: como puede leerse en el artículo de Prado en Ciudad milagro, fue la propia Federación de Instituciones Culturales y Deportivas la que ya en 1977 "sugirió a las autoridades municipales, la conveniencia de designar una Comisión que bajo la dirección del Departamento Ejecutivo y en coordinación con el gobierno de la provincia, fuera recibiendo y planeando sugerencias para la celebración del primer centenario de la ciudad que nació bajo el imperativo histórico de afirmar la concordia entre los argentinos..." (en Lerange, 1982: 31).

La fecha redonda llega, finalmente, en un tiempo de cierta apertura política, en el que se está negociando una salida de la dictadura. Desde principios de 1982 se observaba un "despertar de la sociedad civil", por ejemplo con la asistencia de 5.000 personas a un acto de la Multipartidaria o con la marcha de la Confederación General del Trabajo del 30 de marzo con la consigna Paz, pan y trabajo (Quiroga, 1994: 391-394). Tras la derrota en la guerra de Malvinas, en tanto, registramos hitos como la Marcha de la Resistencia del 21 de septiembre de 1982 -acompañada por un siluetazo- y gran movilización "por la vida" convocada por los organismos de derechos humanos el mes siguiente. Para entonces se inició un proceso de revelación de la masacre represiva -que por su espectacularización suele ser llamado "show del horror"- a partir del cual ya no se podía esquivar fácilmente en el debate público la referencia al "problema de los desaparecidos".

En ese contexto se produce el festejo del centenario de La Plata, cuya profusión editorial constituyó el objeto de estudio focalizado en esta tesis. De 54 títulos analizados, sobran los dedos de una mano para identificar a los que aluden a las víctimas del terror estatal. Los restantes, algunos producidos por el gobierno y muchos otros promovidos por organizaciones

\footnotetext{
${ }^{285}$ El proyecto aprobado "Dictadura, política local y conmemoración. Actores, consensos/resistencias y disputas por los sentidos del pasado en el centenario de La Plata (1982)”, dirigido por Aníbal Viguera, en el Doctorado de Ciencias Sociales de la UNLP, tiene así un sentido de continuidad con este trabajo.
} 
civiles, reiteran el discurso de "ciudad perfecta", celebran una "capital de cultura" con figuras del pasado, y exacerban las consignas sobre la unidad y la conciliación nacional.

Después de leer un borrador del capítulo sobre el "desfile editorial", un colega me planteó críticamente que a la tesis le faltaba “crisis, vanguardia artística, rock and roll”. La explicación es simple: no la hay. Salvo ínfimas excepciones, los textos del centenario constituyen ese bloque macizo, insoportable. No se percibe nada de la apertura.

Sin llegar a ser "discursos de apoyo" en un sentido extremo ${ }^{286}$, los libros del centenario dan cuenta de una producción cultural propia de la dictadura y favorecen un encuadramiento de la memoria que pretende lograr cohesión rechazando cualquier conflicto. Problematizar esas operaciones cobra particular interés al advertir la vigencia de los muchos sentidos plasmados en aquellos textos, favorecida por la escasa investigación posterior y por ciertas continuidades institucionales ${ }^{287}$.

Otra inquietud que deja abierta la tesis, pues, es la necesidad de producir nuevas historias de la ciudad, de asumir el desafío de conocer y comprender a La Plata más allá de sus celebraciones. Dijimos al principio que no sería nuestro objetivo hacer una historia de la ciudad, sino una historia de su historia, focalizada en un contexto específico. Pero una vez explorado ese camino -y sobre todo, advertidos los usos del pasado que resuenan desde aquel contexto-, no está mal imaginar otros relatos posibles, donde Walsh, Yunque, Villafañe o Virus sean parte de la capital cultural, donde la fundación pueda ser contada como una historia de montajes, donde emerja una ciudad capaz de hacerse cargo de sus propios silencios. Acaso sea hora, en fin, de asumir que la ciudad universitaria es también la de las bicicletas, que la cuna de los poetas eximios es también la ciudad del rock, que la creación de la generación del 80 fue también ciudad Eva Perón y que, lejos de cualquier conciliación, La Plata fue diezmada por esa represión sobre la que el festejo del centenario pretendió $-\mathrm{y}$ no pudo- desplegar un manto de olvido.

\footnotetext{
${ }^{286}$ Andrés Avellaneda (1986) llama así a una serie de declaraciones públicas, artículos y libros producidos por personas y grupos no ligados directamente al ejercicio del poder, que constituyen un coro acompañante del discurso oficial, apoyando medidas anunciadas o presionando para que se tomen. Se refiere a sociedades como la Federación Argentina de Entidades Democráticas Anticomunistas, la Liga de Madres de Familia, la Corporación de Abogados Católicos, a representantes de la iglesia católica y a figuras ultraconservadoras. No estamos ante esos casos en la bibliografía platense, pero sí ante una trama civil ambivalente que convive con la política de la dictadura sin demasiados pruritos.

${ }^{287}$ Por ejemplo, en 2003 el Colegio de Abogados local premió al ex intendente Román con el premio Dardo Rocha "a la mejor producción científico-jurídica sobre nuestra ciudad". El jurado que otorgó la distinción estuvo integrado por el historiador Fernando Barba y el ex intendente radical Hipólito Frangi ("Otorgaron a Abel Román el premio jurídico Rocha 2003”, en El Día, 19 de noviembre de 2003).
} 


\section{Fuentes consultadas}

\section{Bibliografía analizada (objeto de estudio)}

Academia Nacional de la Historia (1980). Congreso Nacional de Historia sobre la Conquista del Desierto. Celebrado en la ciudad de General Roca del 6 al 10 de noviembre de 1979. Impreso en Lanús.

Adam, Carlos (1982). "Contribución a una bibliografía platense", en Revista de la Universidad, $\mathrm{N}^{\circ}$ 28, La Plata, Universidad Nacional de La Plata.

Barba, Enrique Mariano (1980). Homenaje al profesor José María Rey. La Plata: Museo y Archivo Dardo Rocha.

Barcia, Pedro Luis -compilador- (1982). La Plata vista por los viajeros. 1882-1912. La Plata: Ediciones del 80 y Librerías Juvenilia.

Bartholomew, Roy -compilador- (1982). Vida espiritual en La Plata. Buenos Aires: Fundación Banco de Boston.

Bernard, Tomás Diego (1982a). El momento histórico de la fundación de La Plata. En el centenario de la nueva capital. Buenos Aires: Revista del Notariado, separata de la revista $\mathrm{N}^{\circ} 784$, julio-agosto.

Bernard, Tomás Diego (1982b). Una vieja amistad con los Rocha. La Plata: Universidad Notarial Argentina.

Calvo, Estela (1982). Rastros y rostros de La Plata. La Plata: sin datos editoriales (Impreso en Artes Gráficas San Miguel).

Ceriale Costa de Apreda, Leila (s/f). La vida musical en los primeros años de La Plata. La Plata: Museo y Archivo Dardo Rocha.

Christmann, Federico (1982). Vivencias y testimonios (de mis últimos 80 años). La Plata: Agremiación Médica Platense.

Cuccorese, Horacio y otros (1982). "Centenario de la ciudad de La Plata 1882-1982. Síntesis esencial de historia socioeconómica", en Económica, Año XXVIII, N 3, La Plata, setiembre-diciembre.

Cygan, Gregorio Manuel (1981 [1979]). La ciudad de La Plata en su centenario. Fundamentos para una nueva argentina. Granada, España: edición de autor, $3^{a}$ edición.

D’Onofrio, Reynaldo (1980). Periodismo, periodistas y algunos recuerdos del diarismo en La Plata. La Plata: Ministerio de Educación, Subsecretaría de Cultura, Dirección de Coordinación de Acción Cultural, Museo y Archivo Dardo Rocha.

Daneri de Rodrigo, Alicia (1981). El Dr. Dardo Rocha y las piezas egipcias del Museo de Ciencias Naturales de La Plata. La Plata: Museo y Archivo Dardo Rocha.

De Gandía, Enrique (1980). Buenos Aires, las dos capitales. La Plata: Ministerio de Educación, Subsecretaría de Cultura, Dirección de Coordinación de Acción Cultural, Museo y Archivo Dardo Rocha.

De Paula, Alberto (1982). "La arquitectura de la fundación”, en Revista Ambiente, № 32, La Plata.

De Santis, Luis (1980). Cien años del Museo de La Plata. La Plata: Ministerio de Educación, Subsecretaría de Cultura, Dirección de Coordinación de Acción Cultural, Museo y Archivo Dardo Rocha. 
De Urraza, Estanislao (1981). La Plata Ciudad de Mayo. La Plata: Colegio de Abogados Departamento Judicial La Plata / Ramos Americana.

Díaz, Benito -director - (1982). La Plata, una obra de arte 1882-1982. La Plata: Universidad Nacional de La Plata.

Familiares de Detenidos Desaparecidos y Presos por Razones Políticas en La Plata (1983). ¡No habrá manto de olvido! La Plata. La Plata: edición de autor.

Girbal de Blanca, Noemí; Durán, Claudia Laurana y Giuliano, Ethel Leonor (1983). Visión histórica de la Banca Platense 1882/1982. La Plata: Asociación Platense de Abogados de Bancos.

Giuliano, Ethel Leonor (1983). Historia del Banco Municipal de La Plata. La Plata: Talleres Gráficos de la División Impresiones de la Municipalidad de La Plata.

Hoor Tempis Livi, Tibor (1982). Conferencia sobre el aporte de los italianos a la construcción de la ciudad de La Plata. La Plata: Hospital Italiano - Asociación Italiana de Socorros Mutuos y Beneficencia Hospital "Humberto $1^{\circ}$ ".

Kilmurray, Jorge Orlando (1980). Docencia e investigación en la facultad de ciencias naturales de La Plata. La Plata: Ministerio de Educación, Subsecretaría de Cultura, Dirección de Coordinación de Acción Cultural, Museo y Archivo Dardo Rocha.

Lahitte, Ana Emilia (1980). La Plata y sus poetas. La Plata: Ministerio de Educación, Subsecretaría de Cultura, Dirección de Coordinación de Acción Cultural, Museo y Archivo Dardo Rocha.

Lahitte, Ana Emilia (1982). "La ciudad herida”, en Revista Ambiente, №32, La Plata.

Lerange, Catalina -directora- (1982). La Plata Ciudad milagro. La Plata: Sociedad de Escritores de la Provincia de Buenos Aires - Ediciones Corregidor.

Luna, Félix (1982). "La Plata y su tiempo", en Revista Ambiente, $\mathrm{N}^{\circ} 32$, La Plata.

Manes de Della Motta, María del Carmen (1982). "Un centenario de revistas platenses. Contribución a su bibliografía", en Revista de la Universidad, $\mathrm{N}^{\circ}$ 28, La Plata, Universidad Nacional de La Plata.

Marquínez, José María (1980). "Atilio Boveri: aspectos de su obra Parque Saavedra - Jardín Científico de Punta Lara", en Revista de la Universidad, N$^{\circ}$ 26, La Plata, Universidad Nacional de La Plata.

Massa, Ricardo (1982). La ciudad de las calles numeradas. La Plata: Banco Platense.

Massimino, María Ester (1981). Dos personalidades relacionadas con La Plata: Nicolás Achaval y Mauricio Mayer. La Plata: Museo y Archivo Dardo Rocha.

Moncaut, Carlos Antonio (1982). La Plata 1882-1982. Crónicas de un siglo. La Plata: Municipalidad de La Plata.

Morea, Luis y Pesci, Rubén (1982). "Una visión crítica del Gran La Plata", en Revista Ambiente, $\mathrm{N}^{\circ} 32$, La Plata.

Moreno Terrero de Benites, Adela (1981). Recuerdos de mi abuelo Francisco P. Moreno. La Plata: Museo y Archivo Dardo Rocha.

Morosi, Julio A. (1978). Reflexiones sobre el proceso urbanístico de la creación de La Plata. La Plata: Ministerio de Educación, Subsecretaría de Cultura, Dirección de Coordinación de Acción Cultural, Museo y Archivo Dardo Rocha.

Morosi, Julio A. -director- (1980a). Documento Avance No 1 "Morfología Urbana Platense". La Plata: Ramos Americana Editora. 
Morosi, Julio A. -director- (1980b). Documento Avance $N^{o} 2$ "Micromorfología Urbana Platense”. La Plata: Ramos Americana Editora.

Morosi, Julio A. -director- (1980c). Documento Avance $N^{o} 4$ "Influencia del elemento vegetal”. La Plata: Ramos Americana Editora.

Morosi, Julio A. (1980b). "Algunos aspectos arquitectónicos y urbanísticos en los orígenes de La Plata”, en Revista de la Universidad, N $^{\circ} 26$, La Plata, Universidad Nacional de La Plata.

Morosi, Julio A. (1981a). "Algunos aspectos arquitectónicos y urbanísticos en los orígenes de La Plata. II. Una faceta arquitectónica", en Revista de la Universidad, $\mathrm{N}^{\circ} 27$, La Plata, Universidad Nacional de La Plata.

Morosi, Julio A. (1981b). "Los médicos higienistas en la génesis de la traza de La Plata", en Quirón, vol. 12, № 1 y 2, enero/junio de 1981.

Morosi, Julio A. -director- (1982a). Documento Avance $N^{o} 3$ "Micromorfología Urbana Platense. Canales Urbanos”. La Plata: Editorial Universidad Nacional de La Plata.

Morosi, Julio A. (1982b). "Inserción de La Plata en el contexto urbanístico mundial", en Revista de la Universidad, $\mathrm{N}^{\circ}$ 28, La Plata, Universidad Nacional de La Plata.

Morosi, Julio A. -director- (1983). LA PLATA Ciudad nueva, ciudad antigua. Historia, forma $y$ estructura de un espacio urbano singular. Madrid: Instituto de Estudios de Administración Local/España y Universidad Nacional de La Plata/Argentina.

Morosi, Julio A. -director- (1984a). Documento Avance $N^{o}$ 6. "Conclusiones Generales y Recomendaciones”. La Plata: Universidad Nacional de La Plata.

Morosi, Julio A. -director- (1984b). Documento Avance No 7. "Bibliografía sobre La Plata". La Plata: Universidad Nacional de La Plata.

Morosi, Julio A. y De Terán, Fernando (1981). "La Plata: formación de un espacio urbano singular", en Ciudad y Territorio, $\mathrm{N}^{\circ} 3$, Madrid.

Nessi, Angel Osvaldo -director- (1982). Diccionario temático de las artes en La Plata. La Plata: Instituto de Historia del Arte Argentino y Americano, Facultad de Bellas Artes, Universidad Nacional de La Plata.

Orsi de Herrero Ducloux, María Cristina (1981). Los árboles de La Plata. La Plata: Museo y Archivo Dardo Rocha.

Ortega, Exequiel (1982). "Último momento poblacional argentino. Inicios de La Plata como capital bonaerense", en Revista de la Universidad, $\mathrm{N}^{\circ}$ 28, La Plata, Universidad Nacional de La Plata.

Prada, Miriam y Zilio, María Cristina (1982). "Estructura industrial del aglomerado platense", en Revista de la Universidad, $\mathrm{N}^{\circ} 28$, La Plata, Universidad Nacional de La Plata.

Prado, José María (1978). Dardo Rocha y Pedro Benoit: el fundador y el artífice en la fundación de la nueva capital. La Plata: Ministerio de Educación, Subsecretaría de Cultura, Dirección de Coordinación de Acción Cultural, Museo y Archivo Dardo Rocha.

SADE La Plata (1982). 12 personalidades del siglo. La Plata: Ediciones Almafuerte.

Sánchez Márquez, Manuel (1978). Historia de la arquidiócesis de La Plata. La Plata: Arzobispado de La Plata.

Soler, Ricardo (1982). 100 años de vida platense. La Plata: El Día - Sociedad Impresora Platense. 
Speroni, Roberto Themis (1982 [1975]). Poesía completa. Edición de homenaje. Ensayo y antología de Ana Emilia Lahitte. La Plata: Colegio de Escribanos de la Provincia de Buenos Aires.

Sureda, Jaime (1982). La Plata. La edad de mi infancia. La Plata: Ramos Americana Editora.

Szelagowski, Miguel Blas (1979). La Plata, los años veinte. La Plata: Librería Editora Platense SRL.

Szelagowski, Miguel Blas (s/f). ¿Será justicia?. La Plata: Colegio de Abogados Departamento Judicial La Plata.

Szelagowski, Miguel Blas (1982a). Si yo fuera intendente. La Plata: Ramos Americana.

Szelagowski, Miguel Blas (1982b). Crónica del centenario. La Plata: Municipalidad de La Plata.

Tartarini, Jorge Daniel (1982). La acción profesional en la fundación de La Plata. Adhesión del Consejo Profesional de la Ingeniería de la Provincia de Buenos Aires al Centenario de la Fundación. La Plata: Consejo Profesional de la Ingeniería de la Provincia de Buenos Aires.

Terrasa, Mary (1982). La Plata y su gente. Primeros habitantes. La Plata: Ediciones Almafuerte.

VV. AA. (1982a). La Plata 100. Guía turística. La Plata: Sociedad de Arquitectos de la Plata.

VV. AA. (1982b). Homenaje al Centenario de la Fundación de La Plata. La Plata: Instituto de Historia del Notariado - Universidad Notarial Argentina.

Zuccalá, Inés y Musmano, Roberto (s/f, estimada 1981). La Plata, una Creación de la Generación del 80. La Plata: Municipalidad de La Plata

\section{Bibliografía adicional en torno a La Plata}

Alessandro, Jorge (2011). La colina táctica del enemigo: un recorrido por el pensamiento y la militancia de los universitarios platenses 1950-1975. La Plata: De la campana.

Allende, Andrés (1971). Julio A. Roca y Dardo Rocha. Una amistad y una enemistad históricas. Buenos Aires: Separata del Boletín de la Academia Nacional de la Historia (volumen XLIV).

Amaral Insiarte, Alfredo (1959). La Plata a través de los viajeros. 1882-1912. La Plata: Ministerio de Educación.

Arlt, Roberto (1928). "Elogio a la ciudad de La Plata", publicado en El Mundo, Buenos Aires, 27 de diciembre.

Arrieta, Rafael Alberto (1935). La ciudad del bosque. Viñetas platenses. La Plata: Biblioteca Humanidades, Tomo XVI.

Artigas, Celina -compiladora- (2010). La Plata, ciudad inventada. La Plata: Primer Párrafo.

Artigas, Celina -compiladora- (2011). 25 años capbauno. 1986-2011 Historia de una construcción. La Plata: CAPBAUNO.

Badenes, Daniel (2010a). "La torta y las hormigas", en Letercermonde, 19 de noviembre (Disponible en http://letercermonde.com/?p=2772).

Barba, Fernando Enrique (1995). La Plata. Orígenes y fundación. La cuestión capital de la República y la fundación de la capital de la Provincia de Buenos Aires. La Plata: edición de autor. 
Barba, Fernando Enrique -director- (2005). La Universidad de La Plata en el centenario de su nacionalización (1905-2005). La Plata: Universidad Nacional de La Plata.

Bejarano, Manuel (1967). "Inmigración y estructura demográfica de La Plata: 1884-1914”, en Boletín de la Dirección de Museos y Lugares Históricos. La Plata: Ministerio de Educación, Subsecretaría de Cultura.

Belinche, Marcelo y Panella, Claudio -compiladores- (2010). Postales de la memoria: un relato fotográfico sobre la identidad de la región. La Plata: Universidad Nacional de La Plata.

Bernazza, Claudia (1994). "El desafío de la identidad platense", en El Día, La Plata, 3 de julio.

Bernazza, Claudia (1997). Crónicas de la ciudad perfecta. La Plata: Ediciones Al Margen

Blasi, Hebe Judith (2004). Dardo Rocha. Un exponente de la generación de 1880. Buenos Aires: Editorial Dunken.

Capdevila, Arturo (1932). Loores platenses. En el cincuentenario de la fundación de La Plata. La Plata: Editorial Cabaut y Cía.

Clarke, Guillermo (2006). "La gobernación Mercante y la creación de la República de los Niños", en: Panella, Claudio -compilador-. El gobierno de Domingo A. Mercante en Buenos Aires (1946-1952). Un caso de peronismo provincial / Tomo II. La Plata: Instituto Cultural de la Provincia de Buenos Aires (Publicaciones del Archivo Histórico de la Provincia de Buenos Aires 'Dr. Ricardo Levene').

Comisión designada por decreto del Poder ejecutivo de fecha noviembre 28 de 1932 (1935). Profesionales que intervinieron en la fundación de La Plata. La Plata: Publicaciones del Ministerio de Obras Públicas de la Provincia de Buenos Aires.

Corrado, Antonio Enrique (2000). Nacimiento y diseño de la ciudad de La Plata. La Plata: edición de autor.

De Luca, Rubén Mario (2002). Familias platenses. La Plata: edición de autor.

Departamento de Geografía - Facultad de Humanidades y Ciencias de la Educación - UNLP (1997). La Plata desde... Geografía y cultura. La Plata: EDULP.

Díaz, César Luis -director- (2000). La Plata. Paseos públicos. Sociabilidad y ocio en la prensa (1882-1900). La Plata: Ediciones Al Margen.

Díaz, César, Mario Giménez y María Passaro (1999). Una mirada periodística sobre la cotidianidad platense. (1882-1900). La Plata: Ediciones de Periodismo y Comunicación.

Duizeide, Juan Bautista (2010). Crónicas con fondo de agua. Vidas secretas del Río de La Plata. Buenos Aires: Ediciones Continente (Cuadernos de Sudestada).

Fernández, Gabriel (s/f). “Apuntes para un contrahomenaje a este lugar del mundo. Sobre frigoríficos, innombrados brillantes, cultura oculta, ajenidad inserta, trazados perfectos e historias personales", en El Resto, Año 1, número 2.

Font, Miguel (1951). Historia espiritual de La Plata. A propósito de un casi gran homenaje en vida a Almafuerte. La Plata: Imprenta Moreno.

Garnier, Alain (1992). El cuadrado roto. Sueños y realidades de La Plata. La Plata: Municipalidad de La Plata y Laboratorio de Investigaciones del Territorio y del Ambiente (LINTA-CIC).

Girbal, Jorge Raúl (2007). Los tranvías que yo he visto. Buenos Aires: Dunken. 
James, Daniel (1987). "17 y 18 de octubre de 1945: el peronismo, la protesta de masas y la clase obrera argentina”, en Desarrollo Económico, No 107, Buenos Aires.

James, Daniel (2004). Doña María. Historia de vida, memoria e identidad política. Buenos Aires: Manantial.

Katz, Ricardo Santiago (2004). Periodismo platense. Génesis y evolución. Edición de autor.

Katz, Ricardo Santiago (2007). Ciudad de La Plata: su historia. Buenos Aires: edición del autor.

Korn, Guillermo -director- (1939). La Plata a su fundador. La Plata: Municipalidad de La Plata.

Laborde, Francisco (1979). Breve historia de Tolosa. La Plata: Municipalidad de La Plata.

Lobato, Mirta Zaida (2001). La vida en las fábricas. Trabajo, protesta y política en una comunidad obrera, Berisso (1904-1970). Buenos Aires: Entrepasados / Prometeo.

Losano, Gabriel (2006). "La Plata: de la ciudad apreciada a la ciudad ignorada", en Geograficando, año 2, $\mathrm{N}^{\circ} 2$ (p. 201-223). Disponible en www.fuentesmemoria.fahce.unlp.edu.ar/art_revistas/pr.360/pr.360.pdf (Consulta julio 2011)

Marne, Raúl Eduardo (1984). Benoit: de la Genialidad y otros en ensueños. La Plata: Ediciones Junta de Estudios Históricos de la Provincia de Buenos Aires (Serie Extensión Cultural $\mathrm{N}^{\circ} 3$ ).

Martínez Estrada, Ezequiel (1991). Radiografía de la pampa (Edición crítica coordinada por Leo Pollmann). París: Allca XX.

Morosi, Julio A. (1999). Ciudad de La Plata. Tres décadas de reflexiones acerca de un singular espacio urbano. La Plata: Laboratorio de Investigaciones del Territorio y el Ambiente, Comisión de Investigaciones Científicas de la Provincia de Buenos Aires.

Napolitano, Américo -editor- (1972). Quién es quién en La Plata. La Plata: Edición de autor, con auspicio de APRILP.

Oitaven, Alberto (1941). La Plata, ciudad ideal. Lo que no se dijo y lo que no se sabe de la ciudad de La Plata. La Plata: Ediciones Municipales.

Paladini, Jorge y Filosso, Ernesto (1986). Guía de la ciudad de La Plata. $75^{\circ}$ Aniversario del Banco Crédito Provincial. La Plata: Ramos Americana Editora.

Pereira de Arruda, Rogério (2011). Cidades-capitais imaginadas pela fotografia: La Plata (Argentina) e Belo Horizonte (Brasil), 1880-1897 (Tesis de Doctorado en Historia). Belo Horizonte: Faculdade de Filosofia e Ciências Humanas, Universidade Federal de Minas Gerais.

Pérez Aznar, Ataulfo (1962). “QQuién fue el fundador de nuestra universidad?”, en El Día, La Plata, 19 de noviembre.

Prado, José María (1961). "El espíritu conciliador de Dardo Rocha y la litografía de la Fundación”, en El Día, La Plata, 19 de noviembre.

Rey, José María (1932). La nueva capital. Los primeros cinco años de su construcción. La Plata: Peuser.

Rey, José María (1939). Ciudad armoniosa (Conferencia pronunciada en el Salón de Actos de la Biblioteca Euforión, el 28 de octubre de 1939). La Plata: Talleres Impresiones Oficiales.

Rey, José María (1957). Tiempo y fama de La Plata. La Plata: Municipalidad de La Plata.

Rey, José María y Salvadores, Antonino (1944). La Plata. 1882-19 de noviembre 1944. Homenaje a la nueva capital. La Plata: Jockey Club de la Provincia de Buenos Aires. 
Reynal, Gualberto (1998). La Historia Oculta de la Ciudad de La Plata. La Plata: edición del autor.

Richeri, Ovidio y otros (1981). Sintesis histórica de la Policía de la Provincia de Buenos Aires 1580-1980. La Plata: Policía de la Provincia de Buenos Aires.

Rocha, Dardo (2000). Dardo Rocha. Fundador y parlamentario. Estudio introductorio y Selección de Textos Parlamentarios: Manuel Urriza. La Plata: La Comuna Ediciones, Municipalidad de La Plata (Colección Textos del Rescate)

Sábato, Juan (1943). Contribución al estudio de la ciudad universitaria. Reproducido en el Boletín del Centro de Estudiantes de Ingeniería.

Salvadores, Antonino (1932). Fundación de la ciudad de La Plata. Documentos éditos e inéditos. La Plata: Archivo Histórico de la Provincia de Buenos Aires.

Salvadores, Antonino (1933). La federalización de Buenos Aires y fundación de La Plata. La Plata: Archivo Histórico de la Provincia de Buenos Aires.

Salvadores, Antonino (1934). El acta de fundación de La Plata (Estudio crítico presentado al Centro de Estudios Históricos Argentinos y leído en acto público realizado el 14 de octubre de 1932). La Plata: Universidad Nacional de La Plata, Centro de Estudios Históricos Argentinos.

Sampay, Arturo Enrique (1950). El Seminario Mayor Arquidiocesano de La Plata en la cultura argentina. La Plata: Ediciones Laboremus.

Seco Villalba, José (1973). "Símil y disímil entre la fundación de la ciudad indiana y la fundación de La Plata”, en Separata del Instituto de Historia del Notariado, N 41.

Seigel, Lázaro (1980). Nuestra Juvenilia. La Plata: Universidad Nacional de La Plata.

Tarruella, Ramón (2006). Mitos y leyendas de La Plata. Breves historias urbanas. La Plata: La Comuna Ediciones (Colección Textos del Rescate).

Troisi, Jorge (2006). Dardo Rocha. El último porteño. La Plata: Instituto Cultural de la Provincia de Buenos Aires, Archivo Histórico 'Dr. Ricardo Levene' (Serie Gobernadores Bonaerenses).

Vallejo, Gustavo (2005). Escenarios de la cultura científica: la ciudad universitaria de La Plata. Historia de un experimento controlado de la modernidad en Argentina. Tesis de Doctorado de Historia. La Plata: Facultad de Humanidades y Ciencias de la Educación, Universidad Nacional de La Plata.

Venturini, Aurora (2010). "El ángel de Estela Calvo “, en revista Domingo, diario El Día, La Plata, 28 de marzo.

VV.AA. (1963). Universidad "Nueva" y Ámbitos Culturales platenses. La Plata: Universidad Nacional de La Plata (Publicación conjunta de la Municipalidad de La Plata y la Facultad de Humanidades y Ciencias de la Educación, con el apoyo del Fondo Nacional de las Artes y la colaboración del Ministerio de Gobierno de la Provincia).

Zapiola, Federico (1941). Luis XVII murió en Buenos Aires?. Hechos y sugestiones extrañas. Buenos Aires: Talleres Gráficos San Pablo.

\section{Bibliografía teórica, metodológica, contextual}

Aguiluz Ibargüen, Maya y Waldman, Gilda -coordinadoras- (2007). Memorias (in)cógnitas. Contiendas en la historia. México: UNAM-Centro de Investigaciones Interdisciplinarias en Ciencias y Humanidades.

Amato, Fernando y Boyanovsky, Christian (2008). Setentistas. Buenos Aires: Sudamericana. 
Anguita, Eduardo y Caparrós, Martín (2010). La Voluntad. Una historia de la militancia revolucionaria en Argentina. Buenos Aires: Booket.

Augé, Marc (2006). Hacia una antropología de los mundos contemporáneos. Barcelona: Gedisa (El Mamífero Parlante), $3^{a}$ edición.

Avellaneda, Andrés (1986). Censura, autoritarismo y cultura: Argentina 1960-1983. Buenos Aires: Centro Editor de América Latina (Biblioteca Política Argentina).

Badenes, Daniel (2006a). "Representaciones sobre el pasado en la disputa por el espacio urbano: La Plata y el imaginario de 'ciudad universitaria", ponencia presentada a las IV Jornadas Nacionales Espacio, Memoria e Identidad, Universidad Nacional de Rosario, octubre.

Badenes, Daniel (2006b). "Restos humanos en el Museo de Ciencias Naturales de La Plata. Trofeos de guerra", en La Pulseada, № 43, La Plata, septiembre.

Badenes, Daniel (2007). “Comunicación y ciudad: líneas de investigación y encuentros con la historia cultural urbana", en Question, vol. 1, N 14, La Plata: Facultad de Periodismo y Comunicación Social, Universidad Nacional de La Plata (Disponible en http://www.perio.unlp.edu.ar/ojs/index.php/question/article/view/354/286)

Badenes, Daniel (2010b). “¿Estudios sociales de memoria? Apuntes sobre la formación del campo académico con un objeto que suena posmoderno pero no lo es", en Question, vol. 1. $\mathrm{N}^{\circ}$ 25, La Plata: Facultad de Periodismo y Comunicación Social: UNLP (Disponible en: http://www.perio.unlp.edu.ar/ojs/index.php/question/article/view/890/791)

Badenes, Daniel y Grassi, Luciano -compiladores- (2011). Historia, memoria y comunicación. Bernal: Universidad Nacional de Quilmes (Cuadernos de Trabajo Ciencias Sociales).

Balandier, Georges (1994). El poder en escenas. De la representación del poder al poder de la representación. Barcelona: Paidós.

Barthes, Roland (1984). "El discurso de la historia", en El susurro del lenguaje. Más allá de la historia y la escritura. Barcelona: Paidós.

Barragán, Ivonne (2011). “Acción obrera durante la última dictadura militar: la represión en una empresa estatal. Astillero Río Santiago (1974-1984)”, en Basualdo, Victoria -compiladora-. La clase obrera argentina en el siglo XX: experiencias de lucha y organización. Buenos Aires: Atuel.

Berenzon Gorn, Boris (2004). Historiografía crítica del siglo XX. México: UNAM.

Bisso, Andrés (2010). "Ricardo Levene y los estudios históricos en La Plata. El distanciado historiador profesional frente a las cercanías temporales y espaciales. Ciertos cruces no siempre predecibles", en: Infesta, María Elena -coordinadora-. El centenario de los estudios históricos en La Plata. La Plata: Facultad de Humanidades y Ciencias de la Educación (disponible en http://cehlp.fahce.unlp.edu.ar)

Borrat, Héctor (1989). El periódico, actor político. Barcelona: Gustavo Gili.

Bruschtein, Luis (2002). "Centro de Estudios Sociales y Legales", Dossier No 5 de "Historia de los organismos de derechos humanos", en Puentes $\mathrm{N}^{\circ}$ 8, La Plata, Comisión Provincial por la Memoria, noviembre.

Bossié, Florencia (2006). Historias en común: censura a los libros en la ciudad de La Plata durante la última dictadura militar (1976-1983). Trabajo final de grado. La Plata: Facultad de Humanidades y Ciencias de la Educación, Universidad Nacional de La Plata (Disponible en: http://www.fuentesmemoria.fahce.unlp.edu.ar/tesis/te.265/te.265.pdf) 
Buck-Morss, Susan (1995). Dialéctica de la mirada. Walter Benjamin y el proyecto de los Pasajes. España: Visor (La balsa de la Medusa).

Calcagno, Alfredo Eric y Eric Calcagno (2004). Para entender la política. Buenos Aires: Catálogos.

Candau, Joël (2001). Memoria e identidad. Buenos Aires: Del Sol.

Canelo, Paula (2008). El proceso en su laberinto. La interna militar de Videla a Bignone. Buenos Aires: Prometeo.

Carlyle, Thomas (1985). Los héroes. Barcelona: Orbis.

Carman, María (2006). Las trampas de la cultura: los intrusos y los nuevos usos del barrio de Gardel. Buenos Aires: Paidós.

Cattaruzza, Alejandro (2007). Los usos del pasado. La historia y la política argentinas en discusión, 1910-1945. Buenos Aires: Sudamericana (Nudos de la historia argentina).

Chartier, Roger (1996). El mundo como representación. Estudios sobre historia cultural. Barcelona: Gedisa.

Connerton, Paul (1993). Como as sociedades recordam. Lisboa: Oerias Editora.

Cosse, Isabela y Vania Markarian (1996). 1975: Año de la Orientalidad. Identidad, memoria e historia en una dictadura. Montevideo: Ediciones Trilce.

Craviotto, J. A. (1966). Quilmes a través de los años. Quilmes: Secretaría de Gobierno y Cultura de la Municipalidad.

Cuesta, Josefina (1993). Historia del presente. Madrid: Eudema.

Cuesta, Josefina -editora- (1998). Memoria e historia. Madrid: Marcial Pons.

Cuesta, Josefina (2007). La odisea de la memoria (Curso de Doctorado). Mimeo, circulación restringida. Universidad Nacional de La Plata, mayo.

Da Silva Catela, Ludmila (2001). No habrá flores en la tumba del pasado. La experiencia de la reconstrucción del mundo de los familiares de desaparecidos. La Plata: Al Margen.

De Certeau, Michel (1993). La escritura de la historia. México: Universidad Iberoamericana, segunda edición revisada.

De Certeau, Michel (1996). La invención de lo cotidiano. I. Artes del hacer. México: Universidad Iberoamericana.

De Diego, José Luis (2003). ¿Quién de nosotros escribirá el Facundo? Intelectuales y escritores en Argentina (1970-1986). La Plata: Al Margen.

De Diego, José Luis (2006). Editores y políticas editoriales en Argentina, 1880-2000. Buenos Aires: Fondo de Cultura Económica.

De Sagastizábal, Leandro (1995). La edición de libros en la Argentina. Una empresa de cultura. Buenos Aires: Eudeba.

De Sagastizábal, Leandro y Fernando Esteves Fros -compiladores- (2002). El mundo de la edición de libros. Buenos Aires: Paidós (Diagonales).

Del Pino, Ponciano y Jelín, Elizabeth -compiladores- (2003). Luchas locales, comunidades e identidades. Madrid: Siglo XXI (Memorias de la represión)

Demasi, Carlos (2004). La lucha por el pasado. Historia y nación en Uruguay (1920-1930). Montevideo: Ediciones Trilce.

Díaz, César -director- (2009). Nos/otros y la violencia política 1974-1982. El Herald, La Prensa y El Día. La Plata: Al Margen. 
Díaz, Diego (2003). “Asamblea Permanente por los Derechos Humanos”, Dossier No 7 de "Historia de los organismos de derechos humanos", en Puentes $\mathrm{N}^{\circ} 10$, La Plata, Comisión Provincial por la Memoria, agosto.

Didi-Huberman, George (2005). Ante el tiempo. Buenos Aires: Adriana Hidalgo.

Feinmann, José Pablo (2010). Peronismo. Filosofía política de una persistencia argentina. Tomo I. Buenos Aires: Planeta.

Franco, Marina y Levín, Florencia (2007). Historia reciente. Perspectivas y desafíos para un campo en construcción. Buenos Aires: Paidós.

Funes, Patricia (2001). "Memorias de las dictaduras en América Latina. Acerca de las Comisiones de verdad en el Cono Sur", en: Groppo, Bruno y Flier, Patricia. La imposibilidad del olvido. La Plata: Al Margen.

Garguin, Enrique (2009). "Civilizing savage minds and bodies. The popular public sphere as a means of social differentiation", ponencia presentada en el XXVIII Congreso de la Asociación de Estudios Latinoamericanos (LASA), Río de Janeiro.

Getino, Octavio (1995). Las Industrias Culturales en la Argentina. Dimensión económica y políticas públicas. Buenos Aires: Colihue.

Gillis, John (2004). "Memoria e identidad: La historia de una relación" ("Memory and identity: the history of a relationship"), en Gillis, John -editor-. Conmemorations. The Politics of National Identity, Princeton University Press. Trad.: Natalie Abad de Ruhr.

Giménez, Gilberto (1997). "Materiales para una teoría de las identidades sociales", en: Valenzuela, Juan Manuel -coordinador- (2000). Auge y decadencia de las identidades. Colegio de la Frontera Norte, México.

Ginzberg, Victoria (2002). "Madres de Plaza de Mayo", Dossier No 3 de "Historia de los organismos de derechos humanos", en Puentes, No 7, La Plata, Comisión Provincial por la Memoria, julio.

González, Luis (1999). Pueblo en vilo. Microhistoria de San José de Gracia. México: Clío.

González, Luis (2009). El oficio de historiar. Zamora, Michoacán: El Colegio de Michoacán, tercera edición.

Gorelik, Adrián (1998). La grilla y el parque. Espacio público y cultura urbana en Buenos Aires, 1887-1936. Bernal: Universidad Nacional de Quilmes (La ideología argentina).

Gorelik, Adrián (2004). Miradas sobre Buenos Aires. Historia cultural y crítica urbana. Buenos Aires: Siglo XXI Editores Argentina.

Graciano, Osvaldo (2008). "Las propuestas culturales de los universitarios socialistas", en Entre la torre de marfil y el compromiso político: intelectuales de izquierda en la Argentina, 1918-1955. Bernal: Universidad Nacional de Quilmes.

Grez Toso, Sergio (2001). "Historiografía y memoria en Chile. Algunas consideraciones a partir del manifiesto de los historiadores". En: Groppo, Bruno y Flier, Patricia. La imposibilidad del olvido. La Plata: Al Margen.

Habermas, Jürgen (1999). "Goldhagen y el uso público de la historia. ¿Por qué el Premio Democracia para Daniel Goldhagen?", en Finchelstein, F. -comp.-. Los alemanes, el Holocausto y la culpa colectiva. El Debate Goldhagen. Buenos Aires: Eudeba.

Invernizzi, Hernán y Gociol, Judith (2003). Un golpe a los libros. Represión a la cultura durante la última dictadura militar. Buenos Aires: Eudeba, segunda edición.

Jauretche, Arturo (1966). El medio pelo en la Sociedad Argentina. Apuntes para una sociología nacional. Buenos Aires: Peña Lillo 
Jelin, Elizabeth (2002a). Los trabajos de la memoria. Madrid: Siglo XXI.

Jelin, Elizabeth -compiladora- (2002b). Las conmemoraciones. Las disputas en las fechas “in-felices”. Madrid: Siglo XXI.

Jelin, Elizabeth (2005). "Exclusión, memorias y luchas políticas", en Daniel Mato -compilador-. Cultura, política y sociedad. Perspectivas latinoamericanas. Buenos Aires: Consejo Latinoamericano de Ciencias Sociales (CLACSO).

Le Goff, Jacques (1991). El orden de la memoria. El tiempo como imaginario. Barcelona: Paidós.

López, Susana Mabel (2003). Representaciones de la Patagonia: colonos, científicos y políticos 1870-1914. La Plata: Al Margen (Colección Universitaria).

Maneiro, María (2005). Como el árbol talado. Memorias del Genocidio en La Plata, Berisso y Ensenada. La Plata: Al Margen (Colección Diagonios).

Mangone, Carlos (2011). "Un proyecto de reconversión cultural y comunicacional", en Badenes, Daniel y Grassi, Luciano -compiladores-. Historia, memoria y comunicación. Bernal: Universidad Nacional de Quilmes.

Marchessi, Aldo (2001). El Uruguay inventado. La política audiovisual de la dictadura, reflexiones sobre su imaginario. Montevideo: Ediciones Trilce.

Miguel, Lucas (2007). "El veterinario de los represores", en revista Materia Pendiente, Año 1, $\mathrm{N}^{\circ}$ 1, noviembre. La Plata: Facultad de Ciencias Exactas de la Universidad Nacional de La Plata.

Milanesio, Natalia (2004). "Del poblado precario a la ciudad opulenta: representaciones del pasado urbano y debate historiográfico en la década de 1920 en torno al surgimiento de Rosario", en VV.AA., Territorio, memoria y relato. Rosario: UNR Editora.

Novaro, Marcos y Vicente Palermo (2003). La dictadura militar (1976-1983). Del golpe de Estado a la restauración democrática. Buenos Aires: Paidós.

Oszlak, Oscar (1991). Merecer la ciudad. Los pobres y el derecho al espacio urbano. Buenos Aires: HVMANITAS / CEDES.

Pereira, José Miguel (1995). "Comunicación, cultura y ciudad. Campo de reflexión, propuestas de investigación", en Signo y Pensamiento, № 27, Universidad Javeriana, Facultad de Comunicación y Lenguaje, Bogotá.

Pérgolis, Juan Carlos (2005). Ciudad express. Arquitectura, literatura, ciudad. Buenos Aires: Nobuko.

Pérgolis, Juan Carlos (2006). Ciudad fragmentada. Buenos Aires: Nobuko.

Philp, Marta (2006). "Héroes guerreros y hombres virtuosos para la salvación de la patria. Usos del pasado durante la última dictadura", trabajo presentado al II Coloquio de Historia y Memoria. Los usos del pasado en las sociedades, Universidad Nacional de La Plata, septiembre.

Pollak, Michel (2006). Memoria, olvido, silencio. La producción social de identidades frente a situaciones límite. La Plata: Al Margen.

Portelli, Alessandro (1991). "Lo que hace diferente a la historia oral", en Schwarzstein, Dora -compiladora-. La historial oral. Buenos Aires: CEAL.

Quiroga, Hugo (1994). El tiempo del "Proceso". Conflictos y coincidencias entre políticos y militares 1976-1983. Rosario: Fundación Ross.

Rousso, Henry (2000). "El duelo es imposible y necesario", entrevistado por Claudia Feld, en Puentes, Año 1, Número 2, La Plata, Comisión Provincial por la Memoria, diciembre. 
Ricœur, Paul (1999). Historia y narratividad. Barcelona: Paidós.

Ricœur, Paul (2008). La memoria, la historia, el olvido. Buenos Aires: Fondo de Cultura Económica, $2^{\text {a }}$ edición.

Rojas, Ricardo (1909). La restauración nacionalista. Informe sobre educación. Buenos Aires: Ministerio de Justicia e Instrucción Pública.

Romero, José Luis (2009). La ciudad occidental. Culturas urbanas en Europa y América (Lecciones y textos editados por Laura Muriel Horlent Romero y Luis Alberto Romero). Buenos Aires: Siglo Veintiuno Editores.

Sábato, Hilda (2008). Buenos Aires en armas. La revolución de 1880. Buenos Aires: Siglo XXI.

Sennett, Richard (1978). El declive del hombre público. Barcelona: Península.

Sennett, Richard (1997). Carne y piedra. El cuerpo y la ciudad en la civilización occidental. Madrid: Alianza Editorial.

Seoane, María y Ruiz Nuñez, Héctor (1986). La noche de los lápices. Buenos Aires: Contrapunto.

Solari, Herminia (1996). "Joaquín V. González: algunas consideraciones alrededor de la idea de Nación", en $C U Y O$, Anuario de Filosofía Argentina y Americana, $N^{\circ} 13$, Año 1996, p.133-142.

Terán, Oscar (1994). "La tradición liberal”, en Punto de Vista, N 50, Buenos Aires.

Thompson, John (1998). Los media y la modernidad. Barcelona: Paidós Comunicación

Vattimo, Gianni (2006). "El olvido imposible", en VV.AA. Usos del olvido. Comunicaciones al Coloquio de Royaumont. Buenos Aires: Nueva Visión.

Vezzetti, Hugo (2003). Pasado y presente. Guerra, dictadura y sociedad en la Argentina. Buenos Aires: Siglo XXI Editores.

VV.AA. (2006). Medios, comunicación y dictadura. Lomas de Zamora: UNLZ.

Weber, Max (1987). La ciudad. Madrid: Ediciones La Piqueta.

Weinberg, Félix -director- (1978). Manual de Historia de Bahía Blanca. Bahía Blanca: Departamento de Ciencias Sociales, Universidad Nacional del Sur.

Williams, Raymond (2000). Marxismo y Literatura. Barcelona: Península, $2^{\text {a }}$ edición.

Yerushalmi, Yosef (2006). "Reflexiones sobre el olvido", en VV.AA. Usos del olvido. Comunicaciones al Coloquio de Royaumont. Buenos Aires: Nueva Visión.

"Familiares de Desaparecidos y Detenidos por Razones Políticas", Dossier No 9 de "Historia de los organismos de derechos humanos", en Puentes N 12, La Plata, Comisión Provincial por la Memoria, septiembre de 2004. Sin datos de autor.

\section{Publicaciones periódicas}

Diario El Día (1982)

Diario La Gaceta (Nov. 1982)

Revista de la Universidad (1979-1982)

Revista Económica (Sep-dic. 1982)

Revista Ambiente (No 32 - Mayo de 1982)

Revista Libertad Creadora $\left(\mathrm{N}^{\circ} 1,1943\right)$ 


\section{Otras fuentes documentales}

Archivo DIPBA, Mesa "Ds", Carpeta Varios Legajo No 20.803, Tomo 1, caratulado "Madres de Plaza de Mayo. Año 1982. Octubre a diciembre". Doce folios.

Municipalidad de La Plata. Programa de Festejos Centenario de la Fundación de la Ciudad de La Plata. 1882-19 de noviembre de 1982 (Folleto).

Julio Ángel Morosi. Curriculum Vitae. En Legajo Personal de la Facultad de Arquitectura Urbanismo (FAU-UNLP), 1981.

Eduardo R. Saguier. Recurso de Nulidad-Falsedad Ideológica Agravada-Prevaricato-Falso Testimonio-Enemistad Manifiestas, dirigido al presidente del CONICET Eduardo H. Charreau. 24 de noviembre de 2004

Boletín Oficial de la República Argentina, $\mathrm{N}^{\mathrm{o}}$ 30.211, 12 de agosto de 2003. http://cncom.gov.ar/Boletines/2003/2Da_Edi/0812.Pdf

Decreto Provincial No 5.892, 26 de junio de 1953.

Decreto-Ley Provincial 10/55. La Plata, 27 de septiembre de 1955

Sitios web

http://sepescritores.zoomblog.com/ - Consultado 26-11-2011.

http://escritores-tradicionalistas.blogspot.com - Consultado 12-01-2012

http://www.noticiasargentinas.com/ant_historicos.php. - Consultado 17-05-2009

http://clavesendiagonal.ar.tripod.com/Numero1/Desdeelfondodeltiempo.htm - Consultado 2011-2011.

http://openlibrary.org/works/OL10945574W/La_Plata_una_creaci\%C3\%B3n_de_la_generaci \%C3\%B3n_del_80-Consultado 21-10-2011.

\section{Entrevistas y consultas realizadas}

Adelina de Alaye, mayo de 2007.

Claudia Bellingeri, julio de 2007.

Ricardo Soler, agosto de 2008.

Cristina Vitalone, julio de 2011

Sergio Pujol, julio de 2011.

Luis Adriani, julio de 2011

Pedro Luis Barcia, octubre de 2011.

Ethel Giuliano, octubre de 2011.

Daniel Benavídez, octubre de 2011.

Blas Cadierno, octubre de 2011. 


\section{Agradecimientos}

"Al «olvidar» el trabajo colectivo dentro del cual se inscribe, al aislar de su génesis histórica el objeto de su discurso, un «autor» práctica pues la negación de su condición real. Pese a las ideologías contrarias de las que puede acompañarse, el poner de lado la relación sujeto-objeto o la relación discurso-objeto constituye la abstracción que genera una simulación de «autor». Borra las huellas de la pertenencia de una investigación a una red [de intercambio], huellas que siempre comprometen, en efecto, los derechos de autor"

(De Certeau, 1996: 52)

Hay muchos tesistas y pocas tesis, dicen. Alguien, algún día, hará una tesis sobre eso. Debe haber muchas razones que lo explican. Y muchas pasiones.

Las tesis tienen un aura de final de ciclo que es acaso lo que nos hace demorarlas. En mi caso, Un pasado para La Plata culmina el recorrido por la maestría que empecé hace casi siete años, a una semana de licenciarme, cuando tenía 22. La página de agradecimientos no puede ser una foto de la última semana, sino un reconocimiento a quienes estuvieron ahí y contribuyeron a un proceso de formación y crecimiento que va mucho más allá de esta tesis.

El primero le corresponde entonces a Alfredo Alfonso, compañero en muchos espacios y director en más de una ocasión, por incentivar mis trabajos, por bancarme siempre y por la generosidad con que aceptó e incentivó mi recorrido por otros caminos y con otros tutores. Porque tuve esa suerte: en mi trayectoria formativa están también el apoyo y las enseñanzas de Tiny Vitalone, Magalí Catino, Aníbal Viguera y especialmente Laura Lenci.

Las tesis llevan una firma única y tienen toda la impronta de un producto individual, pero nadie dedicado al oficio de investigar podría negar que la producción de conocimiento es colectiva siempre. No lo digo sólo por la enriquecedora relación con mi directora, ni por el aporte de los entrevistados. Nuestra inteligencia es social, y la capacidad de problematizar y razonar se produce con otros.

Estas páginas se gestaron en bibliotecas, archivos y librerías de usados, y se escribieron frente a una computadora personal, pero también son el resultado de conversaciones en bares y universidades, casas de amigos y centros culturales. Algunos de quienes aportaron a este trabajo ni siquiera sabían de su existencia. Pero seguro la tesis le debe algo a la cátedra II de Comunicación y Teorías, a los grupos de investigación que integré -aún cuando no tuvieran una vinculación temática directa- y a mis compañeros en la Universidad Nacional de Quilmes.

La idea inicial surgió durante mi desempeño en una Beca de Estudio de la Comisión de Investigaciones Científicas y su desarrollo es deudor de muchas otras instituciones y grupos. Con seguridad, del Programa Jóvenes y Memoria, porque fue uno de los primeros espacios donde reflexioné acerca de disputas sobre el pasado y porque un video realizado por pibes de Carmen de Patagones, en 2006, disparó en mí una pregunta por el centenario platense. Un agradecimiento es para ellos y para quienes desde la Comisión Provincial por la Memoria además me impulsaron a hacer la maestría.

Otro tanto le corresponde a ámbitos de reflexión académica sobre memoria e historia reciente de los que participé en estos años: el Núcleo de Estudios sobre Memoria del IDES y en particular el grupo de trabajo sobre Lugares; el espacio de intercambio sobre Historia, Memoria y Comunicación que generamos junto a Luciano Grassi desde 2009 en la UNQ; y 
más recientemente el Instituto de Investigaciones en Comunicación (IICOM) -con su línea sobre memorias y oralidades- y el Programa para la Reconstrucción de la Memoria sobre el Predio del Ex B.I.M.3. creado por la Facultad de Humanidades.

El trayecto de posgrado, en tanto, me contactó con buenos docentes e investigadores: estas páginas tienen algo de Ludmila da Silva Catela, Claudia Feld, Daniel Lvovich y Martín Retamozo. Compartí el taller de tesis con Alberto Pérez -su coordinador-, Javier Correa, Kristel Best Urday, Sebastián Vargas, Florencia Matas, Luciana Sotelo, Mora González Canosa y Macarena Ordenavía. Allí, hace cinco años, nacieron las primeras ideas. Tiempo después me crucé en un curso con Hernán Apaza, que en un efímero grupo de mails citó el llamado de Edward Thompson a crear "lugares donde nadie trabaje para que le concedan títulos o cátedras, sino para la transformación de la sociedad; donde la crítica y la autocrítica sean duras, pero donde haya también ayuda mutua e intercambio de conocimientos teóricos y prácticos: lugares que prefiguren, en cierto modo, la sociedad del futuro".

De esa actitud fueron parte muchos. Inicialmente Héctor Schmucler, el primer lector de mi proyecto. Le siguió Laura Lenci, a quien le agradezco el acompañamiento y también su paciente espera de avances, desde el primer encuentro en el caluroso diciembre de 2007 hasta los últimos meses de lúcidas sugerencias y atentas correcciones. Luego, en distintas oportunidades, encontré otros agudos lectores que hicieron preguntas y comentarios en diversas jornadas, en reuniones de grupos o a requerimiento personal: Cintia González Leegstra, Esteban Rodríguez Alzueta, Emanuel Kahan, Liliana Brezzo, Andrés Bisso, Elizabeth Jelin, Silvina Jensen, Máximo Badaró, Alfredo Alfonso, Fabián Viegas, Luciana Aon y Soledad López, entre los que recuerdo. En la recta final, mis papás, Rosa Schaposnik y Anselmo Badenes, ofrecieron dos lecturas cuidadosas del primer borrador. Y Chempes me ayudó con la infografía dinámica que expresa la red de relaciones entre las publicaciones.

Agradezco también a los autores o colaboradores de los libros del '82 que me ayudaron a dilucidar sus condiciones de producción y circulación: Ricardo Soler, Claudia Bellingeri, Cristina Vitalone, Sergio Pujol, Luis Adriani, Blas Cadierno, Pedro Luis Barcia, Ethel Giuliano y Nora Sémplici. También aportaron información Adelina de Alaye, Celina Artigas, Ana Barletta, Daniel Galatro, Eduardo González Andía, Magdalena Pérez Balbi, Jerónimo Pinedo, Martín Carranza y posiblemente otros involuntariamente olvidados.

Por último, siempre transité la academia con una pata afuera y por lo tanto es mucho lo que debo a aquellos que comparten militancia y proyectos, no tanto por algunas conversaciones y publicaciones sobre la ciudad -que las hubo-, sino por pequeñas grandes cosas: porque fueron y son respiraderos, como dirían algunos de ellos. Esta tesis no sería lo que es, y yo no sería quien soy, sin mis compañeros de La Pulseada, sin los amigos de La Grieta, sin Chemp, Pili y Dani. Para ellos es el mayor agradecimiento. Y para Jo, mi compañera, por las mismas inquietudes y por el amor que me abrazó durante los meses de escritura de estas páginas. 